\title{
A Revision of the Indo-West Pacific Fossil and Recent Species of Murex s.s. and Haustellum (Mollusca: Gastropoda: Muricidae)
}

\author{
W.F. PONDER ${ }^{1}$ AND E.H. VOKES ${ }^{2}$ \\ ${ }^{1}$ Australian Museum, \\ P.O. Box A285, Sydney South, NSW 2000, Australia \\ ${ }^{2}$ Department of Geology, Tulane University, \\ New Orleans, Louisiana 70118 , U.S.A.
}

\begin{abstract}
The Indo-West Pacific species of Murex and Haustellum are revised and several species heretofore included in Murex s.s. are transferred to Haustellum, which is recognised as a separate genus. In all, 55 species-group taxa are recognised. Of these, 26 species (including six new) or subspecies (including three new) of Murex, and 17 species (including one new) or subspecies of Haustellum, occur in the Recent fauna. Four taxa of fossil Murex and six of Haustellum are also recognised. A subgenus of Murex is described to include one Recent and two fossil species, one from the European Tertiary. All Recent species are redescribed in detail and their distribution given. Ten new species-group taxa are named: Murex falsitribulus, $M$. kerslakae, M. spectabilis, M. queenslandicus, M. spicatus, M. altispira and Haustellum dolichourus n. spp.; and $M$. tenuirostrum africanus, $M$. pecten soelae and M. brevispina ornamentalis $\mathrm{n}$. subspp. The subgenus Promurex is proposed for Murex antelmei.

The known (albeit limited) biological information about these two genera is summarised and comparisons are made with related genera, based upon shell, radular and anatomical data.
\end{abstract}

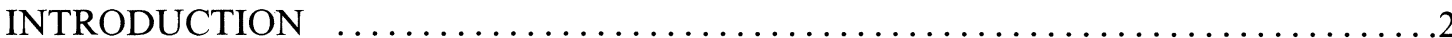

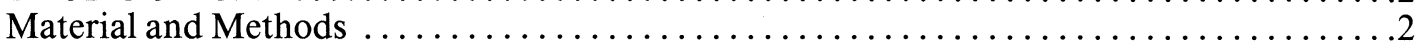

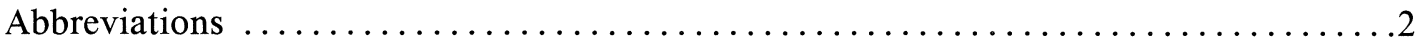

Taxonomic Characters Used in Species Determination $\ldots \ldots \ldots \ldots \ldots \ldots \ldots \ldots$

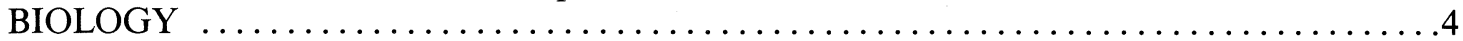

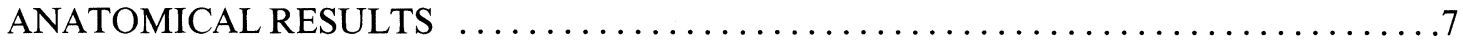

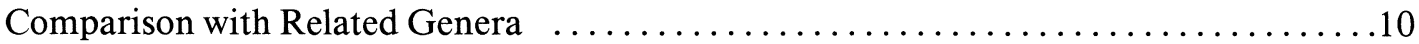

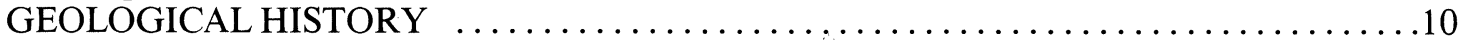

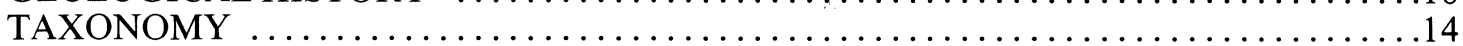

Key to the Indo-West Pacific Recent Species of Murex (Murex) $\ldots \ldots \ldots \ldots \ldots \ldots \ldots$

Key to the Indo-West Pacific Species of Haustellum $\ldots \ldots \ldots \ldots \ldots \ldots \ldots \ldots \ldots \ldots \ldots$

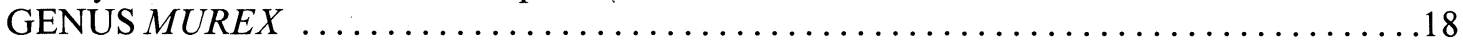

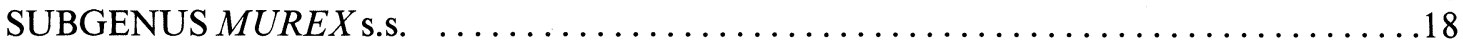

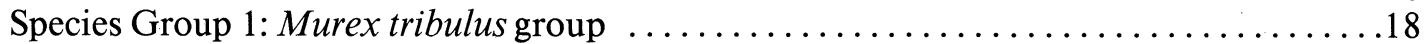

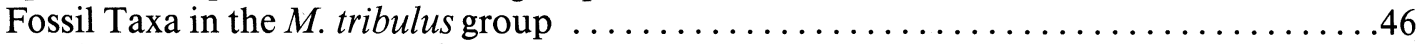

Species Group 2: Murex scolopax group . . . . . . . . . . . . . . . . . . . . . . . . . 49

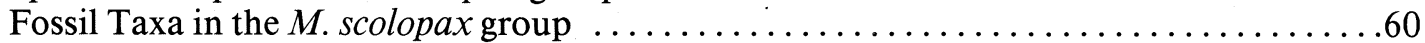

Species Group 3: Murex brevispina group . . . . . . . . . . . . . . . . . . . . . 60 60

Species Group 4: Murex pecten group . . . . . . . . . . . . . . . . . . . . . . . . . . . . 69

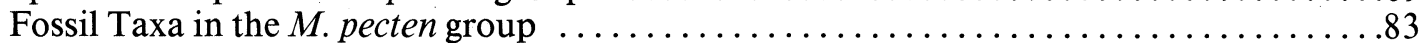

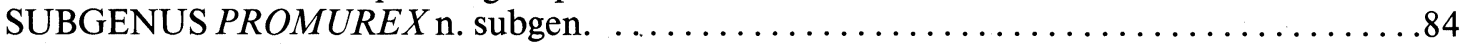

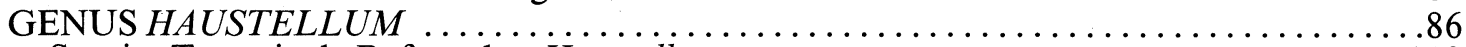

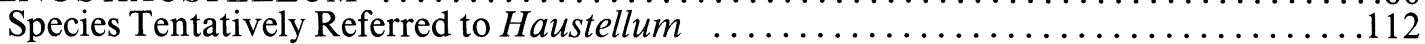

Fossil Taxa of Haustellum in the Indo-West Pacific $\ldots \ldots \ldots \ldots \ldots \ldots \ldots \ldots \ldots \ldots \ldots$

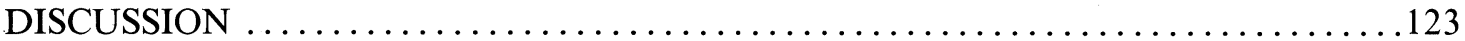

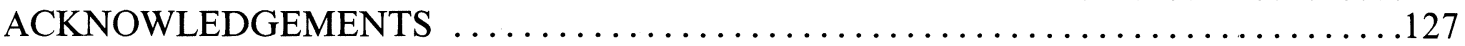

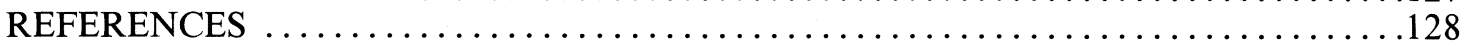




\section{INTRODUCTION}

Muricids have long been one of the most popular groups of molluscs collected and admired by those interested in natural history. The profusion of species, many of which are large and elaborately ornamented, have captured the interest of amateur and professional conchologists, who have named over 800 Recent species in the family Muricidae. The most elaborately sculptured and well known of all the muricids is probably $M$. pecten, the Venus Comb Shell. This species is a member of the complex group of species that often bear long spines and are usually included in the genus Murex in the strict sense. Because of their popularity, many popular and semipopular works have dealt with this group but little serious attempt has been made to review them in this century. The taxonomic confusion in this group is demonstrated by the very different interpretations that appeared in two semipopular reviews of the Muricidae in 1976 (Fair, 1976; Radwin \& D'Attilio, 1976).

A related genus, Haustellum, is convergent with Murex and has been variously interpreted so that species are sometimes included in this genus, or in Murex s.s. Some species that we include in Haustellum have been placed consistently in Murex s.s. by other workers.

This revision has been undertaken to attempt to clarify the taxonomy of the Indo-West Pacific species of Murex and Haustellum and to reassess their generic classification. The Recent western Atlantic species have been reviewed by Clench \& PérezFarfante (1945) and Radwin \& D'Attilio (1976), and the western Atlantic Cenozoic species by Vokes $(1963,1967)$.

\section{Materials and Methods}

Shells have been examined in, and/or borrowed from, many of the institutions listed under Abbreviations. The descriptions have been prepared from a range of material of each species but do not necessarily take into account all of the variation encountered. The material examined is listed under "Records" for each species. Localities are abbreviated and generally conform with the Times Atlas (6th Edition, 1981), thus they do not necessarily agree exactly with original data labels. Minor localities that could not be traced are enclosed in quotation marks. "Fossil Records" include those from the literature. If the material has been examined, a repository is given.

The anatomy of the pallial cavity and the anterior alimentary canal has been examined in a range of species that cover the morphological variation seen in the shells. Radulae were also examined from most of these species using a Scanning Electron Microscope. Few useful differentiating characters were discovered in these analyses, so the shell and opercular characters alone are utilized in the diagnoses. A summary of the anatomical and radular data is given below.

\section{Abbreviations}

AIM Auckland Institute and Museum, New Zealand

AMNH American Museum of Natural History, New York, U.S.A.

AMS The Australian Museum, Sydney

ANSP Academy of Natural Sciences of Philadelphia, U.S.A.

AWBP A.W.B. Powell collection, Auckland Institute \& Museum

BMNH British Museum (Natural History), London

BMR Bureau of Mineral Resources, Canberra, Australia

BPBM Bernice P. Bishop Museum, Honolulu, Hawaii

CAS California Academy of Sciences, San Francisco, U.S.A.

DMNH Delaware Museum, Greenville, U.S.A.

FMNH Field Museum of Natural History, Chicago, U.S.A.

FSM Florida State Museum, Gainesville, U.S.A.

GIT Geological Institute, Tokyo, Japan

GML Rijksmuseum van Geologie en

Mineralogie, Leiden, Holland

GNHM Museo Civico di Storia Naturale "G. Doria," Genoa, Italy

HUJ Hebrew University, Jerusalem, Israel

HUM Museum für Naturkunde, Humboldt Universitat, E Berlin, D.D.R.

IMT Institute of Malacology, Tokyo, Japan

IRSB Institut Royal des Sciences Naturelles de Belgique, Brussels

LACM Los Angeles County Museum of Natural History, California, U.S.A.

MCZ Museum of Comparative Zoology, Harvard University, Cambridge, Mass., U.S.A.

MNT Museum and Art Gallery of the Northern Territory, Darwin, Australia

NHMB Naturhistorisches Museum, Basel, Switzerland

NHMG Muséum d'Histoire Naturelle, Geneva, Switzerland

NHMP Muséum National d'Histoire Naturelle, Paris, France

NHMV Naturhistorisches Museum, Wien, Austria

NM Natal Museum, Pietermaritzburg, South Africa

NMV Museum of Victoria, Melbourne, Australia

NMNZ National Museum of New Zealand, Wellington 
NMW National Museum of Wales, Cardiff, U.K.

NSMT National Science Museum, Tokyo, Japan

NZGS New Zealand Geological Survey, Lower Hutt

OM The University Museum, Oxford, U.K.

OMNH Osaka Museum of Natural History, Japan

PCB Paleontology Collection, Dept. of Paleontology, University of California, Berkeley, U.S.A.

QM Queensland Museum, Brisbane, Australia

RML Rijksmuseum van Natuurlijke Historie, Leiden, Holland

RSM Royal Scottish Museum, Edinburgh, Scotland

SAM South Australian Museum, Adelaide

SDNHM San Diego Natural History Museum, California, U.S.A.

SMF Forschungsinstitut Senckenberg, Frankfurt, W Germany

TGM Instituto di Geologia, Paleontologia e Geografia Fisica, Universita di Torino, Italy

TIU Institute of Geology and Palaeontology, Tôhuku Imperial University, Sendai, Japan

USNM National Museum of Natural History, Washington, D.C., U.S.A.

WAM Western Australian Museum, Perth

YNU Geological Institute, Yokoyama National University, Japan

ZMA Zoölogisch Museum, Universiteit van Amsterdam, Holland

ZMC Zoologisk Museum, Copenhagen, Denmark

\section{Taxonomic Characters Used in Species Determination}

Shell. PROTOCONCH: the protoconch or larval shell has long been a useful character in separating species in various groups of gastropods. Watson (1885) first described differences in the protoconchs of species of Murex but Baker's (1890) was the first and only systematic attempt to use this character. Radwin \& D'Attilio (1976) and Houart (1979) have also described the protoconchs of some species of Murex, Houart using them to distinguish species.

We have found this structure to be extremely useful in species discrimination. In some cases species are hardly separable on teleoconch characters but have completely different protoconchs, presumably at least partly, as a result of the species employing a different developmental strategy.

TELEOCONCH: there are a large number of teleoconch characters that have been employed and, as their use is completely standard, they are only listed. These include the outline of the whorls making up the spire; the aperture and denticulation on the inner lip (Haustellum only); the varices; the spiral sculpture, which is related to spine development, and can generally be classified as primary, secondary or tertiary; and the axial sculpture between the varices. In the case of certain other shell characters an attempt has been made to quantify the usage of otherwise subjective descriptive terms.

Thus, although an occasional specimen may fall outside the values cited, for size the ranges would be as follows: 'very large', more than $110 \mathrm{~mm}$ in total length; 'large', 80-110 mm; 'medium', 50-80 mm; 'small', less than $50 \mathrm{~mm}$ in total length.

The spire height is a function of the angle of the spire, with that angle ranging from the high-spired $H$. mindanaoensis $\left(60^{\circ}\right)$ to the low-spired M. brevispina complex $\left(95^{\circ}-100^{\circ}\right)$. The median is about $72^{\circ}$ and most of the members of the group in this study fall within the $70^{\circ}-80^{\circ}$ range. As a broad generality, inasmuch as the variation within a species is not inconsequential, a spire angle of less than $65^{\circ}$ is 'high-spired', and one greater than $90^{\circ}$ is 'low-spired'. If not stated, the spire angle is considered to be 'average', i.e. between $65^{\circ}-90^{\circ}$.

The extremely long, straight, tube-like siphonal canal is a generic characteristic of the species in this study; therefore, all have greatly extended canals relative to other members of the subfamily. The length of this canal can be expressed in terms of relative percent of total shell length, ranging from over $60 \%$ in some species to only $30 \%$ in $\mathrm{H}$. bobyini. The canal is usually straight, so this fact is not noted, comment only being made when there is some deviation from this rule. The median length for the canal in these species is over $50 \%$ of total body length but frequently the distal ends of the canals are broken off, making the total percentage less in that particular specimen. In order to make comparison between species possible, the following orders of magnitude are used: 'relatively short', less than $40 \%$ of total body length; 'moderately long', $40 \%$ to $50 \%$; 'long', $50 \%$ to $60 \%$; 'very long', more than $60 \%$ of total body length.

Another generic character of the Murex s.s. group is a labral tooth which varies from almost unnoticeable in $M$. troscheli to extremely large in $M$. acanthostephes. The comparisons of 'small', 'large', and 'very large', therefore, are to be construed as relative only to the other members of the subgenus.

Measurements of various shell parameters were taken for representative specimens of most species. These parameters include: a) Length, including the total length, the length of the spire plus the aperture (the anterior edge of the aperture being taken as the anterior-most part of the outer lip [labrum] at the junction of the aperture and the anterior canal), the length of the aperture (the posterior corner of the aperture taken as the posterior-most edge of the labrum) and the length of the anterior canal taken from the anterior edge of the aperture. 
b) Shell width, taken as the maximum horizontal width, including and excluding the spines. This measurement includes the width of the labral varix. Minor damage to the spines was not noted.

c) Spine length, including measurements of the primary shoulder spine, and the length of the longest spine on the anterior canal. The canalicular spines were frequently broken so that the one measured was not necessarily the corresponding spine in all cases.

Significant damage is indicated by an asterix and in all cases actual measurements were taken. Minor damage to the spines, the shell apex, or the tip of the anterior canal was not noted.

Counts were made of the number of spines on the anterior canal and on the labral varix. In both cases, the number of spines is listed in the order of prominence: primary, secondary, tertiary and, rarely, quaternary. An asterix indicates that significant damage prevented an accurate count being made.

The number of major spiral threads between the last two varices on the penultimate and body whorls was counted. This count does not necessarily correspond to the number of primary spirals (which should be equivalent to the number of primary spines) but includes all the spirals of approximately equal strength to the primary spirals. The number of distinct intervarical nodes between the last two varices on the body whorl were also counted.

The measurements given are intended to be used only as an indication of the variation in a taxon and are not intended to be utilized statistically because of the very small sample sizes and the non-random way in which the measured material was selected. Other problems in this regard include the lack of information about potential sexual dimorphism and the difficulty in obtaining accurate measurements from shells that are so readily damaged.

Operculum. The position of the nucleus and the type of sculpture on the outer surface of the operculum are the main characters used. This structure is valuable in separating some species of Murex.

Radula. The radula has not proved to be a useful character, being remarkably uniform in both genera and differing only in one rather minor character between the two genera.

Anatomy. Preserved material of a number of species was examined and the results are summarised below. Few useful differences were observed that were readily quantified. The variation in some species was greater than between other species in those characters that were examined (head-foot, pallial characters, anterior alimentary canal), and the number of specimens of each species that were available for dissection was very small, with few exceptions. The penis and pallial vas-deferens have been used as taxonomic characters because they appear to show reasonably clear differences between some species and are relatively accessable structures that preserve well even in material that is otherwise useless for anatomical work.

\section{BIOLOGY}

Egg Capsules. The egg capsules of only three species of Murex and one of Haustellum have been recorded in the literature: Murex 'trapa' - Natarajan, 1957; M. acanthostephes - Coleman, 1981; M. brevispina macgillivrayi - Ackworth, 1965, and Scott, 1973; and Haustellum messorius (as $M$. recurvirostris rubidus - Bandel, 1976). The capsules are similar to those of at least some species of Siratus, Bolinus and Hexaplex (see Bandel, 1976 for summary of literature). They are not attached to the substrate individually, as in many other muricids, but are laid in a compact mass. In the case of $M$. acanthostephes (Coleman, 1981: 58) the egg mass is stalk-like and fixed in the sediment. The capsules are arranged in a cylinder with their apertures on the inside opening to a narrow, central lumen. Murex tribulus has a similar egg mass (photo provided by J. Berg). Murex 'trapa' has several similarly formed, but more irregular egg masses loosely interconnected. In most of the other species in this group, including $M$. brevispina macgillivrayi, it appears to be laid as an ovoid mass, although, as in Haustellum messorius, the lowest layer of capsules may initially be fixed to the substrate. In these two species the egg masses are produced communally, with up to $30 \mathrm{M}$. brevispina macgillivrayi contributing to a single mass (Ackworth, 1965). The capsules themselves are short, oval and dorsoventrally flattened with a rather large circular aperture on the concave underside. These capsules have been described as being 'tongue shaped'. Each capsule is attached to its neighbours by projections from the basal part, and a narrow space is left between each capsule to allow the hatchlings to escape.

Egg masses of $M$. acanthostephes and M. brevispina macgillivrayi in the AMS are composed of capsules like those described above and, at least in the case of $M$. acanthostephes, they contain eggs that develop into crawl-away larvae (the capsules of $M$. brevispina macgillivrayi are empty). Two dried egg masses in the WAM contain between 5 and 22 (mean 10.8) shells in each capsule, with up to the first two spines developed on the very early teleoconch. There are up to 634 eggs in individual capsules of the AMS specimens. It is thus apparent that nurse eggs are developed in this species. Dried capsules probably belonging to $M$. carbonnieri and $M$. djarianensis poppei are in the ANSP. They are both like the capsules described as $M$. 'trapa' by Natarajan (1957) and it seems likely that Natarajan's 'trapa' is actually $M$. carbonnieri, a common species in southern India.

It is probable that the type of egg mass seen in Murex and Haustellum is an adaptation for life on soft substrates. The capsules are essentially similar in form to the capsules of many species of Chicoreus that 

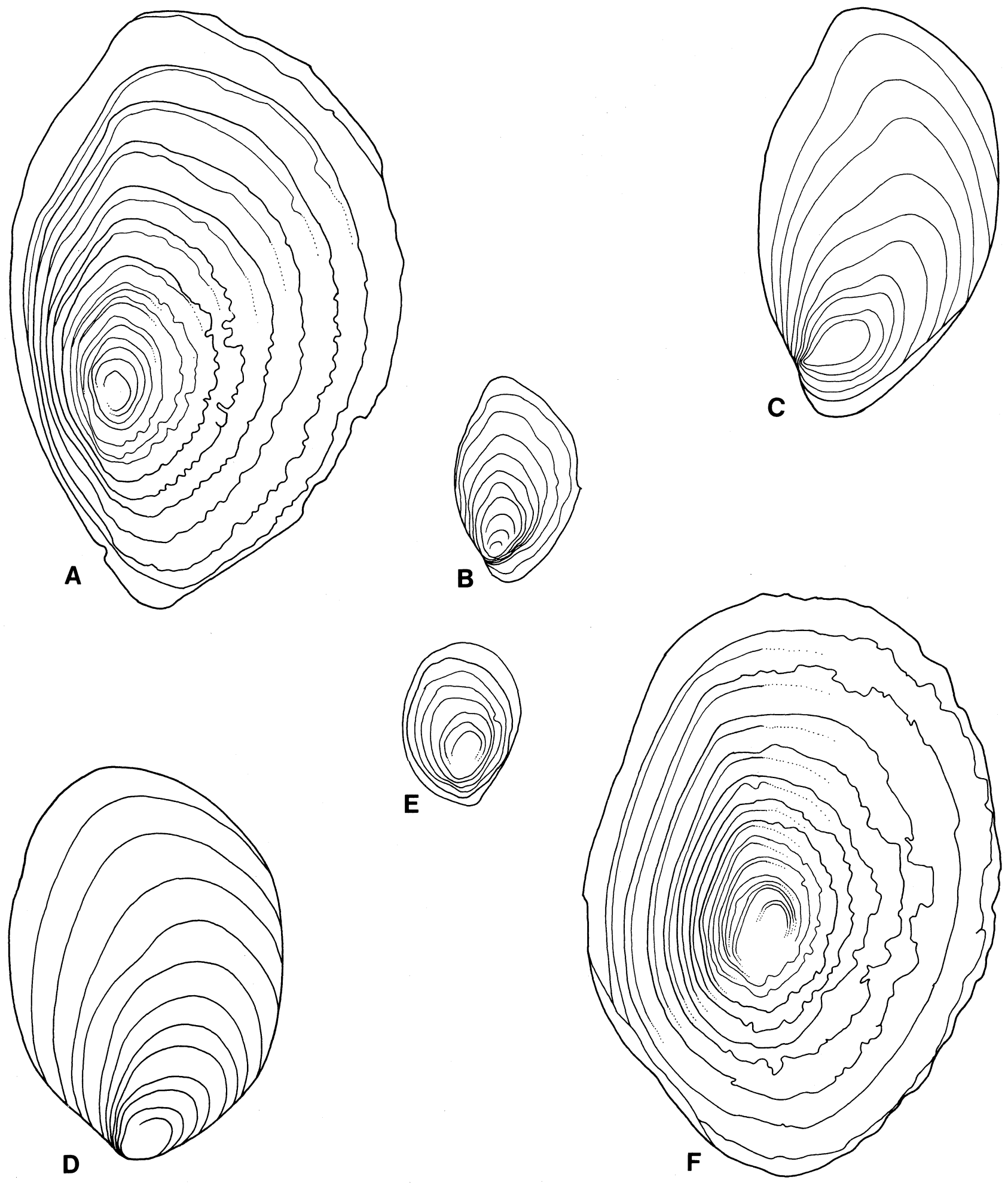

Figure 1. Opercula of species of Murex and Haustellum. A,B: Murex pecten pecten Lightfoot; Yule Island, Papua New Guinea, 9-18 m (AMS, C. 74688). C: Murex tenuirostrum tenuirostrum Lamarck; off Cape Bowling Green, Queensland, 37-40 m (AMS, 74756). D: Haustellum malabaricus (Smith); Bay of Bengal, 119 m (AMS, 3285). E,F: Haustellum haustellum haustellum (Linné). E: Juvenile; Java Sea, 27 m (ZMC). F: Solomon Islands (AMS, C. 36394). All figures to same scale. Scale $=5 \mathrm{~mm}$. 
are vase-shaped with the aperture at the flattened distal end. The piling up of such capsules would necessitate the migration of the aperture away from the distal end because this is where the capsules are attached to one another. The movement of the aperture to the inside face of the capsule would have a major protective advantage because the aperture is the weakest part of the capsule and because the hatchlings would be less vulnerable as they emerged. Many of the species build communal egg masses, several females being involved in their production.

Bandel (1976: fig. 19) has suggested a scheme of evolution of the muricid egg capsule. He suggests that the capsules seen in Hexaplex, Phyllonotus, Siratus and Bolinus (and presumably Murex) are derived from the vase-shaped capsules seen in most species of Chicoreus. All of these genera have nurse eggs. Haustellum (as known only from $H$. messorius) is placed on a different line of evolution not involving nurse eggs, but the capsules are virtually identical. It seems to us that a better scheme would reflect the known evolutionary pattern of the group. Thus the capsules seen in Hexaplex are more likely to be the primitive ones, these giving rise to the vase-shaped capsules of most species of Chicoreus. Thorson.(1940) has described the capsules and development of 'Murex turbinatus' [?= Hexaplex kusterianus (Tapparone-Canefri, 1875)]. This species has a simple capsule with a rounded distal end, produces veliger larvae and does not have nurse eggs. Bandel (1976) has suggested that this type of capsule gave rise to the lines leading to Haustellum on the one hand (without nurse eggs), and to Murex, Chicoreus and Siratus, as well as species of Hexaplex, on the other. Bandel (1976) also showed that Chicoreus brevifrons has a capsule intermediate in form between those of the Murex-Hexaplex group and ' $M$. turbinatus'. Knudsen (1950) described the capsules of 'Murex fasciatus' (= Hexaplex tenuis Sowerby, 1879), which are similar to those of species of Chicoreus. Thus the vase-shaped capsule may have been developed in Hexaplex before it gave rise to Chicoreus. Clearly many more observations are required.

There is too little information at present to utilise the egg capsule data with any degree of certainty, but it does not seem to detract from the classification adopted in this review.

Larval development and distribution. The only published direct observations on the larval development of any species of Murex are those on $M$. 'trapa' $(?=$ M. carbonnieri) by Natarajan (1957) and the observations reported above for $M$. acanthostephes. Haustellum messorius (as $M$. rubidus) (Bandel, 1976) has direct development. Jeanne Berg of Kokopo, New Britain, Papua New Guinea, has reported in detail (in litt., 1983) the development of $M$. tribulus kept in an aquarium. Two nights, during a full moon in September, were taken to complete the laying of the $7 \mathrm{~cm}$ long egg mass by a single female. This egg mass was about $2 \mathrm{~cm}$ in diameter and contained at least 100 capsules. The capsules changed from white to fawn and hatched in 17 days during the night. The minute veligers swam vigorously with four well-developed lobes, but all died within a week of hatching.

The morphology of the protoconch can be used to deduce larval development (Thorson, 1946). It is clear that multispiral, conical protoconchs with a sinusigera varix, like those found in $M$. trapa and $M$. tribulus, indicate a planktotrophic larval life. Shuto (1983) attempted to correlate the presence of an assumed planktotrophic larval life in species with a wide geographical range but results were confused, partly because of the taxonomy he used. In fact, no clear-cut picture emerges (e.g., compare the extensive geographic ranges of $M$. tribulus and $M$. tenuirostrum with the relatively restricted ranges of $M$. coppingeri, M. macgillivrayi and Haustellum hirasei). Species with a small, convex-whorled protoconch of between one and one-half and two and one-half whorls may have lecithotrophic development, spending only a short time in the water column. Species falling into this category probably include the widely dispersed $M$. carbonnieri which, if it is the $M$. 'trapa' of Natarajan (1957), has about two and one-half days after hatching before it settles. A species that could probably also be included in this group is the widely dispersed M. aduncospinosus, and, possibly, the more geographically restricted species such as $M$. kerslakae n. sp., $H$. rectirostris and $H$. multiplicatus. Most of the widely dispersed species in this category show considerable geographic variation suggesting that the gene flow is reduced but apparently sufficient to prevent the formation of distinct taxa.

Species with large, bulbous protoconchs (e.g., Haustellum haustellum fallax, $H$. purdyae and $H$. wilsoni) or large angulated protoconchs (e.g., $M$. scolopax and $M$. djaraniensis poppei) are almost certainly direct developers, and have, as might be expected, limited geographic ranges. It is quite possible that at least some of the species with smaller, one and one-half whorled protoconchs are also direct developers, as has been observed in $H$. messorius. This subject is further expanded in the Discussion.

Feeding. Coleman (1975) has stated that $M$. acanthostephes feeds on bivalves and Radwin \& D'Attilio (1976: 7) state that $M$. tribulus and $H$. haustellum are unselective carrion feeders. We know of no other published observations on the feeding of any species of Murex or Haustellum. Taylor (1980) has noted that the stomachs of $M$. trapa and $M$. sp. (=M. aduncospinosus) contain unidentifiable white muscular material that is possibly molluscan. Some specimens also contain the remains of polychaete worms, fish and crustaceans so they obviously are capable of feeding on a variety of prey.

The species examined anatomically in this study (Table 1) have an accessory boring organ (ABO) so that, presumably, they are capable of drilling holes in the shells of their prey. Mr A. Hinton (pers. comm.) 
has indicated that $M$. pecten feeds on bivalves and that holes were drilled in at least some of the prey. However, Mr P. Pechar (in litt., 1979) observed M. tenuirostrum feeding on Donax sp. in an aquarium and no hole was drilled. Clearly, further observations are needed on feeding biology before any definitive statements can be made about the group.

Spines and siphonal canal. The questions can be asked: "Why do most species of Murex have long spines and why do species of Haustellum and Murex have long anterior canals?" The ancestral forms of both genera have rather long, curved canals and short spines. It is the long canals alone that separate these two genera from most of the rest of the Muricinae and led to them being placed in the same genus by most workers. One advantage that the animal obtains from its long anterior canal is the placement of the inhalent opening at a distance from the body. This provides advance notice of the water ahead, enabling earlier prey detection, before the prey has been disturbed. One of us (W.F.P.) has observed $M$. trapa and $M$. aduncospinosus sweeping the siphon back and forth over the surface of the substrata, by partial rotation of the shell-head on the foot, by way of the muscular column. Some Murex species have also been observed vigorously expelling water from the siphonal canal, ejecting it for $20-30 \mathrm{~cm}$.

The plicate osphradium is located at the base of the siphon, as it is in all neogastropods, so this siphonal extension is simply a minor modification of the normal structural plan in the group. Convergence has presumably resulted in a similar long anterior canal in both Murex and Haustellum, as well as in the muricid genus Bolinus, just as it has in Columbarium and Tudicula (Turbinellidae) and Fusinus (Fasciolariidae).

The formation of spines, too, is an exaggeration of the spines found in Hexaplex and other primitive Muricinae. Paul (1981) has suggested that the spines in Murex pecten form a cage in which the animal can feed safely. This may be the case in M. pecten and in some related species, but for the majority of species the spination on the canal probably serves primarily to discourage predators from attacking the canal. The spines on the shell, too, are presumably primarily protective. Paul has suggested that they may also act as stabilisers, making it difficult for the animal to be rolled over.

Most species of Murex that have been observed alive are often buried. Long spines in a burrowing animal are not likely to be an advantage. Spine reduction, and even loss, has occurred in the $M$. brevispina - M. macgillivrayi group, possibly because of their shallow-water habitat and having to bury themselves amongst the roots of seagrasses in soft sediment.

Species of Murex and Haustellum are clearly not specialised burrowers and have few modifications for this way of life. Their spines, long anterior canal, long cephalic tentacles and small foot are all structural features that argue against an active burrowing habit. In all probability the animals do not truly burrow, but may' enter the sediment to hide from predators, particularly during the day, to prevent desiccation (in the case of intertidal species), or to consume their prey. Species of Haustellum may be more efficient burrowers, most species having very reduced spines or none at all. Both groups probably evolved from species living on soft sediment, which may have evolved long spines, in the case of Murex, to assist in stability on the surface. The protective role may be a secondary consequence. Certainly the orientation of the spines suggests that stabilisation, in particular the prevention of sinking into soft sediment, is the primary function of the spines. This is further corroborated by the parallel development of long spines in many species of Siratus, which also live on soft sediment.

Spine removal is required during growth and this appears to occur by dissolving the base of the spine as observed in Chicoreus brevifrons (Lamarck, 1822) and Hexaplex fulvescens (Sowerby, 1834) by Carriker (1972).

Labral tooth. The tooth on the outer lip of the aperture, the labral tooth or spine, is present in species of Murex, but not in Haustellum. Similar spines also occur in some species of Chicoreus, including the type species of that genus, and some species of Hexaplex, including the type. This raises the possibility that Chicoreus and Hexaplex may not be natural groups. However, a very similar tooth or spine also occurs in other muricid genera such as Jaton, Ceratostoma, Forreria and Acanthina. In the last-named genus the labral spine has been shown to function as a wedge to force apart the opercular valves of barnacles and the valves of bivalves (Malusa, 1985). It is used to open bivalves in Chicoreus ramosus but its function in the other genera is unknown. Paine (1966) showed that in Acanthina angelica Oldroyd, 1918, the spine can also be used as a brace to hold the snail in position while drilling. It would appear that this structure may have arisen independently in several genera or even families. Opeatostoma (Fasciolariidae) has the largest labral tooth of any gastropod, which is also used to pry open barnacles.

\section{ANATOMICAL RESULTS}

The anatomy of several species of Murex and Haustellum was examined (Table 1) to determine the gross morphology of the anterior alimentary canal, the terminal male genitalia, the ctenidium and the osphradium. No other systems were examined because of the state of preservation and because, in many cases, the posterior parts of the animal were not extracted from the shell.

The results show that, in these systems at least, the anatomy of species of both of these genera do not differ significantly, with the exception of one 


\begin{tabular}{|c|c|c|}
\hline Murex & $\begin{array}{l}\text { acanthostephes } \\
\text { aduncospinosus } \\
\text { kerslakae } \\
\text { forskoehlii } \\
\text { brevispina } \\
\text { coppingeri } \\
\text { macgillivrayi }\end{array}$ & $\begin{array}{l}\text { S of Exmouth, Western Australia } \\
\text { Off Tolo Channel, Hong Kong } \\
\text { NE Keppel Bay, Queensland. } \\
46-55 \mathrm{~m} \\
\text { Hejaz, Saudi Arabia (RML): } \\
\text { Nuwciba, Sinai, Israel } \\
\text { Zanzibar, W. Africa (MCZ) } \\
\text { off Karumba, Gulf of } \\
\text { Carpentaria, Queensland } \\
\text { Darwin, Northern Territory } \\
\text { W of Weipa, Gulf of Carpentaria, } \\
18 \text { m } \\
\text { W coast of Nuhu Tjut Kai, } \\
\text { Moluccas, } 46 \text { m (WAM) } \\
\text { Kai, Moluccas, 50 m (ZMC) } \\
\text { Swain Reefs, Queensland } \\
\text { Bataan Prov., Luzon, } \\
\text { Philippines, 2-9 m (WAM) } \\
\text { Tolo Channel, Hong Kong } \\
\text { Lama Channel, Hong Kong, } 36 \text { m } \\
\text { Honiara, Solomon Ids }\end{array}$ \\
\hline Haustellum & $\begin{array}{l}\text { cabritii } \\
\text { dolichourus } \\
\text { m.multiplicatus } \\
\text { haustellum } \\
\text { messorius }\end{array}$ & $\begin{array}{l}\text { Pta Patuca, Honduras } \\
\text { between Warbal and Ur Id, Kai, } \\
\text { Moluccas, } 68 \text { m (WAM) } \\
\text { W coast Wasir Id, W. Wokam: } \\
\text { Aru, Moluccas, } 55 \text { m (WAM) } \\
\text { Magenta, Noumea, New } \\
\text { Caledonia } \\
\text { Pta Patuca, Honduras }\end{array}$ \\
\hline Hexaplex & $\begin{array}{l}\text { princeps } \\
\text { stainforthi } \\
\text { trunculus }\end{array}$ & $\begin{array}{l}\text { Camarines Sur, Philippines: } \\
\text { Banacon Id, Danajon Bank, NW } \\
\text { Bohol Id. Philippines } \\
\text { Barra de Navidad, Mexico } \\
\text { Dampier, Western Australia } \\
\text { Mediterranean Sea (exact loc. } \\
\text { unknown); Tunis, } \\
\text { Tunisia, in fish market (ZMC) }\end{array}$ \\
\hline Siratus & $\begin{array}{l}\text { cailleti } \\
\text { pliciferoides } \\
\text { beauii }\end{array}$ & $\begin{array}{l}\text { W of Dowling Shoals, Anguilla, } \\
\text { W Indies, } 210 \text { m (USNM) } \\
\text { Balayan Bay, Batangas, } \\
\text { Philippines, } 227 \mathrm{~m} \\
\text { S of Dry Tortugas, Florida }\end{array}$ \\
\hline \multirow[t]{2}{*}{ Chicoreus } & $\begin{array}{l}\text { cornucervi } \\
\text { denudatus } \\
\text { longicornis }\end{array}$ & $\begin{array}{l}\text { Darwin Harbour, Northern } \\
\text { Territory } \\
\text { Fairlight, Sydney, N.S.W. } \\
\text { off Cape Moreton, Queensland } \\
\text { (reconstituted dried specimens) }\end{array}$ \\
\hline & capucinus & $\begin{array}{l}\text { Trobriand Ids, Papua New } \\
\text { Guinea }\end{array}$ \\
\hline
\end{tabular}

Bolinus brandaris Monaco, in fish market (ZMC)

Material from AMS collections unless otherwise stated.

Table 1. Species of Muricinae examined anatomically.

character, the pallial vas deferens. After it leaves the pallial prostate, and passes onto the right side of the 'neck' and then to the base of the penis, it becomes swollen in some species, to form what is often termed an ejaculatory duct. In Murex this part of the duct is muscular and, in several species, partly embedded in the body wall. The lumen of the duct is, in some species, a narrow, undulating tube in the centre of the low, muscular ridge, in others a straight muscular tube. In species of Haustellum it is a prominent tube on the surface and essentially non-muscular. In one species (H. haustellum) the duct is an open groove. In the other species of Haustellum the lumen of the duct is a simple tube that does not undulate and lies on the surface with a mid-dorsal line of fusion clearly visible in some species.

Some species in both genera appear to have either lost the accessory salivary glands, or these are very small and have been overlooked in dissection. The details are not given here because of the uncertainty of the negative observations. There are also differences in details of shape in the penes of various species, which are useful at the species level, but there are no characters peculiar to Murex or Haustellum.

The anatomy of a typical species of Murex, $M$. trapa, is described below. As far as the less detailed observations on the other species of Murex and Haustellum are concerned, they appear to be similar in most details.

Head-foot. The oval foot is attached to a muscular column on which the animal swings back and forth as it sweeps its long anterior siphon across the substrate. The foot has a wide propodial flap along its convex anterior edge. A flask-shaped accessory boring organ about $3 \mathrm{~mm}$ long opens in the mid-line of the anterior sole. The dorsal parts of the head-foot are covered with pale, yellowish brown spots, with a few brown streaks on the anterodorsal foot. The very slender yellowish white tentacles have the tiny eyes at their bases which are, in turn, elongated and tentacle like, being about as long as the tentacles.

Pallial cavity. The pallial edge is thick and muscular and has short papillae that correspond to the spines of the shell. The anterior (inhalent) siphon lies at the extreme left side of the cavity. This long, narrow extension of the pallial cavity contains a rod of muscle continuous with the columellar muscle. The lumen is very narrow in section and the mantle edge has the inner lobes well-developed, presumably to provide some control over water entry along the length of the siphon. These same lobes are expanded to form fleshy barriers at the base of the siphon and serve to channel the incoming water over the osphradium.

The pallial cavity contains a large ctenidium, which extends the length of the cavity. It is much broader anteriorly than posteriorly where the apices of the broadly triangular filaments lie near the middle. Further posteriorly, the ctenidial filaments are narrower and their apices lie on the right side. The bipectinate osphradium, which is slightly less than half the length of the ctenidium, lies opposite the anterior end of the ctenidium at the base of the inhalent siphon. It is not quite twice as wide as it is long and the posterior part is considerably narrower than the anterior. A conspicuous hypobranchial gland lies on the pallial roof and secretes a fluid that turns purple when exposed to the air. 
The pallial gonoduct and rectum lie along the right side of the cavity. The gonoduct is conspicuous and occupies much of the length of the right side in both sexes. A black anal gland is easily visible externally as a long strip along the rectum.

The cephalic cavity is filled with the anterior alimentary canal. The unusually short, retracted proboscis (Fig. 2,p) is contained within its sheath and is about $4-5 \mathrm{~mm}$ long in the adult, being about as wide as it is long. The pair of salivary glands (Fig. 2,sg) lie around the posterior part of the proboscis sheath and the buccal mass which protrudes from the sheath, although the majority of these glands lie beneath the posterior end of the proboscis. They are large, yellowish white, rather loosely compacted sheets. Their ducts are short and narrow, entering the wall of the anterior oesophagus immediately in front of the valve of Leiblein (Fig. 2,vl). The accessory salivary glands (Fig. 2,as) are short, blind tubes with swollen distal ends that lie loosely attached to the posteroventral end of the buccal mass. These glands are overlain by, but not embedded in, the anterior part of the salivary glands.

The buccal mass (Fig. 2,bm) fills the retracted proboscis and protrudes behind it. It is $7-8 \mathrm{~mm}$ long and is about half that width. The radular sac and the anterior oesophagus can be seen on the exposed dorsal surface of the posterior part of the buccal mass.

The unusually short (about $2 \mathrm{~mm}$ in length) anterior oesophagus (Fig. 2,ao) passes ventrally around the posterior end of the buccal mass and contains within its lateral walls the salivary ducts. The valve of Leiblein lies just below the posterior part of the buccal mass and immediately in front of the nerve ring. In species with a longer proboscis, the valve of Leiblein (Fig. 2,vl) is usually located in the same position relative to the nerve ring and, consequently, lies well in front of the posterior end of the proboscis. This has the added effect of requiring a longer anterior and posterior oesophagus, and the salivary glands, being tied to the position of the valve of Leiblein because of their short ducts, may lie completely beneath the proboscis. The valve of Leiblein is about $2.5 \mathrm{~mm}$ in length, being larger than in some species. The short mid-oesophagus has translucent orange-brown (in formalin-fixed material) massive glandular walls that make it about as long as it is wide. The short duct to the gland of Leiblein contains this same glandular tissue.

The gland of Leiblein (Fig. 2,gl) is very large and abuts the posterior end of the proboscis sheath. A short anterior section of the gland is wide, occupying the whole width of the haemocoel. The rest of the gland is a narrow rod of glandular tissue that extends to the posterior end of the haemocoel. A narrow, nonglandular appendage with a swollen end is attached to the posterior end of the gland of Leiblein and lies within the main blood sinus behind the cephalic haemocoel.

The narrow posterior oesophagus lies beneath the

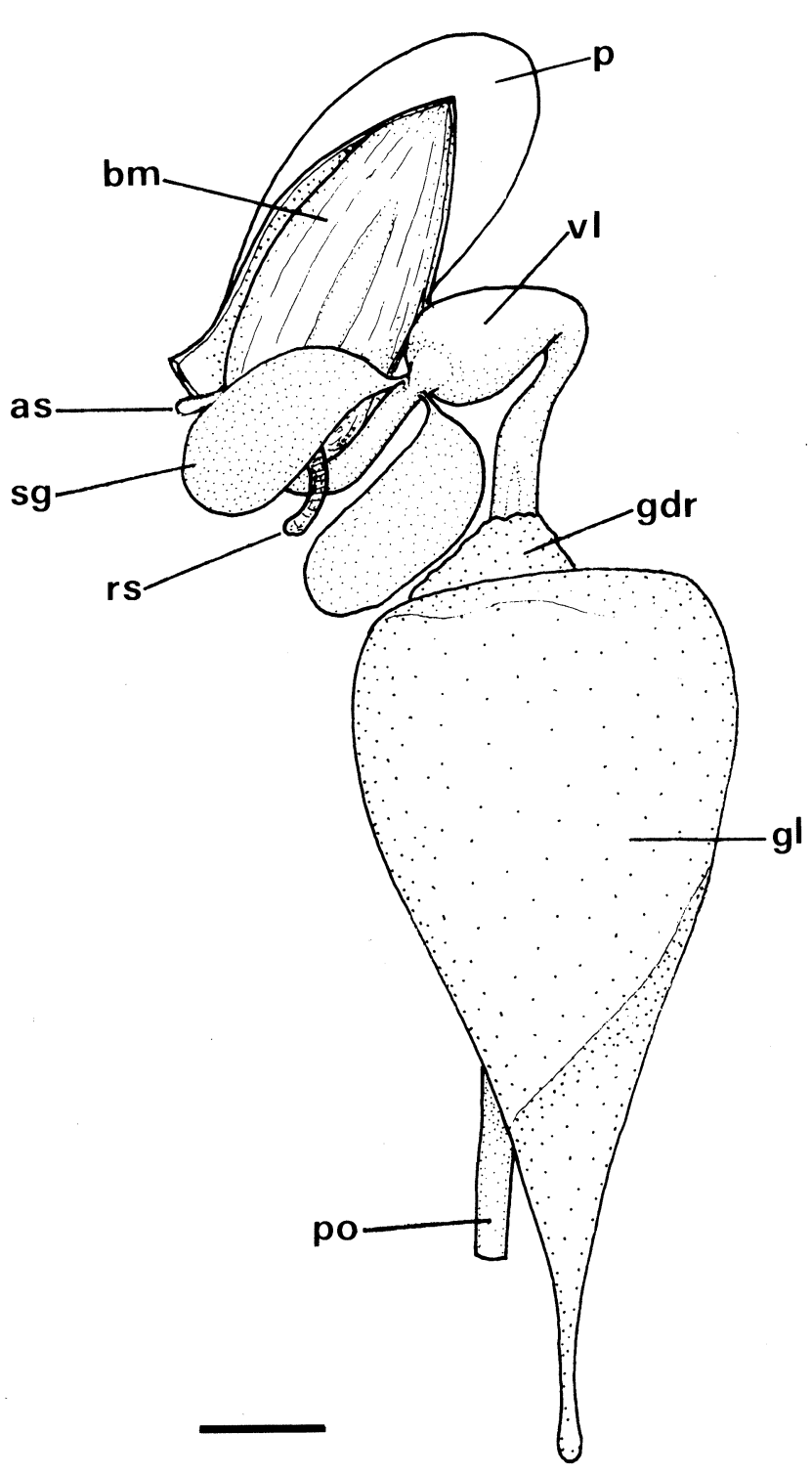

Figure 2. Dorsal view of anterior alimentary canal of Murex trapa Röding. as - left accessory salivary gland (right not shown); bm buccal mass; $\mathbf{g d r}$ - glandular dorsal ridges of mid-oesophagus; $\mathbf{g l ~ - ~}$ gland of Leiblein; p - proboscis; po - posterior oesophagus; rs radular sac; sg - salivary gland; vl - valve of Leiblein. Scale 2 $\mathrm{mm}$.

gland of Leiblein. It enters the stomach after passing over the massive anterior lobe of the digestive gland. The distance from the posterior end of the cephalic cavity to the stomach is about $11 \mathrm{~mm}$. The small stomach is U-shaped, simple and generally similar to that described by Smith (1967) for Trophon truncatus, although it differs in minor details. It has a short, broad posterior caecum with a smooth floor and a ridged roof. The single, large digestive gland opening lies near the anterior edge of the stomach, between the two arms of the $U$, and the intestine opens at its right anterior edge. The posterior edge of the digestive gland opening is bordered by a fold that passes into the narrow oesophageal opening. 
Reproductive systems. The male has a pallial prostate gland, which opens posteriorly to the pallial cavity by way of a short, narrow slit. The gland tapers anteriorly to a narrow tube, the pallial vas deferens. This tube runs for a short distance anteriorly along the junction of the pallial roof and the neck and then passes up onto the neck. It is a narrow, undulating muscular tube, which enters the base of the penis (Fig. 3 ). The penis is a blade-like structure lying on the right side of the head, consisting of a broad basal portion and a narrow, distal filament.

The female reproductive system is dominated by a massive pallial glandular oviduct. The majority of this gland is the anterior capsule gland, which is circular in section and has a narrow, slit-like lumen. The capsule gland opens anteriorly to a narrow, muscular vagina that is about one-fifth the length of the pallial oviduct. Posteriorly the small albumen gland is attached to the capsule gland and abuts against the kidney. The brown ingesting gland lies on the right side of the posterior part of the oviduct glands at the junction of the capsule and albumen glands.

Renal system. The kidney is of the pycnonéphridien type, which is typical of the Muricidae, and empties into the posterior end of the pallial cavity through a small renal opening.

The nervous system and circulatory systems were not examined.

\section{Comparison with Related Genera}

Examination of the anatomy of species of other muricine genera (Table 1) was restricted to the characters of the head-foot, pallial cavity, the anterior alimentary canal and the terminal male genitalia. The results are summarised in Table 2.

If the phylogeny of the Muricinae proposed by Vokes $(1971 \mathrm{~b})$ is in essence correct, then the characters seen in Paziella and Hexaplex might be regarded as primitive. Thus, the common ancestor to Murex and Haustellum would have a long radular sac, the pallial vas deferens would be an open groove on the surface of the neck, and the anterior siphon would be short. There does not appear to have been any significant modification of the anterior gut with the exception of the reduction in importance of the accessory salivary glands and their possible disappearance in some species of Murex and Haustellum. The relative size of the $\mathrm{ABO}$ appears to be smaller in those genera with a short radular sac and small (or absent?) accessory salivary glands. These character states may be correlated with the reduction or cessation of shell drilling.

The shells of species of Siratus appear to be very similar to those of species of Haustellum, differing only in the shorter, curved anterior canal. These similarities are reflected in their almost identical anatomy. Murex differs from both of these genera in having a muscular pallial vas deferens and this is also

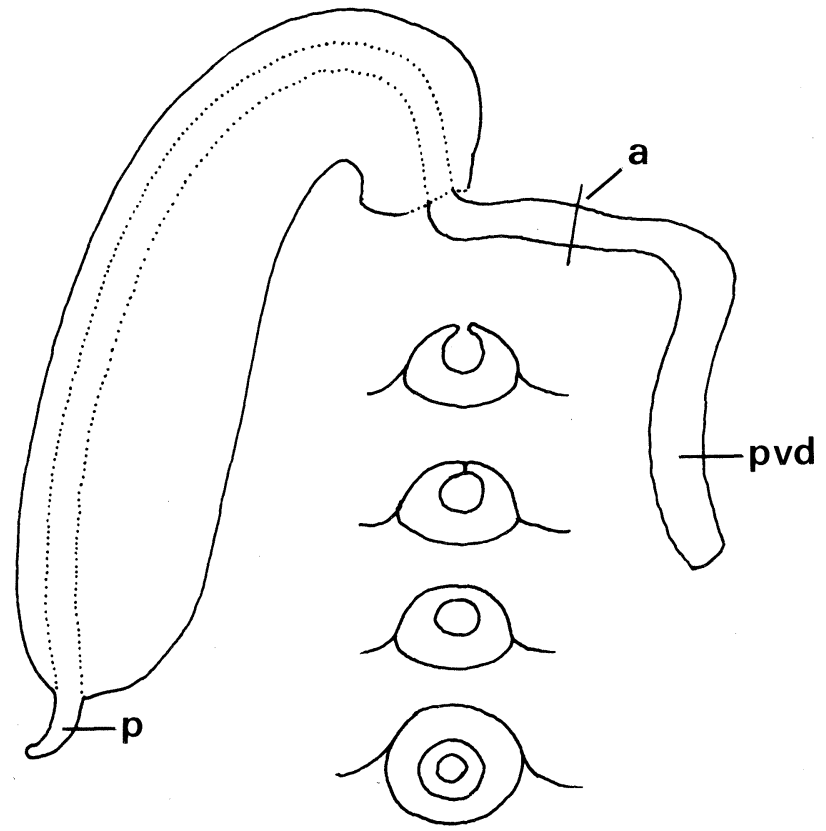

Figure 3. Diagrammatic representation of a penis and parts of the pallial vas deferens of a species of Murex or Haustellum. The line ' $a$ ' marks the position of the representative transverse sections shown in the figure. These show a progressive series from an open vas deferens to a closed, muscular vas deferens. p - papilla; pvd pallial vas deferens.

seen in some species of Chicoreus (e.g., C. denudatus). The pallial vas deferens varies between an open groove and a fused, non-muscular tube in Haustellum and Siratus, as well as in Chicoreus. The overall impression is, however, that as far as the anterior gut, pallial cavity, and male genitalia are concerned, very few anatomical differences can be found between the genera investigated.

\section{GEOLOGICAL HISTORY}

The earliest known record of the subfamily Muricinae (sensu stricto) is a species referable to Paziella in the Late Cretaceous of Europe: Murex armatus Geinitz, 1875, from the Cenomanian of Saxony. Three closely related genera are present in the Paleocene - Poirieria, Paziella and Pterynotus. All three genera are presumed to have world-wide distributions in the early Tertiary, but this is not well documented. These three ancestral forms have continued through the last 70 million years without noticable change, modern species being almost indistinguishable from their Paleocene ancestors.

The genus Hexaplex probably was derived from a Paziella-like ancestor. There is at least one species attributable to Hexaplex in the Paleocene - Murex diderrichi Vincent, 1913, from the Congo. By the Eocene the group had a world-wide distribution but did not undergo a major radiation until the Neogene, 
Cephalic tentacles

(1) short and broad

(2) long and slender

Anterior siphon

(1) long and straight

(2) short and curved

(3) long and curved

Radular sac behind B.M.

(1) longer than buccal mass

(2) about equal in length

to buccal mass

(3) shorter than buccal mass

(4) does not extend behind buccal mass

Vas deferens

(1) an open groove

(2) a simple tube

(3) a muscular tube

Penis

(1) with filament

(1a) filament very short

(1b) filament very long

(about as long as base)

(1c) filament intermediate

between $1 \mathrm{a}$ and $1 \mathrm{c}$

(2) parallel sided with no

filament

Accessory salivary glands

(1) small and adjacent to

salivary glands

(2) small and embedded in salivary glands

Shell varices

(1) more than 3 per whorl

(2) three per whorl

Labral tooth

(1) absent

(2) present

Lateral radular teeth

(1) bases overlap

(2) bases separated

\begin{tabular}{|c|c|c|c|c|c|c|c|}
\hline 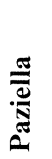 & & $\stackrel{\mathscr{B}}{.}$ & 茪 & 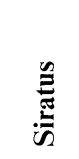 & 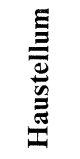 & 总 & \\
\hline 2 & 1 & 1 & 1 & 2 & 2 & 2 & 2 \\
\hline 2 & 2 & 1,3 & 3 & $2-3$ & 1,3 & 1,3 & 1,3 \\
\hline $3 ?$ & $1-3$ & 3 & 1 & 4 & 3 & 3 & 3 \\
\hline$?$ & $1-2$ & 1 & 3 & 1 & $1-2$ & 3 & 3 \\
\hline $1 \mathrm{a}$ ? & $1 \mathrm{c}$ & 2 & $1 \mathrm{c}$ & 2 & $1-2$ & $1-2$ & $1 b$ \\
\hline
\end{tabular}

Table 2. Comparison of some anatomical, shell and radular characters between some genera of Muricinae. Data on Paziella from Harasewych (1984).

by which time Paziella, Poirieria and Pterynotus, which dominated the Paleogene, had all dwindled in importance.

Evidence for the derivation of Hexaplex from a Paziella-like ancestor includes the similarity of their protoconchs, radulae, and the development of the ornamentation of the teleoconch. The teleoconch ornamentation begins with about nine small, angulate ribs on the first postnuclear whorl, of which every third is soon strengthened to become a varix. The two genera differ in that Paziella is smooth between the varices and Hexaplex, from the first whorl, has spiral ornamentation. This feature, combined with frequently strong axial growth lines, gives the shell of Hexaplex a completely different appearance from that of the relatively smooth
Paziella. In other features the shell morphology is similar. Among the living species of Hexaplex a colour pattern of brown spiral bands is almost universal, whereas the other genera mentioned above are essentially monochromatic.

The ancestral Hexaplex morphotype is still represented by the Mediterranean species $H$. trunculus (Linné) but the lineage has undergone a major radiation, the descendants of the Hexaplex line being the most numerous of all the Muricidae. One of these descendants is the genus Murex. The similarities in the radula, protoconch morphology and early teleoconch development certainly suggest this, but the fossil evidence is lacking. One of the earlier species groups that is similar to Murex (s.s.) is the Murex spinicosta Bronn, 1828, complex from 


\begin{tabular}{|c|c|c|c|c|c|}
\hline Figure & $\begin{array}{l}\text { Linné } \\
\mathbf{1 7 5 8}\end{array}$ & $\begin{array}{l}\text { Gmelin } \\
1790\end{array}$ & $\begin{array}{l}\text { Röding } \\
1798\end{array}$ & $\begin{array}{l}\text { Lamarck } \\
1822\end{array}$ & Present \\
\hline $\begin{array}{l}\text { Colonna } \\
\text { pl.60:6 }\end{array}$ & tribulus & $\begin{array}{l}\text { tribulus } \\
\text { form a }\end{array}$ & $\begin{array}{l}\text { trapa or } \\
\text { forskoehlii }\end{array}$ & - & forskoehlii \\
\hline $\begin{array}{l}\text { Olearius } \\
\text { pl.39:1 }\end{array}$ & tribulus & $\begin{array}{l}\text { tribulus } \\
\text { form a }\end{array}$ & $\begin{array}{l}\text { trapa or } \\
\text { forskoehlii }\end{array}$ & - & pecten \\
\hline $\begin{array}{l}\text { Lister } \\
\text { pl.902:22 }\end{array}$ & tribulus & $\begin{array}{l}\text { tribulus } \\
\text { form a }\end{array}$ & $\begin{array}{l}\text { trapa or } \\
\text { forskoehlii }\end{array}$ & crassispina & tribulus \\
\hline $\begin{array}{l}\text { Buonanni } \\
\text { fig. } 269\end{array}$ & tribulus & $\begin{array}{l}\text { tribulus } \\
\text { form a }\end{array}$ & $\begin{array}{l}\text { trapa or } \\
\text { forskoehlii }\end{array}$ & crassispina & pecten \\
\hline $\begin{array}{l}\text { Rumphius } \\
\text { pl.26:G }\end{array}$ & $\begin{array}{l}\text { tribulus } \\
\text { (noble v.) }\end{array}$ & $\begin{array}{l}\text { tribulus } \\
\text { form a }\end{array}$ & $\begin{array}{l}\text { trapa or } \\
\text { forskoehlii }\end{array}$ & crassispina & tribulus \\
\hline pl.26:3 & $\begin{array}{l}\text { tribulus } \\
\text { (noble v.) }\end{array}$ & $\begin{array}{l}\text { tribulus } \\
\text { form } b\end{array}$ & $\begin{array}{l}\text { tribulus or } \\
\text { forskoehlii }\end{array}$ & tenuispina & pecten \\
\hline $\begin{array}{l}\text { Gualtieri } \\
\text { pl.31:A(1-3) }\end{array}$ & $\begin{array}{l}\text { tribulus } \\
\text { (noble v.) }\end{array}$ & $\begin{array}{l}\text { tribulus } \\
\text { form a }\end{array}$ & $\begin{array}{l}\text { trapa or } \\
\text { forskoehlii }\end{array}$ & crassispina & $\begin{array}{l}\text { forskoehlii } \\
\text { tribulus }\end{array}$ \\
\hline pl.31:B(=A4) & $\begin{array}{l}\text { tribulus } \\
\text { (noble v.) }\end{array}$ & $\begin{array}{l}\text { tribulus } \\
\text { form } b\end{array}$ & $\begin{array}{l}\text { tribulus or } \\
\text { forskoehlii }\end{array}$ & tenuispina & pecten \\
\hline $\begin{array}{l}\text { Argenville } \\
\text { pl.19:A }\end{array}$ & $\begin{array}{l}\text { tribulus } \\
\text { (noble v.) }\end{array}$ & $\begin{array}{l}\text { tribulus } \\
\text { form a }\end{array}$ & tribulus & tenuispina & pecten \\
\hline $\begin{array}{l}\text { Martini } \\
\text { pl.113:1052 }\end{array}$ & - & $\begin{array}{l}\text { tribulus } \\
\text { form a }\end{array}$ & tribulus & crassispina & scolopax \\
\hline $\begin{array}{l}\text { pl.113:1053 } \\
\& 1054\end{array}$ & - & $\begin{array}{l}\text { tribulus } \\
\text { form a }\end{array}$ & tribulus & crassispina & ?tribulus \\
\hline pl.113:1055 & - & tribulus & trapa & - & carbonnieri \\
\hline pl.113:1056 & & $\begin{array}{l}\text { tribulus } \\
\text { form a }\end{array}$ & trapa & rarispina & trapa \\
\hline $\begin{array}{l}\text { Seba } \\
\text { pl.78:4 }\end{array}$ & - & $\begin{array}{l}\text { tribulus } \\
\text { form a }\end{array}$ & $\begin{array}{l}\text { tribulus or } \\
\text { forskoehlii }\end{array}$ & crassispina & spicatus \\
\hline pl.78:1-3 & - & $\begin{array}{l}\text { tribulus } \\
\text { form } b\end{array}$ & $\begin{array}{l}\text { tribulus or } \\
\text { forshoehlii }\end{array}$ & tenuispina & pecten \\
\hline $\begin{array}{l}\text { Knorr } \\
\text { pl.11:3.4 }\end{array}$ & - & $\begin{array}{l}\text { tribulus } \\
\text { form } b\end{array}$ & $\begin{array}{l}\text { tribulus or } \\
\text { forskoehlii }\end{array}$ & crassispina & ?tribulus \\
\hline pl.27:1 & - & $\begin{array}{l}\text { tribulus } \\
\text { form } b\end{array}$ & $\begin{array}{l}\text { tribulus or } \\
\text { forskoehlii }\end{array}$ & tenuispina & pecten \\
\hline $\begin{array}{l}\text { Chemnitz } \\
\text { pl.189:1819,1820 }\end{array}$ & - & - & - & crassispina & scolopax \\
\hline $\begin{array}{l}\text { pl.189:1821 } \\
\& 190: 1822\end{array}$ & - & - & - & tenuispina & pecten \\
\hline $\begin{array}{l}\text { Favanne } \\
\text { pl.38:A }\end{array}$ & - & - & - & tenuispina & pecten \\
\hline
\end{tabular}

Table 3. Interpretations of some early figures of Murex.

Europe, which ranges from Middle Miocene to Pliocene. It has a five-whorled conical protoconch, nine small spinose varices on the first teleoconch whorl, and the appearance of the teleoconch closely resembles that of $M$. macgillivrayi Dorhn. The species in this group lack a labral tooth and it appears that they may be an offshoot from an early Murex stock. Another possibility is that they are convergent with Murex and Haustellum, perhaps evolving independently from Hexaplex. A new subgenus of Murex is proposed for this group elsewhere in this monograph. There are two Oligocene taxa described from Hungary, M. guembeli Dreger, 1892, and $M$. guembeli longispina Noszky, 1940, which, from their descriptions and figures, are similar to Murex but both are based on incomplete external moulds, neither of which have the spire preserved. They may be forerunners of the $M$. spinicosta group.

There is insufficient data to indicate where Murex (s.s.) first evolved. Typical species of Murex are first known from the Early Miocene of Japan (Uozumi \& Fujie, 1966) and eastern Africa (Cox, 1927), and the Miocene of India, Japan and Java. By the Pliocene there were several species similar to living species in the Indo-Pacific region and it is probable that the group evolved in the Indo-Pacific in the early Tertiary. Strongest evidence for the supposition that Murex evolved in the Indo-Pacific region is the fact that the genus is represented in the New World by only one Recent species (Murex surinamensis Okutani, 1982; see Fig. 4), whereas nearly every other muricine group in the European fossil record is well 


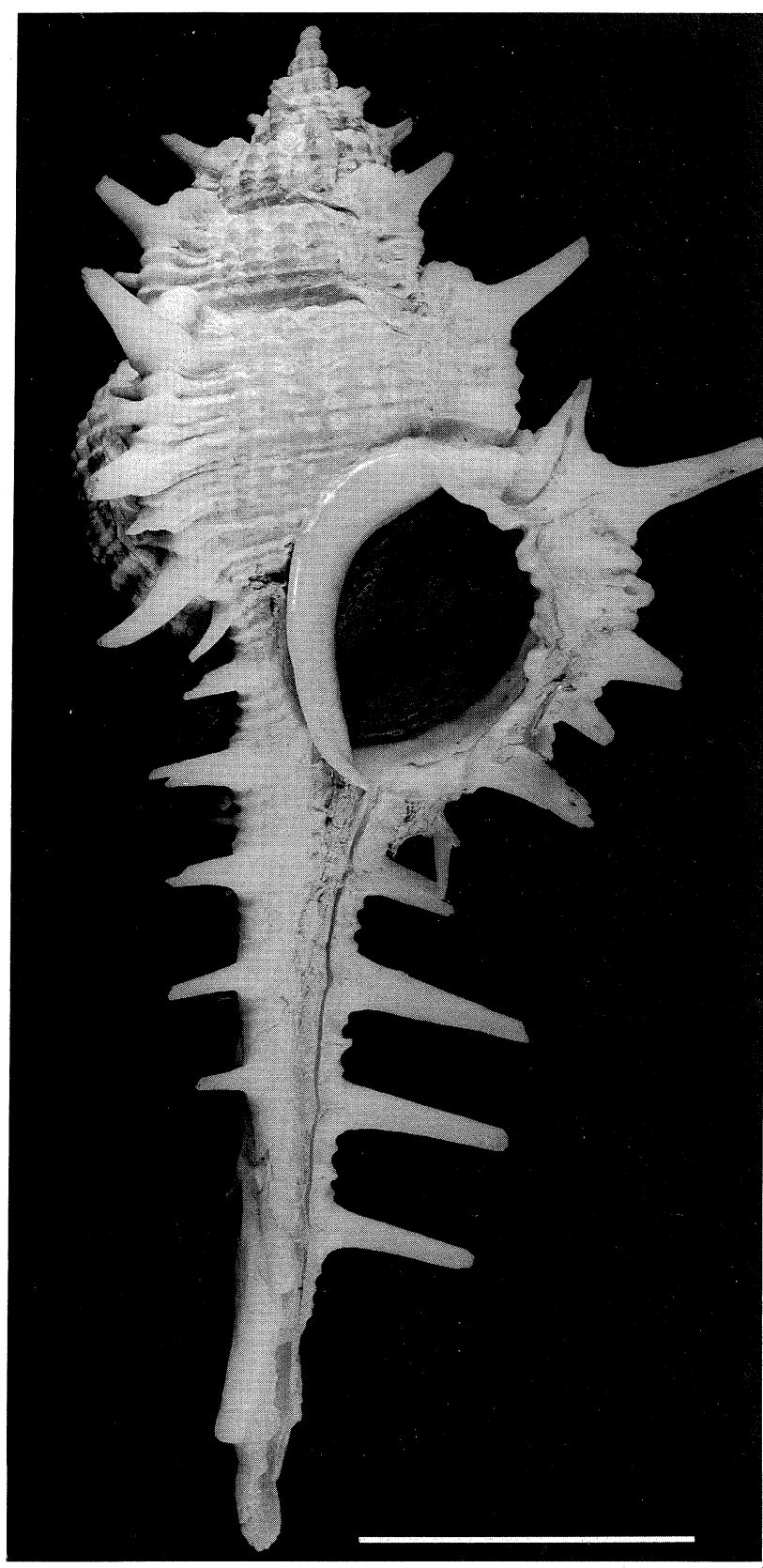

Figure 4. Murex surinamensis Okutani. Holotype; off Surinam, $10^{\circ} 46^{\prime} \mathrm{N} 61^{\circ} 32^{\prime} \mathrm{W}, 94 \mathrm{~m}$ (NSMT, Mo 60021). Scale $2 \mathrm{~cm}$.

established there.

In the Early Miocene of Europe, another species appeared that is readily separable from Hexaplex. It commences with Murex partschi Hörnes, 1853, which has a four-whorled protoconch and ten to twelve small axial nodes on the first teleoconch whorl. On about the fourth or fifth teleoconch whorl every third node develops into a varix, there being four per whorl. These varices each bear two spines, in contrast to the three major spines seen in Murex (s.s). This lineage is separated as the genus Bolinus, which reached its maximum development in the Pliocene of the Mediterranean and today is represented there by $M$. brandaris Linné. Only one species, the west African $M$. cornutus Linné, migrated outside the Mediterranean.

Another branch of the Hexaplex lineage appears to have developed separately in the New World, beginning with species of Phyllonotus in the Eocene. Three lineages evolved from these early Phyllonotus: Phyllonotus s.s., Chicoreus and Siratus.

From Siratus, somewhat prior to the Early Miocene, another lineage may have given rise to a group of species that closely mimic species of Murex (s.s.) and have, indeed, been classified with that genus until this revision.

The first appearance of this Murex-like group is with Murex messorius Sowerby, 1841, in the Early Miocene Baitoa Formation of the Dominican Republic. This species has a paucispiral protoconch, whereas some Recent Indo-Pacific species, which we believe to be closely related, have a multispiral protoconch. This suggests that the group must have evolved from Siratus well before the appearance of $M$. messorius. Unfortunately, there is little fossil evidence available from the Oligocene due to the greatly restricted area of the seas during this period.

Characteristic of this group is an almost nonspinose shell with an aperture bearing several strong rugae on the inner lip, and a colour pattern (seen in the fossils with the aid of ultra-violet light) of broad spiral bands. The early teleoconch ornamentation consists of about twelve axial ribs, every fourth becoming a varix, crossed by spiral cords. The only significant difference between $M$. messorius and typical species of Siratus is the presence of a straight siphonal canal, with the terminations of former canals fused into a tube, in the manner of Murex (s.s.).

Species referable to Murex differ from the Siratus derivative look-alikes in having a more spinose shell; the labium is non-rugose internally, there is a more or less well developed labral tooth on the outer edge of the outer lip, and an essentially monochromatic colour pattern (cream or tan with, at most, brown lines on the spiral cords). The early teleoconch ornamentation is usually of nine small, spinose varices.

A group of Indo-Pacific species, including the type species of Haustellum, M. haustellum Linné, 1758, may have been derived from the New World Siratus group, possibly via Tertiary islands, providing stepping stones for pelagic larvae to bridge the gap between the eastern and western Pacific. There is no evidence, however, apart from morphological similarity, to suggest this. In fact, all the present distribution and fossil evidence points to an origin with the central Indo-West Pacific region (see Discussion). It is conceivable that the Indo-Pacific and New World species originated independantly from local species of Siratus (there are several IndoPacific species, although the rather poor fossil record in the area does not provide an early fossil record of 
the group) or that the whole group was derived from an Indo-Pacific species that migrated to the Americas. Another possibility is that the Indo-Pacific species may be polyphyletic, with one or more origins from Siratus, or from another genus such as Chicomurex and other species that have a Pacific derivation. Because we have no evidence to support either hypothesis we adopt the simpler of the two alternatives and regard all of the Murex-like species similar to Siratus, as belonging to Haustellum. Although the type species of Haustellum is rather unlike the New World species there are several IndoPacific species that are very similar to them and others that are intermediate in form.

Thus, in the Indo-Pacific region, there are at least two independently derived groups of species that have usually been referred to Murex. Both are presumably derived from Hexaplex, but from different lineages within this radiation. This is at variance to the earlier interpretation of the evolution of this group by Vokes (1971b) in which Bolinus, Murex and Haustellum were regarded as a monophyletic radiation. The convergence between these three groups is considerable. Some species of the Siratus group, in particular the western Atlantic M. cabritii Bernardi, 1859, have lost all traces of the brown stripes as well as all but a single anal denticle in the posterior corner of the aperture. Increased spination, including along the anterior canal, has led to shells virtually identical to those typical of Murex s.s. Similar development of the spines in species of Siratus, such as $S$. articulatus (Reeve, 1845), has also resulted in species closely resembling those in Murex s.s., these being. distinguished by their deflected canal, and, in some species at least, by their rugose aperture and colour pattern. The situation is further complicated by some species of Murex having reduced spines. There is also more variation in the number of axial ribs on the early teleoconch whorls amongst the living species of both groups, than amongst the fossil ones.

The fossil history of species of Murex and Haustellum is summarised in the Discussion and in Tables 55 and 56.

\section{TAXONOMY}

\section{Family MURICIDAE}

Neogastropods with varicate shells, radula consisting of a central tooth and a pair of hook-like marginal teeth in each row. An anal gland, a pedal accessory boring organ, accessory salivary glands and a large, triangular gland of Leiblein usually present.

\section{Subfamily MURICINAE}

Muricids with aragonitic shell, operculum with nucleus terminal, subterminal or (rarely) subcentrally located. Central teeth of radula with three large and two small intermediate cusps.

\section{Genus Murex Linné, 1758: 746}

Type species: Murex tribulus Linné, 1758. Recent, IndoPacific. Subsequent designation Montfort, 1810 as Murex pecten Montfort, 1810 with Murex tribulus Linné and Gmelin sp. 2 cited.

Aranea Perry, 1810: pl. 47.Type species: Aranea gracilis Perry, 1810 (= Murex pecten Lightfoot), monotypy.

Tribulus Kobelt, 1877: 144. Type species: Murex tribulus Linné, by tautonymy.

Acupurpura Jousseaume, 1880: 335. Type species: Murex tenuispina Lamarck, originaldesignation.

Tubicauda Jousseaume, 1880: 335.Type species: Murex brevispina Lamarck, original designation.

Diagnosis. Small to relatively large trivaricate shells (50-200 $\mathrm{mm}$ in length), with extremely long siphonal canal, usually as long or longer than length of spire + aperture. Siphonal canal consisting of terminations of previous canals fused into an almost closed tube. Usually nine angulate or rounded ribs on early teleoconch whorls, of which every third is strengthened into a varix leaving, initially, two intervarical nodes. Ornamentation on varices of simple, non-ramose spines. Outer lip of aperture with labral tooth in all species except those in subgenus Promurex. Inner lip usually rather narrow and always smooth. Operculum with terminal to subcentral nucleus, growth lines simple to lamellate. Radula with central teeth having three simple, primary cusps, central longest, with two short intermediate cusps between. No accessory denticles developed. Marginal teeth with expanded, overlapping bases. Ejaculatory duct closed, muscular, usually partly embedded in body wall. Radular sac markedly shorter than buccal mass. Accessory salivary glands very small, possibly absent in some species.

Remarks. The only two genera that closely resemble Murex are Haustellum, which is described below, and Bolinus Pusch, 1837, which has 5-7 varices and no labral tooth. This latter genus appears to be closely related to Hexaplex, its similarity with Murex being only superficial because of the long siphonal canal.

Vokes (1964) and Radwin \& D'Attilio (1976) cite Montfort (1810) as designating the type species of Murex. Cernohorsky (1967a) has argued that this designation, which cites $M$. pecten Montfort as the type species, is invalid. Vokes (1970) has shown that the designation can be accepted on the basis of ICZN Code Article 69a-iv.

We divide the genus Murex into two subgenera, all but one Recent species falling into Murex s.s.

\section{Subgenus Murex s.s.}

Diagnosis. Shell: as for generic diagnosis except labral tooth always present and protoconch of one and one-half to three whorls. Operculum with subcentral to subterminal nucleus. 
Remarks. Genus-group taxa have been proposed for M. pecten and M. brevispina but there does not appear to be any justification for separating these. The group of species around $M$. pecten are characterised by long spines and a foliate operculum with a subcentral nucleus. Long spines are also found in other species of Murex, and the derivation of an operculum with a subcentral nucleus from one with a subterminal nucleus is a simple step which, by itself, appears to be an inadequate reason for recognizing a subgenus.

Murex brevispina differs from most other species of Murex only in its short spines and almost spineless canal. These two characters appear to be correlated and are found in $M$. trapa, for example, which is intermediate between $M$. brevispina and more typical species of Murex in spine development. These differences are not sufficiently clear-cut to warrant the recognition of a subgenus based on M. brevispina.

\section{Subgenus Promurex n. subgen.}

Type species: Murex antelmei Viader, 1938; Recent, Mauritius.

Diagnosis. Similar to Murex s.s., but differing mainly in lacking a labral tooth on the outer lip of the aperture, and in not developing secondary spines, except on the basal part of each varix on the body whorl. Protoconch conical, of three to five very weakly convex volutions. Teleoconch with eight to nine, sometimes up to 12 , axial ribs on first whorl; typically every third strengthening to form a varix on second whorl. Three varices per whorl, each bearing three closed spines on body whorl, each spine at about $45^{\circ}$ to adjacent spine; shoulder and basal spines at about $45^{\circ}$ to vertical axis; basal spines sometimes reduced or absent. Spiral ornament of numerous, narrow threads crossed by lamellate axial growth lines. Aperture typically with smooth inner and outer lips (a few weak denticles developed on both lips in some specimens of $M$. spinicosta), with raised outer edges; anal notch small. Siphonal canal long, tubular, usually slightly curved, closed except for very narrow slit, with a few short spines adjacent to base of body whorl. Operculum with terminal nucleus, growth ridges simple. Radula as for Murex s.s. Anatomy very similar to Murex s.s.; penis with long filament a little shorter than body of penis; pallial vas deferens a closed tube, that part adjacent to penis thickened and muscular, remainder thin-walled. Radular sac short, about one third length of buccal mass. Accessory salivary glands not found but condition of material very poor.

Remarks. The relationships of the species included in the new subgenus are judged to be with Murex and we interpret it as an early offshoot of the ancestral Murex lineage. It is possible, however, that the species included here in Promurex are convergent with Murex and may have been independently derived. The lack of a labral tooth suggests affinity with Haustellum but the long spines, muscular vas deferens and the broad bases on the lateral teeth of the radula suggest a relationship with Murex.

There is some similarity between species of Promurex and some species of Chicoreus, particularly C. longicornis (Dunker, 1864). That species, however, differs from $M$. (P.) antelmei, in having a long radular sac (about equal to the length of the buccal mass), and the lateral teeth of the radula are widely separated and have narrow bases (Fig. 69D); both characters being typical of Chicoreus. The shell of $C$. longicornis differs in having a shorter siphonal canal, only two primary spines on the varices of the body whorl, 12-15 axials on the first teleoconch whorl and a protoconch of one and one-half whorls.

This small group of species is widely scattered, being represented in the mid-Miocene to Pliocene of Europe (M. spinicosta Bronn), probably in the Pliocene of Japan (M. bullocki Yokoyama) and the type species is found at Mauritius. A planktonic larval stage is indicated in at least two of these species by the multispiral protoconch (the protoconch of the Japanese species is unknown). Why the Recent species is not more widely dispersed is unknown.

The type species is the only Recent species in this subgenus and is not included in the following key.

The convention of bracketing the subgeneric name is not followed here in the case of the typical subgenus.

\section{Key to the Indo-West Pacific Recent Species of Murex (Murex)}

In the following key all characters, unless otherwise stated, are shell characters.

1. Half to more than half of anterior canal with several (4 or more) to many long spines; secondary spines usually developed on canal. $\ldots \ldots \ldots \ldots \ldots \ldots \ldots \ldots \ldots \ldots$

A few (0-4) short spines restricted to posterior half of anterior canal; no

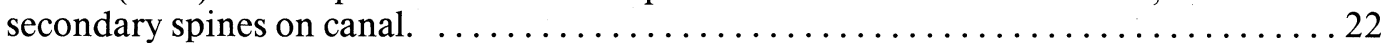

2. Outer lip with fused slits and shallow notches at bases of spines on labral varix,

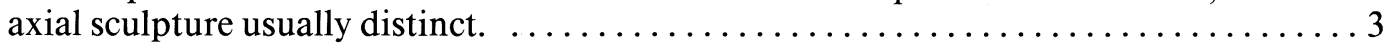

-Outer lip with slits opening to bases of spines on labral varix, or slightly fused with deep notches; secondary axial sculpture usually weak or absent. 
3. Operculum with subterminal nucleus, sculptured with simple concentric ridges.

(M. tribulus species group).

Operculum with subcentral nucleus and sculptured with raised concentric ribs,

foliated in some species. (M. pecten species group) . . . . . . . . . . . . . . . 13

4. Protoconch conical, with $1 \frac{1}{2}-31 \frac{1}{2}$ straight-sided whorls. . . . . . . . . . . . . . 24

Protoconch with $1 \frac{1 / 2}{2}-2^{1 / 2}$ rounded, non-keeled whorls. . . . . . . . . . . . . . 9

5. Teleoconch with weak or absent shoulder and weak to absent intervarical ribs. . . . . 6

Teleoconch with very distinct shoulder and 2 strong intervarical nodes. . . M. coppingeri

6. Teleoconch without brown spiral lines or rows of dots. $\ldots \ldots \ldots \ldots \ldots \ldots \ldots \ldots$

Teleoconch with brown spiral lines or rows of dots. $\ldots \ldots \ldots \ldots \ldots \ldots \ldots \ldots$

7. First teleoconch whorl with $6-7$ angulate ribs. ..................... tribulus

First teleoconch whorl with about 9 rounded ribs. ......... tenuirostrum tenuirostrum

8. Suture deeply impressed. .......................................

Suture simple. ...................................................

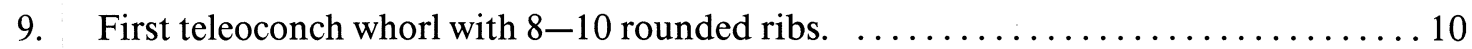

First teleoconch whorl with $12-14$ rounded ribs. ................ falsitribulus

10. Siphonal canal usually flexed in anterior half; intervarical axial ornamentation very weak or absent. $\ldots \ldots \ldots \ldots \ldots \ldots \ldots \ldots \ldots \ldots \ldots \ldots \ldots$. forskoehlii

Siphonal canal usually straight in anterior half; intervarical axial

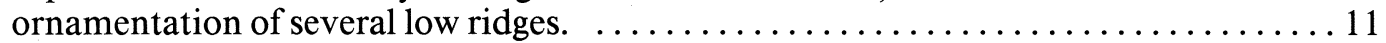

11. Suture channelled; protoconch of less than 2 whorls. $\ldots \ldots \ldots \ldots \ldots \ldots \ldots \ldots \ldots \ldots \ldots \ldots$

Suture not channelled; protoconch of $2-2^{1 / 4}$ whorls. ........ tenuirostrum africanus

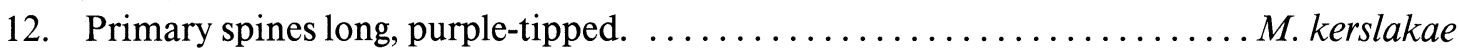

Primary spines short to moderate, without dark tips. ............... aduncospinosus

13. Double row of spines on siphonal canal (i.e., primary spines at right angles to secondary spines).

Without double row of spines on siphonal canal.

M. ternispina

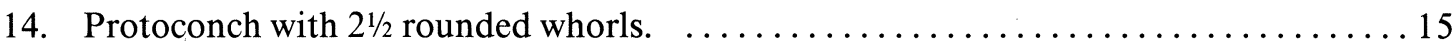

Protoconch with $1 \frac{1 / 2}{2}$ rounded whorls. ................................. spectis

15. Shoulder spines directed apically. ................................ 16

Shoulder spines at right angles to longitudinal shell axis. ........... queenslandicus

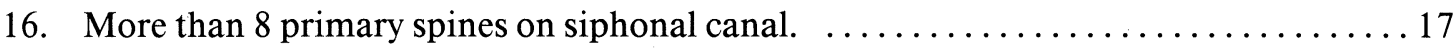

With 6-7 primary spines on siphonal canal.

M. spicatus

17. Protoconch of $2-2^{1 / 2}$ flat whorls and small initial whorl.

M. pecten pecten Protoconch of $2-2 \frac{1 / 4}{4}$ convex whorls and bulbous initial whorl.

.M. pecten soelae

18. Protoconch of $2 \frac{1 / 2}{2}$ whorls.

Protoconch of $1 \frac{1 / 2}{2}$ whorls.

M. altispira

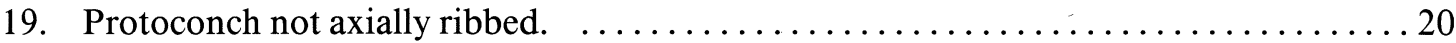

Protoconch axially ribbed.

M. djarianensis poppei

20. Teleoconch surface smooth (except for spiral cords).

Teleoconch surface rough.

M. acanthostephes 
21. Spines short, strongly recurved; spiral cords inconspicuous; two prominent intervarical axial nodules. .................................. occa

Spines short or long, nearly straight or slightly curved; spiral cords conspicuous, axial sculpture lacking. ...........................................

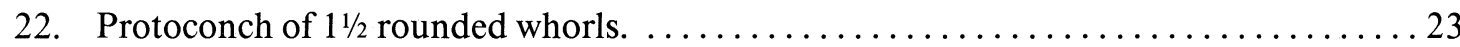

Protoconch conical, of $2 \frac{1 / 2}{2} 3$ more or less straight-sided whorls. . . . . . . . . 25

23. Protoconch keeled; spiral sculpture weak to moderate, no secondary spines developed.

Protoconch not keeled; spiral sculpture conspicuous, secondary spines

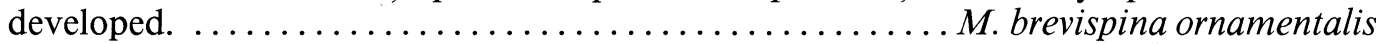

24. Spines absent or short; spiral sculpture inconspicuous; varices solid; labral spine small. ..................................... brevispina brevispina

Spines short to moderate; spiral sculpture moderately developed; varices narrow; labral spine large. ........................... brevispina senilis

25. Length/width ratio of spire + aperture less than $1: 2 \ldots \ldots \ldots$. brevispina macgillivrayi Length/width ratio of spire + aperture more than 1:3. .M. trapa

(Note: Occasional specimens of M. aduncospinosus may sometimes key out to M. trapa but that species invariably has minute secondary spines on the canal and numerous secondary spines on the rest of the shell, unlike the last two species.)

Genus Haustellum Schumacher, 1817: 213

Type species: Murex haustellum Linné, by tautonomy. Brontes Montfort, 1810: 623 (not Fabricius, 1801). Type species: Murex haustellum Linné, original designation.

Brontesia Reichenbach, 1828: 91. New name for Brontes Montfort.

Haustellaria Swainson, 1833: expl. to pl. 100. Type species: Murex erythrostoma Swainson, 1840 (not $M$. erythrostomus Swainson, 1831, = M. haustellum Linné). by subsequent designation Swainson, 1840.

Diagnosis. Shell trivaricate, small to moderately large $(50-150 \mathrm{~mm})$, with or without short spines. Distal tip of siphonal canal slightly deflected in some species, otherwise similar to Murex. Axial ornamentation on early teleoconch whorls of (usually) 12 rounded ribs, of which every fourth strengthens into varix, leaving three intervarical nodes initially. Labral tooth never present. Inner lip often expanded into moderate to very large inductura, frequently bearing rugae or denticles. Operculum with subterminal to subcentral nucleus, growth lines simple to sublamellate. Radula as in Murex but with bases of marginal teeth less expanded in most species so they do not overlap. Ejaculatory duct not embedded in body wall, non-muscular, sometimes open or partly open. Radular sac markedly shorter than buccal mass. Accessory salivary glands very small, possibly absent in some species.

\section{Key to the Indo-West Pacific \\ Recent Species of Haustellum}

This key is based entirely on shell characters.

1. Aperture with more or less well developed rugae on inner lip. ...............

Aperture without more or less well developed rugae on inner lip. ............. 9

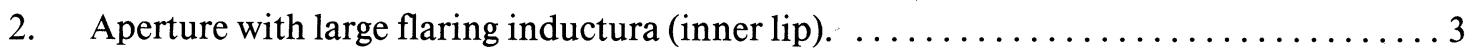

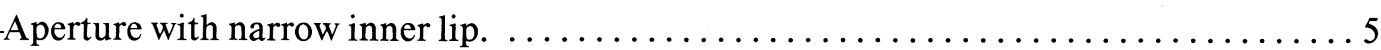

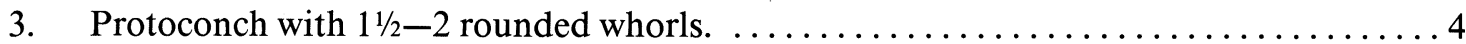

Protoconch conical, of 3 whorls. $\ldots \ldots \ldots \ldots \ldots \ldots \ldots \ldots \ldots \ldots \ldots \ldots$ hirasei

4. Aperture with slit-like notch.

H. haustellum haustellum

Aperture with broadly open anal notch.

.H. dentifer 


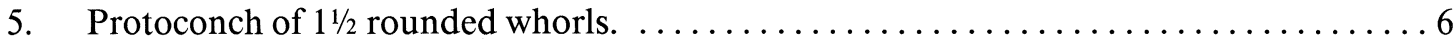

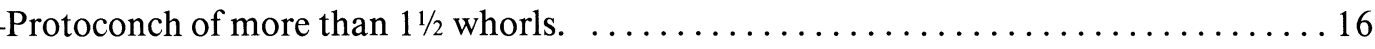

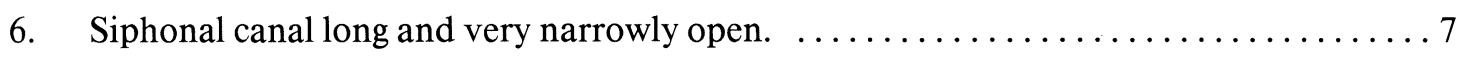

Siphonal canal short and moderately open. $\ldots \ldots \ldots \ldots \ldots \ldots \ldots \ldots$. bobyini

7. Teleoconch with less than 4 intervarical axial ridges on body whorl of adult. H. gallinago

Teleoconch with 4 or more intervarical axial ridges on body whorl of adult. $\ldots \ldots \ldots 8$

8. Secondary spines well developed on body whorl varices. .........H. mindanaoensis

Secondary spines not developed on body whorl varices, only shoulder spine

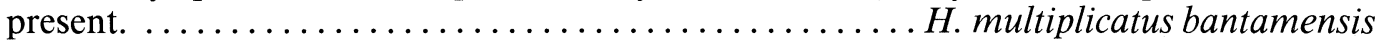

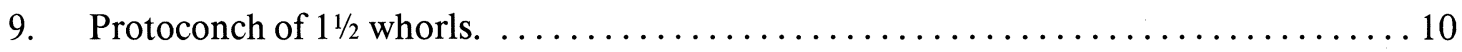

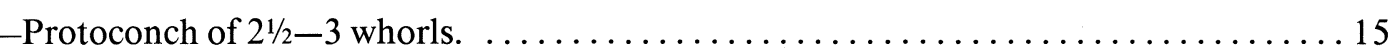

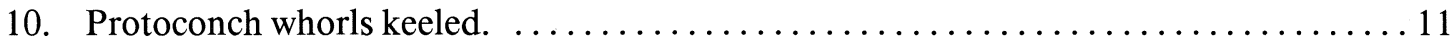

Protoconch whorls convex. ................................ purdyae

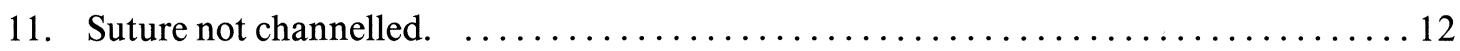

Suture channelled. ..............................................

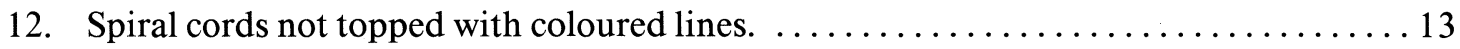

Spiral cords topped with coloured lines. .................... tweedianus

13. Over $75 \mathrm{~mm}$ in total length; heavy in build; with 3-4 intervarical axial ribs.

H. rectirostris

Under $75 \mathrm{~mm}$ in total length; rather light in build; with 2-6 intervarical axial

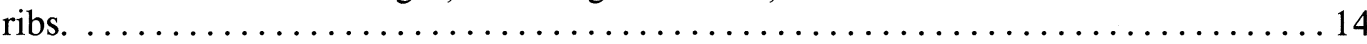

14. Spinose, with $2-3$ intervarical axial ribs. ......................... sobrinus

Rarely with very short spines, typically non-spinose, with 4-6 intervarical ribs.

.................................... multiplicatus multiplicatus

15. Protoconch very large (over $2 \mathrm{~mm}$ in diameter), no spines developed on shoulder of teleoconch. .............................. hastellum fallax

Protoconch small (less than $1 \mathrm{~mm}$ in diameter), short spines developed on shoulder of teleoconch. $\ldots \ldots \ldots \ldots \ldots \ldots \ldots \ldots \ldots \ldots \ldots \ldots \ldots \ldots \ldots \ldots \ldots$. malabaricus

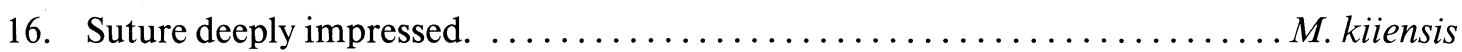

Suture simple. .M. dolichourus

\section{GENUS MUREX}

SUBGENUS MUREX S.S.

The species are arranged in four groups, which include species that are assumed to be closely related.

\section{Species Group 1: Murex tribulus Group}

Murex tribulus Linné, 1758

Figs 5; 6; 67D,E; 70B; 73A,B; 80A; Table 4

Murex tribulus Linné, 1758: 746 (No. 44) (composite of $M$. tribulus, M. pecten and M. forskoehlii) (East Asia; lectotype, here designated, in Linnaean colln, London) (of the 7 figures cited, those referring to our restricted interpretation of this species include Lister, 16851692, pl. 902, fig. 22 and Rumphius, 1705 , pl. 26, fig.
G.); Linné, 1764: 626 (No.292) (only three figures cited, including Rumphius, 1705, fig G); Linné, 1767: 1214 (No. 519) (in part; locality given as "O. Asiae" [= E. Asia] and Java); Born, 1780: 287 (in part); Gmelin, 1791: 3525 (in part); Röding, 1798: 145 (in part) (cites Martini, 1777 , pl. 3, figs 1053-4); Dillwyn, 1817: 682 (in part); Hanley, 1855: 279 (in part); Küster \& Kobelt, 1856: 25, pl. 9, figs 4, 5; Brazier, 1893: 45 (in part); Hinton, 1972: 34, pl. 17, fig. 7; Radwin \& D'Attilio, 1976: 72 (in part); Fair, 1976: 82, pl. 1, fig. 1; Vokes, 1978: 376, pl. 1, fig. 1; Houart, 1980b: 84, pl. 1B; Ladd, 1982: 43, pl. 9, fig. 7.

Murex crassispina Lamarck, 1822: 157 (in part); Blainville, 1827: 401, pl. 17B, fig. 2 .

Murex tenuispina.-Quoy \& Gaimard, 1833: 528, pl. 36, figs 3 (shell and head-foot), 4 (operculum); Gray, 1842: 7, pl. 6, fig. 2 (copy of Quoy \& Gaimard, figure 3) (not of Lamarck).

Murex ternispina.-Sowerby, $1841 \mathrm{a}$ : 1, pl. 197, fig. 110; 
Reeve, 1845: pl. 18, fig. 73; Sowerby, 1879: 4, pl. 1 (of Murex), fig. 1; Tryon, 1880: 78 (in part), pl. 9, fig. 110, pl. 11, fig. 117; Oostingh, 1925: 139 (in part); Melvin, 1966: 94, pl. 37, fig. 1; Kaicher, 1973: fig. 102 (not of Lamarck).

Murex (Tribulus) ternispina.-Poirier, 1883: 30 (in part) (not of Lamarck).

Records. MOZAMBIQUe (DMNH). MADAGASCAR: Nosy Bé (RML); near Diego-Suarez (DMNII). ANDAMAN ISLANDS: (DMNH). BuRMA: Kadan Kyun Id (BMNH). THAILAND: Bangkok (IRSB). SINGAPORE: (HUM). SARAWAK: Sematan (BMNH). BORNEO: Dumaring (USNM). INDONESIA: Sumatra (ZMA); Tjilatjap, Java (RML); 4-15 m, Teluk Awang, Lombok (AMS); Sumbawa Besar, Sumbawa (IRSB); Teluk Slawi, Komodo (FSM); Teluk Oka, Larantuka, Flores (ZMA); Moluccas (ZMA; RML; AMS); Banda Sea (RML); Madjene Gulf, Sulawesi (RML); Kepulauan Banda, south of Seram (RML); Ambon (MCZ; ZMA; RML; ZMC; IRSB); South Loloda Id, west of Halmahera (MCZ); Timor (ZMA; RML); Kupang, Timor (HUM; RML); Irian Barat: Japen Id; Sekru, Fak Fak; Jayapura (all RML); Manokwari (IRSB); Merauke (USNM); Teluk Wandammen (ZMA). PHILIPPINES: Cuyo

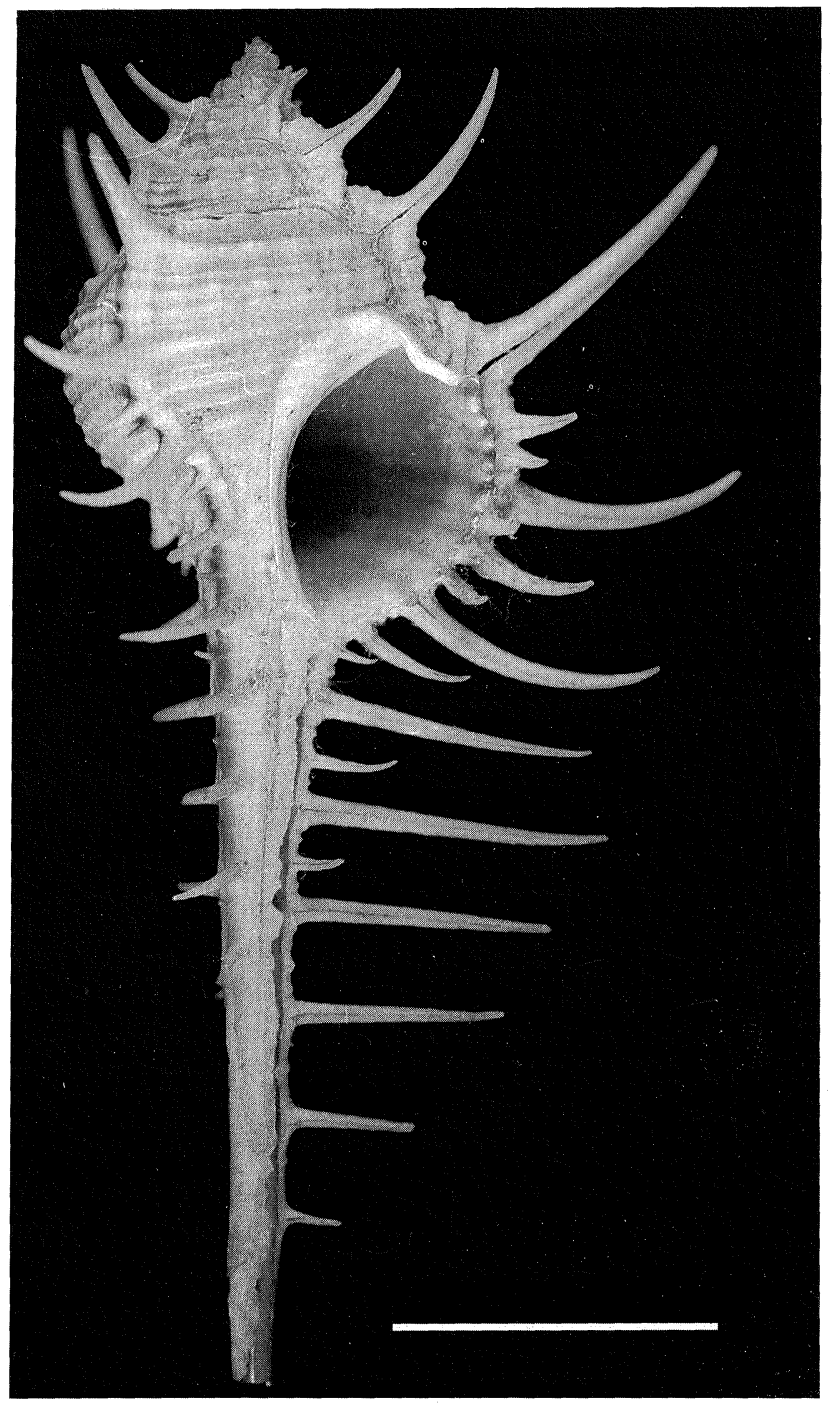

Id, north-east of Palawan (ANSP); Subic Bay, Zambales, Luzon (MCZ); $20 \mathrm{~m}$, South Corregidor Id (ANSP); Mariveles, Luzon (DMNH; ANSP); Talaga Cove, Bataan, Luzon (WAM); 2-9 m, off Bataan, Luzon (WAM); 5-9 m, Sisiman Bay, Bataan, Luzon (MCZ; DMNH); 2-9 m, Wawa, Nasugbu, Luzon (WAM); Bauan, Batangas Bay, Luzon (WAM); 'Topping', Quezon Province (RML); 2-5 $\mathrm{m}$, Quezon Province (DMNH); 5-16 m, Baler and Port Real, Quezon (DMNH); $3 \mathrm{~m}, 1 \mathrm{~km}$ east of Cabcaben, Bataan (ANSP); Ragay Gulf, south-east Luzon (USNM); Olongapo, Luzon (USNM); Tilik, Lubang (USNM); Calapan, Mindoro (AMNH; MCZ); Negros (BMNH); Cebu (AMS); Malabuyoc, Cebu (ANSP); Catbalogan, Samar (MCZ); 'Port Pio', Camiguin (USNM); Santa Cruz; Moro; Davao, Mindanao (all FMNH); Isabela, Basilan (USNM); 'Tanjong Beach', Jolo Id, Sulu (ANSP). JAPAN: Amami O-shima, north Ryukyus (NSMT). PAPUA NEW GUINEA: Murik Lakes, Sepik (AMS); Manus Id (ZMA; AMS); Malai Id, Siassi Ids, West New Britain; 4 m, Tamuniai Id, New Britain; Mongop, East New Ireland (all AMS); $18 \mathrm{~m}$ Bougainville (FMNH); Buin (ANSP; USNM); Kieta (NMV). Australia: Cape Leveque, Western Australia (AMNH) (requires confirmation); Darnley Id, Torres Strait

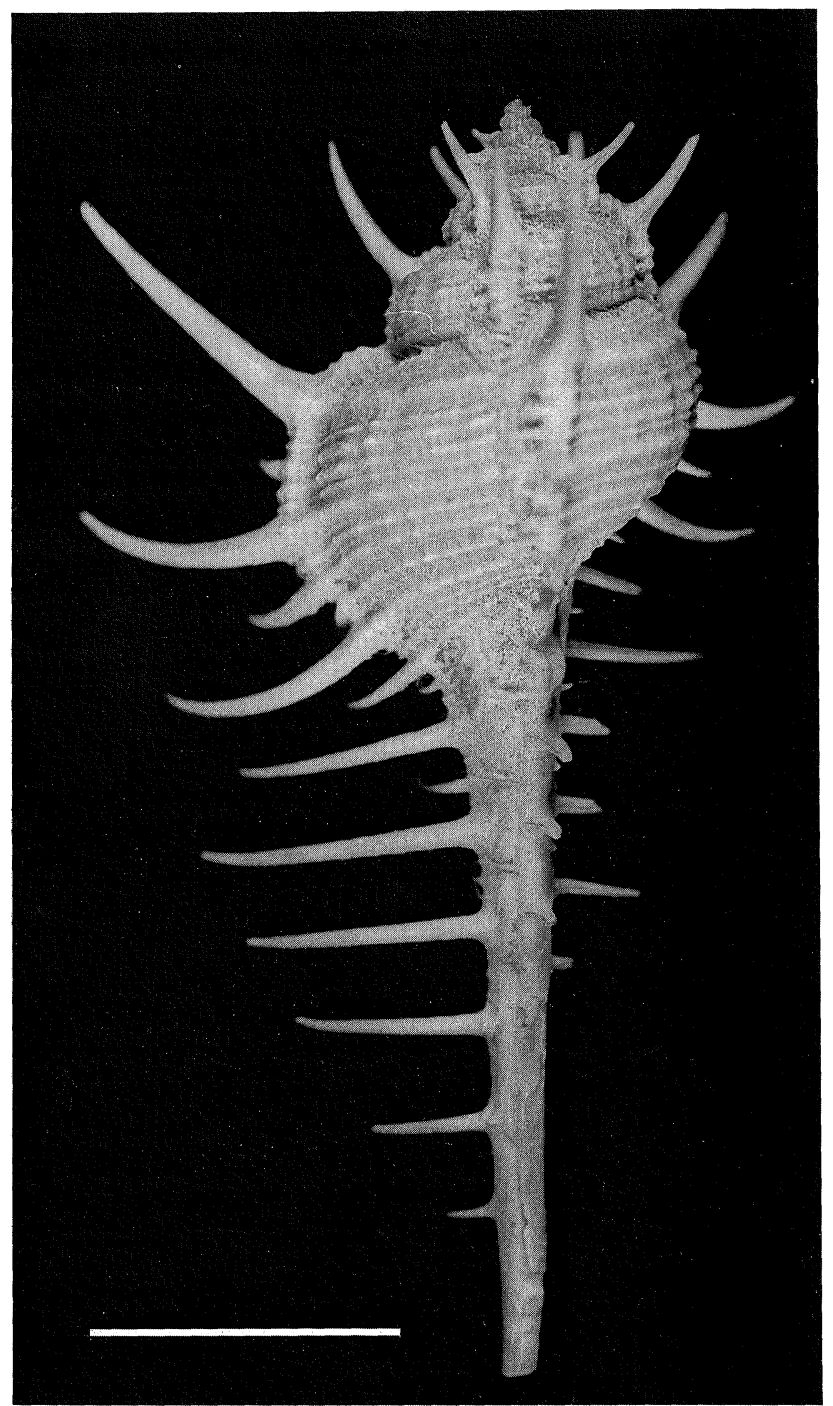

Figure 5. Murex tribulus Linné. Lectotype; East Asia (Linnaean Colln, London). Scale $2 \mathrm{~cm}$. 
(AMS). Solomons: Mbambatana, Sasamungga, Choiseul (AMNH); Sengga, Choiseul(AMNH); New Georgia (AMS); Tulagi Id (DMNH); Santa Isabel Id (AMS); Honiara Yacht Basin, Gaudalcanal (AMS); Lumba, Guadalcanal (USNM); Ususua, Malaita (ANSP). NEw CALEDONIA: Touho Bay (DMNH); Baie de l'Orphelinat, Noumea (ANSP); Poum Bay; Poindimié; 0-2 m, north-west Ile Ste Marie (all AMS). VANUATU: Banks Id; Vila (both AMS). MARSHALL ISLANDS: Majuro Atoll (USNM).

Fossil records. Pleistocene: Espirito Santo, Vanuatu (USNM; recorded by Ladd, 1982).

Description. SHELL. Very large (up to $120 \mathrm{~mm}$ in length), with eight teleoconch whorls.

Protoconch of about three polished conical volutions, with strong keel on last near anterior suture, terminating at sharp crescentic varix.

Spiral ornamentation absent on first two teleoconch whorls; on third whorl about five extremely weak spiral threads (shoulder and peripheral ones slightly stronger), increasing by intercalation until body whorl and siphonal canal marked by pattern of three orders of primary, secondary, and tertiary flattened cords.

Axial ornamentation on first teleoconch whorl of six or seven ribs, flattened on subsutural ramp and drawn out into strong, looped lamellae, extending from shoulder almost to anterior suture. Axial lamellae elongated into spines on second teleoconch whorl; by third whorl spines on two of every three ribs shrinking into intervarical ridges, others strengthening into varices, each with long closed curved spine at shoulder. Intervarical ridges gradually reduced on subsequent whorls until by sixth and later whorls intervarical area not ribbed but crossed with numerous, strong growth lines that give a malleated appearance to shell surface. Three rounded varices per whorl; where crossed by primary spiral cords, three moderately long, slightly apically curved spines on each. Primary spines alternating with three shorter secondary spines, recurved somewhat adaperturally. Very short, sharp tertiary spinelets directed adaperturally, at right angles to other spines, alternate with primary and secondary spines. Number of tertiary spinelets variable. Completely developed spination pattern with (anteriorly from suture) tertiary, primary (shoulder), tertiary, secondary, tertiary, primary (periphery), tertiary, secondary, tertiary, primary (base), secondary, tertiary, tertiary. Siphonal canal with six or seven long primary spines, adaperturally curved near distal ends. Of these, second from base of body whorl longest, others rapidly tapering in length anteriorly so anterior-most one shortest. Several small spinelets alternate with primary spines, those

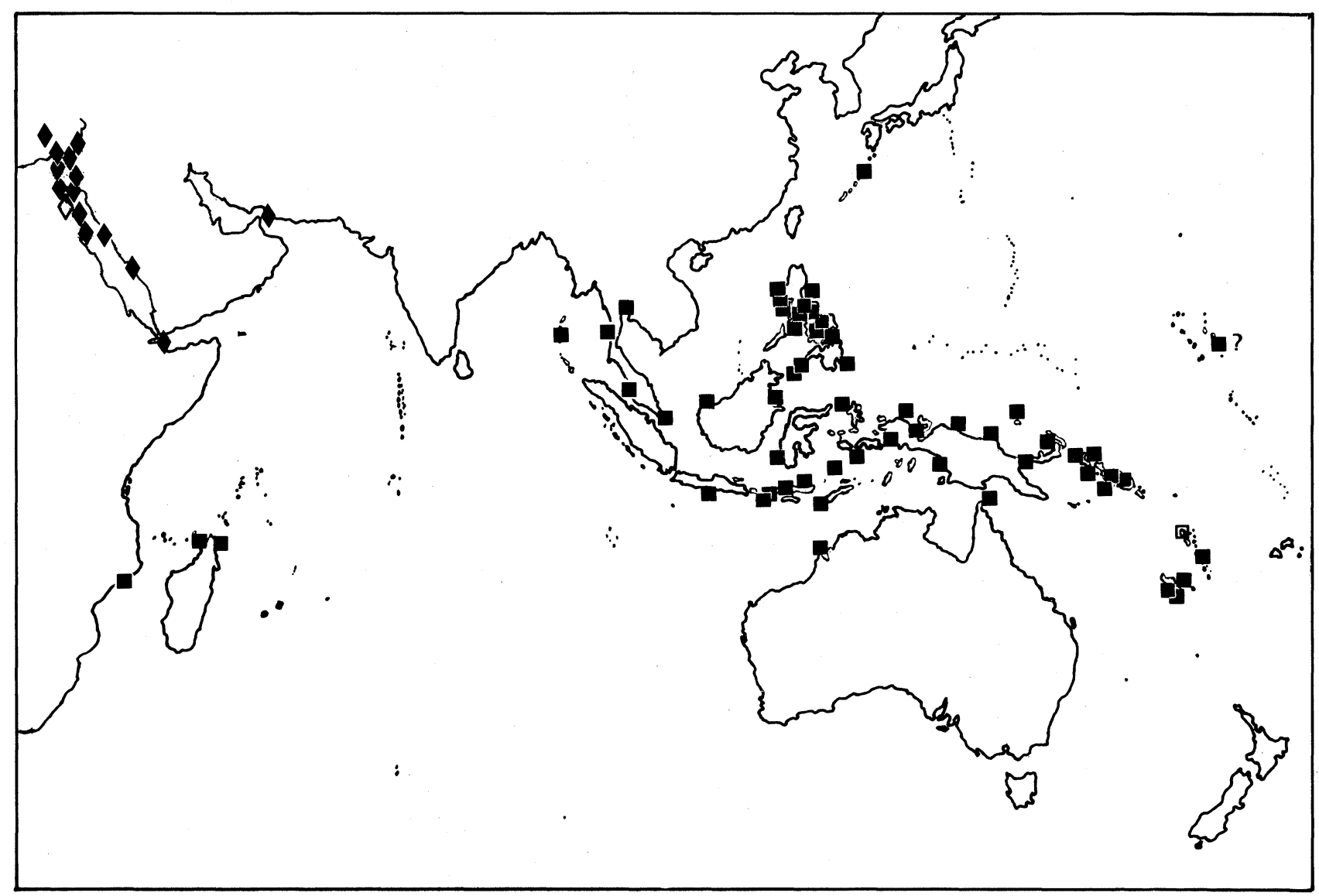

Figure 6. Distribution of $M$ tribulus Linné (square). M. forskoehlii Röding (diamond). and open symbols = fossil records. 
nearest base parallel to adjacent primary spines, but progressively directed adaperturally until anteriormost spinelet at an angle of $90^{\circ}$ to primary spines.

Suture simple, crossed diagonally by growth lamellae.

Aperture ovate; margin of outer lip notched by extension of median groove in spines, notches varying in size according to strength of spine; one inter-notch area on anterior third of lip projecting as large labral tooth. Long, grooved lirations extend into aperture from base of notches. Small anal notch formed between appressed posterior portion of inner lip and extension of shoulder ramp. Flare of inner lip reaching only to level of suture and not visible in advance of varices on previous whorls; anterior threequarters of inner lip free-standing, smooth.

Siphonal canal long; terminations of previous canals fused into tube, open by narrow slit; spinose on posterior two-thirds of length.

Colour yellow brown, with a bluish to purplish tinge in interspaces between spirals; spirals and axial growth ridges lighter in colour, giving a maculated appearance; interior of shell brown, with darker brown lines between lirations, terminating in dark spots in notches of outer lip.

Dimensions. See Table 4.

\begin{tabular}{|c|c|c|c|c|c|c|c|c|c|c|c|c|}
\hline \multirow{2}{*}{$\begin{array}{l}\text { Total } \\
\text { length }\end{array}$} & \multirow{2}{*}{$\begin{array}{l}\text { Length of } \\
\text { spire \& } \\
\text { aperture }\end{array}$} & \multirow{2}{*}{$\begin{array}{l}\text { Length of } \\
\text { anterior } \\
\text { canal }\end{array}$} & \multirow{2}{*}{$\begin{array}{l}\text { Length of } \\
\text { aperture }\end{array}$} & \multicolumn{2}{|c|}{ Total diameter } & \multirow{2}{*}{$\begin{array}{l}\text { Length of } \\
\text { longest } \\
\text { shoulder } \\
\text { spine }\end{array}$} & \multirow{2}{*}{$\begin{array}{l}\text { Length of } \\
\text { longest } \\
\text { canicular } \\
\text { spine }\end{array}$} & \multirow{2}{*}{$\begin{array}{c}\text { No. of } \\
\text { spines on } \\
\text { right side } \\
\text { of anterior } \\
\text { canal }\end{array}$} & \multirow{2}{*}{$\begin{array}{c}\text { No. of } \\
\text { spines on } \\
\text { labial } \\
\text { varix }\end{array}$} & \multirow{2}{*}{$\begin{array}{c}\text { No. of } \\
\text { inter- } \\
\text { varical } \\
\text { nodes on } \\
\text { body } \\
\text { whorl }\end{array}$} & \multirow[b]{2}{*}{$\begin{array}{c}\text { No. of } \\
\text { primary } \\
\text { spiral } \\
\text { threads on } \\
\text { penul- } \\
\text { timate } \\
\text { whorl }\end{array}$} & \multirow[b]{2}{*}{$\begin{array}{c}\text { No. of } \\
\text { primary } \\
\text { spiral } \\
\text { threads } \\
\text { on body } \\
\text { whorl }\end{array}$} \\
\hline & & & & $\begin{array}{l}\text { with } \\
\text { spines }\end{array}$ & $\begin{array}{l}\text { without } \\
\text { spines }\end{array}$ & & & & & & & \\
\hline
\end{tabular}

\begin{tabular}{|c|c|c|c|c|c|c|c|c|c|c|c|c|c|}
\hline Lectotype & 84.5 & 38.2 & - & - & 48.2 & 28.2 & 20.4 & - & - & - & - & - & - \\
\hline $\begin{array}{l}\text { Teluk Awang, } \\
\text { Lombok Id, } \\
\text { Indonesia: AMS. } \\
\text { C.108649 (Fig. } \\
\text { 80A) }\end{array}$ & 105.3 & 47.0 & 57.7 & 23.7 & 61.8 & 34.7 & 29.3 & 23.2 & $6: 2 *: 0$ & $3: 2$ & 0 & 7 & 12 \\
\hline $\begin{array}{l}\text { Banks Id, Vanuatu; } \\
\text { AMS, C. } 84159\end{array}$ & 100.2 & 43.8 & 56.4 & 22.5 & 56.0 & 34.0 & 22.4 & 20.4 & $6: 5: 2$ & $3: 3: 4$ & 0 & 7 & 12 \\
\hline $\begin{array}{l}\text { Kieta, Bouganville; } \\
\text { NMV. }\end{array}$ & 87.3 & 41.9 & 45.4 & 21.5 & 59.2 & 29.6 & 31.5 & 20.7 & $6: 4 *: 0$ & $3: 3: 2$ & 0 & 7 & 11 \\
\hline
\end{tabular}

Table 4. Shell measurement and count data for Murex tribulus Linné.* = damaged.

OpERCULuM. Brown; subterminal nucleus, surrounded by numerous concentric ridges.

RADULA. See Figs 67D, E.

PENIS. Tapering, with short filament (Fig. 70B).

Remarks. There has been much debate concerning the identity of $M$. tribulus, caused by Linné citing eleven figures in seven different references (see Table 3). The most exhaustive discussion by Dodge (1957: 79-84) unravels some of the confusion but his conclusions must be reassessed given the changes that we propose in this revision. As Dodge points out, the original description of $M$. tribulus is so generalized that it could include any species in the group. Several additional figures were cited by Linné in the twelfth edition (1767) but these are of little nomenclatural importance as they do not affect the name. They are discussed at length by Dodge (1957). Typical $M$. tribulus, as determined by examination of the single specimen in the Linnaean collection, was figured in two of the eleven figures cited by Linné. For one of these, Rumphius (1705: fig. G) used the name 'tribulus'; the other is that of Lister (1685-1695). The other figures cited by Linné refer to $M$. pecten (Olearius, 1666: pl. 39, fig. 1; Rumphius, 1705: pl. 26, fig. 3; Buonanni, 1681: fig. 269; Gualtieri, 1742: pl. 31, fig. B*; Argenville, 1742: pl. 19, fig. A) and M. forskoehlii (Gaultieri, 1742: pl. 31, fig. A [three separate figures]; Colonna, 1616: pl. 60, fig. 6). All the cited figures and the Linnaean specimen, which bears the name $M$. tribulus, could be regarded as syntypes. The Linnaean specimen is here designated as lectotype.

Several other species have been misidentified as $M$. tribulus, the details being given in their synonomies. Lamarck (1822) was the first author to attempt to divide the $M$. tribulus complex. Unfortunately, confusion has persisted over the identity of some of his species to the present day.

Some workers have used the name $M$. ternispina for species in the $M$. tribulus group but, in those instances where the specimens listed have not been available for examination, or have not been figured, or, when examined, prove to be mixtures of species, these references are generally not listed in the synonymies that we present.

The shell of Murex tribulus can be distinguished from that of all similar species of Murex by its purplish colour, long siphonal spines, multispiral conical protoconch, weak axial sculpture on the body whorl and strongly spinose axials on the first two teleoconch whorls.

* in the AMS copy there is no fig. B, all 4 Murex being labelled fig. A. 
Murex carbonnieri (Jousseaume, 1881)

Figs 7; 13; 70A; 75A-C; 80G-I; Table 5

?Aranea aculeata Perry, 1811: pl. 46, fig. 2 ('African Seas'; type probably lost).

Acupurpura carbonnieri Jousseaume, 1881:345 (Aden, Red Sea; holotype and 3 paratypes, NHMP).

Murex tribulus.-Baker, 1891: 56; Melvill \& Standen, 1898: 42; Crichton, 1941: 330, pl. 3, fig. 4; Radwin \& D'Attilio, 1976: 72 (in part) (not of Linné).

Murex (Tribulus) carbonnieri.-Poirier, 1883: 31, pl. 4, figs $1 \mathrm{a}, \mathrm{b}$.

Murex (Murex) tribulus var. carbonnieri.-Baker, 1897: 373.

Murex tribulus carbonnieri.-Smith, 1953: 1.

?Murex tribulus aduncospinosus. - Smith, 1953: 1, text fig. d (not of Sowerby).

Murex carbonnieri.-Kaicher, 1974: fig. 535; Fair, 1976:

29, pl. 2, fig. 15; Houart, 1979: 126, pl. 3, figs 6, 6a;

Abbott \& Dance, 1982: 130, fig. in text.

Murex (Murex) carbonnieri.-Vokes, 1978: 378, pl. 1, figs 6,7 .

Records. MadagasCaR: Tulear; Zsimipaika, Nosy Bé (both IRSB). MAURITIUS: (AMS). TANZANIA: Chumbe Is, Zanzibar (FMNH). SOMALIA: 'Caudala' (MCZ); Berbera (NMW). ETHIOPIA: 37-46 m, Ras-Andadda (AMS). RED SEA (AMNH; ANSP). DEMOCRATIC YEMEN: Aden (NMW; BMNH; AMNH; USNM; SAM; IRSB; SMF; AMS); Madinat ash Sha'b (AMS); Badr (RML); Perim Id (BMNH). OMAN: Muscat (AMNH); 82-165 m, Gulf of Oman (BMNH). PERSIAN GULF: 10-31 m (ZMC). UNITED
ARAB EMIRATES: $95 \mathrm{~m}$, east of Sharjah (MCZ). IRAN: $40 \mathrm{~m}$, south-east of Kharg; $44 \mathrm{~m}, 16 \mathrm{~km}$ south-south-west of Kharg; 25-30 m, 4 km east-north-east of north Kharg; 40 $\mathrm{m}$, near Kharg (all ZMC); 110-120 m, $20 \mathrm{~km}$ south-west of Chah Bahar; 110-122 m, $39 \mathrm{~km}$ west of Ras Beris, near Gwatar (both MCZ); Ra's-e Meydani (ZMC). PAKISTAN: $18-20 \mathrm{~m}, 14 \mathrm{~km}$ south of Gwatar Bay; $108 \mathrm{~m}, 20 \mathrm{~km}$ south of Gwatar Bay; 93-100 m, $60 \mathrm{~km}$ west of Ras Muari; $88-91 \mathrm{~m}, 180 \mathrm{~km}$ south-west of Karachi; $110 \mathrm{~m}, 276 \mathrm{~km}$ south of Karachi; $26 \mathrm{~m}, 85 \mathrm{~km}$ south-south-east of Ormara (all MCZ); Karachi (ANSP; AMNH; FMNH; USNM). INDIA: Gujarat: $57 \mathrm{~m}, 166 \mathrm{~km}$ west of Mandvi; $70-72 \mathrm{~m}, 96$ $\mathrm{km}$ west of Mangrol; 79-88 m, $84 \mathrm{~km}$ south-south-west of Dwarka; 49-51 m, $48 \mathrm{~km}$ south of Dwarka; 71-78 m, 74 $\mathrm{km}$ south-south-west of Veraval (all MCZ). Maharashtra: $69 \mathrm{~m}, 131 \mathrm{~km}$ south-south-west of Bassein (MCZ); Bombay (AMS); 46-55 m, west of Harnai (AMS); 'Cheupati Beach', Bombay (NMV). Karnataka: $51 \mathrm{~m}, 46 \mathrm{~km}$ west-south-west of Honavar (BMNH). Tamil Nadu: Tuticorn (USNM); Madras (BMNH; AMNH; SMF; AMS); Adyar Bay, Madras (ZMA); Ennur (NMW); 2-4 m, west of Mandapam, Gulf of Mannar (ANSP); off Mandapam (MCZ). Andrah Pradesh: Waltair (USNM); Waltair Point (MCZ). Orissa: Puri (MCZ). SRI LANKA: (NMV); $21 \mathrm{~km}$ north of Trincomalee (USNM); Nilaveli (AMS). BANGLADESH: $22 \mathrm{~m}, 156 \mathrm{~km}$ south of Chittagong. ANDAMAN ISLANDS: (DMNH; ZMC); $164 \mathrm{~m}$ (BMNH); trawled, Andaman Sea (AMS); Port Blair (NMW; AMNH). INDONESIA: Sumatra: (RML); Padang (HUM; SMF). Java: Tjilatjap (RML); Tjilintjing (ZMA); Pelabuanratu Bay (MCZ; USNM). Sulawesi: (HUM); 'Menado', Busak; Molucca (both RML). Timor: (NMV). PHILIPPINES: Busuanga, Calamian Group; Catbalogan, Samar (both FMNH).

\begin{tabular}{|c|c|c|c|c|c|c|c|c|c|c|c|c|c|}
\hline & $\begin{array}{l}\text { Total } \\
\text { length }\end{array}$ & $\begin{array}{l}\text { Length of } \\
\text { spire \& } \\
\text { aperture }\end{array}$ & $\begin{array}{l}\text { Length of } \\
\text { anterior } \\
\text { canal }\end{array}$ & $\begin{array}{l}\text { Length of } \\
\text { aperture }\end{array}$ & $\begin{array}{c}\text { Total } \\
\text { with } \\
\text { spines }\end{array}$ & $\begin{array}{l}\text { ameter } \\
\text { without } \\
\text { spines }\end{array}$ & $\begin{array}{l}\text { Length of } \\
\text { longest } \\
\text { shoulder } \\
\text { spine }\end{array}$ & $\begin{array}{l}\text { Length of } \\
\text { longest } \\
\text { canicular } \\
\text { spine }\end{array}$ & $\begin{array}{l}\text { No. of } \\
\text { spines on } \\
\text { right side } \\
\text { of anterior } \\
\text { canal }\end{array}$ & $\begin{array}{l}\text { No. of } \\
\text { spines on } \\
\text { labial } \\
\text { varix }\end{array}$ & $\begin{array}{l}\text { No. of } \\
\text { inter- } \\
\text { varical } \\
\text { nodes on } \\
\text { body } \\
\text { whorl }\end{array}$ & $\begin{array}{c}\text { No. of } \\
\text { primary } \\
\text { spiral } \\
\text { threads on } \\
\text { penul- } \\
\text { timate } \\
\text { whorl }\end{array}$ & $\begin{array}{c}\text { No. of } \\
\text { primary } \\
\text { spiral } \\
\text { threads } \\
\text { on body } \\
\text { whorl }\end{array}$ \\
\hline Holotype & 65.4 & - & - & - & 36.3 & 25.5 & - & - & - & - & - & - & - \\
\hline Paratype; NHMP. & 65.3 & - & - & - & 31.1 & 24.6 & - & - & - & - & - & - & - \\
\hline Paratype; NHMP. & 62.5 & - & - & - & 32.1 & 22.5 & - & - & - & - & - & - & - \\
\hline $\begin{array}{l}\text { Coast of Sumatra, } \\
\text { Indonesia; RML, } \\
40 \text { (Fig. } 80 \mathrm{H} \text { ) }\end{array}$ & 122.0 & 53.8 & 69.7 & 26.2 & 63.8 & 35.3 & 32.9 & 26.4 & $6: 4$ & $3: 2: 0$ & 0 & 9 & 17 \\
\hline $\begin{array}{l}\text { Gold Mohur } \\
\text { Beach, Aden, } \\
\text { Democratic } \\
\text { Yemen; AMS, C } \\
143952 \text { (Fig. 80I) }\end{array}$ & 52.9 & 24.5 & 27.3 & 12.6 & 26.3 & 29.2 & 9.5 & $3.2^{*}$ & $5: 0: 0$ & $3: 1: 0$ & 0 & 8 & 14 \\
\hline $\begin{array}{l}\text { Shore W. of } \\
\text { Mandapan, Gulf of } \\
\text { Mannar, SE India; } \\
\text { ANSP, 302559 } \\
\text { (Fig. 80G) }\end{array}$ & 64.9 & 32.8 & 32.6 & 15.8 & 39.8 & 25.6 & 14.7 & 11.2 & $5: 2: 0$ & $3: 2: 1$ & $3-4$ & 9 & 14 \\
\hline $\begin{array}{l}\text { Shore W. of } \\
\text { Mandapan, Gulf of } \\
\text { Mannar, SE India; } \\
\text { ANSP, 302559 } \\
\text { (Fig. 80G) }\end{array}$ & 85.1 & 39.8 & 46.3 & 19.0 & 52.8 & 31.9 & 23.5 & 16.1 & $6: 3: 0$ & $3: 3: 4$ & 4 & 9 & 16 \\
\hline $\begin{array}{l}\text { Gulf of Oman, 82- } \\
164 \text { m; BMNH }\end{array}$ & 91.5 & 43.8 & 48.4 & 23.2 & 66.5 & 35.3 & 33.9 & 21.1 & $7: 3: 1$ & $3: 3: 4$ & 0 & 8 & 14 \\
\hline
\end{tabular}

Table 5. Shell measurement and count data for Murex carbonnieri Jousseaume.* = damaged. 


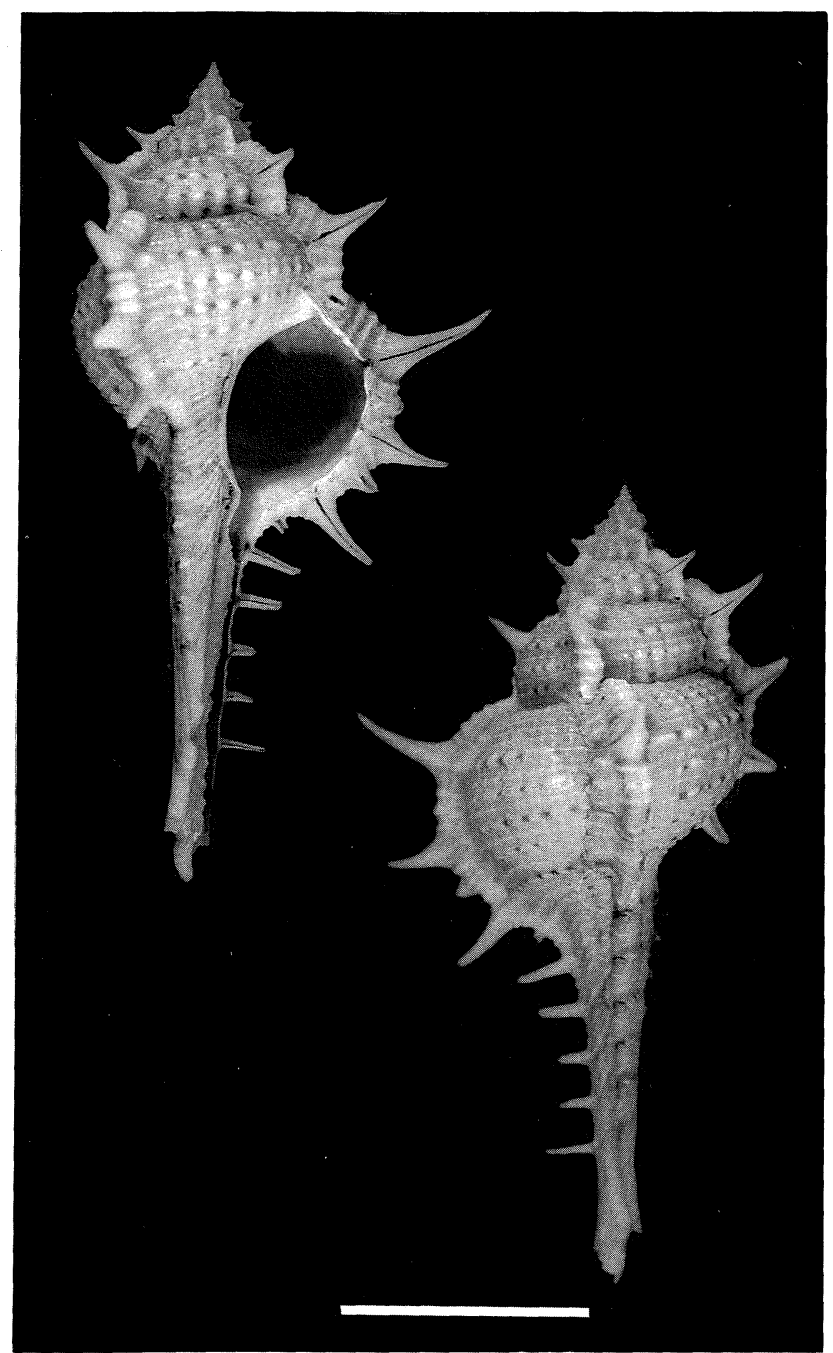

Figure 7. Murex carbonnieri (Jousseaume). Holotype; Aden, Red Sea (NHMP). Scale $2 \mathrm{~cm}$.

Description. SHELL. Very large (up to $125 \mathrm{~mm}$ in length), with eight sub-angulate teleoconch whorls. Protoconch of two and one-half to three and one-half convex volutions, terminating at sharp, crescentic varix.

Spiral ornamentation on first two teleoconch whorls very weak, masked by axial ornament; third whorl with five weak spiral cords, those at shoulder and periphery somewhat heavier; on fourth whorl three or four secondary threads on subsutural ramp. Tertiary threads intercalated between spiral cords anterior to shoulder on subsequent whorls; body whorl and siphonal canal covered by numerous spiral cords of three orders of magnitude. Axial ornamentation on first two teleoconch whorls of nine angulate ribs, each flattened on subsutural ramp and drawn out into two, almost closed, lamellar spinelets, larger one at shoulder and much smaller one at periphery. On third whorl, every third axial rib strengthened to form varix, with short, recurved, closed spine at shoulder; intervening ribs low, rounded, non-spinose. On fourth whorl, a third axial ridge added at adapertural end of intervarical area and on subsequent whorls ridges increase in number, but decrease in strength, until on body whorl indicated only as elongate nodules on spiral cords. Numerous growth lamellae give shagreened appearance to surface. Three rounded varices per whorl, each with three strong spines where crossed by three major spiral cords; spine on shoulder somewhat longer and curved apically. Three secondary spinelets also on each varix, one anterior to each major spine, and a few tertiary spinelets. Siphonal canal with five or six, moderately long, primary spines on adult (sometimes seven on juveniles), alternating with much smaller, adaperturally directed, secondary spinelets.

Suture simple, crossed by growth lamellae.

Aperture ovate; margins of outer lip notched by extensions of median groove in spines, notches varying in size according to strength of spine. One inter-notch area on anterior third of outer lip projecting as small labral tooth. Very small anal notch; inner lip slightly appressed at posterior third of its length; anteriorly free-standing, narrow, smooth.

Siphonal canal long, previous canals fused into tube open by narrow slit; almost straight but distal ends of former terminations and adult canal slightly recurved dorsally; spinose except for anterior onequarter.

Colour creamy white to light tan; in the intervarical areas conspicuous, slightly elongated brown spots between lighter nodes on spiral cords; aperture white, marked by conspicuous brown spots at notches extending into interior of shell as dark brown lines on lighter brown background.

DiMENSIONS. See Table 5.

OPERCULUM. Reddish brown; subterminal nucleus surrounded by about ten concentric ridges, lamellose on side adjacent to outer lip; median crease along length.

PENIS. Tapering, with distal end markedly narrower than base, almost filament-like (Fig. 70A).

Remarks. The shell of this species is readily distinguished by the encircling lines of reddish spots on the primary spiral cords. The length of the spines is variable, tending to become longer with increasing water depth (compare Figs 80G-I).

The earliest figure that appears to represent this species is given by Martini (1777: fig. 1055), and is one of the two figures on which Murex trapa Röding, 1798 , is based. The other figure $(1056)$ has been designated as the type of $M$. trapa by Vokes (1978).

Vokes (1970) suggested that Aranea aculeata Perry, 1811 might be based on this species. Perry's figure is so poor that accurate identification is impossible and this name is best regarded as a nomen nudum. 


\section{Murex tenuirostrum tenuirostrum Lamarck, 1822} Figs 1C; 8-11; 70C; 73C; 80B,C; Table 6

Murex tenuirostrum Lamarck, 1822: 159 (locality unknown; lectotype [the largest of two syntypes, which agrees with Lamarck's dimensions] and paralectotype, here chosen, NHMG, 1099/7).-Deshayes \& MilneEdwards, 1839: 702; ? Gray, 1839: 109; Deshayes, 1843: 569; Catlow \& Reeve, 1845: 251.

Murex (Tribulus) aduncospinosus.-Watson, 1885: 146 (not of Sowerby).

Murex (Murex) verbeeki bentarsariensis.-Wissema, 1947: 176 (not of Oostingh, 1940).

Murex tribulus.-Habe \& Kosuge, 1966: 51, pl. 18, fig. 7; Cernohorsky, 1967a: 115 (in part), pl. 14, fig. 2; Cernohorsky, 1967b: 117 (in part), pl. 23, fig. 139; Hinton, 1972: 34, pl. 17, fig. 6; Hinton, 1978: 33, fig. 2; Houart, 1979: 129 (in part), pl. 1, figs 1, 1a; D'Attilio, 1979: 16, fig. 2; Abbott \& Dance, 1982: 130, fig. in text (not of Linné).

Murex ternispina.-Fair, 1976: 80 (in part), pl. 1, fig. 7 (not of Lamarck).

Records. SEYCHELles: $71 \mathrm{~m} ; 66 \mathrm{~m}, 8 \mathrm{~km}$ south-west of Conception Id, west coast Mahé (both BMNH). YEMEN: Al Mukha (AMNH; DMNH). OMAN: $73 \mathrm{~m}$, off Lumah (BMNH). UNITED ARAB EMIRATES: $79 \mathrm{~m}, 40 \mathrm{~km}$ east of Dabba; 46-48 m, $24 \mathrm{~km}$ west of 'Vadasht'; $60 \mathrm{~km}$ eastnorth-east of Al Fujayrah (all MCZ). IRAN: 71-73 m, $72 \mathrm{~km}$ west-south-west of Kuhestak (MCZ). INDIA: (AMS); Tranquebar, Tamil Nadu (ZMC). ANDAMAN ISLANDS: $38-49 \mathrm{~m}, 24-38 \mathrm{~km}$ north-north-west of Port Blair (ANSP). BURMA: $55 \mathrm{~m}$, Bay of Bengal, north Burma; $110 \mathrm{~km}$ west of Tavoy City; $53 \mathrm{~m}, 85 \mathrm{~km}$ south-west of Irrawaddy River (all ANSP). THAILAND: $42 \mathrm{~m}, 41 \mathrm{~km}$ north-north-west of Phuket Id; $58 \mathrm{~m}, 65$ miles north-north-west of Phuket Id (both ANSP); 36-39 m, north-west of Thalang (ZMC). Malaysia: east coast of Malaysia (AMS). CHINA SEA: 54-91 m, Macclesfield Bank (BMNH). HoNG KonG: (SAM). Indonesia: Tapaktuan, west Atjeh, Sumatra (RML); Belitung Id, south-east Sumatra (ZMA); Veeckens Bay, south Pagi Id (USNM); $88 \mathrm{~m}$, north-east of Madura; 69-91 m, Madura Bay (both ZMA); south Malang Dist, Java (AMS); Banten, Java (USNM); Rembang, Java; Bali Sea (both RML); Bali; Ekas, Lombok (both AMS); south of Selat Bali (ZMC); Makassar, Sulawesi (ZMA); $67 \mathrm{~m}$, southeast of Tikola, south-east Sulawesi (USNM); $36 \mathrm{~m}$, North Point, Pulau Salayar; 75-94 m, Selat Wowoni (both ZMA); 40 m, Selat Butung; $71 \mathrm{~m}$, off 'Kalono Point', Selat Butung (both USNM); 27-45 m, Ambon (BMNH); Timor (RML); 90 m, north of Kepulauan Kai (ZMA); 36-85 m, west coast Nuhu Chut, Kai Besar (ZMC; WAM); 54-72 m, south of Ur Id; 32-36 m, between Duroa \& Dulah Id; 32-36 m, north of Duroa Id, Kepulauan Kai (all WAM); 245 m, north of Kai Besar; 50 m, Duroa Basin, Kai Ids (both ZMC); Irian Barat: $46-91 \mathrm{~m}, 1.5 \mathrm{~km}$ east of Daliwi, East Padeaido Ids (ANSP, AIM); 36-46 m, Pulau Rumwakon, Auri Ids (ANSP); Biak (ZMA); Humboldt Bay, Japayura (RML). PhILIPPINES: Monja Id, near Corregidor, Luzon (USNM); south Cove, Corregidor, Luzon (DMNH); $51 \mathrm{~m}$, off Corregidor, Luzon; 60 m, Subic Bay, Luzon (both USNM); $16 \mathrm{~m}$, west Cochinos Pt, Bataan (ANSP); Lucena Bay, Quezon (AMNH); Bauan, Batangas Bay; 2-9 m, Wawa, Nasugbu (both WAM); 33 m, Malavatuan Id (USNM); 5-9 $\mathrm{m}$, Sisiman Cove, Bataan, Luzon (MCZ); 192-220 m, Verde Island Passage (NHMP); Baler (ZMC); 3-9 m, Lubang (AMNH); Mindoro (ANSP); 5-9 m, Calapan,
Mindoro; 3-9 m, Mindoro Occidental (both AMNH); 1-6 $\mathrm{m}$, Ataa Id, Marinduque (AMS); $15 \mathrm{~m}$, Panay (AMNH); 24 $\mathrm{m}$, off Cebu (AMS); Cebu (AMNH); $95 \mathrm{~m}$, Panglao Id, Bohol; 110 m, 'Lady Id', Bohol (both WAM); 36-43 m, Maqueda Bay, Samar; Catbalogan, Samar (both MCZ); 104 $\mathrm{m}$, off 'Tacbuc Pt', Leyte (USNM); 80 m, west of Bucas Grande (USNM) Zamboanga, Mindanao (AMNH; AMS); 46-64 m, Coronado Bay, Mindanao (WAM); Tawitawi Id, Sulu (DMNH); $33 \mathrm{~m}$, Dammai Id, Sulu (BMNH). PALAU: west reef, opposite Koror; $33 \mathrm{~m}, 3 \mathrm{~km}$ north-east of Cape Gabadaguru, Ngemelis Id (both ANSP). PAPUA NEW GUINEA: Samarai (NMNZ); 55 m, off Oro Bay; 22-33 m, off Yule Id (both AMS); Rabaul, New Britain (AMS; AMNH); $22 \mathrm{~m}$, Torokina Harbour, Bougainville (AMS). Australia: Queensland: Torres Strait; 64 m, Blackwood Channel; 30-37 m, off Townsville; Low Isles, Port Douglas (all AMS); $5 \mathrm{~m}, 9 \mathrm{~km}$ east-north-east of Brook Id Light, off Rockingham Bay (DMNH); Upstart Bay (AMNH); Bramble Reef; off North Palm Id (both DMNH); 33 m, west of Hayman Id; 37-40 m, off Cairns; 31-40 m, off Cape Bowling Green; Holborne Id, off Bowen; Bundaberg; Keppel Bay; 60 m, Tin Can Bay (all AMS). Solomons: 9 m, $30 \mathrm{~m}$, KuKum, east of Honiara (both AMS); Tulaghi Id (DMNH); New Georgia (AMS). NEw CALEDONIA: (NMV; AMS); Belep Id; Ile St Marie; 4-5 m, between Ile St Marie \& Îlot Véré; Poum (all AMS); Lifu, Loyalty Ids (IRSB); 44-68 $\mathrm{m}$, Chesterfield-Bellona Plateau, off Chesterfield Id, Coral Sea (NHMP). VANUATU: (SAM); Espiritu Santo (AMS); 37-46 m, Téouma Bay, south Efate Id (AIM). FIJI:(ANSP); Viti Levu (MCZ; AIM); Sali Sali, Viti Levu (USNM). SAMOA: near Matautu Point, Apia (USNM). ToNGA $20 \mathrm{~m}$, Nukualofa Harbour (BMNH; ZMC); west side Fafa Id, Tongatapu (USNM); Pangaimotu Id, Tonga (NMNZ). MARSHALL ISLANDS: Ebon Is (ANSP).

Fossil Records. Plio-Pleistocene: Papua New Guinea: Upper Wanimo Series: $0.5 \mathrm{~km}$ below Selep Village, Tambau River, Sepik District (BMR); Harech River, Aitape area (BMR). Finsch Coast Series: Kuibal Creek, near Iwam Village, Sepik District (BMR). Awaak Village, Nias, Malay Arch. (GML; recorded as $M$. verbeeki bentarsariensis by Wissema. 1947). Late Pliocene: Java: below Kampong Bodjong Koempai, west Java (PCB).

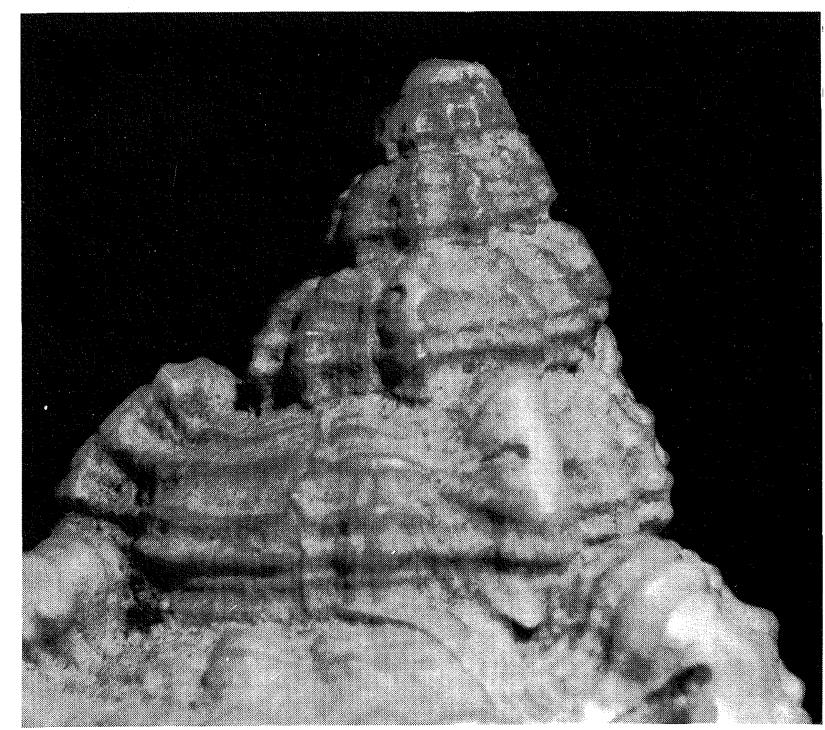

Figure 8. Murex tenuirostrum tenuirostrum (Lamarck).Upper spire of lectotype: unknown locality (NHMG. 1099/7). 

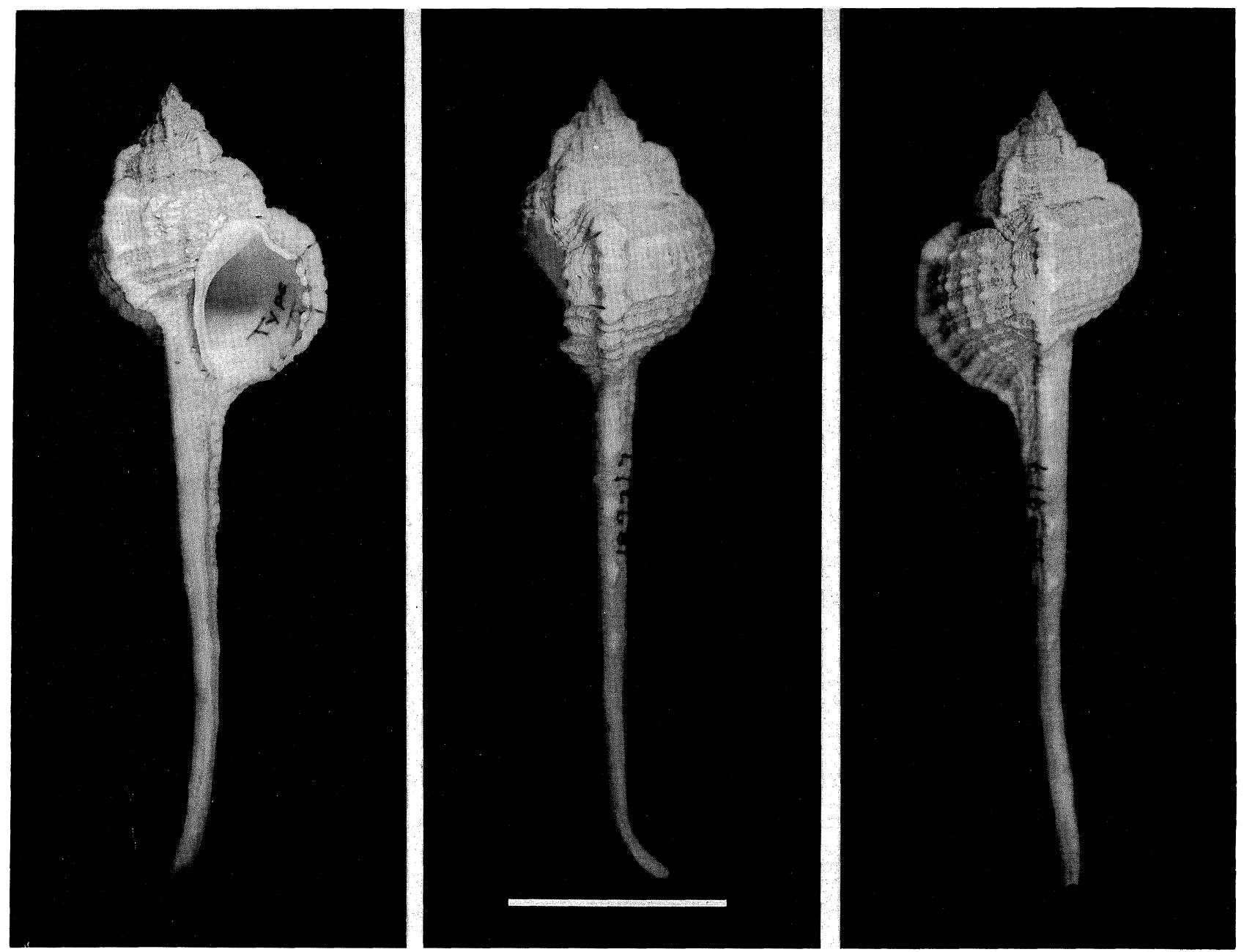

Figure 9. Murex tenuirostrum tenuirostrum (Lamarck).Lectotype: unknown locality (NHMG. 1099/7). Scale = $2 \mathrm{~cm}$

Description. SHELL. Very large (up to $140 \mathrm{~mm}$ in length), teleoconch of up to eight whorls.

Protoconch of about three and one-half polished, conical volutions, terminating in sharp, crescentic varix.

Spiral ornamentation on first teleoconch whorl of two or three rounded cords, often masked by axial ribs. Spirals gradually increase in number until five alternating primary and secondary cords on third whorl. Tertiary threads intercalated until body whorl covered with complex pattern of three orders of magnitude; major cords at shoulder, periphery and base of whorl most prominent.

Axial ornamentation strong; on each of first two teleoconch whorls, nine rounded to weakly angulate ribs with small lamellar flanges looped into short open spinelet at shoulder and periphery of whorl. On third or fourth whorl every third rib strengthened to form small varix with short spine at shoulder and second, smaller, spine at periphery; intervening ribs form elevated ridges lacking spines. On next whorl, an additional axial ridge added at adapertural end of intervarical area; intervarical ridges continue to increase in number but decrease in strength until body whorl; here six to eight rows of nodules formed where very weak axials are crossed by spiral cords. Surface covered with numerous lamellose growth lines, these, together with spiral threads, give shagreened appearance. Three heavy, rounded varices per whorl, each with three long spines at crossing of primary cords. Shoulder spine longest, usually slightly recurved adaperturally. In many individuals, shoulder spine on dorsal (penultimate) varix extremely attenuated. Secondary spine anterior to each major spine shorter and slightly adaperturally curved. Small tertiary spinelets randomly developed on some individuals. Siphonal canal with four or five relatively short major spines, second from base of body whorl longest, anterior two spines usually much shorter; very small adaperturally directed secondary spinelets usually present.

Suture simple, crossed by frilled axial growth lamellae. Aperture ovate; margin of outer lip notched by extensions of median groove in spines, notches varying in size according to strength of spine. One inter-notch area on anterior third of outer lip projecting as a small labral tooth. Anal notch small. Inner lip slightly appressed posteriorly, not flaring, 


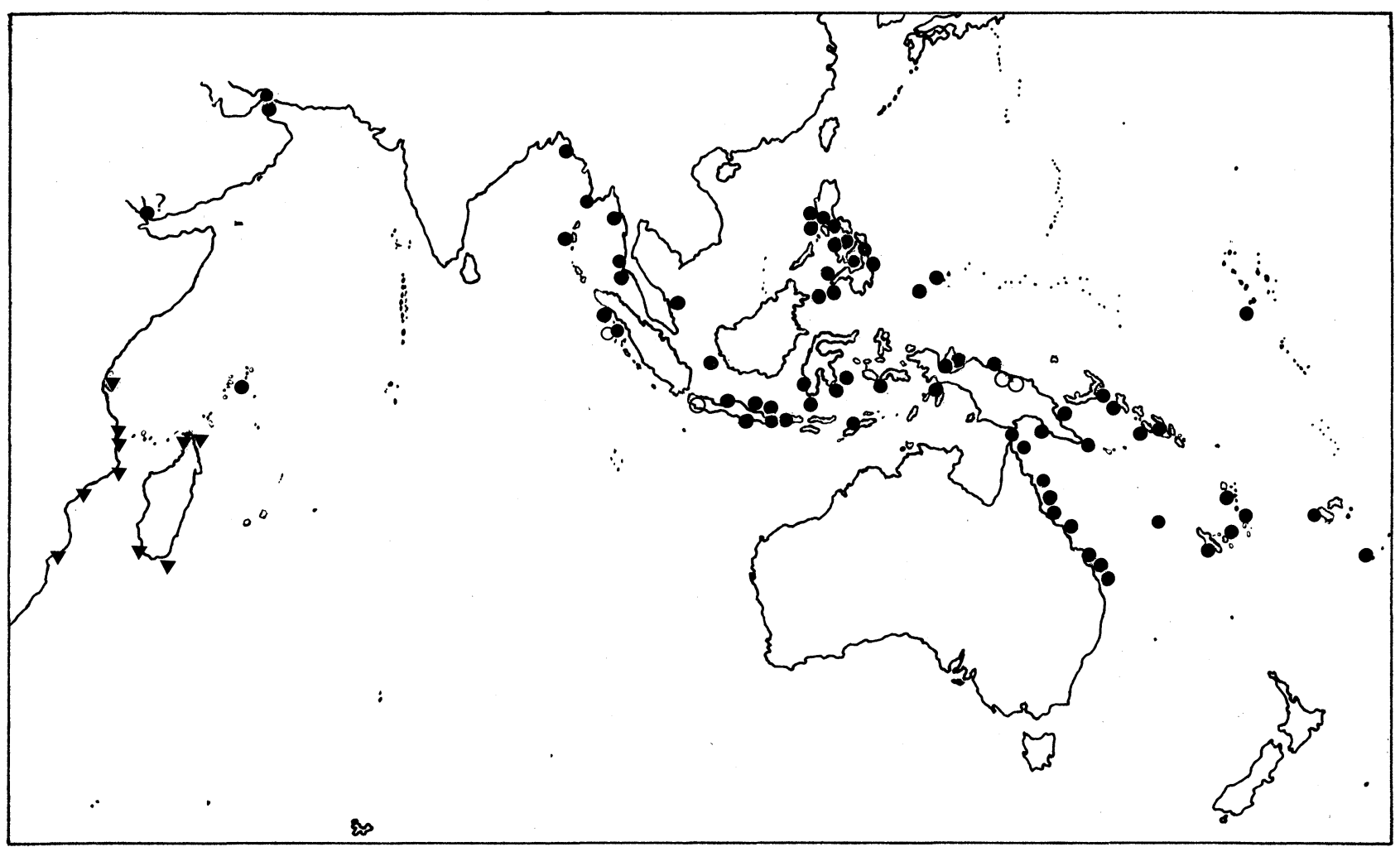

Figure 10. Distribution of M. tenuirostrum tenuirostrum Lamarck (circle); M. t. africanus n. subsp. (inverted triangle), and open symbols $=$ fossil records.

free-standing almost entire length, smooth.

Siphonal canal very long; terminations of previous canals fused into straight tube, open by narrow slit; spinose about three-fourths total length.

Colour ivory to golden brown, intervarical nodules lighter in colour; aperture white with reddish brown spots in and behind notches; interior white to light brown.

Dimensions. See Table 6.

OPERCULUM. Reddish brown; subterminal nucleus, surrounded by numerous concentric ridges; a crease along midline.

PENIS. Tapering, with very small filament (Fig. 70C).

Remarks. The synonomy is abbreviated because it is impossible to know from most references whether or not they refer to this subspecies. Many of the specimens recorded as $M$. tribulus and M. ternispina, for example, probably refer to this species, at least in part, but unless the original material can be checked positive identification is not possible.

Heavy-shelled specimens of both subspecies of $M$. tenuirostrum are difficult to separate from some unicoloured specimens of $M$. aduncospinosus using teleoconch characters alone. The protoconch is the most reliable distinguishing character and the suture in $M$. aduncospinosus is channelled, being only indented in $M$. tenuirostrum. In addition, the axial ribs on the first two teleoconch whorls in $M$. tenuirostrum are simple and generally rounded, whereas in $M$. aduncospinosus they are usually subangulate, often with a rudimentary spine. This latter difference is not, however, consistent enough to be a reliable way to distinguish these taxa. The shell of Murex tribulus, by way of contrast, always has welldeveloped spines on all teleoconch whorls.

The syntypes of $M$. tenuirostrum lack a protoconch but the extremely long siphonal canal, and the teleoconch characters are typical of the subspecies here associated with this name. In addition, the sculpture of the early whorls (Fig. 8 ) is also typical of this subspecies.

The typical subspecies has a wider distribution than M. tribulus, with which it is often confused, and the two taxa are frequently found living together. The shell of $M$. tenuirostrum can be separated from $M$. tribulus by its yellow brown rather than purplish colour, and fewer, much shorter spines on the anterior canal. Both of these taxa possess a conical protoconch suggesting that they have a planktotrophic larval life, and both are widely distributed.

The East African form of this species is described below as a separate subspecies, mainly because of differences in protoconch morphology.

Murex tenuirostrum africanus $\mathrm{n}$. subsp.

Figs 10; 12; 73E,F; 81A,E; Table 7

Murex trapa.-Vokes, 1978: 377, pl. 1, figs 2, 3 (not of Röding). 


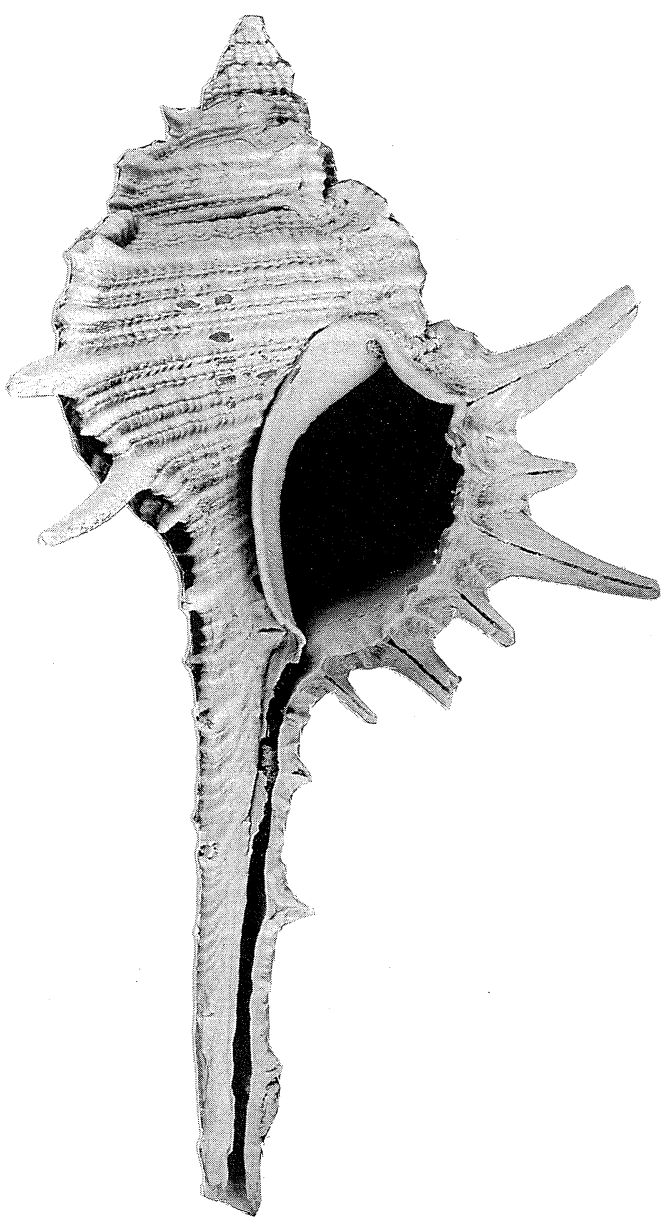

Figure 11. Murex tenuirostrum tenuirostrum Lamarck. Loc. 39, Nias, Malay Archipelago, Plio-Pleistocene (GML). Scale $2 \mathrm{~cm}$.

Type material. HolotyPE: (NM, H1382), south-west Conducia Bay, Conducia, Mozambique Province, $0.3 \mathrm{~m}$ above L.S.T. level, depression in sand flat, some mud, no surf, coll. K.J. Grosch. PARATYPES: one paratype (NM, H209), south-west Conducia, L.S.T. level, sandflats, near deep water, no surf, coll. K.J. Grosch; paratype (NM, H1386), far west Conducia Bay, $0.3 \mathrm{~m}$ above L.S.T. level, sandbank and some mud, current, no surf, coll. K.J. Grosch; paratype (NM, H1381), Conducia Bay, coll. K.J. Grosch; paratype (NM, H1384), south-west Lunga Bay, south-east of Posta, Mozambique Province, $0.5 \mathrm{~m}$ above L.S.T. level, in sandflat, some Thalassodendron, no surf, coll. K.J. Grosch; paratype (ANSP, 234122), Mozambique City, Mozambique, coll. K.J. Grosch; paratype (ANSP, 216867), Mozambique, coll. Cahn; 2 paratypes (AMS, C71879), Mozambique, N. Jackson Colln; 2 paratypes (AMS, C121610); Porto Amelia, Mozambique, R. Stobbs

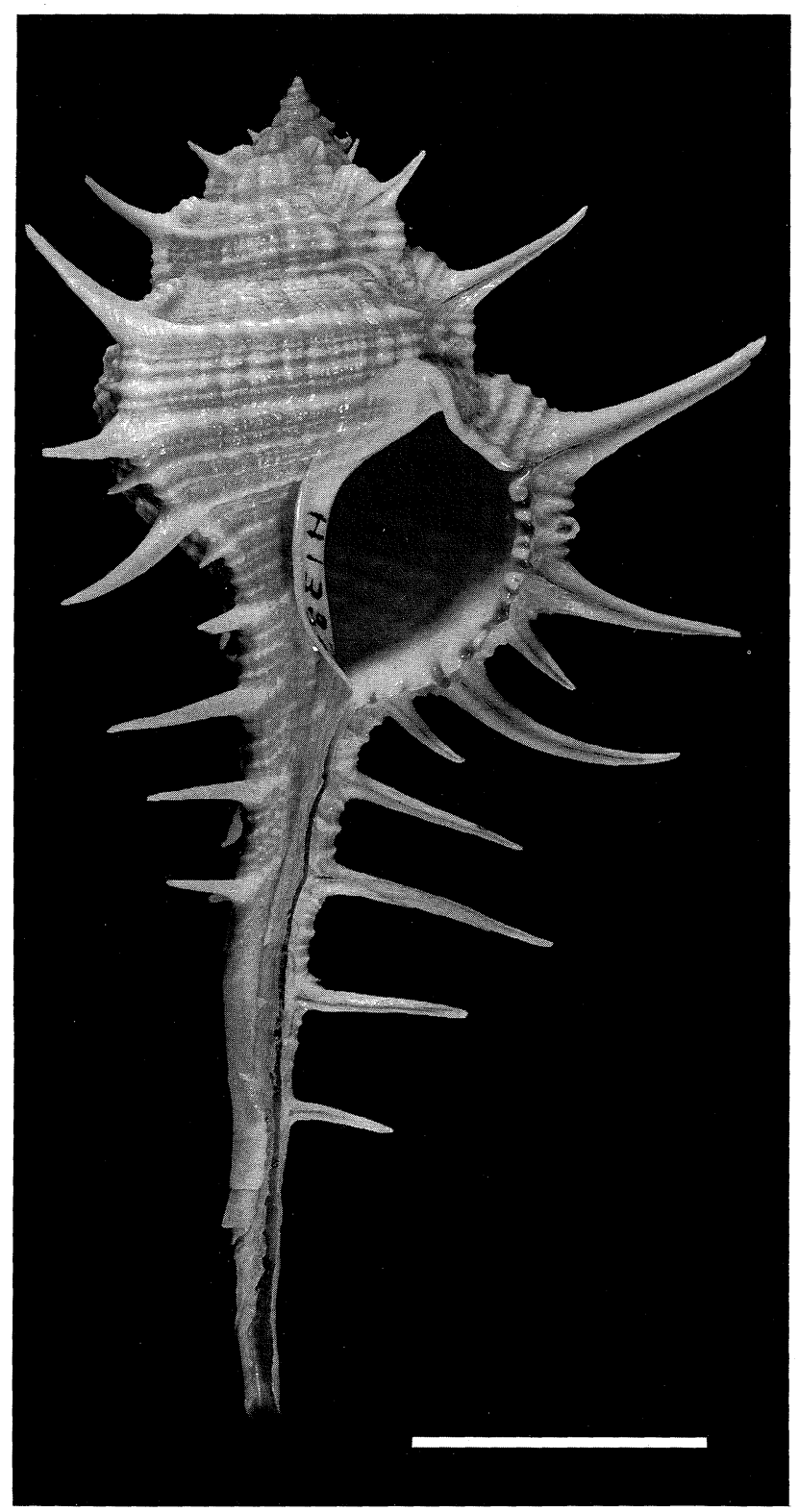

Figure 12. Murex tenuirostrum africanus n. subsp. Holotype; south-west Conducia Bay, Conducia, Mozambique (NM, H 1382). Scale $2 \mathrm{~cm}$.

Colln; one paratype (USNM, 718655), 40 miles south-east of Chinde, Mozambique, $45 \mathrm{M}$; paratype (MCZ, 272753) Nosy Bé, Madagascar, coll. A. Humes; 28 paratypes (MCZ, 263403), Sarodrano, Madagascar, 2 m, coll. R.W. Foster; 2 paratypes (ANSP, 272287), Sarodrano, Tulear, Madagascar, coll. R.W. Foster; paratype (AMS, C84219), Antsakoabé, Nosy Bé, Madagascar, coll. M. Chavane.

Records. Mozambique: (DMNH); Mozambique City (USNM). TANZANIA: $3 \mathrm{~km}$ west of Changa Id, Zanzibar (AIM); Fumba, Zanzibar (AMS); $27 \mathrm{~m}, 3 \mathrm{~km}$ north of Bawi Id, Zanzibar; $18 \mathrm{~m}$, Zanzibar (both ANSP). MADAGASCAR: Tulear (IRSB); Nosy Bé (IRSB; USNM); 2-6 m, Baie du Tsimipaika, Nosy Bé (IRSNB); $18 \mathrm{~m}, 5 \mathrm{~km}$ east of Pte du Tafondro, Nossy Bé; $31 \mathrm{~m}, 7 \mathrm{~km}$ south-west Nosy Tanikely, Nosy Bé (both ANSP); $30 \mathrm{~m}, 14 \mathrm{~km}$ south of Nosy Tanikely (MCZ); 18 m, west of Nosy Faly (MCZ); 2-4 m, Baie 


\begin{tabular}{|c|c|c|c|c|c|c|c|c|c|c|c|c|c|}
\hline & $\begin{array}{l}\text { Total } \\
\text { length }\end{array}$ & $\begin{array}{c}\text { Length of } \\
\text { spire \& } \\
\text { aperture }\end{array}$ & $\begin{array}{l}\text { Length of } \\
\text { anterior } \\
\text { canal }\end{array}$ & $\begin{array}{l}\text { Length of } \\
\text { aperture }\end{array}$ & $\begin{array}{l}\text { Total di } \\
\text { with } \\
\text { spines }\end{array}$ & $\begin{array}{l}\text { Imeter } \\
\text { without } \\
\text { spines }\end{array}$ & $\begin{array}{l}\text { Length of } \\
\text { longest } \\
\text { shoulder } \\
\text { spine }\end{array}$ & $\begin{array}{l}\text { Length of } \\
\text { longest } \\
\text { canicular } \\
\text { spine }\end{array}$ & $\begin{array}{l}\text { No. of } \\
\text { spines on } \\
\text { right side } \\
\text { of anterior } \\
\text { canal }\end{array}$ & $\begin{array}{l}\text { No. of } \\
\text { spines on } \\
\text { labial } \\
\text { varix }\end{array}$ & $\begin{array}{l}\text { No. of } \\
\text { inter- } \\
\text { varical } \\
\text { nodes on } \\
\text { body } \\
\text { whorl }\end{array}$ & $\begin{array}{l}\text { No. of } \\
\text { primary } \\
\text { spiral } \\
\text { threads on } \\
\text { penul- } \\
\text { timate } \\
\text { whorl }\end{array}$ & $\begin{array}{c}\text { No. of } \\
\text { primary } \\
\text { spiral } \\
\text { threads } \\
\text { on body } \\
\text { whorl }\end{array}$ \\
\hline Lectotype & 75.0 & 28.0 & - & - & $\begin{array}{l}\text { No } \\
\text { spines }\end{array}$ & 22.6 & 一 & - & - & - & - & - & - \\
\hline Paralectotype & 83.2 & 31.6 & - & - & $\begin{array}{l}\text { No } \\
\text { spines }\end{array}$ & 24.9 & 一 & - & - & - & - & - & - \\
\hline $\begin{array}{l}\text { Subic Bay, Luzon, } \\
\text { Philippines; } \\
\text { USNM, 285209 } \\
\text { (Fig. 80B) }\end{array}$ & 103.4 & 38.4 & 64.9 & 17.5 & 83.8 & 27.3 & 64.9 & 11.2 & $5: 3: 3$ & $3: 2: 1$ & 0 & 7 & 13 \\
\hline $\begin{array}{l}\text { Poum, N. New } \\
\text { Caledonia; AMS, } \\
\text { C.81955 (Fig. 80C) }\end{array}$ & 100.2 & 42.3 & 58.9 & 21.5 & 55.7 & 32.6 & 25.8 & 17.7 & $5: 3: 0$ & $3: 3: 5$ & 0 & 8 & 13 \\
\hline $\begin{array}{l}\text { Fiji Islands; ANSP, } \\
35320\end{array}$ & 113.3 & 50.1 & 64.4 & 23.7 & 77.9 & 35.2 & 43.2 & 23.1 & $5: 3: 0$ & $3: 3: 5$ & 0 & 8 & 13 \\
\hline $\begin{array}{l}\text { Espiritu Santo, } \\
\text { Vanuatu; AMS, } \\
\text { C.106388. }\end{array}$ & 100.5 & 35.9 & 64.9 & 18.0 & 78.1 & 29.6 & 45.5 & 16.8 & $5: 3: 0$ & 3:3:0 & 0 & 6 & 12 \\
\hline $\begin{array}{l}\text { Espiritu Santo, } \\
\text { Vanuati; AMS, } \\
\text { C.106388. }\end{array}$ & 106.4 & 41.1 & 66.0 & 20.4 & 78.2 & 31.6 & 48.9 & 17.9 & $4^{*}: 3: 3$ & $3: 3: 4$ & 0 & 6 & 11 \\
\hline $\begin{array}{l}\text { Cebu, Philippines; } \\
\text { AMS, C. } 106384 .\end{array}$ & $94.8^{\circ}$ & 34.8 & 59.8 & 16.8 & 64.0 & 26.5 & 38.3 & 17.1 & $4: 3 *: 0$ & $3: 3: 0$ & 0 & 6 & 12 \\
\hline $\begin{array}{l}\text { Téuma Bay, S. } \\
\text { Efate Id, Vanuatu; } \\
\text { AIM. }\end{array}$ & 65.0 & 32.1 & 33.5 & 16.9 & 41.9 & 24.9 & 18.2 & 13.6 & $3: 1: 0$ & $3: 2: 0$ & 0 & 6 & 12 \\
\hline $\begin{array}{l}\text { Cape Bowling } \\
\text { Green, Townsville, } \\
\text { Queensland, } \\
\text { Australia; AMS; } \\
\text { C.106397. }\end{array}$ & 91.0 & 36.5 & 54.8 & 17.9 & 49.7 & 27.4 & 22.8 & 16.7 & $5: 3: 1$ & $3: 3: 3$ & 0 & 6 & 12 \\
\hline $\begin{array}{l}\text { New Caledonia; } \\
\text { NMV, F.27459 }\end{array}$ & 129.0 & 56.1 & 72.4 & 27.3 & 71.6 & 41.2 & 35.4 & 29.0 & $4^{*}: 3 *: 0$ & $3: 3: 4$ & 0 & 8 & 12 \\
\hline
\end{tabular}

Table 6. Shell measurement and count data for Murex tenuirostrum tenuirostrum Lamarck.* = damaged.

d'Ambaro (USNM); 6-8 m, Baie du Cap-Diego (ZMC).

Description. SHELl. As for M. tenuirostrum tenuirostrum except in the following features. Maximum length about $95 \mathrm{~mm}$. Protoconch of two and one-quarter to two and one-half rounded whorls, or more rarely, two whorls; varying between domeshaped and elongate in shape; terminating in sharp, crescentic varix.

Axial sculpture with angulation of ribs on first whorl usually more pronounced and, on third whorl, every third or fourth rib strengthened into varix. Shoulder spine straight or slightly curved, never very long. Spines on siphonal canal with third spine from base of body whorl relatively longer than in typical subspecies, being almost as long as, and sometimes longer than, second spine from base.

Siphonal canal relatively shorter than in many specimens of typical subspecies.

DimENSIONS. See Table 7.

OPERCULUM. As for typical subspecies.
Etymology. A reference to the limited distribution of this subspecies.

Remarks. This subspecies is mainly distinguished from the typical form of the species because of differences in protoconch morphology. The convex whorls and variable form of the protoconch of the East African form are in marked contrast to the uniform, conical protoconch found in the typical subspecies. It suggests that abbreviated development, probably involving a short larval life, occurs in the East African subspecies. There are, in addition, small differences in the teleoconch, as noted in the description. No preserved material of this form has been available to compare penial morphology.

We initially regarded this taxon as a form of $M$. aduncospinosus, but closer examination showed the protoconch and teleoconch morphology has more resemblance to $M$. tenuirostrum. The simple, nonchannelled suture is, for example, one significant teleoconch character that separates both subspecies of $M$. tenuirostrum from $M$. aduncospinosus. Nevertheless, the relationships and status of $M$. 


\begin{tabular}{|c|c|c|c|c|c|c|c|c|c|c|c|c|c|}
\hline & $\begin{array}{l}\text { Total } \\
\text { length }\end{array}$ & $\begin{array}{l}\text { Length of } \\
\text { spire \& } \\
\text { aperture }\end{array}$ & $\begin{array}{l}\text { Length of } \\
\text { anterior } \\
\text { canal }\end{array}$ & $\begin{array}{l}\text { Length of } \\
\text { aperture }\end{array}$ & $\begin{array}{l}\text { Total } \\
\text { with } \\
\text { spines }\end{array}$ & $\begin{array}{l}\text { Imeter } \\
\text { without } \\
\text { spines }\end{array}$ & $\begin{array}{l}\text { Length of } \\
\text { longest } \\
\text { shoulder } \\
\text { spine }\end{array}$ & $\begin{array}{l}\text { Length of } \\
\text { longest } \\
\text { canicular } \\
\text { spine }\end{array}$ & $\begin{array}{l}\text { No. of } \\
\text { spines on } \\
\text { right side } \\
\text { of anterior } \\
\text { canal }\end{array}$ & $\begin{array}{l}\text { No. of } \\
\text { spines on } \\
\text { labial } \\
\text { varix }\end{array}$ & $\begin{array}{l}\text { No. of } \\
\text { inter- } \\
\text { varical } \\
\text { nodes on } \\
\text { body } \\
\text { whorl }\end{array}$ & $\begin{array}{l}\text { No. of } \\
\text { primary } \\
\text { spiral } \\
\text { threads on } \\
\text { penul- } \\
\text { timate } \\
\text { whorl }\end{array}$ & $\begin{array}{c}\text { No. of } \\
\text { primary } \\
\text { spiral } \\
\text { threads } \\
\text { on body } \\
\text { whorl }\end{array}$ \\
\hline Holotype & 90.2 & 41.5 & 48.9 & 22.2 & 51.8 & 32.5 & 18.9 & 16.8 & $4: 2$ & $3: 3$ & 5 & 7 & 12 \\
\hline $\begin{array}{l}\text { Paratype; NM, } \\
\text { H209. }\end{array}$ & 100.3 & 47.1 & 53.7 & 23.0 & 53.4 & 34.2 & 19.8 & 17.7 & $5: 3$ & $3: 3$ & 5 & 7 & 11 \\
\hline $\begin{array}{l}\text { Paratype; NM, } \\
\text { H1386. }\end{array}$ & 88.0 & 42.8 & 45.4 & 21.8 & 53.5 & 33.1 & 21.0 & 20.7 & $5: 4$ & $3: 3$ & 5 & 6 & 11 \\
\hline $\begin{array}{l}\text { Paratype; NM, } \\
\text { H1381. }\end{array}$ & 104.6 & 46.7 & 58.0 & 24.7 & 56.1 & 35.9 & 25.4 & 18.3 & $5: 4$ & $3: 3$ & 4 & 7 & 11 \\
\hline $\begin{array}{l}\text { Paratype; NM, } \\
\text { H1384. }\end{array}$ & 85.4 & 41.5 & 43.9 & 22.2 & 45.8 & 31.9 & 14.2 & 13.9 & $5: 3^{*}$ & $3: 3$ & 4 & 6 & 11 \\
\hline $\begin{array}{l}\text { Paratype; ANSP, } \\
234122\end{array}$ & 100.8 & 44.2 & 57.2 & 23.3 & 52.2 & 34.2 & 22.3 & 18.5 & $6: 2^{*}: 0$ & $3: 2: 1$ & 0 & 6 & 10 \\
\hline $\begin{array}{l}\text { Paratype; ANSP, } \\
216867\end{array}$ & 74.0 & 36.1 & 37.9 & 20.2 & 46.4 & 29.4 & 18.8 & 12.3 & $4: 3$ & $3: 3$ & 4 & 7 & 12 \\
\hline $\begin{array}{l}\text { Paratype; USNM, } \\
718655\end{array}$ & 91.9 & 46.4 & 46.0 & 20.9 & 51.2 & 35.5 & 16.0 & $12.0^{*}$ & $5: 3$ & $3: 2: 2$ & $\begin{array}{l}6 \text { (very } \\
\text { faint) }\end{array}$ & 9 & 13 \\
\hline $\begin{array}{l}\text { Paratype; MCZ, } \\
272753\end{array}$ & 69.0 & 33.4 & 36.2 & 15.6 & 35.2 & 24.2 & 11.7 & $9.3^{*}$ & $4: 2$ & $3: 3$ & 5 & 6 & 11 \\
\hline $\begin{array}{l}\text { Paratype; MCZ, } \\
263403\end{array}$ & 80.8 & 37.2 & 44.4 & 19.5 & 48.4 & 28.1 & $20.8^{*}$ & 17.4 & $4: 3$ & $3: 3: 2$ & 0 & 6 & 12 \\
\hline $\begin{array}{l}\text { Paratype; ANSP, } \\
272287\end{array}$ & 80.7 & 36.0 & 45.2 & 19.0 & 47.2 & 29.2 & 19.4 & 16.0 & $4: 2^{*}$ & $3: 3$ & 0 & 6 & 11 \\
\hline $\begin{array}{l}\text { Paratype; ANSP, } \\
272287\end{array}$ & 84.9 & 37.9 & 46.9 & 19.5 & 46.0 & 29.1 & 28.7 & $12.1^{*}$ & $5: 1^{*}: 0$ & $3: 3$ & 0 & 6 & 12 \\
\hline $\begin{array}{l}\text { Paratype; AMS, } \\
\text { C. } 84219\end{array}$ & 79.6 & 38.2 & 41.7 & 18.5 & 46.0 & 27.9 & 18.5 & 10.0 & $4: 3$ & $3: 3$ & 5 & 6 & 11 \\
\hline
\end{tabular}

Table 7. Shell measurement and count data for Murex tenuirostrum africanus n.subsp.* ${ }^{*}$ damaged.

tenuirostrum africanus are not certain, and examination of anatomical characters may require our conclusions to be revised.

\section{Murex troscheli troscheli Lischke, 1868}

Figs $13 ; 14 ; 70 \mathrm{D} ; 73 \mathrm{H} ; 82 \mathrm{~A}-\mathrm{C}$; Table 8

Murex troscheli Lischke, 1868: 219._Lischke, 1869: 41, pl. 1, figs 1, 2 (Nagasaki, Japan; location of type not known); Baker, 1894: 223, text fig. 1 (protoconch); Baker, 1897: 376; Hirase, 1914: pl. 8, fig. 35; Hirase, 1934: pl. 108, fig. 6; Smith, 1953: 2, text fig. j, pl. 1, fig. 8; Kira, 1955: 47, pl. 23, fig. 17; Oyama \& Takemura, 1957: pl. 1, fig. 4; Oyama \& Takemura, 1958: pl. 3, fig. 2, pl. 4, fig. 3; Kira, 1959: 59, pl. 23, fig. 16; Abbott, 1962: 71 (fig. in text); Kira, 1962: 64, pl. 24, fig. 16; Melvin, 1966: 94, pl. 37, fig. 12; Cernohorsky, 1967b: 117, pl. 24, fig. 141; Kuroda, Habe \& Oyama, 1971: 139, 211, pl. 39; Hinton, 1972: 34, pl. 17, fig. 1; Kaicher, 1973: fig. 106; Dance, 1974: 122, fig. in text; Radwin \& D'Attilio, 1976: 74, pl. 10, fig. 5; Fair, 1976: 83, pl. 1, fig. 5; Abbott \& Dance, 1982: 129, fig. in text.

Murex ternispina.-Tryon, 1880: 79 (in part), pl. 10, fig. 111 (not of Lamarck).

Murex (Tribulus) troscheli.-Poirier, 1883: 36; Schepman, 1911: 342.
Murex (Tribulus) ternispina var. rufolirata Schepman, 1911: 342 (Siboga stn 306, Savu Sea, $8^{\circ} 27^{\prime}$ S, $122^{\circ} 54.5^{\prime} \mathrm{E}, 247 \mathrm{~m}$; lectotype [here designated] and 4 paralectotypes, ZMA; one specimen each from stns 294 and 312 are here designated paralectotypes; the specimen cited from stn 294 by Schepman is $M$. aduncospinosus).

?Murex (Acupurpura) troscheli.-Vredenberg, 1925: 219.

Murex heros Fulton, 1936: 9, pl. 2, fig. 2 (unknown locality; designated as Russel [= Russell] Island, Solomon Islands by Harasewych, 1980: 142; holotype, BMNH, 1936.5.26.1); Fair, 1976: 48, fig. 27; Cernohorsky, 1978: 64, pl. 17, fig. 8; Kaicher, 1980: fig. 2567 (holotype); Harasewych, 1980: 141, figs 1-3; Abbott \& Dance, 1982: 130, fig. in text.

Murex troscheli troscheli.-Altena, 1950: 209.

Acupurpura troscheli.-Allan, 1950: 140.

Murex rufolirata.-Fair, 1976: 73.

Records. ANDAMAN ISLANDS:(BMNH). INDONESIA: 130 $\mathrm{m}$, north of Java (BMNH); $150 \mathrm{~m}$, south-east Bali Sea, near north-east Java (ZMC); Bali (ZMA); Ambon (ZMC); 274 $\mathrm{m}$, north-west of Lombok (ZMA; RML); 247 m, south-west of Timor; $112 \mathrm{~m}$, north-east of Timor (both ZMA). Philippines: $6 \mathrm{~m}$, Davao, Mindanao; $6 \mathrm{~m}$, south coast Bohol Id (both AMS); 280 m, Dumurug Point, Masabate; 246 m, Destacado Id, Samar Sea; 152 m, off Tayabas Light, Luzon (all USNM). TAIWAN: Kao-hsiung (AMNH). JAPAN: 


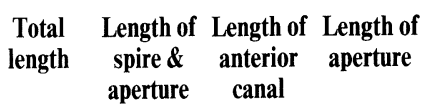

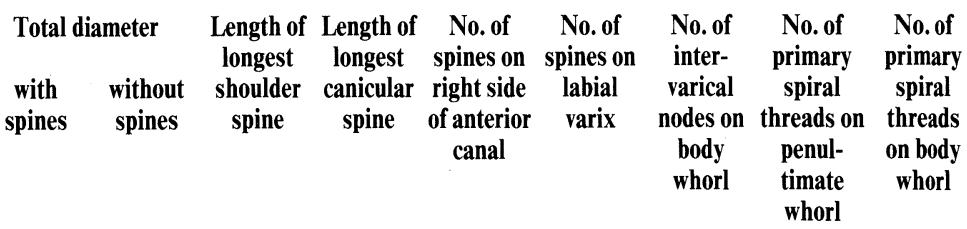

Holotype

176.0

Holotype of $M$.

heros

$\begin{array}{lllll}184.0 & 88.6 & 98.9 & 40.1 & 75.6\end{array}$

63.7

19.1*

$13.3^{*}$

$8: 4: 6 \quad 3: 4: 6: 5$

0

12

18

Kinko Bay,

Kagoshima Pref.,

Japan; AMS,

C.111129 (Fig.

$82 \mathrm{C})$

Philippines; AMS,

C. 106385 (Fig.

$$
82 \mathrm{~A})
$$$$
128.7 \quad 56.4 \quad 73.1
$$$$
32.8
$$

$82.2^{*} \quad 46.8$

38.2

28.

$7: 5: 2 \quad 4: 4: 5: 2 \quad 0$

7

Solomon Ids;

AMS, C.36392

(Fig. 82B)

$\begin{array}{llll}173.0 & 78.1 & 96.0 & 35.9\end{array}$

$81.7 \quad 55.0$

$25.5 \quad 21.2^{*} \quad 8: 6^{*}: 8 \quad 4: 4: 6: 5$

(

Table 8. Shell measurement and count data for Murex troscheli troscheli Lischke. $^{*}=$ damaged.

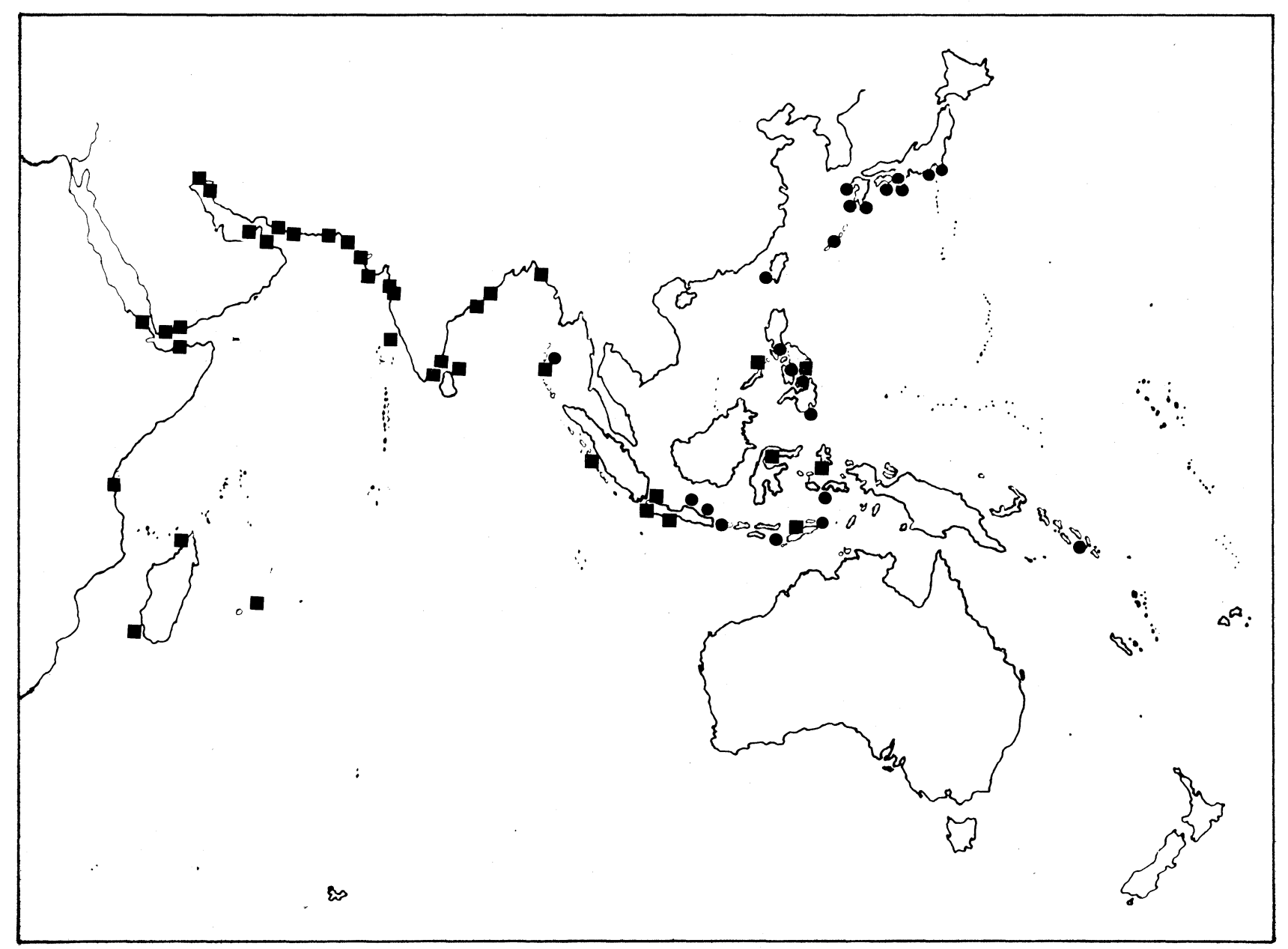

Figure 13. Distribution of $M$. troscheli troscheli Lischke (circle), and M. carbonnieri (Jousseaume) (square). 

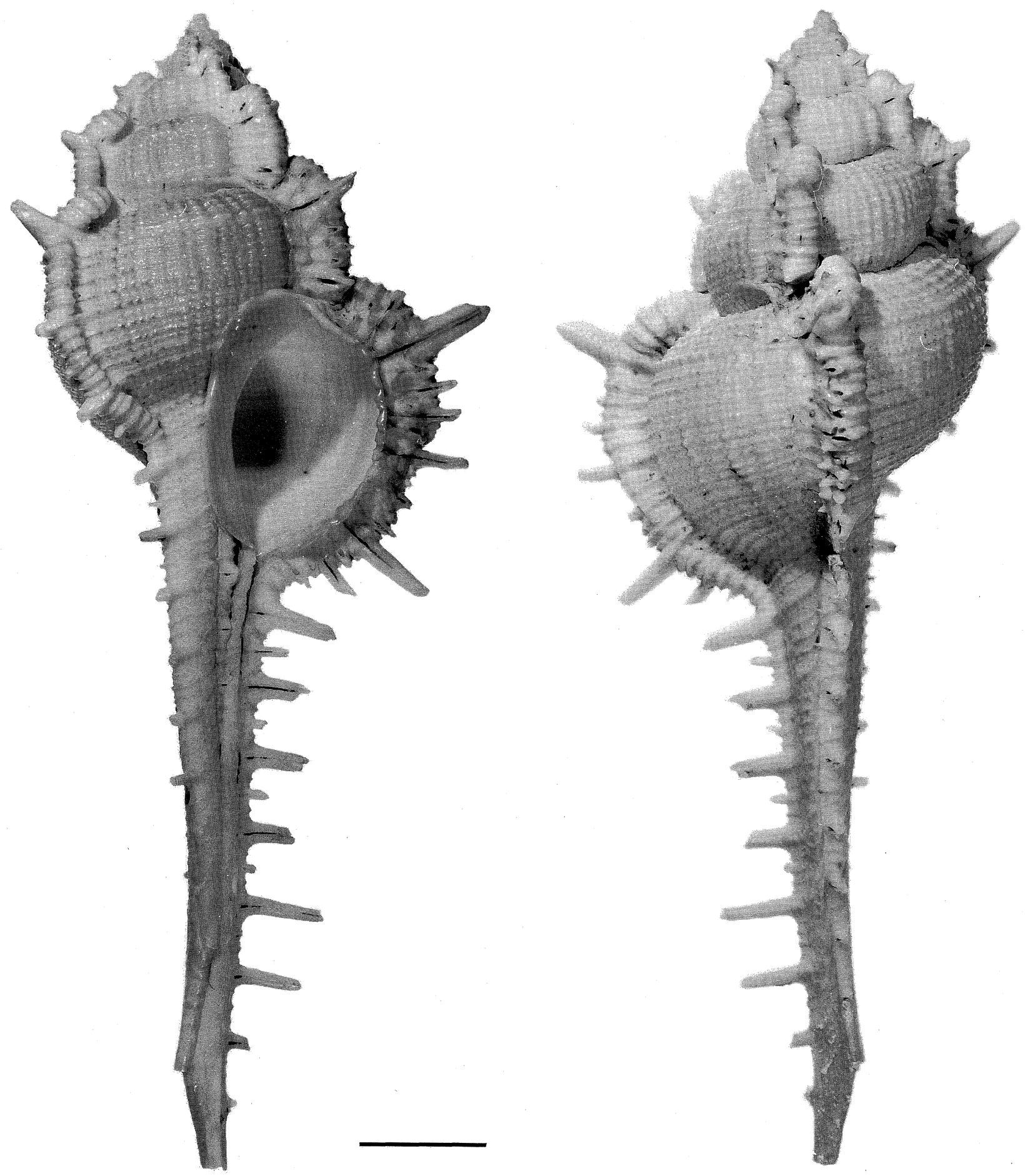

Figure 14. Murex troscheli troscheli Lischke. Holotype of M. heros Fulton; unknown locality (BMNH, 1936.5.26.1). Scale $2 \mathrm{~cm}$. 
Ryukyus (ANSP); Tosa, Shikoku (AMNH; BPBM); Kyoto (AMS); Nagasaki (HUM); Nagashima Id, south Kyushu (ANSP); 82-91 m, Chirinshima, Kagoshima Bay (BPBM); 109 m, Kagoshima (USNM; BPBM); 'Kinko Bay', ShinJima, Kagoshima Pref. (AMS); Enoshima (IRSB); Tanabe Kii (IRSB; AMS); Honshu (AMS); Kii (ANSP; NMW; AMS); 109 m, off Kii (BPBM); Wakayama Pref. (USNM); Tateyama, Chiba Pref. (BPBM; ANSP); Tokyo Bay (USNM). SOLOMON ISLANDS (AMS).

Other records. SOLOMON ISLANDS: Russell Id (Harasewych, 1980).

Fossil records. Vredenberg (1925) records this species from the Pliocene Mekran Beds of Pakistan, but his material is unfigured and we have not examined it. It may be $M$. carbonnieri.

Description. SHELL. Very large (up to $200 \mathrm{~mm}$ in length), with eight teleoconch whorls.

Protoconch of about two and one-half convex volutions, terminating in a weakly curved varix.

Spiral ornamentation on first two teleoconch whorls masked by axial ornament; third whorl with indistinct, brown-coloured cords at shoulder, periphery and suture. On fourth whorl, two or three major spiral cords with alternating minor ones. Body whorl and siphonal canal covered with regularly alternating primary, secondary and tertiary cords.

Axial ornamentation on first two teleoconch whorls of nine, sharply angulate ribs with short, open lamellar spinelet at shoulder. On third whorl every third rib strengthened into varix with long, closed spine at shoulder, intermediate ribs swollen, rounded, non-spinose intervarical ridges. By fifth whorl, third axial ridge added at adapertural end of intervarical area. On later whorls, intervarical axial ridges increasing in number, but weakening in strength, until almost smooth on body whorl except for inconspicuous axial undulations on subsutural ramp. Three low, rounded varices per whorl, each with complicated arrangement of first, second and third order spines. Major spirals at intersection of varices drawn out into long, closed spines; shoulder spine strongest and recurved apically, that at periphery almost as strong but not so recurved; remaining major spiral cords each with long, closed spine almost straight but slightly curved adaperturally at distal ends. Secondary spiral cords produced into closed spines, somewhat shorter than those on major cords and more adaperturally directed. Tertiary spines almost as long as secondary ones, directed somewhat more adaperturally at approximately $45^{\circ}$ to major spines. Spination pattern (anteriorly from suture) with tertiary, secondary, tertiary, primary (shoulder), tertiary, secondary, tertiary, primary (periphery), tertiary, secondary, tertiary, primary (base), tertiary, secondary. Siphonal canal with regularly alternating primary, secondary and tertiary spines; primary spines very long, recurved adaperturally at distal ends, the second from base of body whorl longest, succeeding spines progressively shorter anteriorly. Moderately long secondary spines alternate with primary spines and directed at about $45^{\circ}$ to primary spines; small, needle-like, adaperturally-directed tertiary spinelets at $90^{\circ}$ to primary spines.

Suture very impressed, forming deep, narrow channel.

Aperture ovate; margin of outer lip crenulated by shallow depressions extending from grooves on varical spines. Labral tooth inconspicuous; anal notch shallow; posterior end of inner lip appressed, the anterior three-quarters narrow, free-standing, smooth.

Siphonal canal long; previous canals fused into tube open by narrow slit; recurved at distal end; spinose for almost entire length.

Colour creamy white to light tan, slightly darker immediately in advance of each varix; characteristically marked by having each spiral cord coloured reddish brown, intensity of colour relative to strength of cord with primary cords darkest; aperture white, with brown dots in crenular depressions; interior white.

DIMENSIONS. See Table 8.

OPERCULUM. Reddish brown; subterminal nucleus with ten to twelve heavy concentric ridges; faint median crease along length.

PENIS. Long, distal half bent anteriorly when at rest, tapering to filament-like distal end (Fig. 70D).

Remarks. There is little difficulty in separating the shell of $M$. troscheli from other species of Murex s.s. The large size, brown colour bands and impressed suture are characteristic. The type specimen of $M$. heros has been compared with typical $M$. troscheli and found to be essentially similar. Specimens from the Solomon Islands are very similar to the type of $M$. heros and are also very close to $M$. troscheli in all essential shell characters except shell thickness; relatively stronger varices, which are more deeply excavated abaperturally; shorter varical spines; and distinctly undulating spiral cords, which are coloured brown in the crests resulting in a dotted spiral cord in contrast to the solid colour in the typical form. We conclude that $M$. heros is not specifically separable from $M$. troscheli. It is probable, however, given more material and better distributional data, that a case could be made for recognising $M$. heros as a geographic subspecies. Radwin \& D'Attilio (1976) include $M$. heros in the synonymy of $M$. troscheli without any discussion.

Cernohorsky (1978) has stated that this species has been recorded from the Great Barrier Reef, Australia but we have not seen any specimens from this area.

As noted in the synonymy, the specimens on which the name $M$. ternispina var. rufolirata is based are juvenile $M$. troscheli, except one (from Siboga stn 294) which is $M$. aduncospinosus.

Murex forskoehlii Röding, 1798

Figs 6; 70E; 74A; 82D-F; Table 9

Murex tribulus.-Linné, 1758: 746 (No. 444) (in part: citations of Gualtieri, 1742: pl. 31, fig. A(1-3); Colonna, 
1616: pl. 60, fig. 6); Gmelin, 1791: 352 (in part, cites Colonna and Gualtieri figures); Reeve, 1845: pl. 20, fig. 82; Tapparone-Canefri, 1875: 572 (in part); Sowerby, 1879: 2, pl. 1 (of Murex), fig. 3; Tryon, 1880: 77 (in part), pl. 9, fig. 107; Sturany, 1903: 30 (238); Moazza, 1939: 155; Taylor, 1954: 1111; Vokes, 1964: pl. 1, fig. 2; Barash \& Danin, 1972: 311 (see for additional minor references) (not of Linné).

Murex forskoehlii Röding, 1798: 145 (refers to Murex tribulus Gmelin, which cites Gualtieri, 1742: pl. 31, fig. A (1-3) and Colonna, 1616: pl. 60, fig. 6. Colonna is the first figure cited and we have chosen this as the type figure of the species. Location of illustrated specimen unknown. Röding states that the species is "Arabian").

Murex ternispina._Kiener, 1843: 6, pl. 8, fig. 1, pl. 9, fig. 1; Issel, 1869: 137; Newton, 1900: 511; Oostingh, 1925: 139 (in part); Vokes, 1970: 183 (not of Lamarck).

?Murex occa.-Küster \& Kobelt, 1869: 74 (in part), pl. 26, fig. 4 (not of Sowerby).

Murex tribulus var. aduncospinosus.-Sowerby, 1879: 2, pl. 1 (of Murex), fig. 4 (not of Sowerby, 1841).

Murex(Tribulus) tribulus.-Poirier, 1883: 32 (not of Linné, 1758).

Murex (Acupurpurea) (sic) tribulus.-Pallary, 1938: 27.

Murex s.s. sp.-Fair, 1976: 88, pl. 4, fig. 47.

Murex (Murex) sp. aff. M. ternispina.-Vokes, 1978: 377, pl. 1, figs 4, 5 .

Records. MEDITERRANEAN: Beirut Harbour, Lebanon (MCZ); Port Said, Egypt (MCZ: ZMA); 27-37 m, El Arish, Egypt (AMS); $27 \mathrm{~m}, 64 \mathrm{~km}$ west of Bardawil, east Mediterranean (AMS). SUEZ: 2-3 m, north Bitter Lakes (AMS); Bitter Lakes (ZMA; SMF; RML); beach and lagoon on east and west sides of Bitter Lakes (RML); north shore of Lake Timsah (BMNH); Lake Timsah, Isma'iliya (IRSB); Isma'iliya (SMF). GULF OF SUEZ: (RML; NMV; IRSB); 65 $\mathrm{m}$, north Gulf of Suez (BMNH); $8 \mathrm{~m}$, 'Ature' (AMS); Ras Matarma, Sinai (RML); Ras Za'faranah (FMNH); Al Bala'im, Sinai; El Tur, Sinai; Gulf of Gemsa; 'Ras Shukheir' (all RML); Ras Gharib, Egypt (RML). GuLF OF AQABA: Elat (ZMC; AMS); $20 \mathrm{~m}$, south of Elat; Nuweiba (both AMS). RED SEA: (BMNH; ZMA; NMV; USNM; AMS); Hurghada, Egypt (RZM); Ra's Banas, Egypt (USNM); Dishet Abu Mingar, Egypt (ZMA); Jiddah, Hejaz, Saudi Arabia (RML); 55-75 km north of Jiddah, Saudi Arabia (ZMA; USNM); Assab, Eritrea (RML). Persian Gulf: 11-67 m (RML); Ras Tannurah, Saudi Arabia (USNM).

Fossil records. Pleistocene: Newton (1900) recorded this species from raised beaches in the Red Sea (as $M$. ternispina).

Description. SHELL. High-spired, large (up to $115 \mathrm{~mm}$ in length), with eight inflated teleoconch whorls.

Protoconch of about one and three-quarters bulbous volutions, ending at small, crescentic varix.

Spiral ornamentation on first two teleoconch whorls of one strong cord at shoulder and second at suture. On fourth whorl, intermediate secondary cord of almost primary strength added between first two. Weak tertiary spiral threads alternate with primary and secondary cords so that surface of body whorl and siphonal canal marked by alternating spiral cords of three orders of magnitude.

Axial ornamentation on first two teleoconch whorls of eight or nine sharp, angulate ribs drawn out into sharp, open lamellar spinelets at shoulder and periphery. On third whorl, every third rib strengthened into varix with long, closed, apically directed spine at shoulder; intermediate pair of ribs forming nodulose, weak axial ridges. On fourth whorl, third nodose ridge added at adapertural end of intervarical area. On subsequent whorls, intervarical ridges evanescent, replaced by numerous growth lamellae giving malleated appearance to shell surface. Three low varices per whorl, each with series of stout spines; three primary spines somewhat larger than others, shoulder spine longest and apically directed; peripheral and basal primary spines relatively straight. Secondary spine anterior to each primary spine, in some specimens almost as long as primary spines; weak, adaperturally directed, tertiary spinelets on some specimens. Siphonal canal with five, relatively short, coarse spines, slightly recurved adaperturally.

Suture simple, crossed by axial growth lamellae.

Aperture ovately-rounded; margin of outer lip notched by continuation of groove on varical spines, size of notch proportionate to strength of spine. Labral tooth small; anal notch weak. Posterior end of inner lip slightly appressed, remaining three-fourths free-standing, narrow, smooth.

Siphonal canal moderately long to long, distally recurved; terminations of previous canals fused into tube, open by narrow slit; almost entire length spinose.

Colour creamy white, maculated by tan blotches; spiral cords lighter in colour; aperture white, with brown spots in notches between crenulations, leading to brown lines passing into interior of shell, latter yellowish brown between these lines.

DiMENSIONS. See Table 9.

OPERCULUM. Yellowish brown; subterminal nucleus with ten heavy concentric ridges, laminated on side adjacent to outer lip; indistinct median crease along length.

PENIS. Tapering, lacking filament (Fig. 70E).

Remarks. The shell of Murex forskoehlii may be distinguished from other species of the tribulus group that also have a protoconch of one and one-half bulbous whorls (M. falsitribulus, $M$. aduncospinosus and $M$. kerslakae n. sp.) by the small labral tooth and sculptural details. It differs from $M$. falsitribulus in having fewer (9 versus 12) axial ribs on early whorls and from many specimens of $M$. aduncospinosus and $M$. kerslakae, which also have nine, in having these strongly angulate, not moderately angled or rounded. It also differs from $M$. aduncospinosus and $M$. kerslakae in having more numerous spines and a shorter, bent anterior canal. This species has been regarded as $M$. tribulus by several authors (see synonymy) and also as $M$. ternispina, but Vokes (1978) pointed out that it has been misidentified.

The tendency to develop a spotted colour pattern on the shell recalls $M$. carbonnieri and these two 


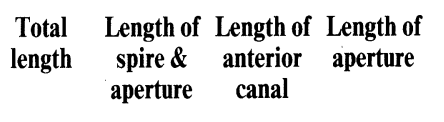

Ature, Gulf of

Suez; AMS,

C. 127317

N. shore of Lake

Timsah,

Isma'iliya, Egypt;

BMNH.

N. shore of Lake

Timsah,

Isma'iliya, Egypt;

BMNH.

$20 \mathrm{~km}$, S. of Eiolat,

Gulf of Aqaba;

AMS, C.127314

Nuweiba, Sinai,

Gulf of Aqaba;

AMS, C. 138490

(Fig. 82E)

Nuweiba, Sinai,

Gulf of Aqaba;

AMS, C. 138490

(Fig. 82E)

$$
\begin{array}{r}
107.5 \\
114.8 \\
101.4 \\
93.8 \\
103.8
\end{array}
$$$$
114.8 \quad 65.7
$$

65.7

93.8

40.1

45.0

59.5

21.4
51.0

28.9

18.0

22.6

$8: 2$

$4: 4: 0$

(1)

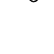

$\begin{array}{lllll}103.4 & 53.4 & 50.2 & 29.0 & 8\end{array}$

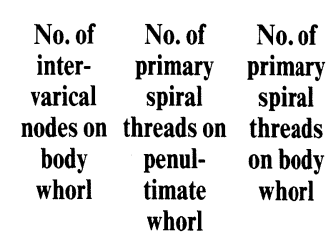

Table 9. Shell measurement and count data for Murex forskoehlii Röding.* = damaged.

species may, indeed, be closely related.

The name $M$. forskoehlii is used for this species for the following reasons. (a) Röding indirectly refers to two early figures of this taxon, including the first cited by referring to his species as Murex tribulus of Gmelin. No previous figure designations are known to us. (b) Röding (1798) specifically refers to this species as being Arabian. Only three shallow-water Murex species occur in that area: M. scolopax, $M$. carbonnieri and the present species. Röding also states that the species is banded (or striped). This description could possibly apply to all three species, although it fits $M$. scolopax best. (c) Given the locality cited by Röding, we do not believe that this name should be regarded as a synonym of $M$. tribulus as suggested by Dall (1915) and Vokes (1971a) because that species does not occur in the Arabian area. Similarly, the other species cited by Gmelin as the typical form of M. tribulus, to which Röding refers his species name (Röding restricts $M$. tribulus to Gmelin's variety B of M. tribulus), does not occur in the Arabian area, with the exception of a possible figure of $M$. carbonnieri. The other figures include $M$. tribulus, $M$. pecten, $M$. spicatus n.sp., $M$. trapa and possibly $M$. troscheli. Some of the figures are of $M$. scolopax, this being referred to Gmelin's var. B, which Röding regarded as typical $M$. tribulus. (d) The use of the name $M$. forskoehlii for $M$. scolopax or $M$. carbonnieri would predate both. Consequently, in the interests of stability, and to avoid the necessity to introduce another new taxon, we have selected
Colonna's figure as the type of the otherwise nameless Red Sea species. This figure shows the features of the species very clearly and, consequently, we see no necessity to choose a neotype.

This species lives in the Mediterranean Sea where it is a recent immigrant, the first record being that of Pallary (1938: 27). It is extremely common in the Suez Canal, thriving in Lake Timsah and the hypersaline lagoons (Moazzo, 1939: 156; Taylor, 1954: 1111). Taylor (1954) has discussed the variation of this species in the Great Bitter Lake, Egypt.

Murex aduncospinosus Sowerby, 1841

Figs 15; 16; 71D-F; 75D-H; 77G,I; 81B,C, F-H; Table 10

Murex ternispina var. aduncospinosus (Beck MS) G.B. Sowerby, 1841a: 1, pl. 188, fig. 68 (East Indies; figured specimen apparently lost; specimens bearing this name in BMNH; Philippine Islands, Cuming Colln and two specimens bearing Beck's MS name in ZMC from the "Southern Ocean." These latter specimens are similar to the BMNH specimens but cannot be regarded as possible types as it is extremely unlikely that Sowerby saw them).

Murex aduncospinosus.-Reeve, 1845: pl. 23, fig. 93; H. \& A. Adams, 1858: 71; A. Adams, 1863: 370; Brazier, 1893: 47 (in part); Dunker, 1882: 3; Kaicher, 1973: fig. 108; Fair, 1976: 18, pl. 2, fig. 13; Houart, 1979: 125, pl. 2, figs 3A-D; Abbott \& Dance, 1982: 130, fig. in text.

?Murex concinnus Reeve, 1845: pl. 25, fig. 104 (no location; 
types not located in BMNH); Küster \& Kobelt, 1870: 122, pl. 36, fig. 11; Sowerby, 1879: 2, pl. 1 (of Murex), fig. 5; Tryon, 1880: 79, pl. 11, fig. 122; Kaicher, 1974: fig. 543; Fair, 1976: 32, pl. 1, fig. 12; Houart, 1979: 128, pl. 3, figs 7, 7A, 7B and two text figures; Abbott \& Dance, 1982: 130, fig. in text.

?Murex tribulus. - H. \& A. Adams, 1858: 71, pl. 8, fig. 1C (not of Linné).

?Murex ternispina.-Küster \& Kobelt, 1868: 57, pl. 22, figs 3, 4 (not of Lamarck).

Murex (Tribulus) aduncospinosus._Kobelt, 1877: 145; Poirier, 1883: 31.

Murex ternispina.-Tryon, 1880: 78 (in part), pl. 10, fig. 114; Brazier, 1893: 46 (in part) (not of Lamarck).

Murex (Tribulus) ternispina.-Watson, 1885: 149 (not of Lamarck).

?Murex (Murex) tribulus var. aduncospinosus. - Baker, 1897: 373

Murex (Tribulus) aduncospinosus var.-Schepman, 1911: 343.

Murex (Tribulus) aduncospinosus var. concinna.Schepman, 1911: 343, pl. 24, fig. 9 (radula).

?Murex (Murex) verbeecki bentarsariensis Oostingh, 1940: 59, pl. 19, figs 335-337 (Süd-Bantam, Java; Pliocene; location of types not known).

Murex trapa.-Cernohorsky, 1967a: 115 (in part), pl. 14, fig. 1; Cernohorsky, 1967b: 117 (in part), pl. 23, fig. 138; Kaicher, 1974: fig. 538 (not of Röding).

?Murex (Murex) sp. cf. M.(M.) rectirostris aduncospinosus.-Shuto, 1969: 104.

?Murex aduncospinosus.-Fair, 1976: 18, pl. 2, fig. 13.

Murex cf. concinnus.-Fair, 1976: 32, pl. 4, fig. 45.

Murex cf. tribulus.-Fair, 1976: 88, pl. 4, fig. 44 (not of Linné).

Murex unidentatus.-Fair, 1976: pl. 2, fig. 22; Houart, 1979: 132 (in part) (not of Sowerby).

Murex s.s.-Fair, 1976: 87, pl. 2, figs 26, 26 a.

Murex (Murex) tribulus. -Ladd, 1982: 43, pl. 9, fig. 7 (not of Linné).

Records. ANDAMAN ISLANDS: (DMNH; ZMC; BMNH). Gulf OF THAILAND: $135 \mathrm{~m}$ (ZMC). SingaPORE: (ZMC); dredged, Pulau Sudong (AMS). SARAWAK: $104 \mathrm{~km}$ north of Sarawak (USNM); 119-157 m, north of Kuching (BMNH). SABAH: $29 \mathrm{~m}, 25 \mathrm{~km}$ south-south-west of Balambangan Pulau (WAM); Agal Bay (WAM); Sapang Ayer; Sandakan (both USNM); $51 \mathrm{~m}$, north of Kota Kinabalu (BMNH). INDONESIA: Bangka, Sumatra (ZMA); 29 m, Selat Sunda (ZMC); 22 m, off north-east Java (ZMC); Slamadatang Teluk, Banten, Java (USNM); Keledjitan, Banten Java (USNM); $60-88 \mathrm{~m}$, north of Kangean (ZMC; RML); 82-88 m, north of Madura (ZMA); Java Sea (RML, ZMC); beach, $14 \mathrm{~km}$ north of Mahakam River mouth, Kalimantan (AMS); $49 \mathrm{~m}$, Banguey Channel, Sabah (WAM); 2029 m, off Makassar, Sulawesi (ZMA); 21-96 m, off Makassar (NHMP); 59 m, 'Borneo Bank', Makassar Straits; 72 m, off Sumalata, north Sulawesi; Moluccas; 36 m, Dangar-Besar Pulau, Saleh Teluk, Sumbawa; $1091 \mathrm{~m}$, Flores Sea; $2050 \mathrm{~m}$, south of Timor; $35 \mathrm{~m}$, east of Timor (all ZMA). Irian Barat: $46-91 \mathrm{~m}, 1.5 \mathrm{~km}$ east of Daliwi, east Padeaido Ids (ANSP). PHILIPPINES: Mantaquin, Palawan (USNM); 37-49 m, $15 \mathrm{~km}$ west of Cape Melville Light, Balabac Id, south Palawan (WAM); Calapan, Mindoro (AMNH); 5-16 m, Baler, Luzon (USNM; DMNH); Manila Bay, Luzon (MCZ); Mariveles Bay (DMNH); between Corregidor and Mariveles Bay (MCZ); Batangas (USNM); Tagcawayan, Luzon (AMS); Masbate Id (DMNH; MCZ;
USNM; NMV; ANSP; AIM); Cawayan, Masbate (ANSP); $44 \mathrm{~m}$, Antonia Id, off east Panay; $47 \mathrm{~m}$, north-east Panay; Iloilo, Panay; $91 \mathrm{~m}$, north off Marinduque; Victorias, Negros; Santa Cruz, Negros (all USNM); Cebu (NMV); 0-6 m, off Santa Rosa Id, near Cebu (AMS); $27 \mathrm{~m}$, off Tanauan, Leyte; 146 m, north of Biliran Id, Samar Sea (both USNM); 37-73 m, Magueda Bay, Samar (MCZ); Catbalogan, Samar (MCZ); $44 \mathrm{~m}$, south-east of South Gigante Id; $47 \mathrm{~m}$, north of Daram Id; $58 \mathrm{~m}$, Daram Channel (all USNM); Borongan Village, east Samar (DMNH; ANSP); Zamboanga, Mindanao (MCZ); Davao, Mindanao (DMNH); Mambajao, Camiguin (ANSP). HoNG KoNG: (RML; NMV); 18-25 m, south-east Hong Kong; 61-97 m; $87-97 \mathrm{~m}$, and $116-128 \mathrm{~m}$, off Hong Kong; trawled, entrance to Tolo Harbour; 20 m, near Tap Mun Chau, Mirs Bay (all AMS). TAIWAN: (AMS). CHINA: (IRSNB; NMV; AMS); 'Ha Trai Huang' (IRSB); $161 \mathrm{~m}$, north-west off Tung-sha Tao (USNM); $180 \mathrm{~m}$, off Pratas Id (USNM); China Sea (USNM). JAPAN: (AMS); Kii (BMNH); 100 m, Tsushima Strait (ZMC). SolomONS: (AMS). FIJI: (NMV). Viti Levu: Suva Point (USNM); Nandi Bay; Suva; Tailevu; Deuba (all AMS); 'Natoui' (WAM). TONGA: Pangaimotu, Tongatapu (NMNZ).

Fossil records. Pleistocene marls, Espirito Santo, Vanuatu (USNM; recorded by Ladd, 1982). ?Pliocene: South Banten, Java (types of $M$. verbeeki bentarsariensis).

Description. SHELL. Varying in size, typical form of medium size $(60-90 \mathrm{~mm}$ in length) but variant populations from China Sea larger (up to 110 $\mathrm{mm}$ in length); up to about eight teleoconch whorls.

Protoconch of about one and three-quarters bulbous volutions, sometimes developing angulate keel immediately adjacent to suture; terminating in small, straight varix.

Spiral ornamentation on first teleoconch whorl of two rounded cords; relatively strong secondary cords intercalated on second whorl, increasing in strength until nearly equal to primary cords. Few tertiary threads appear on succeeding whorls; body whorl and siphonal canal covered with series of alternating stronger and weaker cords.

Axial ornamentation of about nine swollen, rounded to weakly angled ribs on first two teleoconch whorls, these smooth or bearing rudimentary spine; on third whorl every third rib strengthened into varix, with short closed spine at shoulder; intermediate axial ribs become high, rounded axial ridges. On fourth or fifth whorl, third axial ridge developed at adapertural part of intervarical area; fourth axial ridge appears by seventh whorl, but axials then weaken, until, on body whorl, their presence indicated only by undulations on spiral cords. Three rounded varices per whorl, each with three, straight primary spines at shoulder, periphery, and base of whorl; spine at shoulder not much longer than others. Smaller secondary spine anterior to each primary spine; alternating tertiary spinelets on apertural face sometimes developed from tertiary threads (developed in specimens from China Sea, almost lacking in typical specimens). Siphonal canal with four or five (rarely small sixth) short primary spines, second one from base of body whorl longest; small to 
very small, slender, adaperturally directed, secondary spines intercalated between primary spines. Strength and development of spines on canal, like those on spire, vary in specimens from different populations; particularly poorly developed in specimens from China Sea.

Suture impressed to moderately channelled.

Aperture ovate; outer lip crenulated, notches developed as extensions of grooves in varical spines, size of notches reflecting relative strength of spines; notch at shoulder curving into spinal groove. Inter-notch area posterior to basal primary spine drawn out into a labral tooth (very large in specimens from China Sea, smaller in typical specimens and those from Fiji). Siphonal canal long; previous canals fused into tube, open by narrow slit; spinose for about two-thirds of total length.

Colour variable, often creamy white to tan with primary and secondary spiral cords lighter in colour; area between primary and secondary spirals, including tertiary threads, reddish brown (especially in specimens from Fiji and some from Philippines; in typical form, brown colour restricted to tops of tertiary threads only). Some specimens with several or few dark brown primary spirals (concinnus form). Apertural lips white, with grooves of notches reddish brown.

DimEnSIONS. See Table 10.
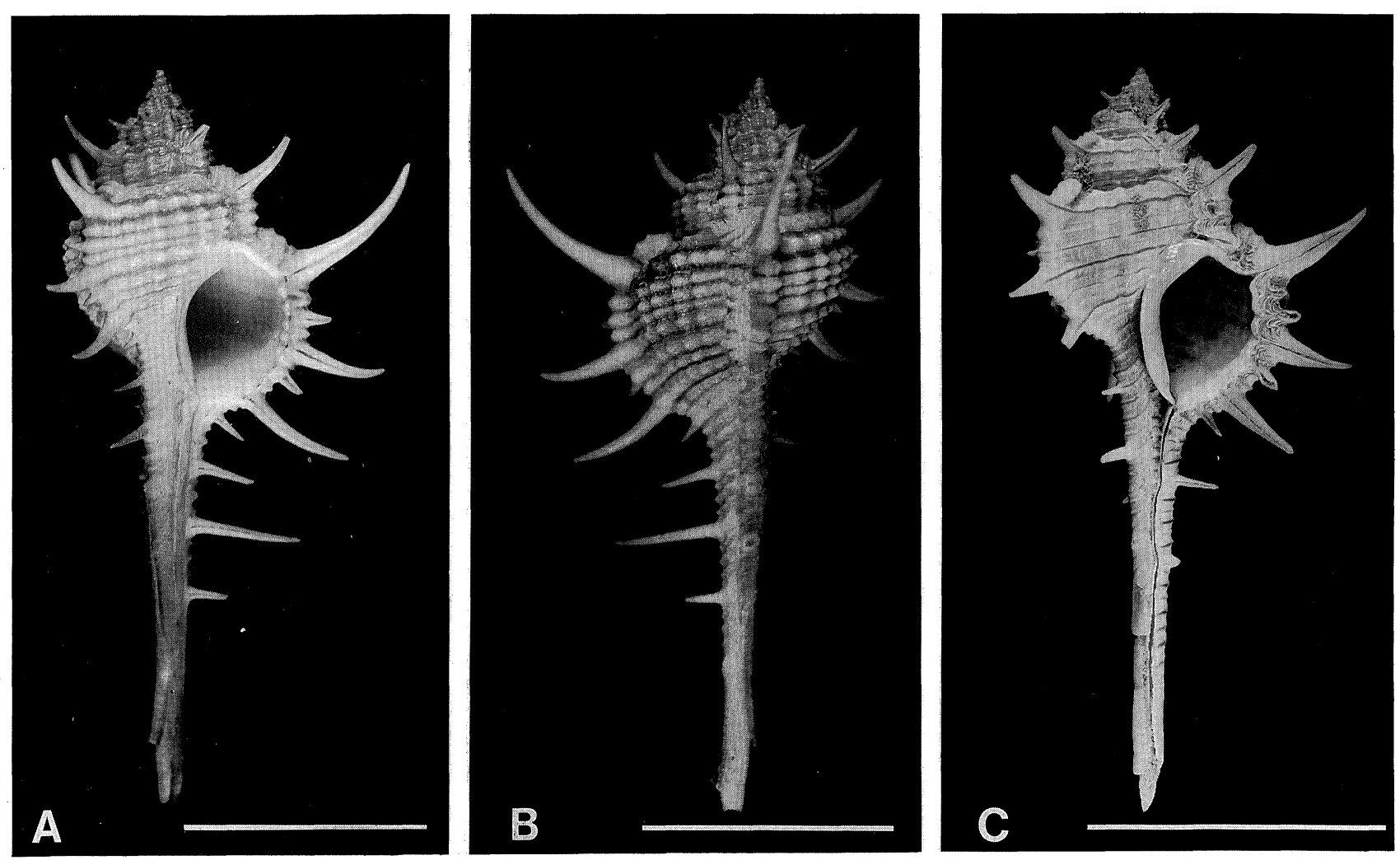

Figure 15. Murex aduncospinosus Sowerby. A,B: possible syntype; Philippine Ids, ex Cuming Colln (BMNH). C: Makassar Straits, $85 \mathrm{~m}$ (NHMP) (concinnus form). Scales $2 \mathrm{~cm}$.

OPERCULUM. Reddish brown with golden tinge; subterminal nucleus, surrounded by numerous faint concentric corrugations.

PENIS. Distal half to third bent anteriorly and forming large filament-like structure (Figs 71D-F).

Remarks. The names Murex aduncospinosus and $M$. concinnus are based on very similar specimens, which are probably conspecific, the most obvious difference being that the shell of $M$. concinnus has some of the spiral ribs coloured brown and that of $M$. aduncospinosus often has the spaces between the spiral ribs brown. Two ZMC specimens, in the same lot, which bear Beck's MS name, show both types of colour pattern but are otherwise almost identical. The specimen with the concinnus colour pattern has a slightly larger labral tooth, more sharply angulate axials on the first two teleoconch whorls and a slightly smaller protoconch. These differences appear to be consistent in specimens of concinnus from the Philippines. Whereas these small differences can be detected in some samples, we have found it difficult to separate these forms consistently, most of the characters in concinnus being found in specimens of 'typical' aduncospinosus. Shells of both of these colour varieties are of light build, have rather short spines, a few brown spiral lines and narrow varices. These forms are found on the continental shelf and in shallower water from the Philippines to southern 
Japan and Indonesia. Another shell form, usually regarded as typical $M$. aduncospinosus because of the specimen figured by Reeve (1845) under this name, is larger, uniformly coloured pale brown, the shell thicker (heavier), and the varices stouter. This form appears to be confined to the China Sea and, as far as we can determine from the available material, there is no sharp demarcation between this form and the typical form. One intermediate shell form is found in shallow water in the Philippines and has uniformlydark colouration, very short spines and narrow varices. A similar form that also shows intermediate morphology is found in Fiji and Samoa. The latter, identified as $M$. trapa by Cernohorsky $(1967 \mathrm{a}, \mathrm{b})$ and M. tribulus by Fair (1976), has the interspaces between the spiral ridges coloured dark brown and has short spines and moderate varices. The Philippines form differs from most populations in having a keel on the last whorl of the protoconch. This character is, however, also seen in a few individuals from other areas, especially Fiji, and intermediates from other localities are found which have the keel just emergent from the suture.

None of the geographic varieties have been named and, although it is possible in many instances to readily recognise them, local populations and individual specimens are often difficult to assign to a particular variety. For this reason we prefer not to formally recognise the geographic races, or $M$. concinnus, as distinct taxa. A greater range of material from the critical overlap areas needs to be examined and larger samples from a range of habitats and depths should be analysed to determine whether or not the relatively trivial characters that appear to distinguish the various forms are consistent. Geographic differentiation has occurred in this species because it presumably has direct development or an abbreviated larval life, as suggested by the morphology of the protoconch. There is some evidence that speciation or subspeciation may have occurred because of some differences in penial morphology (compare Figs 71D and $E$ with $F$ ) but far too little material has been examined to see if these differences are consistent.

Murex verbeeki bentarsariensis differs from the Pliocene species $M$. troscheli verbeeki. according to Oostingh (1940), in the more rounded first two whorls of the teleoconch. The two primary spirals on these whorls have a strong secondary spiral between them that does not appear until the second whorl in M. t. verbeeki. In addition, there are weak varices only on the third whorl, whereas these appear on the

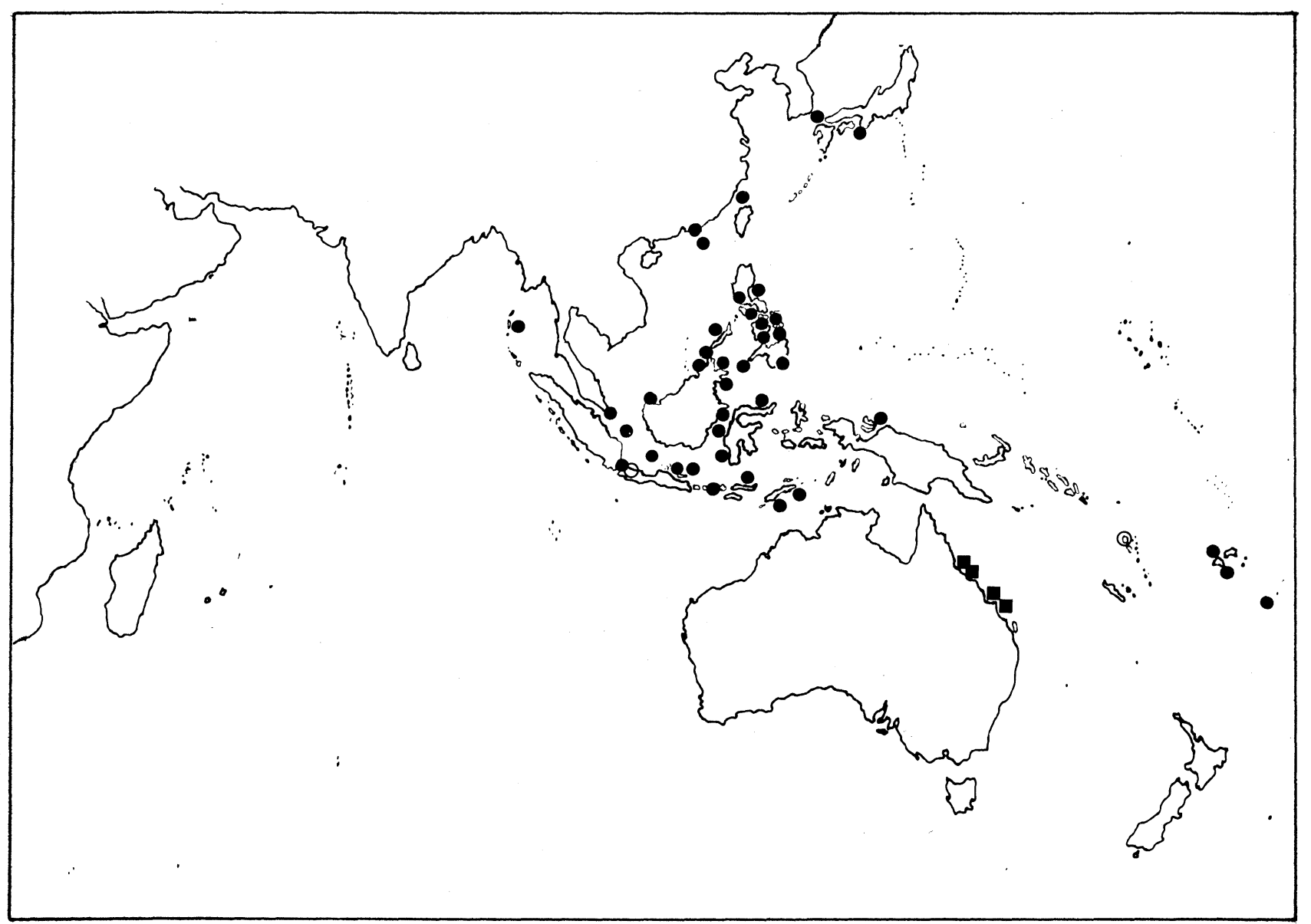

Figure 16. Distribution map of $M$. aduncospinosus Sowerby (circle): $M$. kerslakae n. sp. (square). Open symbols = fossil records. 

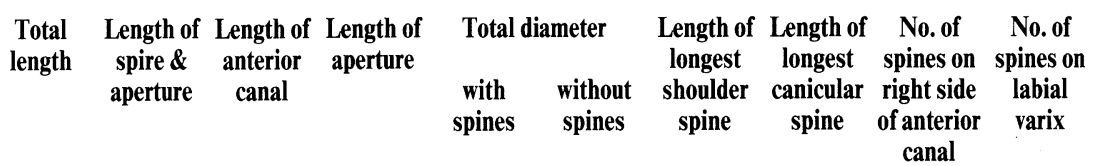

No. of No. of No. of

inter- primary primary varical spiral spiral nodes on threads on threads body penul- on body whorl timate whorl

Cebu, Philippines;

NMV, F.27448

(Fig. 81G)

Baler, Luzon,

Philippines;

USNM, 632540

(Fig. 81B)

$\begin{array}{llll}75.4 & 34.5 & 40.6 & 18.2\end{array}$

Taiwan, AMS,

C.88339 (Fig. 81C

Suva, Fiji; AMS,

C.143941 (Fig.

$81 \mathrm{~F})$

$\begin{array}{llll} & & & \\ & & & \\ & 45.7 & 56.4 & 21.6\end{array}$

$40.2 \quad 28.9$

$101.7 \quad 45.0$

$93.2 \quad 43.8$

$49.4 \quad 19$

$55.5 \quad 34.8$

$18.1 \quad 16.0$

$4: 3: 0$

$3: 3: 4$

0

15

11

Nadi Bay, Viti

Levu, Fiji; AMS,

C.67446 (Fig. 81H)

$\begin{array}{lll}78.6 & 37.1 \quad 42.0\end{array}$

"Philippine Ids";

BMNH, 1974094

"Philippine Ids"

BMNH, 1974094

$90.6 \quad 43.8 \quad 47.6$

$42.0 \quad 17.1$

$47.6 \quad 21.6$

$90.7 \quad 39.7$

51.

20

"Philippine Ids",

BMNH, 1974094

88.

51.5

18.5

$40.4 \quad 29.1$

15.2

13.5

o

12

Philippine Ids;

BMNH, Cuming

Collection. (Fig.

15A,B)

$60.0 \quad 27.2$

34.1

19.4

Philippine Ids;

BMNH, Cuming

Collection. (Fig.

15A,B)

56

6.426.

6.4

Mambajao,

Camiguin Id,

Philippines;

ANSP, 223777

87.8

47.

19.0

36.9

29.1

$11.8^{*}$

8.0

4:3:0

$3: 2: 0$

0

Manila Bay,

Luzon,

Philippines; MCZ,

147499

$\begin{array}{lllllllllllll}109.1 & 55.8 & 53.9 & 25.7 & 56.0^{*} & 37.8 & 16.8^{*} & 10.0^{*} & 3 *: 3: 0 & 3: 2: 0 & 0 & 8 & 13\end{array}$

China; AMS,

C. 35539

M. aduncospinosus

(concinna form)

Malassar Straits,

NHMP, (Fig. 15C)

$11.4 \quad 24.3 \quad 17.5$

8.2

4.3

$2: 1$

$3: 3: 1$

Table 10. Shell measurement and count data for Murex aduncospinosus Sowerby.* = damaged.

second whorl in M.t. verbeeki. The protoconch is said to be similar to $M$. $t$. verbeeki, but only has one and one-half whorls in the one complete specimen available to Oostingh. This taxon appears to us to be so similar to $M$. aduncospinosus that we tentatively included it in synonymy. We have not been able to examine the type material. Wissema's (1947: 176) record of this taxon is based on the large series of $M$. tenuirostrum. This species can be distinguished from the very similar $M$. tribulus and $M$. tenuirostrum by the weakly angulate, usually very weakly spined axial ribs on the first two whorls. In $M$. tribulus these ribs are strongly spinose and in $M$. tenuirostrum simple and rounded.

This species ranges through the central Indo-West Pacific, reaching as far west as Indonesia. A record from Tranquebar, India (ZMC) needs to be confirmed. 
Murex kerslakae n. sp.

Figs 16; 71A; 75I; 81D; Table 11

Murex aduncospinosa.-Coleman, 1975: 276, fig. 757 (not of Sowerby).

Murex nigrospinosus (sic).-Wilson \& Gillett, 1971: 84, pl. 57, fig. 1; Coleman, 1974: 6, fig. in text (not of Reeve).

Murex tribulus.-Radwin \& D'Attilio, 1976, 1976: 72 (in part), pl. 10, fig. 9 (not of Linné).

Murex nigrispinosus.-Hinton, 1978: 33, fig. 4 (not of Reeve).

Type material. HOLOTYPE: (AMS, C.150000), $40 \mathrm{~km}$ north-east off Keppel Bay, Queensland, $60 \mathrm{~m}$, ex N. Coleman. PARATYPES: (AMS, C.106393), same data; 4 paratypes (AMS, C.149484), same data, 46-55 m; one paratype (AMS, C.143953) Keppel Bay, 49 m, ex R. \& D. Brown; five paratypes (QM, ex AMS, C. 149486 (3) and AMS, C.75759 (2)) east of Keppel Islands, Keppel Bay, 46-49 m, Sept. 1970, coll. T. Nielsen; paratype (NHMP, ex AMS, C. 106478), Keppel Bay, 57 m, ex N. Coleman; paratype (AMS,C. 149584) off North Keppel Island, 51 m, coll. T. Nielsen.

Records. AUSTRALIA: Queensland: $4 \mathrm{~m}, 8 \mathrm{~km}$ eastnorth-east of Brook Id Light, east of Rockingham Bay (DMNH); $59 \mathrm{~m}$, south-east of Percy Id (AMS); south-east of Mackay, trawled (WAM).

Description. SHELL. Large (90 $\mathrm{mm}$ in length), with about six teleoconch whorls.

Protoconch of one and three-quarters bulbous, convex volutions, terminating in raised, straight varix; smooth except for weak axial threads on last half whorl.

Spiral ornamentation on first teleoconch whorl of two cords, very weak secondary threads intercalcated on second half whorl increasing in strength until nearly equal to primary cords. A few weak threads present on adult whorls between major spirals.

Axial ornamentation of 9-11 swollen, rounded to weakly angled ribs on first two teleoconch whorls, these rarely bearing short spine at shoulder. On second or third whorl every third rib strengthened into varix with short, narrowly-open spine at shoulder. Intervarical axial ribs strong, rounded, extending from suture to suture, rendered gemmate by spiral cords; three on antepenultimate whorl, three to five on penultimate whorl and body whorl; weaker on body whorl than on rest of shell. Three strong, rounded varices per whorl, excavated on abapertural side; each with three primary spines at shoulder, periphery and base; shoulder and peripheral spines long and straight, shoulder spine longest, basal spine much shorter and curved adapically. Very small secondary spines developed on penultimate whorl in some specimens, secondary and tertiary spines well developed on body whorl between primary spines; tertiary spines projecting at almost $90^{\circ}$ to primary spines. Siphonal canal with five (rarely six) slightly curved primary spines, second from base of body whorl longest; short secondary spines projecting at right angles to primary spines.

Suture weakly to moderately channelled.

Aperture ovate; outer lip crenulated, notches developed as extensions to grooves in varical spines, strength of notches reflecting relative strength of spines, notch at shoulder deepest. Large labral spine formed from inter-notch area posterior to basal spine.

Siphonal canal straight, previous canals fused into tube, open by narrow slit; spinose for about threequarters of total length. Colour white, three very faint yellow-brown bands in some specimens on shoulder, periphery and base; siphonal canal and primary spines tinged with yellow-brown; tips of primary spines usually dark purple. Aperture white, grooves on outer lip sometimes pale brown. Protoconch white.

Dimensions. See Table 11.

OPERCULUM. Reddish brown; terminal nucleus, with weak growth ridges.

PENIS. Distal half broader than proximal part, with two swollen areas into which long slit opens (Fig. 71A). Interior of club-shaped distal end finely ridged, ridges at right angles to longitudinal axis (description based on three specimens).

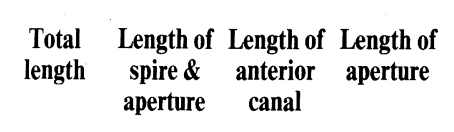

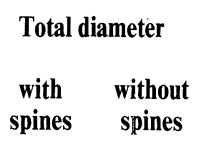

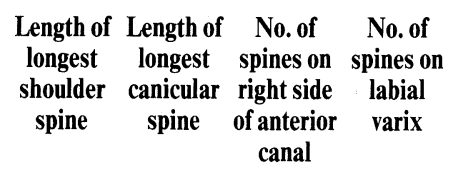

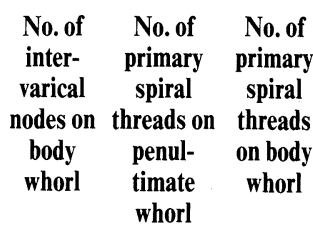

whorl

\begin{tabular}{|c|c|c|c|c|c|c|c|c|c|c|c|c|c|}
\hline Holotype & 78.7 & 32.1 & 46.7 & 16.3 & 51.4 & 27.1 & $22.1^{*}$ & 16.5 & $5: 3: 0$ & $3: 3: 5$ & 0 & 7 & 11 \\
\hline $\begin{array}{l}\text { Paratype; AMS, } \\
\text { C.106393 }\end{array}$ & 73.6 & 29.8 & 44.5 & 15.1 & 50.8 & 25.4 & 24.8 & 13.6 & $5: 2: 2$ & $3: 4: 3$ & 3 & 7 & 14 \\
\hline $\begin{array}{l}\text { Paratype, AMS, } \\
\text { C. } 75759\end{array}$ & 85.5 & 38.9 & 46.3 & 18.7 & 57.3 & 30.5 & $24.1^{*}$ & 19.2 & $5: 4: 0$ & $3: 3: 5$ & 0 & 7 & 14 \\
\hline $\begin{array}{l}\text { Paratype; AMS, } \\
\text { C. } 143953\end{array}$ & 84.3 & 36.7 & 48.4 & 18.0 & 56.1 & 29.5 & 27.0 & 17.1 & $5: 2: 0$ & $3: 3: 5$ & 5 & 7 & 13 \\
\hline Paratype; NHMP. & 87.6 & 40.6 & 47.6 & 18.7 & 49.8 & 30.6 & 20.9 & $9.2^{*}$ & $5: 1: 0$ & $3: 2: 3$ & 5 & 7 & 11 \\
\hline Paratype; QM. & 85.6 & 38.7 & 47.6 & 19.0 & 53.7 & 29.7 & 22.6 & $13.2^{*}$ & $3 *: 2 *: 0^{*}$ & $3: 3: 5$ & 0 & 7 & 12 \\
\hline
\end{tabular}

Table 11. Shell measurement and count data for Murex kerslakae n. sp. * = damaged. 
Remarks. The shell of this species is similar to that of $M$. aduncospinosus in protoconch and teleoconch characters but differs markedly in penial characters. The penis in this species is the most distinctive in the genus, being completely different from $M$. aduncospinosus or any other species of Murex.

The shell differs from $M$. aduncospinosus in its long, straight shoulder spines and in the primary spines being purple-tipped. The secondary and tertiary spines are better developed than in most specimens of $M$. aduncospinosus, as are the primary spines on the siphonal canal.

This species also superficially resembles $M$. ternispina as the shell develops purple-tipped spines, but is immediately distinguished by the operculum having a subterminal, not a subcentral nucleus. Some forms of $M$. acanthostephes also have purple-tipped spines but this species has a strongly keeled protoconch as well as differing in sculptural details.

This species appears to be restricted to the midQueensland shelf. It is named as a small tribute to the late Mrs Joy Kerslake, a valued Associate of the Australian Museum for many years.

\section{Murex falsitribulus n. sp.}

Figs 21; 77E; 80D-F; Table 12

Murex nigrospinosus (sic).-Melvin, 1966: 98, pl. 39, fig. 1 (not of Reeve).

Murex tribulus.-Kaicher, 1973: fig. 151 (not of Linné).

Type material. HOLOTYPE: (AMS, C.106340), Balabac, south Palawan, Philippine Ids, ex N. Coleman Colln. PARATYPES: Seven paratypes (FMNH, 140646), same locality Nov 1959, ex F. Dayrite; 2 paratypes (ANSP, 226360); 9 paratypes (ANSP, 223816), same locality and collector, 1958; figured paratype (ANSP, 196387), Palau Ids, Philippine Ids, 1955, J. Petydon; 3 (one figured) paratypes (USNM, 657812), Mandidarah Id, north Sabah, Aug 1963, M. Saul; paratype (AMS, C.143940), Zamboanga, Philippine Ids, ex J. Kerslake Colln.

Records. SABAH: Mandidarah Pulau (USNM; ANSP; DMNH). INDONESIA: $36 \mathrm{~m}$, Semau Id, south Timor (RML). PhilipPINes: Cuyo Id, north-east Palawan (USNM); Mantaquin Bay, Palawan (USNM); trawled, Tara Id, Sulu (WAM); 64 m, north-west off Basilan (USNM); Basilan Id (USNM); Sulu Archipelago (AMNH); Bongao Channel, Sulu Archipelago (ANSP); $33 \mathrm{~m}$, north-west of Tawitawi (USNM); Zamboanga (NMV); Davao, Mindanao (DMNH); Cebu (AMS). JAPAN: Okinawa (ANSP); Ryukyu Ids (DMNH). CAROLINES: Yap Id (USNM).

Description. SHELl. Medium-sized (up to 80 $\mathrm{mm}$ in length), with seven teleoconch whorls. Protoconch of about one and one-half polished brown bulbous volutions, ending at small, sharp varix.

Spiral ornamentation on first two teleoconch whorls of three rounded cords of equal strength, with fourth, weaker spiral on subsutural ramp. Numerous secondary and tertiary spiral threads appearing on third whorl, increasing in number until body whorl and siphonal canal covered with numerous, alternating primary, secondary and tertiary cords in a complex pattern.

Axial ornamentation on first two teleoconch whorls of twelve to fourteen low, rounded ribs, which, together with spiral cords, give cancellate appearance to early whorls. On third whorl every third rib strengthened into small varix, with short, closed spine at shoulder. Intermediate axial ribs remain as rounded intervarical ridges. Fourth whorl with additional ridge added at adapertural end of intervarical area. All axial ridges rapidly weakening on subsequent whorls so that on body whorl their presence indicated only by low undulations on spiral cords. Entire surface covered by myriad growth lamellae, fimbriated by spiral ornamentation giving shell shagreened surface. Three varices per whorl, each with three moderately long, straight, primary spines. Anterior to each primary spine, a shorter secondary spine and numerous tertiary spinelets. Spination pattern complex, with (anteriorly from suture) primary (shoulder), tertiary, secondary, primary (periphery), secondary, tertiary, primary (base), secondary, secondary. Tertiary, and sometimes secondary, spines at an angle to major spines, directed adaperturally. Siphonal canal with four or five relatively short, straight, closed primary spines with secondary spines only between two or three major spines nearest base of body whorl.

Suture simple, crossed diagonally by growth lamellae.

Aperture ovate; outer lip crenulated, notches developed as extension of grooves in spines, their size relative to strength of spine. Each internotch area drawn out into projection, that posterior to basal primary spine longer than others, forming small labral tooth. Notches between projections extend into aperture as elongate lirations: anal notch shallow. Inner lip appressed at posterior end; anterior two-thirds narrow, free-standing, smooth.

Siphonal canal with distal end slightly deflected, terminations of previous canals fused into tube, open by narrow slit; almost entire length spinose.

Colour creamy white, some specimens with area between white spiral cords tan to dark brown; tending to be darker in colour near shoulder; tips of spines frequently purplish; aperture white, with brown lirations deep inside.

\section{Dimensions. See Table 12 .}

OPERCULUM. Reddish brown to yellow; subterminal nucleus, surrounded by numerous faint concentric undulations.

Etymology. Refers to this species superficial resemblance to $M$. tribulus.

Remarks. The shell of Murex falsitribulus differs from all similar species of Murex s.s. in having twelve to fourteen rounded ribs on the early teleoconch whorls; only $M$. ternispina, with which $M$. falsitribulus has been confused, has the same number 


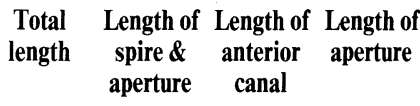

$\begin{array}{ccc}\text { Total } & \begin{array}{c}\text { Length of } \\ \text { spire \& }\end{array} & \begin{array}{c}\text { Length of } \\ \text { anterior } \\ \text { length }\end{array} \\ & \text { aperture } & \text { canal }\end{array}$

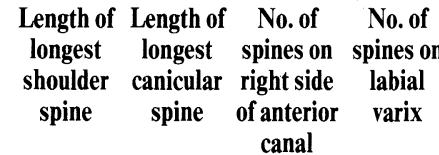

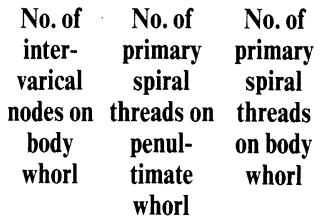

whorl

\begin{tabular}{|c|c|c|c|c|c|c|c|c|c|c|c|c|c|}
\hline Holotype & 69.4 & 32.2 & 37.7 & 17.2 & 25.3 & 44.0 & 18.0 & 14.8 & $5: 2$ & $3: 3: 1$ & 0 & 6 & 11 \\
\hline $\begin{array}{l}\text { Figured paratype; } \\
\text { ANSP, } 196387\end{array}$ & 71.4 & 32.0 & 39.9 & 16.5 & 24.4 & 44.3 & 20.0 & 12.8 & $5: 1$ & $3: 3: 3$ & 0 & 6 & 11 \\
\hline $\begin{array}{l}\text { Figured paratype } \\
\text { Mandi Darrah Id, } \\
\text { N. Borneo; } \\
\text { USNM, } 657812\end{array}$ & 72.5 & 34.3 & 38.3 & 18.5 & 27.3 & 42.7 & 15.0 & 11.5 & $4: 1$ & $3: 3: 1$ & 4 (faint) & 6 & 11 \\
\hline $\begin{array}{l}\text { Figured paratype; } \\
\text { ANSP, } 226360\end{array}$ & 67.5 & 32.2 & 36.4 & 16.8 & 24.5 & 46.7 & 23.6 & $9.8^{*}$ & $5: 2$ & $3: 3: 2$ & 0 & 5 & 12 \\
\hline $\begin{array}{l}\text { Paratype } \\
\text { Zamboanga, } \\
\text { Philippines; AMS, } \\
\text { C. } 143940\end{array}$ & 62.8 & 27.2 & 35.4 & 13.8 & 21.0 & 39.2 & $20.1^{*}$ & 13.2 & $4: 1$ & $3: 3: 0$ & 0 & 5 & 11 \\
\hline $\begin{array}{l}\text { Okinawa, Ryukyu } \\
\text { Ids; ANSP, } 241571\end{array}$ & 62.0 & 28.9 & 33.2 & 15.3 & 22.7 & 39.8 & 19.4 & 10.3 & $4: 1$ & $3: 3: 2$ & 0 & 6 & 10 \\
\hline
\end{tabular}

Table 12. Shell measurement and count data for Murex falsitribulus n. sp. ${ }^{*}=$ damaged.

but that species has a concentrically foliate operculum with a subcentral nucleus, not a terminal nucleus as in $M$. falsitribulus. The protoconch in $M$. ternispina is of two whorls rather than one and onehalf as in $M$. falsitribulus.

Murex trapa Röding, 1798

Figs 17-19; 67G,H; 71B,C; 73D; 83G,H; Table 13

Purpura hystrix Martini, 1777: 363 (in part), pl. 113, fig. 1056 (not binominal).

Murex trapa Röding, 1798: 145 (refers to Martini, 1777: pl. 113, figs 1055, 1056) (Amboina, Indonesia designated type locality by Cernohorsky, 1967a: 115, but Tranquebar given by Martini, 1777: 368; original of figure 1056 not located but this figure [not fig. 1055] was designated as "type-figure" by Vokes, 1978: 378. A neotype is designated herein); Crichton, 1941: 331, pl. 3, fig. 5; Wissema, 1947: 174; Altena, 1950: 209; Oyama \& Takemura, 1958: pl. 3, fig. 3, pl. 4, fig. 4; Habe, 1961: 49, pl. 25, fig. 1; Habe, 1964: 78, pl. 25, fig. 1; Nuttall, 1965: 171; Wu, 1965: 98, fig. 13 (radula); Habe \& Kosuge, 1966: 50, pl. 18, fig. 6; Cernohorsky, 1967a: 115 (in part); Dance, 1974: 122, fig. in text; Radwin \& D'Attilio, 1976: 72, pl. 10, fig. 14; Fair, 1976: 82, pl. 1, fig. 2; Abbott \& Dance, 1982: 130, fig. in text.

Murex rarispina Lamarck, 1822: 158 (in part; refers to Martini, 1777: pl. 113, fig. 1056, but Lamarck's type specimen is the same species as Murex formosus Sowerby, 1841, a species of Siratus. However, the Martini fig. 1056 can also be regarded as a syntype and is here designated the lectotype, thus this name becomes a synonym of $M$. trapa); Deshayes \& Milne-Edwards, 1839: 702 (in part); Sowerby, 1841a: 1, pl. 66, fig. 52; Reeve, 1842: pl. 237, fig. 52; Deshayes, 1843: 567 (in part); Sowerby, 1879: 3, pl. 1 (of Murex), fig. 2 (as $M$. rarispinosus).

Murex unidentatus Sowerby, 1834: pl. 66, fig. 52 (East
Indies; figured specimen not located, presumably lost); Catlow \& Reeve, 1845: 251; Dautzenberg \& Fischer, 1907: 155; Kaicher, 1973: fig. 107; Fair, 1976: 85 (in part); Houart, 1979: 132.

Murex duplicatus Pusch, 1837: 135, pl. 12, fig. 1a (refers to Martini, 1777: pl. 113, figs 1055, 1056. Fig. 1056 is here designated as the lectotype); Vokes, 1971a: 43; Fair, 1976: 38 (homonym of $M$. duplicatus Donovan, 1804).

Murex martinianus Reeve, 1845: pl. 18, fig. 72 (refers to Martini, 1777: pl. 113, fig. 1056; locality unknown; holotype, BMNH, 1874.12.11.204); Reeve, 1846: 88; Küster \& Kobelt, 1868: 59, pl. 9, fig. 3, pl. 22, figs 7, 8; Tapparone-Canefri, 1876: 116; Dunker, 1882: 3; Crosse \& Fischer, 1889: 285; Morlet, 1889: 137; Fischer, 1891: 146(62); Baker, 1897: 375; Smith, 1953: 2, text fig. i (homonym of $M$. martinianus Pfeiffer, 1840).

Murex ternispina.-Tryon, 1880: 78 (in part), pl. 11, fig. 118; Martin, 1884: 97 (in part) (not of Lamarck).

Murex (Tribulus) martinianus.-Kobelt, 1877: 146; Poirier, 1883: 34; Horst \& Schepman, 1894: 135; Schepman, 1911: 343, pl. 24, fig. 10 (radula); Oostingh, 1923: 111; Oostingh, 1925: 141.

Murex adunco-spinosus. - King \& Ping, 1931: 280, text fig. 15 (not of Sowerby).

Acupurpura tropa (sic).-Cotton, 1956: unnumbered page (as synonym of $A$. martinianus).

Acupurpura cospinosus.-Cotton, 1956: unnumbered page (error for aduncospinosus) (not of Sowerby).

Records. MADAGASCAR: $4 \mathrm{~m}$, Ankify Province, Nosy Bé (IRSB). MAURITIUS: (RML). INDIA: Madras (BMNH); Tuticorin (USNM; DMNH). ANDAMAN ISLANDS: (DMNH). SRI LANKA: (AMNH). ThaIlAND: (ZMC); Songkhla Province (USNM); Songkhla (ANSP); $36 \mathrm{~m}$, 10-12 km west of Ko Chang (ZMC); Bangkok (AMNH; IRSB); Gulf of Thailand (ZMC); Ban Si Racha, Gulf of Thailand (USNM); Ban Hua Hin, Gulf of Thailand (MCZ; AMNH); Nakhon Si Thammarat (MCZ); 1.5 m, Ban Ang Sila, Chon Buri Province (MCZ). VietnAM: Ba Lang (ANSP); 'Dai Lghm' (AMNH); 'Vung Tau' (ANSP); Cam 
Ranh Bay (DMNH). South Vietnam: 'Vong Tsu'; Ben Pinh, Vong Tsu; Rung Sat (all ANSP). CHINA: (ANSP; ZMA; USNM; BMNH; AMS); Chi Mei, Hsia-men (ANSP); 'Nanta-wu', Hsia-men (USNM); 'Chien Bay', Fukien Province (ANSP); Hsi-yang Tao, Fukien Province(USNM); Fuzhou, Fukien Province (USNM). HONG KONG: numerous localities, to 55 m (AMNH; USNM; BMNH; AMS; ANSP; NMV). TAIWAN: (AMNH); West coast (ANSP); $21 \mathrm{~m}$, Tsoying Chun-kang (AMS); Kao-hsiung (AMNH; USNM); Chin-men; 'Anpin' (both ANSP). JAPAN: Ryukyu Islands (AMNH). PHILIPPINES: (ANSP; AMNH; AMS); Palawan (MCZ); Malampaya Sound, Palawan (USNM); Negros (AMNH); Port Banga, Mindanao (AMS). Malaysia: Nenasi; Mersing (both AMS); Penang (ZMC; ANSP; AMS); Port Dickson; Johor Lama (both AMS); Endau (BMNH; AMS); trawled off Pulau Langkawi (BMNH; AMS); Melaka (= Malacca) (AMS). SARAWAK: (AMS); Sematan (BMNH). SABAH:(AMS); Sandakan(USNM); Monoyan Id, Sandakan (ANSP); Kudat (AMNH); 33 m, Marudu Bay (ANSP, USNM); Tambisan (USNM); Tanjong Aru, Kota Kinabalu (ANSP). SINGAPORE: (numerous localities, AMNH; BMNH; NMW; USNM; ANSP; AMS). INDONESIA: Sumatra: $21-54 \mathrm{~m}$, north of Bengkalis (RML); $25 \mathrm{~m}$, Lampung Bay (ZMC); Bangka (ZMA); Kelian Tandjung, Bangka (ZMA); east coast of Aceh (RML; ZMA); $59 \mathrm{~m}$, north-east of Kepulauan Lingga (BMNH). Java: Madura (RML); beach at mouth of Tji Lamaja (RML); Djakarta (ZMA; RML); Tandjung Periuk (RML); Air-ketjil Id (ZMA); Cirebon (RML); Tegal; Pekalongan (both ZMA); Rembang (RML); Surabaja (RML; ZMA; SMF); Bay of Popoh (RML); Pasuruan (RML); 'Bantam Pruput' (USNM) 9-15 m, 'Teluk Awans', Lombok (AMS); Borneo: Bandjarmasin, Borneo (IRSB); Singkawang (RML); Balikpapan (ZMA; RML); Kotabaru (RML); Bandjarmasin (RML); beach, north of Mahakam River mouth (AMS). Sulawesi: west of Buol; Badjo (both RML); Makasar (ANSP); Gulf of Madjene (RML); Pabbiring Arch. (ZMA); Obi Id; Ambon; Banda Id (all RML).

Fossil records. Plio-Pleistocene: Nias, Malay Arch. (Wissema, 1947); Dent Peninsula, Sabah, Malaysia (BMNH; recorded by Nuttall, 1965). Pliocene(?): Semarang, Java (GML; recorded by Martin, 1884); Kendeng Beds, E Java (Altena, 1950).

Description. SHELL. Large (up to $115 \mathrm{~mm}$ in length), with up to eight teleoconch whorls.

Protoconch of about three conical volutions, last two with sharp keel adjacent to suture, terminating at sharp, crescentic varix.

Spiral ornamentation absent on first two teleoconch whorls; on third whorl two extremely weak spiral cords, one at shoulder, other at periphery. On fourth whorl, three even weaker secondary spiral threads, one on subsutural ramp, one between primary cords and third between suture and periphery. Number of spirals increase by intercalation on subsequent whorls, until body whorl and siphonal canal covered with alternating primary, secondary and tertiary cords, all flattened and relatively weak.

Axial ornamentation on first two teleoconch whorls of eight or nine ribs, flattened on subsutural ramp and drawn out into two almost closed, lamellar spinelets, one at shoulder and slightly smaller one at

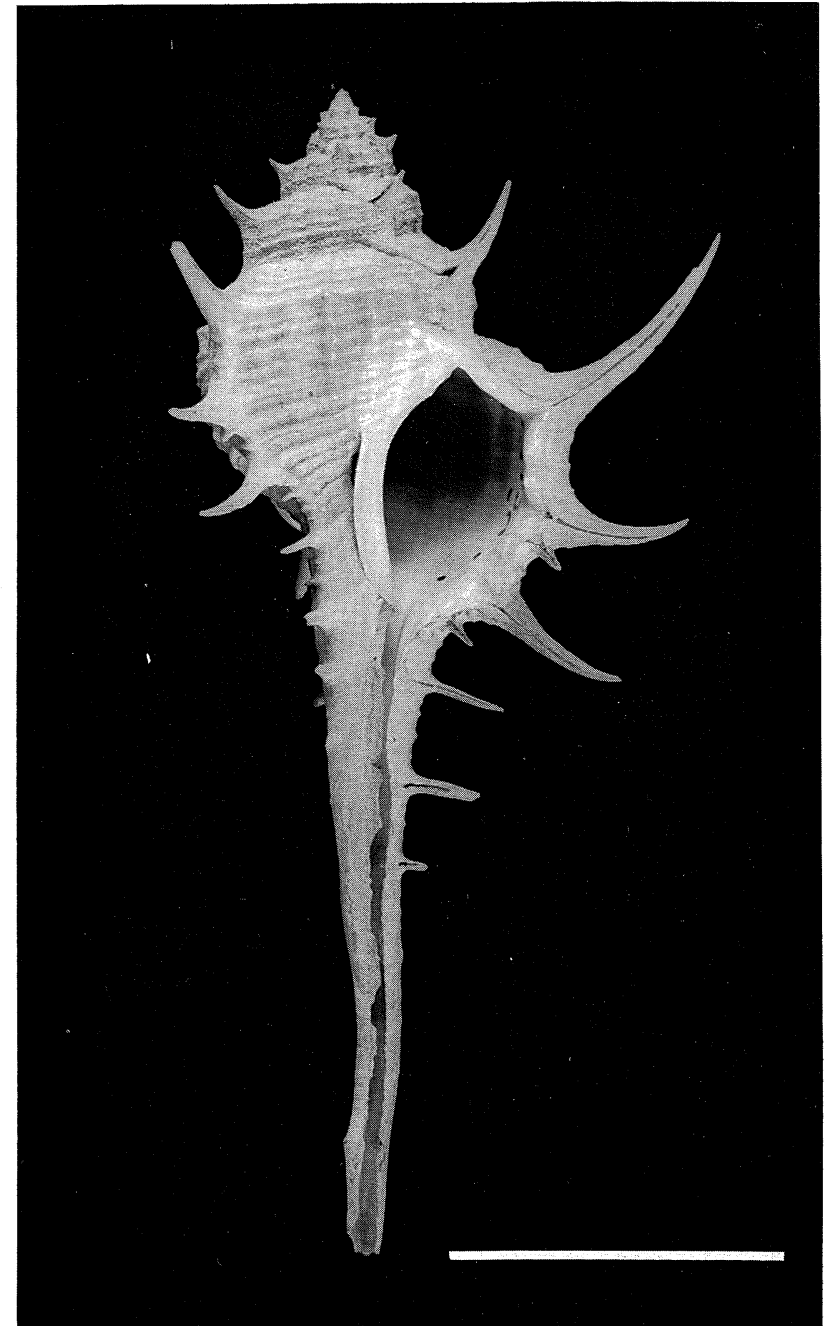

Figure 17. Neotype of $M$. trapa Röding. Scale $2 \mathrm{~cm}$.

periphery. On third whorl every third axial rib strengthened into varix with moderately long, slightly open, apically curved shoulder spine; smaller spine at periphery; two intervarical ribs reduced to low rounded ridges lacking spines. On fourth whorl, third axial rib added at adapertural end of intervarical area. Intervarical ridges added, but weak on subsequent whorls until, on body whorl, there are five very low, rounded axial ridges marked mainly by weak elongate nodules where crossed by spiral cords. Three low varices per whorl, each with three, usually short, slightly apically recurved (but not so much as on earlier varices) primary spines. Three smaller, straight, secondary spines alternate with primary spines and directed approximately in same plane as primary spines, although, between shoulder and peripheral spines, usually no spine developed. Spination pattern typically (anteriorly from suture) of primary (shoulder), primary (periphery), secondary, primary (base), secondary. Siphonal canal with about four short, straight primary spines; juvenile specimens with five, or occasionally six, such spines. Alternating with primary spines on canal are 
tiny, adaperturally directed, secondary spinelets at right angles to major spines.

Suture simple, crossed diagonally by numerous growth lamellae appressed against anterior portion of preceeding whorl.

Aperture ovate; outer lip margin notched, with centres of notches recurved into grooves of primary and secondary spines, giving low, rounded, forwardly-directed projections. Projection posterior to major spine at base of body whorl drawn out into very large labral tooth. Posterior end of outer lip formed by projecting shoulder ramp, with the truncated remnant of peripheral spine from preceding whorl fused into it. Shoulder ramp forms outer margin of anal notch. Posterior third of inner lip strongly appressed, flared, with flare extending onto preceding whorl to level of secondary spinelet between shoulder and peripheral spines, this extension forming relict structure on preceding whorls. Anterior two-thirds of inner lip narrow, freestanding but flattened against columella.

Siphonal canal moderately long; terminations of previous canals fused into straight tube, open by narrow slit; about one-half total length spinose.

Colour yellow-tan with bluish tinge between spiral cords; aperture white at margin with brown interior, occasional darker brown lines terminating at grooves in spines.

DIMENSIONS. See Table 13.

OPERCULUM. Brown, with subterminal nucleus,

\begin{tabular}{|c|c|c|c|c|c|c|c|c|c|c|c|c|}
\hline $\begin{array}{l}\text { Total } \\
\text { length }\end{array}$ & $\begin{array}{c}\text { Length of } \\
\text { spire \& } \\
\text { aperture }\end{array}$ & $\begin{array}{l}\text { Length of } \\
\text { anterior } \\
\text { canal }\end{array}$ & $\begin{array}{l}\text { Length of } \\
\text { aperture }\end{array}$ & $\begin{array}{l}\text { Total } \\
\text { with } \\
\text { spines }\end{array}$ & $\begin{array}{l}\text { Imeter } \\
\text { without } \\
\text { spines }\end{array}$ & $\begin{array}{l}\text { Length of } \\
\text { longest } \\
\text { shoulder } \\
\text { spine }\end{array}$ & $\begin{array}{l}\text { Length of } \\
\text { longest } \\
\text { canicular } \\
\text { spine }\end{array}$ & $\begin{array}{l}\text { No. of } \\
\text { spines on } \\
\text { right side } \\
\text { of anterior } \\
\text { canal }\end{array}$ & $\begin{array}{c}\text { No. of } \\
\text { spines o } \\
\text { labial } \\
\text { varix }\end{array}$ & $\begin{array}{c}\text { No. of } \\
\text { inter- } \\
\text { varical } \\
\text { nodes } 0 \\
\text { body } \\
\text { whorl }\end{array}$ & $\begin{array}{c}\text { No. of } \\
\text { primary } \\
\text { spiral } \\
\text { threads on } \\
\text { penul- } \\
\text { timate } \\
\text { whorl }\end{array}$ & $\begin{array}{c}\text { No. of } \\
\text { primary } \\
\text { spiral } \\
\text { threads } \\
\text { on body } \\
\text { whorl }\end{array}$ \\
\hline
\end{tabular}

\begin{tabular}{|c|c|c|c|c|c|c|c|c|c|c|c|c|}
\hline Neotype & 68.9 & 31.4 & 37.5 & 16.8 & 32.6 & 22.8 & 14.5 & 5.7 & $3: 0$ & $3: 2: 0$ & 4 & 7 \\
\hline $\begin{array}{l}\text { Holotype of } M \text {. } \\
\text { martinianus }\end{array}$ & 114.1 & 48.7 & 65.6 & 26.1 & 47.3 & 31.8 & 17.3 & 9.6 & $4: 1$ & $3: 2: 0$ & 3 & 7 \\
\hline $\begin{array}{l}\text { Chau Wan Bay, } \\
\text { Lamma Id, Hong } \\
\text { Kong; AMS, } \\
\text { C.94492 (Fig. } 83 \mathrm{H} \text { ) }\end{array}$ & 112.9 & 52.4 & 61.7 & 26.7 & 52.7 & 33.9 & 17.9 & $8.6^{*}$ & $3: 1$ & $3: 2: 0$ & 3 & 7 \\
\hline $\begin{array}{l}\text { Cheung Chau Id, } \\
\text { Hong Kong; AMS, } \\
\text { C.108985 }\end{array}$ & 100.9 & 47.1 & 54.2 & 23.4 & 39.8 & 31.1 & $15.1^{*}$ & $8.9^{*}$ & $4: 1$ & $3: 2: 0$ & 4 & 8 \\
\hline $\begin{array}{l}\text { Teluk Awans, } \\
\text { Lombok Id, } \\
\text { Indonesia; AMS, } \\
\text { C. } 108648\end{array}$ & 95.2 & 40.3 & 55.6 & 20.4 & 44.9 & 28.6 & 15.7 & $10.3^{*}$ & $3: 1$ & $3: 3: 0$ & 4 & 7 \\
\hline $\begin{array}{l}\text { Sea-home, Penang, } \\
\text { Malaysia; AMS, } \\
\text { C. } 90612\end{array}$ & 92.2 & 42.4 & 50.3 & 21.8 & 37.9 & 29.9 & 9.2 & 11.2 & $4: 1$ & $3: 2: 0$ & 4 & 7 \\
\hline
\end{tabular}

Table 13. Shell measurement and count data for Murex trapa Röding.* = damaged.

faint concentric ridges and a strong median crease along its length.

RADULA. See Figs 67G, $\mathrm{H}$.

PENIS. Parallel-sided, with very narrow filament (Figs $71 \mathrm{~B}, \mathrm{C}$ ).

Description of neotype. SHELL. Medium-sized (69 $\mathrm{mm}$ in total length), with six teleoconch whorls. Protoconch of about three conical volutions, somewhat decorticated in neotype.

Spiral ornamentation on earliest preserved teleoconch whorls of two narrow cords; smaller cords intercalated on later whorls. Body whorl with about eight, flattened major cords, alternating with minor cords, two additional minor cords on subsutural ramp. Axial ornamentation on earliest preserved whorl of nine flange-like ribs, pointed at shoulder. On approximately third teleoconch whorl, every third rib strengthened into varix, with remaining two ribs persisting as intervarical ridges. By fourth teleoconch whorl, an additional ridge added to each intervarical area and on fifth, another, resulting in body whorl with four weak ridges in each intervarical area. Each varix on spire with single sharp spine at shoulder and smaller spine at periphery, peripheral spine almost enveloped by succeeding whorl. On body whorl each varix with three moderately long spines, that at shoulder only slightly longer, second at periphery and third at base of body whorl; two small spinelets anterior to each of latter two spines. An additional three major spines on each varix of siphonal canal; series of smaller spinelets (most lacking in neotype) alternate with major spines and directed adaperturally, at right angles to major spines.

Suture simple, crossed diagonally by series of growth lamellae. Aperture ovate, margin of outer lip notched and drawn out into grooves of major 

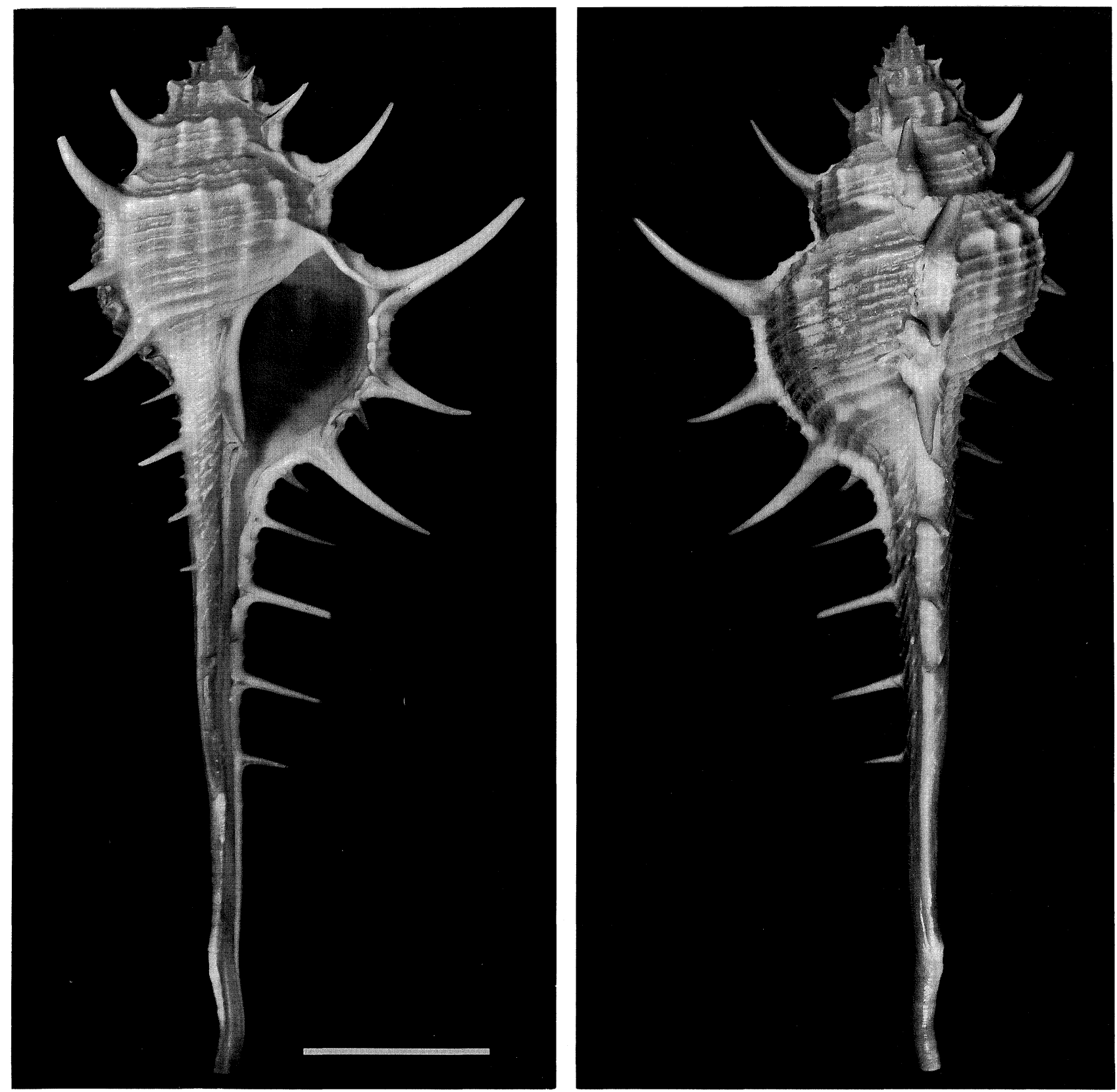

Figure 18. Murex trapa Röding. Holotype of Murex martinianus Reeve; unknown locality (BMNH, 1874.12.11.204). Scale $2 \mathrm{~cm}$.

spines. Between two anterior-most spines, edge of lip drawn out into very large labral tooth. Inner lip smooth, appressed at posterior end, standing free for anterior two-thirds.

Siphonal canal long, terminations of previous canals fused into straight tube, open by narrow slit; about one-half total length spinose.

Colour tan, aperture white.

DimENSIONS. See Table 13.

Locality. Tranquebar, India.

Location of neotype. ZMC (not registered).

Remarks. Of the two Martini (1777) figures cited by Röding, Vokes (1978) selected fig. 1056 as the type. Figure 1055, from the East Indies, probably represents a short-spined specimen of $M$. carbonnieri. Reeve (1845) recognised that the Martini figure was his $M$. martinianus but presumably was unaware of Röding's earlier name.

A neotype is selected for this species because of the poor quality of the 'type-figure' and the problems that have been caused by its identification in the past. The specimen on which Martini's figure is based could not be found in the ZMC and no other likely repository is known. The designated type locality (Cernohorsky, 1967a) of Amboina is the locality where the specimen figured in fig. 1055 is said to have been collected. Martini (1777: 358) gives Tranquebar (India) as the 


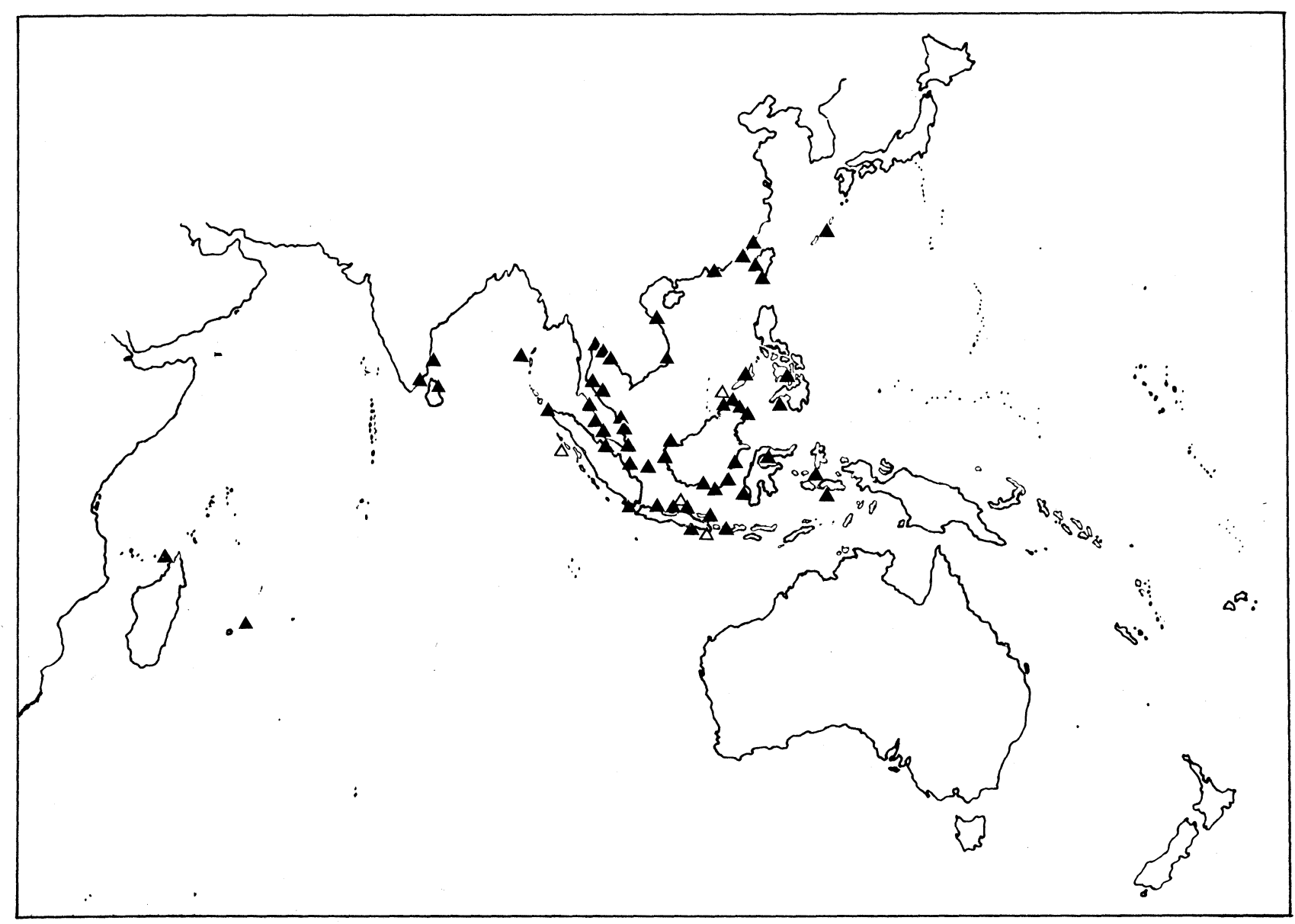

Figure 19. Distribution of $M$. trapa Röding, and open triangles = fossil records.

locality of his figure 1056 and indicates that it is very common at that locality. A specimen collected in Tranquebar has been selected as the neotype.

The relationships of this species may be with the $M$. scolopax species group, which it resembles in most shell characters except for having a 'closed', not 'open' outer lip. It is included in the M. tribulus species group, which is undoubtedly heterogenous, because of this character and because of its resemblance to some forms of $M$. aduncospinosus.

The shell of this species is readily distinguished by its tall spire, angulated whorls and short spines. It is very abundent in shallow water in parts of southeastern Asia.

Murex coppingeri Smith, 1884

Figs 20; 21; 70F; 77A; 80J; Table 14

Murex coppingeri Smith, 1884: 42, pl. 5, fig. A (Dundas Straits, Arafura Sea, 17 fathoms [31 m]; holotype, BMNH, 1882.12.6.9); Brazier, 1893: 50; Baker, 1897: 374; Hedley, 1918: 281; Smith, 1953: 1; Wilson \& Gillett, 1971: 84, pl. 57, fig. 4; Hinton, 1972: 34, pl. 17, fig. 5; Kaicher, 1973: fig. 111; Coleman, 1975: 275, fig. 754; Fair, 1976: 33, pl. 1, fig. 10; Radwin \& D'Attilio, 1976: 64, text fig. 35 (protoconch), pl. 11, fig. 1; Hinton, 1978: 33, fig. 5; Cernohorsky, 1978: 64, pl. 17, fig. 9; Wells, 1981: 258 .
Records. InDONESIA: Irian Barat: Merauke (ZMA; RML); beach near 'Lampoe Satoe', Merauke (RML). PaPua New GuInEA: 9-13 m, off Jokea Id, west of Yule Id; 22-33 m, off Yule Id, Papua; $27 \mathrm{~m}$, off Cape Possession, near Yule Id (all AMS). AUSTRALIA: Western Australia: Buccaneer Archipelago (AMS). Northern Territory: West Head, Port Keats (AMS); Darwin area (MNT; AMS); Mission, Melville Id; Smith Point, Cobourg Peninsula; Milingimbi Mission, east Arnhem Land; 72 and $84 \mathrm{~m}$, Arafura Sea; $124 \mathrm{~m}, 170 \mathrm{~km}$ north of Croker Id (all AMS). Queensland: trawled, $48 \mathrm{~km}$ south off Sweers Id; trawled off Albert River; Karumba; 4-7 m, off Holroyd River; 18 m, off Edward River, $25 \mathrm{~m}$, west of Edward River, $4 \mathrm{~m}$, off Gilbert River; 14 m, off Mitchell River; 7 m off Nassau River; Van Diemen River Inlet; 18 m, off Mapoon Mission, west Cape York; Darnley Id, east Torres Strait; Bowen; 57 $\mathrm{m}$, east of Broad Sound (all AMS).

Description. SHELl. Medium-sized (up to 60 $\mathrm{mm}$ in length), with seven strongly shouldered teleoconch whorls.

Protoconch of about three polished conical volutions, with sharp keel abutting suture and ending at small crescentic varix. Spiral ornamentation on first teleoconch whorl almost absent, with only single ill-defined cord at shoulder and second at periphery. By third or fourth whorl, faint spiral threads develop, increasing in number until body whorl covered with 


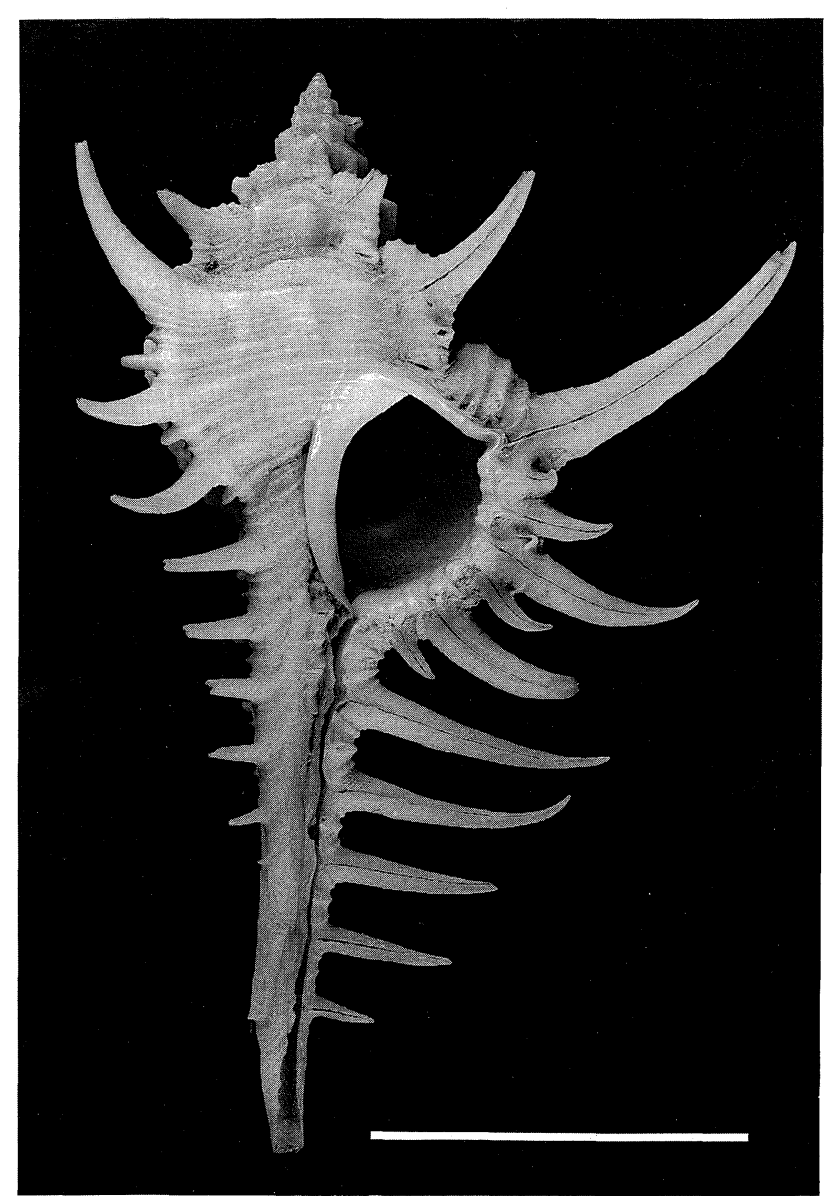

Figure 20. Murex coppingeri Smith. Holotype. Scale $2 \mathrm{~cm}$.

alternating fine threads of two orders of magnitude.

Axial ornamentation on first teleoconch whorl of nine angulate ribs, each with small open spines at shoulder and periphery. On second whorl, every third spiral rib strengthened into small varix; intervening ribs persisting as intervarical ribs, two between each pair of varices up to about fifth whorl, then gradually weakening until sometimes absent on body whorl. Growth lamellae gives shell surface shagreened appearance. Three varices per whorl, each with three stout, closed spines, that at shoulder longest, those at periphery and base of body whorl somewhat shorter. Siphonal canal with four or five stout spines; smaller adaperturally directed spinelets alternating with major spines on body whorl and canal.

Suture simple, slightly sinuated by axial ridges.

Aperture triangularly ovate; flattened at shoulder; outer lip crenulated with faint denticulations and also notches corresponding to extensions of median grooves in spines, notches varying in size according to strength of spine. Labral tooth very small. Inner lip free-standing, only slightly appressed at anterior end, smooth.

Siphonal canal moderately long, terminations of previous canals fused into tube, slightly curved at distal end, open by narrow slit; almost entire length

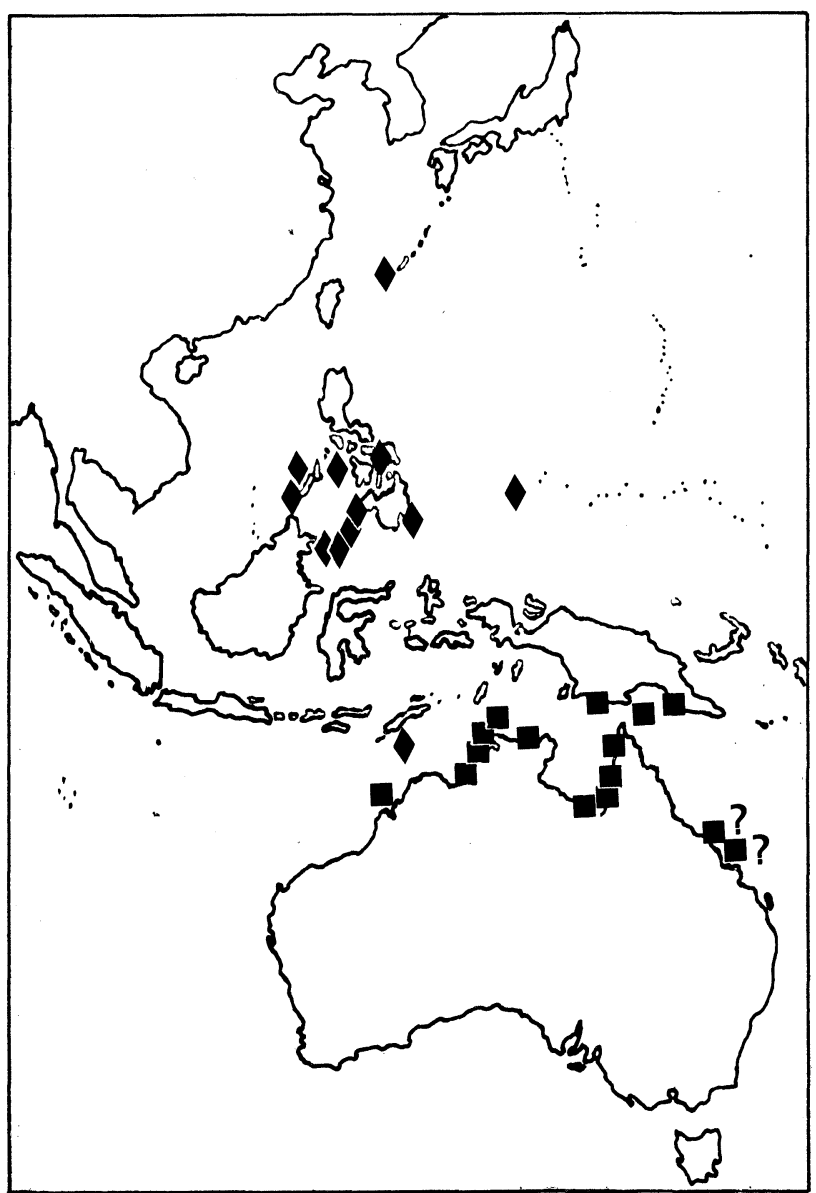

Figure 21. Distribution of Murex falsitribulus $\mathrm{n}$. $\mathrm{sp}$. (diamond), and $M$. coppingeri Smith (square).

spinose.

Colour ivory to pale flesh-coloured over entire surface.

DIMENSIONS. See Table 14.

OPERCULUM. Reddish brown; subterminal nucleus, surrounded by low concentric lamellae.

PENIS. Distal third tapers, remainder approximately parallel-sided, no filament (Fig. 70F).

Remarks. This distinctive species has a restricted geographic range (Fig. 21) and a remarkably simple nomenclatural history with only one wrong usage of the name, that of Cernohorsky (1967b) who has used it for Murex queenslandicus $\mathrm{n}$. sp. The only closely related taxon appears to be $M$. ejectus from the Pliocene of Java.

A series from Karumba (AMS) show sexual dimorphism in size, and this may be typical of the species. Males (6 specimens) have a mean length of $20.6 \mathrm{~mm}$ (S.D. 1.49), whereas 10 females are $25.2 \mathrm{~mm}$ in length (S.D. 2.28).

\section{Fossil Taxa in the M. tribulus Group.}

\section{Murex troscheli verbeeki Martin, 1895}

Figs 22; 73G,I; Table 15

Murex (s.s.) Verbeeki Martin, 1895: 125, pl. 19, figs 278, 


\begin{tabular}{|c|c|c|c|c|c|c|c|c|c|c|c|c|c|}
\hline & $\begin{array}{l}\text { Total } \\
\text { length }\end{array}$ & $\begin{array}{l}\text { Length of } \\
\text { spire \& } \\
\text { aperture }\end{array}$ & $\begin{array}{l}\text { Length of } \\
\text { anterior } \\
\text { canal }\end{array}$ & $\begin{array}{l}\text { Length of } \\
\text { aperture }\end{array}$ & $\begin{array}{l}\text { Total d } \\
\text { with } \\
\text { spines }\end{array}$ & $\begin{array}{l}\text { Imeter } \\
\text { without } \\
\text { spines }\end{array}$ & $\begin{array}{l}\text { Length of } \\
\text { longest } \\
\text { shoulder } \\
\text { spine }\end{array}$ & $\begin{array}{l}\text { Length of } \\
\text { longest } \\
\text { canicular } \\
\text { spine }\end{array}$ & $\begin{array}{c}\text { No. of } \\
\text { spines on } \\
\text { right side } \\
\text { of anterior } \\
\text { canal }\end{array}$ & $\begin{array}{c}\text { No. of } \\
\text { spines on } \\
\text { labial } \\
\text { varix }\end{array}$ & $\begin{array}{l}\text { No. of } \\
\text { inter- } \\
\text { varical } \\
\text { nodes on } \\
\text { body } \\
\text { whorl }\end{array}$ & $\begin{array}{l}\text { No. of } \\
\text { primary } \\
\text { spiral } \\
\text { threads on } \\
\text { penul- } \\
\text { timate } \\
\text { whorl }\end{array}$ & $\begin{array}{c}\text { No. of } \\
\text { primary } \\
\text { spiral } \\
\text { threads } \\
\text { on body } \\
\text { whorl }\end{array}$ \\
\hline Holotype & 57.9 & 29.8 & 28.7 & 13.2 & 39.3 & 22.5 & 18.7 & 14.5 & $5: 3: 0$ & $3: 3: 3$ & 1 & 9 & 14 \\
\hline $\begin{array}{l}\text { Off Cape } \\
\text { Possession, Papua } \\
\text { New Guinea; } \\
\text { AMS, C.88002 } \\
\text { (Fig. 80J) }\end{array}$ & 60.7 & 32.7 & 29.0 & 14.6 & 40.6 & 24.3 & 23.3 & 14.0 & $5: 1: 0$ & $3: 3: 2$ & 1 & 9 & 14 \\
\hline $\begin{array}{l}\text { Off Cape } \\
\text { Possession, Papua } \\
\text { New Guinea; } \\
\text { AMS, C.88002 } \\
\text { (Fig. 80J) }\end{array}$ & 59.5 & 33.0 & 27.1 & 14.8 & 35.0 & 25.0 & 18.4 & 10.8 & $4: 1: 0$ & $3: 3: 4$ & 2 & 10 & 16 \\
\hline $\begin{array}{l}\text { Off Darwin, } \\
\text { Northern } \\
\text { Territory, } \\
\text { Australia; AMS, } \\
\text { C. } 76517\end{array}$ & 62.0 & 32.6 & 30.1 & 15.3 & 38.7 & 24.1 & 20.4 & 13.4 & $5: 3: 0$ & $3: 3: 2$ & 1 & 9 & 14 \\
\hline $\begin{array}{l}\text { Off Darwin, } \\
\text { Northern } \\
\text { Territory, } \\
\text { Australia; AMS, } \\
\text { C. } 76517\end{array}$ & 58.5 & 30.4 & 28.8 & 13.2 & 41.2 & 23.4 & 21.8 & 13.5 & $5: 2: 0$ & $3: 3: 2$ & 1 & 8 & 12 \\
\hline $\begin{array}{l}\text { W. of Holroyd R., } \\
\text { Gulf of } \\
\text { Carpentaria, } \\
\text { Queensland, } \\
\text { Australia; AMS, } \\
\text { C. } 107294\end{array}$ & 56.0 & 29.8 & 26.5 & 13.7 & 33.8 & 22.9 & 15.7 & 10.5 & 4:1:0 & $3: 3: 2$ & 0 & 10 & 13 \\
\hline $\begin{array}{l}\text { W. of Holroyd R., } \\
\text { Gulf of } \\
\text { Carpentaria, } \\
\text { Queensland, } \\
\text { Australia; AMS, } \\
\text { C.107294 }\end{array}$ & 52.3 & 27.2 & 25.7 & 12.3 & 32.1 & 20.0 & 16.0 & 7.8 & $5: 2: 0$ & $3: 3: 0$ & 0 & 9 & 13 \\
\hline
\end{tabular}

Table 14. Shell measurement and count data for Murex coppingeri Smith.

280, 281 (stn 9631, Tjikeusik, Java, Pliocene; lectotype [designated by Altena, 1950: 209, as Martin's figure 281] GML, 9631 and paralectotypes, GML, 9633, from Sonde, Java, Pliocene).

?Murex ternispina var. Verbeeki.-Tesch, 1915: 63, pl. 81 (9), fig. 139.

Murex(Murex) verbeeki verbeeki.-Oostingh, 1940: 58, pl. 19, fig. 339; Wissema, 1947: 175 (see for more detailed synonymy).

Murex (Murex) verbeeki. -Altena \& Beets, 1944: 41.

Murex troscheli verbeecki.-Altena, 1950: 209.

?Murex (Murex) troscheli verbeeki.-Shuto, 1969: 102 (in part), text figs $23,24(2)$.

Description. Shell very similar to $M$. troscheli troscheli, differing mainly in smaller size (maximum length, excluding siphonal canal, $42 \mathrm{~mm}$ ), relatively weaker axial ribs between varices on spire, and more delicate (and shorter?) spines. Protoconch of two and one-half whorls in paralectotype; first whorl small (Fig. 73I), one and one-half to two whorls with swollen first whorl in other populations (Fig. 73G).
Dimensions. See Table 15.

Remarks. This taxon appears to be very similar to $M$. troscheli and because direct comparisons of typical specimens of $M$. troscheli and the types of $M$. verbeeki show very few differences they are here regarded as chronosubspecies. Of the material available, the type series has only one juvenile with an intact protoconch (Fig. 73I) but another series from the Late Pliocene of Java (Kampong Bodjong, Koempai, West Java, PCB, A5393; Fig. 22C,D) consistently shows a different protoconch with a swollen first whorl (Fig. 73G). No other differences were observed between these forms so they are tentatively regarded as consubspecific.

A single specimen lacking most of the siphonal canal was identified as this species by Wissema (1947) from Nias (GML). It has a protoconch of only one and one-half whorls, the shell is smaller (apex and spire $25.3 \mathrm{~mm}$ ), and the spines shorter, but the suture is indented. It is possibly a form derived from $M$. verbeekei and does not seem to have any 


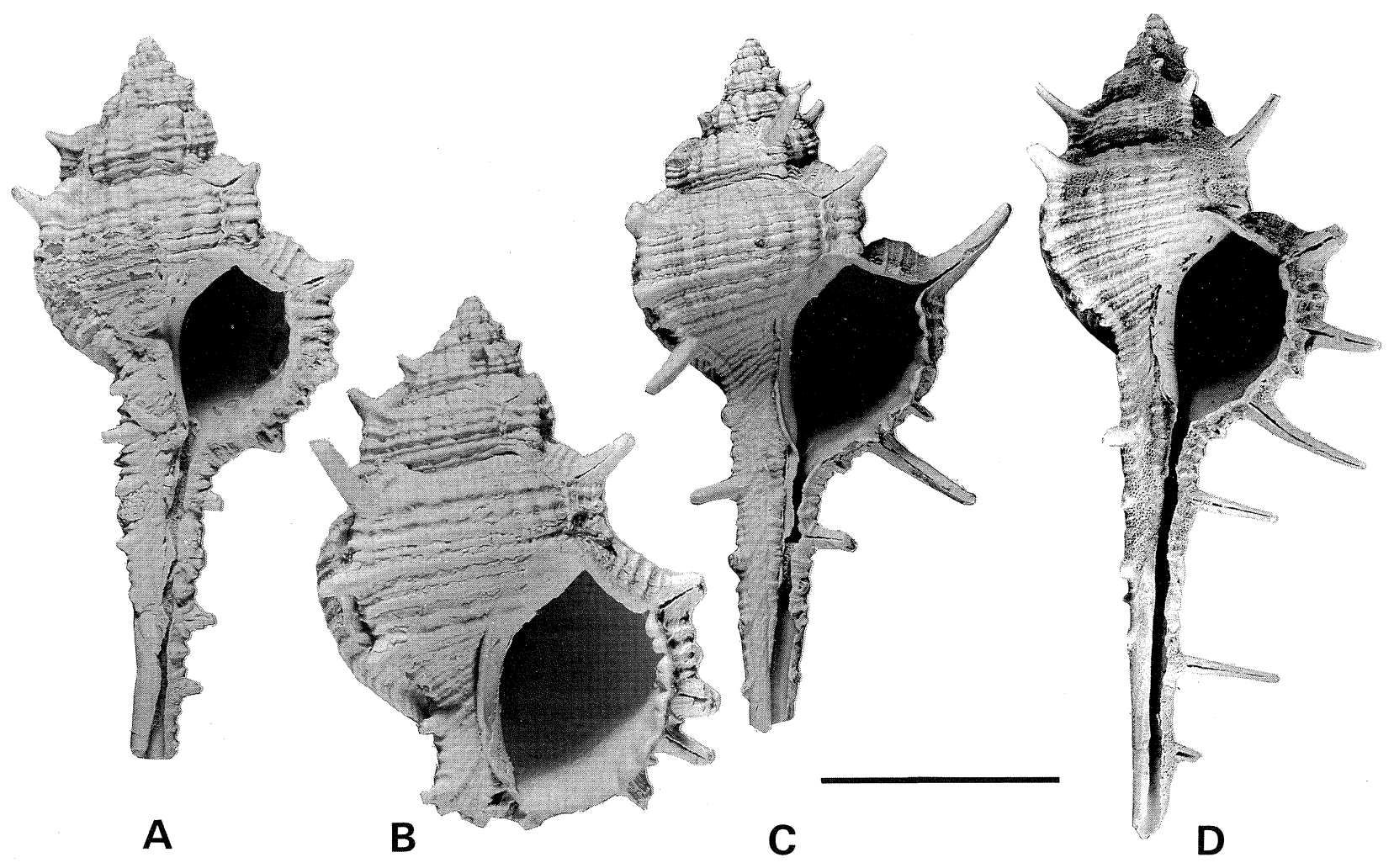

Figure 22. Murex troscheli verbeeki Martin. A: lectotype; Tjikeusik. Java. Pliocene (GML, 9631). B: paralectotype: Sonde, Java. Pliocene (GML, 9633). C,D: Kampong Bodjong. Koempai, Java. Pliocene (PCB, 5393). Scale $2 \mathrm{~cm}$.

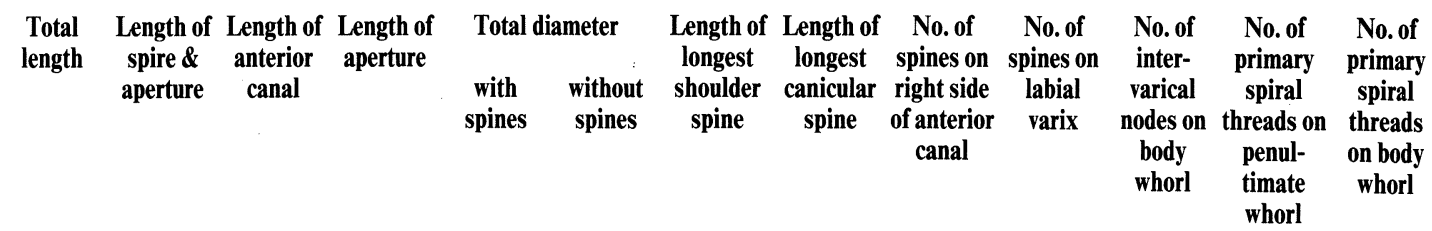

\begin{tabular}{|c|c|c|c|c|c|c|c|c|c|c|c|c|}
\hline Lectotype & 61.1 & 34.8 & 27.0 & 15.8 & 27.7 & 25.2 & 4.3 & 3.2 & $4: 3: 0$ & $5^{*}$ & 5 & 7 \\
\hline Paralectotype & $\begin{array}{c}\text { (broken } \\
\text { canal) }\end{array}$ & 41.9 & - & 21.5 & 32.3 & 30.7 & 8.9 & - & - & $6^{*}$ & 5 & 7 \\
\hline
\end{tabular}

\section{Kampong}

Bodjong,

Koempai, W. Java,

Pliocene; PCB,

A5393 (Fig. 22D)

71.

35

35.8

\section{Kampong}

Bodjong,

Koempai, W. Java,

Pliocene; PCB,

A5393 (Fig. 22C)

59.6

36.7

23.7

17.0

33.2

26.8

10.3

$5.6 \quad 1^{*}: 2: 0 \quad 2 *: 3: 0$

7

Bodjong

Koempai, W. Java,

Pliocene; PCB,

$$
\text { A5393 }
$$

$34.9 \quad 29.6$

15.7

27.5

24.1

6.8

3.9

4:3:0

Table 15. Shell measurement and count data for Murex troscheli verbeeki Martin.* ${ }^{*}$ damaged. 
close similarity with any living species. The elucidation of the relationship of this form must await a more detailed study of the Indonesian fossil species.

This species has been recorded from several localities outside Java but these identifications should be treated with caution. Shuto (1969) records $M$. troscheli verbeeki from the Miocene and Pliocene of Panay Island. His Pliocene material (as judged by his text figure 23) certainly resembles this species but could equally well be $M$. aduncospinosus. The Miocene specimens he attributes to this species, as far as can be judged from the photographs of the fragmentary specimens, appear to be similar to Haustellum mindanaoensis.

Shuto's (1961) record of Murex cf. verbeeki from the Miyazaki Group, Japan (Pliocene?), if it is this species, suggests that $M$. verbeeki may have had a similar geographic range to that of the present-day $M$. troscheli.
One of the specimens figured by Martin (1895: fig. 279 ) is M.pecten (Altena, 1950 and confirmed by one of us [WFP]).

\section{Murex ejectus Martin, 1895}

Fig. 23

Murex(s.s.) ejectus Martin, 1895: 125, pl. 19, figs 287, 287a (Kalang, Anjar, Java, Pliocene; lectotype [here chosen as the specimen figured by Martin], GML, 9655).

Murex ejectus._Altena, 1950: 210.

Remarks. This species appears to be related to $M$. coppingeri from which the shell differs in its much heavier spines, single intervarical node, lack of secondary spines, and apparently weaker spines of the anterior canal. None of the three lots in the Martin collection (GML) have specimens with protoconchs. The length of the lectotype is $38.3 \mathrm{~mm}$ and its width (including spines) is $27.7 \mathrm{~mm}$.
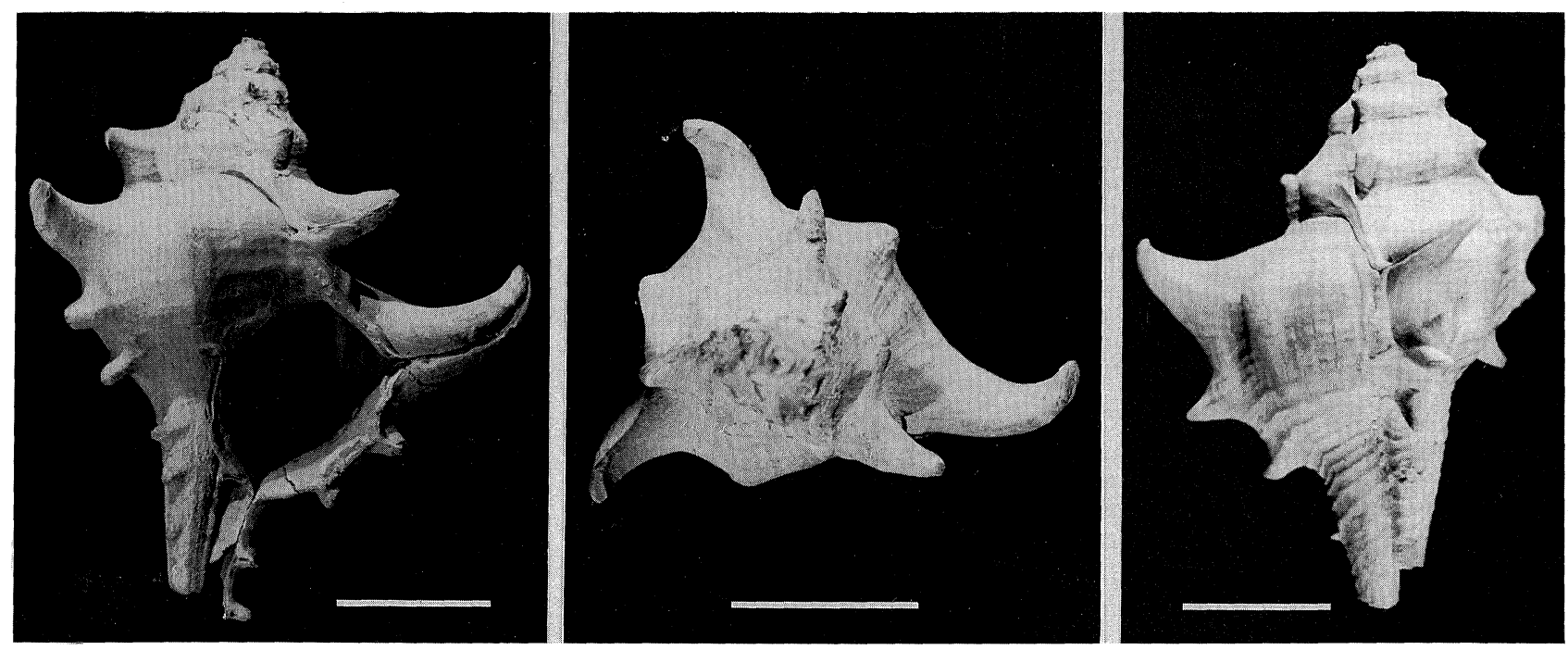

Figure 23. Murex ejectus Martin. Lectotype; Kalang, Anjar, Java, Pliocene (GML, 9655). Scale $1 \mathrm{~cm}$.

\section{Species Group 2: Murex scolopax Group}

Murex scolopax Dillwyn, 1817

Figs $24 ; 25$; 72C; 76A,B; 84A-C; 85E; Table 16

Purpura hystrix Martini, 1777: 363 (in part), pl. 113, fig. 1052 (not binominal).

Murex tribulus maximus Chemnitz, 1795: 101, pl. 189, figs 1819,1820 (not binominal); Deshayes \& MilneEdwards, 1839: 701 (in synonymy of $M$. crassispina); Deshayes, 1843: 565 (in synonymy of $M$. crassispina).

Murex scolopax Dillwyn, 1817: 681 (Red Sea; refers to Chemnitz, 1795: figs 1819, 1820, and Martini, 1777: fig. 1052 [restricted to Chemnitz figs by Houart, 1979: 143]; lectotype designated by Dean, 1936: 231, as a specimen in Dillwyn Colln [NMW]; the specimen figured by Chemnitz, also extant in ZMC); Wood, 1818: 119; pl. 25, fig. 3; Deshayes, 1843: 610; Reeve, 1845: pl. 22, fig. 89; Küster \& Kobelt, 1856: 26 (in part), pl. 9, fig. 2, pl. 11, figs 1, 2; Sowerby, 1879: 2, pl. 1 (of Murex), fig. 8; Tryon, 1880: 77 (in part), pl. 9, fig. 106; Baker, 1890: 66, text fig.
1 (protoconch); Smith, 1891: 404 (in part); Sturany, 1903: 30(238); Melvill, 1928: 104; Smith, 1953: 1, text fig. a, pl. 8, fig. 3; Biggs \& Grantier, 1960: 388; Vokes, 1970: 182; Biggs, 1973: 366; Dance, 1974: 122, fig. in text; Radwin \& D'Attilio, 1976: 71 (in part), text fig. 39, pl. 10, fig. 6; Fair, 1976: 76, pl. 3, fig. 41; Lindner, 1977: 176, pl. 27, fig. 9; Houart, 1979: 137 (+ text fig.), pl. 4, figs 3, 3A; Abbott \& Dance, 1982: 129, fig. in text (lectotype from NMW).

Murex crassispina Lamarck, 1822: 157 (Indian Ocean; NHMG, 2 syntypes, the smaller agrees well with Lamarck's dimensions and is here designated lectotype [1098/96], the other paralectotype [1098/97]); Deshayes \& Milne-Edwards, 1839: 701 (in part); Deshayes, 1843: 564 (in part); Kiener, 1843: 4, pl. 4, fig. 1, pl. 5, fig. 1.

Murex hystrix 'Martini' Márch, 1852: 98; H. \& A. Adams, 1858: 71; Tapparone-Canefri, 1875: 571 (based on Martini, 1777: pl. 113, fig. 1052) (preocc. by M. hystrix Linné, 1758).

Murex(Tribulus) scolopax.-Poirier, 1883: 33.

Murex occa.-Webb, 1936: 58, fig. in text (not of 


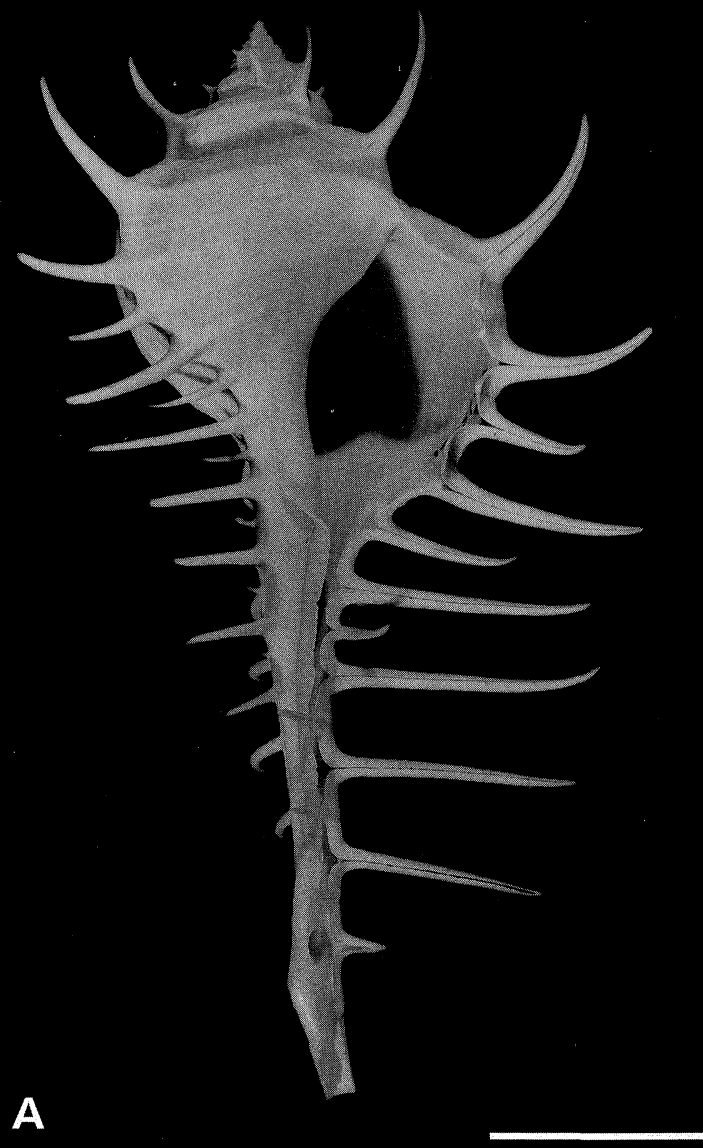

C

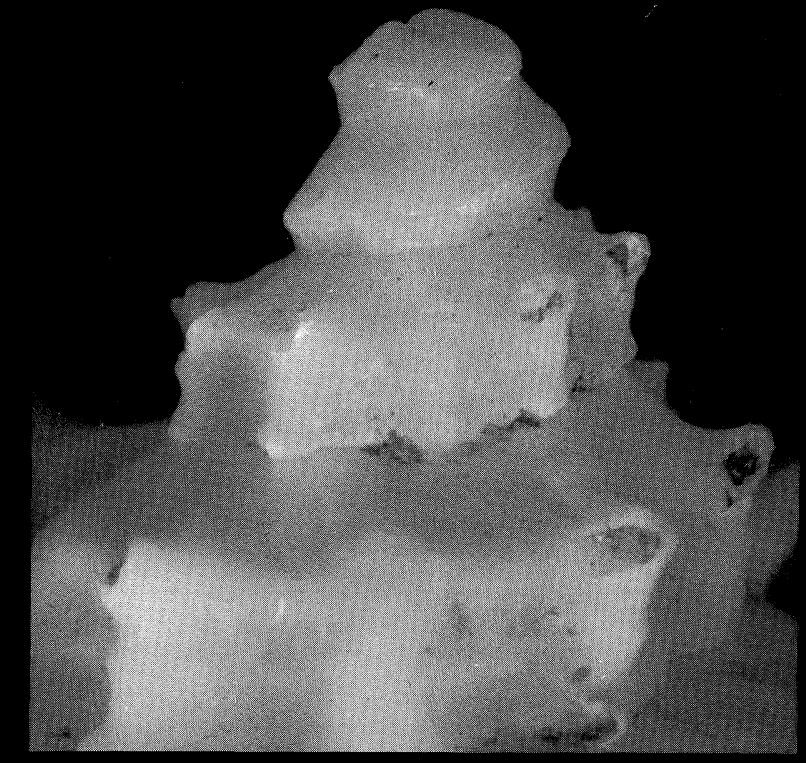

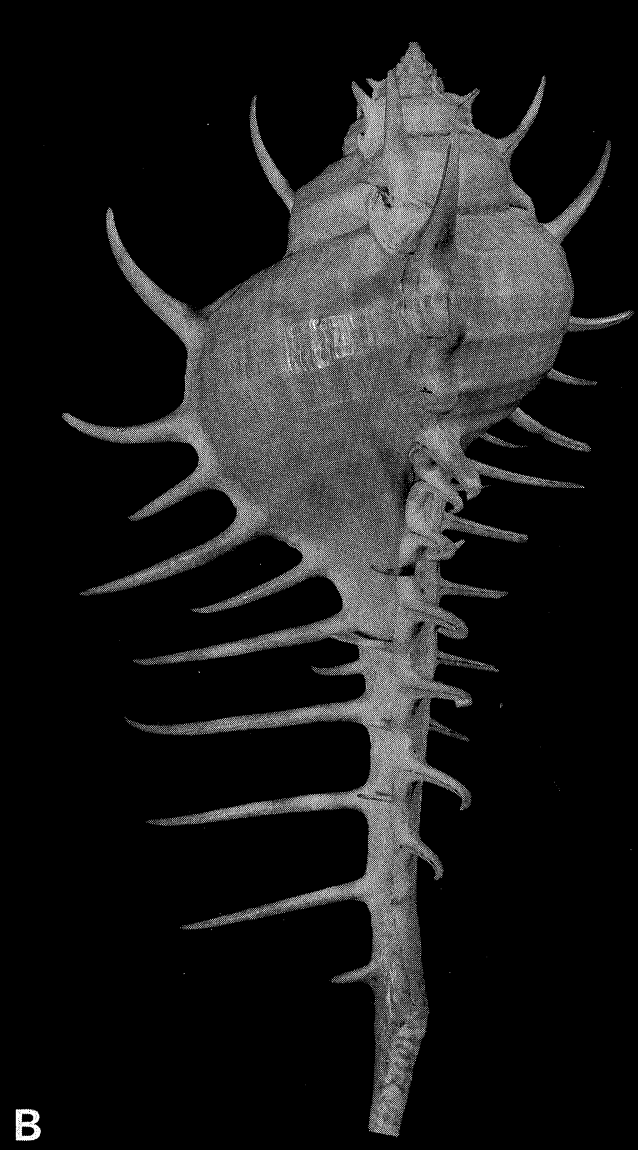

D

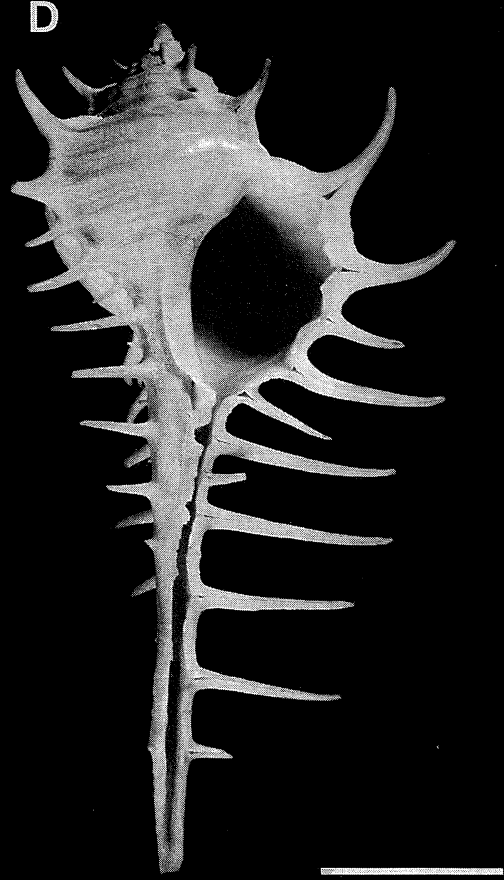

Figure 24. Murex scolopax Dillwyn. A-C: lectotype of M. crassispina Lamarck; Indian Ocean (NHMG, 1098/96). D: lectotype of M. scolopax; Red Sea (NMW). Scales $2 \mathrm{~cm}$. 
Sowerby).

Murex acanthostephes.-Kaicher, 1973: fig. 100 (not of Watson).

Murex tribulus._Ahmed, 1975: 23, figs 18a, 18b, (not of Linné).

Records. RED SEA: (AMS; AMNH; USNM; IRSB). ETHIOPIA: 5-6 m, 'Taulud Id' (AMS); Massawa (SMF); Green Id, Massawa (MCZ); 4 m, Dahlak Id (AMS); Dahlak Archipelago (RML). EGYPT: (AMNH). DEMOCRATIC YEMEN: Beach near Al Hudaydah (USNM); between Al Mukalla and 'Qurn' (WAM); Aden (AMS; BMNH; AMNH; RML); Bir Fuqum, Little Aden (AMS); Ras Mukaliab Hadi, Little Aden (ANSP); 4 m, Bir Ali (WAM); Badr (USNM; ANSP). OMAN: $14 \mathrm{~m}$, Gulf of Masirah (BMNH); 82-165 m, Gulf of Oman (BMNH); Masirah Id (AMNH; AMS); Muscat (BMNH; FMNH; MCZ; AMS; USNM; AMNH; ANSP; DMNH). PERSIAN GULF: 10-17 m (MCZ); $31 \mathrm{~m}$ (MCZ; BMNH; AMNH; AMS); Dabayy, U.A.E. (ANSP; AMNH) Qatar (ZMC); Al Manamah, Bahrain (AMS); 33 $\mathrm{m}$, Bahrain (ZMC); Bahrain (MCZ); Kuwait (USNM). SAUDI ARABIA: Tarut Bay, Gulf of Bahrain (ANSP; AMS; AMNH; USNM); $79 \mathrm{~m}, 40 \mathrm{~km}$ east of Dubai (MCZ); Dhahran (ZMC); Ra's Tannurah (ANSP; DMNH).

Fossil Record. Pleistocene: Zufaf Id, Farasan Ids, Red Sea (BMNH).

Description. SHELL. Very large (up to $190 \mathrm{~mm}$ in length, average length about $150 \mathrm{~mm}$ ), with seven inflated teleoconch whorls.

Protoconch of about two and one-half angulate volutions, ending in small, straight varix.

Spiral ornamentation on first teleoconch whorl of two or three weak cords masked by axial ribs, continuing very weakly on succeeding whorls. On third whorl, two minor cords appearing on subsutural ramp and another between each pair of major cords. Body whorl with four very low and flattened major spiral cords, each separated by two or three exceedingly weak spiral threads. Spiral ornamentation on siphonal canal visible only where drawn out into spines.

Axial ornamentation on first teleoconch whorl of nine ribs, angulate at shoulder; on second whorl, every third rib strengthened into varix with short, stout, apically recurved spine at shoulder; intervarical ribs rounded ridges. By fourth whorl, intervarical ribs completely lost and succeeding whorls ornamented solely by weak spiral threads. Three low, narrow varices per whorl, bearing stout spines, spines at shoulder and periphery apically recurved, anterior ones more adaperturally directed; three primary spines on varices on body whorl, one secondary between that at periphery and base, another at juncture of base and canal; some specimens with single adaperturally-directed small spine between shoulder and peripheral spines. Siphonal canal with five or six long, stout, adaperturally-recurved spines, decreasing in length anteriorly, posterior-most longest. Secondary spines alternating with primary spines, approximately half as long and bent adaperturally at increasingly greater angle to primary spines; posterior-most spine almost parallel and anterior-most at angle of $90^{\circ}$.
Suture impressed, crossed diagonally by lamellate growth lines, posterior ends of lamellae directed adaperturally.

Aperture elongate-oval; outer lip deeply notched by median groove of spines, size of notches corresponding to strength of spines. Tooth-like projections separated by notches in advance of varix; projection posterior to spine at base of body whorl elongated to form large labral tooth. Prominent anal notch at posterior end of aperture between projecting end of subsutural ramp and thin appressed end of inner lip; edge of subsutural ramp extending above suture reaching almost to shoulder of preceding whorl. Anterior two-thirds of inner lip free-standing, narrow, smooth.

Siphonal canal long; terminations of previous canals fused into tube, open by narrow slit; spinose for almost entire length.

Colour creamy white with major spiral cords coloured golden brown on tops but not extending on to spines; often a darker blotch on subsutural area mid-way between varices; aperture white, interior light brown with slightly darker brown lines corresponding to spiral ornamentation.

DiMENSIONS. See Table 16.

OPERCULUM. Brown; subterminal nucleus, with eight to ten strong concentric ridges, angulate at line extending along length.

PENIS. Very long, slightly tapering, with terminal papilla (Fig. 72C).

Remarks. Lamarck (1822) named $M$. crassispina as a replacement name of $M$. tribulus for which he was criticised by Deshayes (1838-45). Lamarck's concept of $M$. crassispina, like Linné's concept of $M$. tribulus, has long been recognised as a composite species. Dodge (1957) pointed out this fact and suggested that Lamarck's name should not be used. Our action of designating Lamarck's specimen of $M$. crassispina (which was figured by Keiner) as the lectotype of that species reduces this name to a definite synonym of $M$. scolopax.

This species is confined to the Red Sea and Persian Gulf. The shell of the Persian Gulf form differs from shells of typical Red Sea specimens in usually having a longer, more adapically directed shoulder spine and a secondary spine is usually developed between the shoulder spine and the spine below. In addition, the inner lip is less expanded over the parietal wall. The protoconch of most Persian Gulf specimens lacks a keel and the axial colour lines are usually better developed. None of these characters are, however, consistent and we do not think that subspecific status for the Persian Gulf populations is warranted.

Shells of deep-water specimens tend to develop longer, more slender spines than shallow-water specimens (compare Figs $84 \mathrm{a}-\mathrm{c}$ and $85 \mathrm{E}$ ).

Murex occa Sowerby, 1834

Figs 25-27; 76D-F; 85F; Table 17

Murex occa G.B. Sowerby II, 1834: pl. 64, fig. 45 

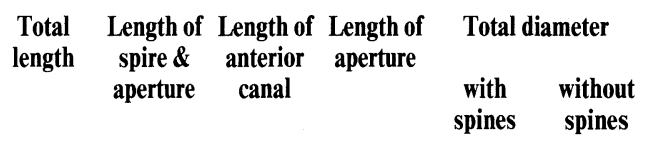

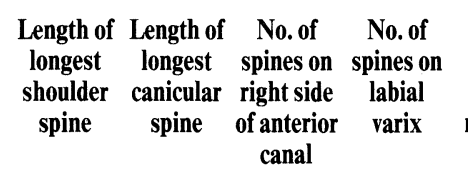

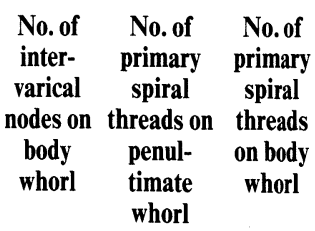

Lectotype of $M$. crassispina

Chemnitz figured specimen; ZMC (Fig. 84C)

Gulf of Oman; BMNH (Fig. 85E)

Dahlak Id, Red

Sea; AMS C. 88338

(Fig. 84B)

Muscat, Oman,

Arabian Sea; AMS, C.127147 (Fig. 84A)

153.8

69.0

Muscat, Oman, C. 72198

Dahlak Id, E. of Ethiopia; AMS, C. 127312

Muscat, Oman, Gulf of Oman;

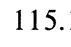

182.0

106.4

117.9
85.5

128.5

110.8
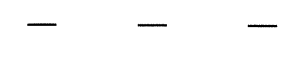

43.6

$$
97.3
$$$$
46.7
$$$$
48.9
$$$$
59.5
$$

92.0

61.2

62.2

34.3

28.3

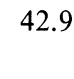

$5: 5$

3:2:0

0

9

15

14

55.0
Arabian Sea; AMS, AMS, C. 127206

31.9

$65.8^{*}$

41.7

18.5

32.4

5:5:1

3:2:0

0

8

17

61.6

40.1

71.4

51.3

36.3

36.

38.7

$5: 5:$

$3: 3: 0$

0

6

10

3

Table 16. Shell measurement and count data for Murex scolopax Dillwyn.* = damaged.
(Nicobar Ids; 3 possible syntypes, BMNH, 197492/13); Sowerby, 1841b: 137; Reeve, 1845: pl. 20, fig. 81; Issel, 1869: 137 (in part); Küster \& Kobelt, 1869: 74 (in part) (figure may possibly represent $M$. forskoehlii); Tapparone-Canefri, 1875: 573; Sowerby, 1879: 3, pl. 2 (of Murex), fig. 12; Baker, 1890: 67, text fig. 2 (protoconch); Baker, 1897: 371; Smith, 1953: 1, pl. 22, fig. 1, text fig. b (protoconch); Kaicher, 1974: fig. 524; Fair, 1976: 63, pl. 2, fig. 21 (syntype); Houart, 1979: 137, figs 2, 2A; Abbott \& Dance, 1982: 130, fig. in text.

Murex coca (sic).-Kiener, 1843: 7, pl. 10, fig. 1.

Murex scolopax.-Tryon, 1880: 77 (in part), pl. 9, fig. 108; Radwin \& D'Attilio, 1976: 71 (in part), pl. 10, fig. 7 (not of Dillwyn).

Murex(Tribulus) occa.-Poirier, 1883: 34.

Murex lebacanus Martin, 1895: 19, figs 285, 286 (Tji Mantjeurih, near Rajah, Lebak, Banten, Java, Pliocene; lectotype [here chosen; the specimen figured by Martin], GML, 9649); Altena, 1950: 210.

Murex djarianensis.-Martin, 1928: 10, 25 (in part, fide Altena, 1950: 210; not of Martin, 1895).

Murex(Murex) lebacanus.-Oostingh, 1940: 59, pl. 19, figs $338 \mathrm{a}, \mathrm{b}$.

Murex trapa.-Tantanasiriwong, 1978: 13, fig. 174 (not of Röding).

Records. NICOBAR ISLANDS: (NMW; NMV; MNT). ThAILAND: Phuket Id (MCZ); 'Luam Yamu', east Phuket Id (ANSP); Butang Group (ZMC). MalaYsia: Pulau Langkawi (AMS); Tg Kubu, Pulau Langkawi (WAM); Pinang (BMNH; MCZ; ZMA; MNT; ZMC; AMS); east coast of Malaysia; Batu Feringgi, Pinang; Tenggarroh; Kuantan; Melaka; Pasir Panjong; Port Dickson, north of Malacca; 'Pantai Merdeka Beach', Kedah Coast; Pontian Kechil (all AMS); Kuala Kedah; Telok Bahang, south of Pinang; trawled off Lumut, west coast Malaysia; Pangkor (all BMNH). Singapore: (NMW). IndONESIA: Sumatra (MNT); Belawan, Sumatra (RML; MCZ); Aceh Province, Sumatra (ZMA); Djakarta Teluk, Java (RML); Deli Id, south-west Java (ZMA); 'Moluccas' (RML).

Fossil Records. Late Pliocene: Type Badjong, below Bodjong, Koempai, west Java (PCB). Pliocene: Java (as $M$. lebecanus; see Altena (1950) for additional records).

Description. SHELl. Large (up to $95 \mathrm{~mm}$ in length), with six shouldered teleoconch whorls. Protoconch of about two and one-half angulate volutions with top flattened and tip submerged, ending at small crescentic varix.

Spiral ornamentation on first two teleoconch whorls visible only as sharp angle at shoulder; on subsequent whorls only faint, minor threads barely visible even on body whorl.

Axial ornamentation on first two teleoconch whorls of nine angulate ribs, each with sharp open spine at shoulder. On third whorl, every third rib strengthened, forming varix bearing stout, closed, apically curved spine; intervening two axial ribs strongly nodose at shoulder. By fifth and subsequent whorls, weaker third axial ridge developed in adapertural portion of intervarical area; on body 


\begin{tabular}{|c|c|c|c|c|c|c|c|c|c|c|c|c|c|}
\hline & $\begin{array}{l}\text { Total } \\
\text { length }\end{array}$ & $\begin{array}{l}\text { Length of } \\
\text { spire \& } \\
\text { aperture }\end{array}$ & $\begin{array}{l}\text { Length of } \\
\text { anterior } \\
\text { canal }\end{array}$ & $\begin{array}{l}\text { Length of } \\
\text { aperture }\end{array}$ & $\begin{array}{l}\text { Total d } \\
\text { with } \\
\text { spines }\end{array}$ & $\begin{array}{l}\text { Imeter } \\
\text { without } \\
\text { spines }\end{array}$ & $\begin{array}{l}\text { Length of } \\
\text { longest } \\
\text { shoulder } \\
\text { spine }\end{array}$ & $\begin{array}{l}\text { Length of } \\
\text { longest } \\
\text { canicular } \\
\text { spine }\end{array}$ & $\begin{array}{l}\text { No. of } \\
\text { spines on } \\
\text { right side } \\
\text { of anterior } \\
\text { canal }\end{array}$ & $\begin{array}{l}\text { No. of } \\
\text { spines on } \\
\text { labial } \\
\text { varix }\end{array}$ & $\begin{array}{l}\text { No. of } \\
\text { inter- } \\
\text { varical } \\
\text { nodes on } \\
\text { body } \\
\text { whorl }\end{array}$ & $\begin{array}{l}\text { No. of } \\
\text { primary } \\
\text { spiral } \\
\text { threads on } \\
\text { penul- } \\
\text { timate } \\
\text { whorl }\end{array}$ & $\begin{array}{c}\text { No. of } \\
\text { primary } \\
\text { spiral } \\
\text { threads } \\
\text { on body } \\
\text { whorl }\end{array}$ \\
\hline Syntype & 87.6 & 41.5 & 47.1 & 24.8 & 36.1 & 30.2 & 14.3 & 14.6 & $5: 2: 0$ & $3: 3: 0$ & 2 & 5 & 10 \\
\hline Syntype & 83.0 & 40.5 & 44.0 & 23.6 & 40.7 & 30.0 & 16.7 & 9.1 & 5 & $3: 1: 0$ & 2 & 6 & 8 \\
\hline Syntype & 92.2 & 39.0 & 53.2 & 23.2 & 44.7 & 29.6 & 19.3 & 14.2 & $6: 2$ & $3: 3: 0$ & 2 & 5 & 11 \\
\hline $\begin{array}{l}\text { Lectotype of } M \text {. } \\
\text { lebacanus }\end{array}$ & 77.5 & - & - & - & 36.9 & 35.0 & - & - & - & - & - & - & - \\
\hline $\begin{array}{l}\text { East coast of } \\
\text { Malaysia; AMS, } \\
\text { C.122630 (Fig. } \\
85 \text { F) }\end{array}$ & 93.7 & 45.1 & 49.2 & 28.4 & 50.7 & 35.5 & 17.4 & 11.8 & $5: 2^{*}$ & 3:3:1 & 2 & 8 & 13 \\
\hline $\begin{array}{l}\text { Nicobar Id; NMV, } \\
\text { F27442 }\end{array}$ & 79.0 & 39.2 & 41.2 & 23.2 & 33.7 & 29.1 & 8.0 & 11.2 & $5: 4: 0$ & $3: 3: 0$ & 1 & 7 & 13 \\
\hline $\begin{array}{l}\text { Penang, Malaysia; } \\
\text { ZMC }\end{array}$ & 64.3 & 35.2 & 28.8 & 21.3 & 36.3 & 27.8 & 16.5 & 9.5 & $5: 1: 0$ & $3: 1: 0$ & 2 & 6 & 12 \\
\hline $\begin{array}{l}\text { Penang, Malaysia; } \\
\text { ZMC }\end{array}$ & 63.8 & $36.1^{*}$ & 27.8 & 22.1 & 40.0 & 26.8 & 17.2 & 6.7 & $4: 1: 0$ & $3: 3: 0$ & 2 & 6 & 11 \\
\hline $\begin{array}{l}\text { Below Kampong } \\
\text { Bodjong, } \\
\text { Koempai, W. Java, } \\
\text { Pliocene; PCB, } \\
\text { A.5393 }\end{array}$ & 51.2 & 27.0 & 24.4 & 15.4 & 25.0 & 19.7 & 5.8 & 4.5 & $5: 0: 0$ & $3: 3: 0$ & 2 & 5 & 11 \\
\hline $\begin{array}{l}\text { Below Kampong } \\
\text { Bodjong, } \\
\text { Koempai, W. Java, } \\
\text { Pliocene; PCB, } \\
\text { A.5393 }\end{array}$ & 51.5 & 26.1 & 25.5 & 15.4 & 24.1 & 19.7 & 4.6 & 6.3 & $5: 1: 0$ & $3: 1: 0$ & 2 & 5 & 10 \\
\hline
\end{tabular}

Table 17. Shell measurement and count data for Murex occa Sowerby.* = damaged.

whorl these appearing only as nodules, one at shoulder and weaker one at periphery. Three low varices per whorl, each with three short, stout closed spines, sharply recurved apically, one each at shoulder, periphery, and base of body whorl. Alternating with primary spines are smaller, short secondary spines, curving slightly adaperturally. Siphonal canal with five relatively short, straight primary spines, slightly recurved adaperturally. Short, slender secondary spines alternate with primary spines, directed adaperturally at right angles to major ones.

Suture simple, slightly appressed.

Aperture elongate-ovate; no true outer lip, apertural edge of varix scalloped into grooves of major spines, giving rise to a series of tooth-like projections. Projection posterior to major spine at base of body whorl, elongated into large labral tooth. Weak anal notch formed by projection of subsutural ramp and appressed posterior portion of inner lip; this structure visible in advance of preceeding varices. Anterior two-thirds of inner lip freestanding, narrow, smooth.

Siphonal canal long, terminations of previous canal fused into tube, open by narrow slit; spinose three-quarters of length.

Colour creamy white; aperture white, brown interior; some specimens with darker brown spiral lines inside aperture, corresponding to major spiral cords.

Dimensions. See Table 17.

OPERCULUM. Yellowish brown; subterminal nucleus located on side adjacent to outer lip, with about nine concentric ridges; strongly creased at midline along length.

Habitat. On mud flats seaward of mangrove forests (Tantanasiriwong, 1978).

Remarks. The shell of this species is readily differentiated from that of $M$. scolopax, with which it is closely allied, by its smaller size, more strongly angled whorls, shorter, hooked spines and uniform colouration. It also occupies a different geographic area (Fig. 25), being confined to south-eastern Asia and Indonesia.

The type material of Murex lebacanus Martin is virtually identical to Recent shells, no distinguishing characters being found. Martin (1895) separated his fossil form from $M$. occa by the protoconch being "drawn out like a corkscrew" (free translation) and in having shorter spines. Both of these characters can be found in Recent specimens. There are eight lots of $M$. lebacanus in the Martin collection (GML), two identified as M. djarianensis $(9646,47079)$, one lot of 
three specimens as $M$. brevispina (9662), and five lots correctly identified (9649 [Martin's fig. 286] and here designated lectotype; 9646, 9650 [Martin's fig. 285], 9651, and 9652, all lots of one specimen).

\section{Murex acanthostephes Watson, 1883}

Figs 25; 28; 67F; 72B; 76J-L; 85A-D; Table 18

?Murex crassispina.-Menke, 1843: 23 (not of Lamarck).

Murex (Tribulus) acanthostephes Watson, 1883: 596 (west of Cape York, off south-west point of Papua, $9^{\circ} 59^{\prime} \mathrm{S}, 139^{\circ} 42^{\prime} \mathrm{E}, 28$ fathoms [51 m], in green sand, HMS 'Challenger', 10 Sept 1874; lectotype [here chosen as Watson's figured specimen] and two paralectotypes, BMNH, 87.2.9.519-521; 4 paralectotypes, same data, AMS, C.2964); Watson, 1885: 149, pl. 10, fig. 2.

Murex acanthostephes.-E.A. Smith, 1884: 43, pl. 5, fig. B; Brazier, 1893: 50; Baker, 1897: 375; Smith, 1953: 1; Wilson \& Gillett, 1971: 84, pl. 57, figs 3, 3a; Coleman, 1975: 209, fig. 588; Fair, 1976: 17, pl. 2, fig. 16; Hinton, 1978: 33, fig. 3; Houart, 1979: figs 1, 1A; Coleman, 1981: 58 (photograph of female on egg mass).

Murex tribulus.-Hedley, 1916: 213; Odhner, 1917: 11; Takemura \& Okutani, 1955: 100, pl. 6, fig. 6; Cotton, 1956: pl. 8 (not of Linné).
Murex trapa.-Hedley, 1916: 213 (not of Röding).

Murex nigrispinosus.-Abbott \& Dance, 1982: 130, fig. in text (not of Reeve).

Records. Australia: Western Australia: Cardabia Station, Carnarvon (WAM; AMS); Coral Bay, south of Exmouth; inner coast, North West Cape; Exmouth Gulf; Bundegi Reef, Exmouth; $17 \mathrm{~m}$, south of Exmouth (all AMS); Learmonth, Exmouth Gulf; Bay of Rest, Exmouth Gulf (both WAM); Thevenard Id, Onslow (AMS); north of Long Id, Onslow; west of Flat Id, near Long Id, off Onslow; 13 m, east of Mary Ann Passage, Onslow (all WAM); 'Black Tank', Point Samson (WAM; Causeway Beach, Dampier (AMS); off Jarman Id (WAM); 0-5 m, Rosemary Id, Dampier Archipelago (WAM); Nickol Bay (AMS); 'Pretty Pool Reef', Port Hedland; Condon; Eighty Mile Beach (all WAM); Roebuck Bay (AMS); 5-9 m, $3 \mathrm{~km}$ north-east of Cape Bossut (WAM); off La Grange Bay, south of Broome (ANSP); $40 \mathrm{~m}$, north of Cape Jaubert (WAM); Broome (WAM; AMS); Sunday Id, Derby (WAM); Beagle Bay (AMS); Yampi Sound (WAM; AMS); $58 \mathrm{~m}, 360 \mathrm{~km}$ eastnorth-east of Troughton Id (WAM); $69 \mathrm{~m}$, Holothuria Bank (BMNH). Northern Territory: $25 \mathrm{~m}$, Darwin (AMS) 58-65 $\mathrm{m}$, Arafura Sea near Darwin (BMNH); $72 \mathrm{~m}$, Arafura Sea (AMS); north of Melville Id (MNT); Melville Id; Cape Don, Cobourg Peninsula; Millingimbi, Crocodile Ids; 65 m, 75

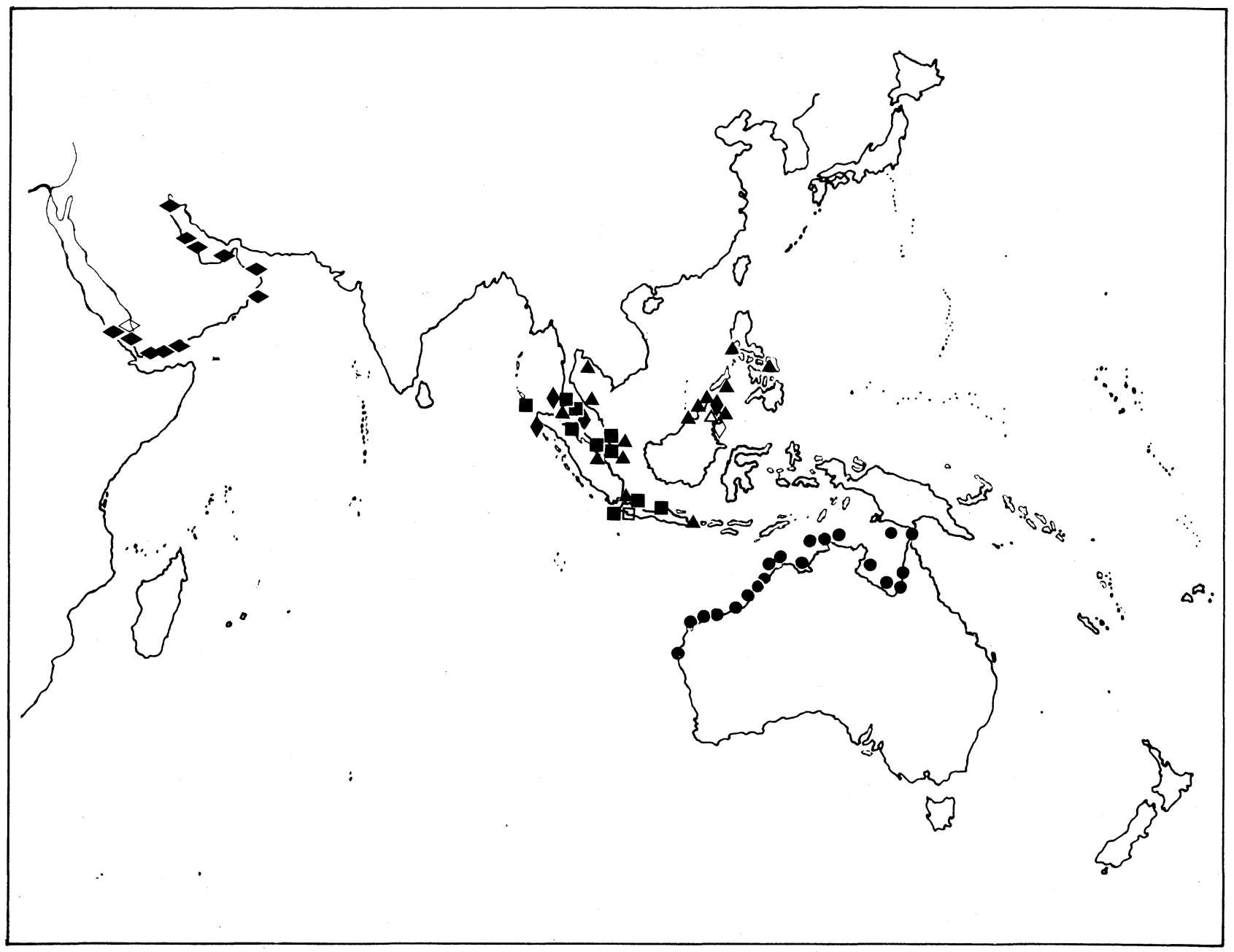

Figure 25. Distribution of species in the Murex scolopax group $M$. scolopax Dillwyn (horizontal diamond): $M$. occa Sowerby (square); $M$. acanthostephes Watson (circle); M. altispira n. sp. (triangle); $M$. djarianensis poppei Hobuart (diamond) and open symbols $=$ fossil records. 


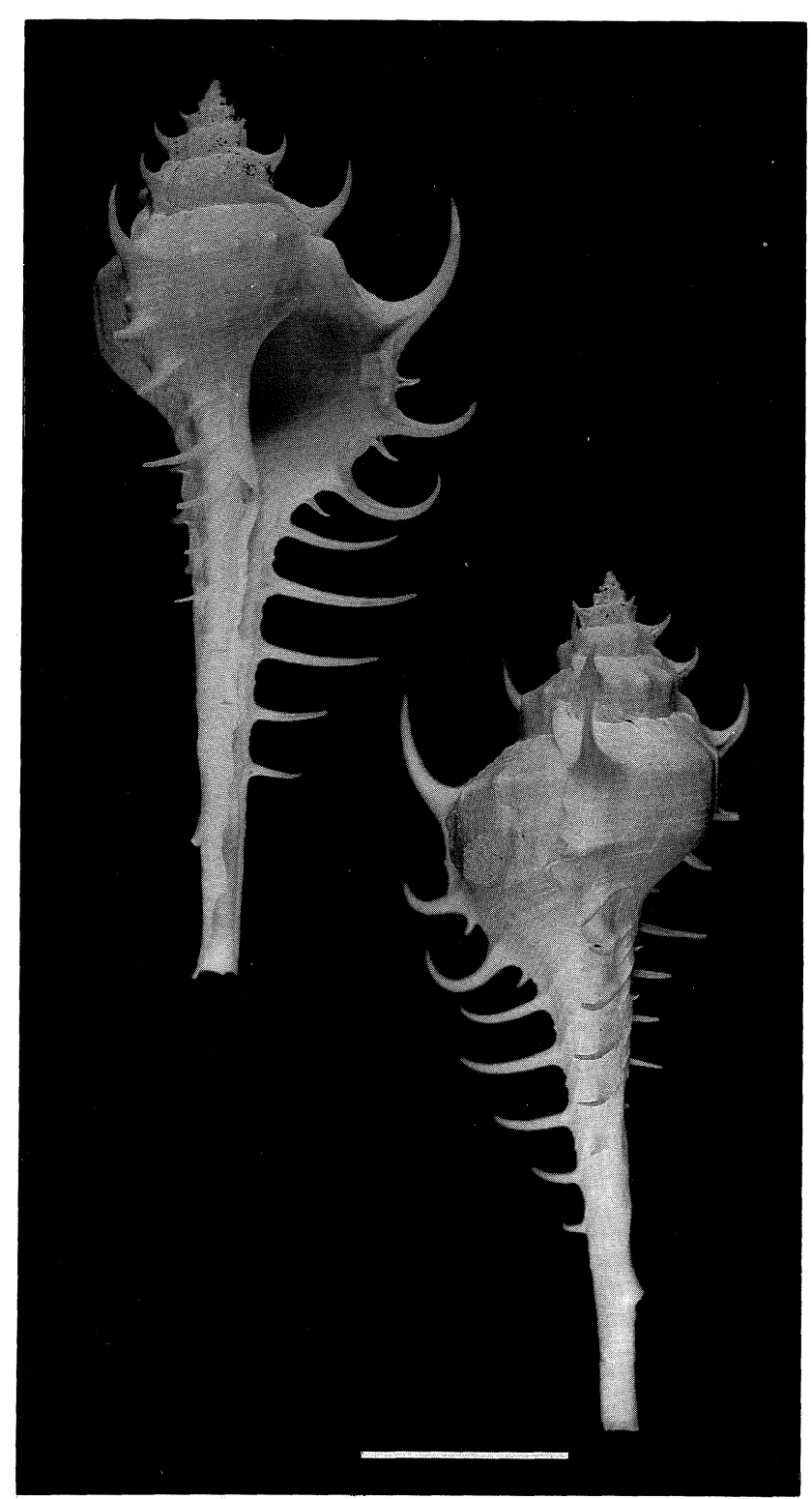

Figure 26. Murex occa Sowerby. Possible syntype; Nicobar Ids $(\mathrm{BMNH}, 197492 / 1)$. Scale $=2 \mathrm{~cm}$.

km north of Croker Id (all AMS); Jones Shoal, Port Essington (MNT); Groote Eylandt (SAM; AMS); Umbakumba, Groote Eylandt (AMS). Queensland: Mornington Id (ANSP); $20 \mathrm{~m}$, north-east of Sweers Id; Karumba; $18 \mathrm{~m}$ and $25 \mathrm{~m}$, west of Topsy Creek, Mitchell River mouth; $18 \mathrm{~m}$, west of Pt Burrows; $25 \mathrm{~m}$, west of Nassau River; 18-22 m, west of Edward River, Gulf of Carpentaria; Torres Strait (all AMS); Thursday Id (MNT).

Fossil Records. None known (but see below).

Description. SHELL. Large (up to $110 \mathrm{~mm}$ in length), with seven teleoconch whorls.

Protoconch of about two and one-half volutions, angulate to rounded on sides, varying in diameter from about 1 to $1.5 \mathrm{~mm}$, top flattened, ending at small, straight varix.

Spiral ornamentation on first two teleoconch whorls masked by axial ribs, made apparent only by

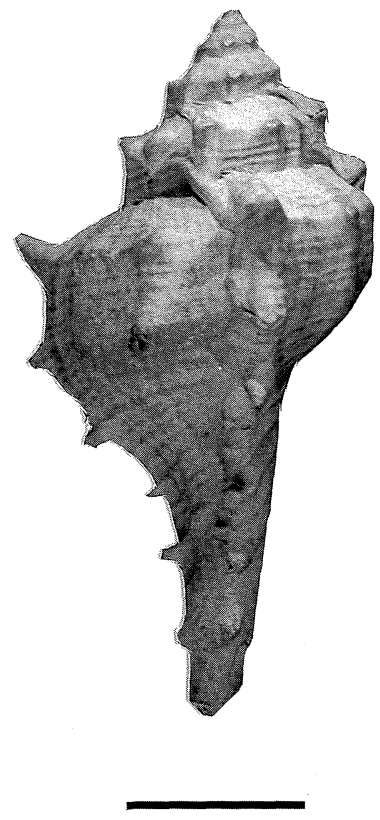

Figure 27. Murex occa Sowerby. Lectotype of M. lebacanus Martin; Tji Mantjeurih, near Rajah, Lebak, Bantam, Java, Pliocene (GML, 9649). Scale $2 \mathrm{~cm}$.

two small spines on each rib. By third whorl a strong secondary spiral cord between two major cords and numerous tertiary threads developed between major cords and on subsutural ramp. Body whorl with alternating spiral cords of three orders of magnitude in variable arrangement. Siphonal canal with regularly alternating major and minor cords.

Axial ornamentation on first teleoconch whorl of nine angulate ribs bearing two open spines on each; apically directed, one at shoulder stronger, second near suture. On second whorl, every third rib strengthened to form varix with very long, apically directed shoulder spine; intermediate ribs reduced to nodules on spiral cords. Subsequent whorls with no intervarical ornamentation except strong growth lamellae sinuated by spiral ornamentation, giving a malleated appearance to intervarical areas. Three low, rounded varices per whorl, each with long, sharp spines; three primary spines at shoulder, periphery, and base of varices on body whorl, spine at shoulder always directed somewhat apically. Shoulder spine, in some specimens nearly vertical and exceedingly long, and, in these specimens peripheral spine usually recurved apically and equally long. Shorter-spined examples with peripheral spine nearly horizontal. Anterior-most spine always long, nearly straight and directed horizontally; in short-spined individuals basal spine longest on body whorl. Alternating with primary spines are three shorter, narrower, adaperturally-recurved secondary spines. Siphonal canal with five or six adaperturally-recurved primary spines alternating with secondary spines; second 

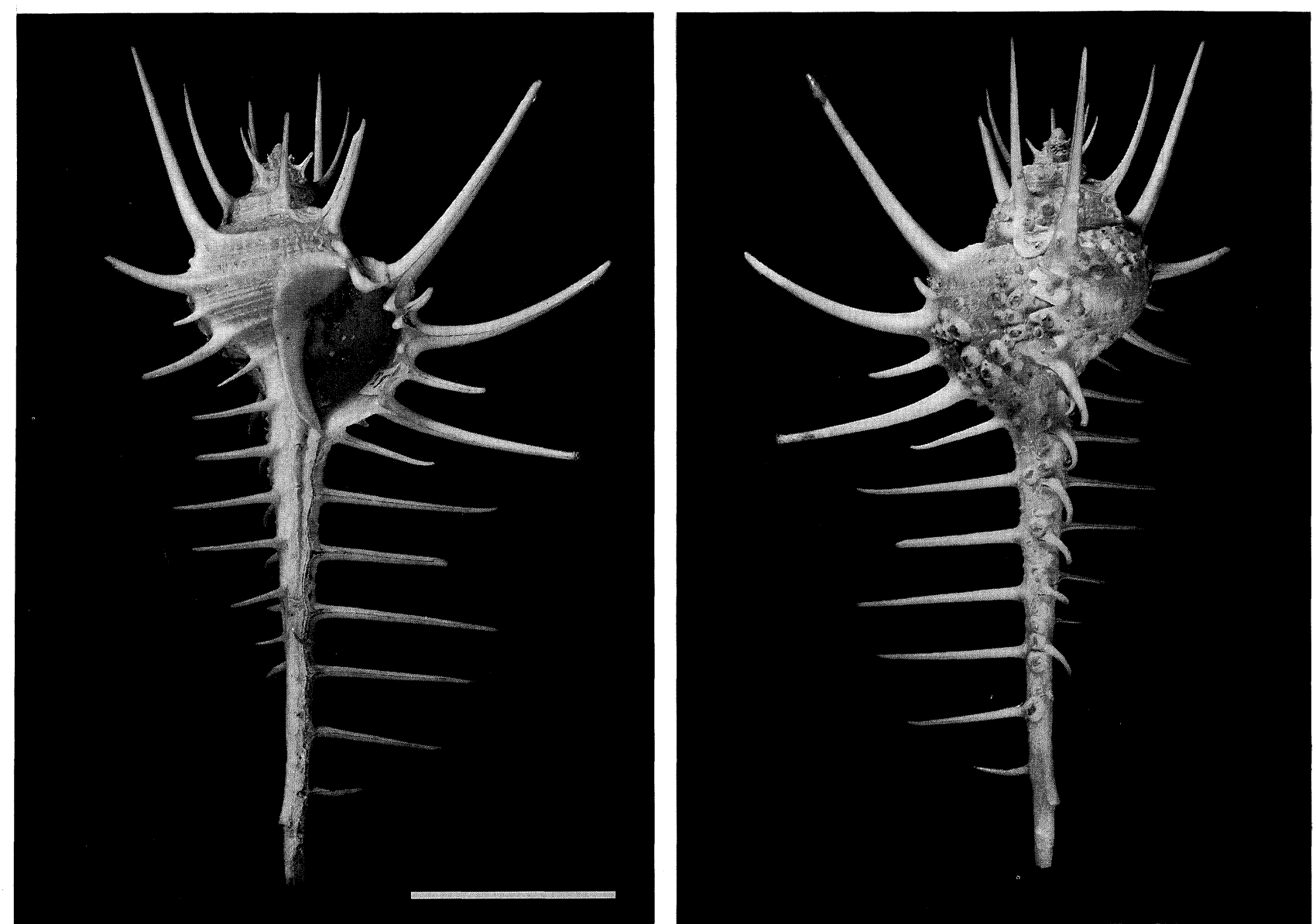

Figure 28. Murex acanthostephes Watson. Lectotype; west of Cape York, off south-west point of Papua New Guinea, 51 m (BMNH, 87.2.9.519). Scale $2 \mathrm{~cm}$.

primary spine from body whorl always longest spine on shell, others decreasing in length anteriorly. Secondary spines short, sharp, tending adaperturally at an angle to major spines, angle increasing anteriorly; posterior-most secondary spine almost parallel with adjacent primary spines but anteriormost at angle greater than $90^{\circ}$.

Suture impressed, crossed diagonally by fine growth lamellae, directed adaperturally at posterior end.

Aperture ovate; no true outer lip, apertural edge of varix scalloped into spines as series of deep notches, their size corresponding to strength of spines. Notches result in series of tooth-like projections in advance of varix, projection posterior to spine at base of body whorl elongated into large labral tooth. Strong anal notch formed by projecting edge of subsutural ramp and appressed portion of inner lip, extending above suture to level of periphery of preceding whorl. Anterior two-thirds of inner lip freestanding, narrow, smooth.

Siphonal canal long; terminations of previous canals fused into tube, open by narrow slit, spines extending almost to slightly recurved distal end of canal.

Colour creamy white, maculated with light tan blotches, most deeply coloured in interspaces between spirals, but with growth lamellae lighter in colour causing spirals to have appearance of elongated nodes; aperture and interior of shell white.

DiMENSIONS. See Table 18.

OPERCULUM. Reddish brown; subterminal nucleus, with eight to ten strong concentric ridges, strongly creased along median line.

RADULA. See Fig. 67F.

PENIS. Long, slightly tapering, with terminal papilla. Surface marked with longitudinal striae (Fig. 72B).

Remarks. The shell of this species is similar to that of $M$. scolopax but can be readily distinguished by the malleated surface and pale primary spiral cords. It is confined to the north and north-west of Australia (Fig. 25).

The length of the spines in this species and the size of the shell appears to be correlated with depth and sediment. The series figured (Figs 85A-D) illustrates this well. The larger, shortest spined specimen came from a sand habitat at low tide, the other intertidal specimen was collected in muddy sand. The smaller, longer spined specimens were collected in deeper water on muddy sediment. 


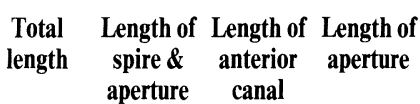

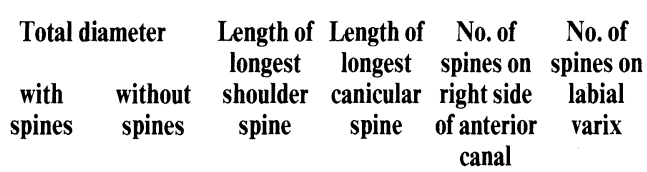

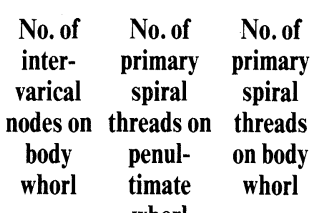
whorl

Paratype; $\mathrm{BMNH}$,

1887.2.9.519-521.

Paratype; BMNH,

1887.2.9.519-521.

$\begin{array}{lllll}73.2 & 28.5 & 44.7 & 17.3 & 49.4 \\ 56.7 & 24.8 & 32.5 & 13.9 & 35.5\end{array}$

23.1

25.0

$18.7 \quad 7: 4^{*}: 0 \quad 3: 3: 0$

$0 \quad 5$

13

$14.1^{*}$
(3rd last

$\begin{array}{lllll}15.2 & 6: 4: 0 & 3: 3: 1 \quad 0 & 7\end{array}$

Darwin, Northern

Territory,

Australia, $25 \mathrm{~m}$;

AMS, C. 113883

(Fig. 85C)

30.2

40.9

19.1

48.2

22.9

26.3

23.0

$8: 6$

$3: 3: 3$

5

Northern

Territory,

Australia, $72 \mathrm{~m}$;

AMS, C. 126516

(Fig. 85D)

Dampier, Western

Australia; AMS,

C.106392 (Fig.

85A)

55.4

68.9

32.1

24.

Inner Coast, N.W.

Cape, Western

Australia; AMS,

108.1

48.5

60.9

23.6

55.4

35.1

12.5

25.3

$5: 3$

Murex aff.

acanthostephes

Cape Possession,

Papua New

Guinea, Pliocene;

BMR, F.2390 (Fig.

29D)

\begin{tabular}{|c|c|c|c|c|c|}
\hline 72.2 & 34.8 & 37.6 & 20.8 & - $^{*}$ & $\begin{array}{cc}27.6^{*} & 8.0^{*} \\
\text { (labial } & \text { (2nd last } \\
\text { varix } & \text { varix) } \\
\text { broken) } & \end{array}$ \\
\hline
\end{tabular}

14

Table 18. Shell measurement and count data for Murex acanthostephes Watson.* ${ }^{*}$ damaged.

Coleman (1975) states that this species feeds mainly on bivalves and (Coleman, 1981: 58) lays its egg capsules as a column fixed to a suitable base anchored in sand.

Three specimens from the Mio-Pliocene of Papua New Guinea are, in teleoconch characters, very similar to $M$. acanthostephes. One specimen has a protoconch and this differs considerably, being much smaller than any Recent examples (Fig. 76I). It is probable that this material represents a chronosubspecies of acanthostephes but the available specimens are inadequate for formal description. The localities are: Mio-Pliocene, $3 \mathrm{~km}$ east of Amaimon, Madang area (1 spm, BMR); Pliocene, Cape Possession, Yule District (2 specimens, BMR; Fig. 29D).

\section{Murex altispira n.sp.}

Figs 25; 76C; 84D,E: Table 19

Murex martinianus.-Cox, 1948: 43, pl. 4, figs 7a, b (not of Reeve).

Murex scolopax.-Kaicher, 1973: fig. 105 (not of Dillwyn).

Type material. HolOTYPe: (USNM, 657929A), Tambisan, Sabah, Feb. 1963, M. Saul. Three paratypes (USNM, 657929), same locality. PARATYPES: 4 paratypes (ANSP, 295510); trawled off Nonoyan Island, Sandakan, Sabah, March 1963, M. Saul; paratype, Kuantan, East Malaysia, on beach, coll. W.F. Ponder, 28 Aug 1979; 4 paratypes (AMS, C117019); Sarawak, East Malaysia 1963, W. Rudman colln.

Records. Thailand: Cliff Rock, Gulf of Thailand (ZMC); Ko Samet, north-east of Phuket (USNM); Songkhla 
(USNM, ANSP, DMNH). MALAYSIA. SARAWAK: Baram River (ANSP). SABAH: Kampong Tanjong Aru, Kota Kinabalu (USNM; ANSP; DMNH); 17 km north-west of Kinabatangan R; Agal Bay, north-west Sabah; 29 m, 17 km from Balambangan Id, north Sabah (both WAM); 9 m, off Tambisan, east coast; Sandakan (both USNM). INDONESIA: $24 \mathrm{~m}$, south-west Pulau Tunda, north-west Java; north-west of Tanjung Karawang, north-west Java (both ZMC); $59 \mathrm{~m}$, north-east of Kepulauan Lingga (BMNH); Selat Bali (ZMC). PHILIPPINES: $35 \mathrm{~m}$, off Aborlan, Palawan; between Corregidor and Mariveles Bay, Bataan Peninsula, Luzon (both MCZ); 59 m, Daram Channel, east of Samar (USNM).

Fossil records. Plio-Pleistocene: Dent Peninsula, Sabah, Malaysia (NHMB; recorded by Cox, 1948, as $M$. martinianus).

Description. SHELL. Very high-spired, very large (up to $150 \mathrm{~mm}$ in length) with eight teleoconch whorls. Protoconch of about one and one-half papillose volutions, angulated on last whorl by sharp keel and ending in small crescentic varix.

Spiral ornamentation on early teleoconch whorls of single weak cord at shoulder, visible only where crossed by axial ridges; on third whorl, single secondary cord added between shoulder and suture. Tertiary spiral threads on fifth whorl, one on subsutural ramp, one between shoulder and secondary cord, and third between secondary cord and suture. Additional spiral cords added on subsequent whorls until, on body whorl, numerous alternating spirals of three orders of magnitude.

Axial ornamentation on first and second teleoconch whorls of seven angulate ribs, each with open spine at shoulder. On third whorl, every third axial rib strengthened into varix with long closed spine at shoulder; intermediate ribs remain as rounded, nonspinose intervarical ridges, three in number between each pair of varices by fifth whorl. Intervarical ridges weakened on subsequent whorls until, on body whorl, marked only by numerous weak axial lines looking like slightly modified growth lines. Three low varices per whorl, each with three long, closed, slightly curved spines, one each at shoulder, periphery, and base of body whorl, with alternating smaller, somewhat adaperturally curved, secondary spines; no tertiary spinelets. Siphonal canal with six primary spines, first just anterior to base of body whorl, these alternating with shorter secondary spines. Secondary spines trending adaperturally at angle to primary spines, angle increasing anteriorly with posterior-most almost parallel to primary spines and anterior-most at angle of $90^{\circ}$.

Suture simple, crossed by slightly separated growth lamellae; posterior ends of lamellae directed adaperturally.

Aperture ovate; no true outer lip, apertural edge of varix scalloped into spines, as series of deep notches corresponding in width and depth to strength of spine. Tooth-like projections in advance of varix, one posterior to spine at base of body whorl elongated into very large labral tooth. Strong anal notch formed by projecting subsutural ramp and posterior end of appressed portion of inner lip; this structure, rising above suture line and visible in advance of each preceeding varix. Anterior two-thirds of inner lip free-standing, narrow, smooth.

Siphonal canal long, straight; terminations of previous canals fused into tube, open by narrow slit; spines extending almost to slightly recurved distal end of canal.

Colour creamy white to greyish tan, mottled with white in intervarical areas; varices white on ventral side, mottled tan on dorsal side; aperture white with

\begin{tabular}{|c|c|c|c|c|c|c|c|c|c|}
\hline \multirow{2}{*}{$\begin{array}{l}\text { Total } \\
\text { length }\end{array}$} & \multirow{2}{*}{$\begin{array}{l}\text { Length of } \\
\text { spire \& } \\
\text { aperture }\end{array}$} & \multirow{2}{*}{$\begin{array}{l}\text { Length of } \\
\text { anterior } \\
\text { canal }\end{array}$} & \multirow{2}{*}{$\begin{array}{l}\text { Length of } \\
\text { aperture }\end{array}$} & \multicolumn{2}{|c|}{ Total diameter } & \multirow{2}{*}{$\begin{array}{c}\text { Length of } \\
\text { longest } \\
\text { shoulder } \\
\text { spine }\end{array}$} & \multirow{2}{*}{$\begin{array}{l}\text { Length of } \\
\text { longest } \\
\text { canicular } \\
\text { spine }\end{array}$} & \multirow{2}{*}{$\begin{array}{l}\text { No. of } \\
\text { spines on } \\
\text { right side } \\
\text { of anterior } \\
\text { canal }\end{array}$} & \multirow{2}{*}{$\begin{array}{l}\text { No. of } \\
\text { spines on } \\
\text { labial } \\
\text { varix }\end{array}$} \\
\hline & & & & $\begin{array}{l}\text { with } \\
\text { spines }\end{array}$ & $\begin{array}{c}\text { without } \\
\text { spines }\end{array}$ & & & & \\
\hline
\end{tabular}

\begin{tabular}{|c|c|c|c|c|c|c|c|c|c|c|c|c|c|}
\hline Holotype & 126.6 & 59.8 & 67.9 & 30.2 & 76.5 & 37.0 & 32.4 & 26.7 & $6: 2 *: 0$ & $3: 3: 0$ & 0 & 9 & 10 \\
\hline $\begin{array}{l}\text { Paratype; } \\
\text { Tambisan, Sabah; } \\
\text { USNM, } 657929\end{array}$ & 150.5 & 62.0 & 87.2 & 31.8 & $59.6^{*}$ & 40.0 & $18.6^{*}$ & 28.2 & $4 *: 5: 0$ & $3: 2: 0$ & 0 & 8 & 10 \\
\hline $\begin{array}{l}\text { Paratype; } \\
\text { Tambisan, Sabah; } \\
\text { USNM, } 657929\end{array}$ & 108.6 & 52.0 & 57.9 & 26.8 & $55.4^{*}$ & 45.5 & $20.2^{*}$ & $15.9 *$ & $6^{*}: 5^{*}: 0$ & $3 *: 3 *: 0$ & 0 & 9 & 12 \\
\hline $\begin{array}{l}\text { Paratype; } \\
\text { Nonoyan Island, } \\
\text { Sandakan, Sabah; } \\
\text { ANSP, } 295510\end{array}$ & 119.2 & 60.0 & 60.6 & 31.0 & $77.9 *$ & 40.4 & 42.2 & $17.1^{*}$ & $4^{*}: 4^{*}: 0$ & $3: 3: 0$ & 0 & 8 & 11 \\
\hline $\begin{array}{l}\text { Off coast of } \\
\text { Aborlan, Palawan, } \\
\text { Philippine Ids; } \\
\text { MCZ, } 272756\end{array}$ & 102.7 & 51.3 & 50.8 & 25.8 & $65.3^{*}$ & 34.3 & 33.1 & 28.7 & $5 *: 4: 0$ & $3: 3: 0$ & 0 & 8 & 12 \\
\hline
\end{tabular}

Table 19. Shell measurement and count data for Murex altispira n.sp.* $=$ damaged. 
strong brown lines in interior of aperture.

DimENSIONS. See Table 19.

OPERCULUM. Brown; subterminal nucleus, surrounded by about eight heavy lamellose concentric ridges.

Etymology. From high-spired appearance of shell.

Remarks. The shell of this new species differs from that of M. acanthostephes and M. scolopax in its higher spire, less recurved spines, and different protoconch (compare Figs 76A,B; 76C; 76J-L). It has much more strongly developed spiral sculpture and longer spines than $M$. occa. When the spines are broken it is rather similar to $M$. trapa but has more spines on the canal, a completely open outer lip (i.e., formed from non-connected projections) and a different protoconch (compare Figs 76C, 73D).

This species appears to be confined to the central part of the tropical Indo-Pacific (Fig. 25).

\section{Murex djarianensis poppei Houart, 1979}

Figs 25; 29A; 76H; 84F; Table 20

Murex ternispina.-Nuttall, 1965: 171 (not of Lamarck). Murex (Murex) poppei Houart, 1979: 141, text figs 1, 2B, pl. 5, figs 1, 1A, 2, 3 (Andaman Sea, near Burma; holotype, IRSB, 25.997/356).

Records. ThaIland: $3-5 \mathrm{~m}$, Phuket Id(ANSP). SABAH: 'Monoyan Id' Sandakan (USNM). MALAYSIA: Negeri Sembilan (AMNH); Tg Rhu, Pulau Langkawi; Pulau Rebuk, Pulau Langkawi (both WAM). INDONESIA: northwest coast, Aceh, north-west Sumatra (RML).
Fossil records. Plio-Pleistocene: Dent Peninsula, Sabah, Malaysia (BMNH; recorded by Nuttall, 1965, as $M$. ternispina).

Description. SHELL. Very large (up to $130 \mathrm{~mm}$ in length), with seven rounded teleoconch whorls.

Protoconch of about two and one-half angulate, axially ribbed volutions, approximately 17 ribs on last protoconch whorl, top flattened but not ribbed, ending at large varix.

Spiral ornamentation on first two teleoconch whorls of three flattened cords, one at periphery and two at shoulder. On third whorl, secondary cords intercalated; by fourth whorl, numerous tertiary threads appearing. Body whorl covered with a complex series of alternating major and minor cords separated by tertiary threads. Siphonal canal with similar pattern to body whorl, bearing eight sets of major and minor cords.

Axial ornamentation on first teleoconch whorl of 12 rounded ribs; by third whorl, every fourth rib strengthened to form small varix with apically directed, short, sharp spine at shoulder. Intervarical axial ribs rapidly weaken, until by fourth whorl, no longer visible; remaining whorls lack all intervarical axial ribbing but covered with strong growth lamellae which, together with spiral ornamentation, give shagreened appearance to surface. Three low varices per whorl, each with three long primary spines arising from major spiral cords. Two posterior-most primary spines, particularly that at shoulder, curve apically. Alternating with primary spines are three smaller, adaperturally recurved, secondary spines. Siphonal
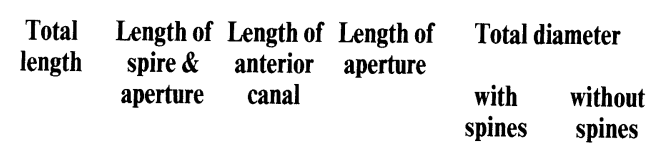

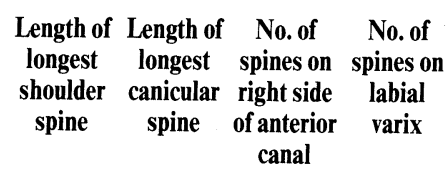

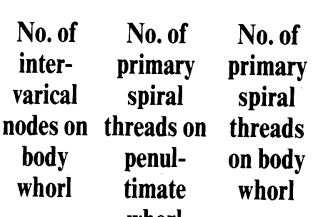

whorl
Holotype

Dent Peninsula,

Sabah, Malaysia,

Plio-Pleistocene;

BMNH, G21568

(Fig. 29A)

\section{0}
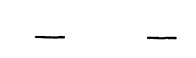

83.8

c. $48.1^{*}$ c. $37.8^{*} \quad ?$
(aper-
tural lip
broken)

40.5

33.3

8.0*

$5.5^{*}$

5:5:

$3: 3: 0$

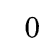

7

c. 14

broken)

W. coast of Atjeh,

NW Sumatra,

Indonesia; RML.

131.0

55.2

76.2

32.8

76.7*

40.2

32.1

39.0

$8: 4^{*}$

$3: 3: 1$

0

7

18

Langkawi, W.

Malaysia; WAM,

781-85(1).

118.3

58.3

61.5

31.2

55.5

42.8

19.3

29.3

$6: 5: 0$

$3: 3: 1$

0

7

12

Tg Rhu, Pulau

Langkawi, W.

Malaysia; WAM,

$782-85(2)$.

$\begin{array}{llll}121.6 & 56.2 & 66.0 & 30.6\end{array}$

60.0

42.3

18.1

22.0

$6: 5: 0$

$3: 3: 0$

0

7

12

Table 20. Shell measurement and count data for Murex djarianensis poppei Houart. *= damaged. 
canal with additional seven or eight long, closed spines, adaperturally recurved at distal ends; spines anterior to base of body whorl longest, equal to major spines on body, with adjacent spines progressively shorter anteriorly. Alternating shorter secondary spines on canal trend adaperturally at angle to primary ones, angle increases anteriorly; posterior ones almost parallel to primary spines, anterior-most at angle greater than $90^{\circ}$.

Suture crossed by series of large, curved growth lamellae, posterior ends directed adaperturally.

Aperture ovate; margin of outer lip notched by extensions of median grooves in spines; notches varying in size according to strength of corresponding spine. Inter-notch area immediately posterior to primary spine at base of body whorl much elongated into large labral tooth. Large anal notch formed between projecting portion of subsutural ramp and appressed posterior portion of inner lip; this structure visible in advance of preceding varices. Anterior third of inner lip free-standing, narrow, smooth.

Siphonal canal long; terminations of previous canals fused into tube, open by narrow slit; entire length spinose.

Colour creamy white, major spiral cords light tan on tops; aperture white.

DimENSIONS. See Table 20.

OPERCULUM. Reddish brown; subterminal nucleus, with ten heavy concentric ridges; with strong median crease.

Remarks. This species is related to M. scolopax, but its shell differs in protoconch details, in having a larger labral tooth, more pronounced spiral sculpture and thinner spines. The Recent specimens of this species, on which the name M. poppei is based, appear to agree very closely with the typical fossil subspecies. Although the specimens on which Martin based his species are in poor condition, most of the important specific characters are available and we can find few significant differences to separate them. The type material suggests that the typical fossil form has a smaller shell, a relatively smaller protoconch, a thicker outer lip, and less well-developed secondary and tertiary spines than all Recent specimens examined. Because of these differences, the Miocene fossil and Recent forms are separated as chronosubspecies. The one Plio-Pleistocene example appears to be indistinguishable from the Recent form.

Houart (1979) states that figure 1052 of Martini (1777) "may be considered as type figure of $M$. poppei". This figure, however, is of the Persian Gulf form of $M$. scolopax, judging from the weak labral tooth on the varix clearly shown in the figure. Houart's (1979) statement cannot be considered as designating Martini's figure as the type of $M$. poppei because he also designated a holotype.

Shuto's (1982) record of this species from the Miocene of Negros Island, Philippines appears to be based on another species, the identity of which is doubtful because of the condition of the material (which we have not seen). The protoconch drawing he provides shows it is not $M$. djarianensis.

Fossil taxa in the M. scolopax Group.

Murex djarianensis djarianensis Martin, 1895

Figs 29B,C; 76G; Table 21

Murex (s. str.) djarianensis Martin, 1895: 124, pl. 19, figs 282-4 (Miocene, Tji Burial, Java; lectotype [here chosen as specimen illustrated in fig. 283], GML, 9640; figured paralectotype, same data).

?Murex (Murex) djarianensis._Oostingh, 1935: 64 (material not seen).

Remarks. The available material is in poor condition so a full description is not offered but measurement data is given in Table 21. The main distinguishing features from $M$. djarianensis poppei are: smaller adult size (maximum length of shell, minus siphonal canal $38 \mathrm{~mm}$, compared with $56 \mathrm{~mm}$ for Recent specimens), a smaller protoconch with about two rounded whorls, apparently lacking axial ribbing, and with a raised terminal varix (the only available specimen is worn); a more thickened aperture and less well developed secondary spines, tertiary spines being absent. In other characters the two forms appear to agree closely.

Of the original Martin material in the GML several specimens are of doubtful identity because of their very poor condition $(47078,9644,9645,9647,9648)$, specimens 9641 and 9642 are small specimens which appear to be this species as are the two specimens in lot 9643 (one of these is Martin's figure 284). The material identified as this species in lots 47079 and 9646 are Murex occa.

Makiyama (1927) recorded Murex (Acupurpura) cf. djarianensis from Hônohasi, Japan on the lower part of the Kakegawa Series, Tôtômi Province, Japan (Pliocene). This record may be based on the same species on which Yokoyama's (1926) record of Murex spinicosta was based (see under Murex bullocki below).

\section{Species Group 3: Murex brevispina Group}

Murex brevispina brevispina Lamarck, 1822

Figs 30; 32; 67A; 72F; 74C; 83A-C; Table 22

Murex brevispina Lamarck, 1822: 159 (unknown locality; NHMG, 1099/5, two specimens ex Lamarck, from "Arabia", which are slightly smaller than the dimensions given by Lamarck); Sowerby, 1841a: 1, pl. 59, fig. 10; Deshayes \& Milne-Edwards, 1839: 702; Kiener, 1843: 13, pl. 13, fig. 2; Deshayes, 1843: 567; Reeve, 1845: pl. 19, fig. 77; Küster \& Kobelt, 1868: 58, pl. 22, figs 5, 6; Troschel, 1869: 115, pl. 10, fig. 20 (radula); Tapparone-Canefri, 1875: 572; Sowerby, 1879: 3 (in part); Tryon, 1880: 79 (in part), pl. 11, fig. 121; Baker, 1890: 69, text fig. 5 (protoconch); Braga, 1952: 76, pl. 3, fig. 5; Smith, 1953: 3, pl. 9, fig. 8; Barnard, 1959: 193; Franca, 1960: 73, pl. 10, fig. 1; Moura, 1969: 

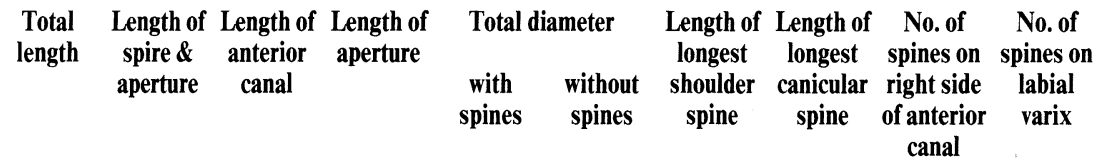

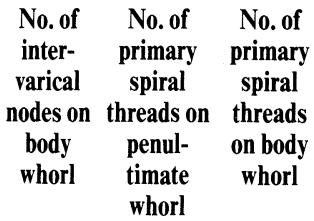

whorl
Lectotype;

Preanger, Java,

Miocene; GML,

Sr. 9640.

$$
\begin{gathered}
\text { (canal } \\
\text { broken) }
\end{gathered}
$$

Paralectotype;

Preanger, Java,

Miocene; GML,

Sr. 9640
$9640 \quad \begin{gathered}- \\ \text { (canal } \\ \text { broken) }\end{gathered} \begin{gathered}28.0^{*} \\ \text { broken) }\end{gathered}$
bre 21. Shell measurement and count data for Murex djarianens
24, pl. 8, fig. 10; Kaicher, 1973: fig. 114; Radwin \&
D'Attilio, 1976: 62, pl. 11, fig. 2; Lindner, 1977: 176, pl.

27, fig. 4; Kilburn \& Rippey, 1982: 81, pl. 18, fig. 5.

Murex (Tribulus) brevispina.-Poirier, 1883: 35.

Tubicauda brevispina.-Jousseaume, 1880: 335.

Murex (Murex) brevispina._-Vokes, 1978: 380.

Murex brevispinatus (sic)._Aoki \& Baba, 1984: 77.

Records. SOUTH AFrICA: Durban (RML; BMNH; AMS); Natal (NMW); Algoa Bay, Port Elizabeth (AMS). MozAmbIQUE: Inhaca Id (ANSP; RML; ZMA); $15 \mathrm{~m}$, Delagoa Bay (ZMC); Maputo (ZMA; RML); Inhambane (AMS); Porto Amelia (USNM); 20-21 m, Nacala (ANSP); Lumbo (MCZ); Bazaruto Bay (ZMC). TANZANIA: Dar es Salaam (BMNH); Mboamaji (USNM); Zanzibar: (ANSP; ZMA; AMNH; AMS); 3-5 m, Mtoni; Kizimkazi; 2-7 m, Malindi Spit (all AMS); $1 \mathrm{~m}$, Bweleo, north of Fumba (ANSP); Bungi, Kiwani Bay (USNM); Mkokotoni (AMNH); 9-20 m, south-west Nguruwe Id; $2.4 \mathrm{~km}$ westsouth-west of Ras Nungwi; Mazizini; $1-5 \mathrm{~km}$ south-west of Ras Shangani; 14-21 m, 1.5 km east of Bawi Id (all ANSP); Pemba (BMNH). KenYA: Kilindini Harbour; Port Reitz, Mombasa (both AMS). Somalia: $12 \mathrm{~m}$, 'Serpenti' Id, Chisimaio (ANSP). DEMOCRATIC YEMEN: Aden (BMNH); 'Bandar Fugum' (USNM). MAURITIUS: (FMNH). NICOBAR ISLANDS: (AMNH). The last two records require confirmation.

Additional records. Durban and Mozambique - several localities in detail (Vokes, 1978).

Fossil records. Holocene: raised beach, Bagamaya, Tanzania (BMNH). Quaternary: Mozambique (Moura, 1969) (see also Remarks).

Description. SHELL. Low-spired, of medium size (up to $85 \mathrm{~mm}$ in length), with seven stronglyshouldered teleoconch whorls.

Protoconch usually decorticated, of about two and one-half bulbous, keeled volutions; keel variable in strength, immediately posterior to suture; terminating in straight varix.

Spiral ornamentation of first three teleoconch whorls masked by axial ribs. Fourth whorl with six spiral cords, all of about same strength, three on subsutural ramp, one at shoulder, and two anterior to shoulder. Spirals increase by intercalation; body whorl and siphonal canal covered with numerous faint spiral cords of varying strength.

Axial ornamentation on first two teleoconch whorls of nine or ten angulate ribs, with small open spine at shoulder; on third whorl, every third rib strengthened to form small varix with stout, apicallyrecurved spine at shoulder; remaining ribs rounded, non-spinose intervarical ridges. This pattern persists to body whorl, where intervarical ridges are represented only as rounded nodules at shoulder and periphery. Three heavy, rounded varices per whorl; formation of spines ranging from three relatively short spines at shoulder, periphery, and base of body whorl to single very short spine at base of whorl. Siphonal canal without spines or with one, rarely two, short spines, located posteriorly near base of body whorl.

Suture simple, undulated by weak peripheral nodes on preceeding whorl.

Aperture large, rounded; outer lip formed by flange in advance of varix; margin of outer lip crenulated by median grooves of major spines, those at periphery and base of body whorl being wider and deeper, delineating large labral tooth; margin of lip somewhat outwardly recurved anteriorly to this tooth, forming a strombid-like notch. Anal notch weak. Posterior half of inner lip flaring, appressed; anterior half with a wide, free-standing, strongly projecting inductura.

Siphonal canal moderately long to long; terminations of previous canals fused into tube, open by narrow slit; spinose only immediately adjacent to base of body whorl.

Colour pale yellowish brown to greyish white, frequently with bluish tinge; aperture white, brown within. 

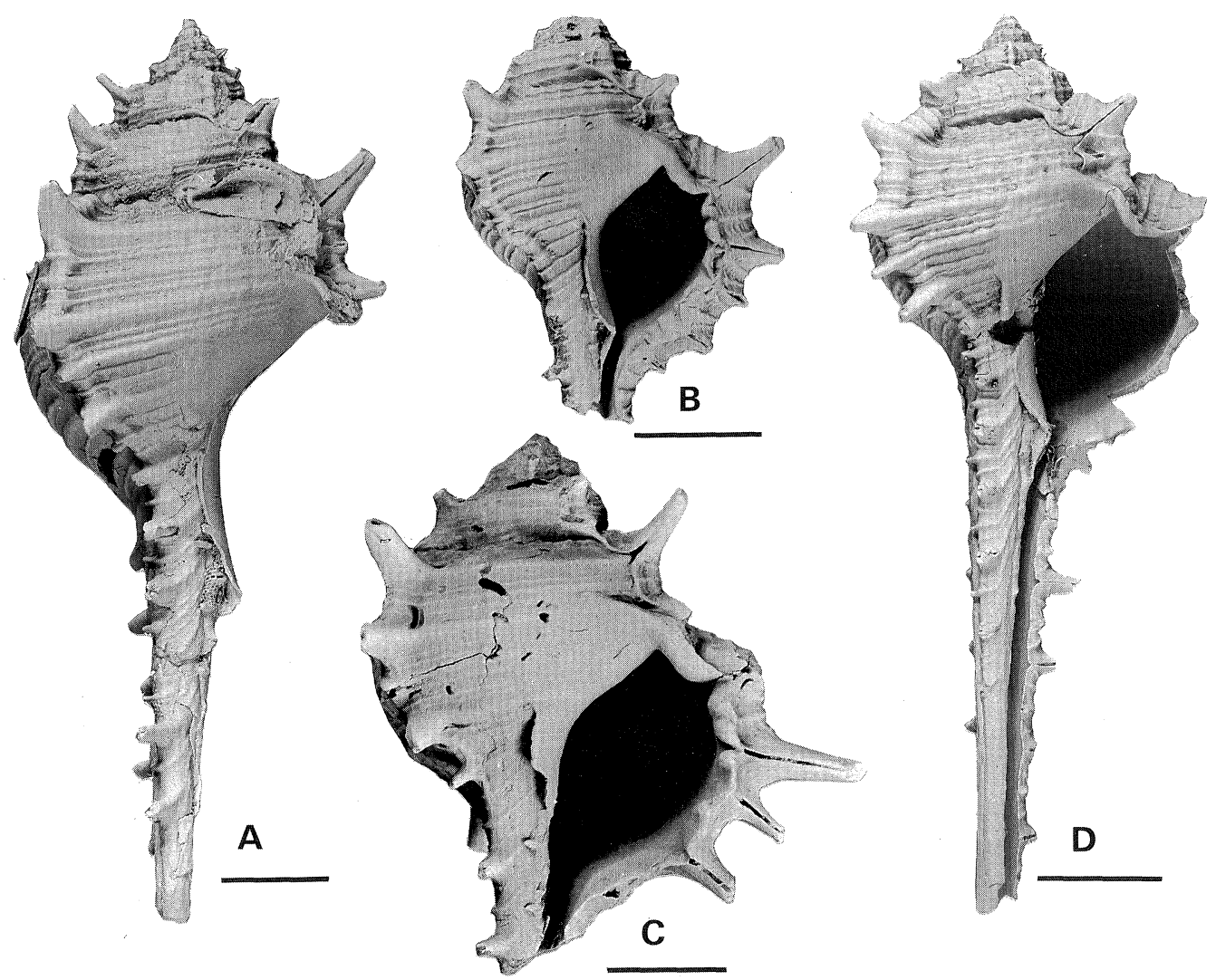

Figure 29. A: Murex djarianensis poppei Houart; Togopi River, Dent Peninsula, Sabah, Plio-Pleistocene (BMNH, G21568). B,C: Murex djarianensis djarianensis Martin. B: lectotype; Tji Burial, Java (GML 9640). C: paralectotype; same data. D: Murex aff. acanthostephes Watson; Cape Possession, Papua New Guinea (BMR, F2390). All scales $1 \mathrm{~cm}$.
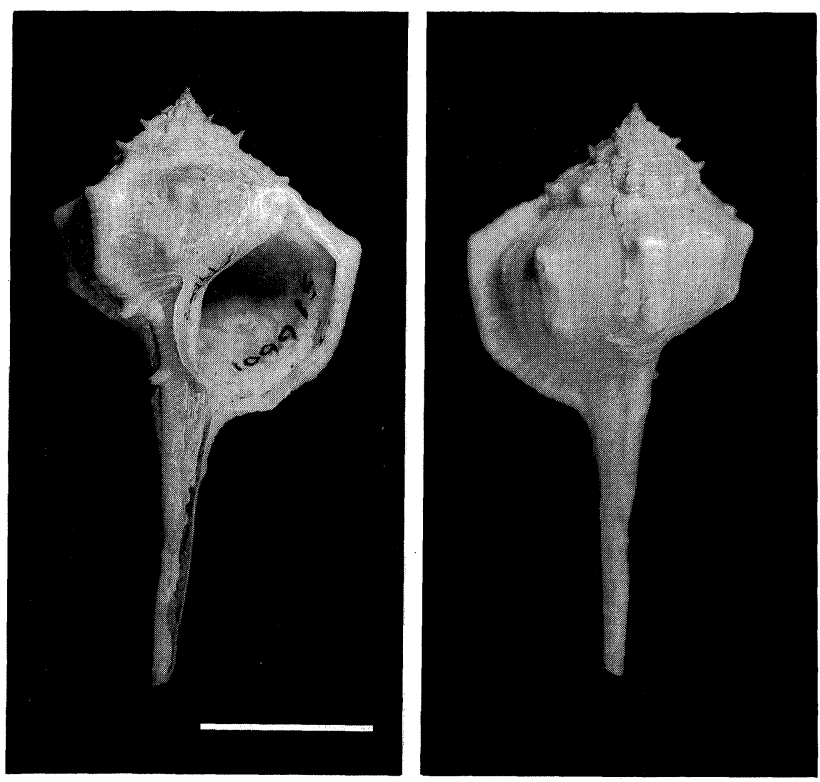

Figure 30. Murex brevispina brevispina Lamarck. Possible syntype; "Arabia", ex Lamarck Colln (NHMG. 1099/5). Scale $2 \mathrm{~cm}$.
Dimensions. See Table 22.

OPERCULUM. Brown; subterminal nucleus, with numerous faint concentric ridges.

RADUla. See Fig. 67A.

Penis. Base swollen, distal end tapering to filament-like extremity (Fig. 72F).

Habitat. This species lives in the intertidal and sublittoral zones on sand and muddy sand flats, often amongst seagrasses (Vokes, 1978).

Remarks. This distinctive species is here divided into three geographic subspecies. The typical form described above, appears to be confined to the eastern Indian Ocean. Some East African populations are discussed in detail by Vokes (1978: 380).

A specimen from the Middle Miocene of Ras Tungwe, Pemba Island, Zanzibar (Cox, 1927) is very like M. brevispina macgillivrayi in teleoconch characters (Fig. 35D and Table 25) but the protoconch is missing. It is probable that this specimen represents the ancestral form of $M$. 


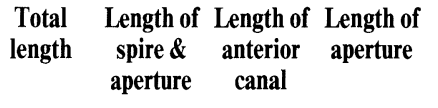

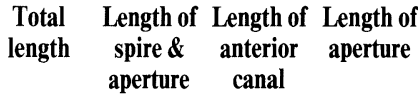

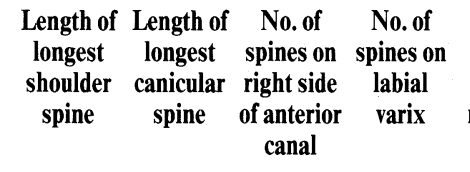

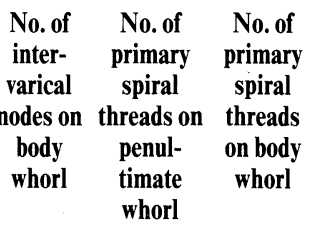

\begin{tabular}{|c|c|c|c|c|c|c|c|c|c|c|c|c|c|}
\hline Syntype & 65.5 & - & - & - & - & - & - & - & - & - & - & - & - \\
\hline $\begin{array}{l}\text { Mazizini, W. } \\
\text { Zanzibar; ANSP, } \\
214688 \text { (Fig. 83C) }\end{array}$ & 84.7 & 41.0 & 44.0 & 24.5 & 37.7 & 36.8 & 6.7 & 7.2 & 1 & 2 & 2 & 7 & 14 \\
\hline $\begin{array}{l}\text { Inhambane, } \\
\text { Mozambique, } \\
\text { Africa; AMS, } \\
\text { C.121484 (Fig. } \\
\text { 83A) }\end{array}$ & 65.8 & 36.5 & 30.1 & 24.7 & 38.3 & 37.5 & - & 1.3 & 0 & 1 & 2 & 6 & 16 \\
\hline $\begin{array}{l}\text { Inhambane, } \\
\text { Mozambique, } \\
\text { Africa; AMS, } \\
\text { C.121484 (Fig. } \\
\text { 83A) }\end{array}$ & 75.3 & 40.3 & 35.6 & 25.4 & 40.1 & 39.8 & - & 3.1 & 0 & 0 & 2 & 7 & 16 \\
\hline $\begin{array}{l}\text { Ras Mungwe, } \\
\text { N.W. Zanzibar; } \\
\text { ANSP, } 212686\end{array}$ & 55.8 & 28.4 & 27.7 & 18.8 & 29.2 & 26.9 & 5.0 & 6.8 & 1 & 2 & 2 & 7 & 14 \\
\hline $\begin{array}{l}\text { Ras Mungwe, } \\
\text { N.W. Zanzibar; } \\
\text { ANSP, } 212686\end{array}$ & 56.3 & 25.1 & 30.7 & 15.9 & 26.8 & 23.7 & 5.8 & 5.4 & 1 & 3 & 2 & 6 & 15 \\
\hline $\begin{array}{l}\text { Nicobar Islands; } \\
\text { AMNH, } 5740 \mathrm{~A}\end{array}$ & 55.0 & 28.0 & 27.3 & 17.7 & 31.9 & 26.5 & 8.7 & 5.7 & 1 & 3 & 2 & 7 & 15 \\
\hline
\end{tabular}

Table 22. Shell measurement and count data for Murex brevispina brevispina Lamarck.

brevispina, which we interpret as a form close to $M$. brevispina macgillivrayi. A change to direct development presumably resulted following partial isolation of the East African populations, resulting in subspeciation. Similar, but almost certainly independent changes probably occurred in Indonesia and the Philippines. The original stock survives today only in tropical Australia.

A single shell supposed to be from the Nicobar Islands (AMNH, 5740: fig. 83B) is similar to $M$. brevispina senilis in its long spines but in other features resembles $M$. brevispina brevispina. This locality record, and the record from Mauritius, needs to be confirmed.

\section{Murex brevispina senilis Jousseaume, 1874}

Figs $31 ; 32 ; 74 \mathrm{~B} ; 83 \mathrm{D}$; Table 23

Murex senilis Jousseaume, 1874: 5, pl. 1, figs 5, 6 (Philippines; holotype, NHMP).

Murex brevispina.-Tryon, 1880: 79 (in part), pl. 24, fig. 209 (not of Lamarck).

Murex macgilliwrayi (sic).-Poirier, 1883: 35 (in part) (not of Dohrn).

Murex brevispina senilis.-Smith, 1953: 3.

Records. PhILIPPINES: Cuyo Islands (MCZ, BMNH); Surigoa (ANSP).

Description. Shell. Similar to $M$. brevispina ornamentalis n. subsp. and $M$. brevispina macgillivrayi, but slightly larger than $M . b$. macgillivrayi and with lower spire, a more expanded free inner lip, relatively thinner spines and a paucispiral instead of multispiral protoconch. Differs from $M$. brevispina ornamentalis in lacking intermediate spines, having much longer primary spines, much larger labral tooth and wide, flaring, free inner lip, even more developed than in typical subspecies. Protoconch similar to that of $M$. brevispina brevispina. Differs from typical subspecies in having longer spines, more pronounced spiral ornamentation, stronger labral tooth, weaker varices and thinner shell.

DiMENSIONS. See Table 23.

Remarks. This apparently rare taxon is distinguished as a geographic subspecies apparently restricted to the central Philippines, so far as is known. It is contrasted with the other similar subspecies in the diagnosis above.

\section{Murex brevispina ornamentalis $\mathbf{n}$. subsp.} Figs 32; 74D; 83F; Table 24

Murex brevispina.-Fair, 1976: 27 (in part), pl. 2, fig. 19 (not of Lamarck).

Type material. Holotype: (ANSP, 275165A), Tamjong Aru, Kota Kinabalu (= Jesselton), Sabah, 1962, M. Saul. 4 paratypes (ANSP, 275165B) from same locality; one paratype (AMS, C.66932) Brunei Bay, Sabah, T.A. Garrard Colln.

Records. INDONESIA: Java (RML); Moluccas (ZMA). 


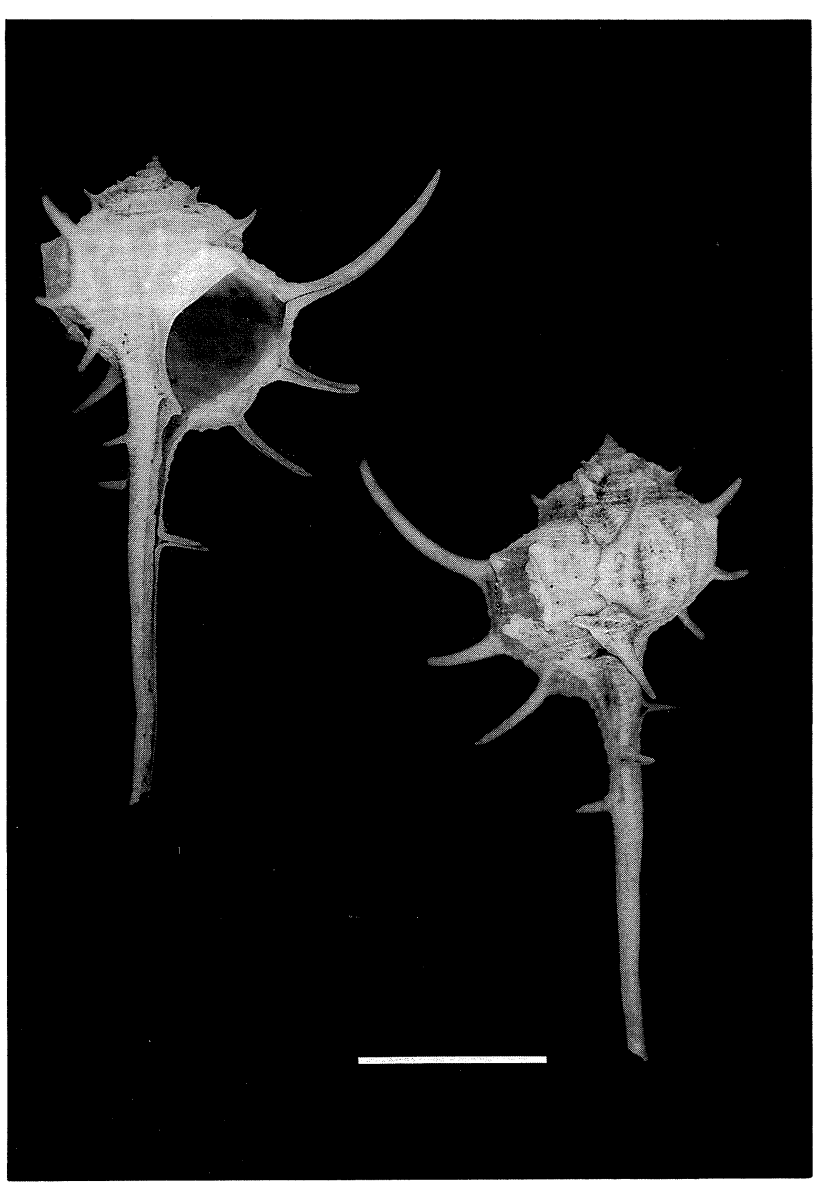

Figure 31. Murex brevispina senilis Jousseaume. Holotype; Philippines Ids (NHMP). Scale $2 \mathrm{~cm}$.
BORNEO: 'North Borneo - Malacca' (BMNH).

Description. SHELL. Similar to M. brevispina s.s. but higher-spired, smaller (maximum length $60 \mathrm{~mm}$ ), with seven teleoconch whorls.

Protoconch similar to $M$. brevispina s.s.

Spiral ornamentation stronger and sharper, than typical subspecies.

Axial ornamentation with more spinose varices, with short primary spines at shoulder, periphery, and base of body whorl. Alternating with primary spines, are slightly smaller secondary spines, occasionally including one on subsutural ramp. Siphonal canal usually with two equi-sized spines posteriorly, near base of body whorl.

Aperture with inner lip attached or only slightly raised above parietal area in contrast to wider, free inner lip of typical subspecies. Outer lip with weaker labral spine than typical subspecies.

Colour dark to pale purplish brown with axial ribs and most primary spiral lines yellow-brown to almost white. Darker olive-brown band below shoulder visible in some specimens.

Other features as in typical subspecies.

Dimensions. See Table 24.

Etymology. From more highly-ornamented nature of shell, relative to typical form of $M$. brevispina.

Remarks. The shell of this subspecies may be distinguished from that of the typical form of $M$. brevispina by the presence of secondary spines, which are never seen even in the most spinose examples of the typical subspecies, or of M. brevispina senilis, and
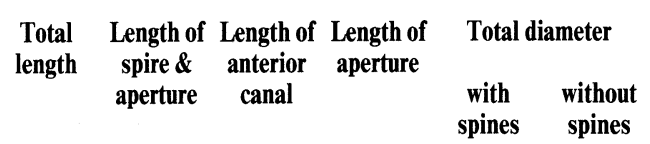

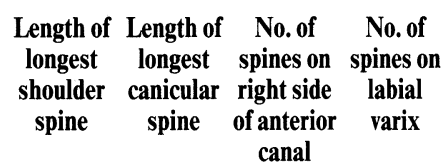

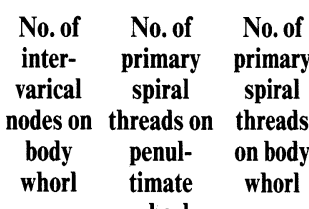
whorl

\begin{tabular}{|c|c|c|c|c|c|c|c|c|c|c|c|c|c|}
\hline Holotype & 66.6 & - & - & - & 41.5 & 21.0 & 20 & - & - & - & - & - & - \\
\hline $\begin{array}{l}\text { Surigoa, } \\
\text { Philippines; } \\
\text { ANSP, } 35361\end{array}$ & 71.3 & 33.8 & 36.7 & 20.8 & 36.4 & 30.4 & 8.0 & 4.8 & -* & 3 & 2 & 6 & 21 \\
\hline $\begin{array}{l}\text { Surigoa, } \\
\text { Philippines; } \\
\text { ANSP, } 35361\end{array}$ & 67.2 & 32.9 & 34.5 & 21.5 & 38.9 & 30.2 & 9.3 & 4.1 & - $^{*}$ & 3 & 2 & 8 & 22 \\
\hline $\begin{array}{l}\text { Cuyo, Palawan, } \\
\text { Philippines; } \\
\text { BMNH. }\end{array}$ & 86.8 & 37.7 & 49.2 & 24.1 & 40.9 & 34.3 & 12.5 & 5.6 & 1 & 3 & $2-3$ & 9 & 22 \\
\hline $\begin{array}{l}\text { Cuyo, Palawan, } \\
\text { Philippines; } \\
\text { BMNH }\end{array}$ & 74.1 & 36.8 & 37.3 & 24.3 & 46.8 & 34.4 & 12.3 & 9.2 & 2 & 3 & 2 & 9 & 22 \\
\hline $\begin{array}{l}\text { Cuyo, Palawan, } \\
\text { Philippines; MCZ, } \\
35163\end{array}$ & 62.5 & 45.2 & 27.9 & 22.8 & 39.0 & 30.7 & 10.5 & 2.7 & 一 $^{*}$ & 3 & 2 & 8 & 21 \\
\hline
\end{tabular}

Table 23. Shell measurement and count data for Murex brevispina senilis Jousseaume.* ${ }^{*}$ damaged. 


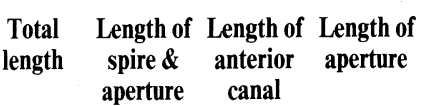

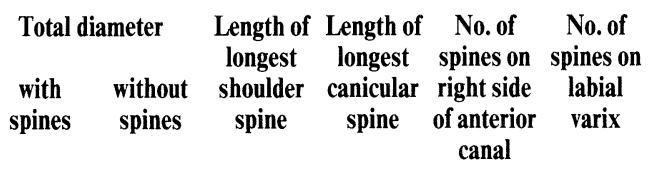

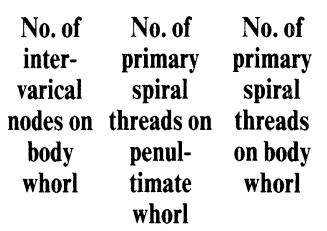

whorl

\begin{tabular}{|c|c|c|c|c|c|c|c|c|c|c|c|c|}
\hline Holotype & 54.3 & 28.5 & 26.5 & 15.8 & 27.1 & 24.6 & 3.8 & 4.2 & 2 & $3: 4: 1$ & 2 & 6 \\
\hline $\begin{array}{l}\text { Paratype; ANSP, } \\
275165 \mathrm{~B}\end{array}$ & 55.9 & 28.4 & 28.4 & 16.8 & 26.5 & 24.5 & 4.1 & 4.6 & 3 & $4: 2: 2$ & $1-2$ & 6 \\
\hline $\begin{array}{l}\text { Paratype; ANSP, } \\
275165 \mathrm{~B}\end{array}$ & 47.2 & 22.3 & 25.0 & 11.9 & 19.4 & 17.5 & 3.8 & 3.2 & 2 & $3: 2: 0$ & 2 & 6 \\
\hline $\begin{array}{l}\text { "North Borneo- }- \\
\text { Mallaca"; BMNH }\end{array}$ & 59.2 & 30.9 & 29.9 & 17.2 & 29.4 & 26.3 & 3.9 & $1.3^{*}$ & 1 & $4: 1: 0$ & 2 & 7 \\
\hline $\begin{array}{l}\text { "North Borneo- - } \\
\text { Mallaca"; BMNH }\end{array}$ & 60.6 & 30.3 & 31.0 & 16.6 & 28.3 & 25.0 & 4.3 & 4.4 & 2 & $3: 1: 2$ & 2 & 7 \\
\hline $\begin{array}{l}\text { "North Borneo- } \\
\text { Mallaca"; BMNH }\end{array}$ & 55.1 & 28.0 & 27.8 & 15.5 & 26.6 & 24.1 & 4.5 & 3.4 & 2 & $3: 2: 1$ & 2 & 7 \\
\hline
\end{tabular}

Table 24. Shell measurement and count data for Murex brevispina ornamentalis n.subsp.* = damaged.

also by the smaller size, higher spire, and stronger spiral ornamentation. This geographic subspecies appears to be confined to Indonesia (including Borneo), but is apparently not common through most of this area. It appears to have been derived from $M$. brevispina macgillivrayi, which was present in the area it now occupies during the Pliocene and PlioPleistocene. It differs from that subspecies in having a paucispiral protoconch and in the development of secondary spines on the teleoconch.

\section{Murex brevispina macgillivrayi Dohrn, 1862}

Figs 32-35; 67C; 72A; 74E; 83E; Table 25

Murex macgillivrayi Dohrn, 1862: 203 (Lizard Island, Queensland; 3 syntypes, BMNH, 1971007); Sowerby, 1879: 3, pl. 17 (of Murex), fig. 162 (wrongly coloured; cites Mörch as author); Smith, 1884: 44, pl. 5, fig. C; Brazier, 1893: 49; Baker, 1897: 372; Smith, 1953: 1, pl. 1, fig. 12; Wilson \& Gillett, 1971: 84, pl. 57, fig. 5; Hinton, 1972: 34, pl. 17, fig. 9; Kaicher, 1973: fig. 126; Coleman, 1975: 27, fig. 47; Fair, 1976: 55, pl. 2, fig. 27; Abbott \& Dance, 1982: 130, fig. in text.

Murex brevispina(us)._-Brazier, 1877: 169; Sowerby, 1879: 3 (in part), pl. 2 (of Murex), fig. 10; Melvill \& Standen, 1899: 161; Hedley, 1916: 212; Odhner, 1917: 11, 55; Cox, 1948: 42, pl. 4, figs 8a, b; Altena, 1950: 210; Radwin \& D'Attilio, 1976: 62 (in part); Hinton, 1978: 33, fig. 6; Wells, 1981: 258; Abbott \& Dance, 1982: 130, fig. in text (not of Lamarck).

Murex scolopax.-Tryon, 1880: 77 (in part), pl. 24, fig. 208 (not of Dillwyn).

Murex (Tribulus) macgilliwrayi (sic) 'Mörch'.-Poirier, 1883: 35 (in part).

Murex (Tribulus) acanthodes Watson, 1883: 599; Watson, 1885: 151, pl. 10, figs 1a-c (off Albany Id, Cape York, Australia, 3-12 fathoms [6-22 m]; 2 syntypes, BMNH, 1887.2.9.522-3).

Murex (Tribulus) macgillivrayi.-Watson, 1885: 147; Schepman, 1911: 344.

Murex (s. str.) brevispina var.-Martin, 1895: 126, pl. 19, figs 291, 291a (not of Lamarck).

Murex (Murex) acanthodes._Baker, 1897: 373.

Acupurpura macgillivrayi.-Allan, 1950: 140; Rippingale \& McMichael, 1961: 96, pl. 12, fig. 4.

Murex acanthodes Smith, 1953: 1, pl. 21, fig. 16; Melvin, 1966: 108, pl. 44, fig. 7; Fair, 1976: 17, pl. 2, fig. 25 (syntype).

Haustellum macgillivrayi.-Cernohorsky, 1967b: 118, pl. 25 , fig. 145.

Tubicauda brevispina.-Habe \& Kosuge, 1966: 50 (in part), pl. 18, fig. 2 (not of Lamarck).

Records. InDONESIA: $57 \mathrm{~m}$, off Kepulauan Aru; Kaimana, Irian Barat; Merauke, Irian Barat (all ZMA). Papua New Guinea: Fisherman's Id, Port Moresby (AMS). AUSTRALIA: Western Australia: Exmouth Gulf (ZMA); Onslow (WAM; AMS); Eighty Mile Beach; Wallal, 350 km south of Broome; Pt Torment, King Sound; Yampi Sound; trawled, Roebuck Bay (all AMS); Sandflats, Broome; Perry Harbour, Admiralty Gulf (both WAM); Vansittart Bay (AMS). Northern Territory: Port Keats; 72 m, Arafura Sea (both AMS); numerous localities, Darwin area (AMS; WAM; ANSP; MNT); Cape Conder, Melville Id; Cape Don; Croker Id, and Smith Pt area, Cobourg Peninsula; Berkeley Bay, Port Essington; Goulburn Id; Boucaut Bay, Arnhem Land (all AMS); Crocodile Id, Milingimbi (MNT); Yirrkala, Groote Eylandt, Gulf of Carpentaria; Centre Id, Sir Edward Pellew Group (all AMS); North Id, Sir Edward Pellew Group (MNT). Queensland: $9-22 \mathrm{~m}$, south of Sweers Id, Gulf of Carpentaria; 13 m, west of Fitzmaurice Pt; Forsyth Id; Karumba; 14-25 m, off Edward River; 22 m; 25-145 m, off Mitchell River; $20 \mathrm{~m} ; 25 \mathrm{~m}$, off Nassau River; $11 \mathrm{~m}$ and $18 \mathrm{~m}$, west of Pt Burrowes; 14-18 m, 15 and $22 \mathrm{~m}$, off Weipa; Mapoon; $18 \mathrm{~m}, 5 \mathrm{~km}$ east of Turtle Head Id, Cape York; 7-25 m, Albany Id, Cape York; Darnley Id, Torres Straits; Thursday Id; Albany Pass; Saibai Id (all AMS); 17 km west of Badu Id (ZMA); 12-16 $\mathrm{m}$, Prince of Wales Channel (BMNH); Lizard Id (IRSB); Low Isles, Port Douglas; Trinity Bay; Cairns Harbour; Cleveland Bay; Ellison Reef; trawled, Townsville; Lucinda, north-east of Ingham; Seaforth, Mackay; Lindeman Id; 42 $\mathrm{m}$, east of Sarina; $40 \mathrm{~m}$, Cape Upstart; $24 \mathrm{~m}$, Whitsunday Passage; Long Beach, Emu Park; 40 m, Bowen; 33 m, west 


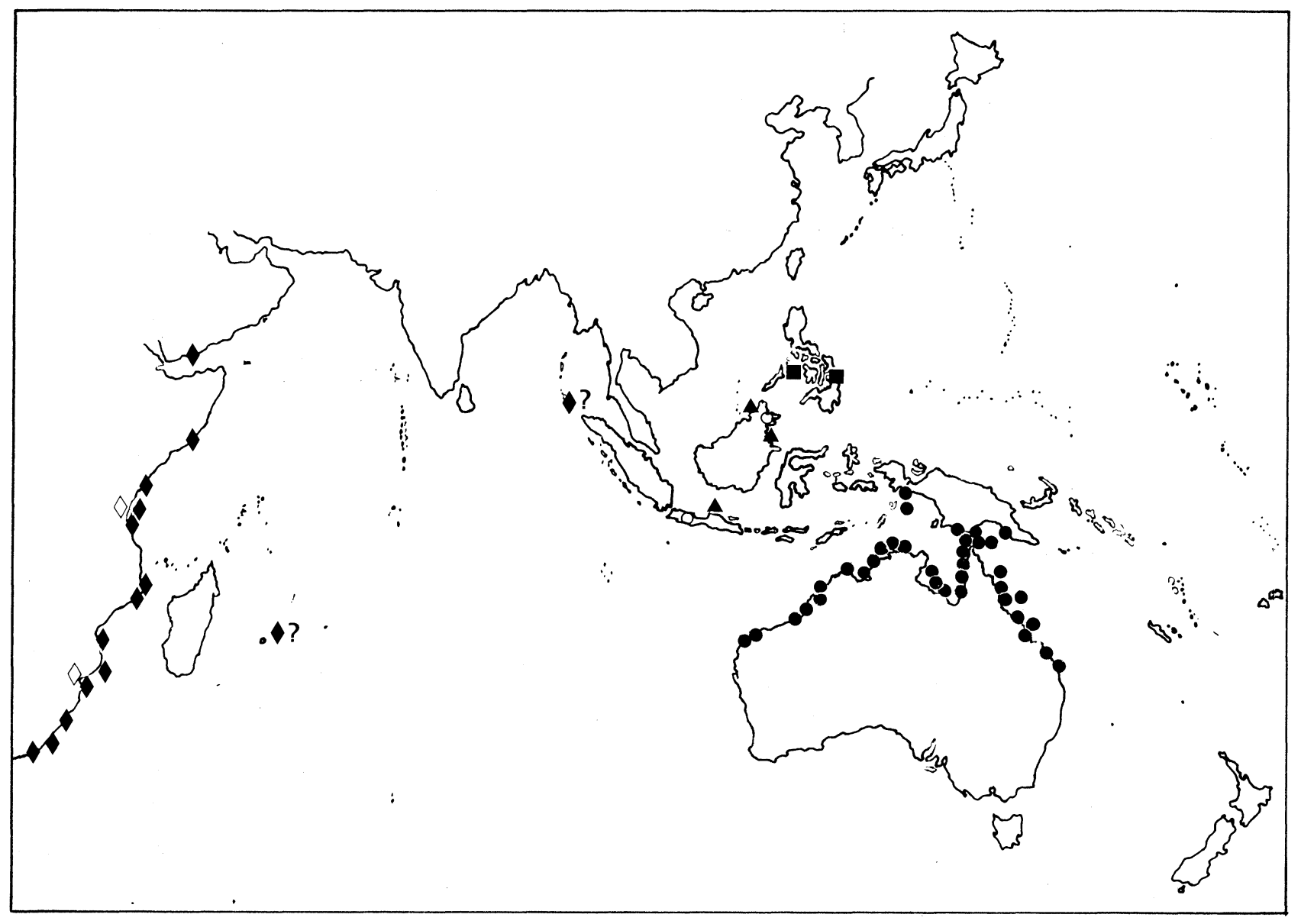

Figure 32. Distribution of species of the Murex brevispina group. M. brevispina brevispina Lamarck (closed diamond: open diamond = fossil records); $M$. brevispina senilis Jousseaume (square); $M$. brevispina ornamentalis $\mathrm{n}$. subsp. (triangle); $M$. brevispina macgillivrayi Dohrn (circle); (open symbols = fossil record).

of Hayman Is; Sinclair Bay; $5 \mathrm{~m}$, Bluff Point, south of Yeppoon; Yeppoon; south Keppel Id; 42 m, east of Sarina (all AMS); Keppel Sands (ANSP; AMS); 25 m, Port Molle (BMNH; AMS); $20 \mathrm{~m}$, Keppel Bay; 72-90 m and $8 \mathrm{~m}$, off Double Head, Keppel Bay (all AMS); Port Curtis (BMNH; AMS); Quoin Id, Gladstone Harbour, Gladstone (AMS); Torquay (ANSP); 18 m, Tin Can Bay; Pt Vernon (both AMS).

Fossil records. Plio-Pleistocene: Dent Peninsula, Sabah, Malaysia (NHMB; recorded by Cox, 1948). Pliocene: Java (GML, five lots; recorded by Martin, 1895, and Altena, 1950).

Description. SHELL. Low-spired, of medium size (up to $80 \mathrm{~mm}$ in length) with seven shouldered teleoconch whorls.

Protoconch of about two and one-half conical volutions, ending in small crescentic varix.

Spiral ornamentation on first teleoconch whorl of three rounded cords; on second and third whorls, one additional cord added to each primary spiral cord until body whorl and siphonal canal covered with numerous spiral cords all of approximately same size.

Axial ornamentation on first two teleoconch whorls of nine ribs, varying from rounded to sharply angulate; angulate ribs with small open spines at shoulder. On third whorl, every third rib strengthened to form varix with short, sharp closed spine at shoulder; intervening ribs forming rounded intervarical ridges lacking spines. Body whorl with two weak intervarical ridges, nodulose at shoulder, periphery and base of whorl, nodules decreasing in strength anteriorly. Three heavy, rounded varices per whorl, each with three apically curved spines, spine at shoulder much elongated in some specimens. Siphonal canal with one spine near base of body whorl.

Suture simple, slightly impressed.

Aperture rounded; outer lip formed by flange in advance of varix, margin crenulated and notched by median grooves in major spines. Notches at periphery and base of body whorl wider and deeper than others and delineating large labral tooth; margin of outer lip somewhat outwardly recurved anterior to this tooth, forming strombid-like notch. Anal notch small. Anterior portion of inner lip appressed; posterior two-thirds free-standing, narrow, smooth.

Siphonal canal moderately long to long; straight; previous canals fused into tube, open by narrow slit; 

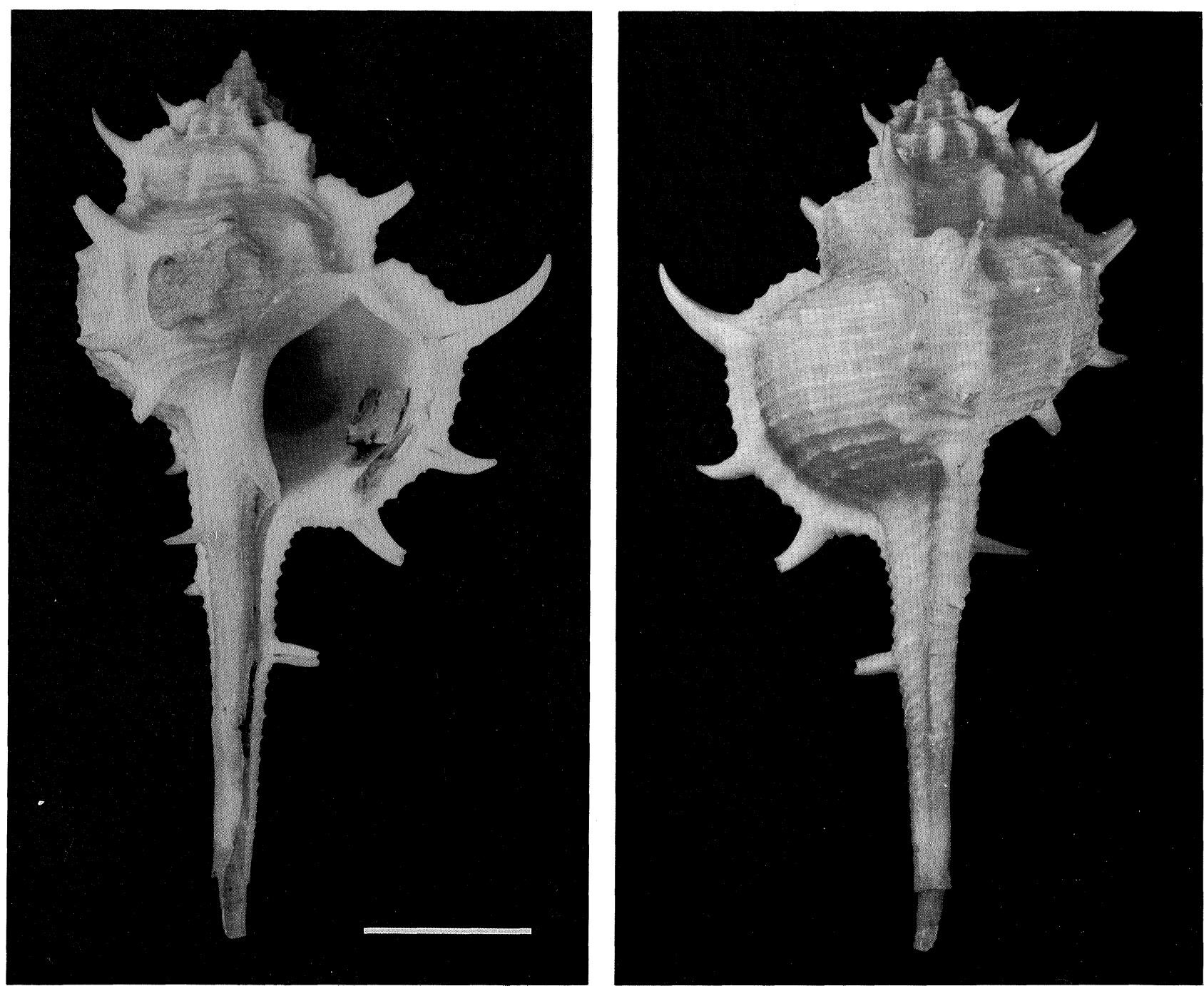

Figure 33. Murex brevispina macgillivrayi Dohrn. Syntype; Lizard Island, Australia (BMNH, 1971007). Scale $1 \mathrm{~cm}$.
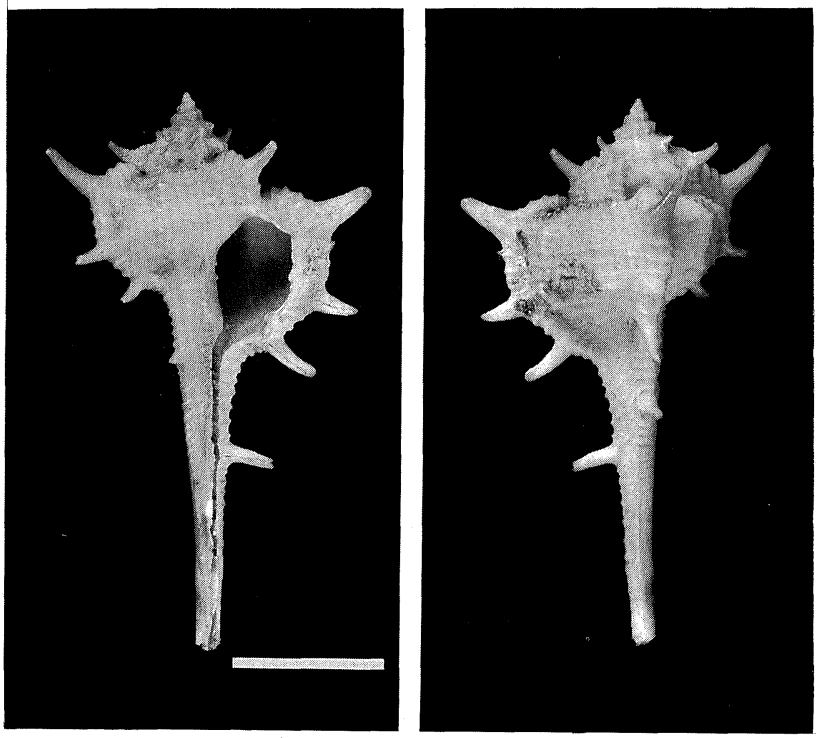

Figure 34. Murex brevispina macgillivrayi Dohrn. Syntype of $M$. acanthodes Watson; off Albany Id, Cape York, Australia 6-22 m (BMNH, 1887.2.9.522-3). Scale $1 \mathrm{~cm}$. spinose only immediately adjacent to base of body whorl.

Colour ivory to golden brown, with three diffuse brown bands; one each at shoulder, periphery and base of body whorl; these bands best seen on inside of shell. Spiral cords brown, especially adaperturally from axial ridges; aperture white; deep inside aperture often light brown, with aforementioned darker bands.

DIMENSIONS. See Table 25.

OPERCULUM. Reddish brown; subterminal nucleus, surrounded by numerous faint concentric ridges.

RADUla. See Fig. 67C.

PENIS. Distal half distinct from basal part, bent anteriorly, slightly tapering, blunt (Fig. 72A).

Remarks. This subspecies differs from other subspecies of $M$. brevispina in the shell having a multispiral protoconch and is almost certainly the most primitive form of this species. It is for this reason that a detailed description has been offered. The teleoconch differs from the typical form of $M$. 


\begin{tabular}{|c|c|c|c|c|c|c|c|c|c|c|c|c|c|}
\hline & $\begin{array}{l}\text { Total } \\
\text { length }\end{array}$ & $\begin{array}{l}\text { Length of } \\
\text { spire \& } \\
\text { aperture }\end{array}$ & $\begin{array}{l}\text { Length of } \\
\text { anterior } \\
\text { canal }\end{array}$ & $\begin{array}{l}\text { Length of } \\
\text { aperture }\end{array}$ & $\begin{array}{l}\text { Total d } \\
\text { with } \\
\text { spines }\end{array}$ & $\begin{array}{l}\text { ameter } \\
\text { without } \\
\text { spines }\end{array}$ & $\begin{array}{l}\text { Length of } \\
\text { longest } \\
\text { shoulder } \\
\text { spine }\end{array}$ & $\begin{array}{l}\text { Length of } \\
\text { longest } \\
\text { canicular } \\
\text { spine }\end{array}$ & $\begin{array}{l}\text { No. of } \\
\text { spines on } \\
\text { right side } \\
\text { of anterior } \\
\text { canal }\end{array}$ & $\begin{array}{l}\text { No. of } \\
\text { spines on } \\
\text { labial } \\
\text { varix }\end{array}$ & $\begin{array}{c}\text { No. of } \\
\text { inter- } \\
\text { varical } \\
\text { nodes on } \\
\text { body } \\
\text { whorl }\end{array}$ & $\begin{array}{l}\text { No. of } \\
\text { primary } \\
\text { spiral } \\
\text { threads on } \\
\text { penul- } \\
\text { timate } \\
\text { whorl }\end{array}$ & $\begin{array}{c}\text { No. of } \\
\text { primary } \\
\text { spiral } \\
\text { threads } \\
\text { on body } \\
\text { whorl }\end{array}$ \\
\hline Syntype & 58.6 & 29.1 & 30.5 & 15.5 & 30.0 & 24.4 & 8.0 & 4.7 & 1 & 3 & 1 & 6 & 11 \\
\hline Syntype & 53.2 & 28.4 & 25.1 & 14.9 & 29.0 & 23.4 & 9.1 & $2.7^{*}$ & 1 & 3 & 2 & 6 & 12 \\
\hline Syntype & 44.8 & 21.0 & 24.2 & 11.3 & 24.8 & 18.2 & 7.3 & 4.1 & 1 & 3 & 2 & 6 & 11 \\
\hline $\begin{array}{l}\text { Syntype of } M \text {. } \\
\text { acanthodes Cape } \\
\text { York, Australia. }\end{array}$ & 36.3 & 17.2 & 19.7 & 9.1 & 19.9 & 14.9 & $\begin{array}{c}7.6^{*} \\
\text { (penulti- } \\
\text { mate } \\
\text { varix) }\end{array}$ & 3.2 & 1 & 3 & 2 & 5 & 11 \\
\hline $\begin{array}{l}\text { Syntype of } M \text {. } \\
\text { acanthodes Cape } \\
\text { York, Australia. }\end{array}$ & 27.4 & 13.2 & 14.4 & 7.7 & 16.0 & 12.4 & 6.9 & 3.3 & 1 & 3 & 2 & 6 & 12 \\
\hline $\begin{array}{l}\text { W. of Weipa, Gulf } \\
\text { of Carpentaria, } \\
\text { Queensland; AMS, } \\
\text { C.107105, (Fig. } \\
83 E \text { ) }\end{array}$ & 79.1 & 39.9 & 39.7 & 19.9 & 44.8 & 31.2 & 14.4 & 9.3 & 1 & 3 & 2 & 10 & 14 \\
\hline $\begin{array}{l}\text { W. of Weipa, Gulf } \\
\text { of Carpentaria, } \\
\text { Queensland; AMS, } \\
\text { C.107105, (Fig. } \\
83 \mathrm{E} \text { ) }\end{array}$ & 76.5 & 35.4 & 42.1 & 18.0 & 40.0 & 27.7 & 12.8 & 8.8 & 1 & 3 & 2 & 9 & 14 \\
\hline $\begin{array}{l}\text { Keppel Bay, } \\
\text { Queensland; AMS, } \\
\text { C.72211 (Fig. 35C) }\end{array}$ & 66.4 & 32.8 & 34.5 & 16.8 & 32.9 & 27.2 & 6.9 & 5.8 & 1 & 3 & 2 & 9 & 14 \\
\hline $\begin{array}{l}\text { Keppel Bay, } \\
\text { Queensland; AMS, } \\
\text { C.72211'(Fig. 83C) }\end{array}$ & 72.7 & 36.5 & 37.8 & 18.3 & 35.9 & 30.1 & 7.2 & 8.1 & 1 & 3 & 1 (faint) & 9 & 14 \\
\hline $\begin{array}{l}\text { Keppel Bay, } \\
\text { Queensland; AMS, } \\
\text { C.72211 (Fig. 83C) }\end{array}$ & 65.7 & 32.8 & 34.2 & 17.1 & 33.1 & 28.5 & 5.4 & 6.3 & 1 & 3 & 2 & 9 & 14 \\
\hline $\begin{array}{l}\text { Dent Peninsula, } \\
\text { Sabah; Plio- } \\
\text { Pleistocene; } \\
\text { NHMB, H.14428 } \\
\text { (Fig. 35A) }\end{array}$ & 68.6 & 32.3 & 36.9 & 15.8 & 30.0 & 25.0 & 6.6 & $3.5^{*}$ & 1 & 3 & 2 & 9 & 14 \\
\hline $\begin{array}{l}\text { Tji Talahab, } \\
\text { Preanger, Pliocene; } \\
\text { GML, St } 9664\end{array}$ & $\begin{array}{c}38.1^{*} \\
\text { (broken } \\
\text { canal) }\end{array}$ & 28.3 & - & 14.9 & 28.9 & 25.0 & 6.3 & - & - & 3 & 2 & 9 & 14 \\
\hline $\begin{array}{l}\text { M. brevispira aff. } \\
\text { macgillivrayi Ras } \\
\text { Tungwe, Pemba } \\
\text { Id, Zanzibar } \\
\text { Protectorate; } \\
\text { Miocene; BMNH, } \\
\text { G.41406 }\end{array}$ & $\begin{array}{c}45.9^{*} \\
\text { (broken } \\
\text { canal) }\end{array}$ & 36.2 & - & 21.9 & 36.5 & 32.5 & 7.0 & - & - & 2 & 2 & 8 & 14 \\
\hline
\end{tabular}

Table 25. Shell measurement and count data for Murex brevispina macgillivrayi Dohrn.* = damaged.

brevispina in having a less inflated body whorl, a higher spire, and a smaller aperture lacking the large flaring inductura. The spiral cords are heavier, the varical spines are always developed, and the siphonal canal is longer in proportion. The shell of some juvenile specimens of the typical subspecies are, however, very similar to $M$. brevispina macgillivrayi. The presence of the brown colour bands on the shell is also distinctive; this is one of only two species of Murex to have them, although there is an indication 


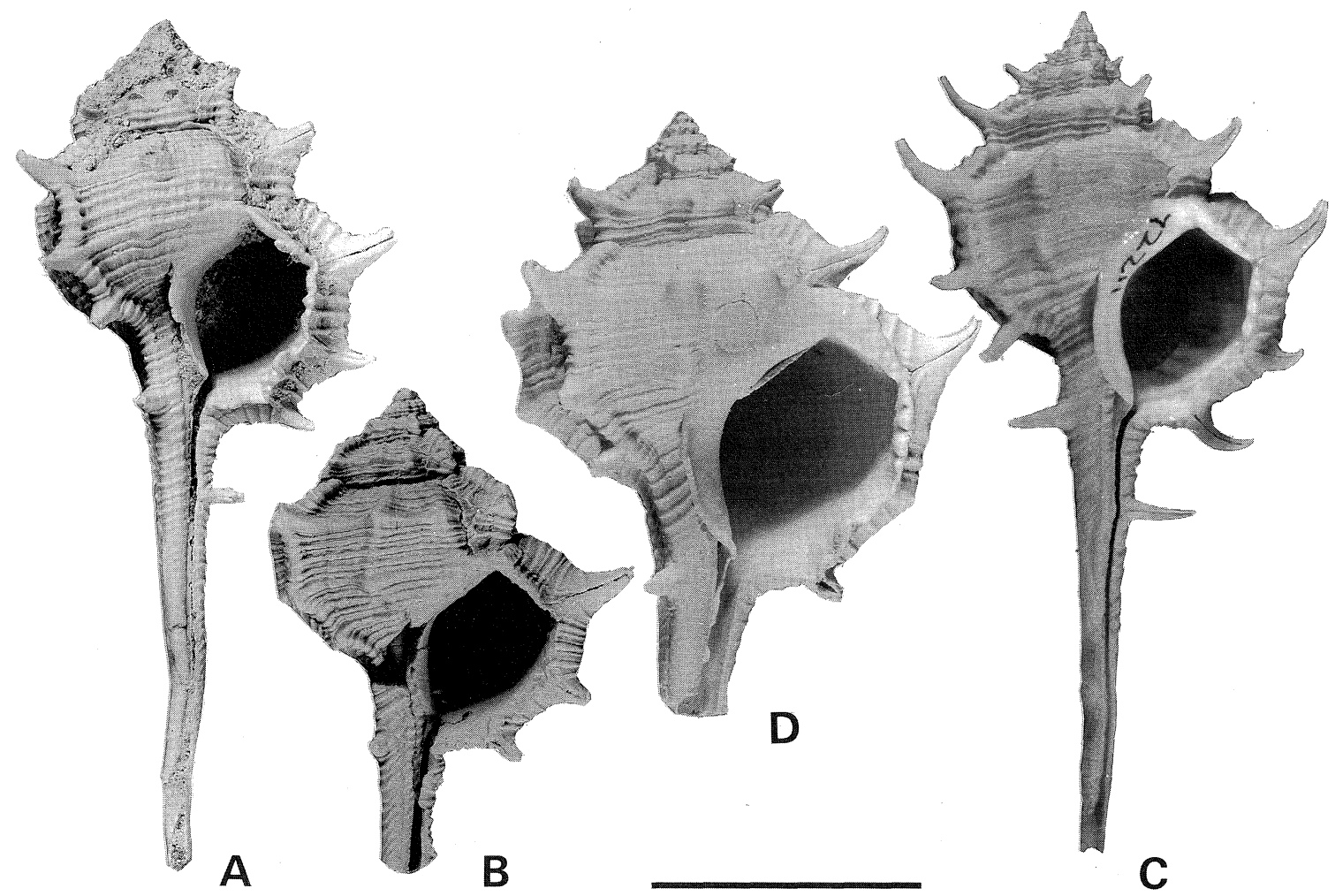

Figure 35. A-C: Murex brevispina macgillivrayi Dohrn. A: Togopi, Dent Peninsula, Sabah, Pliocene (NHMB, H14428). B: Tji Talahab, Preanger, Java, Pliocene (GML, 9664). C: Keppel Bay, Queensland (AMS, C.72211). D: Murex brevispina aff. macgillivrayi Dohrn. Ras Tungwe. Pemba Id, Zanzibar, Middle Miocene (BMNH, G41406). Scale $2 \mathrm{~cm}$.

of banding in M. brevispina ornamentalis.

Specimens of $M$. brevispina macgillivrayi from the Pliocene of Java and the Plio-Pleistocene of Malaysia have enough of the protoconch intact to show that it is multispiral. The teleoconch is virtually identical to Australian specimens. These records suggest that $M$. brevispina macgillivrayi has undergone a considerable range contraction.

Dey (1961: 77, pl. 27, fig. 24) has recorded $M$. maeqillivrayi (sic) from the Miocene of Quilon, Kerala, India, but his material has not been examined. It is likely that this material represents an ancestral form of M. brevispina close to M. brevispina macgillivrayi.

\section{Species Group 4: Murex pecten Group}

Murex pecten pecten Lightfoot, 1786

Figs 1A,B; 36; 39; 68F; 71G,H; 77H; 86H; Table 26

Murex tribulus._Linné, 1758: 746 (No. 444) (in part - references to figures in Buonanni, 1681: fig. 269; Argenville, 1742; pl. 18, fig. A; Olearius, 1666: pl. 39, fig. 1; Rumphius, 1705; pl. 26, fig. 3; and Gualtieri, 1742: pl. 31 , fig. B, apply to this species); Wood, 1818: 119, pl. 25, fig. 4; Wood \& Hanley, 1856: 126, pl. 25, fig. 4, (not of Linné).

Murex tribulus var. pecten Lightfoot, 1786: 188 (No. 4001) (based on Rumphius, 1705: pl. 26, fig. 3) (Amboina; whereabouts of figured specimen unknown. Rumphius figure 3 here designated lectotype).

Murex tribulus duplicatus Chemnitz, 1795: 103, pl. 189, fig. 1821, pl. 190, fig. 1822 (not binominal); Dillwyn, 1817: 682 (in synonymy of $M$. tribulus); Deshayes \& MilneEdwards, 1839: 701 (in synonymy of $M$. tenuispina); Deshayes, 1843: 566 (in synonymy of $M$. tenuispina).

Murex histrix Röding, 1798: 145 (No. 1820) (refers to Favanne, 1784, pl. 38, figs A1, A2 and Knorr, 1757-72, pl. 20 [=27], fig. 1) (not M. hystrix Linné, 1758).

Murex pecten Montfort, 1810: 619, pl. 155; Rehder, 1967: 33; Cernohorsky, 1967a: 115; Hinton, 1972: 34, pl. 17, fig. 2; Kaicher, 1973: fig. 99; Dance, 1974: 121; Coleman, 1975: 212, fig. 595; Fair, 1976: 66; Radwin \& D'Attilio, 1976: 69, text fig. 38, pl. 10, fig. 1; Lindner, 1977: 176, pl. 
27, fig. 8; Hinton, 1978: 33, fig. 1; Abbott \& Dance, 1982: 129, fig. in text.

Aranea gracilis Perry, 1810: pl. 47 (locality unknown; type said to be in BMNH by Perry) (not Murex gracilis Montagu, 1803).

Aranea triremis Perry, 1811: pl. 45, fig. 3 ("Sumatra and other parts of the East Indies"; type lost); Hedley, 1902: 27.

Haustellum nobile Schumacher, 1817: 214 (refers to Chemnitz, 1777, figs 1821, 1822).

Murex tenuispina Lamarck, 1822: 158 ("l'Ocean des grandes Indies et des Moluques"; three syntypes, NHMG, 1098/98-100, none of which agrees exactly with Lamarck's dimensions); Sowerby, 1828: pl. 225, fig. 2; Deshayes, 1832: 896; Deshayes \& Milne-Edwards, 1839: 701; Sowerby, 1841a: 1; Deshayes, 1843: 566; Kiener, 1843: 5, pl. 6, fig. 1, pl. 7, fig. 1; Reeve, 1845: pl. 21, fig. 85; Küster \& Kobelt, 1856: 27, pl. 11, fig. 3, pl. 20, fig. 3; A. Adams, 1863: 370 (as tenuispinus); Macdonald, 1868: 242, pl. 16, fig. 3 (radula); Lischke, 1869: 42; Smith, 1884: 42 (as tenuispira); Brazier, 1877: 169; Sowerby, 1879: 2, pl. 1 (of Murex), fig. 7; Tryon, 1880: 78, pl. 10, fig. 113 (as tenwispina); Baker, 1890: 70, text fig. 8 (protoconch); Brazier, 1893: 46; Melvill \& Standen, 1901: 397; Dautzenberg, 1910: 2; Hirase, 1915: pl. 55, fig. 272.

Murex duplicatus 'Chemnitz' Mörch, 1852: 98; H. \& A. Adams, 1858: 71.

Murex tribulus nobilior 'Linné', Mörch, 1852: 98 (in synonymy of $M$. duplicatus. Refers to Linné's [1758: 746] "Nobilior varietas" which we do not believe was intended as a formal introduction of a name); Wood \& Hanley, 1856: 126 (in synonymy).

Murex (Tribulus) tenuispina.-Kobelt, 1877: 145 (sp. 3); Poirier, 1883: 32; Watson, 1885: 148; Schepman, 1911: 341 , pl. 24, fig. 7 (radula).

Acupurpura tenuispina.-Jousseaume, 1880: 335; Allan, 1950: 140, pl. 22, fig. 5; Cotton, 1956: pl. (unnumbered), fig. 2.

Murex(s.str.) verbeeki.-Martin, 1895: 123 (in part), pl. 19, fig. 279 (fide Altena, 1950: 208; not of Martin).

Murex (Murex) tenuispina.-Oostingh, 1925: 139.

Murex triremis.-Hirase, 1934: 78, pl. 108, fig. 7; Altena, 1950: 208; Smith, 1953: 2, pl. 1, fig. 10, text fig. h; Oyama \& Takemura, 1957: pl. 1, fig. 1; Oyama \& Takemura, 1958, pl. 3, fig. 1, pl. 4, fig. 6; Abbott, 1962: 71 (fig. in text); Arakawa, 1964: 359, pl. 21, fig. 1 (radula); Wu, 1965: 98, fig. 12 (radula); Melvin, 1966: 96, pl. 38, fig. 6; Cernohorsky, 1967b: 117, pl. 23, fig. 140.

Murex (Acupurpura) triremis.-Wissema, 1947: 177.

Acupurpura triremis.-McMichael, 1960: 110, fig. 245.

Murex (Aranea) triremis.-Kira, 1955: 47, pl. 23, fig. 16; Kira, 1959: 58, pl. 23, fig. 15; Kira, 1962: 63, pl. 24, fig. 15.

Murex pecten 'Solander'.-Wilson \& Gillett, 1971: 84, pl. 57, fig. 2.

Murex (Murex) pecten.-Vokes, 1978: 381; Paul, 1981: 285-294, figs $1-3$, 4A, pl. 9, figs $1-4,6-7$, pl. 10, figs 1 , 5; Ladd, 1982: 43, pl. 9, figs 3, 4.

Records. MADAGASCAR: $5 \mathrm{~km}$ south-east of Nosy Iranja, south-west of Nosy Bé (ANSP). MAURITIUS: $61 \mathrm{~m}$, Grande Riviere Noire Bay (AMNH); Pt aux Sables (ANSP). TANZANIA: Dar es Salaam (AMS); $1.5 \mathrm{~km}$ east of Nyange Id, Zanzibar (ANSP). SRI LANKA: (BPBM; AMS); $59 \mathrm{~m}$,
Koddiyar Bay (AMS); Trincomalee (BMNH). ANDAMAN ISLANDS: (BMNH). BURMA: $39 \mathrm{~m}, 96 \mathrm{~km}$ north-west of Tavoy Id; $68 \mathrm{~m}, 60 \mathrm{~km}$ west of Tavoy Id; $55 \mathrm{~m}, 26 \mathrm{~km}$ southsouth-east of Akyab (all ANSP). SINGAPORE (SMF). INDONESIA: Straits of Malacca (BMNH); Moluccas (ANSP; AMNH; ZMC; WAM); 60-72 m, west of Wasir, west Wokam, Aru (WAM); 128-164 m, 'Udfor Kombir', Kepulauan Banda; $50 \mathrm{~m}$ and $85 \mathrm{~m}$, Kai Besar, Kepulauan Kai (all ZMC); 36-54 m, Mitduan Reef, west coast of Nuhu Tjut, Kai Ids (WAM); Ambon (ZMC; IRSB); Makassar, Sulawesi (ZMC); $59 \mathrm{~m}$, Makassar Straits; 75-94 m, between Wowoni and Butung (both ZMA); $71 \mathrm{~m}$, Butung Strait; $67 \mathrm{~m}$, south-east of Tikola, Butung (both USNM); 24 $\mathrm{m}$, south-west Pulau Tunda; $25 \mathrm{~m}$, south-east of Pulau Tunda, north-west Java; north-west of Tandjung, Karawang, north-west Java; $70 \mathrm{~m}$, west of Tanjung Prantjak, Selat Bali; Pabbiring Kepulauan, south-west Sulawesi (all ZMC); 55 m, Bima Teluk, Sumbawa; 32 m, Tanahdjampea, north of Flores; Tanette, north Kabia Id (all ZMA). Irian Barat: 83-141 m, north of Waigeo (ZMA); Berau Teluk (HUM); east Padeaido Id (ANSP). PHILIPPINES: $10-18 \mathrm{~m}$, east end of Corregidor Id (ANSP); 82-340 m, off San Fernando, Luzon (USNM); Calapan, Mindoro (AMNH); San Andres Id, north-west Marinduque (AMS); Magellan Bay, off Mactan Id, Cebu (ZMC); Cebu City (ANSP; USNM); 44 m, south-east of South Gigante Id; $80 \mathrm{~m}$, west Bucas Grande Id; $138 \mathrm{~m}$, north-east Pangasinan Id, Sulu (all USNM); Lady Id, Bohol (WAM); South Lagoon, Sitankai, Sibutu, Sulu (BPBM). HoNG KoNG: $35-37 \mathrm{~m}, 2.4 \mathrm{~km}$ off east Lamma Channel (AMS). TAIWAN: Kao-hsiung (ANSP; USNM); An-p'ing, T'ai-nan (ANSP). JAPAN: (AMS); Okinawa (ANSP; AMNH; USNM: BPBM); 18-22 m, off Naha, Okinawa (BPBM); Yonabaru, south Okinawa (USNM); 36-91 m, Tosa, Shikoku (ANSP; AMNH); 60-100 m Kashiwa-Jima, south Shikoku (ZMC); Kishu coast, Kii Province (USNM); 91-183 m, Tanabe, Honshu (ANSP; BPBM; IRSB; FMNH); Kii, Honshu (AMNH; USNM; ZMC); Hokkaido (AMS). PAPUA NEW GUINEA: Port Moresby (BPBM); Kerepuna, south of Port Moresby; 9-18 m, off Yule Id; Blanche Bay, New Britain (all AMS). AUSTRALIA: Northern Territory: $22 \mathrm{~m}$, Arafura Sea (BMNH). Queensland: 27-36 m, Torres Strait; Bramble Cay, Torres Strait; Thursday Id; Darnley Id (all AMS); $27 \mathrm{~m}$, off Magnetic Id, Townsville (AMNH). SOlOMONS: Shortland Id (ANSP). NEW CALEDONIA: Noumea (IRSB). VANUATU: Eromanga; Tanna (both AMS). FIJI: (AMS).

Additional records. Conducia Bay, northern Mozambique (Vokes, 1978); Karachi, India, 36-55 m fathoms (Melvill \& Standen, 1901).

Fossil records. Pleistocene: Upper Kepe River, Espiratu Santo, Vanuatu (USNM; recorded by Ladd, 1982). Plio-Pleistocene: Village of Awaaj, Sòwu Id, Nias Id, Malay Arch. (GML; recorded by Wissema, 1947). Upper Pliocene, west Java: below Kampong Bodjong, Koempai (PCB). Pliocene: Kendeng Beds, east Java, Indonesia (Altena, 1950).

Description. SHELL. Very large (up to $150 \mathrm{~mm}$ in length), with eight inflated teleoconch whorls.

Protoconch subconical, of about two and one-half volutions, first whorl small, ending at small straight varix.

Spiral ornamentation on early whorls masked by axial ornament; two rather indistinct primary spiral 

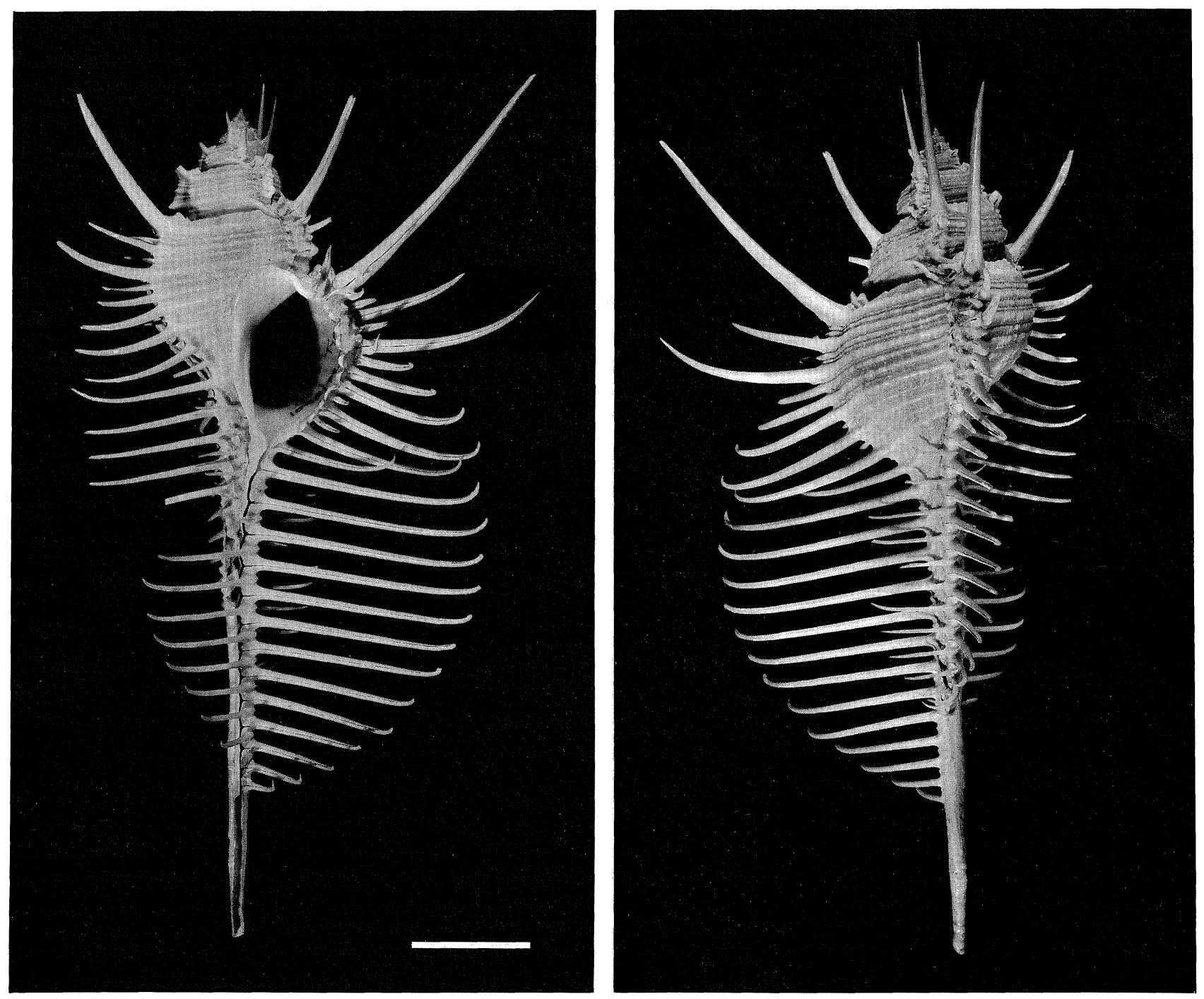

Figure 36. Murex pecten pecten Lightfoot. Syntype of M. tenuispina Lamarck; "l'Ocean des grandes Indies et des Moluques" (NHMG, 1098/99). Scale $2 \mathrm{~cm}$.

cords on third teleoconch whorl, one at shoulder and one at periphery, plus four minor cords, one between each pair of major cords and two on subsutural ramp. Tertiary threads gradually intercalated until body whorl patterned with complex alternation of four orders of spiral cords.

Axial ornamentation on first two teleoconch whorls of nine to 12 angulate axial ribs; on second whorl each with open spine at shoulder. On third whorl every third or fourth rib strengthened into small varix, with long, adapically directed spine at shoulder; remaining ribs rounded intervarical ridges. By fifth whorl, intervarical ridges essentially lost; remainder of shell lacking axial ribbing but covered with strong growth lamellae which, together with spiral threads, gives shagreened appearance to entire surface. Three varices per whorl, each with complicated arrangement of primary, secondary and tertiary spines. Major spiral cords drawn out into long, closed spines, those at shoulder strongest and recurved apically, those at periphery almost as strong, not quite so recurved. Remaining major spirals each with long, closed spines, adaperturally recurved at distal ends. Secondary spiral cords produced into closed spines, somewhat shorter than those on the major cords, and more adaperturally directed. In addition, especially on posterior half of body whorl, tertiary threads produced into adaperturally directed short spines, almost at right angles to spines on major cords. On body whorl, spination pattern approximately (anteriorly from the suture): tertiary, secondary, tertiary, primary (shoulder), tertiary, tertiary, secondary, tertiary, tertiary, primary (periphery), tertiary, secondary, primary, secondary, tertiary, primary (base), tertiary, secondary. Details of spination pattern rather variable, with principal feature being three tiers of spines, one (longest spines) perpendicular to shell axis, second (shortest) at right angles to longest spines, and third set intermediate between them in direction and length. Siphonal canal 
with only two tiers of spines; about twelve primary spines perpendicular to axis and same number of secondary spines at right angles to primary ones; primary spines at base of canal longer than those on adjacent portion of body whorl and almost equal in length to shoulder spine.

Suture deeply but narrowly canaliculate, crossed by numerous growth lamellae.

Aperture ovate; margin of outer lip notched by extensions of median groove in spines; notches varying in size according to strength of corresponding spine. One inter-notch area on anterior third of outer lip projects to form small labral tooth. Inner lip appressed at posterior end in large flare extending up onto previous whorl and persisting as small, smooth relict structure in advance of preceding varices; anterior two-thirds of inner lip free-standing and smooth within.

Siphonal canal very long; terminations of previous canals fused into straight tube, open by narrow slit, sometimes recurved at distal tip; canal exceedingly spinose (as described above), except for anterior one- quarter of total length.

Colour of protoconch white; teleoconch creamy white to tan, with spiral cords tending to be lighter in colour than interstitial areas; aperture white, with reddish brown spots in notches.

DimENSIONS. See Table 26.

OPERCULUM. Dark brown; subcentral nucleus, with about ten to 12 foliose concentric laminae.

RADUla. See Figure 68F.

PENIS. Tapers to narrow, pointed distal end (Figs $71 \mathrm{G}, \mathrm{H})$.

Remarks. This, the most popularised of the species of Murex, has a wide distribution due, presumably, to a pelagic larval stage. The possible function of the spines of this species has been discussed at length by Paul (1981), who concludes that the spines form a protective cage beneath which the animal can feed in safety. The shell of this species differs from all others in the genus in the number and arrangement of its spines. A new subspecies from Western Australian is described below.

$\begin{array}{cc}\text { Total } & \text { Length of Length of Length of } \\ \text { length } & \begin{array}{c}\text { spire \& anterior aperture } \\ \text { aperture }\end{array} \\ & \text { canal }\end{array}$

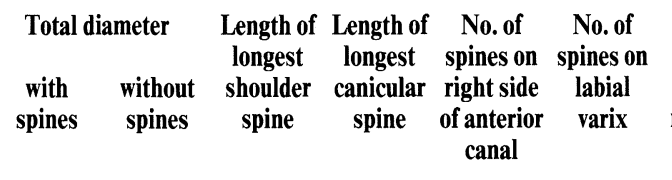

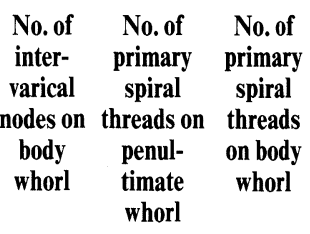

Torres Strait,

Queensland; AMS, C.61885 (Fig. 36H)

Off Yule Id, Papua

New Guinea;

AMS, C.74688

Philippine Ids;

AMS, C.53742

Thursday Id,

Queensland; AMS,

C. 97274

Thursday Id,

Queensland; AMS,

C. 97274

$$
107.7
$$

43.4

64.4

22.1

55.5

30.9

27.5

34.0

$11: 9: 0 \quad 5: 5: 4: 3$

0

5

10

132.6

49.1

83.9

$140.8 \quad 65.4$

75.9

25.3

71.9

34.9

37.9

43.3

31.2

$59.2^{*}$

41.4

$23.2^{*}$

40.

$11: 12: 0 \quad 5: 6: 4: 3$

0

5

10

$108.3 \quad 43$

65.7

21.4

60.8

30.2

$24.5^{*}$

36.0

$10:$

$6^{*}: 17 * \quad 5: 6: 5: 4$

0

5

10

85

$\begin{array}{llll}34.0 & 51.3 & 19.2 & 46.0\end{array}$

25.6

22.2

26.9

$11: 9 \quad 5: 5: 3: 1$

0

4

Table 26. Shell measurement and count data for Murex pecten pecten Lightfoot.* = damaged.

\section{Murex pecten soelae $\mathrm{n}$. subsp.}

Figs 37; 39; 77C; Table 27

Type material. HOLOTYPE: (WAM, 727.85) $70 \mathrm{~km}$ north of Port Hedland, Western Australia, $19^{\circ} 59^{\prime} \mathrm{S} 117^{\circ} 16^{\prime} \mathrm{E}$, 50-52 m, silt, sand and bryozoa, coll. L. Marsh, F.R.V. 'Soela', 15 April 1982. PARATYPES (all Western Australia): paratype (WAM, 3241-83), south-west of Imperieuse Reef, Rowley Shoals, $18^{\circ} 00^{\prime} \mathrm{S}, 118^{\circ} 20^{\prime} \mathrm{E}, 385 \mathrm{~m}$, mud, coll. N. Sinclair, F.R.V. 'Courageous'; paratype (AMS, C.146709), $81 \mathrm{~km}$ north Port Hedland, $19^{\circ} 56.7^{\prime}-56.9^{\prime}$, $117^{\circ} 53.6^{\prime}-53.4^{\prime} \mathrm{E}, 40 \mathrm{~m}$, sand, coll. B. Jenkins, F.R.V. 'Soela'; paratype (WAM, 728-85), $66 \mathrm{~km}$ north Port Walcott, $19^{\circ} 59^{\prime}-20.0^{\prime} \mathrm{S}, 117^{\circ} 08^{\prime}-10^{\prime} \mathrm{E}, 50 \mathrm{~m}$, silty sand and large sponges, coll. L. Marsh, F.R.V. 'Soela'; paratype
(AMS, C.146710) north-west Port Hedland, 2001.2'S, $116^{\circ} 57.5^{\prime} \mathrm{E}, 52 \mathrm{~m}$, coll. C.S.I.R.O.; paratypes (WAM, 2813-67), south of Enderby Id, Dampier Archipelago, $36.6 \mathrm{~m}$, sand and shell, coll. B.R. Wilson on W.A. Hawaiian Expedition, one paratype (WAM, 101-65) near Long Id, off Onslow, coll. W.A. Hawaiian Expedition; paratype (Fig. 37A) (WAM, 10-66), west of Dirk Hartog Id, $25^{\circ} 31^{\prime} \mathrm{S}$, $112^{\circ} 29^{\prime} \mathrm{E}, 130 \mathrm{~m}$, coll. C.S.I.R.O.; paratype (WAM, 159270) between Shark Bay and Nickol Bay, coll. W.P.W. Poole, F.R.V. 'Bluefin'.

Other records. Western Australia: $71 \mathrm{~m}$, Holothuria Bank (BMNH); 73 m, north-east of Adele Id; $200 \mathrm{~m}, 194 \mathrm{~km}$ north-west of Port Hedland; 154-201 m, 204-213 km north of Port Hedland (all WAM); $44 \mathrm{~m}$, north-west of Port Hedland; $81 \mathrm{~m}, 141 \mathrm{~km}$ north-north-east of Port Hedland; 
116-120 m, $157 \mathrm{~km}$ north-north-west of Port Hedland (all AMS); 99-128 m, north-west of Bluff Pt, Dampier; 37-39 $\mathrm{m}, 50 \mathrm{~km}$ north-north-east of Cape Lambert; 52-54 m, 72 $\mathrm{km}$ north-north-east of Cape Lambert; off Legendre Id; 180-190 m $139 \mathrm{~km}$ north of Legendre Id; 65-70 m, north of Enderby Id; 58-59 m, $72 \mathrm{~km}$ north of Enderby Id; 50-52 m, $70 \mathrm{~km}$ north of Port Walcott (all WAM); Cape Preston, north of Onslow (AMNH); $51 \mathrm{~m}, 12 \mathrm{~km}$ north of Long Id, Onslow (WAM).

Description. SHELl. Very similar to $M$. pecten pecten but differs in morphology and colour of protoconch and details of sculpture and colour of teleoconch.

Protoconch of two to two and one-quarter whorls; first whorl bulbous, terminated by prominent, flanged varix.

Teleoconch as in $M$. pecten pecten except for following characters.

Spiral ornamentation of 3-4 prominent cords on first teleoconch whorl; on later whorls, consisting of primary, secondary and tertiary spirals; quaternary spirals extremely weak. Spines as in typical subspecies except secondary and tertiary spines relatively shorter than in most specimens of $M$. pecten

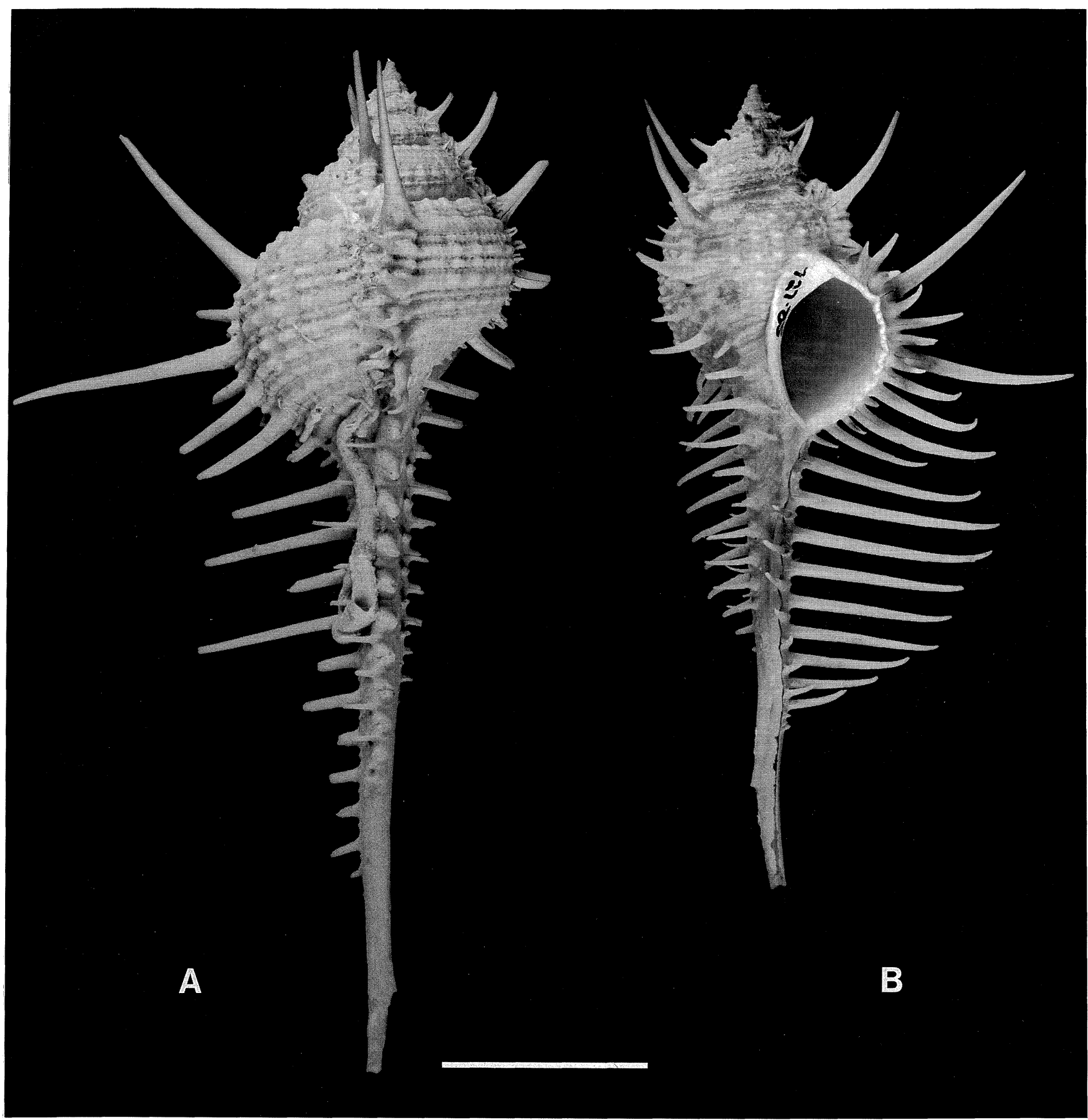

Figure 37. Murex pecten soelae $n$. subsp. A: paratype; west of Dirk Hartog Id, Western Australia, 130 m (WAM, 10-66). B: holotype; off Port Hedland, Western Australia, 50-52 m (WAM, 727.85). Scale $2 \mathrm{~cm}$. 


\begin{tabular}{|c|c|c|c|c|c|c|c|c|c|c|c|c|c|}
\hline & Total & Length of & Length of & Length of & Total & ameter & Length of & Length of & No. of & No. of & No. of & & No. of \\
\hline & & $\begin{array}{c}\text { Spire } \alpha \\
\text { aperture }\end{array}$ & canal & & $\begin{array}{c}\text { with } \\
\text { spines }\end{array}$ & $\begin{array}{c}\text { without } \\
\text { spines }\end{array}$ & $\begin{array}{l}\text { shoulder } \\
\text { spine }\end{array}$ & $\begin{array}{l}\text { canicular } \\
\text { spine }\end{array}$ & $\begin{array}{l}\text { right side } \\
\text { of anterior } \\
\text { canal }\end{array}$ & $\begin{array}{l}\text { labial } \\
\text { varix }\end{array}$ & $\begin{array}{l}\text { varical } \\
\text { nodes on } \\
\text { body } \\
\text { whorl }\end{array}$ & $\begin{array}{l}\text { primary } \\
\text { spiral } \\
\text { threads on } \\
\text { penul- } \\
\text { timate } \\
\text { whorl }\end{array}$ & $\begin{array}{c}\text { primary } \\
\text { spiral } \\
\text { threads } \\
\text { on body } \\
\text { whorl }\end{array}$ \\
\hline Holotype & 80.3 & 34.8 & 45.2 & 17.0 & 45.9 & 25.5 & 18.7 & 20.4 & 9:9:0 & $3: 4: 6: 2$ & 4 & 6 & 12 \\
\hline $\begin{array}{l}\text { Paratype; WAM, } \\
10-66\end{array}$ & 101.2 & 39.3 & 62.6 & 19.8 & 54.6 & 29.4 & 24.1 & 18.5 & 11:11:0 & $3: 4: 6: 2$ & 4 & 6 & 13 \\
\hline $\begin{array}{l}\text { Paratype; WAM, } \\
\text { 3241-83(1) }\end{array}$ & 94.6 & 48.9 & 46.5 & 23.6 & 51.3 & 35.5 & $15.7^{*}$ & 17.5 & $9: 9: 0$ & $3: 4: 7: 1$ & 0 & 8 & 14 \\
\hline $\begin{array}{l}\text { Paratype; WAM, } \\
2813-67(1)\end{array}$ & 68.8 & 39.0 & 31.0 & 18.4 & 48.4 & 27.3 & 14.9 & 22.4 & $7: 7: 0$ & $3: 4: 6: 0$ & 3 & 6 & 13 \\
\hline $\begin{array}{l}\text { Paratype; WAM, } \\
2813-67(2)\end{array}$ & 64.5 & 30.2 & 34.9 & 15.4 & 38.4 & 23.5 & 10.7 & 18.3 & $7: 7: 0$ & $3: 4: 5: 0$ & 3 & 6 & 12 \\
\hline $\begin{array}{l}\text { Paratype; WAM, } \\
728-85(1)\end{array}$ & 68.1 & 28.6 & 40.2 & 14.3 & 42.5 & 21.4 & 20.1 & 14.0 & $9: 9: 1$ & $3: 4: 6: 1$ & 4 & 6 & 12 \\
\hline $\begin{array}{l}211 \mathrm{~km} \text { N. of Port } \\
\text { Hedland, Western } \\
\text { Australia, } 210 \mathrm{~m} \text {; } \\
\text { WAM, } 726-85\end{array}$ & 105.5 & 53.5 & 51.9 & 26.2 & 50.7 & 40.4 & 19.8 & $8.7^{*}$ & $8: 3 *: 0$ & $3: 4: 4^{*}$ & 0 & 6 & 14 \\
\hline
\end{tabular}

Table 27. Shell measurement and count data for Murex pecten soelae n.subsp.* = damaged.

pecten, particularly on anterior canal. In most specimens shoulder spines less adapically directed than in $M$. pecten pecten.

Axial ornamentation differs in markedly more persistent intervarical nodes, these persisting until beginning of body whorl in largest specimens. Low axial growth lamellae prominent over whole surface but not as raised in interspaces between spiral cords as in typical subspecies.

Colour of protoconch brown. Teleoconch pale orange-brown background, often with diffuse white bands below suture, on periphery and on upper base, resulting in background colour remaining as brown bands in most specimens. Axial ribs and Varices, as well as three diffuse spirals crossing them, tend to be white to dirty white. Spirals between axials usually brown, often darker than interspaces, resulting in spotted pattern in some specimens. Spines dirty white with pale brown tinge. Aperture white, usually with brown spots in grooves in outer lip.

DimENSIONS. See Table 27.

OPERCULUM. As for M. pecten pecten.

Etymology. Named for F.R.V. Soela, the vessel that was involved in the collection of much of the material on which this species is based.

Remarks. The shells of Western Australian specimens of $M$. pecten are consistent in the differences described above from specimens from other parts of the Indo-West Pacific. The brown, bulbous protoconch, the more strongly developed axial ribs and the development of colour bands are the most distinctive features of the new subspecies. The other most similar taxon is described below.

\section{Murex queenslandicus $\mathrm{n}$. sp.}

Figs 39; 67B; 71I; 77B; 86F, G; Table 28

Murex coppingeri.-Cernohorsky, 1967b: 117, pl. 23, fig. 137 (not of Smith).

?Murex tribulus.-Radwin \& D'Attilio, 1976: 72 (in part), text figs 40-43 (not of Linné).

Type material. HolOTYPE: (AMS, C.149487); off Townsville, Queensland, $37 \mathrm{~m}$; 2 paratypes (AMS, C.86587) from same locality. ADDITIONAL PARATYPES: (AMS, C.74897) off Townsville, $37 \mathrm{~m}$; (AMS, C.106396) same locality, $40 \mathrm{~m}$; 4 (AMS, C.102589 [3]; NHMP [1]) same locality, $30 \mathrm{~m} ; 3$ (AMS, C.106399) off Cape Bowling Green, off Townsville, 20 m; 2 (AMS, C.74757; QM) same locality, 30-33 m

Records. AUSTRALIA: Queensland: $40 \mathrm{~m}, 9-10 \mathrm{~km}$ east of Keeper Reef; 37-40 m, off Townsville; 3-10 m, Swain Reefs; 64 m, 2.5 km north-east of west side of Gillett Cay, Swain Reefs; 155 m, Capricorn Channel; 46-55 m, 48 km north-east of Yeppoon; $46-55 \mathrm{~m}, 48 \mathrm{~km}$ north-east of Keppel Id; 46-49 m, east of Keppel Id (all AMS).

Description. SHELl. Large (up to $95 \mathrm{~mm}$ in length), with about eight rounded teleoconch whorls.

Protoconch of about two and one-half polished, convex volutions, ending at small, straight varix.

Spiral ornamentation on first two teleoconch whorls masked by axial ribs; on third teleoconch whorl, two rounded major spiral cords, at shoulder and periphery, and two weaker cords, on subsutural ramp and between pair of major cords. Additional spiral threads intercalated on subsequent whorls; body whorl covered by alternating primary and secondary cords and few weak tertiary threads.

Axial ornamentation on first teleoconch whorl of about nine angulate ribs, each with open spine on 
shoulder. On second whorl, every third rib strengthened to form varix with long, sharp spine at shoulder; two intermediate ribs losing spines and persisting as swollen intervarical ridges. Axial ridges added adaperturally from fourth teleoconch whorl until, on body whorl, usually five ridges between each pair of varices, these marked by elongate nodules where crossed by primary and secondary spiral cords. Three low varices per whorl, with long primary and secondary spines; three primary spines perpendicular to axis at shoulder, periphery, and base of body whorl, anterior-most being longer than other two. Alternating with primary spines are slightly shorter secondary spines, somewhat more forward in direction. Between primary and secondary spines are very short, sharp, adaperturally-curved tertiary spinelets. Spination pattern (anteriorly from suture) of tertiary, primary (shoulder), tertiary, secondary, tertiary, primary (periphery), tertiary, secondary, tertiary, primary (base), secondary. Siphonal canal with six very long, perpendicular primary spines, slightly curved adaperturally at distal end. Alternating with primary spines are small secondary spinelets, directed at right angles to primary spines. Second spine from base of body whorl longest on shell, those anterior to it progressively shorter.

Suture deeply channelled.

Aperture ovate; margin of outer lip notched by extensions of median groove in spines; size of notch varying with strength of spine; one internotch area, posterior to basal primary spine, projecting as small labral tooth. Inner lip appressed at posterior end with large, projecting flare extending on to previous whorl and persisting as small, smooth relict structure in advance of preceeding varices. Anterior two-thirds of inner lip free-standing, smooth.

Siphonal canal long; terminations of previous canals fused into tube, distal end slightly deflected, open by narrow slit; anterior third of canal lacking spines.

Colour of protoconch yellowish white; teleoconch varies from white (in some populations, e.g., Swain Reefs) to tan; spiral cords on latter with white nodules where crossed by axial ridges; aperture white; brown spots within notches of coloured shells.

Dimensions. See Table 28.

OPERCULUM. Brown; subcentral nucleus, surrounded by about nine to 11 concentric, foliated laminae.

RADULA. See Figure 67B.

PENIS. Similar to $M$. pecten pecten; tapers to pointed distal end (Fig. 71I).

Etymology. From location of species along Queensland coast.

Remarks. Murex queenslandicus is similar to $M$. pecten in opercular and shell characters but the shell differs in being relatively lower spired, smaller, having fewer spines, particularly on the siphonal canal; the shoulder spines are less apically directed and the spiral ornamentation is more nodulose. The axial ornamentation is markedly stronger than in $M$. pecten pecten but only marginally stronger than in $M$. pecten soelae. All of the specimens from the Swain Reefs appear to represent a geographic 'albino' form, the shells having no trace of colour. Occasional specimens from off Townsville have a suggestion of banding on the body whorl of the shell reminiscent of that in M. pecten soelae, and the other details of the colour pattern also approach that subspecies.

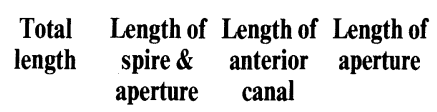

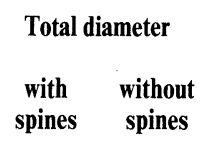

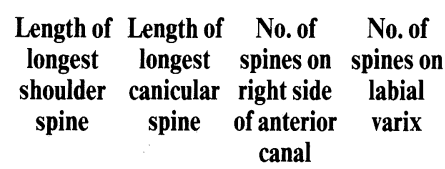

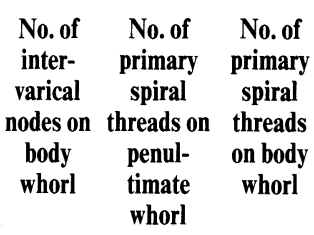

whorl

\begin{tabular}{|c|c|c|c|c|c|c|c|c|c|c|c|c|c|}
\hline Holotype & 91.7 & 40.4 & 51.4 & 19.9 & 52.0 & 31.5 & 18.3 & 25.5 & $7 *: 5$ & $3: 4: 3$ & 5 & 6 & 11 \\
\hline $\begin{array}{l}\text { Paratype; AMS, } \\
\text { C. } 74897\end{array}$ & 86.2 & 35.5 & 51.0 & 17.5 & 44.7 & 27.7 & 17.6 & 20.5 & $5: 5$ & $3: 4: 2$ & 5 & 7 & 12 \\
\hline $\begin{array}{l}\text { Paratype; AMS, } \\
\text { C. } 106396\end{array}$ & 90.5 & 37.1 & 52.9 & 17.8 & $38.2^{*}$ & 28.8 & $12.0^{*}$ & 20.9 & $6: 5$ & $3: 4: 4$ & 5 & 7 & 13 \\
\hline $\begin{array}{l}\text { Paratype; AMS, } \\
\text { C. } 102598\end{array}$ & 77.9 & 32.7 & 44.7 & 17.7 & 42.4 & 25.9 & 16.6 & 17.7 & $6: 3^{*}$ & $3: 4: 4$ & 5 & 7 & 13 \\
\hline $\begin{array}{l}\text { Swain Reefs, } \\
\text { Queensland; AMS } \\
\text { C.106401 (Fig. } \\
86 G \text { ) }\end{array}$ & 89.9 & 38.1 & 51.6 & 19.9 & 49.8 & 28.6 & 18.2 & 24.7 & $6: 3^{*}$ & $3: 4: 5$ & 3 & 7 & 13 \\
\hline $\begin{array}{l}\text { Swain Reefs, } \\
\text { Queensland; AMS } \\
\text { C.106401 (Fig. } \\
86 \mathrm{G} \text { ) }\end{array}$ & 85.1 & 36.4 & 49.2 & 19.5 & 48.3 & 29.1 & 14.0 & 23.4 & $6: 2^{*}$ & $3: 4: 6$ & 5 & 7 & 13 \\
\hline
\end{tabular}


Murex spectabilis $\mathbf{n}$. sp.

Figs 38; 39; 77D; 86A; Table 29

Murex ternispina.-Hirase, 1934: 77, pl. 108, fig. 5 (not of Lamarck).

Murex pecten.-Fair, 1976: pl. 1, fig. 11.

Type material. HolOTYPE (AMS, C.147946), off Bulan, Sorsogon Province, Luzon Island, Philippines, ex J. \& R. Bennett (no other data). PARATYPES: 2 (AMS, C.147947; SDNHM, 89262), Palawan Id, Philippines, from fishermen (ex Bibby colln); 2 paratypes (NM, G3001 and G9052) Sorsogon Bay, Philippines.

Other records. PHILIPPINES (R. Fair Colln). THAILAND: south-west of Kapoe, Andaman Sea (ZMC).

Description. SHELL. High-spired, very large (up to $140 \mathrm{~mm}$ in length) with eight inflated teleoconch whorls.

Protoconch of about one and one-half bulbous volutions, ending at small straight varix.

Spiral ornamentation on first two teleoconch whorls of three cords; on third whorl, four strong minor cords added, two on subsutural ramp and one between each pair of major cords. On subsequent whorls additional cords intercalated until body whorl covered with an alternation of strong major and minor cords and occasional tertiary threads. Siphonal canal only weakly marked. Axial ornamentation on first two teleoconch whorls of nine ribs, each with lamellar spine on shoulder; by third whorl every third rib strengthened to form varix with one stout spine at shoulder, intervening ribs remaining as rounded axial ridges. On fourth whorl, an additional intervarical ridge developed in adapertural portion of intervarical area, but all weaken on subsequent whorls; body whorl marked only by undulations on spiral cords. Shell covered with strong growth lamellae, giving fimbriated appearance to spiral cords and shagreening entire surface. Three heavy varices per whorl, each with long, adaperturally curved spines; that at shoulder
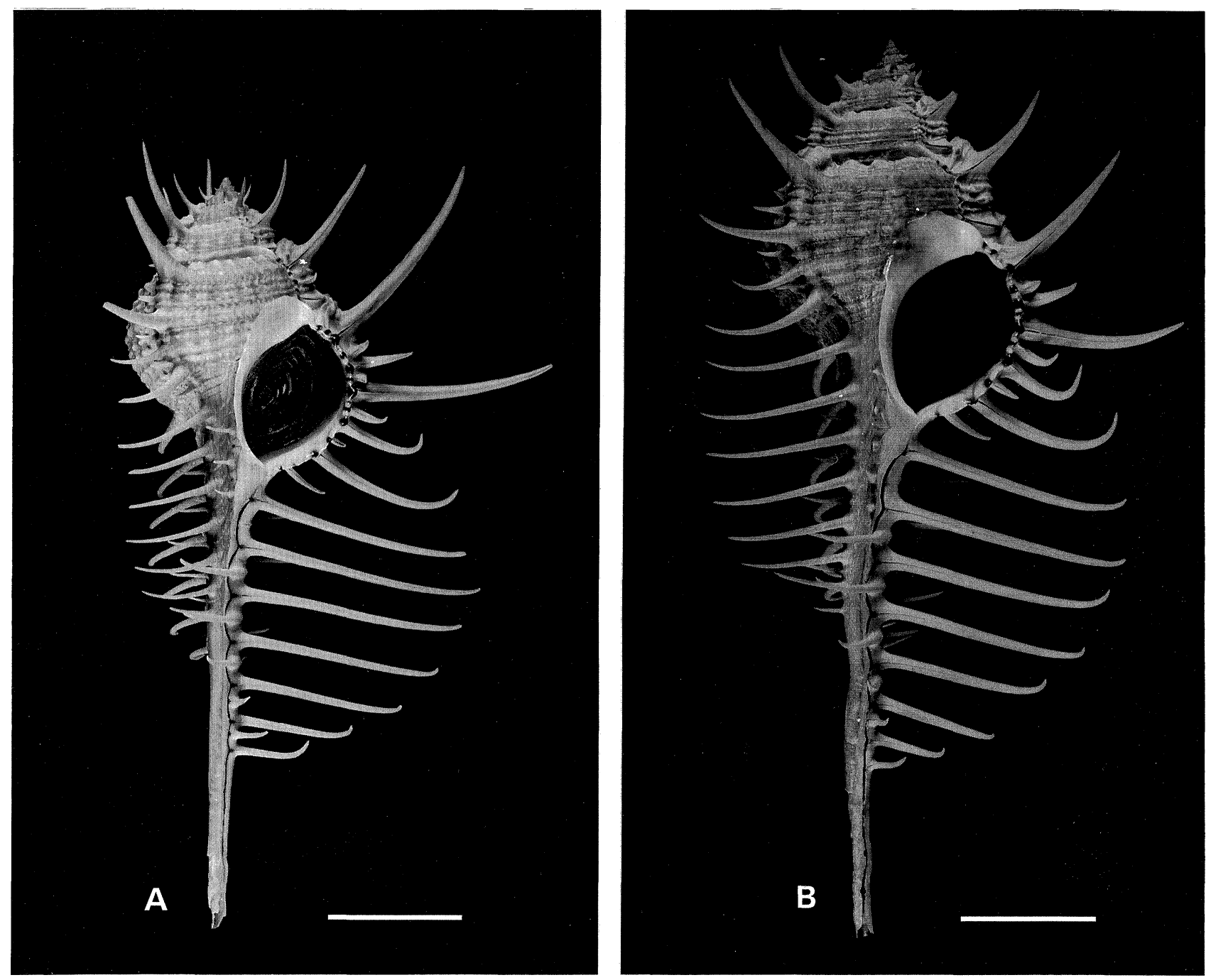

Figure 38. Murex spectabilis n. sp. A: holotype; off Bulan, Sorsogon Province, Luzon Id, Philippine Ids (AMS, C.147946). B: paratype; Palawan, Philippine Ids (AMS, C.147947). Scales $2 \mathrm{~cm}$. 
shortest of major spines and almost straight; spine at periphery slightly longer and more recurved; that at base of body whorl longest and most recurved of spines on body whorl. Very large secondary spine immediately posterior to basal primary spines. Minor spiral cords give rise to secondary spines, even more adaperturally curved; that on shoulder ramp little more than spinelet perpendicular to aperture, others slightly longer and intermediate in direction between major spines and spinelet. Spination pattern (anteriorly from suture) of tertiary, primary (shoulder), secondary, primary (periphery), secondary, longer secondary, primary (base), secondary. Siphonal canal with seven long spines very adaperturally recurved, second spine from base of body whorl longest spine on shell, that posterior to it only slightly shorter; anteriorly each spine somewhat shorter with entire row of spines twisting adaperturally, posterior-most spine at about $70^{\circ}$ angle to anterior-most spine. Alternating with primary spines are much smaller, needle-like secondary spines, anterior-most perpendicular to aperture. Anteriorly, primary and secondary spines separated by progressively smaller angles until posterior-most primary and secondary spines separated by less than $30^{\circ}$; at posterior end of canal, separated by up to about $120^{\circ}$.

Suture slightly channelled, crossed by growth lamellae, their posterior ends directed adaperturally.

Aperture ovate; margin of outer lip notched by extensions of median grooves in spines, notches varying in size according to strength of spines. Internotch area immediately posterior to basal primary spine projecting as small labral tooth. Inner lip appressed at posterior end with projecting flare extending onto previous whorl, persisting as large, flattened area in advance of varices on preceding whorls. Anterior two-thirds of inner lip narrow, freestanding, smooth.

Siphonal canal long; terminations of previous canals fused into tube, open by narrow slit, scalloped by median grooves of major spines; anterior onequarter lacking spines.

Colour bluish grey; spiral cords and spines golden to pinkish brown; apertural lips white, with dark brown spots in notches; interior of shell pinkish brown with darker brown lirations.

DimENSIONS. See Table 29.

OPERCULUM. Red brown; similar to M. pecten, with central nucleus and about ten concentric

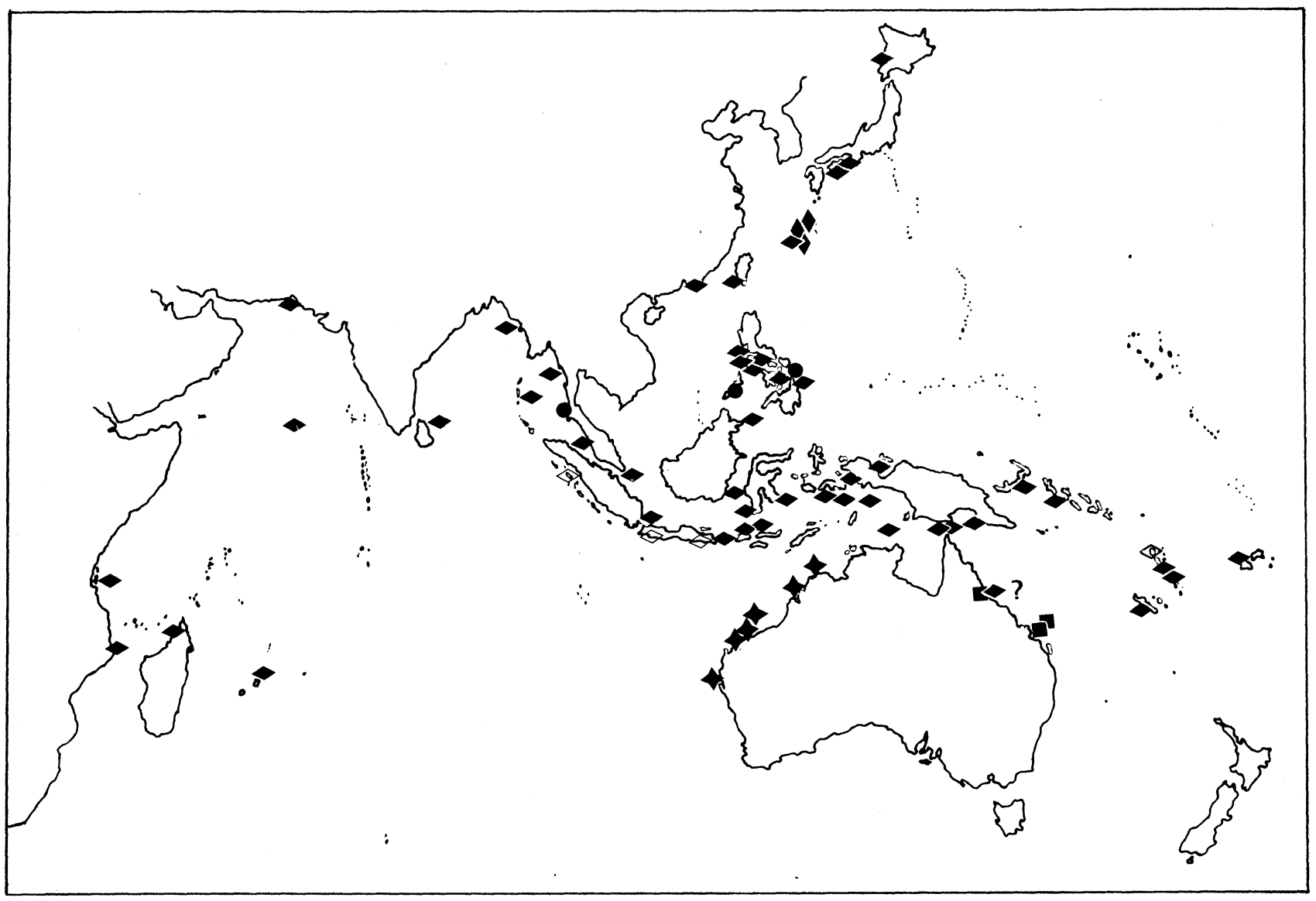

Figure 39. Distribution of Murex pecten species group. M pecten pecten Lightfoot (horizontal diamond); M. pecten soelae n. subsp (star); $M$ queenslandicus n. sp. (square). M. spicatus n. sp. (diamond); M. spectabilis n. sp. (circle), and open symbols $=$ fossil records. 

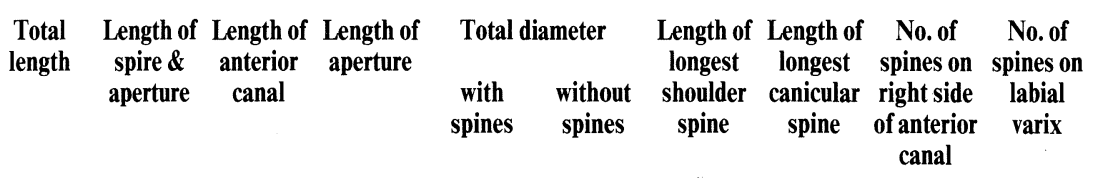

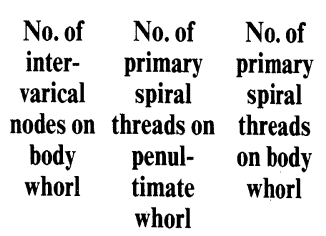

Holotype
Paratype;
SDNHM, 89262
Paratype; AMS,
C.147947
Paratype; NM,
G.3001
Sorsogan,
Philippines; NM
G.9052

\begin{tabular}{|c|c|c|c|c|}
\hline 113.4 & 44.6 & 69.5 & 25.0 & 68.0 \\
\hline 135.1 & 54.0 & 81.4 & 25.4 & 81.0 \\
\hline 134.1 & 56.7 & 79.0 & 28.9 & 70.4 \\
\hline 117.2 & 55.4 & 64.9 & 28.7 & 83.6 \\
\hline 87.6 & 34.2 & 53.4 & 19.4 & 46.6 \\
\hline
\end{tabular}

Remarks. A member of the $M$. pecten group, the shell of this new species is like that of $M$. spicatus $\mathrm{n} . \mathrm{sp}$. and $M$. queenslandicus $\mathrm{n}$. sp. in having fewer spines than $M$. pecten. It differs, however, in the strongly recurved nature of the individual spines, and, especially, their curving plane with reference to the axis of the shell, in contrast to the other three species (and indeed all other species of Murex s.s.), which have the siphonal spines in a straight row. In addition, the protoconch has but one and one-half whorls instead of the two to two and one-half volutions of the other three species.

\section{Murex spicatus n. sp.}

Figs 39; 40; 77F; 86D,E; Table 30

Aranea tribulus.-Perry, 1811: 45, fig. 2 (not of Linné). Murex ternispina.-Reeve, 1845: pl. 19, fig. 76; Kira, 1955: 47, pl. 23, fig. 15; Oyama \& Takemura, 1957: pl. 1, fig. 3; Oyama \& Takemura, 1958: pl. 4, fig. 9; Kira, 1959: 58, pl. 23, fig. 14; Kira, 1962: 63, pl. 24, fig. 14; Fair, 1976: 80 (in part), pl. 1, fig. 9 (not of Lamarck).

Type material. HOLOTYPE(BPBM, 6891c); Okinawa Id, Ryukyus, Japan, ex Thaanum-Langford Colln. PARATYPES: two paratypes (one figured) (USNM, 622048), north side Motobu Peninsula, Okinawa Id, Japan, E. and B. Albert.

Other records. JAPAN: Ryukyus: (BPBM; USNM); Okinawa (BPBM); north side Motobu-Hanto, Okinawa (USNM); Kume-Jima (BPBM); 14 m, off Nago, Okinawa (BPBM); Amami Id (NSMT).

Description. SHELL. Very large (to $140 \mathrm{~mm}$ in length), with seven teleoconch whorls.

Protoconch elongate, of about two and one-half polished, rounded volutions, ending at straight varix.
Spiral ornamentation on first teleoconch whorl masked by axial ribs; on second whorl, three major cords, at shoulder, periphery and near suture. On third whorl, strong secondary spiral cords appear, one on subsutural ramp and one between each pair of primary cords. On subsequent whorls, tertiary threads intercalated resulting in a regular pattern of alternating primary, secondary and tertiary cords covering body whorl and siphonal canal.

Axial ornamentation on first teleoconch whorl of nine angulate ribs with open spines at shoulder; on second whorl, every third rib strengthened to form varix with long, apically directed spine at shoulder; two intermediate ribs reduced to simple, rounded axial ridges. On third whorl, a third intervarical ridge added; by fifth whorl intervarical ridges reduced in strength until body whorl devoid of intervarical axial ornamentation except growth lamellae. Three low varices per whorl; major spiral cords give rise to three closed primary spines on each varix, spine at shoulder longest, strongly recurved apically. Secondary spiral cords give rise to much shorter, more adaperturally directed spines; tertiary spinelets short, perpendicular to aperture. Spination pattern (anteriorly from suture) of tertiary, primary (shoulder), tertiary, secondary, tertiary, primary (periphery), tertiary, secondary, primary, tertiary (base), secondary. Siphonal canal with six or seven very long, perpendicular primary spines, slightly curved adaperturally at distal ends, alternating with small secondary spines directed at an angle greater than $90^{\circ}$ to primary spines; this angle increasing with size of shell.

Suture slightly channelled, crossed by axial growth lamellae.

Aperture ovate; margin of outer lip notched by extensions of median grooves in spines, notches varying in size according to strength of spines; internotch area immediately posterior to basal primary spine projecting as small labral tooth. Inner lip 

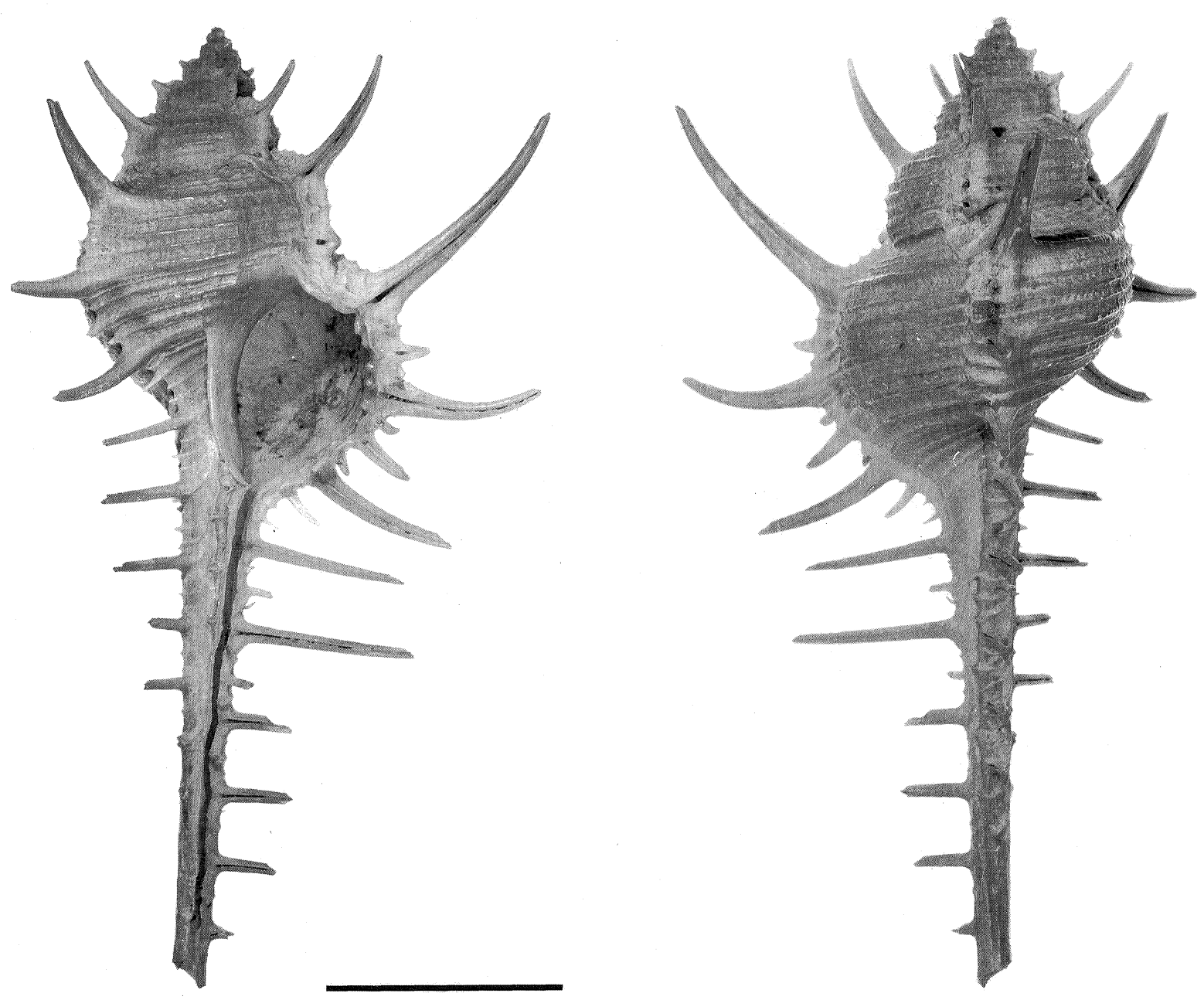

Figure 40. Murex spicatus n. sp. Specimen figured by Reeve (1845: pl. 19, fig. 76) as M. ternispina; Bombay (BMNH). Scale $2 \mathrm{~cm}$.

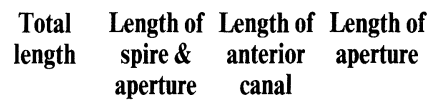

$\begin{array}{ccc}\text { Total } & \begin{array}{c}\text { Length of } \\ \text { Length of }\end{array} & \text { Length of } \\ \text { length } & \text { spire \& } \\ \text { aperture } & \text { anterior anal } \\ & \text { canerture }\end{array}$

$\begin{array}{cccccc}\text { Total diameter } & \begin{array}{c}\text { Length of } \\ \text { longest }\end{array} & \begin{array}{c}\text { Length of } \\ \text { longest }\end{array} & \begin{array}{c}\text { No. of } \\ \text { spines on }\end{array} & \begin{array}{c}\text { No. of } \\ \text { spines on } \\ \text { with }\end{array} & \text { without } \\ \text { spines } & \text { spines } & \begin{array}{c}\text { spoulder } \\ \text { spine }\end{array} & \begin{array}{c}\text { canicular } \\ \text { spine }\end{array} & \begin{array}{c}\text { right side } \\ \text { of anterior } \\ \text { canal }\end{array} & \begin{array}{c}\text { labial } \\ \text { varix }\end{array} \\ & & & & & \end{array}$

$\begin{array}{ccc}\text { No. of } & \text { No. of } & \text { No. of } \\ \text { inter- } & \text { primary } & \text { primary } \\ \text { varical } & \text { spiral } & \text { spiral } \\ \text { nodes on } & \text { threads on } & \text { threads } \\ \text { body } & \text { penul- } & \text { on body } \\ \text { whorl } & \text { timate } & \text { whorl } \\ & \text { whorl } & \end{array}$

Holotype

$\begin{array}{rrrrrrrrrrrrr}138.5 & 59.5 & 79.4 & 32.3 & 80.3 & 44.0 & 35.3 & 41.5 & 7: 6 & 5: 4: 2 & 0 & 7 & 12 \\ 96.3 & 60.0 & 36.3 & 20.3 & 62.7 & 29.7 & 30.5 & 25.8 & 6: 6 & 5: 3: 2 & 0 & 7 & 12 \\ 121.5 & 45.6 & 77.0 & 25.8 & 69.4 & 35.7 & 37.5 & 29.6 & 6: 7 & 5: 4: 2 & 0 & 7 & 14 \\ 113.6 & 43.8 & 70.7 & 23.6 & 78.9 & 35.6 & 34.6 & 29.2 & 6: 4^{*} & 5: 3: 0 & 0 & 7 & 13 \\ 117.5 & 47.5 & 71.0 & 24.9 & 67.1 & 36.7 & 32.1 & 30.8 & 6: 7 & 5: 4: 2 & 0 & 7 & 13\end{array}$

Figured Paratype;

USNM, 622048

Ryukyu Islands;

USNM, 343946

Nago, Okinawa,

Japan; BPBM,

6891,a.

Kume-Jima,

Ryukyu Islands

BPBM, 6891,b.

Table 30. Shell measurement and count data for Murex spicatus n.sp. ${ }^{*}=$ damaged. 
appressed at posterior end with projecting flar extending onto previous whorl, persisting as a smal smooth relic structure in advance of precedin varices. Anterior two-thirds of inner lip free standing, smooth.

Siphonal canal with terminations of previou canals fused into straight tube, open by narrow sli 1 anterior two-thirds lacking spines.

Colour creamy white, spiral cords slightly darke1 aperture white with brown spots in notches.

DimENSIONS. See Table 30.

OPERCULUM. Light brown, subcentral nucleus surrounded by well-spaced, foliated concentri laminae.

Etymology. Latin, spicatus, to put forth ears o grain or points-referring to upturned shoulde spines.

Remarks. This species has generally beer incorrectly identified as M. ternispina. Although figured in one, eighteenth century work (Seba, 173465: pl. 78, fig. 4) it was never given a name. It is rather similar to M. pecten in size and in the development of the primary spines and in opercular characters. Murex spicatus is similar to M. queenslandicus in having a lesser number of spines than in M. pecten, particularly on the siphonal canal, but differs in that the shoulder spines are directed distinctly adapically, as in M. pecten. Of the three species, M. spicatus has the least ornamented shell, and even less axial ornamentation than $M$. pecten. It is also the most massive form with a heavier shell and thicker varices than either of the other two.

Other similar species include $M$. ternispina and $M$. spectabilis, which are contrasted with M. spicatus in the remarks on these species.

\section{Murex ternispina Lamarck, 1822}

Figs 41-43; 77J; 86B,C; Table 31

Murex ternispina Lamarck, 1822: 158 (Indian Ocean; holotype, NHMG, 1099/4); Deshayes \& MilneEdwards, 1839: 702; Deshayes, 1843: 567 (in part); Küster \& Kobelt, 1856: 57 (in part); ?Smith, 1891: 404.

Murex nigrispinosus Reeve, 1845: pl. 20, fig. 79 (unknown locality; holotype, Saul colln, University of Cambridge); Reeve, 1846: 88; Küster \& Kobelt, 1869: 75, pl. 26, fig. 5; Sowerby, 1879: 4, pl. 2 (of Murex), fig. 11; Poirier, 1883: 33; Baker, 1890: 69, text fig. 6; Wissema, 1947: 177; Oyama \& Takemura, 1958: pl. 3, figs 4, 10; Vokes, 1970: 182; Hinton, 1972: 34, pl. 17, figs 3, 4; Kaicher, 1974: fig. 518; Dance, 1974: 121; Fair, 1976: 61, pl. 1, fig. 3; Bishop \& Way, 1976: 42; Lindner, 1977: 176, pl. 27, fig. 7; Houart, 1979: 129, pl. 3, figs 4, 4A, 4B, text figure; D'Attilio, 1979: 16, fig. 1 .

Murex nigrospinosus (sic)._-Tryon, 1880: 78, pl. 9, fig. 109 (as form of M. tribulus).

Murex (Tribulus) ternispina.-Poirier, 1883: 30 (in part).

Murex (Tribulus) nigrispinosus.-Poirier, 1883: 33; Schepman, 1911: 340, pl. 24, fig. 6 (radula).

Murex (Tribulus) nigrospinosus (sic).-Watson, 1885: 147.

Murex (Murex) tribulus var. nigrospinosus (sic).-Baker, 1897: 372.

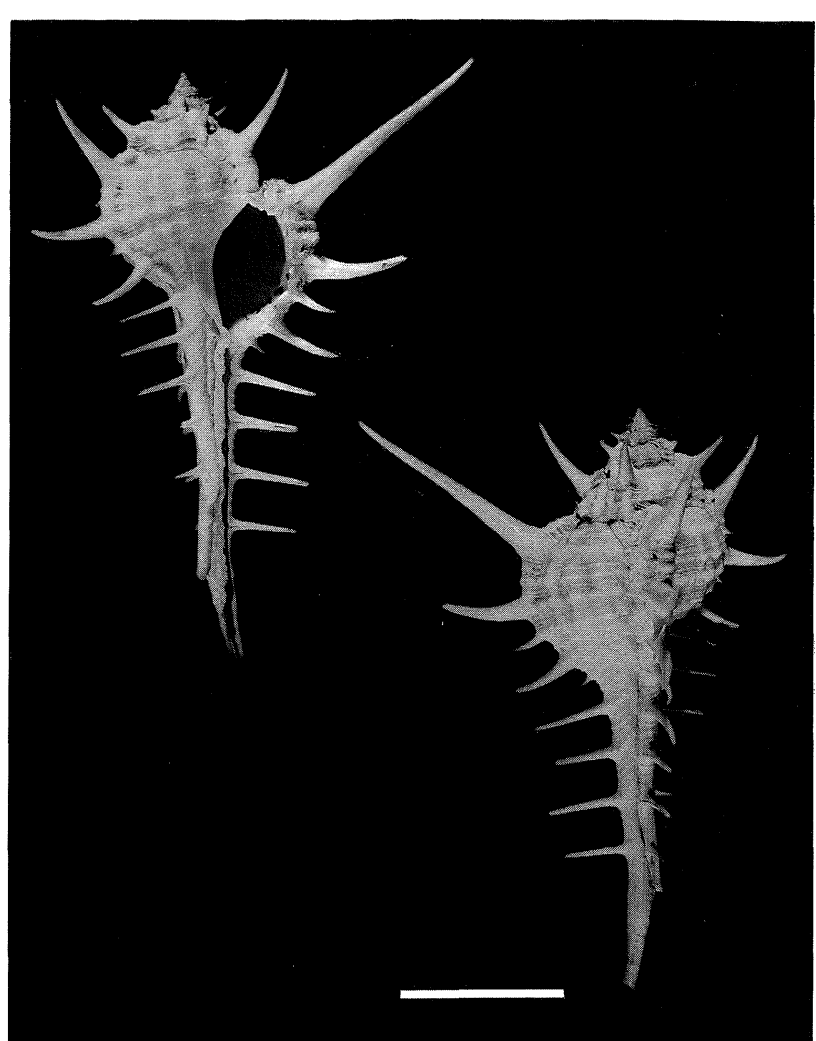

Figure 41. Murex ternispina Lamarck. Holotype; Indian Ocean (NHMG, 1099/4). Scale $2 \mathrm{~cm}$.

Murex(Aranea) nigrispinosus.-Habe, 1961: 49, pl. 25, fig. 2.

Murex (Acupurpura) nigrispinosus.-Habe, 1964: 78, pl. 25 , fig. 2.

Acupurpura nigrispinosa.-Habe \& Kosuge, 1966: 51, pl. 18, fig. 9.

?Murex cf. nigrispinosus.-Fair, 1976: 88, pl. 3, fig. 43.

Murex tribulus. - Radwin \& D'Attilio, 1976: 72 (in part), pl. 10, fig. 8 (not of Linné).

Records. SRI LANKA: $62 \mathrm{~m}$, off south coast (BMNH). ANDAMAN ISLANDS: (ZMC); Port Blair, South Andaman (BMNH). SINGAPORE: (USNM); Tanjong Katong (NMW); Pulau Sudong (AMS); Bedok Beach (USNM); south-east of Sultan Shoal Lighthouse (ZMC). INDONESIA: 16-24 m, Sibutu, Sulu Archipelago (WAM); Toboali, Bangka Id; Sungailiat, Bangka Id; Pulautelo Id, Batu Ids (all ZMA); 38 $\mathrm{m}$, west of Pulau Tunda, north-west Java; Java Sea, northeast of Pulau Merak; 35 m, off Serang, Java (all ZMC); Kerandin, Lingga Islands, Sumatra; Deli Id, south-west Java; Pasuruan, east Java; Situbondo, east Java; Pulau Siklopo, Java (all RML); Lombok; $55 \mathrm{~m}$, Bay of Bima, Sumbawa; Bay of Nangamesi, Sumba (all ZMA); Teluk Slawi, Komodo (FSM); Larantuka, Flores (ZMA; RML); Semau Id, south Timor (RML); Lirung, Talaud Id, north Sulawesi; south Sulawesi; Salayar, Kabia Id, south Sulawesi; Pabbiring Archipelago, south Sulawesi (all ZMA); Panikiang Id, Pabbiring Archipelago; Samauru, Seram (both RML); 46-92 m, $1.5 \mathrm{~km}$ east of 'Dauwi' Id, Padeaido Ids, Irian Barat (AIM); 36-45 m, $1.5 \mathrm{~km}$ northeast of Rumwakon Id, Auri Ids, Irian Barat (ANSP); 25 m, north of Duroa, Kai Ids (ZMC); 27-36 m, north of Kai Ketchil, Kai Ids (WAM). SABAH: 9 m, Marudu Bay (ANSP). 
HONG KONG: (SAM). PHILIPPINES: Luzon (NSMT); 11-18 m, Manila Bay, Luzon (ANSP; DMNH; USNM; AMNH); Corregidor Id, Luzon (DMNH); Bataan-Corrigedor Strait (DMNH); 13 m, Lusong Cove, south-west Bataan, Luzon (ANSP); 2-9 m, Wawa, Nasugbu, Luzon (WAM); Cebu (AMS; ANSP; AMNH); Santa Rosa Id, off Cebu (AMS); Banacon Id, Bohol (AMS); 3-7 m, north-west end of Bohol (ANSP); $69 \mathrm{~m}$, Sibuco Bay, west Mindanao (USNM); Davao, Mindanao (DMNH); Mindoro (BMNH); Calapan, Mindoro (USNM); Port Galera, Mindoro (MCZ); Sulu Archipelago (AMNH); south Lagoon, Sibutu, Sulu Archipelago (WAM). JAPAN: Okinawa (USNM); Cape Ashizuri, south Shikoku (NSMT). PAPUA NEW GUINEA: Aromot Id, Siassi Ids; 'Malai Id', Siassi Ids, west New Britain (both AMS). SolOMONS: Rove, Guadalcanal (AMS); Florida Id (NMV). Australia: Townsville, Queensland (AMS requires confirmation).

Fossil records. Plio-Pleistocene: Nias, Malay Archipelago (Wissema, 1947); "Kolo", Timor (BMNH). Pliocene: Semarang, Java (GML).

Description. SHELL. Moderately low-spired, large (up to $110 \mathrm{~mm}$ in length), with eight teleoconch whorls. Protoconch of about two smooth, bulbous volutions, terminating at small, almost straight varix.

Spiral ornamentation on first three teleoconch whorls of three rounded primary cords and fourth secondary cord on subsutural ramp; by fourth whorl, secondary spirals intercalated. Body whorl and posterior part of siphonal canal marked by series of strong, nodulose primary and secondary cords separated by numerous weak tertiary threads.

Axial ornamentation on first two teleoconch whorls of 12 to 14 rounded ribs; on third whorl every third rib strengthened to form varix bearing long, heavy, apically-directed shoulder spine and smaller spine (truncated) at periphery. By fifth whorl, third intervarical axial ridge added at adapertural end of intervarical area; on sixth whorl, fourth ridge appearing in advance of other three; on body whorl four, occasionally five, low intervarical ridges, nodulose where crossed by spiral cords. Numerous lamellose growth lines give surface shagreened appearance. Three heavy rounded varices per whorl, each with three usually very coarse and heavy primary spines; that at shoulder sometimes very long and apically directed; those at periphery and base of whorl of approximately equal length and slightly curved. One strong secondary spine between periphery and basal primary spines; much weaker

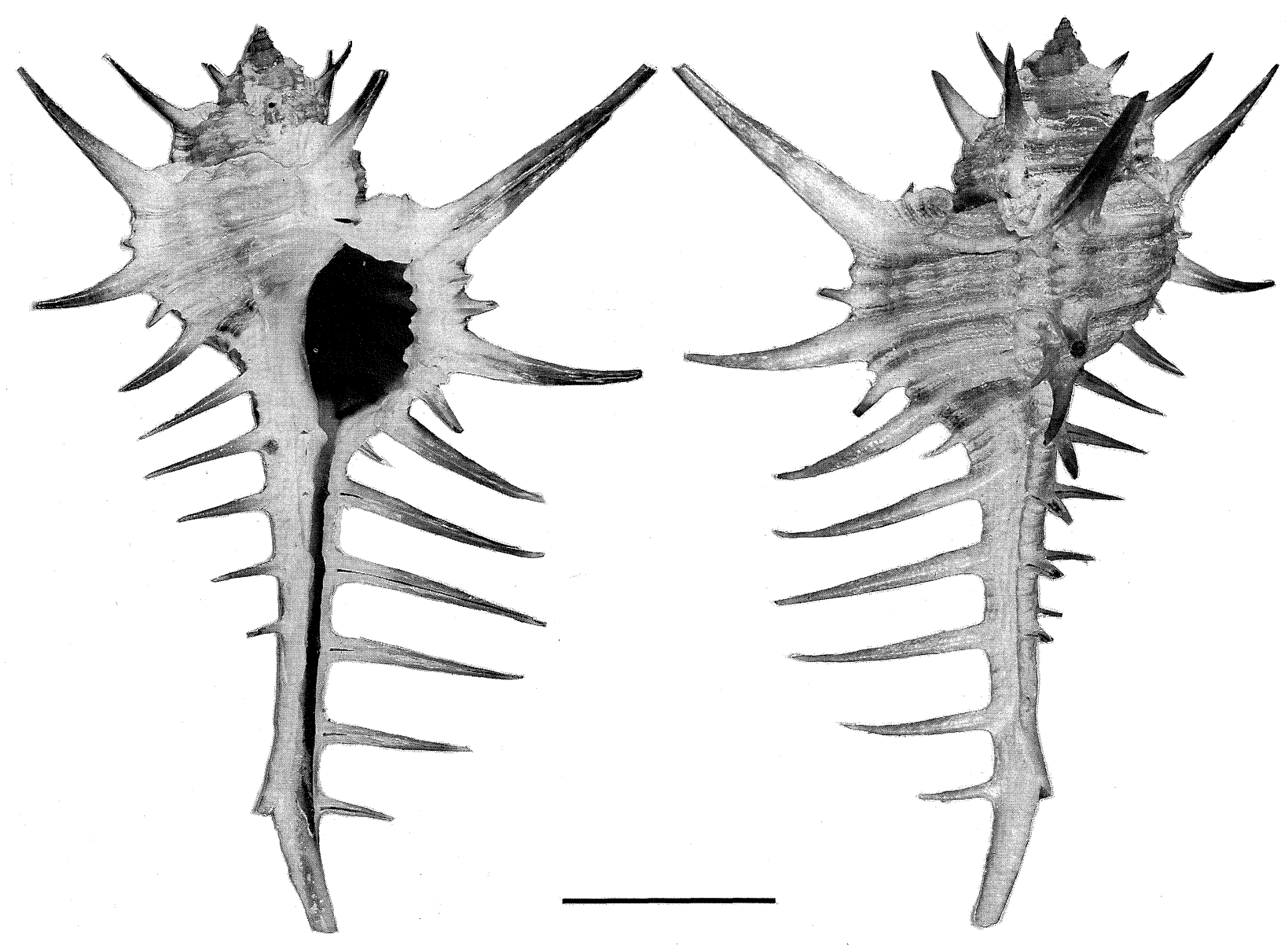

Figure 42. Murex ternispina Lamarck. Holotype of Murex nigrispinosus Reeve: locality unknown (Saul Colln. University of Cambridge). Scale $2 \mathrm{~cm}$. 
one, often adaperturally directed, between primary spines on periphery and shoulder; another anterior to basal primary spine extremely weak and often lacking. Minute, adaperturally-directed tertiary spinelets only rarely developed on varical face. Body whorl giving appearance of having only three large and one small spine on each varix.

Siphonal canal with five to seven long, closed primary spines, slightly adaperturally-recurved at distal ends; secondary spines lacking.

Suture simple, crossed diagonally by terminations of growth lamellae from succeeding whorl.

Aperture ovate; outer lip crenulated, with size of notches reflecting relative strength of spiral ornamentation, each inter-notch area drawn out into projection, that posterior to basal primary spine longer than others, forming small labral tooth. Notches extending well into aperture as elongate lirations; when outer lip incomplete, notches opening into spines as in $M$. scolopax group (N.B. this incomplete stage more commonly present than in most species, suggesting a longer period of lip maturation). Anal notch shallow. Inner lip heavy, with posterior end barely appressed, anterior twothirds free-standing, smooth.

Siphonal canal moderately long to long; terminations of previous canals fused into tube with distal end slightly recurved, open by narrow slit; almost total length spinose. Colour creamy white to light tan, with tips of primary spines sometimes tinged in purple; aperture white.

DIMENSIONS. See Table 31.

\begin{tabular}{|c|c|c|c|c|c|c|c|c|c|c|c|c|c|}
\hline & \multirow{2}{*}{$\begin{array}{l}\text { Total } \\
\text { length }\end{array}$} & \multirow{2}{*}{$\begin{array}{l}\text { Length of } \\
\text { spire \& } \\
\text { aperture }\end{array}$} & \multirow{2}{*}{$\begin{array}{l}\text { Length of } \\
\text { anterior } \\
\text { canal }\end{array}$} & \multirow{2}{*}{$\begin{array}{l}\text { Length of } \\
\text { aperture }\end{array}$} & \multicolumn{2}{|c|}{ Total diameter } & \multirow{2}{*}{$\begin{array}{l}\text { Length of } \\
\text { longest } \\
\text { shoulder } \\
\text { spine }\end{array}$} & \multirow{2}{*}{$\begin{array}{l}\text { Length of } \\
\text { longest } \\
\text { canicular } \\
\text { spine }\end{array}$} & \multirow{2}{*}{$\begin{array}{l}\text { No. of } \\
\text { spines on } \\
\text { right side } \\
\text { of anterior } \\
\text { canal }\end{array}$} & \multirow{2}{*}{$\begin{array}{l}\text { No. of } \\
\text { spines on } \\
\text { labial } \\
\text { varix }\end{array}$} & \multirow{2}{*}{$\begin{array}{l}\text { No. of } \\
\text { inter- } \\
\text { varical } \\
\text { nodes on } \\
\text { body } \\
\text { whorl }\end{array}$} & \multirow{2}{*}{$\begin{array}{l}\text { No. of } \\
\text { primary } \\
\text { spiral } \\
\text { threads on } \\
\text { penul- } \\
\text { timate } \\
\text { whorl }\end{array}$} & \multirow{2}{*}{$\begin{array}{c}\text { No. of } \\
\text { primary } \\
\text { spiral } \\
\text { threads } \\
\text { on body } \\
\text { whorl }\end{array}$} \\
\hline & & & & & $\begin{array}{l}\text { with } \\
\text { spines }\end{array}$ & $\begin{array}{l}\text { without } \\
\text { spines }\end{array}$ & & & & & & & \\
\hline Holotype & 61.2 & - & - & - & - & - & - & - & - & - & - & - & - \\
\hline $\begin{array}{l}\text { Rove, } \\
\text { Guadalcanal, } \\
\text { Solomon Ids; } \\
\text { AMS, C.148209 } \\
\text { (Fig. 86B) }\end{array}$ & 117.7 & 49.4 & 69.7 & 27.9 & 81.2 & 37.8 & 33.8 & $28.2^{*}$ & 7 & $3: 3: 1$ & 0 & 4 & 13 \\
\hline $\begin{array}{l}\text { Okinawa, } \\
\text { Ryukyus; USNM, } \\
670350 \text { (Fig. 86C) }\end{array}$ & 93.1 & 41.0 & 53.1 & 21.7 & 65.3 & 31.6 & 35.1 & 23.2 & 6 & $3: 3: 2$ & 4 & 4 & 12 \\
\hline $\begin{array}{l}\text { Luzon Id, } \\
\text { Philippines; } \\
\text { NSMT }\end{array}$ & 80.7 & 39.3 & 42.6 & 19.7 & 52.5 & 31.3 & 23.9 & 19.8 & 6 & $3: 3: 4$ & 3 & 5 & 14 \\
\hline
\end{tabular}

Table 31. Shell measurement and count data for Murex ternispina Lamarck.* = damaged.

OPERCULUM. Reddish brown; subcentral nucleus with well-spaced, raised, non-foliose, concentric lamellae.

Remarks. There are two specimens marked "ternispina Lamarck" in the NHMG, which are from the Lamarck collection. These are both the species named $M$. nigrispinosus by Reeve. One of these specimens is marked "type" and, as Lamarck referred to only one specimen, this is regarded as the holotype. The second specimen (NHMG, 1099/3) has no type status. The name Murex ternispina has been misinterpreted by most authors and Vokes (1978) has already indicated that $M$. ternispina and $M$. nigrispinosus are the same species, but suggested regarding the name $M$. ternispina as a nomen dubium. The existence of a holotype, however, requires the recognition of the name $M$. ternispina.

Most of the literature records of $M$. ternispina refer to other species and, in many cases, probably more than one species. It has not been possible to check all the literature records and, consequently, these are listed in the synonymy with a query, or omitted.

The species most similar in shell characters to $M$. ternispina are M. falsitribulus and M. spicatus. Murex falsitribulus is readily distinguished by the lack of distinct axial sculpture, angulated whorls and a different operculum. The shell of Murex spicatus is similar to that of $M$. ternispina, especially to some large, pale-coloured, thin shelled specimens from the Solomon Islands. These specimens have reduced axial sculpture and although in most shell characters they resemble $M$. spicatus, $M$. ternispina has a smaller protoconch (cf. figs $77 \mathrm{~F}, 77 \mathrm{~J}$ ), that of $M$. spicatus being about $1.2-1.5 \mathrm{~mm}$ in diameter compared with $0.8-1 \mathrm{~mm}$ in diameter for M. ternispina. In addition, the shell of $M$. spicatus has lost the axial ribs and nodules characteristic of $M$. ternispina, which are found, although reduced, in the large Solomon Island specimens referred to above, and has a channelled suture. Murex pecten has a shell with more numerous spines, including secondary spines on the siphonal canal. 


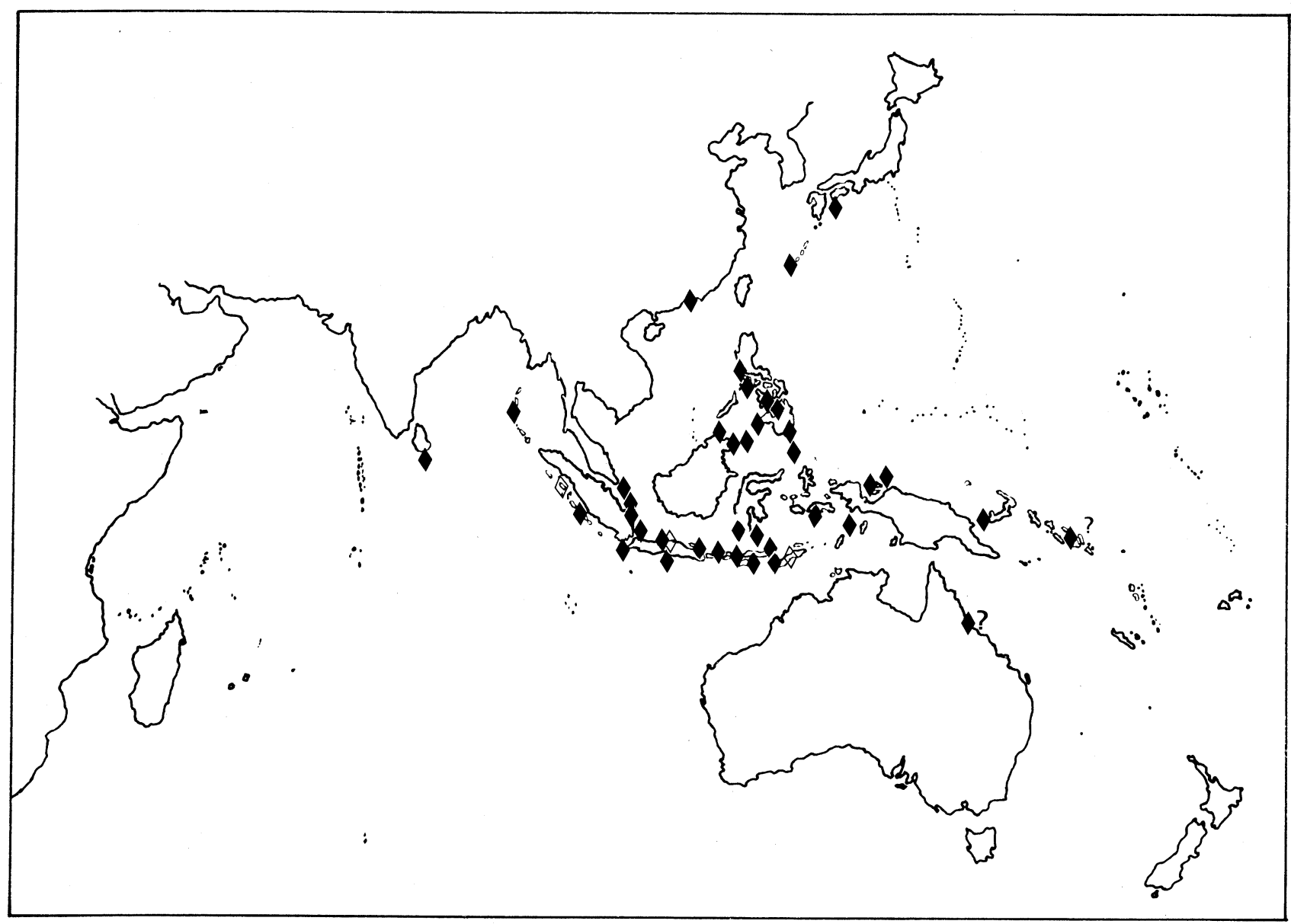

Figure 43. Distribution of Murex ternispina Lamarck and open diamonds = fossil records.

Fossil Taxa in the M.pecten Group

Murex guppyi Ladd, 1977

Fig. 44

Murex (Murex) guppyi Ladd, 1977: 37, pl. 13, figs 6, 7 (Pliocene, stn 817, Vanua Levu, Fiji; holotype USNM, 175003).

Murex cf. M. multispinosus._Ladd, 1977: 38, pl. 13, figs 4, 5 (not of Sowerby, 1904).

Description. SHELL. Of medium size (estimated length about $80 \mathrm{~mm}$ ), total number of teleoconch whorls and nature of early whorls unknown.

Spiral ornamentation on body whorl and siphonal canal of regularly alternating primary and secondary cords, with few tertiary threads; those major cords at shoulder and periphery much stronger.

Axial ornamentation on earliest preserved whorls of three or four small ridges between each pair of varices, evanescing with growth, essentially lost on body whorl. Adult shell having strong growth lamellae only, which, together with spiral ornament, gives shagreened surface to entire shell. Three high, rounded varices per whorl, each with series of primary and secondary spines; primary spiral cords drawn out into long spines at shoulder, periphery, and base of body whorl. Secondary spiral cords with smaller spines, and a few tertiary spinelets. Siphonal canal with at least ten strong primary spines perpendicular to axis; secondary spines alternate with these and directed at right angles to them.

Suture deeply impressed, crossed by numerous growth lamellae, directed extremely adaperturally, almost parallel to suture. Subsutural ramp flattened and nearly at right angles to axis.

Aperture presumed ovate, margin of outer lip notched by extensions of median groove in spines; inter-notch area posterior to major spine at base of body whorl projecting as small labral tooth. Subsutural ramp almost parallel to suture and persisting as relict structure on earlier whorls. Inner lip appressed at posterior end, anterior two-thirds free-standing, smooth within.

Siphonal canal very long; terminations of previous canals fused into straight tube, open by narrow slit; presumably spinose almost entire length.

Remarks. The shell of Murex guppyi has features of that of both $M$. pecten and $M$. queenslandicus. The extremely spinose canal with remains of ten major spines is comparable only to $M$. pecten but that species has no tertiary threads on the canal. Murex queenslandicus, on the other hand, has tertiary threads between every pair of major and minor cords along the entire length of the canal. Murex guppyi is thus intermediate in this character, with tertiary 


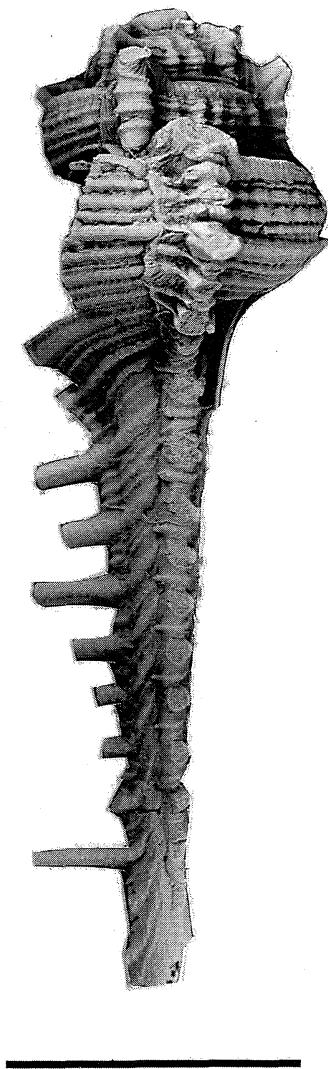

Figure 44. Murex guppyi Ladd. Holotypc: Vanua Levu, Fiji. Pliocene (USNM, 175003). Scale $2 \mathrm{~cm}$.

threads on about one-half the length of the canal. The scabrous shell, in which the spiral cords overshadow the axial ridges, is also most like $M$. pecten; but $M$. guppyi has even stronger spiral cords, especially at the shoulder and periphery. Although the flattened subsutural ramp in M. guppyi is very conspicuous and seemingly would serve to distinguish this species immediately from any other, examination of the holotype suggests that there is a possibility that some of this flattening may be due to distortion with fossilization. Another specimen figured by Ladd at the same time as M. guppyi, which he cited under the name "Murex cf. M. multispinosus Sowerby"* seems to be another example of $M$. guppyi that has not been crushed. The spire in this specimen is still much lower than $M$. pecten or M. queenslandicus.

In some features $M$. guppyi is most similar to $M$. spicatus, having only four primary spines on the body whorl, the secondary spines being greatly reduced. The nature of the spiral cords is also similar, with those at the shoulder and periphery being much heavier than the others. However, M. spicatus has a * This reference to M. multispinosus has to be an error as there is no resemblance whatsoever to the latter form, a small species tentatively included in Murexsul, with eight varices. Presumably Ladd intended to use the name $M$. aduncospinosus Sowerby, 1841, which does have at least a generic similarity. However, the aperture of Ladd's specimen is nearer to that of the M. pecten group, with its small labral tooth and very flaring inner lip. smaller number of spines on the siphonal canal, arranged farther apart. From M. spectabilis, another similar species, $M$. guppyi also differs in the more numerous and more crowded spines on the siphonal canal. In addition, the spiral cords on the body whorl of $M$. spectabilis are less distinct and the spines more recurved.

In the final analysis, this Pliocene form is not directly related to any living member of the group but shares features found in all of them. If addition of the spines is the direction that evolution takes in the $M$. pecten group (as seems likely) then only M. pecten is a possible candidate for a direct descendant, as the primary difference between the two is the more numerous secondary spines on the body portion of the varices in the living form.

\section{SUBGENUS PROMUREX n. subgen.}

\section{Murex (Promurex) antelmei Viader, 1938 Figs 45; 67I; 72D; 74F; Table 32}

Murex antelmei Viader, 1938: 6, pl. 1, figs 8, 9 (off Port Louis Harbour, Mauritius, 60 fathoms [110 m]; 6 ?syntypes, Mauritius Institute); Radwin \& D'Attilio, 1976: 61, fig. 33; Fair, 1976: 21; Rouillard, 1980: 4, fig. in text.

Murex antermai (sic).-Shuto, 1983: 538.

Records. MAURITIUS: (BMNH); 274-311 m, Arsenal Bay (ZMC).

Description. SHELL. Medium-sized (up to 75 $\mathrm{mm}$ in length), with six teleoconch whorls.

Protoconch of three conical volutions, terminating in small varix.

Spiral ornamentation on first two teleoconch whorls of three rounded cords; on third and subsequent whorls, secondary cords intercalated, until body whorl and posterior portion of siphonal canal covered with numerous spiral cords, all approximately of same strength except for four which are slightly stronger where crossing axial ridges.

Axial ornamentation on first teleoconch whorl of nine rounded ribs; on second whorl every third one strengthened into varix with long, apically-directed closed spine; second smaller and slightly abapicallydirected spine at periphery. Intermediate ribs lack spines and form swollen, rounded intervarical ridges which gradually weaken with growth; no additional ridges added; body whorl bears only two rows of elongate nodules. Entire surface shagreened by numerous growth lamellae. Three rounded varices per whorl, slightly excavated abaperturally, each with three closed spines; that at shoulder strongly apically directed; that at periphery slightly abapically directed; and that at base of body whorl strongly abapically directed, the angle between anterior and posterior spines being $90^{\circ}$ or more; one minute, adaperturally-directed spinelet at juncture of body whorl and canal; canal with one to three short straight spines at posterior end near base of body whorl.

Suture simple. 


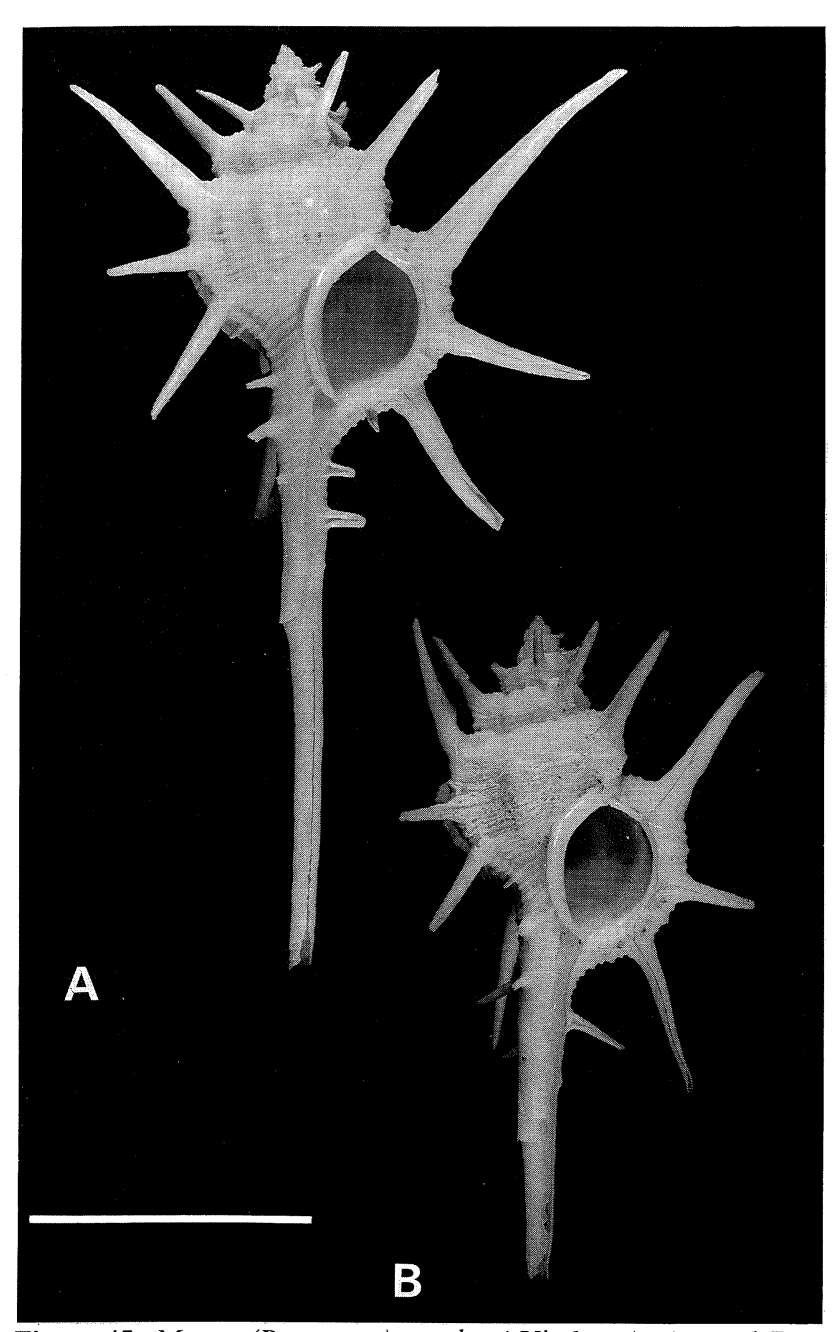

Figure 45. Murex (Promurex) antelmei Viader. A: Arsenal Bay, Mauritius, 274-311 m(ZMC). B: Mauritius, ex Antelme (BMNH). Scale $2 \mathrm{~cm}$.

Aperture ovately rounded; outer lip erect, finely crenulated on margin; small narrow anal notch; inner lip only slightly adherent at posterior end; anterior three-quarters free-standing, smooth; inner and outer lips forming trumpet-shaped peristome.

Siphonal canal long, formed in two parts: posterior half consisting of fused terminations of previous canals; extending anteriorly from this latest canàl making long, thin dorsally-deflected tube open by very narrow slit; in places almost sealed; spinose only immediately adjacent to body whorl. Colour ivory; aperture and interior white.

DimENSIONS. See Table 32.

OperCulum. Yellowish brown; subterminal nucleus, surrounded by eight heavy, concentric ridges.

Radula. See Fig 67I.

PENIS. Basal part tapers to long, narrow distal portion (Fig. 72D).

Remarks. The straight primary spines are arranged at $60-70^{\circ}$ to one another and give the shell of this species a very distinctive character. It does not appear to be closely allied to any other known Recent species.

This species has been included in Murex by all reviewers to date. It is similar to Chicoreus longicornis Dunker, 1844, the spination pattern being similar as are the shape and general features of the shell, but differs markedly in the early teleoconch sculpture. Murex spinicosta Bronn, 1828, from the Miocene and Pliocene of Europe is similar to $M$. (P.) antelme $i$ in the early teleoconch sculpture and in the protoconch morphology (Fig. 74G), so we include this species in Promurex.

Murex longicornis and $M$. cervicornis Lamarck, 1822 , were included in Murex s.s. by Radwin \& D'Attilio (1976). The shell morphology and radulae (Fig. 69D-H) show that these species are better placed in Chicoreus. The early sculpture on the teleoconch differs from that of Murex s.s. with 12-15 axial ribs, every fourth becoming a varix.

\section{Murex (Promurex) bullocki Yokoyama, 1924}

Murex(Phyllonotus) bullocki Yokoyama, 1924: 51, pl. 6 [pl. 7], figs 5,6 (Miocene [=Pliocene], Takinai, Shinjo-mura, Nishi-Muro-gun, Tanabe, Japan: lectotype [fig. 5 designated by Hatai \& Nisiyama, 1952: 216, as "holotype"], Geol. Inst., Tokyo University); Yokoyama, 1926: 340, pl. 38, fig. 13 [as (Phyllonotos)]; Hatai \& Nisiyama, 1952: 216 .

$$
\begin{gathered}
\text { Total } \\
\begin{array}{c}
\text { Length of } \\
\text { spire \& }
\end{array} \\
\text { length anth of } \\
\text { aperture } \\
\text { canal }
\end{gathered}
$$

\begin{tabular}{|c|c|c|}
\hline $\begin{array}{l}\text { Length of } \\
\text { longest } \\
\text { shoulder } \\
\text { spine }\end{array}$ & $\begin{array}{l}\text { Length of } \\
\text { longest } \\
\text { canicular } \\
\text { spine }\end{array}$ & $\begin{array}{l}\text { No. of } \\
\text { spines on } \\
\text { right side } \\
\text { of anterior } \\
\text { canal }\end{array}$ \\
\hline
\end{tabular}

Total diameter

\begin{tabular}{|c|c|}
\hline $\begin{array}{c}\text { No. of } \\
\text { inter- } \\
\text { varical } \\
\text { nodes on } \\
\text { body } \\
\text { whorl }\end{array}$ & $\begin{array}{c}\text { No. of } \\
\text { primary } \\
\text { spiral } \\
\text { threads on } \\
\text { penul- } \\
\text { timate }\end{array}$ \\
\hline
\end{tabular}

$\begin{array}{cc}\text { with } & \text { without } \\ \text { spines } & \text { spines }\end{array}$

Topotype;

Mauritius; BMNH,

1933-5-26-62

49.5

Arsenal Bay,

Mauritius; ZMC

Arsenal Bay,

Mauritius; ZMC

$\begin{array}{rrrrrrrrrrrrr}49.5 & 25.1 & 25.4 & 11.3 & 28.8 & 19.1 & 15.1 & 5.5 & 1 & 3 & 2 & 5 & 9 \\ 74.9 & 29.4 & 46.2 & 12.6 & 41.4 & 21.4 & 20.3 & 4.3 & 1 & 3 & 2 & 6 & 9 \\ 67.1 & 27.4 & 41.7 & 12.1 & 38.7 & 19.8 & 21.3 & 5.9 & 2 & 3: 1: 0 & 2 & 7 & 11\end{array}$

Table 32. Shell measurement and count data for Murex (Promurex) antelmei Viader. 
Murex spinicosta.-Yokoyama, 1926: 340, pl. 38, figs 25, 26 (not of Bronn, 1828).

?Murex (Acupurpura) cf. djarianensis.-Makiyama, 1927: 127.

Murex yokoyamai Hatai \& Nisiyama, 1952: 217 (Pliocene, Dainichi, Ugarimura, Suchi-gun, Sz. Kakegawa, Japan) (new name for $M$. spinicosta Yokoyama not Bronn).

Ocenebra bullocki.-Makiyama, 1957: pl. 7, figs 5, 6 (refig. of Yokoyama, 1923 [1924], pl. 6 [pl. 7]; Makiyama, 1958: pl. 50, fig. 13 (refig. of Yokoyama, 1926, pl. 38).

cf. Murex djarianensis.-Makiyama, 1958: pl. 50, figs 25, 26 (refig. of Yokoyama, 1926, pl. 38).

?Murex noboriensis Aoki \& Baba, 1984: 76, figs 34, 35.

Remarks. Fragmentary material from three Pliocene localities in Japan have been given three different names; however, comparison of the illustrations shows that they are similar and we tentatively refer them to one species. These specimens have a strong morphological similarity to $M$. spinicosta Bronn, a species we include in Promurex (as, indeed, one of the specimens was originally cited), and for this reason $M$. bullocki is included in Promurex.

\section{GENUS HAUSTELLUM}

Haustellum haustellum haustellum (Linné, 1758)

Figs 1E,F; 46A-D; 47; 68D; 72I; 78D; 87A-C; Table 33

Murex haustellum Linné, 1758: 746 (refers to 5 figures: Buonanni, 1685-1691: pl. 268; Rumphius, 1705: pl. 26, fig. F; Gualtieri, 1742: pl. 30, fig. E; Argenville, 1742: pl. 16, fig. B; Klein, 1753: pl. 4, fig. 81) (Asiatic Ocean; 2 syntypes in Linnaean colln, London); Gmelin, 1791: 3524; Dillwyn, 1817: 680; Wood, 1818: 119, pl. 25, fig. 1; Lamarck, 1822: 159; Blainville, 1827: 401, pl. 19, fig. 5; Deshayes \& Milne-Edwards, 1839: 702; Kiener, 1843: 10, pl. 13, fig. 1; Deshayes, 1843: 568; Reeve, 1845: pl. 23, fig. 95; Küster \& Kobelt, 1856: 35, pl. 14, fig. 3; Hanley, 1855: 279; Tapparone-Canefri, 1875: 10; Sowerby, 1879: 5, pl. 2 (of Murex), fig. 17; Tryon, 1880: 83, pl. 13, fig. 137; Brazier, 1893: 50 (see for additional minor references prior to this date); Hirase, 1914: pl. 18, fig. 84; Hirase, 1934: 77, pl. 108, fig. 2; Moura, 1969: 24, pl. 8, fig. 11; Abbott \& Dance, 1982: 129, fig. in text.

Haustellum fimbriato-nodosum Martini, 1777: 376, pl. 115, fig. 1066 (not binominal).

?Murex scolopaceus Röding, 1798: 144 (refers to Favanne, 1784: pl. 38, fig. B2).

Aranea denudata Perry, 1811: pl. 45, fig. 1 ("African coasts and seas"; location of type unknown).

Haustellum laeve Schumacher, 1817: 213 (Coromandel, India; refers to Martini, 1777: pl. 115, fig. 1066; figured specimen not located).

?Murex erythrostoma Swainson, 1840: 296 (not $M$. erythrostomus Swainson, 1831).

Murex (Haustellum) haustellum.-Tapparone-Canefri, 1875: 574; Smith, 1953: 3, pl. 1, fig. 1; Beets, 1941: 96; Kira, 1955: 47, pl. 23, fig. 12; Oyama \& Takemura, 1957: pl. 2, figs 1, 5; Kira, 1959: 58, pl. 23, fig. 11; Kira, 1962: 63, pl. 24, fig. 11; Cernohorsky, 1967a: 116, pl. 14, fig. 3; Lindner, 1977: 176, pl. 27, fig. 5; Vokes, 1978: 381, pl. 1, fig. 8.
Haustellum haustellum.-Jousseaume, 1880: 335; Allan, 1950: 140, pl. 22, fig. 7; Cotton, 1956, pl. 1, fig. 1; Rippingale \& McMichael, 1961: 97, pl. 12, fig. 9; Cernohorsky, 1967b: 118, pl. 24, fig. 142; Hinton, 1972: 34, pl. 17, fig. 10; Kaicher, 1973: fig. 123; Dance, 1974: 122, figs in text; Coleman, 1975: 26, pl. 46, fig. 46; Fair, 1976: 47, pl. 4, fig. 49; Radwin \& D'Attilio, 1976: 49, pl. 11, fig. 10; Hinton, 1978: 33, fig. 8.

Murex (Tribulus) haustellum.-Poirier, 1883: 42; Schepman, 1911: 344.

Murex haustellum var. longicaudus Baker, 1891: 56 (not preocc. by $M$. longicaudus Wood, 1818 which is Fusus longicaudus Lamarck, 1816) (Red Sea; holotype, ANSP, 60965).

Murex(Murex) haustellum.-Martin, 1895: 127; Oostingh, 1925: 138.

Murex haustellum longicaudum.-Smith, 1953: 3.

Murex (Haustellum) kurodai Shikama, 1964: 33, pl. 3, figs 1, 2 (Arafura Sea, collected by pearl shell divers; holotype, Geological Institute, Yokohama National University).

Haustellum kurodai._Habe \& Kosuge, 1966: 50, pl. 18, fig. 3.

Haustellum longicaudus (m).-Kaicher, 1973; fig. 124; Fair, 1976: 55, pl. 4, fig. 50.

Murex longicaudus.-Abbott \& Dance, 1982: 129, fig. in text.

Haustellum vicdani Kosuge, 1980: 57, pl. 17, figs 2, 4 (Bulan, Sorsogon, Philippines; holotype, IMT, 80-3: paratype, IMT, 80-47).

Records. Mozambique: (AMS); Mozambique City; 20-21 m, Nacala (both ANSP); Porto Amelia (AMNH). TANZANIA: Kunduchi (USNM); Zanzibar: (MCZ; RML); $15 \mathrm{~m}$, west-south-west Ras Nungwi; 20-32 m, south Pwakuu Id; $1 \mathrm{~m}$, Chumbe Id; 9-20 m, Nguruwe Id; $2 \mathrm{~m}$, Ras Mbweni (all ANSP); north of Fumba (ANSP; AMNH); Bawi Id (FMNH); Ras Michamvi (FMNH; ANSP). KENYA $2 \mathrm{~m}$, Shimoni (AMS). MadaGaSCAR: $20-23 \mathrm{~m}$, Nosy Bé (IRSB; ANSP; MCZ); $16 \mathrm{~m}$, Ankify (AMS; ANSP); $1 \mathrm{~km}$ south-west Nosy Toloho; Nosy Iranja; $40 \mathrm{~m}$, Baie d'Ambaro (all ANSP). DEMOCRATIC Yemen: Aden (FMNH; ANSP; USNM; BMNH; WAM); Madinat ash Sha'b, Aden (AMS). INDIA: Calcutta (USNM); Gulf of Mannar(ANSP); Mandapam (ANSP). SRI LANKA:(FMNH; ANSP; BMNH; AMS); Colombo (FMNH); Trincomalee (MCZ; BMNH). ANDAMAN ISLANDS: (BMNH). NICOBAR ISLANDS: (ZMC). MALAYSIA: Pulau Tioman (BMNH). SABAH: Mandidarah Pulau; Kota Kinabalu; Cowie Harbour, Tawau (all ANSP); Semporna; Sapi Id (both USNM). SINGAPORE: (USNM). INDONESIA: Java (ANSP); Sumbawa (ZMA); Kangean Id (ZMA); Butung Pulau (RML); 'Pulau Meramo', Makassar, Sulawesi(ANSP); Piru Bay, Seram (WAM); Ambon (RML; ZMC; ZMA; IRSB); Ambon Bay, Ambon (WAM); Waai, Seram (FMNH); Waai, Seram (BMNH); Banda Sea (ZMA); Larantuka, Flores (ZMA; RML); 45-47 m, south-east Rumadan Id, Kai Ids; $36 \mathrm{~m}$, north of Duroals, north of Nuhu Rowa, Kai Ids; $54 \mathrm{~m}$, off Elat Bay, west coast of Nuhu Tjut, Kai Ids; 62-71 m, between Warbal and Ur Ids, Kai Ids (all WAM); Irian Barat: Maransabadi Pulau, Auri Ids; 32-36 m, Matas Pulau, Auri Ids; Nukori Id, Padeaido Ids (all ANSP). PHILIPPINES: Sulu Sea (ANSP; AMNH; AMS); Siasi, Sulu (AMNH); Laminusa Id, Sulu (AMNH): Jolo Id, Sulu (ANSP; ZMA; AMNH); Balabac, south Palawan (AMNH); Cuyo Id, north Palawan (ANSP); Lubang Id (MCZ); Calapan, Mindoro 


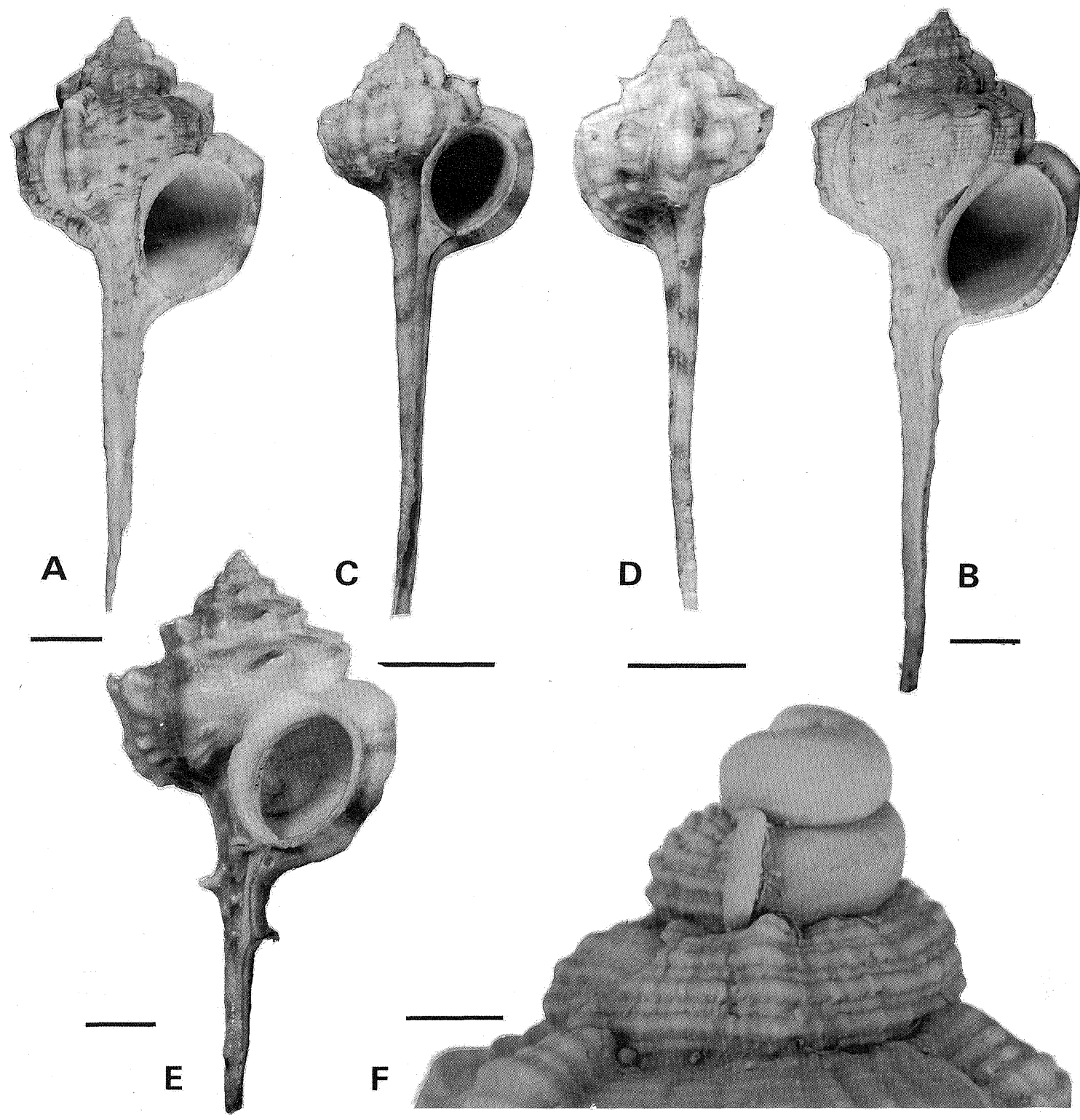

Figure 46. A-D: Haustellum haustellum haustellum (Linné). A,B: syntypes; Asiatic Ocean (Linnaean Colln, London). C,D: holotype of Murex haustellum var. longicaudus Baker; Red Sea (ANSP, 60965). E,F: Haustellum haustellum fallax (Smith). E: holotype; $16 \mathrm{~km}$ off Durban, South Africa, 73 m (BMNH, 1902.5.18.9). F: Durban, South Africa (NM, 5830). Scales: A-E $1 \mathrm{~cm}$, F $1 \mathrm{~mm}$.

(MCZ; AMNH); Port Galera, Mindoro (MCZ); Libagon, Leyte (MCZ); Cebu City, Cebu (ANSP; MCZ; AMNH); Pta Engano, Mactan Id, Cebu; Mandaue, Cebu; Bulan, south Luzon (all AMS); Manila Bay: 10-18 m, east end of Corregidor Id, Luzon; west side, Handayan Id, north-west Bohol (all (ANSP); Mambajao, Camiguin (AMS): $128 \mathrm{~m}$. 'Lady Id', Bohol (WAM); 36-72 m, Maqueda Bay, Samar (MCZ); Mindanao: Overton, north Mindanao (both AMS); Zamboanga (ANSP); Davao (FMNH). JAPAN: Kii
Peninsula; Kochi Pref., Shikoku (both NSMT); Kyushu (ANSP); Ryukyus (BPBM; FMNH); 73-90 m, off Itoman, Okinawa (BPBM); Okinawa (USNM); Amami-o-Shima, Ryukyus (ANSP; MCZ); O-shima, north Bonins (ANSP; USNM; IRSB). PAPUA NEW GUINEA: 12-15 m, 'Watson's Bay', Madang (AMS); Ali Id (FMNH); Manus Id (ZMA); New Hanover; Mongop, New Ireland; Talili Bay, New Britain; Jacquinot Bay, New Britain (all AMS); Rabaul (ANSP; AMNH; AMS); Kumbun, near Kandrian, west 
New Britain (ANSP); Duke of York Id (AMS); Bougainville (AMNH; AMS); Sohano, Bougainville (AMS); Torres Strait (AMS). AUSTRALIA: Cooktown, Queensland (ANSP; AMS). SOLOMONS: (ZMA; AMS); Shortland Id (ANSP), 'Rua-Lusa Id' (IRSB). CAROLINES: (FMNH). NEW CALEDONIA: (IRSB; AMS); Noumea (AMS); Baie des Isoles, Magenta (AMS); Magenta; $4 \mathrm{~m}, 0.5 \mathrm{~km}$ north-east of Anse Vata Bay; 0-4 m, north-east side Brun Id; $1 \mathrm{~m}, 3.8 \mathrm{~km}$ north of Dumbéa Pass (all ANSP); Bourail; Ile Ste Marie (both AMS).

Fossil records. Quaternary: Mozambique (Moura, 1969). Plio-Pleistocene: Nias Id, Malay Archipelago(GML, Wissema, 1947). Pliocene: Tjikeusik, Banten, Java (GML, recorded by Martin, 1895). Miocene: Borneo (Beets, 1941).

Description. SHELL. Low-spired, very large (up to $150 \mathrm{~mm}$ in length, including siphonal canal), with eight inflated teleoconch whorls.

Protoconch of about two and one-half bulbous volutions, terminating in small straight varix.

Spiral ornamentation on first three teleoconch whorls of three rounded cords; on fourth whorl, minor cords appearing, alternating with major ones, plus an additional one on subsutural ramp. Body whorl and siphonal canal covered with alternating major and minor cords.

Axial ornamentation on first three teleoconch whorls of 12 to 14 small, swollen ribs, cancellated by spiral cords. On fourth whorl, every fourth axial rib strengthened into varix, intervening ribs persisting as three intervarical ridges. Intervarical axial ridges gradually reduced in strength until represented on body whorl only by swollen nodules at crossings of major spiral cords. On body whorl, in typical form, fourth intervarical ridge usually added adaperturally; in form kurodai, three persisting; in form vicdani, third ridge often adaperturally evanescing, leaving only two ridges. Three rounded varices per whorl, slightly excavated behind and curved adaperturally on subsutural ramp. Where varices crossed by shoulder spiral short, sharp spine sometimes developed on fourth to sixth whorls only (in form kurodai). Subsutural ramp with three or four open spinelets on adapertural side of varix, corresponding to spiral cords; occasionally a few small prickles also near anterior end of varix; varices otherwise nonspinose. One relatively long, sharp spine on siphonal canal near base of body whorl in typical form and form kurodai.

Suture impressed (in typical form) to slightly canaliculate (in forms kurodai and vicdani), sinuated by axial nodes of previous whorl.

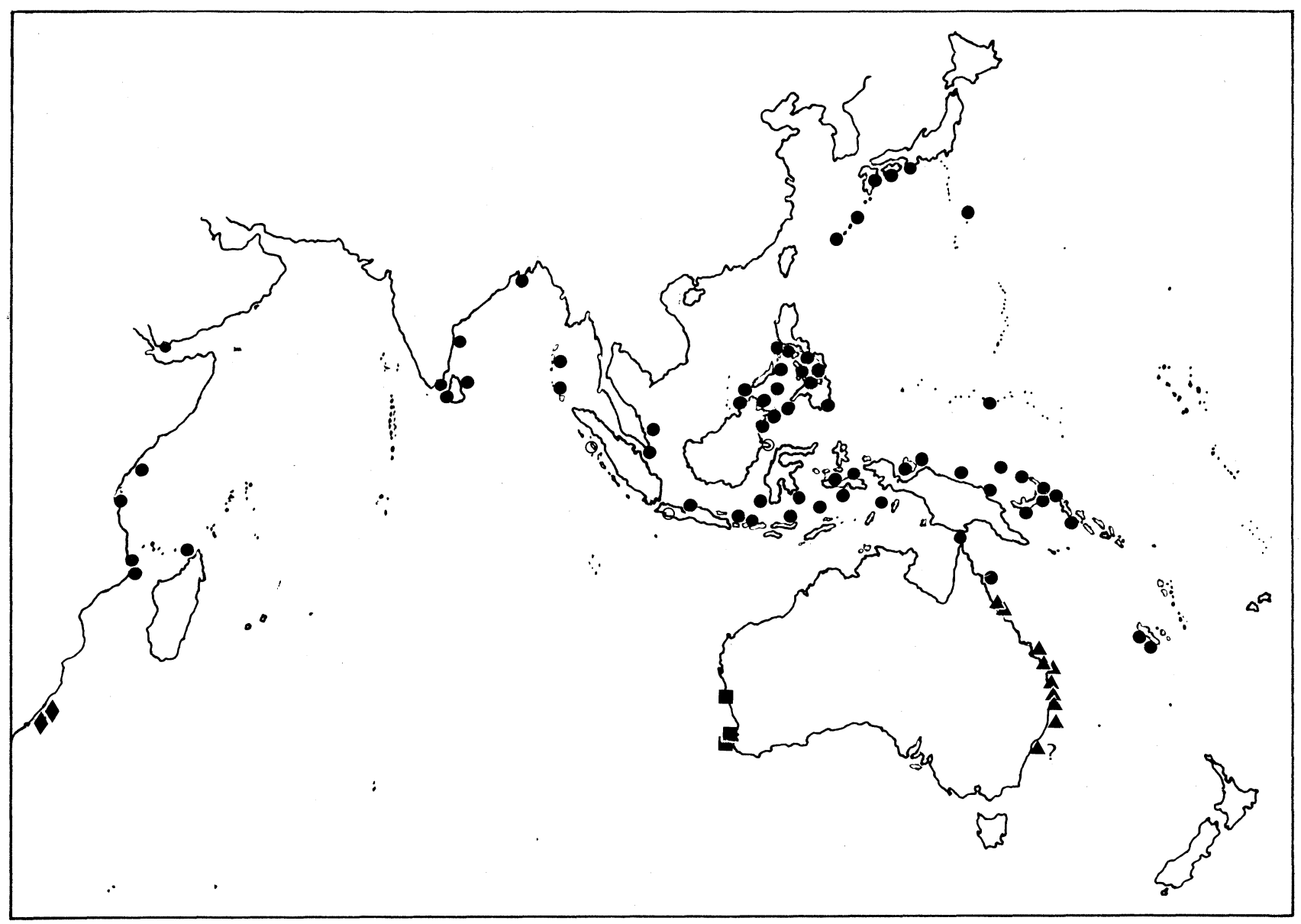

Figure 47. Distribution of Haustellum spp. H. haustellum haustellum (Linné) (circle). H. haustellum fallax (Smith) (diamond); H. wilsoni D. Attilio \& Old (square) H. tweedianus (Macpherson)(triangle) and open symbols = fossil records. 
Aperture obliquely ovate; surrounded by raised, trumpet-like peristome formed by large, weakly crenulate flange. This flange projects, especially its anterior half, in advance of varix. Inner lip extremely projecting, free-standing and flaring; inner and outer lips separated posteriorly by small constricted anal notch and anteriorly by sinuous extension of slit in siphonal canal. Inner side of outer lip with up to 24 lirations, usually paired, each terminating in pointed tooth at forward edge of margin. Inner side of inner lip frequently covered with small lirae on posterior half; outer side of inner lip noticeably wrinkled.

Siphonal canal long (very long in form longicaudus); terminations of previous canals fused into straight tube, open by narrow slit; non-spinose except for possible single spine (per varix) near base of body whorl.

Colour creamy white, but in typical form each spiral cord topped with reddish brown, overall colour appearing darker; some examples (forms kurodai and vicdani) lack darker spirals, and overall colour appears lighter. Brown blotches in advance of varices and on adapertural side of each nodule of intervarical ridges; varices with three colour bands, one each at shoulder, periphery, and base of whorl, but portion of varix on subsutural ramp always cream coloured, so when viewed from posterior, varices appear much lighter in colour than remainder of shell. Inner margins of apertural lips vary from apricot to white; interior of shell white; siphonal canal light brown with spiral cords slightly darker.

DimENSIONS. See Table 33.

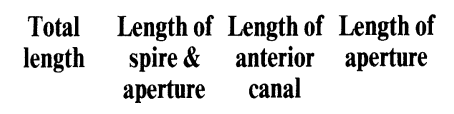

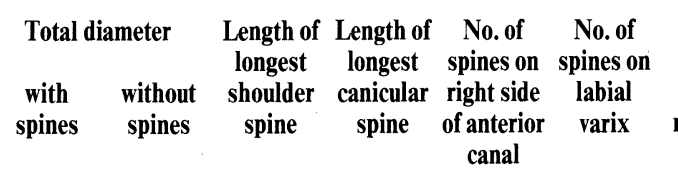

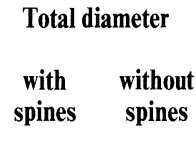

Syntype

Syntype

Holotype of Murex

haustellum

longicaudus Baker

Holotype of

Haustellum v

Sulu Seas, S.
Philippines; AMS,

C.71875 (Fig. 87A)

Bulan, S. Luzon Id,

Philippines; AMS,

C.94514 (Fig. 87B)

New Caledonia;

AMS, C. 106402

(Fig. 87C)

New Caledonia;

AMS, C. 106402

(Fig. 87C)

108.8

43.

102.3

42.6

114.5

44

88.

41.

49.1

21.1

No
spine

38.7

Nos

Nos
spines

38.9

No

34.5

Zamboanga,

Mindana. Id,

Philippines;

ANSP, 223721

AMS, C.36394

$\begin{array}{lll}142.1 & 50.0 & 94 . \\ 117.8 & 55.0 & 64.8 \\ & & \end{array}$

Solomon Ids;

AMS, C.36394
$114.8 \quad 60$

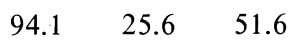

64.8

27.0

No
spines

50.9

$6.27 .9^{*}$

52.2

0

2.8

1

$0: 3: 1$

52.0

0

$2.5^{*}$

spines

\begin{tabular}{|c|c|}
\hline $\begin{array}{c}\text { No. of } \\
\text { inter- } \\
\text { varical } \\
\text { nodes on } \\
\text { body } \\
\text { whorl }\end{array}$ & $\begin{array}{c}\text { No. of } \\
\text { primary } \\
\text { spiral } \\
\text { threads on } \\
\text { penul- } \\
\text { timate }\end{array}$ \\
\hline
\end{tabular}

whorl

horl 洒 
OperCUlum. Dark brown; central nucleus, surrounded by about eight raised concentric lamellae.

RADULA. See Fig. 68D.

PENIS. Tapers to blunt distal end. Penial duct closed but line of fusion visible. Pallial vas deferens open (Fig. 72I).

Habitat. Low tidal sand flats (Vokes, 1978) on sandy substrates in the sublittoral and on the continental shelf.

Remarks. This is the largest and most distinctive of all the species of Haustellum and is a well-known and common species. Kosuge (1980: 58) has discussed and illustrated the various forms of $H$. haustellum. Although he and some others consider these as distinct species, because of the presence of intermediates between the forms, and because we have no evidence that they have different protoconchs (the number of specimens we have seen with intact protoconchs is very small), we tentatively suggest that only one taxon can be recognised amongst the tropical Indo-Pacific populations. We admit the possibility, however, that with the availability of additional data, more than one species may prove to be recognisable*. The South African form can be shown to be distinct and is treated as a geographic subspecies below.

\section{Haustellum haustellum fallax (Smith, 1901)}

Figs 46E,F; 47; Table 34

Murex fallax Smith, 1901: 113, pl. 1, fig. 9(10 miles [16 km] off Durban, South Africa, in fish caught in 40 fathoms [73 m]; holotype, BMNH, 1902.5.18.9); Sowerby, 1903: 227; Smith, 1903: 375; Barnard, 1959: 193, fig. 41b (protoconch).

Haustellum fallax.-Fair, 1976: 42, fig. 24; Kaicher, 1980: fig. 2538.

Murex (Haustellum) fallax.-Vokes, 1978: 381, pl. 1, fig. 9 (protoconch).

Additional records. SOUTH AFrICA: off Umtwalumi River, Natal, 25 fathoms (46 m) (Barnard, 1959); off Port Shepstone, 36 fathoms (66 m) (Sowerby, 1903); off Durban (Vokes, 1978).

Description. SHELL. Medium-sized (about 80 $\mathrm{mm}$ in length), teleoconch with six inflated whorls.

Protoconch very large (over $2 \mathrm{~mm}$ in diameter), of about one and one-half bulbous volutions, ending at heavy, straight varix (figured by Barnard, 1959: fig. $41 \mathrm{~b}$ and Vokes, 1978: pl. 1, fig. 9).

Spiral ornamentation on first teleoconch whorl of about four strong primary cords and alternating weaker secondary cords; secondary cords gradually increase in strength until by third or fourth whorl little difference noticeable between two orders of magnitude. Spiral ornamentation evanescent, visible

\footnotetext{
*Since the manuscript was completed, Mr R. Houart (pers. comm.) has pointed out that he has a specimen of $H$. longicaudus from the Red Sea with an intact paucispiral protoconch. It therefore appears that the Red Sea populations of $H$. haustellum may be subspecifically separable (as $H$. haustellum longicaudus).
}

on body whorl only at crossings of axial ornamentation as nodules on varices and axial ridges; interspaces almost smooth.

Axial ornamentation totally lacking on first teleoconch whorl; on second whorl, three low, rounded varices only. By third whorl, three indistinct axial ridges added between each pair of varices, this number diminishing to two on body whorl. Varices and intervarical ridges nodulose as noted above. Three swollen varices per whorl, slightly angulate at shoulder and base of body whorl, spines only on siphonal canal; here one or two small short spines immediately adjacent to body whorl.

Suture deeply impressed.

Aperture obliquely ovate, almost circular; surrounded by raised peristome formed by small, crenulated flange in advance of terminal varix and an extremely projecting, free-standing and flaring inner lip. Inner and outer lips separated by narrow anal notch and sinuous extension of slit in siphonal canal. Inner lip smooth; outer lip with several small denticles within.

Siphonal canal moderately long; terminations of previous canals fused into tube, open by narrow, sinuated slit; spinose only immediately adjacent to base of body whorl.

Colour creamy white; three indistinct brown bands at shoulder, periphery and base of body whorl visible primarily on tops of varices and axial ridges; siphonal canal also tinted brown; aperture white.

DimENSIONS. See Table 34.

OPERCULUM. Unknown, assumed to be like that of $M$. haustellum haustellum.

Remarks. The shell of the South African form of $H$. haustellum differs from the typical subspecies in having a larger protoconch (missing in the holotype) and in having a white aperture, as well as in minor sculptural details. It presumably has direct development, whereas the typical subspecies has planktotrophic development.

\section{Haustellum wilsoni D'Attilio \& Old, 1971 Figs 47; 78C; 87E; Table 35}

Haustellum wilsoni D'Attilio \& Old, 1971: 316, figs 1, 2 (off Jurien Bay, Western Australia; holotype, WAM, N/3981); Kaicher, 1974: fig. 509; Coleman, 1975: 215, fig. 600; Fair, 1976: 86, pl. 4, fig. 51; Radwin \& D’Attilio, 1976: 50, pl. 23, fig. 15 .

Murex (Haustellum) wilsoni.-Vokes, 1974: 13, figs 1a-c.

Records. WESTERN AUSTRALIA: $16.5 \mathrm{~m}$, off Dunsborough (WAM); $12 \mathrm{~m}$, Bunbury (AMS); $22 \mathrm{~m}$, off Bunbury (WAM).

Additional records. $27-37 \mathrm{~m}$, Beagle Id; $9 \mathrm{~m}$, Hall's Bank, Fremantle; Leighton Beach, Perth (D'Attilio \& Old, 1971).

Description. SHELl. Low-spired, of medium size (about $75 \mathrm{~mm}$ in length), with five inflated teleoconch whorls. 

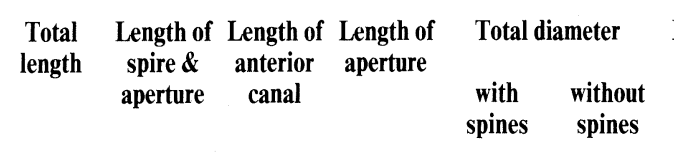

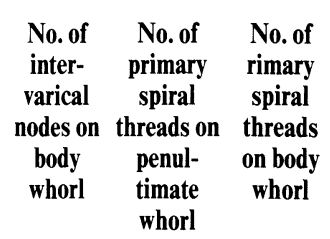

Holotype
78.
$40.3 \quad 38.6$
19.5

Length of $\mathrm{L}$
longest
shoulder
spine

\begin{tabular}{|c|c|c|}
\hline $\begin{array}{l}\text { Length of } \\
\text { longest } \\
\text { canicular } \\
\text { spine }\end{array}$ & $\begin{array}{l}\text { No. of } \\
\text { spines on } \\
\text { right side } \\
\text { of anterior } \\
\text { canal }\end{array}$ & $\begin{array}{l}\text { No. of } \\
\text { spines on } \\
\text { labial } \\
\text { varix }\end{array}$ \\
\hline
\end{tabular}

40.4
No
spines

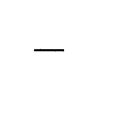

8.7

\section{(1)}

$4 ?$
(Spiral -
orna-
ment,
very
weak)

Table 34. Shell measurement and count data for Haustellum haustellum fallax (Smith).

Protoconch of about one and one-half very large (over $2 \mathrm{~mm}$ in diameter), bulbous volutions; faint keel adjacent to suture on anterior-most half whorl, ending at small, sharp varix.

Spiral ornamentation on early teleoconch whorls of several weak cords, three a little more pronounced; becoming broad, flattened bands on subsequent whorls; indistinct on body whorl, visible only where crossing axial ridges.

Axial ornamentation on first teleoconch whorl of about nine indistinct swollen ribs; on second and third whorls about 12 rounded ribs; every fourth becoming enlarged, forming varix, others persisting as intervarical ridges. Two to four weak axial ridges between each pair of varices, best seen where crossed by spiral cords, giving rise to flattened nodules. Intersection of very faint axial growth lines and equally faint spiral grooves give malleated surface. Varical formation somewhat irregular, usually three per whorl, one or more often greatly reduced; almost absent on later whorls. When distinct, varices rounded, excavated behind, completely lacking spines.

Suture deeply channelled, smooth, but crossed by varices. Aperture obliquely ovate; surrounded by low peristome. Outer lip with weakly crenulate margin; about 12 lirations within. Inner lip freestanding, smooth.

Siphonal canal moderately long; terminations of previous canals fused into tube, open by narrow slit; not spinose but nodulose at crossings of major spiral cords.

Colour creamy white to light brown or pink, with three very faint, brown spiral bands at shoulder, periphery and base of body whorl. Bands best seen as darker blotches adaperturally from varices. Adapertural edges of varices with series of brown spots marking terminations of major spiral cords, most noticeable at darker bands. Apertural lips white, brown within; siphonal canal often darker than body whorl.

Dimensions. See Table 35.

OPERCUluM. Not known.

Remarks. This rare, south Western Australian species is not closely allied to any living species of Haustellum although it may have some affinity with $H$. haustellum. The large, bulbous protoconch suggests few, very yolky eggs and direct development,

\begin{tabular}{|c|c|c|c|c|c|c|c|c|c|c|c|c|}
\hline $\begin{array}{l}\text { Total } \\
\text { length }\end{array}$ & $\begin{array}{c}\text { Length of } \\
\text { spire \& } \\
\text { aperture }\end{array}$ & $\begin{array}{c}\text { Length of } \\
\text { anterior } \\
\text { canal }\end{array}$ & $\begin{array}{l}\text { Length of } \\
\text { aperture }\end{array}$ & $\begin{array}{l}\text { Total } \\
\text { with } \\
\text { spines }\end{array}$ & $\begin{array}{c}\text { without } \\
\text { spines }\end{array}$ & $\begin{array}{c}\text { Length of } \\
\text { longest } \\
\text { shoulder } \\
\text { spine }\end{array}$ & $\begin{array}{l}\text { Length of } \\
\text { longest } \\
\text { canicular } \\
\text { spine }\end{array}$ & $\begin{array}{c}\text { No. of } \\
\text { spines on } \\
\text { right side } \\
\text { of anterior } \\
\text { canal }\end{array}$ & $\begin{array}{c}\text { No. of } \\
\text { spines on } \\
\text { labial } \\
\text { varix }\end{array}$ & $\begin{array}{c}\text { No. of } \\
\text { inter- } \\
\text { varical } \\
\text { nodes on } \\
\text { body } \\
\text { whorl }\end{array}$ & $\begin{array}{c}\text { No. of } \\
\text { primary } \\
\text { spiral } \\
\text { threads on } \\
\text { penul- } \\
\text { timate } \\
\text { whorl }\end{array}$ & $\begin{array}{c}\text { No. of } \\
\text { primary } \\
\text { spiral } \\
\text { threads } \\
\text { on body } \\
\text { whorl }\end{array}$ \\
\hline
\end{tabular}

\begin{tabular}{|c|c|c|c|c|c|c|c|c|c|c|c|c|c|}
\hline Holotype & 76.0 & - & - & - & - & - & - & - & - & - & - & - & - \\
\hline Largest Paratype & 73.5 & - & - & - & - & - & - & - & - & - & - & - & - \\
\hline $\begin{array}{l}\text { Bunbury, Western } \\
\text { Australia; AMS, } \\
\text { C. } 106404 \text { (Fig. } \\
87 \mathrm{H} \text { ) }\end{array}$ & 66.5 & 34.4 & 32.8 & 17.4 & $\begin{array}{c}\text { No } \\
\text { spines }\end{array}$ & 33.2 & - & - & 0 & 0 & 0 & 6 & 10 \\
\hline $\begin{array}{l}\text { Off Dunsborough, } \\
\text { Western Australia; } \\
\text { WAM, } 71-72\end{array}$ & 53.0 & 36.0 & $17.7^{*}$ & 17.5 & $\begin{array}{c}\text { No } \\
\text { spines }\end{array}$ & 33.3 & - & - & 0 & 0 & 0 & 6 & 11 \\
\hline
\end{tabular}


a feature typical of many southern Australian species (Wilson, 1985).

Vokes (1974) has shown that this species has a close resemblance to an undescribed species of Haustellum from the Pliocene of Las Calderas, Island of Cubangua, Venezuela. No Recent species of Haustellum have the deeply-channelled suture seen in this species, although a weak sutural channel is present in the hirasei form of $H$. haustellum, and in $H$. kiiensis.

\section{Haustellum tweedianus (Macpherson, 1959)} Figs 47; 78A,B; 87D; Table 36

Murex (Murex) espinosus Macpherson, 1959: 51, fig. 1 (shell), 1a (radula) (Tweed Head, New South Wales, Australia, 30 fathoms [55 m]; holotype, NMV, F17960); (preoccupied by $M$. espinosus Hutton, 1886).

Haustellum espinosus.-Garrard, 1961: 26; Rippingale \& McMichael, 1961: 96, pl. 12, fig. 5.

Murex tweedianus Macpherson, 1962: 176 (new name for $M$. espinosus Macpherson, 1959, not $M$. espinosus Hutton, 1886); Dance, 1974: 122, fig. in text; Radwin \& D'Attilio, 1976: 75, pl. 10, fig. 13; Abbott \& Dance, 1982: 131, fig. in text.

Haustellum tweedianum.-Garrard, 1966: 10; Cernohorsky, 1967b: 118, pl. 25, fig. 146; Wilson \& Gillett, 1971: 84, pl. 55 (part of head-foot of living animal), pl. 57, figs 6, 6a; Hinton, 1972: 34, pl. 17, fig. 11; Kaicher, 1973: fig. 128; Coleman, 1975: 278, fig. 764.

Chicoreomurex (sic) espinosus. - Habe \& Kosuge, 1966: 50, pl. 18, fig. 1 .

Haustellum tweedianus.-Fair, 1976: 84, pl. 4, fig. 46.

Murex tweedianum. - Hinton, 1978: 33, fig. 9.

Records. Australia: Queensland: Bramble Reef, off Ingham; off north Palm Island (both DMNH); Townsville; $28 \mathrm{~m}$ and $30 \mathrm{~m}$, Keppel Bay; Hervey Bay; $46 \mathrm{~m}$, off Burnett Heads, Bundaberg; 64 m, off Wide Bay; 73 m, Fraser Id; 55 $\mathrm{m}$, Tin Can Bay; 46-59 m, south end of Stradbroke Id; $73 \mathrm{~m}$ and $183 \mathrm{~m}$, off Caloundra; $128-183 \mathrm{~m}$, off Cape Moreton; $32 \mathrm{~m}$, off Double Id Point, Mooloolaba; $77 \mathrm{~m}$, off Moreton Bay; Southport. New South Wales: 44 m, 55 m, 63 m, 128$137 \mathrm{~m}, 146 \mathrm{~m}$ and 152-155 m, off Tweed Heads; Brunswick Heads; $128-139 \mathrm{~m}$ and $128-150 \mathrm{~m}$, Cape Byron; 137 m, off Ballina; Black Rocks, Richmond River; $55 \mathrm{~m}$, off Evans Head; $46 \mathrm{~m}$, Wooli; $165 \mathrm{~m}$, NE of Woolgoolga; Coffs Harbour; 143 m, north-east off Solitary Id; $82 \mathrm{~m}$, off Broken Bay (last record requires confirmation) (all AMS).

Description. SHELL. Medium-sized (about $75 \mathrm{~mm}$ in length), with seven inflated to strongly-shouldered teleoconch whorls.

Protoconch of about one and one-half bulbous volutions, varying from 1 to $1.5 \mathrm{~mm}$ in diameter, with a rounded keel near anterior suture and ending at strong varix.

Spiral ornamentation on first teleoconch whorl of four relatively strong rounded cords; by third whorl, alternating minor cords intercalated between each pair of major cords, and weak tertiary threads added. Spiral ornamentation gradually weakening until body whorl and canal covered with only major cords separated by very faint secondary threads.

Axial ornamentation on first three teleoconch whorls of 12 to 18 rounded ribs which, together with spiral cords, give cancellate appearance to spire. On fourth or fifth whorl, every third or fourth rib strengthened to form small varix, remaining ribs persisting as rounded intervarical ridges. On subsequent whorls, one to three intervarical ridges present, nodulose at crossing of spiral cords. Adapertural ridge in each intervarical set sometimes evanesces, leaving body whorl with two intervarical ridges, sometimes weak third. Myriad fine axial growth lamellae give shagreened appearance to entire shell surface. Three rounded varices per whorl, strongly nodose where crossed by major spiral cords, with small, open spinelets on apertural face of each varix corresponding to major spiral cords. Spinelets longer and coalescing into flange on anterior third of varix; flange terminates sharply at juncture of siphonal canal. Three or four (per varix) short spines develop on siphonal canal at crossing of major spiral cords, decreasing in length away from base of body whorl.

Suture simple, sinuated by axial ridges of previous whorl.

Aperture obliquely-ovate; margin of outer lip with 11 or 12 tooth-like projections corresponding to terminations of tertiary spirals (i.e., between the primary and secondary spiral cords); frequently an excavated gutter inside terminal varix with 11 or 12 lirations behind it marking continuation of tooth-like projections. Inner lip appressed posteriorly, freestanding anteriorly; smooth.

Siphonal canal short; previous canals fused, except at recurved distal ends, where they form tube-like structure, open by narrow slit; spinose only adjacent to base of body whorl.

Colour pinkish brown, with remnants of three, faint brown bands most visible adjacent to varices; spiral cords topped by golden yellow threads. Siphonal canal usually slightly darker than rest of teleoconch; apex purplish in colour; apertural lips white, lavender within.

DimENSIONS. See Table 36.

OPERCULUM. Reddish brown; subterminal nucleus, surrounded by about eight heavy concentric ridges.

Remarks. This distinctive eastern Australian species does not appear to have any close relationship with any other known species and may have been independently derived from Siratus. It has two forms; one an inflated form with 2 to 3 weak intervarical ridges and the other a more elongate, strongly shouldered form with two strong intervarical ridges on the body whorl. In other characters, these forms appear to be very similar. They may be ecomorphs but, unfortunately, most of the material has been obtained from fishing trawlers, and the depth and other data is not reliable. Some such samples contain both forms but these may not have actually been 


\begin{tabular}{|c|c|c|c|c|c|c|c|c|c|c|c|c|}
\hline \multirow{2}{*}{$\begin{array}{l}\text { Total } \\
\text { length }\end{array}$} & \multirow{2}{*}{$\begin{array}{l}\text { Length of } \\
\text { spire \& } \\
\text { aperture }\end{array}$} & \multirow{2}{*}{$\begin{array}{l}\text { Length of } \\
\text { anterior } \\
\text { canal }\end{array}$} & \multirow{2}{*}{$\begin{array}{l}\text { Length of } \\
\text { aperture }\end{array}$} & \multicolumn{2}{|c|}{ Total diameter } & \multirow{2}{*}{$\begin{array}{l}\text { Length of } \\
\text { longest } \\
\text { shoulder } \\
\text { spine }\end{array}$} & \multirow{2}{*}{$\begin{array}{l}\text { Length of } \\
\text { longest } \\
\text { canicular } \\
\text { spine }\end{array}$} & \multirow{2}{*}{$\begin{array}{l}\text { No. of } \\
\text { spines on } \\
\text { right side } \\
\text { of anterior } \\
\text { canal }\end{array}$} & \multirow{2}{*}{$\begin{array}{c}\text { No. of } \\
\text { spines on } \\
\text { labial } \\
\text { varix }\end{array}$} & \multirow{2}{*}{$\begin{array}{c}\text { No. of } \\
\text { inter- } \\
\text { varical } \\
\text { nodes on } \\
\text { body } \\
\text { whorl }\end{array}$} & \multirow{2}{*}{$\begin{array}{l}\text { No. of } \\
\text { primary } \\
\text { spiral } \\
\text { threads on } \\
\text { penul- } \\
\text { timate } \\
\text { whorl }\end{array}$} & \multirow{2}{*}{$\begin{array}{c}\text { No. of } \\
\text { primary } \\
\text { spiral } \\
\text { threads } \\
\text { on body } \\
\text { whorl }\end{array}$} \\
\hline & & & & $\begin{array}{c}\text { with } \\
\text { spines }\end{array}$ & $\begin{array}{l}\text { without } \\
\text { spines }\end{array}$ & & & & & & & \\
\hline
\end{tabular}

\begin{tabular}{|c|c|c|c|c|c|c|c|c|c|c|c|c|c|}
\hline $\begin{array}{l}\text { Paratype; AMS, } \\
\text { C. } 72216\end{array}$ & 72.5 & 44.4 & 28.4 & 21.9 & 36.7 & 35.6 & - & 5.4 & 2 & 0 & 3 & 4 & 7 \\
\hline $\begin{array}{l}\text { Paratype; AMS, } \\
\text { C. } 72216\end{array}$ & 66.4 & 37.1 & 30.9 & 19.7 & 34.8 & 33.9 & - & 6.7 & 3 & 0 & 2 & 4 & 7 \\
\hline $\begin{array}{l}\text { Off Wide Bay, } \\
\text { Queensland; AMS, } \\
\text { C. } 66961\end{array}$ & 76.7 & 45.1 & 33.5 & 22.2 & 40.2 & 38.9 & - & 5.8 & 3 & 0 & 2 & 4 & 8 \\
\hline $\begin{array}{l}\text { Off Wide Bay, } \\
\text { Queensland; AMS, } \\
\text { C.66961 }\end{array}$ & 75.1 & 44.6 & 31.1 & 23.4 & 39.0 & 37.2 & - & 6.4 & 2 & 0 & 3 & 5 & 8 \\
\hline $\begin{array}{l}\text { Coffs Harbour, } \\
\text { New South Wales, } \\
\text { Australia; AMS, } \\
\text { C. } 106480\end{array}$ & 68.2 & 38.6 & 28.4 & 18.8 & 33.8 & 31.7 & - & - & 0 & 0 & 3 & 3 & 7 \\
\hline $\begin{array}{l}\text { Off Tweed Heads, } \\
\text { New South Wales; } \\
\text { AMS, C. } 67011\end{array}$ & 63.9 & 34.0 & 30.9 & 17.7 & 32.0 & 31.0 & - & 5.3 & 0 & 0 & 2 & 4 & 7 \\
\hline
\end{tabular}

Table 36. Shell measurement and count data for Haustellum tweedianus (Macpherson).

living together. This species appears to be confined to eastern Queensland and northern New South Wales, living on the Continental Shelf.

Haustellum rectirostris (Sowerby, 1841)

Figs 48; 52; 72G; 79D; 88D; 89F; Table 37

Murex rectirostris Sowerby, $1841 \mathrm{a}:$ pl. 197, fig. 111 (as rectirostrum) (Hong Kong, ex Cuming; 3 syntypes, BMNH, 19716); Sowerby, 1841b: 138; Reeve, 1845: pl. 22, fig. 91; Küster \& Kobelt, 1869: 61, pl. 23, fig. 5; Sowerby, 1879: 4, pl. 2 (of Murex), fig. 15; Baker, 1897: 378 (in part); Habe, 1961: 49, pl. 25, fig. 3; Habe, 1964: 78, pl. 25, fig. 3; Kaicher, 1973: fig. 104; Fair, 1976: 71, pl. 2, fig. 17; Radwin \& D'Attilio, 1976: 70 (in part), pl. 11, fig. 3; Abbott \& Dance, 1982: 130, fig. in text.

Murex recurvirostris form rectirostris.-Tryon, 1880: 81, pl. 12, fig. 126.

Murex (Tribulus) rectirostris.-Poirier, 1883: 37.

Murex (Murex) rectirostris.-Lindner, 1977: 176, pl. 27, fig. 6 .

Records. HONG KONG: (AMS; BMNH; IRSB; USNM); 116-128 m, south-east of Hong Kong, (AMS). JAPAN: Nogita, Fukuoka Pref. (AMS). TAIWAN: (AMNH); trawled (AMS; AMNH). CHINA SEA: (AMS); $161 \mathrm{~m}$ off Tung-sha Tao (USNM).

Description. SHELL. High-spired, of medium size (up to $80 \mathrm{~mm}$ in length), with seven teleoconch whorls.

Protoconch of about one and one-half bulbous volutions, having rounded keel on anterior half and ending in large, straight varix.

Spiral ornamentation on first two teleoconch whorls of three rounded cords; fourth, anteriorly situated, developing by third whorl. Weak minor spiral cords appearing by fifth whorl; body whorl and siphonal canal covered with alternating major and minor cords.

Axial ornamentation much stronger than spiral, especially on early whorls, nine to 12 swollen ribs on first three teleoconch whorls; ribs more strongly developed in specimens with few ribs. On third or fourth whorl, every third rib strengthened into varix; intervening two ribs persisting as intervarical ridges. On fourth or fifth whorl, third ridge added on adapertural side of intervarical area, by fifth whorl fourth often appearing. Body whorl usually with three or four intervarical ridges with swollen nodes where crossed by spiral cords. Three rounded varices per whorl, deeply excavated behind, each with short, closed spine at shoulder; smaller open spinelets sometimes on adapertural face of varix, especially on anterior portion. Siphonal canal with one or two small spines near base of body whorl.

Suture simple, strongly sinuated on earlier whorls, becoming canaliculate on later whorls.

Aperture circular; surrounded by raised peristome formed by crenulate margin of outer lip and freestanding inner lip; outer lip lirate within; inner lip occasionally with about five very faint rugae anteriorly.

Siphonal canal very long, straight; terminations of previous canals fused into tube, open by narrow slit; spinose only immediately adjacent to base of body whorl.

Colour creamy white to tan, with faint brown bands at shoulder and base of body whorl; aperture white; spirals not coloured.

Dimensions. See Table 37. 


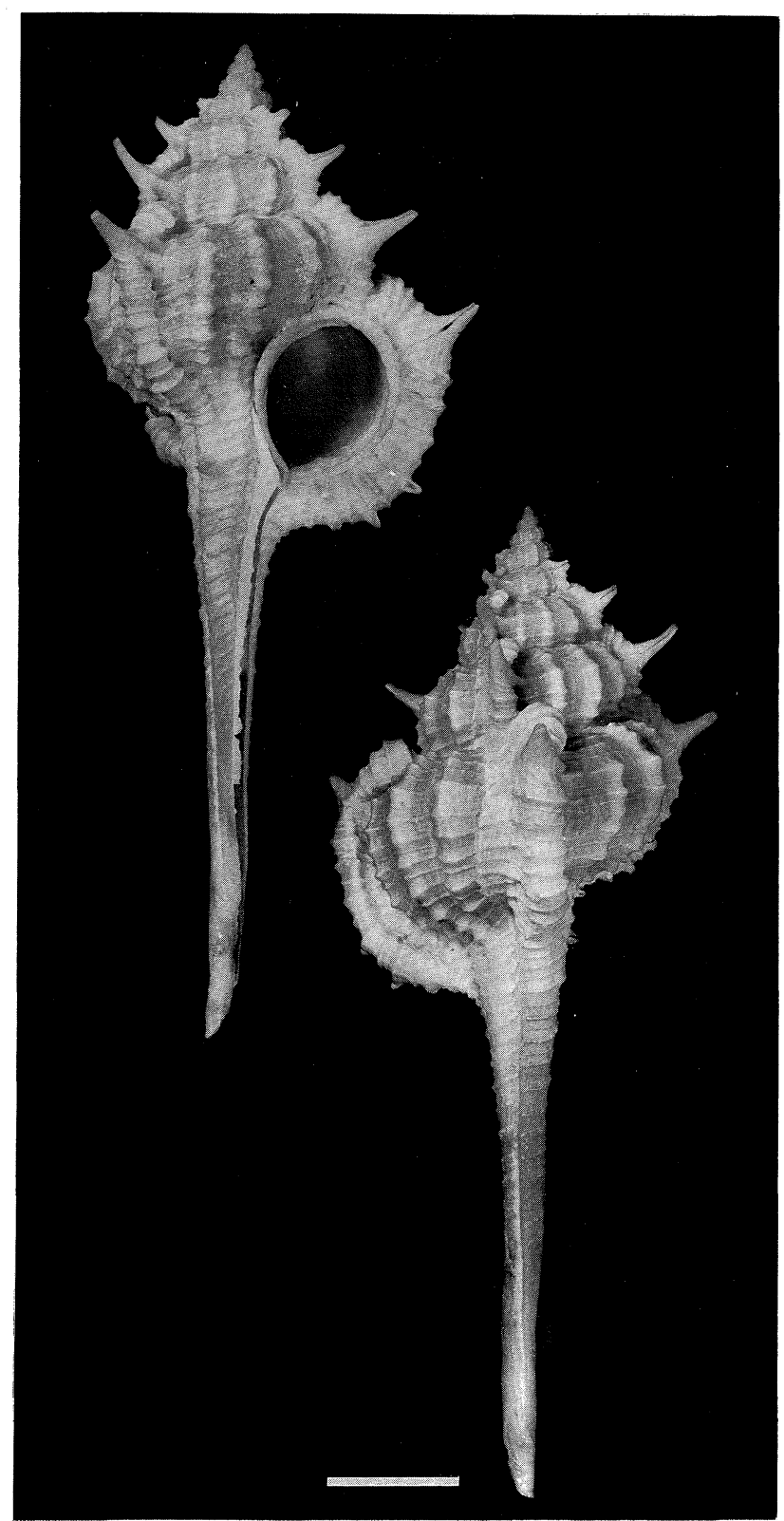

Figure 48. Haustellum rectirostris (Sowerby). Syntype; Hong Kong (BMNH; 1971006). Scale $1 \mathrm{~cm}$.

OPERCULUM. Reddish brown; subterminal nucleus, surrounded by about ten heavy concentric ridges.

PENIS. Short, U-shaped when at rest, with short filament (Fig. 72G). Pallial vas deferens broad beneath middle part of penis, narrow, and possibly with open slit, near base of penis.

Remarks. This species differs from other similar species of Haustellum in its larger, heavier shell, two to three very strong intervarical ribs, heavy, rounded varices and short spines. The most similar species, $H$. sobrinus, was regarded as a variant of $H$. rectirostris by Radwin \& D'Attilio (1976) but is smaller, lighter in build, has relatively weaker intervarical axial ribs and has a longer shoulder spine (often about twice the length of the spine in $H$. rectirostris of similar size) and short spines on the varices on the body whorl anterior to the shoulder spine. These spines are usually lacking in $H$. rectirostris. In addition, the suture is more distinctly channelled in H. sobrinus. Both species have a similar protoconch but we have not seen any material that suggests that they intergrade in teleoconch characters.

Shuto (1969: 104, pl. 8, figs 4, 15, 16) records Murex sp. cf. rectirostris aduncospinosus from the Dingle Formation, Panay Id, Philippines (Miocene). This record appears to be based on a taxon similar to $H$. rectirostris but differs in its strongly denticulate inner lip. It could represent an ancestral form of several species similar to $H$. rectirostris but we have not seen the specimens on which the record is based. Another specimen of this taxon appears to be that figured by Shuto (1969: pl. 7, figs 14, 15) as Murex (Haustellum) bonneti.

Haustellum rectirostris appears to be confined to the South China Sea and is rather common on the Continental Shelf in that area.

\section{Haustellum multiplicatus multiplicatus}

(Sowerby, 1895)

Figs 49; 52; 72H; 79E; 89E; Table 38

Murex eximius Brazier, 1877: 170 (Darnley Id, Torres Strait, 30 fathoms [ $55 \mathrm{~m}$ ], sand bottom; holotype, AMS, A.124); Tryon, 1880: 80; Brazier, 1893: 50; Smith, 1953: 2 (not Murex eximius Bellardi, 1873).

Murex multiplicatus Sowerby, 1895: 216, pl. 13, fig. 5 ("West Australia"; holotype, NMW, 1955.158.13); Smith, 1953: 3; Radwin \& D'Attilio, 1976: 68, pl. 11, fig. 16, text fig. 37 (protoconch); Abbott \& Dance, 1982: 129 , fig. in text.

Murex aduncospinosus.-Hedley, 1901: 123 (not of Sowerby).

Murex (s.str.) embryoliratus.-Fischer, 1927: 78, figs $50 \mathrm{a}, \mathrm{b}, 51$ (Timor, Pliocene; location of type not known).

Haustellum multiplicatus.-Cotton, 1956: unpaginated.

Haustellum multiplicatum.-Habe \& Kosuge, 1966: 51, pl. 18, fig. 8, Wilson \& Gillett, 1971: 84, pl. 57, figs 7, 7a; Kaicher, 1973: fig. 125; Coleman, 1975: 211, pl. 593; Fair, 1976: 60, pl. 4, fig. 48.

Murex multiplicatum.-Hinton, 1978: 33, fig. 7.

Records. Australia: Western Australia: 126-135 m, west-south-west of Cape Vlaming, Rottnest Id; $146 \mathrm{~m}$, north-west of Rottnest Id, 135-140 m, west of Rottnest Id; 128-131 m, south-west of Dongara; $128 \mathrm{~m}$, north-west of Bluff Point; $131 \mathrm{~m}$ west of Bluff Pt; between Shark Bay \& Onslow; $60 \mathrm{~m}$, south-west of Point Cloates; east side of South Pasco Id, Barrow Id; $12 \mathrm{~m}$, east end of Mary Ann Passage, offOnslow; 119 m, 36 km north-west of Anchor Id, Onslow (all WAM); Onslow area (AMS; WAM); Nickol Bay (AMS; BMNH); 3 m, Rosemary Id, Dampier; 110 m, 128 km north-north-west of Dampier (both AMS); Port Hedland (AMS; WAM); Roebuck Bay; Cape Jaubert, south of Broome; King Sound, Derby (all AMS); sandflats, Broome (ANSP; AMS; WAM); Point Samson (AMNH); 82 and $91 \mathrm{~m}$, approx. $150 \mathrm{~m}$ east-north-east Troughton Id, 


\begin{tabular}{|c|c|c|c|c|c|c|c|c|c|c|c|c|c|}
\hline . & $\begin{array}{l}\text { Total } \\
\text { length }\end{array}$ & $\begin{array}{l}\text { Length of } \\
\text { spire \& } \\
\text { aperture }\end{array}$ & $\begin{array}{l}\text { Length of } \\
\text { anterior } \\
\text { canal }\end{array}$ & $\begin{array}{l}\text { Length of } \\
\text { aperture }\end{array}$ & $\begin{array}{c}\text { Total } \\
\text { with } \\
\text { spines }\end{array}$ & $\begin{array}{l}\text { ameter } \\
\text { without } \\
\text { spines }\end{array}$ & $\begin{array}{c}\text { Length of } \\
\text { longest } \\
\text { shoulder } \\
\text { spine }\end{array}$ & $\begin{array}{l}\text { Length of } \\
\text { longest } \\
\text { canicular } \\
\text { spine }\end{array}$ & $\begin{array}{l}\text { No. of } \\
\text { spines on } \\
\text { right side } \\
\text { of anterior } \\
\text { canal }\end{array}$ & $\begin{array}{c}\text { No. of } \\
\text { spines on } \\
\text { labial } \\
\text { varix }\end{array}$ & $\begin{array}{c}\text { No. of } \\
\text { inter- } \\
\text { varical } \\
\text { nodes on } \\
\text { body } \\
\text { whorl }\end{array}$ & $\begin{array}{l}\text { No. of } \\
\text { primary } \\
\text { spiral } \\
\text { threads on } \\
\text { penul- } \\
\text { timate } \\
\text { whorl }\end{array}$ & $\begin{array}{r}\text { No. of } \\
\text { primary } \\
\text { spiral } \\
\text { threads } \\
\text { on body } \\
\text { whorl }\end{array}$ \\
\hline Syntype & 76.0 & 34.4 & 42.2 & 13.0 & 30.0 & 28.5 & 6.2 & $\begin{array}{c}3.6^{*}(3 \mathrm{rd} \\
\text { last } \\
\text { varix })\end{array}$ & 0 & $1: 2: 0$ & 3 & 6 & 9 \\
\hline Syntype & 71.1 & 31.7 & 40.4 & 13.7 & 30.0 & 27.3 & 6.4 & $\begin{array}{c}1.9^{*}(3 \mathrm{rd} \\
\text { last } \\
\text { varix })\end{array}$ & 0 & 1:0:0 & 3 & 7 & 9 \\
\hline Syntype & 71.8 & 36.1 & 35.4 & 12.8 & 28.3 & 26.7 & $\begin{array}{c}5.0^{*} \\
\text { penulti- } \\
\text { mate } \\
\text { varix) }\end{array}$ & $\begin{array}{c}2.0^{*}(3 \mathrm{rd} \\
\text { last } \\
\text { varix })\end{array}$ & 0 & $1: 3: 0$ & 3 & 6 & 8 \\
\hline $\begin{array}{l}\text { Off Taiwan; } \\
\text { AMNH, 164923 } \\
\text { (Fig. 88D) }\end{array}$ & 79.9 & 35.6 & 44.7 & 13.9 & 32.3 & 28.5 & 5.5 & $\begin{array}{c}2.1^{*} \\
\text { (penulti- } \\
\text { mate } \\
\text { varix) }\end{array}$ & $\begin{array}{c}0(2 \\
\text { spines } \\
\text { on } \\
\text { penulti- } \\
\text { mate } \\
\text { varix })\end{array}$ & $1: 3: 1$ & 3 & 6 & 9 \\
\hline $\begin{array}{l}\text { SE of Hong Kong; } \\
\text { AMS, C.142910 } \\
\text { (Fig. 89F) }\end{array}$ & 47.8 & 23.5 & 24.9 & 8.8 & 24.8 & 19.7 & 6.7 & $\begin{array}{c}2.3^{*} \\
\text { (penulti- } \\
\text { mate } \\
\text { varix) }\end{array}$ & $\begin{array}{c}0(3 \\
\text { spines } \\
\text { on } \\
\text { penulti- } \\
\text { mate } \\
\text { varix })\end{array}$ & $1: 1: 0$ & 3 & 5 & 9 \\
\hline $\begin{array}{l}\text { SE of Hong Kong; } \\
\text { AMS, C.142910 } \\
\text { (Fig. 89F) }\end{array}$ & 40.6 & 22.7 & 17.9 & 8.1 & 24.4 & 17.0 & 7.5 & 2.7 & 1 & $1: 1: 2$ & 3 & 6 & 9 \\
\hline $\begin{array}{l}\text { Hong Kong; AMS, } \\
\text { C. } 79641\end{array}$ & 62.3 & 30.7 & 32.0 & 11.9 & 31.5 & 24.8 & 7.8 & - & 0 & $1: 3: 2$ & 3 & 6 & 8 \\
\hline $\begin{array}{l}\text { Hong Kong; AMS, } \\
\text { C.79641 }\end{array}$ & 62.0 & 29.9 & 31.4 & 11.7 & 30.2 & 25.0 & 6.1 & $\begin{array}{l}4.0^{*}(3 \mathrm{rd} \\
\text { last } \\
\text { varix })\end{array}$ & 1 & $1: 1^{*}: 2$ & 3 & 6 & 9 \\
\hline
\end{tabular}

Table 37. Shell measurement and count data for Haustellum rectirostris (Sowerby). * = damaged.

(WAM); $64 \mathrm{~m}, 240-340 \mathrm{~km}$ east-north-east of Troughton Id (WAM; AMNH); 73-166 m, off Adele Id(WAM); 69-93 $\mathrm{m}$, north-west of Holothuria Bank (BMNH). Northern Territory: Arafura Sea, near Darwin (ANSP); $400 \mathrm{~km}$ north-east of Croker Id, Arafura Sea; Melville Id; Port Keats (all AMS); 48-57 m, Clarence Straits, south of Bathurst Id (WAM); Tree Point, Darwin (AMS) Jones Shoal, Port Essington (MNT). Queensland: Trawled, south Sweers Id, Gulf of Carpentaria; off Karumba; $18 \mathrm{~m}$, Mapoon, Gulf of Carpentaria; Thursday Id; 17-22 m, Albany Pass, Cape York Peninsula (all AMS). INDONESIA: off Cape Sele, west Irian Barat (AMS); Kepulauan Aru: 46-64 m, south-west of Tg Ratoe, Maikoor (WAM); 11-15 m, west of Tg Lelar, Trangan (WAM); 49-59 m, west of Wasir Id, west Wokam, (WAM).

Fossil record. Pliocene: Timor (Fischer, 1927, as $M$. embryoliratus).

Description. SHELl. Medium-sized (up to 60 $\mathrm{mm}$ in length), with six inflated teleoconch whorls.

Protoconch of about one and one-half bulbous volutions, varying in size from 1 to $1.5 \mathrm{~mm}$ in diameter; a strong keel near anterior edge of last whorl; ending in strong varix.

Spiral ornamentation on early teleoconch whorls of four rounded cords, that between shoulder and suture slightly weaker, these persisting to body whorl; only faint intercalary minor threads present. Body whorl and canal covered with flattened cords, separated by barely visible secondary threads.

Axial ornamentation on first three teleoconch whorls of about 14 axial ribs; on fourth whorl every fourth rib strengthened into varix, intervening three ribs persisting as rounded intervarical ridges. On fifth whorl, an additional axial ridge added to adapertural portion of intervarical area and on sixth another; body whorl with four to six intervarical ridges. Where 
intervarical ridges crossed by spiral cords, swollen nodes produced. Three rounded varices per whorl, slightly to deeply excavated behind, with single short, sharp spine at shoulder of each in typical form but often completely lacking; no other spines on varix or siphonal canal.

Suture deeply impressed, almost channelled.

Aperture circular; surrounded by raised peristome formed by crenulated margin of outer lip and freestanding inner lip; outer lip bearing ten to 12 lirations within; inner lip smooth or rarely, minutely wrinkled.

Colour creamy white with three interrupted brown bands, wide one at shoulder and narrower one at periphery and base of body whorl; nodules on intervarical ridges white, even in banded areas; aperture white; spirals not coloured.

DiMENSIONS. See Table 38.
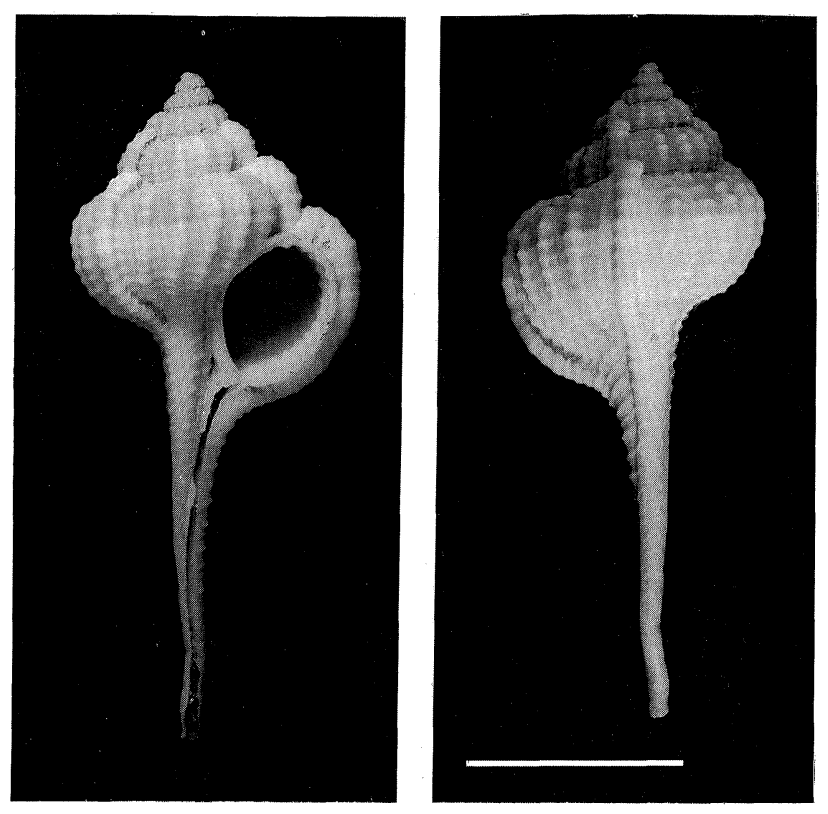

Figure 49. Haustellum multiplicatus multiplicatus (Sowerby). Holotype; Western Australia (NMW, 1955.158.13). Scale $2 \mathrm{~cm}$.

OPERCULUM. Reddish brown, subterminal nucleus, surrounded by about eight strong concentric ridges.

PENIS. Short, coiled when at rest, with pointed distal end. Pallial vas deferens with distinct line of fusion (Fig. 72H).

Remarks. There is a complete gradation between the shell of the spined form, like the type specimen of $M$. eximius, and the broader, smooth-shouldered typical form, although the smooth shells are certainly characteristic of most shallow-water Western Australian populations.

Hedley (1901) stated that there were "two individuals" in the type series of $M$. eximius, although Brazier (1877) did not indicate how many specimens he had. There is only one specimen in the type series now and that is regarded here as the holotype.

The inclusion of M. embryoliratus in the synonymy of $H$. multiplicatus multiplicatus needs to be confirmed by the examination of the type material but Fischer's (1927) detailed description and figures make us rather confident of this decision.

The fossil taxon Murex bantamensis Martin, 1895, is closely related to $M$. multiplicatus. It differs in having fewer axial ribs between the varices (usually four) and a smaller, non-keeled protoconch. Some Recent specimens also have these features and both these and the fossils are treated here as a subspecies. Sowerby's name was introduced in March, 1895, but the month of publication of Martin's M. bantamensis is not known. It is here taken to be later than March. Another fossil taxon, Murex darraghi Ludbrook, is retained as a chronosubspecies below.

Haustellum multiplicatus bantamensis (Martin, 1895) Figs 50A-J; 52; 79C,I; 89C; Table 39

Murex (s.str.) bantamensis Martin, 1895: 126, pl. 19, figs 288-290; (Kampong Tjikeusik, Tjibaliung, Java, Pliocene; holotype, GML, 9656); ? Wanner \& Hahn, 1935: 253.

Murex (Haustellum) bantamensis oostinghi Wissema, 1947: 172, pl. 6, fig. 148; (loc. 39, village of Awaaj, Sowu Id, Nias Id, Indonesia, Plio-Pleistocene; holotype, GML and many paratypes).

Murex bantamensis Cox, 1948: 43, pl. 4, figs 4a, b, c. Murex(Brontes) bantamensis.-Dey, 1961: 78.

Records. INDONESIA: 'Keledjitan', Batam, Java (USNM); 27 m, Java Sea (ZMC). SABAH: Marudu Bay, 33 m (ANSP); $46 \mathrm{~m}$, Banggi Channel, off Balembangan Id (WAM); $71 \mathrm{~m}$, off Sandakan Lgt (USNM); $5 \mathrm{mls}$ west of Agal Bay, north-west Sabah (WAM); 106 m, off 'Manlagule Id', north Balabac Strait, $84 \mathrm{~m}$, off Observatory Park, north-west Palawan (both USNM). PHILIPPINES: 36-49 m, $13 \mathrm{~km}$ north of Cape Melville Ligt, Balabac Id (WAM). NEW GUINEA: off 'Durangit', Hansa Bay, north-west of Madang (R. Houart colln; AMS).

Fossil records. ?Pleistocene: Vigo Formation, Bondoc Peninsula, Luzon, Philippines (Popenoe \& Kleinpell, 1978); Plio-Pleistocene: Nias Id, Malay Archipelago (type of $M$. bantamensis oostinghi); Dent Peninsula, east Sabah (NHMB; recorded by Cox, 1948). Pliocene?: Papua New Guinea: Upper Wanimo Series, $0.5 \mathrm{~km}$ below Selep Village, Tambau River, Sepik District (BMR); Finsch Coast Series, Piye Creek, Aitape area (BMR); Yowai Creek, Maimai Dome, Aitape area (BMR); Marakabi River, ca. $1.6 \mathrm{~km}$ downstream from Yekieli Creek, south-south-west of Karaiti Village, south-west of Aitape, west Sepik District (NMV). Pliocene: west Java (type).

Description. SHELL. Medium-sized (up to 80 $\mathrm{mm}$ in length), with up to seven and one-half teleoconch whorls. 


\section{Total Length of Length of Length of length spire \& anterior aperture aperture canal}

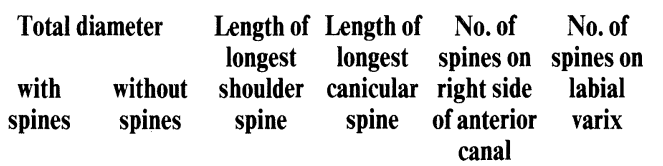

$\begin{array}{ccc}\begin{array}{c}\text { No. of } \\ \text { inter- }\end{array} & \begin{array}{c}\text { No. of } \\ \text { primary }\end{array} & \begin{array}{c}\text { No. of } \\ \text { primary }\end{array} \\ \text { varical } & \text { spiral } & \text { spiral } \\ \text { nodes on } & \text { threads on } & \text { threads } \\ \text { body } & \text { penul- } & \text { on body } \\ \text { whorl } & \begin{array}{c}\text { timate } \\ \text { whorl }\end{array} & \text { whorl } \\ & \end{array}$

Holotype

Holotype of $M$. eximius

King Sound,

Western Australia;

AMS, C. 106365

(Fig. 89E)

NW Anchor Id, Onslow, Western

Australia; WAM, 72-72(1)

Broome, NW

Australia; WAM,

91-72

$50 \mathrm{ml} \mathrm{N}$ of $\mathrm{E}$.

Adelie Id, N.

Western Australia;

WAM, 99-72(1)

\begin{abstract}
57.8
\end{abstract}
46.6

20.6

53.8

24.8

28.5

11.6

No
spines

20.9

No
spines

24.7

18.4

16.9

3.2

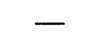

0

1

4

6

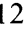

$\begin{array}{rrrrc}42.1 & 20.9 & 21.4 & 8.6 & 18.8 \\ 54.1 & 28.9 & 25.4 & 13.8 & \begin{array}{c}\text { No } \\ \text { spines }\end{array}\end{array}$

\author{
17.3 \\ 25.4
}

4.1

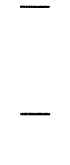

0

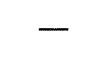

0

0

4

6

12

32.9

19.1

1.9

8.2

16.6

15.3

2.8

-

0

1

5

6

11
Protoconch of about one and one-half bulbous volutions, ending at small crescentic varix.

Spiral ornamentation on first two teleoconch whorls of three rounded cords, on third whorl two additional smaller cords, one on either side of suture. Secondary threads intercalated on subsequent whorls; tertiary threads appear as late as body whorl in some specimens, on earlier whorls in others; body whorl and posterior half of siphonal canal covered with alternating major and minor cords.

Axial ornamentation on first three teleoconch whorls of about ten high, rounded ribs; on fourth whorl, varical formation initiated on irregular basis, with from every second to every fourth rib being strengthened into small varix; other axial ridges remain as intervarical ridges. By fifth whorl, number stabilized to three, with three to five axial ridges between each pair of varices; number gradually increasing in larger forms until as many as seven between each pair on body whorl. Three rounded varices per whorl, each with single, short, sharp, spine at shoulder, otherwise non-spinose except for some examples having small spine on posterior end of siphonal canal. A few small prickles sometimes appear on adapertural face of varices where major spiral cords cross.

Suture impressed, sinuated by axial ridges of previous whorl. Aperture obliquely ovate; surrounded by raised peristome formed by free- standing inner lip and crenulated margin of outer lip. Small anal notch often present. Outer lip with series of denticulations along outer edge, lirate within. Inner lip with elongate, irregular rugae more or less well developed in anterior half or, in some specimens, extending over most of inner lip. Siphonal canal very long; previous canals fused into long, straight tube, open by narrow slit; non-spinose except for, on some examples, single small spine on each varix immediately adjacent to base of body whorl.

Colour light tan, with three slightly darker brown spiral bands at shoulder, periphery and base of body whorl. Major spiral cords topped with reddish brown lines in specimens from Papua New Guinea, these darker in banded areas; cords in most other material white; apertural lips white, brown dots at terminations of brown spiral cords, light tan within (description based on Recent specimens).

DimENSIONS. See Table 39.

OPERCULUM. Reddish brown; subterminal nucleus surrounded by numerous faint concentric ridges. One large Papua New Guinea specimen with subcentral nucleus (probably freak specimen).

Remarks. The shell of this taxon closely resembles $H$. multiplicatus multiplicatus but the two subspecies have different protoconchs, that of the typical subspecies having a keel, whereas $H$. multiplicatus bantamensis has a simple protoconch. 


\begin{tabular}{|c|c|c|c|c|c|c|c|c|c|c|c|c|c|}
\hline & Total & Length of & Length of & Length of & Total di & ameter & Length of & Length of & No. of & No. of & No. of & & No. of \\
\hline & gen & $\begin{array}{l}\text { Spire d } \\
\text { aperture }\end{array}$ & $\begin{array}{l}\text { anterior } \\
\text { canal }\end{array}$ & e & $\begin{array}{l}\text { with } \\
\text { spines }\end{array}$ & $\begin{array}{c}\text { without } \\
\text { spines }\end{array}$ & $\begin{array}{l}\text { longest } \\
\text { shoulder } \\
\text { spine }\end{array}$ & $\begin{array}{l}\text { longest } \\
\text { canicular } \\
\text { spine }\end{array}$ & $\begin{array}{l}\text { Spines on } \\
\text { right side } \\
\text { of anterior } \\
\text { canal }\end{array}$ & $\begin{array}{l}\text { spines on } \\
\text { labial } \\
\text { varix }\end{array}$ & $\begin{array}{l}\text { inter- } \\
\text { varical } \\
\text { nodes on } \\
\text { body } \\
\text { whorl }\end{array}$ & $\begin{array}{l}\text { primary } \\
\text { spiral } \\
\text { threads on } \\
\text { penul- } \\
\text { timate } \\
\text { whorl }\end{array}$ & $\begin{array}{c}\text { primary } \\
\text { spiral } \\
\text { threads } \\
\text { on body } \\
\text { whorl }\end{array}$ \\
\hline Lectotype & 36.2 & 22.3 & 14.1 & 8.9 & $\begin{array}{l}\text { No } \\
\text { spines }\end{array}$ & 16.8 & - & - & 0 & 0 & $\begin{array}{l}\text { ? (Inter- } \\
\text { varical } \\
\text { part of } \\
\text { body } \\
\text { whorl } \\
\text { missing) }\end{array}$ & 4 & 7 \\
\hline Paralectotype & $\begin{array}{c}\overline{-} \\
\text { (broken } \\
\text { canal) }\end{array}$ & 20.3 & - & 7.9 & $\begin{array}{l}\text { No } \\
\text { spines }\end{array}$ & 17.0 & - & $?$ & $?$ & 0 & 3 & 4 & 8 \\
\hline $\begin{array}{l}\text { Kampong } \\
\text { Bodjong, } \\
\text { Koempai, W. Java, } \\
\text { Pliocene; PCB, } \\
\text { A5393 (Fig. 50I) }\end{array}$ & 29.9 & 18.4 & 11.7 & 7.1 & 16.0 & 14.3 & 1.7 & - & 0 & $1: 0: 0$ & 4 & 5 & 8 \\
\hline $\begin{array}{l}\text { Kampong } \\
\text { Bodjong, } \\
\text { Koempai, W. Java, } \\
\text { Pliocene; PCB, }\end{array}$ & & & & & & & & & & & & & \\
\hline A5393 (Fig. 50J) & $\begin{array}{c}24.1^{*} \\
\text { (broken } \\
\text { canal) }\end{array}$ & 17.9 & $6.2^{*}$ & 6.7 & 15.3 & 14.0 & 2.5 & 1.0 & $1: 0: 0^{*}$ & $1: 2: 0$ & 4 & 5 & 8 \\
\hline $\begin{array}{l}27 \text { m, Java Sea; } \\
\text { ZMC (Fig. 50F) }\end{array}$ & 40.8 & 19.3 & 21.9 & 7.1 & 18.4 & 14.0 & 4.5 & - & 0 & $1: 2: 0$ & 4 & 5 & 8 \\
\hline $\begin{array}{l}27 \text { m, Java Sea; } \\
\text { ZMC (Fig. 50F) }\end{array}$ & 37.5 & 17.7 & 19.8 & 6.3 & 17.1 & 12.4 & 4.5 & 1.4 & 0 & $1: 3: 0$ & 4 & 4 & 8 \\
\hline $\begin{array}{l}\text { Maruda Bay, } \\
\text { Sabah; } \\
\text { ANSP, 255561 } \\
\text { (Fig. 50D) }\end{array}$ & 40.7 & 21.3 & 18.4 & 8.6 & 17.8 & 17.2 & 2.3 & - & 0 & $1: 0: 0$ & 4 & 5 & 8 \\
\hline $\begin{array}{l}\text { Marakabi R, W. } \\
\text { Sepik District, } \\
\text { Papua New } \\
\text { Guinea, ? Pliocene; } \\
\text { NMV, p.111587 } \\
\text { (Fig. 50G) }\end{array}$ & $\begin{array}{l}\text { (broken } \\
\text { canal) }\end{array}$ & 28.9 & - & 12.1 & $\begin{array}{l}\text { No } \\
\text { spines }\end{array}$ & 21.8 & (broken) & - & 0 & $1 *: 0: 0$ & 4 & 6 & 10 \\
\hline $\begin{array}{l}\text { Nias, Malay Arch., } \\
\text { Plio-Pleistocene; } \\
\text { GML (Fig. 50A) }\end{array}$ & 50.3 & 25.8 & 25.0 & 9.2 & 19.2 & 17.1 & 2.5 & - & 0 & $1: 1: 0$ & 4 & 5 & 8 \\
\hline $\begin{array}{l}\text { Nias, Malay Arch., } \\
\text { Plio-Pleistocene; } \\
\text { GML (Fig. 50A) }\end{array}$ & 47.3 & 23.7 & 23.9 & 9.4 & 18.1 & 16.7 & 2.2 & 1.0 & 1 & 1:0:0 & 4 & 5 & 9 \\
\hline $\begin{array}{l}\text { Dent Pen., Sabah, } \\
\text { Pliocene; NHMB, } \\
\text { H } 14431\end{array}$ & 32.4 & 22.5 & 9.7 & 8.5 & 16.2 & 15.7 & 3.5 & 1.3 & $\begin{array}{l}0^{*} \text { (One } \\
\text { on } \\
\text { previous } \\
\text { varix) }\end{array}$ & $1: 0: 0$ & 4 & 5 & 8 \\
\hline $\begin{array}{l}\text { Hansa Bay, Papua } \\
\text { New Guinea; (R. } \\
\text { Houart colln) }\end{array}$ & 57.1 & 21.4 & 35.9 & 9.5 & 18.7 & 15.8 & 3.7 & 1.7 & 1 & $1: 0: 0$ & 6 & 6 & 11 \\
\hline $\begin{array}{l}\text { Hansa Bay, Papua } \\
\text { New Guinea; (R. } \\
\text { Houart colln) }\end{array}$ & 72.3 & 30.2 & 42.4 & 13.0 & 24.9 & 23.3 & 3.3 & - & 0 & $1: 0: 0$ & 6 & 7 & 12 \\
\hline
\end{tabular}


Tambau R., Sepik Dist., Papua New Guinea, ? Pliocene; BMR, F9655 1043-1045

Piye Ck, Aitape Area, Papua New Guinea,? Pliocene; BMR, F6035 26.

N. of Cape

Melville Lgt,

Balabac Id,

Palawan; WAM, 103-72(3)

$\begin{array}{llll}34.4 & 28.4 & 6.8^{*} & 11.2\end{array}$

20.7

spines
$1.7^{*}$

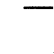

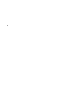

Table 39. Shell measurement and count data for Haustellum muliplicatus bantamensis (Martin). ${ }^{*}=$ damaged.

The teleoconch has a few coloured spiral lines, and the oval aperture in most specimens has marked rugae on the inner lip in contrast to the smooth inner lip of $H$. multiplicatus multiplicatus. A smooth inner lip is also seen in some other species of similar size, $H$. sobrinus and $H$. rectirostris.

Shells of fossil and Recent specimens of this species are variable but are similar in most important shell characters, including the protoconch. This species appears to have much the same distribution in the Pliocene and Pleistocene as at present, judging from the available fossil material.

The fossil syntypes are two worn, damaged specimens with very worn early whorls and with the fine surface detail lost. They appear to have possessed short spines on the adult whorls and have three to four intervarical axials. The holotype is unusual in that the terminal varix is an additional one, being formed only slightly in advance of the preceding varix. Hence the unusual positioning of the varices in the figure of this specimen.

According to Martin (1895) the protoconch of $H$. multiplicatus bantamensis consists of two smooth whorls but we have not seen this material, unless it is based on the specimen he figured as a variety (Martin's fig. 290; our Fig. 50K). This Miocene specimen has a broken protoconch, which appears to be the base of a smooth, conical protoconch of the planktotrophic type. In teleoconch characters it is very similar indeed to the Pliocene syntypes. The lirae on the inner lip in this specimen are very poorly developed. It may represent an ancestral form of $H$. dolichourus n. sp., which may have given rise to $H$. multiplicatus. A specimen recorded by Wanner \& Hann (1935: 253) from the Miocene of Rembang, Java, has not been figured, or examined by us. A single specimen (Fig. 63C, D) from the Miocene of Fiji has a similar teleoconch to $H$. multiplicatus but lacks a protoconch and, consequently, we do not asign it to a species. Shuto (1969: 101, pl. 8, figs 8, 13, 14) described and illustrated a Miocene taxon, as $H$. bonneti, similar to $H$. multiplicatus bantamensis but which lacks any trace of shoulder spines. Another specimen he figured (pl. 7, figs 14,15) as this taxon appears to be conspecific with a taxon related to $H$. rectirostris, which Shuto records as Murex sp. cf. $M$. rectirostris aduncospinosus.

The question as to whether the Pliocene type material is consubspecific with Recent shells will have to await more detailed discussion once better preserved topotypic material has been examined.

The known Recent material has been collected from a small area in the southern end of Sumatra and the western end of Java, the area around Northern Borneo and Palawan, and one sample from the north coast of Papua New Guinea. The material from the last two localities is more similar to the type of the species than that from western Java - southern Sumatra. The single fossil from Borneo and the fossil material from Papua New Guinea closely resemble the specimens still living in those areas. Some additional Pliocene material from Java also closely resembles the Recent specimens from that area. It is thus possible that at least subspeciation has occurred but, given the small number of specimens available, and the variation seen in the Borneo-Palawan samples, we prefer to adopt a conservative classification.

Nomura (1935: 107) has recorded (and figured) specimens as Murex rarispina from the Pliocene of Taiwan resembling $H$. multiplicatus bantamensis and he also admits this similarity. The figured specimen has a shoulder spine on the varices of the last three whorls and about five intervarical axial ribs. We have not seen this material but consider that it may be ancestral to $H$. sobrinus.

Haustellum nasongoensis, from the Miocene of Fiji, appears to be similar to $H$. multiplicatus bantamensis. As best can be ascertained from the incomplete holotype (Fig. 64), the only material available of $H$. nasongoensis, $H$. multiplicatus bantamensis differs from $H$. nasongoensis in size, being smaller, and in having small spines invariably developed at the shoulder, whereas $H$. nasongoensis 

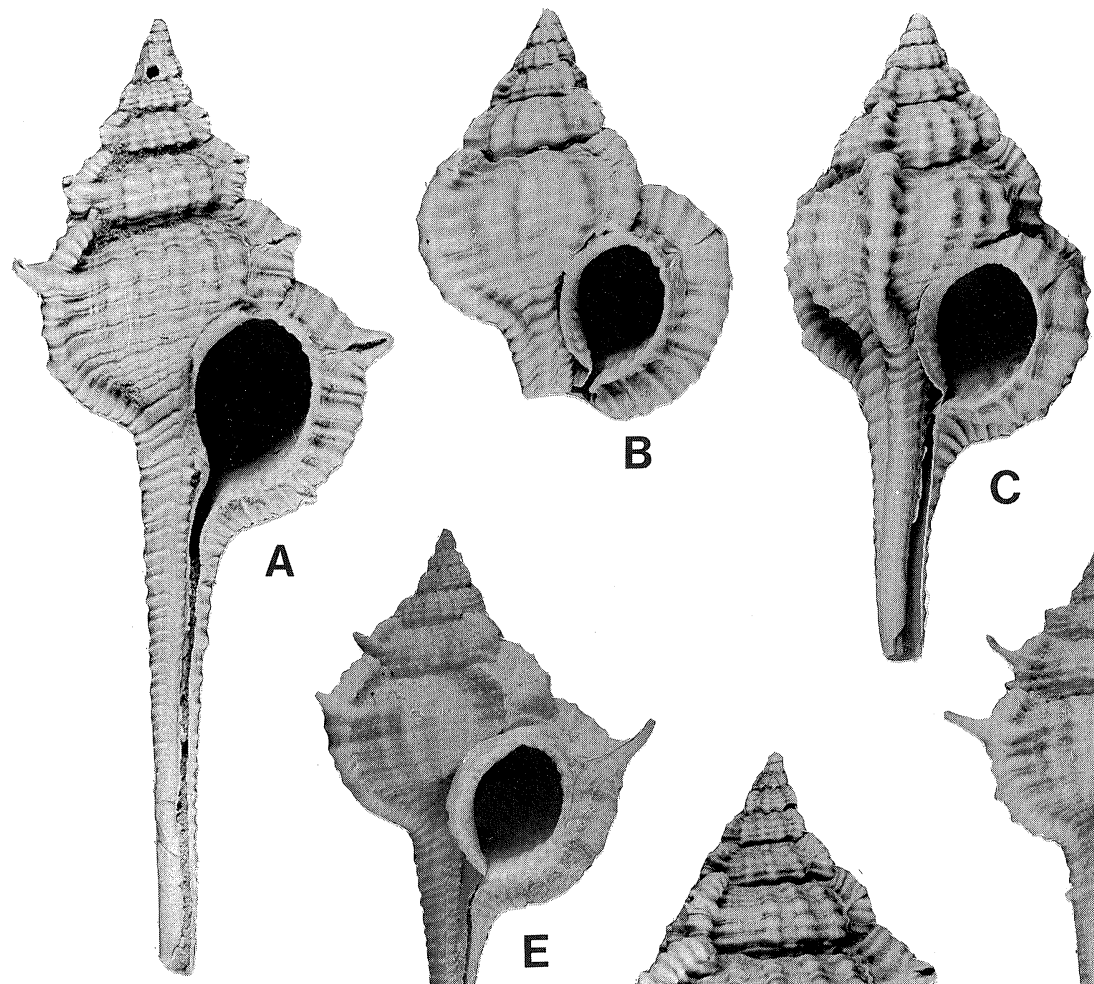

B
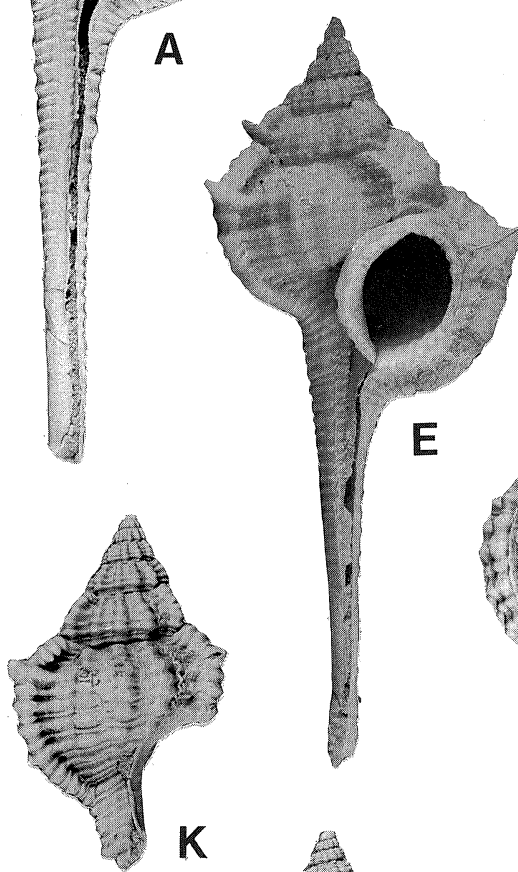

K
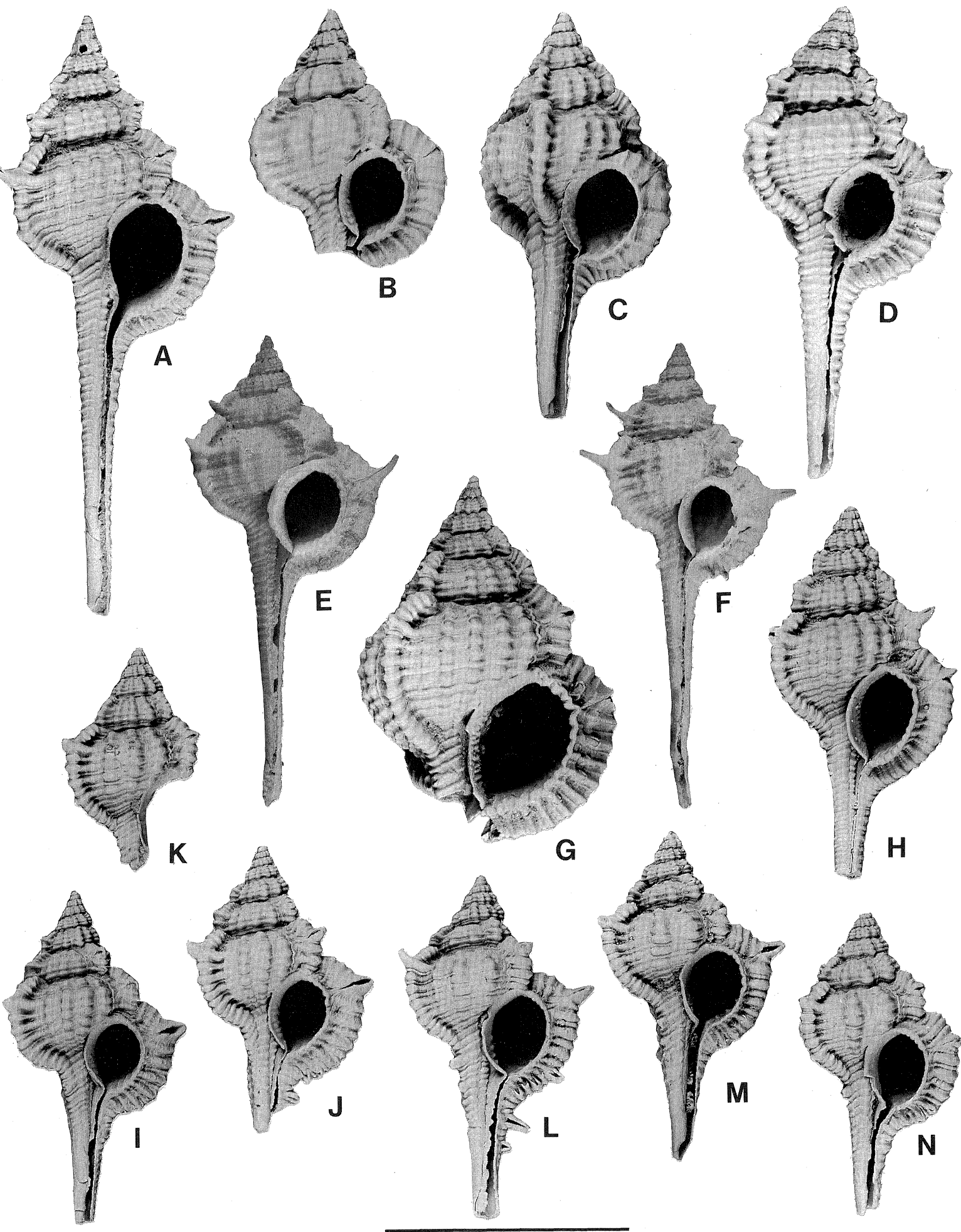

C
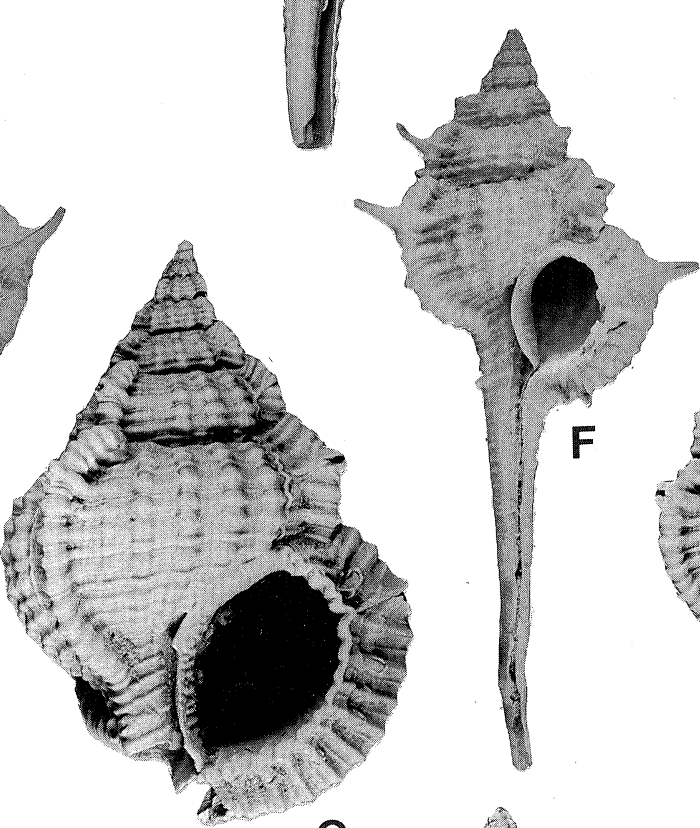

F

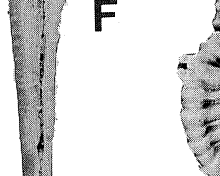

Figure 50. A-J: Haustellum multiplicatus bantamensis (Martin). A: loc. 39, Kamp Awaaj, Nias, Malay Archipelago, PlioPleistocene (GML). B,C: paralectotype (B) and lectotype (C); Tjikeusik, Java, Pliocene (GML, 9656). D: Marudu Bay, Sabah, 33 m (ANSP, 255561). E: west of Cape Melville Light, Balabuc Id, Palawan, Philippine Ids, 37-49 m (WAM, 103-72). F: Java Sea, 27 m (ZMC). G: Marakabi River, West Sepik District, Papua New Guinea, ?Pliocene (NMV, 111587). H: Dent Peninsula, Sabah, Pliocene (NHMB, H14437). I,J: Kampong Bodjong, Koempai, Java, Upper Pliocene (PCB, A5393). K: Haustellum aff. dolichourus n. sp.; Selatjan, Preanger, Java, Upper Miocene (GML, 9657). L-N: Haustellum dolichourus n. sp.; Kampong Bodjong, Koempai, Java, Upper Pliocene (PCB, A5393). Scale $2 \mathrm{~cm}$. 
has no evidence of any spines even on the earliest whorls present. It may well be that the PlioceneRecent and Miocene forms are no more than stratigraphic subspecies, but without any idea of the nature of the early whorls of $H$. nasongoensis, the two will be kept separate at this time.

\section{Haustellum sobrinus (A. Adams, 1863)}

Figs 51; 52; 79B; 89D; Table 40

Murex sobrinus A. Adams, 1863: 370 (Satanomosaki, 55 fathoms [100 m]; Gotto, 48 fathoms [ $88 \mathrm{~m}$ ]; Kuro-Sima, 29 fathoms [53 m]; all Japan; types not located in BMNH); Smith, 1879: 199, pl. 20, fig. 30; Tryon, 1880: 79, suppl. pl. 70, fig. 536; Hirase, 1934: 77, pl. 108, fig. 3; Smith, 1953: 2, pl. 6, fig. 6; Kira, 1955: 47, pl. 23, fig. 13; Oyama \& Takemura, 1957: pl. 2, fig. 3; Oyama \& Takemura, 1958: pl. 4, fig. 7; Kira, 1959: 58, pl. 23, fig. 12; Kira, 1962: 63, pl. 24, fig. 12; Kaicher, 1973: fig. 103; Fair, 1976: 77, pl. 1, fig. 6.

Murexcoronatus. - Sowerby, 1879: 3, pl. 21 (of Murex), fig. 199 (not of A. Adams, 1863).

Murex (Tribulus) sobrinus.-Poirier, 1883: 36.

Murex rectirostris. - Radwin \& D'Attilio, 1976: 70 (in part), pl. 13, fig. 2 (not of Sowerby).

Records. KOREA STRAIT: 93 m (BMNH). JAPAN: 97129 m, Sea of Japan (USNM); Kyoto Pref. (AMS); Fukura, Iyo, Shikoku (ANSP); $91 \mathrm{~m}$, Tosa Bay, Shikoku (AMS); 128 m, Tosa Bay, Shikoku (AMNH; ANSP; FMNH); 98 m, W of Gotō Rettō (BMNH); Seto Naikai (USNM); Nagasaki (USNM); Sagami Bay, Honshu (BPBM; ANSP); $22 \mathrm{~m}$, 'Hiuga', east coast, central Honshu (ANSP); Tanabe, Honshu (BPBM; IRSB; USNM); Kii Peninsula, Honshu (NMW; USNM; ANSP; AMS; RSM).

Description. SHELL. High-spired, small (up to $50 \mathrm{~mm}$ in length), with seven teleoconch whorls. Protoconch of about one and one-half bulbous
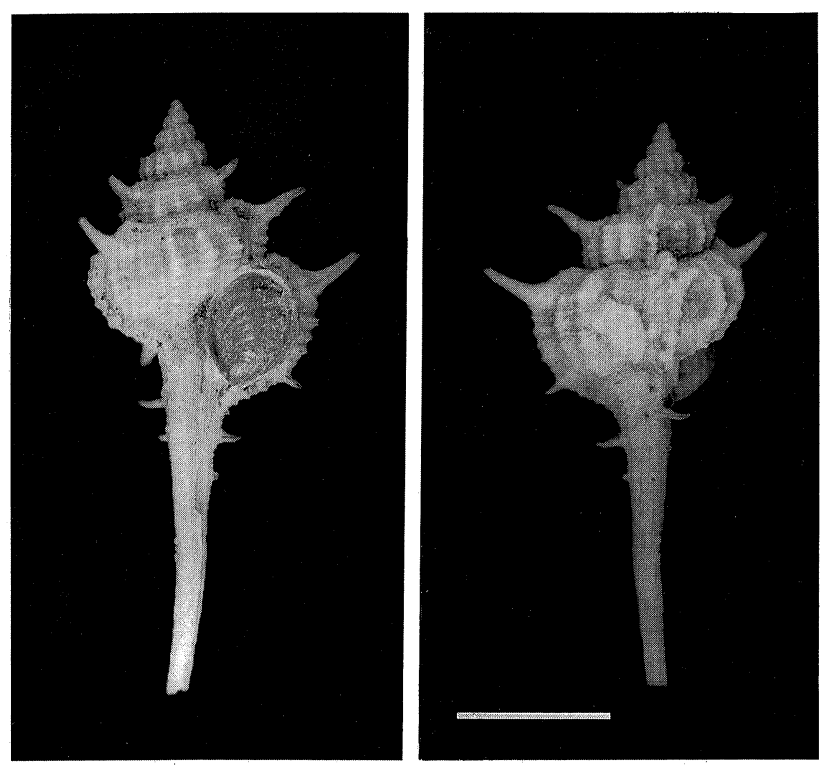

Figure 51. Haustellum sobrinus (Adams). Specimen figured by Sowerby (1879, pl. 21, fig. 199, as “M. coronatus") (BMNH). Scale $1 \mathrm{~cm}$. volutions, having rounded keel on anterior half and terminating in sharp, straight varix.

Spiral ornamentation on first teleoconch whorl of three rounded cords; fourth slightly smaller cord adjacent to suture. On third whorl, minor spiral cords added between shoulder and suture; total of four or five primary spiral cords on body whorl. Secondary and tertiary threads added between initial primary cords until body whorl and siphonal canal covered with cords of three orders of magnitude. Whorls become increasingly shouldered by an angulation at cord on shoulder; subsutural ramp becoming almost at right angles to axis of shell.

Axial ornamentation on first two teleoconch whorls of about 12 weak, flattened ribs; on third whorl, every fourth rib strengthened into varix, leaving three weak intervarical ridges between each pair of varices on all subsequent whorls. Adapertural intervarical axial rib evanescing in some individuals. Three rounded varices per whorl, each with relatively long, closed spines at shoulder and base of body whorl; a few secondary open spinelets at other major spinal cords and even at some secondary cords. Number of secondary spinelets variable, some examples with none, others with spination pattern (anteriorly from suture) of tertiary, secondary, tertiary, primary (shoulder), tertiary, secondary, tertiary, primary (base), tertiary, tertiary, tertiary. An additional three or four small spines on siphonal canal.

Suture simple, sinuated by axial ridges of preceding whorl. Aperture circular, surrounded by raised peristome formed by slightly crenulate margin of outer lip and free-standing inner lip; inner side of both lips smooth.

Siphonal canal long; terminations of previous canals fused into tube, open by narrow slit; spinose only adjacent to base of body whorl.

Colour creamy white to tan, with two indistinct brown bands, one at shoulder, one at base of body whorl; spiral cords not coloured; aperture white.

\section{DiMENSIONS. See Table 40.}

OPERCULUM. Reddish brown; subterminal nucleus, surrounded by about seven heavy concentric ridges.

Remarks. This species is smaller and lighter in build than $H$. rectirostris, although it is generally similar in most other features. It does, however, differ also in having longer shoulder spines and relatively narrower varices.

Nomoura (1935: 159, pl. 8, fig. 7) figured a specimen, similar to $H$. sobrinus, as $M$. rarispina, from the Pliocene of Taiwan. It differs from $H$. sobrinus in possessing five intervarical ribs instead of three on the body whorl. This fossil Taiwanese form may represent an ancestral form of $H$. sobrinus, but we have not seen this material. 
Total Length of Length of Length of length spire \& anterior aperture aperture canal

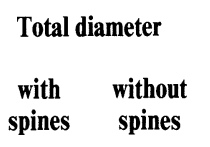

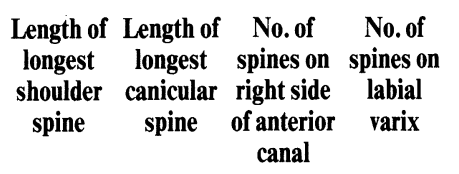

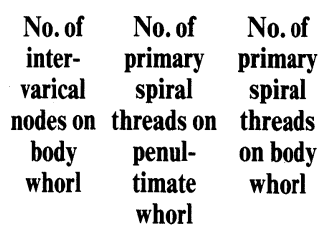

Kyoto, Japan;

AMS, C.72210

(Fig. 89D)

47.3

23.4

24.3

9.2

23.9

$17.6 \quad 7.5$

1.1

2

$1: 3$

3

6

9

Kyoto, Japan;

AMS, C.72210

$\begin{array}{llll}43.0 & 20.8 & 22.5 & 7.9 \\ 37.9 & 21.3 & 16.8 & 8.8\end{array}$

$19.6 \quad 14.5$

$\begin{array}{ll}4.8 & 2.7\end{array}$

$\begin{array}{cc}2 & 1: 0: 1 \\ 2 & 1: 2 *: 0\end{array}$

3

7

9

Japan; RSM

$\begin{array}{llllllll}37.9 & 21.3 & 16.8 & 8.8 & 22.9 & 16.2 & 7.3 & 2.0\end{array}$

Table 40. Shell measurement and count data for Haustellum sobrinus (Adams) ${ }^{*}=$ damaged.

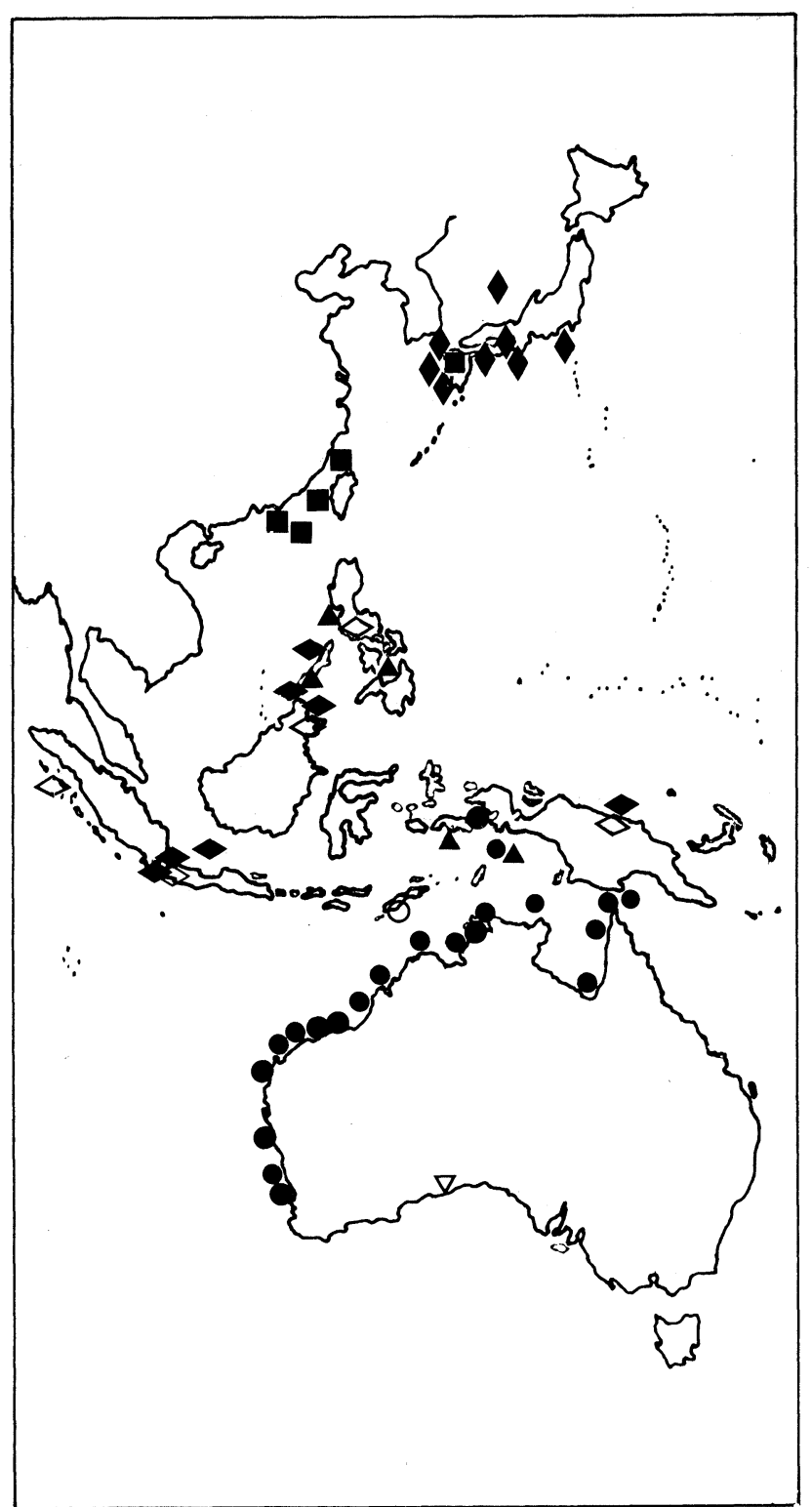

Figure 52. Distribution of Haustellum $\mathrm{spp} . H$. rectirostris (Sowerby) (square); H. multiplicatus multiplicatus (Sowerby) (circle); H. multiplicatus bantamensis (horizontal diamond); $H$. sobrinus Adams) (diamond); $H$. dentifer (Watson) (triangle); $H$. multiplicatus darraghi (Ludbrook) (inverted triangle) and open symbols $=$ fossil records.
Haustellum dentifer (Watson, 1883)

Figs 52; 53; 79G; 88H,I; Table 41

Murex (Pteronotus) sp. (Murex dentifer n. sp.) Watson,

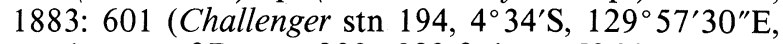
south-west of Papua, 200-300 fathoms [366-549 m], volcanic mud, 29 Sept 1874, = near Banda Island, Molluccas, Indonesia; holotype, BMNH, 1887,2,9.524).

Murex(Haustellum) sp.-Watson, 1885: 153.

Murex (Tribulus) funiculatus.-Schepman, 1911: 344 (in part; stn 166 only) (not of Reeve, 1845).

Murex (Haustellum) dentifer.-Cernohorsky, 1974: 123, fig. 5.

Murex hirasei.-Abbott \& Dance, 1982: 131, fig. in text (not of Hirase).

Records. PHILIPPINES: $183 \mathrm{~m}$, Cebu; $107 \mathrm{~m}$, off Mactan Id, Cebu; 183 m, Leyte; 37 m, off Bohol Id; south-east coast of Palawan Id (all AMS); 109-128 m, off 'Lady Id,' Bohol (WAM); 184-193 m, west of Bataan Peninsula, Luzon (NHMP). INDONESIA: 144-157 m, Haruku Id, east of Ambon (WAM), $118 \mathrm{~m}$, Ceram Sea, Siboga Stn 166, $2^{\circ} 28.5^{\prime} \mathrm{S}, 131^{\circ} 3.31^{\prime} \mathrm{E},(\mathrm{ZMA})$.

Description. SHELl. Large (up to $100 \mathrm{~mm}$ in length and more if attenuated canal present), with eight inflated teleoconch whorls.

Protoconch of about one and three-quarters bulbous volutions, ending at small, sharp varix.

Spiral ornamentation on first teleoconch whorl of three major cords; an additional major cord on second and succeeding whorls. On fourth whorl, minor cords intercalated, until body whorl and posterior half of siphonal canal covered with alternating major and minor cords.

Axial ornamentation on first two teleoconch whorls of 12 rounded ribs, crossing of spiral cords giving a cancellate appearance to early whorls; on third whorl, every fourth rib strengthened into varix, remaining three ribs persisting as strong, rounded axial ridges which extend from suture to base of body whorl. Fourth axial ridge often added in the adapertural portion of intervarical area. Two middle intervarical ridges continuing past base of body whorl onto siphonal canal forming notable bulge between varical extensions. Three heavy, rounded varices per whorl, deeply excavated behind. Small open spinelets formed on adapertural face of varices where crossed 


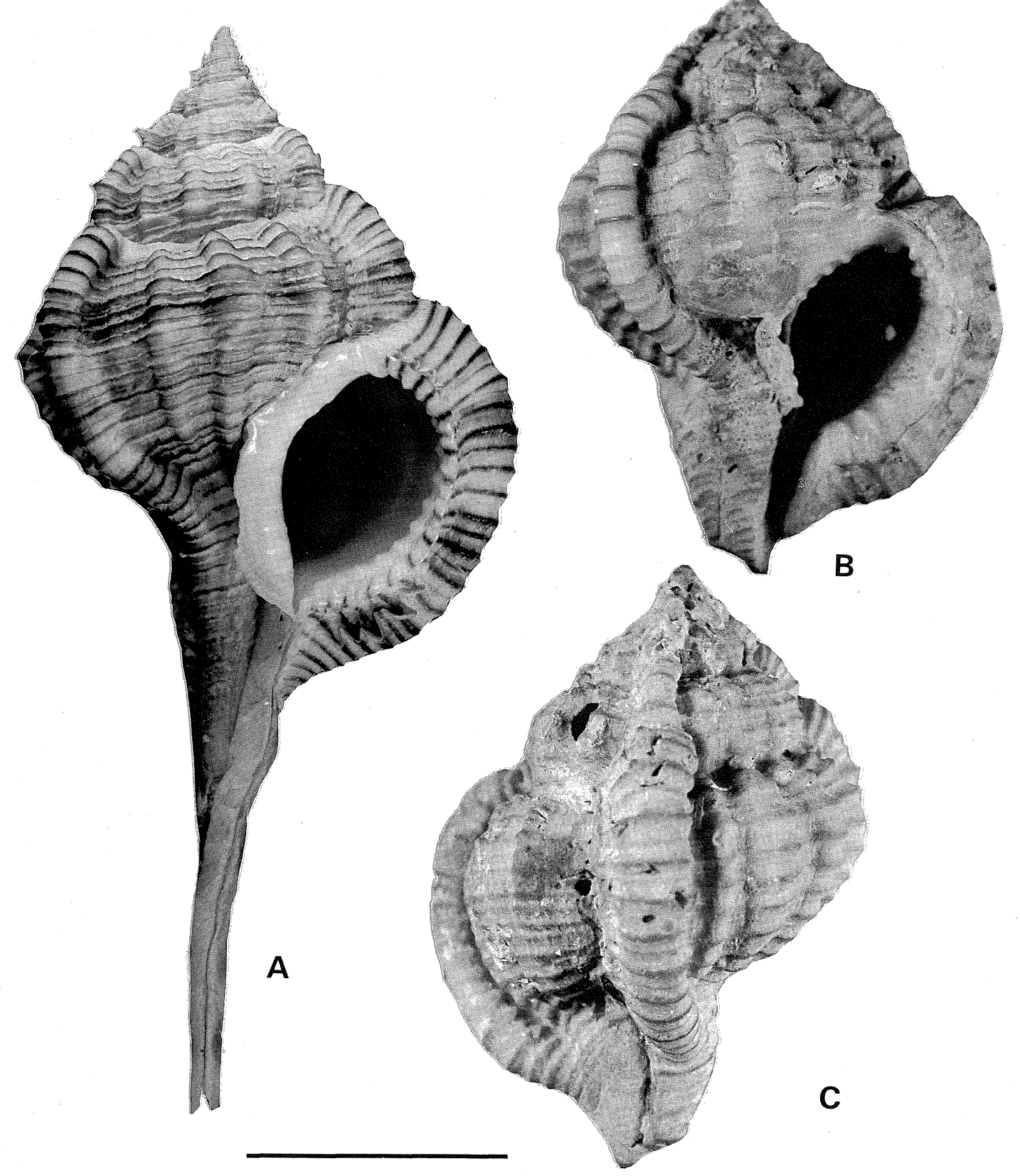

Figure 53. Haustellum dentifer (Watson). A: south-east coast of Palawan, Philippine Ids, in fishing nets (AMS, C.148023). B,C: holotype; near Banda Island, Molluccas, Indonesia, 366-549 m (BMNH, 1887.2.9.524). Scale $2 \mathrm{~cm}$.

by major spiral cords; slightly stronger spine at shoulder on early whorls, usually absent in adult stage. Siphonal canal with one small spine (on each varix) near base of body whorl.

Suture indented, strongly sinuated by axial ridges of previous whorl.

Aperture obliquely ovate; outer lip scalloped by approximately 15 tooth-like projections, corresponding to interspaces between spiral cords; inner side of outer lip with about 12 lirations. Inner lip appressed at posterior end; anterior two-thirds with large, flaring inductura. Ten to 12 elongate rugae distributed over entire length of inner lip, but stronger anteriorly; large anal ridge at posterior end.

Siphonal canal moderately long to long, slightly recurved at distal end; terminations of previous canals fused into tube, open by narrow slit; spinose only immediately adjacent to base of body whorl.

Colour cream, with three diffuse spiral brown bands at shoulder, periphery, and base of body whorl. 
Major spiral cords topped with reddish brown lines, colour more intense in banded areas; aperture white, brown lines between each of the crenulations within outer lip, marking termination of spiral cords; siphonal canal often with brown blotches.

DiMENSIONS. See Table 41.

OPERCULUM. Reddish brown; subterminal nucleus, surrounded by about eight strong, concentric ridges.

Remarks. The shell of this species differs from $H$. hirasei, which it most closely resembles, in having a paucispiral protoconch and coarser spiral sculpture (see under $H$. hirasei for further details). The holotype is a battered shell lacking a protoconch and canal but agrees in all essential respects with the material listed above. The identity of the specimens attributed to this species is given further weight by the specimens from Haruku Island (Fig. $88 \mathrm{H}$ ) being collected near the type locality.

Two specimens from off Surigao, Philippines, in $183 \mathrm{~m}$ (AMS, C.147965) are very similar to $H$. dentifer but have a smaller protoconch of about two whorls and less-indented suture.
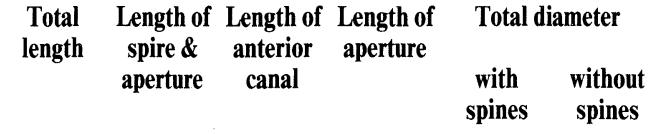

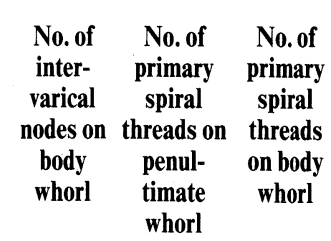

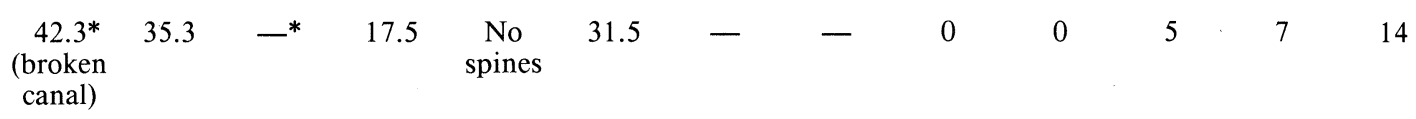

Off "Lady Id",

Bohol, Philippines;

WAM, 1593-70

(Fig. 88I)

79.8

44.1

16.3

30.1

28.0

3.5

2.6

$2: 1$

$1: 12: 1$

4

7

Haruku Id, E. of

144-157 m; WAM,

1582-70 (Fig. $88 \mathrm{H}$ )

73.

37.

38.9

15.5

30.4

30.1
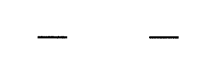

0

0

4

7

Cebu Id,

Philippines; AMS,

C. 145687

81

$47.4 \quad 36.9$

20.2

No
spines

37.3

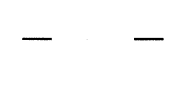

0

0

4

7

16

SE coast of

Palawan Id,

Philippines; AMS,

C. 148023

102

$47.0 \quad 58.9$

20.7

No
spines

39.6

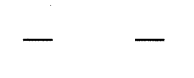

0

0

2

16

Table 41. Shell measurement and count data for Haustellum dentifer (Watson) ${ }^{*}=$ damaged.

\section{Haustellum hirasei (Hirase, 1915)}

Figs 56; 79H; 88G; Table 42

Murex hirasei (Dautzenberg MS) Hirase, 1915: pl. 47, fig. 232 (Japan; it is not known whether the figured specimen from the Hirase collection is in existence); Hirase, 1934:77, p1. 108, fig.4; Smith, 1953: 3, p1.1, fig. 14; Oyama \& Takemura, 1957: p1.2, fig.5; Oyama \& Takemura, 1958: p1.4, fig. 1; Habe, 1961: 49, pl. 25, fig. 4; Habe, 1964: 78, p1.25, fig.4; Radwin \& D'Attilio, 1976: 66, pl. 11, fig. 12; Fair, 1976: 48, fig. 28; Dance, 1974: 121, fig. in text.

Haustellum hirasei._Kaicher, 1973: fig. 127.

Murex kiiensis._Fair, 1976: 52 (in part), pl. 2, fig. 20, pl. 4, fig. 52 (not of Kira).

Records. JAPAN: Kii Peninsula, south of Osaka (ANSP; NMW; NSMT); Tosa, Kochi Pref., Shikoku (AMS; ANSP; BPBM; IRSB); 146-218 m, Tosa (AMNH); Hyotan-se
Bank, near Sado-shima, Sea of Japan (NSMT). NEW Caledonia: 290 m, Passe de Dumbéa, Noumea (NHMP).

Description. SHELl. Medium-sized (up to 75 $\mathrm{mm}$ in length), with seven teleoconch whorls.

Protoconch of about three polished, conical volutions, ending at sharp, straight varix.

Spiral ornamentation on first teleoconch whorl of two weak cords, increasing in number by intercalation of secondary and tertiary threads; body whorl covered with weak cords of three orders of magnitude.

Axial ornamentation on first two teleoconch whorls of 12 rounded ribs; at intersection of spiral and axial ornamentation, sharp pointed nodes developed, giving prickly appearance to early whorls. On third whorl, every fourth rib strengthened, forming small varices; intervening three (sometimes 
two or four) ribs remaining as weak axial ridges; this number persisting to body whorl. Three rounded varices per whorl; on whorls three to six, very short open spines often produced at shoulder, but later whorls non-spinose or, rarely, with very weak, short spines. Suture simple, sinuated by axial ridges of previous whorl. Aperture ovate; outer lip crenulated, with about ten elongated denticles on inner side and small, expanded flange on anterior portion. Inner lip appressed at posterior end, with large flaring inductura on anterior two-thirds, weakly rugose posteriorly but with four strong, elongate rugae at anterior end.

Siphonal canal long, recurved at distal end; previous terminations fused forming tube, in some specimens partially sealed over by thin plate; nonspinose.

Colour cream, with brown lines topping each major spiral cord; their colour strongest on two cords at shoulder and three at periphery; aperture white; siphonal canal darker at distal end.

DIMENSIONS. See Table 42.

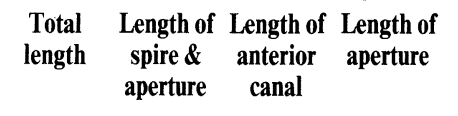

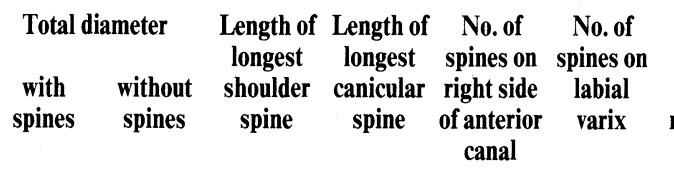

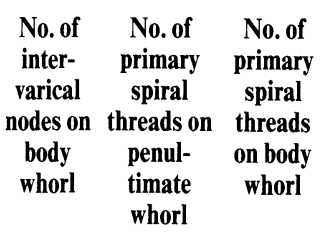

whorl

Kii Pen., Japan;

ANSP, 241550

(Fig. 88G)

33.4

41.2

15.1

No
spines

26.3

-

1.5

2

0

3

6

10

Passe de Dumbéa,

New Caledonia;

NHMP

65.6

32.9

32.9

15.5

No
spines

26.8

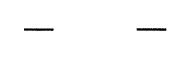

0

0

3

7

10

Table 42. Shell measurement and count data for Haustellum hirasei (Hirase).

OPERCULUM. Light brown; subterminal nucleus, surrounded by weak concentric ridges.

Remarks. The shells of Haustellum dentifer and $H$. hirasei are much alike, but most specimens of $H$. dentifer have heavier varices, stronger spiral cords, and heavier intervarical axial ribs. The colour of $H$. dentifer is more intense, with brown spiral bands in addition to the coloured topping of the cords. The protoconchs are completely different (Figs 79G, $79 \mathrm{H}$ ) as are the early whorls, those of $H$. dentifer being simple and rounded and those of $H$. hirasei with minute spines. The body whorl in $H$. dentifer has small spines along the anterior edge of the varices as well as a small spine at the base of the canal, whereas in $H$. hirasei these spines are usually lacking.

The very disjunct distribution shown by this species may be the result of inadequate collecting. The single New Caledonian specimen is identical to Japanese examples of this species.

\section{Haustellum dolichourus n.sp.}

Figs 50L-N; 56; 68H; 72E; 79A; 88F; 89H; Table 43

Murex (Tribulus) funiculatus._Schepman, 1911: 344 (in part) (not of Reeve, 1845).

?Murex (Haustellum) bonneti.-Wissema, 1947: 173, pl. 6, fig. 149 (not of Cossmann).

Murex kiiensis.—Radwin \& D'Attilio, 1976: pl. 11, fig. 14; Tantanasiriwong, 1978: 13, fig. 1 (not of Kira).

?Murex sobrinus.-Popenoe \& Kleinpell, 1978: 46, pl. 5, fig. 67 (not of Adams).

Murex (Murex) rectirostris.—Ladd, 1982: 43, pl. 9, figs 5, 6 (not of Sowerby).

Type material. HoLOTYPE:(ANSP, 291504); R/V Anton Bruun Stn 19, north-north-west of Phuket Id, south-west Thailand; $08^{\circ} 29^{\prime} \mathrm{N}, 97^{\circ} 59^{\prime} \mathrm{E}, 42 \mathrm{~m}$, sandy mud, International Indian Ocean Expedition. PARATYPES: five paratypes (ANSP, 364135) same data; 25 paratypes (ANSP, 292058); R/V Anton Bruun Stn 28, 12 miles (19 km) northwest of Port Blair, off south Andaman Id, $11^{\circ} 49^{\prime} \mathrm{N}$, $92^{\circ} 53^{\prime} \mathrm{E}, 90 \mathrm{~m}$, sand and shell, International Indian Ocean Expedition; two paratypes, same data as last (AMS, C149547); two paratypes (AMS, C.147970), Bohol, Philippines, $183 \mathrm{~m}, \mathrm{~V}$. Dan.

Records. OMAN: $79 \mathrm{~m}, 40 \mathrm{~km}$ east of Daba (MCZ). MADAGASCAR: 308-520 m, off Nosy Bé (AMS, DMNH, NHMP). REUNION: 73-225 m (NHMP). MAURITIUS: lagoon, Port Louis (ANSP). ANDAMAN ISLANDS: (NMW); $90 \mathrm{~m}, 20 \mathrm{~km}$ north-west of Port Blair (ANSP). PAKISTAN: $110 \mathrm{~m}, 273 \mathrm{~km}$ south of Karachi (MCZ). INDIA: $43 \mathrm{~m}, 24 \mathrm{~km}$ south of Veraval, Gujarat (MCZ). BURMA: $39 \mathrm{~m}, 91 \mathrm{~km}$ north-west of Tavoy Id; $62 \mathrm{~m}, 104 \mathrm{~km}$ west of Tavoy City (both ANSP). THAILAND: $42 \mathrm{~m}, 43 \mathrm{~km}$ north-north-west of Phuket Id; $72 \mathrm{~m}, 88 \mathrm{~km}$ west of Ranong (both ANSP). MALAYSIA: $100 \mathrm{~m}, 100 \mathrm{~km}$ off Sarawak (USNM); Maruda Bay, Sabah (USNM). PHILIPPINES: 99 m, off Maducang Id, east of Palawan; 190 m, off north Burias, Ragay Gulf (both USNM); 70-76 m, off Bataan Penin.; 85-180 m, off Lubang Ids (both NHMP); 109-128 m, off 'Lady Id', Bohol; 95 m, Panglao Id, Bohol (both WAM). INDONESIA: $85 \mathrm{~m}$, off Samarinda, east Borneo; $96 \mathrm{~m}$, off Santan, east Borneo (both NHMP); 40-57 m, west coast Wasir Id, west Wokam, Aru (USNM); south of Selat Bali; Bali Sea, north of 
Bali, $150 \mathrm{~m}$ (both ZMC); 57-59 m, between Warbal and Ur Ids, west of Kai Ketchil (WAM). PAPUA NEW GUINEA: 37-48 m, $2.4 \mathrm{~km}$ south-west of Yule Id, Papua (AMS). Australia: $134 \mathrm{~m}$, off North Reef, Capricorn Channel, Queensland (AMS).

Fossil records. Pleistocene: Vigo Formation, Bondoc Peninsula, Luzon, Philippines (Popenoe \& Kleinpell, 1978; material not seen but probably this species); Espiritu Santo, Vanuatu (USNM; recorded by Ladd, 1982). ?PlioPleistocene: Nias, Malay Archipelago (Wissema, 1947). Upper Pliocene: below Kampong Bodjong Koempai, west Java (PCB).

Description. SHELL. High-spired, small (average length under $50 \mathrm{~mm}$, unless very long siphonal canal present), with seven teleoconch whorls.

Protoconch of about two and one-half minutely granulose, convex volutions, usually with weak keel visible just adapical to suture and ending at small, sharp varix.

Spiral ornamentation in general weak, beginning on first teleoconch whorl with three rounded cords, plus fourth immediately adjacent to suture; on second whorl, fifth smaller cord appears between shoulder and suture. Additional weak, intercalary, minor spiral cords appear on fourth whorl, one between each pair of major cords. On fifth whorl alternating tertiary threads appear.

Axial ornamentation much stronger than spiral, with 12 swollen ribs on first teleoconch whorl, diminishing to ten or 11 on second and third whorl. By fourth whorl, every fourth rib strengthened into small varices, other three remaining as intervarical ridges. Adapertural ridge in each intervarical set progressively weakened until only two strong axial ridges and one weak (if any) third ridge between each pair of varices on ultimate whorl. Three rounded varices per whorl, deeply excavated adaperturally, with short, open spines where crossed by spiral cords, strongest at shoulder, much weaker on anterior portion of varix. One or two short spines on siphonal canal immediately adjacent to base of body whorl.

Suture simple, strongly sinuated by previous intervarical ridges, especially on early whorls.

Aperture rounded, with raised peristome completely encircling outer edge; crenulated along margin of outer lip, with about eight elongated lirations within. Inner lip sometimes with several rugae, better developed at anterior end when present; differing in development between individuals and entirely lacking in some (including holotype), but as many as nine in others. Siphonal canal long; terminations of previous canals fused together into straight tube, open by narrow slit.

Colour creamy white; faint brown spiral bands at shoulder and base of body whorl; spiral cords lightly topped with reddish brown lines, colour strongest where crossing varices; aperture white.

DimENSIONS. See Table 43.

OPERCULUM. Brown; subterminal nucleus, with about nine heavy concentric ridges.
RADULA. See Fig. $68 \mathrm{H}$.

PENIS. Simple, tapering to point (Fig. 72E).

Etymology. Greek dolicho, long + oura, tail; in reference to the extremely long siphonal canal.

Remarks. This species falls between $H$. rectirostris and $H$. dentifer in teleoconch characters. Like $H$. rectirostris the shell has a very long, straight canal, deeply impressed suture and small aperture lacking a flaring inductura; some specimens have a few small rugae on the anterior portion of the inner lip but it is smooth in many. It has the coloured spiral cords of $H$. dentifer, but, unlike that species, has a multiwhorled protoconch. The protoconch has a keel that is sometimes visible just emerging from the lower suture on the last part of the last whorl and, in this respect, as well as in other shell characters, shows its close relationship to $H$. rectirostris and $H$. sobrinus.

Three large, heavy specimens from off Madagascar (Fig. 89G,I) have a short canal, heavier varices and very short spines. The other shell features including the protoconch, however, are, identical and we tentatively regard these specimens as being conspecific. A smaller (immature) specimen from the same locality has the same protoconch but has short spines.

A few specimens that may be this species are known from 134-139 $\mathrm{m}$ in the Capricorn Channel, Queensland (Scott, 1979: 1, figs in text). Of the three specimens of this species that are known, none have a protoconch. Only one is in a museum collection (AMS, C.148024).

It is possible that $H$. dolichourus could be $H$. bonneti (Cossmann, 1903) from the Pliocene of India. We do not use Cossmann's name for the following reasons: (1) we have not been able to examine type or topotypic material; (2) this is one of two Recent species (one unnamed - see below) that are very similar in shell characters to $H$. bonneti but have different protoconchs; the morphology of the protoconch of $H$. bonneti is not known; (3) there are some minor morphological differences. These are: (a) the Recent species has a more deeply incised suture; (b) the siphonal canal is thicker at the base, more spinose and more widely open, however, some fossil specimens of $H$. dolichourus do approach this; (c) there are three, not two, strong axial ribs between the varices on the last whorl in the Recent species. Some fossil specimens of $H$. dolichourus do, however, have two or three with the third weak, or three strong ribs. Cossmann's (1903) figure 27 suggests that a third weak rib is present in the type of $H$. bonneti.

Two specimens, one juvenile (USNM, 229268) and one adult (USNM, 238468) from the Philippines are similar to $H$. dolichourus in teleoconch characters but have a smooth protoconch of two rounded whorls. This species is also very similar to $H$. bonneti. It has 3-4 intervarical ribs on the last whorl, the canal is closed. These specimens probably represent an undescribed taxon but it should not be named until 
Total Length of Length of Length of

length spire \& anterior aperture

aperture canal
Total diameter

with without

spines spines
Length of Length of No. of No. of

longest longest spines on spines on

shoulder canicular right side labial

spine spine of anterior varix
No. of No. of No. of

inter- primary primary

varical spiral spiral

nodes on threads on threads

body penul- on body

whorl timate whorl

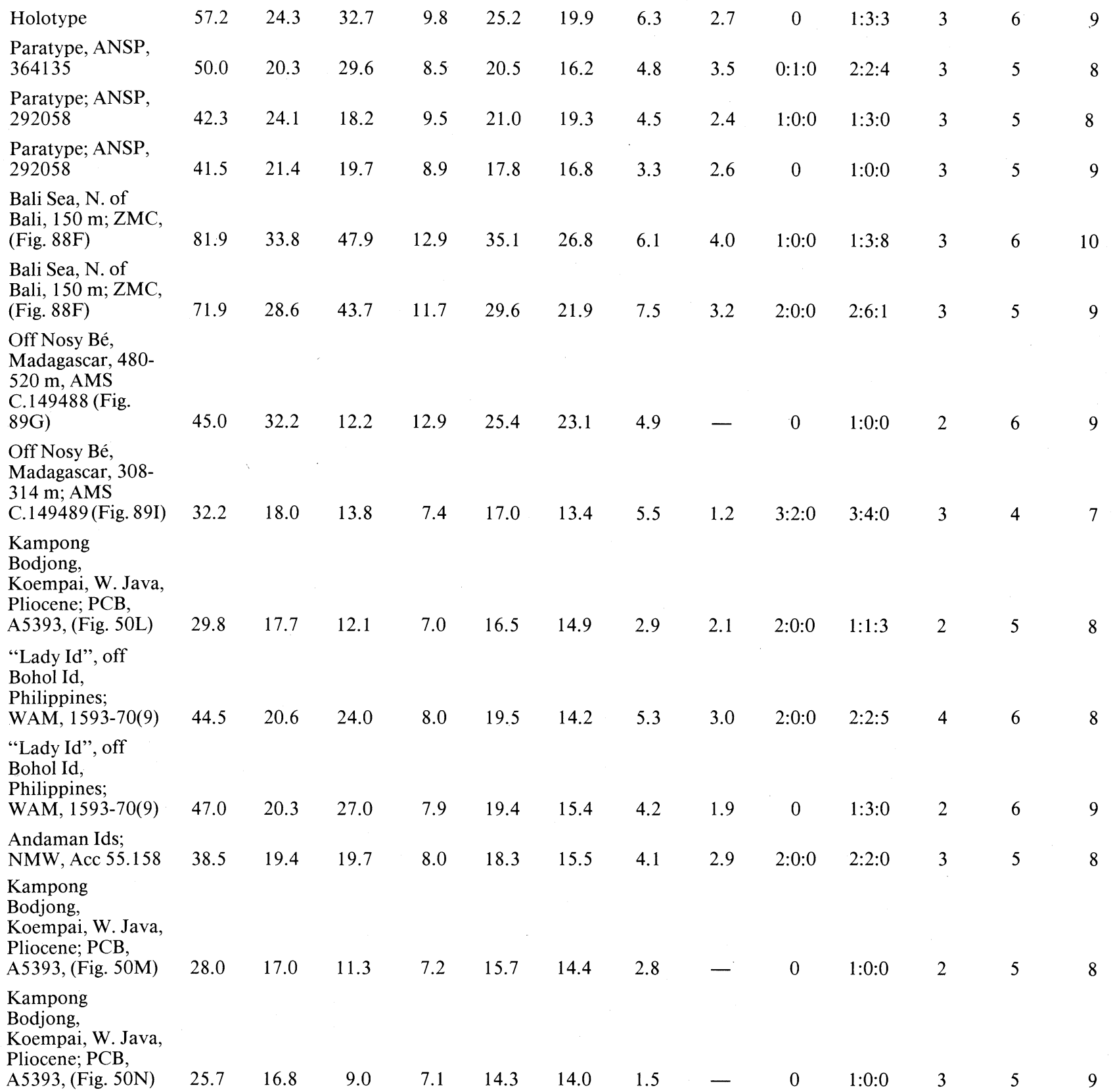

Table 43. Shell measurement and count data for Haustellum dolichourus n.sp.

more material is available, and more about $H$. bonneti known. The localities are: off Corandagos Island, east Palawan, 99 m (USNM, 238468) and off southern Luzon, Corregidor Light, 54 m (USNM, 229268).

A Miocene specimen from Java has the remains of what may be a conical, multispiral protoconch and may represent an ancestral form of $H$. dolichourus (for further discussion see under $H$. multiplicatus bantamensis).

Haustellum gallinago (Sowerby, 1903)

Figs 54; 55C; 56; 78F; 89A,B; Table 44

Murex gallinago Sowerby, 1903: 496 (Hahajima, 
Ogasawara Ids, Japan; holotype, BMNH, 1903.12.7.13); Kaicher, 1974: fig. 525; Fair, 1976: 45, pl. 6, fig. 72; Radwin \& D'Attilio, 1976: 66, pl. 7, fig. 11.

?Nassaria monospina Nomura, 1935: 148, pl. 7, figs 37a, b (Pliocene of Taiwan; types, T.I.U., 53459, 53498).

?Murex cf. bonneti.-MacNeil, 1960: 63, pl. 3, fig. 5 (not of Cossmann).

Murex (Haustellum) gallinago.-Oyama \& Takemura, 1957: pl. 2, fig. 4; Oyama \& Takemura, 1958: pl. 4, fig. 2; Shikama, 1970: 21, pl. 1, figs 8, 9 .

Murex (s.s.) rectirostris senkakuensis Shikama, 1973: 6, pl. 1, figs 5-7 (off Uotsuri Id, Senkaku Ids; 3 syntypes, YNU); Houart, 1980a: 10, fig. 2.

Siratus gallinago.-Fair, 1976: 45, pl. 6, fig. 72.

Murex kiiensis.-Abbott \& Dance, 1982: 131, fig. in text (not of Kira).

Record. MozambiQue: $112 \mathrm{~m}$, off Bay de Lourenço Marques, (USNM); $106 \mathrm{~m}, 96 \mathrm{~km}$ east of Xai Xai (USNM). BORNEO: $96 \mathrm{~m}$, Makassar Strait, north-east of Bantang (NHMP); PHILIPPINES: 143-320 m. north-east of Lubang Ids (NHMP); $150-199 \mathrm{~m}$, north of Lubang (NHMP). EAST China SEa: $120 \mathrm{~m}, 26^{\circ} 55-56^{\prime} \mathrm{N}, 125^{\circ} 00-02^{\prime} \mathrm{E}$ (NSMT). JAPAN: $200 \mathrm{~m}$, Ryukyu Ids (=Okinawa Pref.) (NSMT); Hahajima, Ogasawara (ANSP; RSM).

Fossil records. Pliocene: Taiwan (Nomura, 1935); ?Miocene: Okinawa (MacNeil, 1960).

Description. SHELL. High-spired, large (up to $100 \mathrm{~mm}$ in length); with eight teleoconch whorls.

Protoconch of about one and one-half to two bulbous volutions, ending in small varix.

Spiral ornamentation on early teleoconch whorls of three rounded cords, increasing to four major cords, with intercalated minor threads. Body whorl and posterior half of siphonal canal covered with alternating major and minor cords.

Axial ornamentation on first three teleoconch whorls of 11-12 rounded ribs, crossing of spiral cords giving a cancellate appearance to early whorls. By fourth whorl, every third or fourth rib strengthened, forming small varix with short, open spine at shoulder; intervening ribs remaining as intervarical ridges, two or three between each pair of varices (if three present, usually third varix weak). Three rounded varices per whorl, weakly excavated behind, each with single, short, open spine at shoulder. In addition, on anterior portion of adapertural face of each varix, small open spinelets often develop and merge into crenulate flange.

Suture appressed, sinuated by axial ridges of previous whorl. Aperture obliquely ovate; surrounded by slightly raised peristome formed by finely crenulate margin of outer lip and free-standing inner lip. Outer lip lirate within; inner lip with three to ten elongate rugae, best developed anteriorly.

Siphonal canal moderately long, slightly deflected at distal end; termination of previous canals fused into tube, open by narrow slit.
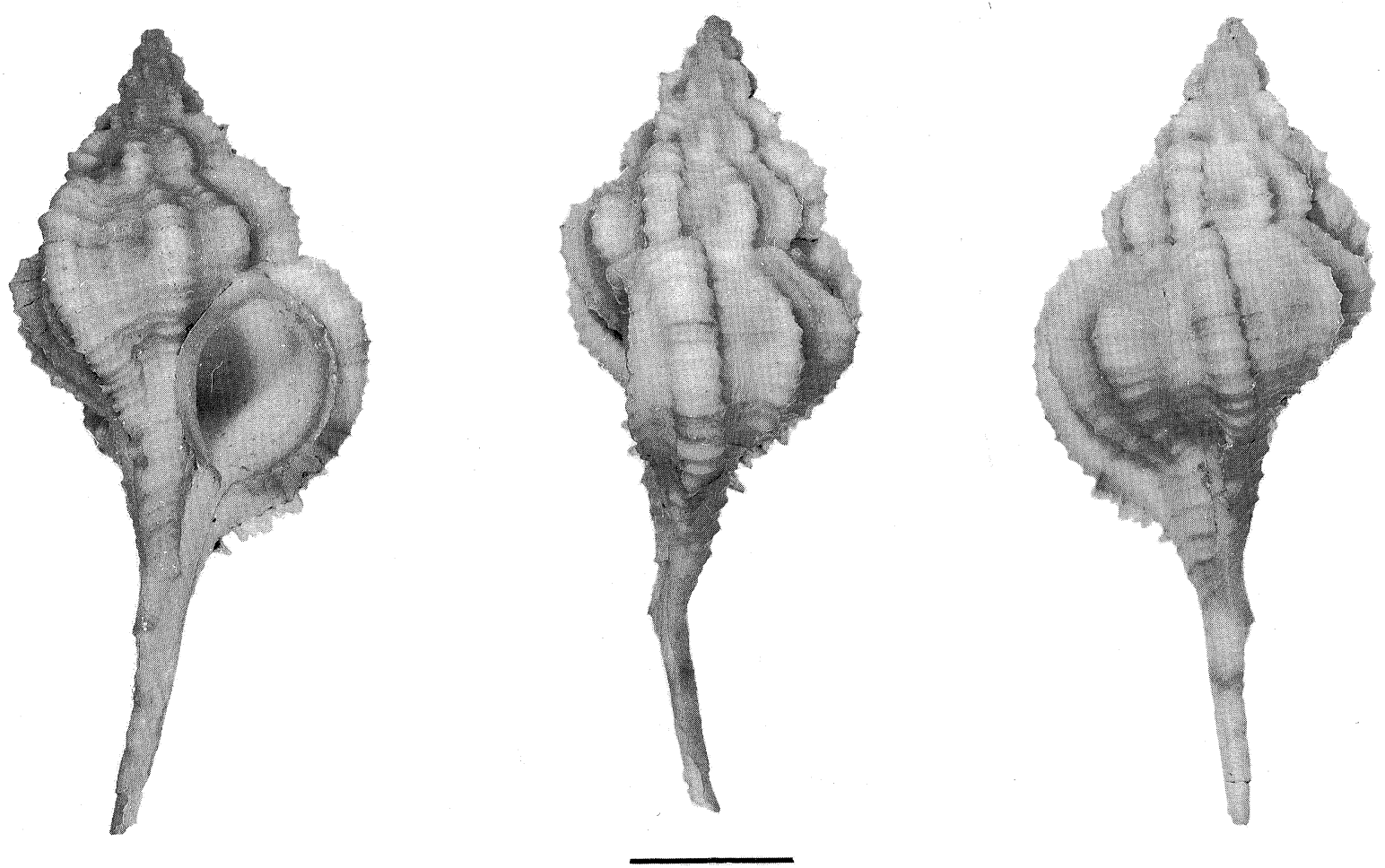

Figure 54. Haustellum gallinago (Sowerby). Holotype; Hahajima, Ogasawara, Japan (BMNH, 1903.12.7.13). Scale $1 \mathrm{~cm}$. 
Colour creamy white, sometimes with pale yellow brown background; some specimens with few spiral brown lines on some spiral cords, these diffuse in some specimens, distinct in others. Aperture white, margin of outer lip often with brown lirations marking terminations of spiral cords.

DimENSIONS. See Table 44.

OPERCULUM. Brown, subterminal nucleus, surrounded by numerous prominent concentric ridges.

Remarks. This rather variable species is typified by the open, rather short spines, thin crenulate flange on the anterior part of the body whorl varices, usually two to three (the third weak) intervarical nodules, simple suture and paucispiral protoconch. It is very similar to H. kiiensis, with which it is compared below.

The type specimen of $H$. gallinago is a shell with an unusual form, having an appressed suture, two intervarical nodes between each pair of varices, and virtually no spines, just a crenulate flange along the anterior face of the varix. The shells of most specimens of this species develop short, open spines.

A few poorly-preserved specimens from East Africa are tentatively referred to this species. They agree in most essential shell features but may, eventually, prove to be distinguishable.

\begin{tabular}{|c|c|c|c|c|c|c|c|c|c|c|c|c|c|}
\hline & $\begin{array}{l}\text { Total } \\
\text { length }\end{array}$ & $\begin{array}{l}\text { Length of } \\
\text { spire \& } \\
\text { aperture }\end{array}$ & $\begin{array}{l}\text { Length of } \\
\text { anterior } \\
\text { canal }\end{array}$ & $\begin{array}{l}\text { Length of } \\
\text { aperture }\end{array}$ & $\begin{array}{l}\text { Total d } \\
\text { with } \\
\text { spines }\end{array}$ & $\begin{array}{l}\text { ameter } \\
\text { without } \\
\text { spines }\end{array}$ & $\begin{array}{l}\text { Length of } \\
\text { longest } \\
\text { shoulder } \\
\text { spine }\end{array}$ & $\begin{array}{l}\text { Length of } \\
\text { longest } \\
\text { canicular } \\
\text { spine }\end{array}$ & $\begin{array}{l}\text { No. of } \\
\text { spines on } \\
\text { right side } \\
\text { of anterior } \\
\text { canal }\end{array}$ & $\begin{array}{l}\text { No. of } \\
\text { spines on } \\
\text { labial } \\
\text { varix }\end{array}$ & $\begin{array}{c}\text { No. of } \\
\text { inter- } \\
\text { varical } \\
\text { nodes on } \\
\text { body } \\
\text { whorl }\end{array}$ & $\begin{array}{l}\text { No. of } \\
\text { primary } \\
\text { spiral } \\
\text { threads on } \\
\text { penul- } \\
\text { timate } \\
\text { whorl }\end{array}$ & $\begin{array}{c}\text { No. of } \\
\text { primary } \\
\text { spiral } \\
\text { threads } \\
\text { on body } \\
\text { whorl }\end{array}$ \\
\hline Holotype & 48.8 & 28.9 & 22.4 & 12.8 & 22.4 & 22.2 & $\begin{array}{l}-(\mathrm{No} \\
\text { spines })\end{array}$ & 1.1 & 1 & 0 & 2 & 6 & 9 \\
\hline $\begin{array}{l}\text { Topotype } \\
\text { (?Paratype); } \\
\text { Hahajima, } \\
\text { Ogasawara Ids; } \\
\text { RSM (Fig. 89B) }\end{array}$ & 42.0 & 23.3 & 19.4 & 10.3 & 16.9 & 16.8 & $1.8^{*}$ & $1.0^{*}$ & 0 & $0: 1: 2$ & 2 & 5 & 10 \\
\hline $\begin{array}{l}\text { Kii Pen, Japan; } \\
\text { ANSP, 241549 }\end{array}$ & 62.9 & 34.0 & 29.7 & 14.5 & 28.7 & 27.4 & $5.5^{*}$ & 3.9 & $2: 0: 0$ & $1: 1: 2: 1$ & 3 & 7 & 11 \\
\hline $\begin{array}{l}\text { E. China Sea, } \\
120 \mathrm{~m} \text {; NSMT } \\
\text { (Fig. 89A) }\end{array}$ & 63.7 & 36.6 & 27.9 & 14.8 & 28.6 & 26.6 & 4.0 & $2.2^{*}$ & $2 *: 1: 0$ & $1: 3: 4$ & 2 & 6 & 11 \\
\hline $\begin{array}{l}\text { E. China Sea, } \\
120 \text { m; NSMT } \\
\text { (Fig. 89A) }\end{array}$ & 54.0 & 35.7 & 18.0 & 14.9 & 30.5 & 26.5 & 4.9 & 3.1 & $2: 2: 0$ & $1: 4: 2$ & 3 & 6 & 12 \\
\hline $\begin{array}{l}\text { E. of Xai Xai, } \\
\text { Mozambique, } \\
106 \text { m; USNM, } \\
761552\end{array}$ & 46.7 & 31.3 & 15.8 & 12.2 & 27.5 & 22.5 & $2.2^{*}$ & $\begin{array}{c}1.8^{*} \\
\text { (None } \\
\text { on last } 2 \\
\text { varices) }\end{array}$ & 0 & 0 & 2 & 7 & 14 \\
\hline $\begin{array}{l}\text { E. of Xai Xai, } \\
\text { Mozambique, } \\
106 \text { m; USNM, }\end{array}$ & & & & & & & & & & & & & \\
\hline 761552 & 43.3 & 32.4 & 10.9 & 12.7 & 22.3 & 21.9 & $2.5^{*}$ & $\begin{array}{c}1.3^{*} \\
\text { (None } \\
\text { on last } 2 \\
\text { varices) }\end{array}$ & 0 & $0: 2: 0$ & 2 & 9 & 14 \\
\hline $\begin{array}{l}\text { E. of Lubang Ids, } \\
\text { Philippines, 174- }\end{array}$ & & & & & & & & & & & & & \\
\hline 193 m; NHMP & 56.8 & 28.7 & 29.0 & 11.3 & 22.4 & 20.4 & $4.7^{*}$ & $\begin{array}{c}1.8^{*} \\
\text { None } \\
\text { on last } 2 \\
\text { varices) }\end{array}$ & 1 & $1: 3: 5$ & 3 & 7 & 12 \\
\hline $\begin{array}{l}\text { Off Lubang Ids, } \\
\text { Philippines, 195- }\end{array}$ & & & & & & & & & & & & & \\
\hline $\begin{array}{l}\text { Ryukyu Ids, Japan; } \\
\text { NSMT }\end{array}$ & 82.6 & 40.6 & 44.0 & 15.4 & 33.5 & 29.3 & 6.9 & 2.5 & 1 & $1: 3: 3$ & 3 & 8 & 12 \\
\hline
\end{tabular}

Table 44. Shell measurement and count data for Haustellum gallinago (Sowerby). ${ }^{*}=$ damaged. 
A rather battered shell said to be from $140 \mathrm{~m}$, off Caloundra, southern Queensland (AMS, C.106357) may possibly be referable to this species but the Australian record needs to be confirmed with additional material.

\section{Haustellum kiiensis (Kira, 1959)}

Figs 55A,B; 56; 78E; Table 45

Murex kiiensis (Kuroda MS) Kira, 1955: 47, pl. 23, fig. 10 (no description); Oyama \& Takemura, 1957: pl. 2, fig. 2; Oyama \& Takemura, 1958: pl. 4, fig. 8 (no description); Kira, 1959: 58, pl. 23, fig. 10 (desc. in Japanese); Kira,
1962: 63, pl. 24, fig. 10 (desc. in English) (central Honshu, 50-100 fathoms [91-183 m]; lectotype here designated as the figured specimen, OMNH 6069); Kaicher, 1974: fig. 573; Fair, 1976: 52 (in part); Radwin \& D’Attilio, 1976: 67 (in part), pl. 13, fig. 5; Houart, 1980a: pl. 10, fig. 3.

Murex (s.s.) kiiensis forma nagaidesu Shikama, 1970: 20 , pl. 1, figs 6-7 (South China Sea; holotype, YNU); Houart, 1980a: 9, fig. 4.

Records. PHILIPPINES: Mactan Id; $183 \mathrm{~m}$ off Bohol Id; $183 \mathrm{~m}$, off Leyte (all AMS). JAPAN: Wakayama Pref. (=Kii) (ANSP, NSMT); Shikoku, Kochi Pref. (NSMT); Tosa (ANSP); 210 m, off Tosa, Shikoku, Kochi Pref. (AMNH).

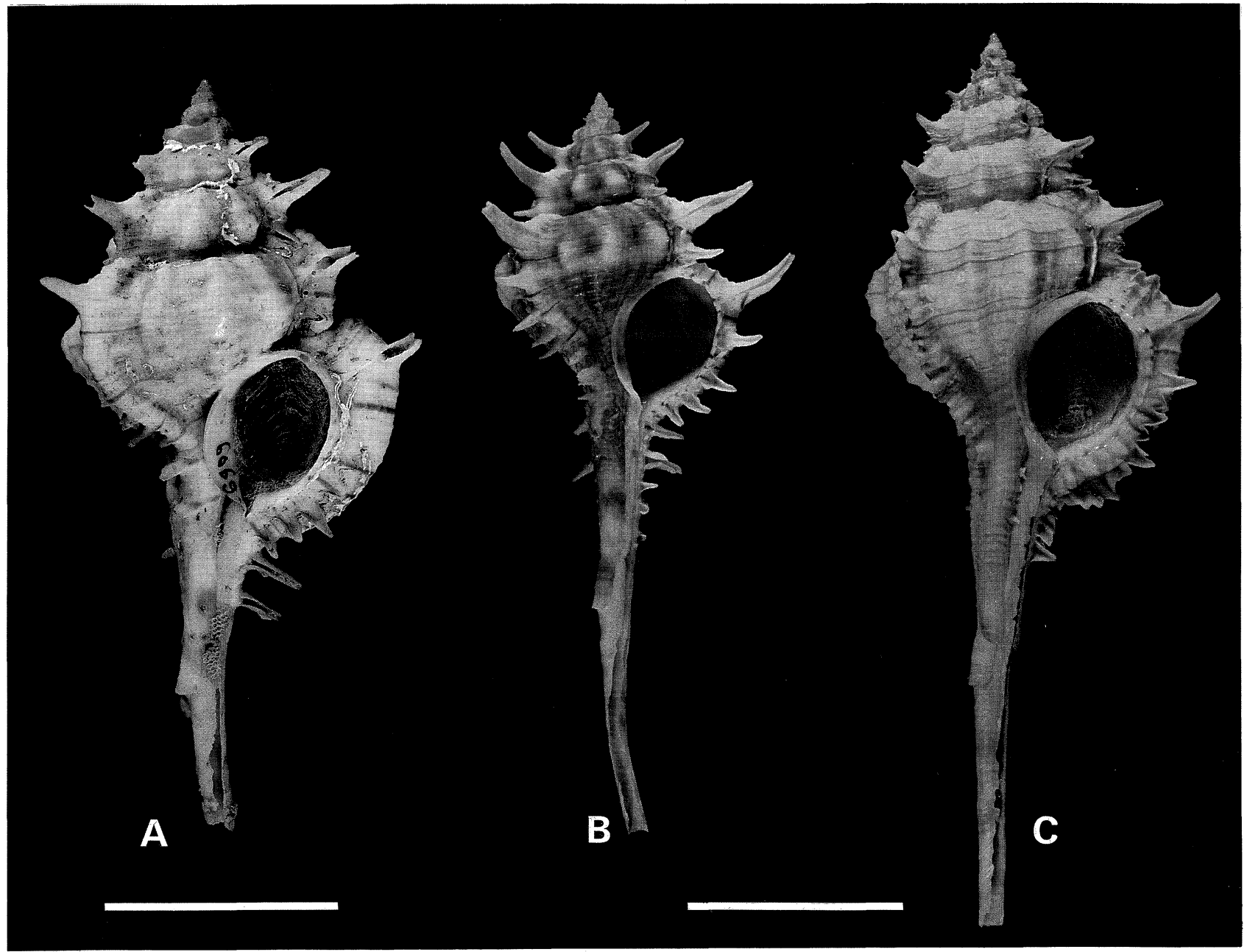

Figure 55. A,B: Haustellum kiiensis (Hirase). A: lectotype. B: Mactan Id, Philippines (AMS, C. 147958). C: Haustellum gallinago (Sowerby); Okinawa, Japan, $200 \mathrm{~m}$ (NSMT). Scales $2 \mathrm{~cm}$.

Description. SHELL. Medium-sized (up to 80 $\mathrm{mm}$ in length, rarely more if attenuated canal present), with up to eight teleoconch whorls.

Protoconch of about three to three and one-half conical volutions, ending at small, sharp varix.

Spiral ornamentation on first teleoconch whorls of three rounded cords; fourth major spiral cord added on subsutural ramp by fourth teleoconch whorl.
Numerous secondary cords intercalcated, until body whorl and posterior half of siphonal canal covered with alternating major and minor cords, with occasional tertiary threads.

Axial ornamentation on first two teleoconch whorls of $12-13$ rounded ribs, nodulated by spiral cords; on third whorl, every third rib strengthened into varix, remaining two ribs persisting as axial 
ridges. Weaker third axial ridge often added in adapertural portion of intervarical area. Three rounded varices per whorl; small open spinelets typically formed on adapertural face of varices where crossed by major spiral cords; that at shoulder, if present, somewhat larger; three or four smaller spinelets on anterior portion of varix in more spinose specimens, others with none or rudimentary spines. Spines not merged to form flange.

Suture deeply impressed, weakly channelled and sinuated by axial ridges.

Aperture obliquely ovate; surrounded by raised peristome formed by free-standing inner lip and finely crenulate outer lip, indentations in latter corresponding to spiral cords. Outer lip usually with six to eight elongate denticles set well within; inner lip with up to 12 oblique rugae, often absent; if present, best-developed anteriorly.

Siphonal canal long, deflected at distal end; previous canals fused into tube, open by narrow slit, frequently partially sealed over by thin plate of shelly material extended from columellar edge; non-spinose except for one to four small spines on each varix, adjacent to body whorl.

Colour cream to fawn or purplish, with (in some examples) three faint broad spiral brown bands, at shoulder, periphery and base of body whorl. Spiral cords often topped with reddish brown lines, better developed in banded areas and on varices; extending to edge of outer lip. Canal mottled with brown blotches. Aperture white.

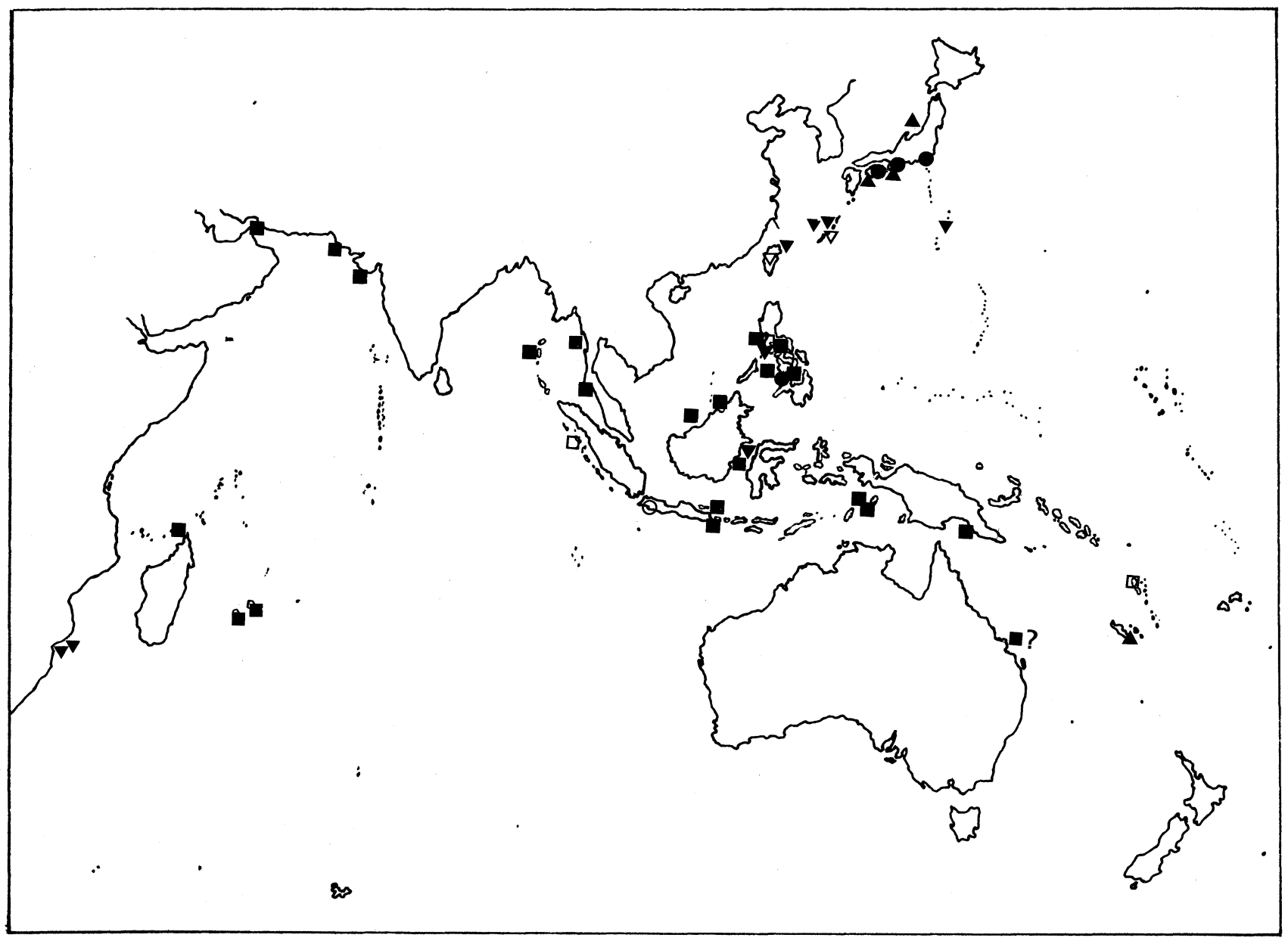

Figure 56. Distribution of Haustellum spp. H. hirasei (Hirase) (triangle); $H$ dolichourus n. sp. (square); H. gallinago (Sowerby) (inverted triangle); H. kiiensis (Hirase) (circle) and open sysmbols = fossil records.

Dimensions. See Table 45.

OPERCULUM. Reddish brown, subterminal nucleus, with numerous, faint concentric ridges.

Remarks. This species has a shell very similar to that of $H$. gallinago and the two are compared below. Haustellum rectirostris also has a somewhat similar shell but is smaller, has a paucispiral, keeled protoconch, straighter siphonal canal and usually only a single, almost closed, spine on each varix.

The two species $H$. gallinago and $H$. kiiensis have superficially similar shells but they may be distinguished by their different protoconchs. In addition, the suture is not as deeply impressed in $H$. gallinago, and the varices and siphonal canal are 


$\begin{array}{ccc}\text { Total } & \text { Length of Length of Length of } \\ \text { length } & \begin{array}{c}\text { spire \& } \\ \text { aperture }\end{array} & \begin{array}{c}\text { anterior anal } \\ \text { canerture }\end{array}\end{array}$

Lectotype

64.7

37.1

28.5

13.6
31.5

$28.7 \begin{gathered}6.4 *(3 \mathrm{rd} \\ \text { last } \\ \text { varix })\end{gathered}$

$2: 0: 0$

$1: 3: 0$

Mactan Id

Philippines; AMS

C.147958 (Fig.

55B)

\section{8.}

30.3

39.0

12.1

28.5

23.0

7.9

4.3

Shikoku, Japan;

NSMT

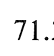

Off Bohol Id,

Philippines; AMS,

C. 146598

35.

36.4

13.7

28.3

25.9

5.5

4.9

4:0:0

$1: 4: 3$

$1: 4: 1$

$3: 1: 0$

$1: 1: 4$

$\begin{array}{rrrr}74.9 & 36.5 & 39.5 & 13.4 \\ 67.8 & 35.5 & 33.0 & 12.8\end{array}$

Pref., Japan;

AMNH, 91787

Table 45. Shell measurement and count data for Haustellum kiiensis (Kira). * = damaged.

never spinose, except for the shoulder spine; the only ornamentation being a lamellar flange along the anterior half of the varix. On the portion of the siphonal canal immediately adjacent to the body whorl there may be one or two small 'prickles' but no true spines are developed. Haustellum dentifer has the same type of paucispiral protoconch but its teleoconch may be recognized by its much more expanded columellar lip, more inflated body whorl, and by the rounded shoulder, which has only tiny 'spines on the early whorls and none in the adult.

Houart (1980a) reviewed the muricid species described by Shikama and suggested that $M$. kilensis form nagaidesu was a very spinose specimen of $M$. hirasei. We disagree with this conclusion because, after examining shells identical with Shikama's illustration, we find them to be referable to $H$. kiiensis. Houart (1980) decided that M. rectirostris senkakuensis Shikama was a form of $H$. kiiensis, but it has all of the shell characters of $H$. gallinago.

Species Tentatively Referred to Haustellum.

Haustellum malabaricus (E.A. Smith, 1894)

Figs 1D; 57; 58; 78G; 88A,B; Table 46

Murex malabaricus E.A. Smith, 1894: 162, pl. 3, fig. 3 (off Malabar coast, $11^{\circ} 05^{\prime} 45^{\prime \prime} \mathrm{N}, 75^{\circ} 04^{\prime} 08^{\prime \prime} \mathrm{E}, 36$ fathoms [66 m]; holotype, Calcutta, paratype, BMNH, 1894.11.14); Smith, 1897-98: pl. 1, figs 1, 1a, 1b; Melvill \& Standen, 1901: 397; Kaicher, 1974: fig. 526; Kaicher, 1980: fig. 2573 (paratype).

Murex (s.s.?) malabaricus.-Vokes, 1971a: 68; Fair, 1976: 56, pl. 2 , fig. 23 (paratype).

Murex serratospinosus. - Radwin \& D'Attilio, 1976: 72 (in part), pl. 10, fig. 2; Houart, 1980a: pl. 10, fig. 5 (not of
Dunker).

Murex (s.s.) tunghaiensis Shikama \& Oishi in Shikama, 1977: 13, pl. 2, figs 7a, 7b (East China Sea; holotype, YNU).

Murex mindanoensis (sic)._-Abbott \& Dance, 1982: 130, fig. in text (not of Sowerby).

Records. UNITED ARAB EMIRATES: 92-95 m, east of Duhat, Sharjah, (MCZ). OMAN: 83-100 m, east of Salalah; $900 \mathrm{~m}$, south of Oman; $73 \mathrm{~m}$, off Fahl Id, near Masqat (all BMNH); Fahal Id (NMW); Red Sea (AMS). NORTH ARABIAN SEA: 73 m (BMNH). IRAN: 109-120 m, 20 $\mathrm{km}$ south-west of Chah Bahar, south-east Iran (MCZ); 100 $\mathrm{m}$, south-east of Jask (MCZ). PAKISTAN: Karachi (IRSB); 80-82 m, south-west of Karachi (MCZ). INDIA: $150 \mathrm{~m}$, Gujarat (NHMV); Gujarat Coast (IRSB); 71-79 m, southsouth-west of Veraval, Gujarat (MCZ); 108-113 m, west of Dwarka, Gujarat (MCZ); 95-100 m, west of Jaigarh, Maharashtra (MCZ), Malabar Coast, Kerala (ANSP; ANMH; BMNH); $70 \mathrm{~km}$ north of Mangalore (AMNH); 119-149 m, Bay of Bengal (AMS; RSM).

Description. SHELL. High-spired, large (about $110 \mathrm{~mm}$ in length), with eight teleoconch whorls.

Protoconch of two and one half to three and onehalf conical whorls, ending at sharp varix.

Spiral ornamentation on first teleoconch whorl of three cords, gradually intercalating secondary and then tertiary cords, with secondary ones increasing in strength until equal to three initial primary cords. Body whorl and posterior half of siphonal canal covered with alternating major and minor cords, with some alternating tertiary threads.

Axial ornamentation on first two teleoconch whorls of 12 rounded ribs; on third or fourth whorl, every fourth rib strengthened into varix, other ribs remain as three intervarical ridges. Intervarical ridges gradually weaken and increase in number by 


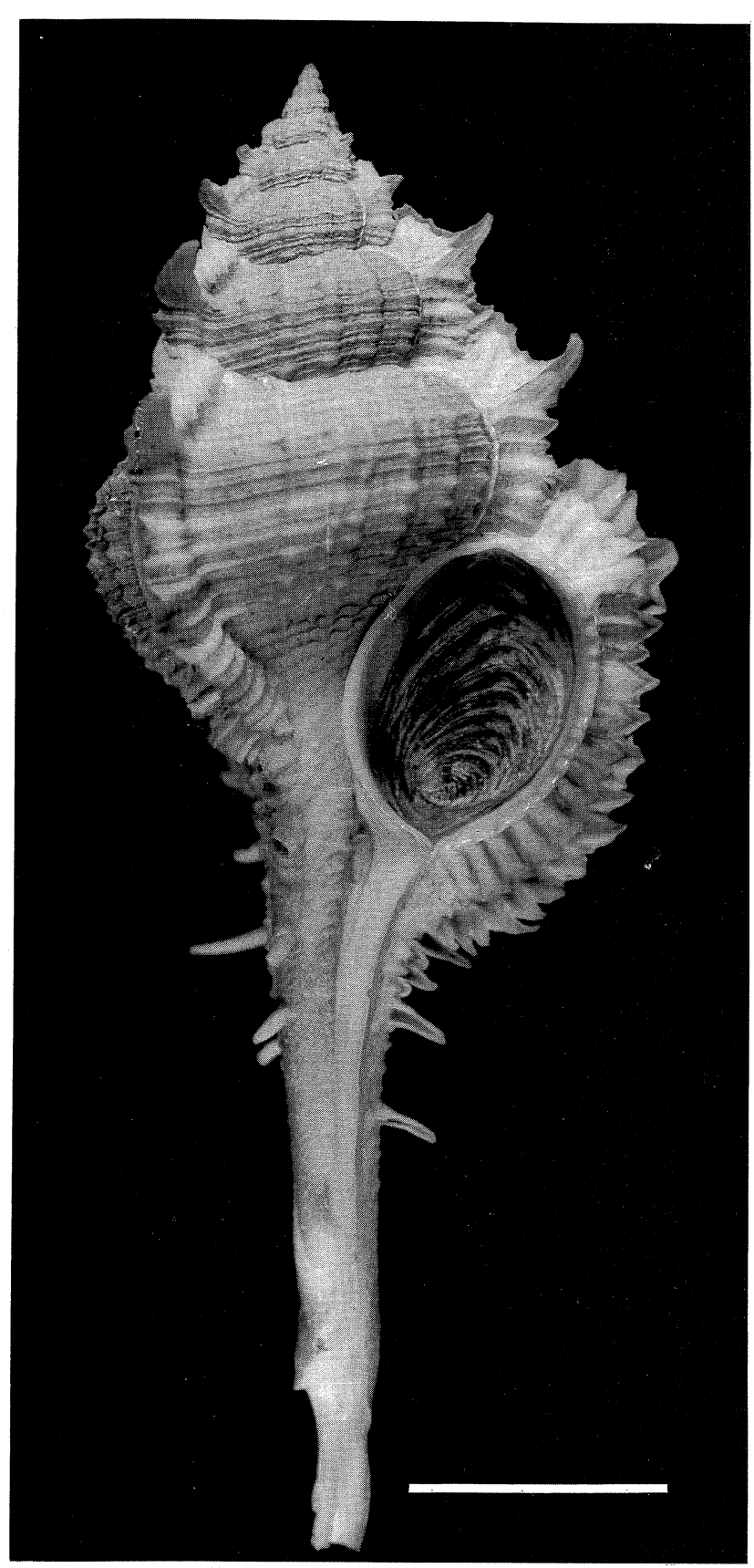

Figure 57. Haustellum malabaricus (Smith). Paratype; off Malabar coast, India, $66 \mathrm{~m}$ (BMNH, 1894.9.11.14). Scale $2 \mathrm{~cm}$.

addition on adapertural side; body whorl with five or six weak intervarical ridges extending from suture to base of siphonal canal. Three rounded varices per whorl, excavated adaperturally; small open spinelets produced at intersection of spiral cords, spine at shoulder most strongly developed, remainder joined together to form narrow flange along entire length of varix. Three to six short open spines on siphonal canal, immediately adjacent to base of body whorl.

Suture slightly appressed.

Aperture ovate, no anal notch; outer lip slightly crenulate, inner side usually smooth but sometimes about eight very faint elongate denticles; inner lip barely attached at posterior end, almost completely free-standing with a small, smooth inductura.

Siphonal canal moderately long, slightly recurved at distal end; terminations of previous canals fused into tube, open by narrow slit; spinose only near base of body whorl.

Colour creamy white, with three brown spiral bands at shoulder, periphery and base of body whorl. Spiral cords topped with brown; colour more intense in areas of colour bands, very weak in areas between bands on body whorl. Siphonal canal tipped with brown, each successive coloured tip giving canal banded brown and white appearance. Aperture white, edge of outer lip with solid brown margin at colour bands, brown dots at terminations of coloured spiral cords, especially at subsutural ramp.

DiMENSIONS. See Table 46.

OPERCULUM. Dark brown; subterminal nucleus, surrounded by about ten heavy concentric ridges.

Remarks. The shell of this species is similar to that of $M$. mindanaoensis but it differs in having a straighter anterior canal, usually weak axial ribs, a smooth inner lip and in possessing colour bands. The protoconch also differs; $H$. mindanaoensis having only one and one-half whorls whereas that of $H$. malabaricus has two and one-half to three and onehalf whorls.

Houart (1980a) has stated that M. tunghaiensis is a synonym of $M$. serratospinosus, which he, like Radwin \& D'Atillio (1976), regarded as a synonym of $H$. malabaricus. Judging from the illustration it certainly appears that $M$. tunghaiensis is $H$. malabaricus, but the locality data is suspect if this is so.

\section{Haustellum mindanaoensis (Sowerby, 1841)}

Figs 58-60; 78H; 88C; Table 47

Murex mindinaoensis (sic) Sowerby, $1841 \mathrm{a}: 2$, pl. 194, fig. 92 (Cagayan, Mindanao, Philippines, 25 fathoms [46 $\mathrm{m}$ ], coll. H. Cuming; holotype, BMNH, 197485); Sowerby, 1879: 5, pl. 2 (of Murex), fig. 21.

Murex mindanaensis (sic).-Sowerby, 1841b: 139; Catlow \& Reeve, 1845: 249.

Murex mindanensis (sic).-Reeve, 1845: pl. 19, fig. 78; Küster \& Kobelt, 1869: 111, pl. 34, fig. 8; Baker, 1897: 379; Smith, 1953: 2, pl. 7, fig. 10.

Murex rarispina var. mindanensis (sic).-Tryon, 1880: 79, pl. 11, fig. 119.

Murex (Tribulus) mindinaoensis (sic).-Poirier, 1883: 39.

Murex serrato-spinosus Dunker, 1883: 35, pl. 1, figs 4, 5 (Flores Id, Indonesia; holotype, HUM).

Murex serratospinosus.-Baker, 1897: 374; Fair, 1976: 77, fig. 56; Radwin \& D'Attilio, 1976: 72 (in part).

?Murex bantamensis. - Tesch, 1915: 63, pl. 81 (9), fig. 140 (not of Martin).

?Murex bantamensis var. teschi Koperberg, 1931: 114 (Timor, Mio-Pliocene; holotype, the specimen figured by Tesch, 1915: pl. 81(9), figs 140a, 140b; whereabouts not known).

Murex mindanaoensis (justified emend.).--Vokes, 1971a: 70; Kaicher, 1973: fig. 109; Fair, 1976: 59, pl. 1, fig. 4; 


Total
$\begin{gathered}\text { Length of } \\ \text { length }\end{gathered}$
spire \&
aperture
anterior of
canal

$\begin{array}{cc}\text { Total diameter } \\ \text { with without } \\ \text { spines } & \text { spines }\end{array}$

\begin{tabular}{|c|c|c|}
\hline $\begin{array}{l}\text { Length of } \\
\text { longest } \\
\text { shoulder } \\
\text { spine }\end{array}$ & $\begin{array}{l}\text { Length of } \\
\text { longest } \\
\text { canicular } \\
\text { spine }\end{array}$ & $\begin{array}{l}\text { No. of } \\
\text { spines on } \\
\text { right side } \\
\text { of anterior } \\
\text { canal }\end{array}$ \\
\hline
\end{tabular}

No. of

primary primary

spiral spiral

nodes on threads on threads

body penul- on body

whorl timate whorl

Paratype; BMNH,

1894.9 .11 .14

$\begin{array}{lllll}111.8 & 58.8 & 53.9 & 23.0 & 44.8\end{array}$

44.8

41.3

$6.0^{*} \quad 8.9^{*}$
$(2$ nd last $(2$ nd last

$3: 1: 0 \quad 1: 0: 0^{*}$

4

9

Paratype?; Bay of

Bengal, India

$119 \mathrm{~m}$; AMS,

C.3285 (Fig. 88A)

$01.9 \quad 55.5$

Paratype?; Bay of

Bengal, India

$119 \mathrm{~m}$; AMS,

C.3285

78.

42

35.

17

29.8

$5.3^{*}$

$3.6^{*}$

$2: 0$

$1: 1 *: 4$

Red Sea; AMS

C.106328 (Fig.

88B)

90.

48.

44.2

19.7

$35.5 \quad 33.9$

$2.8 \quad 3.1$

$2: 2$

Fahal Id, Gulf of

Oman; NMW,

Acc. 55.158

87.1

46.5

43.5

17.8

$33.1 \quad 31.6$

$3.43 .1^{*}$

3:0

$2.2: 5$

Table 46. Shell measurment count data for Haustellum malabaricus (Smith) * = damaged.

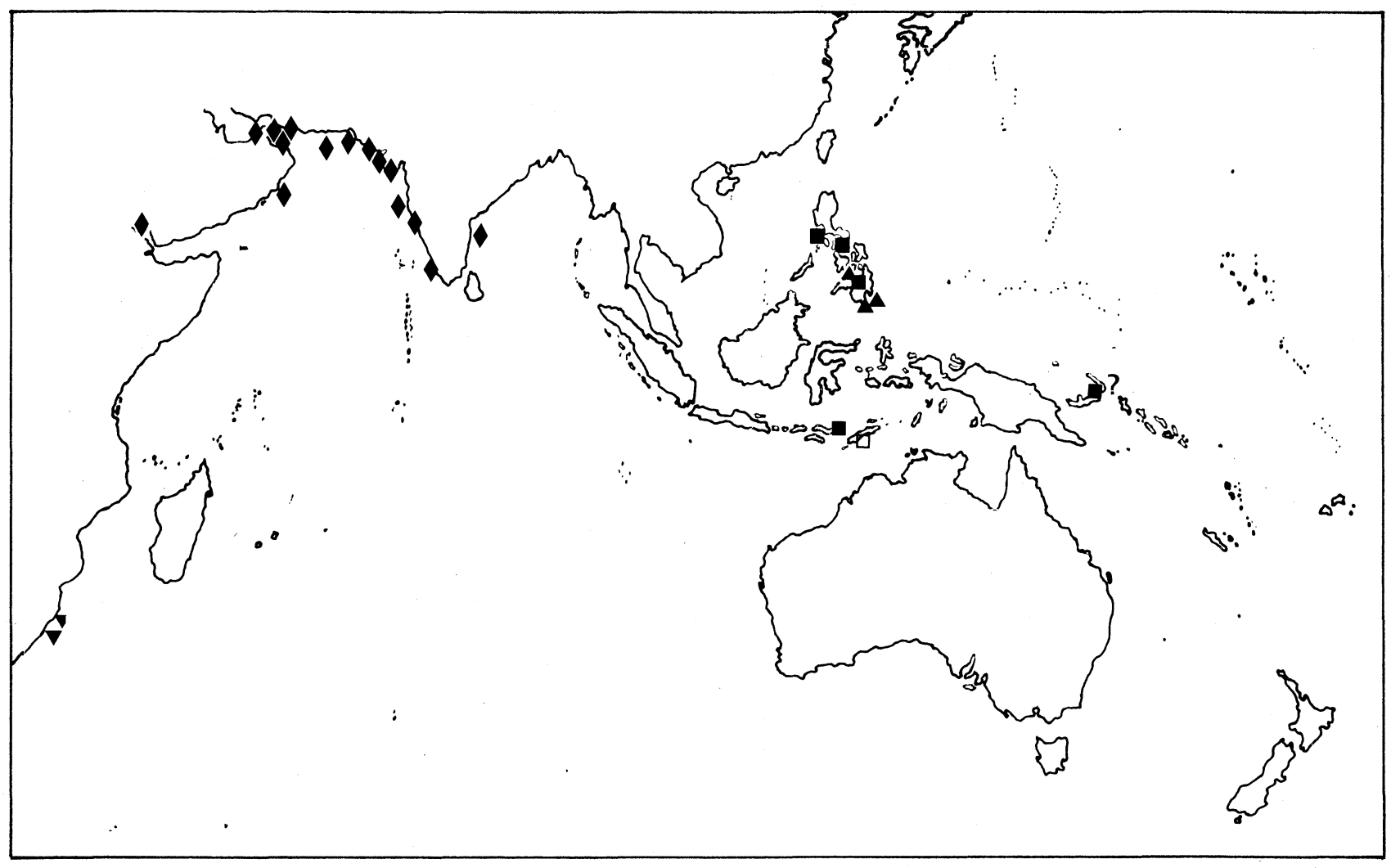

Figure 58. Distribution of Haustellum spp. H. malabaricus (Smith) (triangle); H. mindanaoensis (Sowerby) (square); $H$. purdyae (Radwin \& D'Attilio) (inverted triangle); H. bobyini (Kosuge) (triangle) and open square = fossil records 
Radwin \& D'Attilio, 1976: 68, pl. 10, fig. 4. Siratus (?) serratospinosus.—Vokes, 1971a: 97.

Records. PhILIPPINES: (BMNH; AMS); 7-182 m, Tayabas Bay, south Luzon (AMNH; ANSP; USNM; AMS); 164 m, Pitogo, Luzon; 192 m, south of Pagbilao Id, Tayabas Bay, Luzon; 280 m, Domorog Point, south Masbate Id (all USNM); Mindanao (ZMA).

Additional records. PAPUA NEw GuINEA: Rabaul, New Britain (A. Richards coll.)

Fossil records. Pliocene: Kolo, Timor (BMNH); Noil Tuke, Timor (BMNH). Mio-Pliocene: Timor, Indonesia (Tesch, 1915, types of M. bantamensis var teschi).

Description. SHELL. Very high-spired, large (up to $100 \mathrm{~mm}$ in length), with eight teleoconch whorls.

Protoconch of about one and one-half bulbous volutions, demarcated only by advent of teleoconch sculpture.

Spiral ornamentation on early teleoconch whorls of only three faint, flattened cords, persisting on each subsequent. whorl but weakening and being augmented by intercalation of secondary cords. Body whorl covered with alternating primary and secondary cords almost equal in strength, with tertiary thread between each pair.

Axial ornamentation on first teleoconch whorl of 12 small, angulate ribs, each with small spine at spiral cord on shoulder; decreasing to only nine axial ribs on third whorl, with every third rib strengthening into varix. Each varix bears strong shoulder spine and smaller secondary spine at periphery; intervening ribs remain as two intervarical ridges. On about fifth whorl, additional axial ridges added adaperturally until body whorl marked by (usually) four weak intervarical ridges, weak fifth sometimes present. Three small varices per whorl, with short, sharp spines at crossing of each major spiral cord; smaller secondary spines at crossing of secondary cords, located in advance of primary spines; third order of spinelets at tertiary threads, even more adaperturally directed than secondary spines. Two to five primary spines on siphonal canal.

Suture impressed, simple.

Aperture ovate; outer lip scalloped with about 15 crenulations, corresponding to major spiral cords; weak lirations extend into aperture. Inner lip appressed at posterior end, free-standing for anterior two-thirds; marked by numerous elongate rugae best developed on anterior part.

Siphonal canal long, recurved at distal end; previous canals fused into tube, open by narrow slit but divaricating at terminations.

Colour light golden tan, with extremely faint spiral bands of slightly darker gold at shoulder, periphery and base of body whorl, best seen on abapertural side of varices. Apex and siphonal canal usually darker gold; edge of outer lip with darker spots at termination of spiral cords.

Dimensions. See Table 47.

OpERCULUM. Reddish brown; subterminal nucleus surrounded by about ten heavy concentric ridges.

Remarks. This species is similar to $H$. malabaricus and is compared under that species.
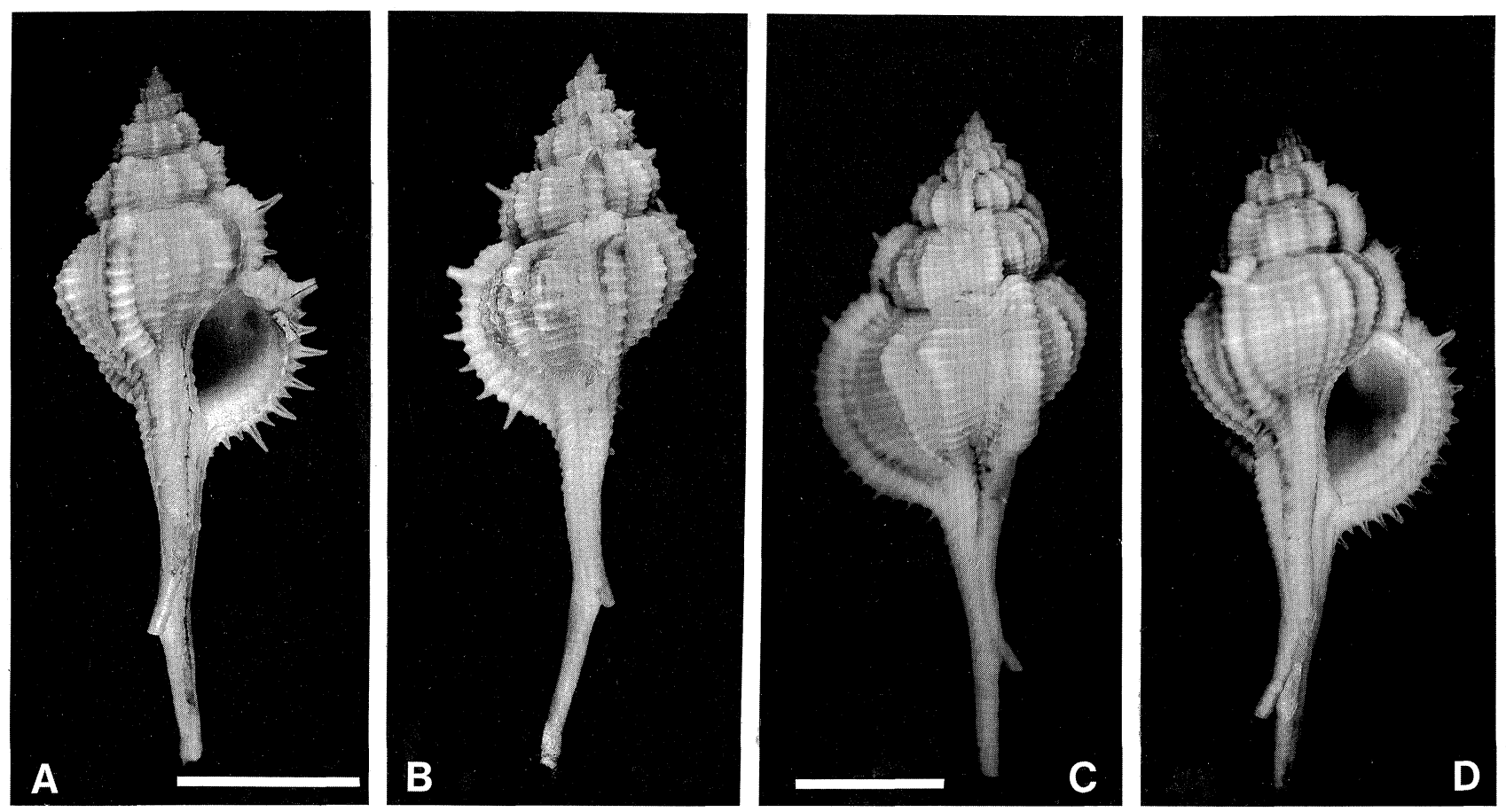

Figure 59. Haustellum mindanaoensis (Sowerby). A,B: holotype; Cagayan, Mindanao, Philippine Ids, 46 m (BMNH, 197485). C,D: holotype of Murex serratospinosus Dunker; Flores Id, Indonesia. Scale $2 \mathrm{~cm}$. 


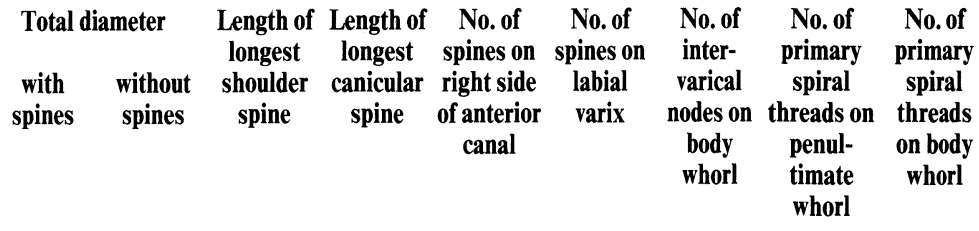

Total $\begin{gathered}\text { Length of } \\ \text { spire \& }\end{gathered}$ Length of $\begin{gathered}\text { Length of } \\ \text { anterior } \\ \text { length aperture } \\ \text { aperture canal }\end{gathered}$

66.7
$1: 4: 6$

3

7

13
Holotype

27.1

Philippines; AMS, C. 103863 (Fig. $88 \mathrm{C})$

$37.3 \quad 30.1 \quad 15.0$

51.6

19.2

32.6
Tayabas Bay, off

Marindugue Id,

Philippines;

AMNH, 125533

Off Tayabas Lgt,

Luzon,

Philippines;

USNM, 238064

Meyer Naide;

Tayabas Bay,

Philippines;

ANSP, 315059

Kolo, Timor:

Pliocene; BMNH

(Pal.) G.52179-83

(Fig. 60A)

95.2
- $^{*}$
(Canal \&
lower
part of
aperture
broken)

95.2
-
(Canal \&
lower
part of
aperture
broken)

95.2
-*
(Canal \&
lower
part of
aperture
broken)

95.2
(Canal \&
lower
part of
aperture
broken)

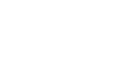

31.0

4.9

$3.6^{*}$

$2.0^{*}$
(2nd last
varix)

0

$\begin{array}{lllllllllllll}81.7 & 39.9 & 42.8 & 16.6 & 29.8 & 26.2 & 6.1 & 4.8 & 4: 2 & 7: 6: 0 & 3 & 9 & 14 \\ 84.2 & 47.1 & 37.6 & 29.5 & 35.0 & 30.4 & 6.2 & \cdot 3.4 & 2: 0 & 7: 4: 2 & 3 & 9 & 15\end{array}$

Noil Tobe, Timor,

Pliocene; BMNH

(Pal.), G.51579-81

(Fig.60B)

$27.2 \quad 19.4 \quad 12.9-19.6$

19.4

Table 47. Shell measurement and count data for Haustellum mindanaoensis (Sowerby) $*=$ damaged.

There have been an unusually large number of spellings of the specific name of this species. These are listed in the synonymy with the exception of a further misspelling by Abbott \& Dance (1982) who figure a specimen of $H$. malabaricus as " $M$. mindanoensis". The emended spelling by Vokes (1971a) is justified because the name is clearly based on the Island of Mindanao. The earlier emendation by Sowerby $(1841 \mathrm{~b})$ corrects the original spelling but also drops the 'o', an unjustified action.

A number of examples of this species have recently appeared from various Indo-Pacific localities, especially the Philippine Islands and are rather similar to the type of $M$. serratospinosus. The shell is more massive than the typical $H$. mindanaoensis, with usually two or three heavy intervarical ridges, in contrast to the four weak ridges seen in the typical form. The varices are much stronger, the spines are shorter and, except for that one at the shoulder, directed forward almost at right angles to the varical plane. The relative spire height is less in these specimens than in typical $H$. mindanaoensis (approximately $70^{\circ}$ vs. $60^{\circ}$ ) and the length of the siphonal canal is somewhat less. However, the protoconch and early whorls of the two forms are identical and the differences in the strength of the varices and intervarical ridges is rather variable within $H$. mindanaoensis.

In addition, six specimens from the Pliocene of Timor (BMNH) have been examined. These agree closely with Recent Philippine specimens, although being slightly broader. The type material of $M$. teschi, based on a Mio-Pliocene specimen from Timor, has not been available but the illustration agrees closely with the material in hand. We conclude that the fossil Indonesian material is conspecific with $M$. mindanaoensis.

Figures of two Miocene specimens from the Philippines (Shuto, 1969: pl. 7, figs 5, 12, pl. 8, fig. 12; as Murex troscheli verbeeki and Murex (Haustellum) bonneti, in part) resemble this species but we have not been able to examine this material. The protoconch of the Miocene taxon (Shuto, 1969: text fig. 24, 1a, 1b) has two and one-half whorls and presumably could be 


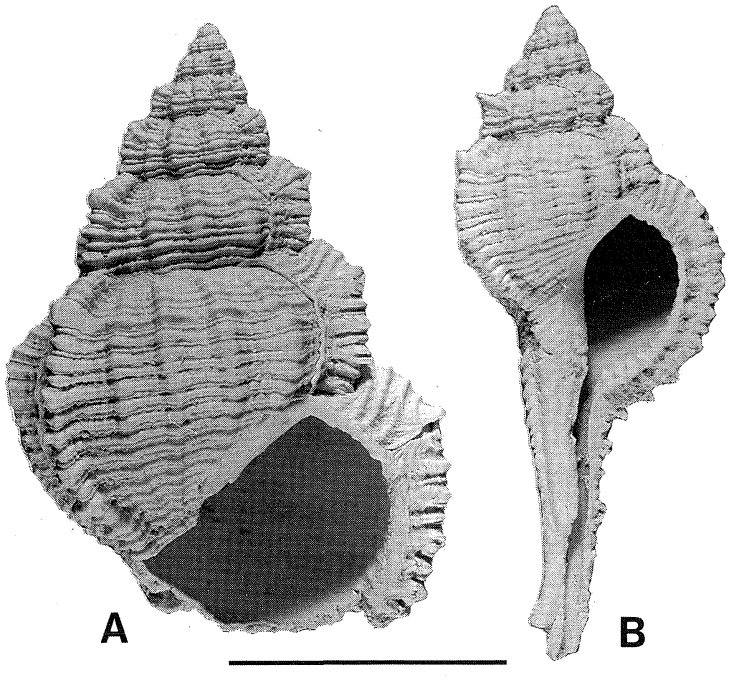

Figure 60. Haustellum mindanaoensis (Sowerby). A: Kolo, Timor, Pliocene (BMNH, G52179-83). B: Noil Tobe, Timor, Pliocene (BMNH, G51579-81). Scale $2 \mathrm{~cm}$.

regarded as a chronosubspecies of H. mindanaoensis.

Haustellum purdyae (Radwin and D'Attilio, 1976) Figs 58; 61

Murex sp.-Barnard, 1959: 197, figs 41d, 41e.

Murex purdyae Radwin \& D'Attilio, 1976: 229, figs 177 (shell), 178 (protoconch), 179 (radula) (off Tugela River mouth, Natal, South Africa, 160 m; holotype, SDNHM, 63024); Kaicher, 1979: fig. 2032.

Murex (Murex) purdyae.-Vokes, 1978: 378, pl. 2, fig. 7.

Additional records. SOUTH AFRICA: $275 \mathrm{~m}$, off Durban (Vokes, 1978); off Cape Natal, 156 m (Barnard, 1959).

Description. SHELL. High-spired, of medium size (up to $60 \mathrm{~mm}$ in length) with five teleoconch whorls.

Protoconch of about one and one-half very large (over $2 \mathrm{~mm}$ in diameter) bulbous volutions, ending at varix.

Spiral ornamentation on early teleoconch whorls consisting of only very faint flattened cords; that at periphery a little stronger, a second at shoulder almost as strong, with slightly weaker cord between and numerous, even weaker, tertiary threads. Body whorl and siphonal canal covered with alternating primary and secondary cords, tertiary thread between each pair, best developed on adapertural sides of varices.

Axial ornamentation on early teleoconch whorls of only three relatively strong varices, perfectly aligned on succeeding whorls, each with short open spine at shoulder and narrow, more or less continuous, flange along outer side. Between each pair of varices two or three faint axial ridges. Numerous fine growth lines, together with spiral ornamentation give linen-like texture to entire shell surface.

Suture appressed.

Aperture ovate, with small anal notch; outer lip weakly crenate; inner lip slightly appressed at posterior end, narrow, free-standing for anterior twothirds, smooth within.

Siphonal canal moderately long, slightly recurved at distal end; terminations of previous canals fused into tube, open by narrow slit.

Colour pale pink or orange, with three indistinct bands of slightly darker colour at shoulder, periphery and base of body whorl, these best seen on varices; aperture white.

DIMENSIONS (of holotype). Length $57.9 \mathrm{~mm}$. Diameter $24.1 \mathrm{~mm}$.

OPERCULUM. Reddish brown; subterminal nucleus, surrounded by fine concentric lines.

Remarks. This species is endemic to South Africa and may be related to $M$. gallinago from which it differs in the sculptural details and the large protoconch.

\section{Haustellum bobyini (Kosuge, 1983)}

Figs 58; 78I; 88E; Table 48

Murex bobyini Kosuge, 1983: 135, pl. 47, figs 4-7 (Taligod, Davao, Philippines, 120 fathoms [220 m]; holotype, IMT, 83.16,17).

Records. Philippines: South Cebu; Balut Id (both AMS).

Description. SHELL. High-spired, of medium size (up to $70 \mathrm{~mm}$ in length), with six teleoconch whorls.

Protoconch of about one and one-half bulbous volutions, ending at small varix.

Spiral ornamentation on early teleoconch whorls of three or four flattened cords, that at shoulder weakest; by fourth whorl, faint secondary cords intercalated. Body whorl and siphonal canal covered with alternating indistinct major and minor cords.

Axial ornamentation on first two teleoconch whorls of ten or 11 angulate ribs, each with small lamellar flange, strongly recurved abaperturally at shoulder. On third whorl, every third or fourth rib strengthened into varix, each with small, open spine at shoulder and weaker spine at periphery. Intervening axial ribs remaining as intervarical ridges for about one whorl but evanescing, until by fifth whorl no axial ornamentation evident except fine growth lines which, together with weak spiral cords, give a linen-like appearance to shell surface. Three weak varices per whorl, with short open spines at crossing of each spiral cord, strength relative to that of cord. Spination pattern somewhat variable but essentially of (anteriorly from suture) primary (shoulder), secondary, primary (periphery), 

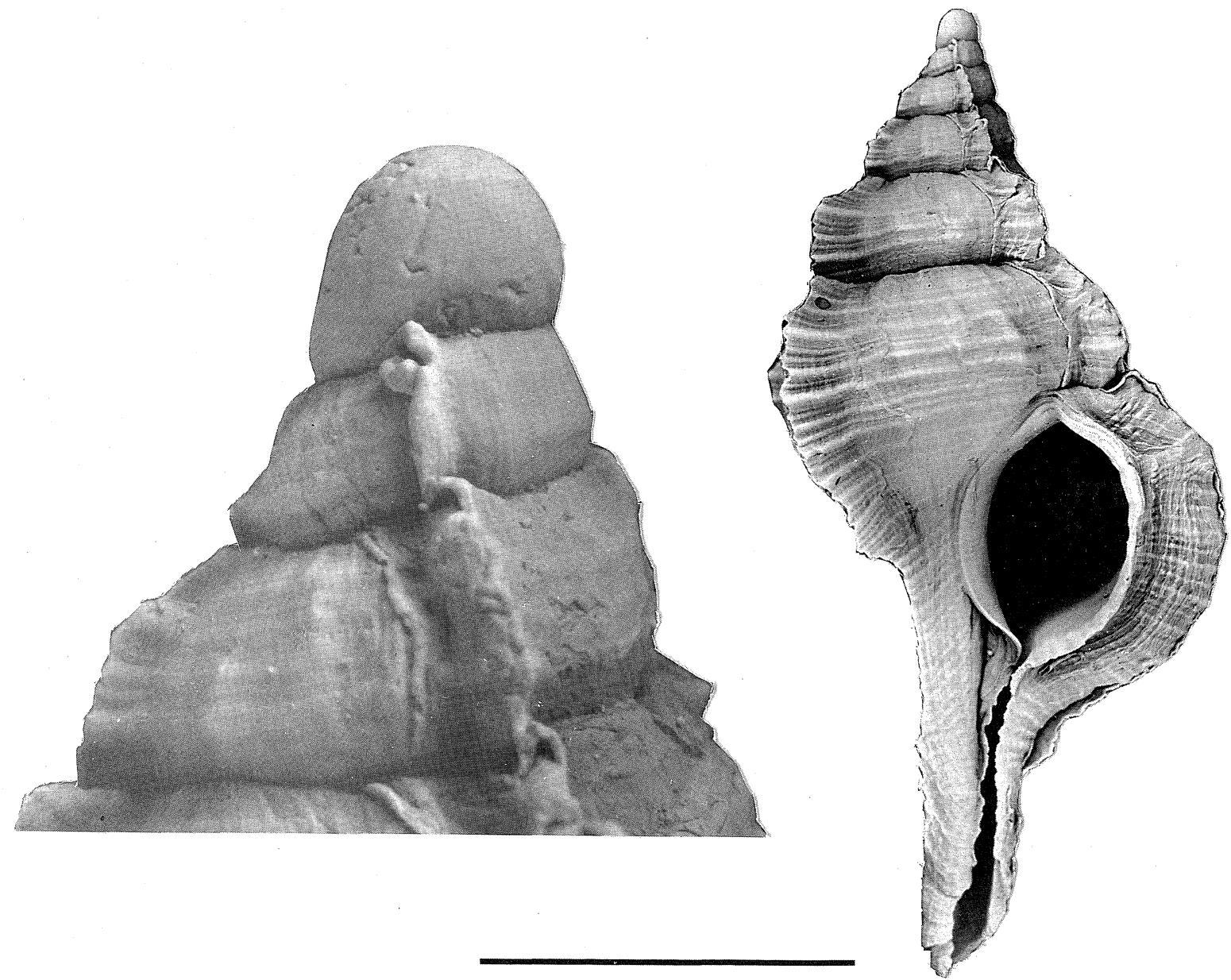

Figure 61. Haustellum purdyae (Radwin \& D'Attilio); off Natal, South Africa (NM, A67). Scale (for right hand figure) $2 \mathrm{~cm}$.

secondary, primary, primary, primary (one of these being the basal spine). Two short spines on siphonal canal immediately adjacent to base of body whorl.

Suture impressed.

Aperture ovate, no anal notch; outer lip thin, crenulate at margin, about 12 weak lirae within. Inner lip thin, narrow, appressed along entire length, about eight indistinct rugae on anterior half.

Siphonal canal short, recurved at distal end; terminations of previous canals fused into tube, open by narrow slit; spinose only adjacent to base of body whorl.

Colour pale golden brown, varices slightly darker shade; aperture white at margins, golden within.

DIMENSIONS. See Table 48.

OPERCULUM. Reddish brown; subterminal nucleus, surrounded by numerous comcentric ridges; median crease along length.

Remarks. This species has some resemblance to species of Murex with its angulate early whorls, but these number ten or 11, of which every third or fourth is strengthened into a varix, giving a resemblance to some species of Haustellum. It has, in particular, some resemblance to $H$. mindanaoensis and, for this reason, it is here tentatively placed in Haustellum. It differs from $H$. mindanaoensis in having weaker ornamentation, both axial and spiral, as well as lessdeveloped varices; however, those of $H$. bobyini are more elaborately spined. The siphonal canal differs in being shorter, more spinose and widely open. This later character in particular suggests that this species may be better included in Siratus.

\section{Fossil taxa of Haustellum in the Indo-West Pacific}

Remarks. Several taxa have been described that are all at least superficially similar. We have not had the opportunity to compare the types of all of these species, or to examine a range of comparative material. Thus our judgements on their taxonomic 


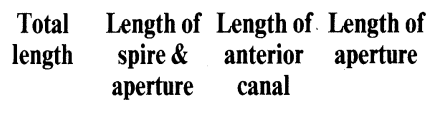

Total diameter

with without

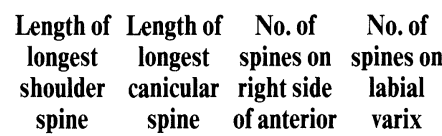

canal

$\begin{array}{ccc}\begin{array}{c}\text { No. of } \\ \text { inter- }\end{array} & \begin{array}{c}\text { No. of } \\ \text { primary }\end{array} & \begin{array}{c}\text { No. of } \\ \text { primary }\end{array} \\ \text { varical } & \begin{array}{c}\text { spiral } \\ \text { spiral }\end{array} \\ \text { nodes on } & \begin{array}{c}\text { threads on } \\ \text { threads }\end{array} \\ \text { body } & \text { penul- } & \text { on body } \\ \text { whorl } & \begin{array}{c}\text { timate } \\ \text { whorl }\end{array} & \text { whorl } \\ & \text { whorl }\end{array}$

\begin{tabular}{|c|c|c|c|c|c|c|c|c|c|c|c|c|}
\hline Holotype & 66.0 & - & - & - & $\begin{array}{c}\text { No } \\
\text { spines }\end{array}$ & 31.5 & - & - & - & - & - & - \\
\hline Paratype & 52.8 & - & - & - & $\begin{array}{c}\text { No } \\
\text { spines }\end{array}$ & 25.7 & - & - & - & - & - & - \\
\hline
\end{tabular}

South Cebu,

Philippines; AMS,

C.143411 (Fig.

$88 \mathrm{E})$

$\begin{array}{lllll}51.9 & 35.6 & 17.4 & 16.4 & 25.9\end{array}$

$23.3 \quad 5.2 \quad 5.3 \quad 2: 1: 0 \quad 7: 3: 0$

0

5

9

South Cebu,

Philippines; AMS,

C.143411 (Fig.

$88 \mathrm{E})$

$\begin{array}{llllll}56.1 & 37.1 & 20.0 & 16.6 & 25.5 & 22.8\end{array}$

Table 48. Shell measurement and count data for Haustellum bobyini (Kosuge).

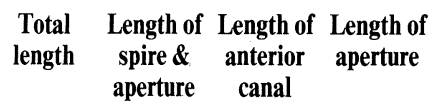

Total diameter

with without

spines spines $\begin{array}{cccc}\text { Length of } & \text { Length of } & \text { No. of } & \text { No. of } \\ \text { longest } & \text { longest } & \text { spines on } & \text { spines on } \\ \text { shoulder } & \text { canicular } & \text { right side } & \text { labial } \\ \text { spine } & \text { spine } & \text { of anterior } & \text { varix }\end{array}$ canal

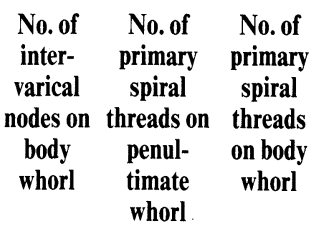

whorl

Holotype
Paratype; WAM,

70.26

$47.4 \quad 25.4 \quad 22.6$

$35.4 \quad 24.6 \quad 11.6$

$11.8-$

22.1

$-\quad-\quad 0$

4

7

10

$3-4^{*}$
(body

whorl

dam-

aged)

Topotype; WAM,

80.223
Topotype; WAM,

$42.1 \quad 26.9 \quad 14.8$

12.7

$\begin{array}{lllll}40.2 & 21.5 & 18.8 & 9.9 & -\end{array}$

22.7

80.223

$\begin{array}{lllll}40.2 & 21.5 & 18.8 & 9.9 & - \\ 38.6 & 24.8 & 14.0 & 11.5 & -\end{array}$

$17.3-\quad-$

Topotype; AMS,

C. 148213

$38.6 \quad 24.8 \quad 14.0$

21.7

49.

22.

27.3

10.2

18.5

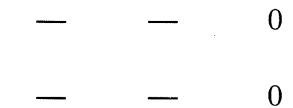

Table 49. Shell measurement and count data for Haustellum multiplicatus darraghi (Ludbrook). * $=$ damaged.

status and relationships are tentative. Nevertheless, it is clear that some of the names listed below have been incorrectly applied in the literature.

\section{Haustellum bonneti (Cossmann, 1903)}

Murex bonneti Cossmann, 1903: 150, pl. 5, figs 26, 27

(Karikal, India, Pliocene; holotype, apparently lost, not

in Cossmann colln, Univ. of Pierre \& Marie Curie, Paris,

fide Pajaud and Bouchet, in lit.)

Murex (Tubicauda) bonneti._Eames, 1950: 246.

Murex (Tubicauda?) bonneti.-Dey, 1961: 79.
Remarks. The shell of this species closely resembles $H$. sobrinus in having few (2-3?), prominent intervarical ribs but differs in its heavier varices. Wissema (1947) records and figures a similar specimen, which he attributes to this taxon, from the Plio-Pleistocene of Nias, Malay Archipelago, but this is tentatively referred to $H$. dolichourus $\mathrm{n}$. sp. above.

Shuto (1969: 101, pl. 7, figs 3, 12, 14, 15, pl. 8, figs 8, $13,14)$ recorded specimens that he attributed to this species from the Neogene of Panay Island, Philippines. These specimens have three to five axial intervarical ribs and an apparently smooth protoconch of two and one-quarter whorls. 
Specimens from Kampong Bodjong, Koempai, Java (Pliocene) are very similar to $M$. bonneti and have a multi-whorled, conical protoconch similar to that of $H$. dolichourus. The teleoconchs of the two forms differ, with $H$. bonneti having two strong intervarical axial ribs whereas most specimens of $H$. dolichourus have three, although the third is sometimes weak, and very rarely two. In other respects the Recent and fossil forms are very similar and the Java specimens are referred to $H$. dolichourus above. It is possible that $H$. dolichourus could eventually prove to be $H$. bonneti but, until the protoconch of the typotypic material is described, they may be regarded as separate species. The identity of all the material recorded as $H$. bonneti is suspect.

Haustellum multiplicatus darraghi (Ludbrook, 1978) Figs 52; 62; 79F; Table 49

Murex (Haustellum) darraghi Ludbrook, 1978: 143, pl. 15, figs 19, 20 (Hampton Microwave Repeater Tower, west of Eucla, south Western Australia, early Pleistocene or late Pliocene; holotype, WAM 70.25).

Remarks. This taxon is very similar to $H$. multiplicatus multiplicatus differing in having only four heavier intervarical axial ribs and in never developing a shoulder spine. The protoconch is also slightly larger in the fossil form. Shell dimensions are given in Table 49.

\section{Haustellum coulsoni (Ladd, 1977)}

Figs $63 \mathrm{~A}, \mathrm{~B}$; Table 50

Murex (Murex) coulsoni Ladd, 1977: 38, pl. 13, figs 12-15 (Station 817, Vanua Levu, Fiji, Pliocene; holotype, USNM, 174997; one paratype from the Miocene of Viti Levu is reidentified as $H$. aff. multiplicatus. Figs $63 \mathrm{C}, \mathrm{D})$.

Remarks. The specimens on which this species is based are similar to $H$. dolichourus $\mathrm{n}$. sp., in all teleoconch characters except the very weak to absent shoulder spines, and in having prominent denticles on the inner apertural lip, this latter character being only occasionally seen in $H$. dolichourus. This taxon may prove to be only subspecifically separable from $H$. dolichourus and/or $H$. bonneti but until the protoconch details are known, no decision can be made. Shell dimensions are given in Table 50.

One of the specimens (paratype $\mathrm{C}$ ) attributed to this taxon by Ladd is a specimen that is similar to $H$. multiplicatus bantamensis.

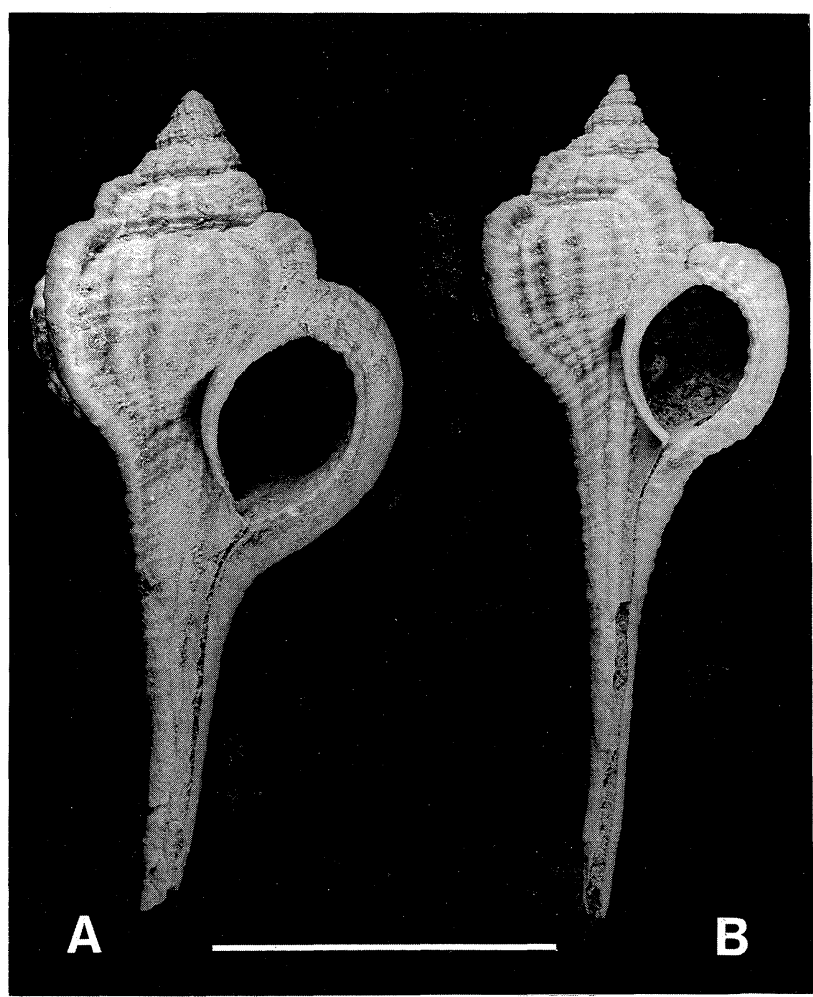

Figure 62. Haustellum multiplicatus darraghi (Ludbrook). A: holotype; Hampton Microwave Repeater Tower, Madura district, Roe Plains, Western Australia (WAM, 70.25). B: topotype (WAM, 80.250 ). Scale $2 \mathrm{~cm}$.

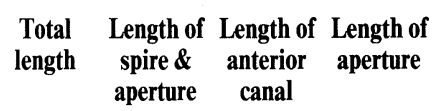

Total diameter

with
spines

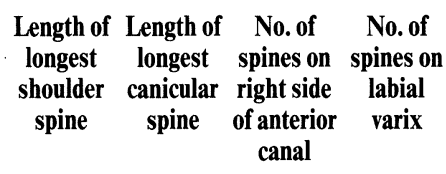

spines inter- primary primary varical spiral spiral nodes on threads on threads body penul- on body whorl timate whorl whorl

Holotype

$$
\begin{aligned}
& \text { (broken } \\
& \text { canal) }
\end{aligned}
$$$$
18.5
$$

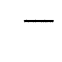

\section{9}

No
spines

15.7

Paratype; USNM, 174998

$$
\begin{gathered}
\text { (broken } \\
\text { canal) }
\end{gathered}
$$$$
17.6-7.6
$$$$
\begin{gathered}
\text { No } \\
\text { spines }
\end{gathered}
$$$$
14.9
$$

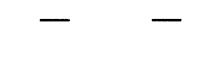




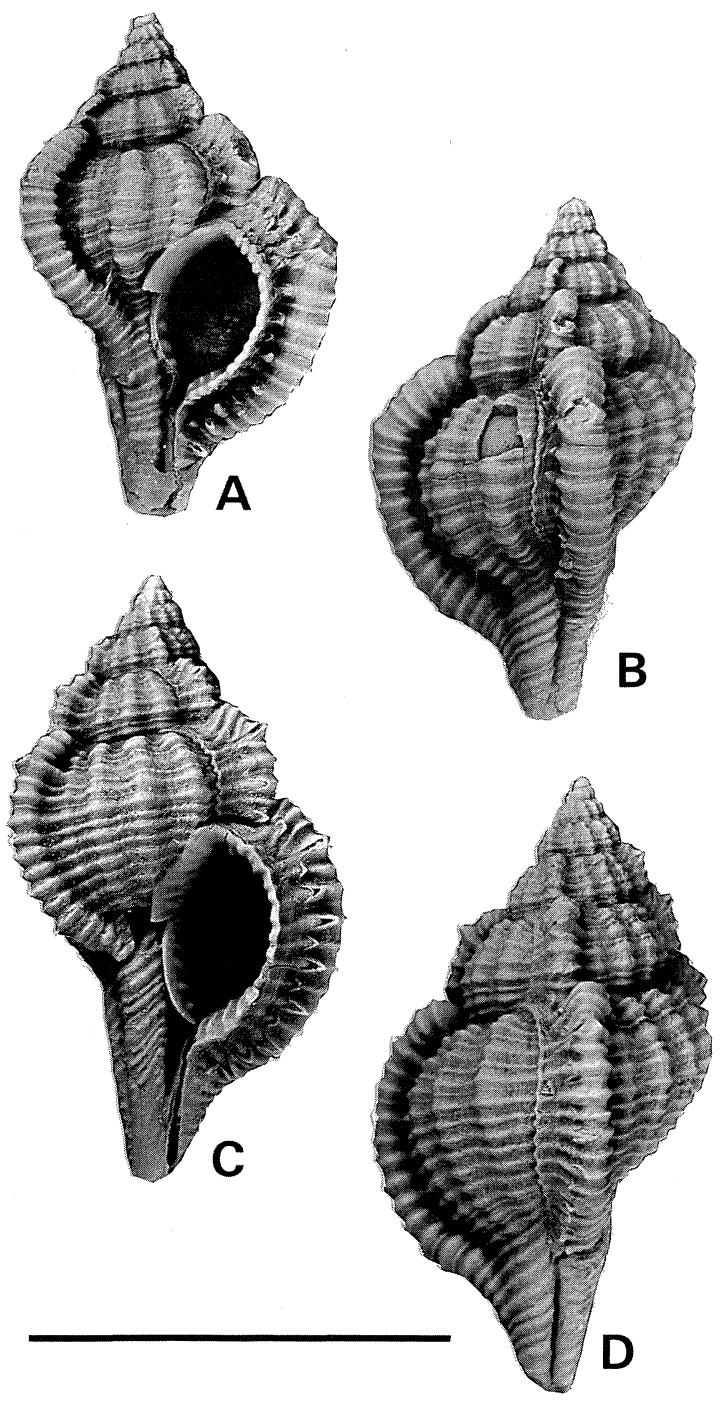

Figure 63. A,B: Haustellum coulsoni (Ladd). Holotype; stn 817, Vanua Levu, Fiji, Pliocene (USNM, 174997). C,D: Haustellum aff. multiplicatus bantamensis (Martin). Paratype C of $H$. coulsoni; stn 165, Viti Levu, Fiji, Upper Miocene (BPBM, 1209). Scale $2 \mathrm{~cm}$.

\section{Haustellum nasongoensis (Ladd, 1977)}

Fig. 64; Table 51

Murex (Murex) recurvirostris._Ladd, 1934: 224 (in part), pl. 40, figs 3, 4 (not fig. 5).

Murex cf. M. recurvirostris.-Cernohorsky, 1967a: 129 (in part).

Murex (Murex) nasongoensis Ladd, 1977: 37, pl. 13, figs 8, 9 (Station 59, 1 mile west of Nasongo, Viti Levu, Fiji, probably Miocene; holotype, BPBM, 1208).

Remarks. The single, incomplete specimen on which this taxon is based bears a superficial resemblance to $H$. dentifer, differing in the larger

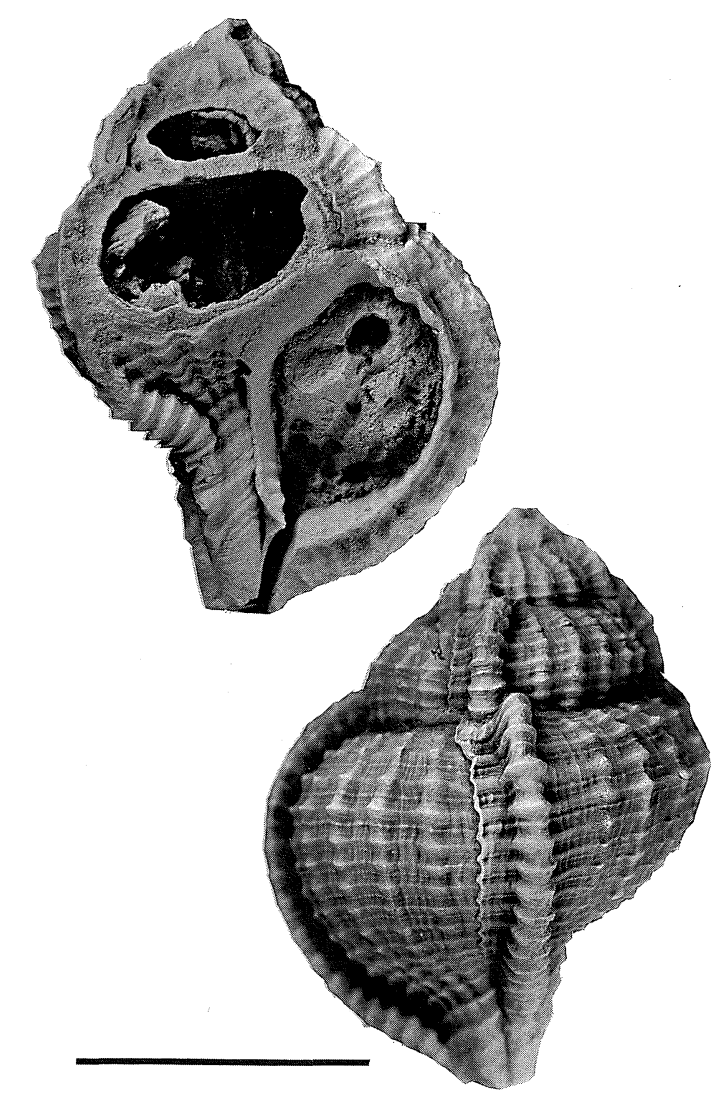

Figure 64. Haustellum nasongoensis (Ladd). Holotype; stn 59, Viti Levu, Fiji, probably Miocene (BPBM, 1208). Scale $2 \mathrm{~cm}$.

number of intervarical ribs (five compared with three [rarely four] on the penultimate whorl) and weaker varices and lack of denticulation over most of the inner lip. There is some resemblance to $H$. multiplicatus bantamensis, the two taxa differing in size (spire + aperture about $40 \mathrm{~mm}$ in the Fijian fossil, compared with about $33 \mathrm{~mm}$ in the largest specimen of $H$. multiplicatus bantamensis) as well as the lack of spines of $H$. nasongoensis. Shell dimensions are given in Table 51.

\section{Haustellum saplisi (MacNeil, 1960)}

Fig. 65; Table 52

Murex saplisi MacNeil, 1960: 63, pl. 8, figs 14, 15 (Shinzato tuff member, Okinawa, Upper Miocene; holotype, USNM, 562821 and figured paratype, 562822).

?Murex (Haustellum) bantamensis saplisi._Shuto, 1969: 100, pl. 8, fig. 6 .

Remarks. This taxon has a shell with three rather strong intervarical axial ridges and a well-developed shoulder angulation. Shuto (1969) recorded it from the Miocene of Panay Island, Philippines, but we 
Total
$\begin{gathered}\text { Length of } \\ \text { length }\end{gathered}$
$\begin{gathered}\text { spire \& } \\ \text { aperture }\end{gathered}$
anterior of
anal

Total diameter

with without

spines spines
Length of Length of No. of No. of

longest longest spines on spines on

shoulder canicular right side labial

spine spine of anterior varix canal
No. of No. of No. of inter- primary primary varical spiral spiral

nodes on threads on threads body penul- on body whorl timate whorl whorl

Holotype

$$
34.7 \underset{\begin{array}{c}
\text { (canal } \\
\text { broken) }
\end{array}}{-}
$$$$
19.2 \quad \begin{gathered}
\text { No } \\
\text { spines }
\end{gathered}
$$$$
31.3
$$

-

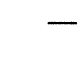

\section{0}

0

5

6

Table 51. Shell measurement and count data for Haustellum saplisi (MacNeil).

\begin{tabular}{|c|c|c|c|c|c|c|c|c|c|c|c|c|c|}
\hline & $\begin{array}{l}\text { Total } \\
\text { length }\end{array}$ & $\begin{array}{c}\text { Length of } \\
\text { spire \& } \\
\text { aperture }\end{array}$ & $\begin{array}{l}\text { Length of } \\
\text { anterior } \\
\text { canal }\end{array}$ & $\begin{array}{l}\text { Length of } \\
\text { aperture }\end{array}$ & $\begin{array}{l}\text { Total d } \\
\text { with } \\
\text { spines }\end{array}$ & $\begin{array}{l}\text { Imeter } \\
\text { without } \\
\text { spines }\end{array}$ & $\begin{array}{l}\text { Length of } \\
\text { longest } \\
\text { shoulder } \\
\text { spine }\end{array}$ & $\begin{array}{l}\text { Length of } \\
\text { longest } \\
\text { canicular } \\
\text { spine }\end{array}$ & $\begin{array}{l}\text { No. of } \\
\text { spines on } \\
\text { right side } \\
\text { of anterior } \\
\text { canal }\end{array}$ & $\begin{array}{l}\text { No. of } \\
\text { spines on } \\
\text { labial } \\
\text { varix }\end{array}$ & $\begin{array}{c}\text { No. of } \\
\text { inter- } \\
\text { varical } \\
\text { nodes on } \\
\text { body } \\
\text { whorl }\end{array}$ & $\begin{array}{l}\text { No. of } \\
\text { primary } \\
\text { spiral } \\
\text { threads on } \\
\text { penul- } \\
\text { timate } \\
\text { whorl }\end{array}$ & $\begin{array}{c}\text { No. of } \\
\text { primary } \\
\text { spiral } \\
\text { threads } \\
\text { on body } \\
\text { whorl }\end{array}$ \\
\hline Holotype & $\begin{array}{c}- \\
\text { (broken } \\
\text { canal) }\end{array}$ & 19.6 & - & 8.8 & $\begin{array}{c}\text { No } \\
\text { spines }\end{array}$ & 17.5 & - & - & $?$ & 0 & 2 & 5 & 7 \\
\hline Paratype & $\begin{array}{c}\text { - } \\
\text { (broken } \\
\text { canal) }\end{array}$ & 19.5 & - & 9.2 & $\begin{array}{c}\text { No } \\
\text { spines }\end{array}$ & 18.3 & - & - & $?$ & 0 & 3 & 4 & 7 \\
\hline
\end{tabular}

Table 52. Shell measurement and count data for Haustellum nasongoensis Ladd.

\begin{tabular}{|c|c|c|c|c|c|c|c|c|c|c|c|c|}
\hline \multirow{2}{*}{$\begin{array}{l}\text { Total } \\
\text { length }\end{array}$} & \multirow{2}{*}{$\begin{array}{l}\text { Length of } \\
\text { spire \& } \\
\text { aperture }\end{array}$} & \multirow{2}{*}{$\begin{array}{l}\text { Length of } \\
\text { anterior } \\
\text { canal }\end{array}$} & \multirow{2}{*}{$\begin{array}{l}\text { Length of } \\
\text { aperture }\end{array}$} & \multicolumn{2}{|c|}{ Total diameter } & \multirow{2}{*}{$\begin{array}{c}\text { Length of } \\
\text { longest } \\
\text { shoulder } \\
\text { spine }\end{array}$} & \multirow{2}{*}{$\begin{array}{c}\text { Length o } \\
\text { longest } \\
\text { canicular } \\
\text { spine }\end{array}$} & \multirow{2}{*}{$\begin{array}{l}\text { No. of } \\
\text { spines on } \\
\text { right side } \\
\text { of anterior } \\
\text { canal }\end{array}$} & \multirow{2}{*}{$\begin{array}{c}\text { No. of } \\
\text { spines on } \\
\text { labial } \\
\text { varix }\end{array}$} & \multirow{2}{*}{$\begin{array}{c}\text { No. of } \\
\text { inter- } \\
\text { varical } \\
\text { nodes on } \\
\text { body } \\
\text { whorl }\end{array}$} & \multirow{2}{*}{$\begin{array}{c}\text { No. of } \\
\text { primary } \\
\text { spiral } \\
\text { threads } \\
\text { penul- } \\
\text { timate } \\
\text { whorl }\end{array}$} & \multirow{2}{*}{$\begin{array}{r}\text { No. of } \\
\text { primar } \\
\text { spiral } \\
\text { thread } \\
\text { on bod } \\
\text { whorl }\end{array}$} \\
\hline & & & & $\begin{array}{l}\text { with } \\
\text { spines }\end{array}$ & $\begin{array}{c}\text { without } \\
\text { spines }\end{array}$ & & & & & & & \\
\hline
\end{tabular}

Syntype; GML, St.

9667 (Fig. 66)

$$
\text { (broken } 15.3
$$

$$
6.8 \quad \begin{gathered}
\text { No } \\
\text { spines }
\end{gathered}
$$

$-$

$-$

0

0

2

8

Syntype; GML, St.

9667 (Fig. 66)

$$
\begin{aligned}
& \text { (broken } \\
& \text { canal) }
\end{aligned}
$$

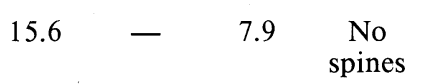

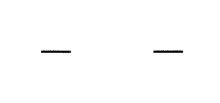

0

(n)

Syntype; GML, St. 9668

$$
\begin{aligned}
& \text { (broken } \\
& \text { canal) }
\end{aligned}
$$

Syntype; GML, St. 9668

$$
\begin{aligned}
& \text { (broken } \\
& \text { canal) }
\end{aligned}
$$

Syntype; GML, St. 46992

$$
\begin{array}{llll}
\begin{array}{c}
\text { (broken } \\
\text { canal) }
\end{array} & 15.1 & - & 7.2 \\
\text { spines } & \text { No }
\end{array}
$$

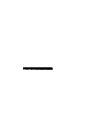$$
-
$$

$\begin{array}{lllll}0 & 0 & 2 & 4 & 11\end{array}$

Table 53. Shell measurement and count data for Haustellum wanneri (Martin). 


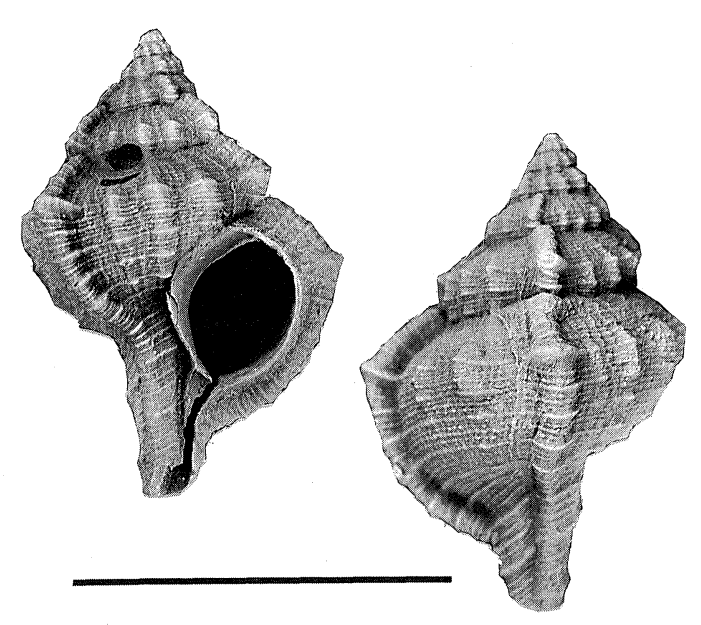

Figure 65. Haustellum saplisi (MacNeil). Holotype; Shinzato tuff member, Okinawa, Upper Miocene (USNM, 562821). Scale $2 \mathrm{~cm}$.

have not been able to confirm his identification. The protoconch is missing in the type series but the shape and sculpture details of this species are so distinctive that it does not appear to be closely allied to any other species. The most distinctive features are the closely spaced spiral sculpture comprised of primary, secondary and tertiary threads crossed by fine growth lines giving the surface a finely granular texture. The inner lip is smooth and spination is reduced to single, very short spines at the shoulder on each varix on the last one and one-half whorls. Shell dimensions are given in Table 52.

\section{Haustellum wanneri (Martin, 1916)}

Fig. 66; Table 53

Murex (Haustellum) wanneri Martin, 1916: 240, pl. 2, figs 37, 37a, 38 (Java, Miocene; syntypes, GML). ?Haustellum wanneri.-Vokes, $1971 \mathrm{a}: 117$.

Remarks. The worn material of this species differs from all other species of Haustellum in its massive varices and 2 heavy intervarical ribs. It is probably related to the bonneti-rectirostrisdolichourus group of species. Shell dimensions are given in Table 53.

\section{DISCUSSION}

The fossil history of the species of Murex and Haustellum is summarised in Tables 54 and 55. In the genus Murex we recognise five main groups - some of which have fossil histories reaching back to the Miocene but which presumably are derived from

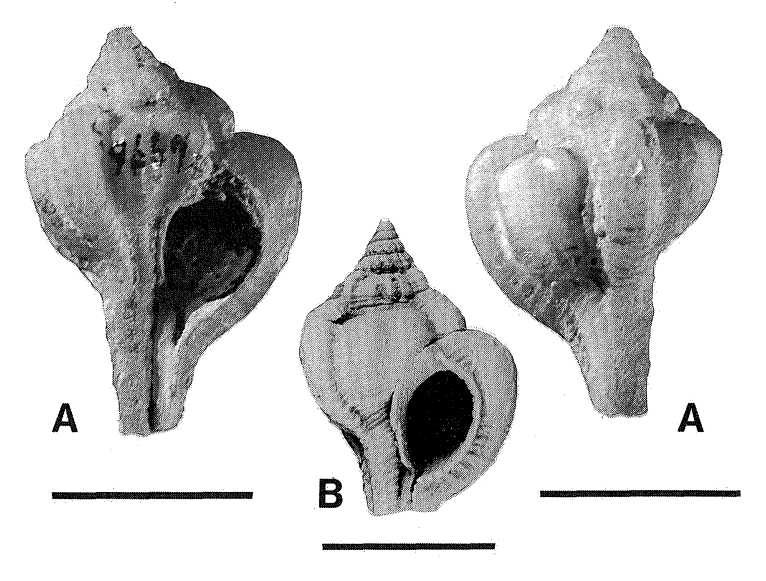

Figure 66. Haustellum wanneri (Martin). Syntypes; Java, Miocene (GML). All scales $1 \mathrm{~cm}$.

ancestors in the Oligocene or earlier. A small group including only $M$. ejectus and $M$. coppingeri are first known in the Pliocene of Java. The tribulus-like species may be first represented in the Miocene of Japan whereas the scolopax group is first known in the Miocene of Java and the brevispina group in the Miocene of East Africa.

Many of the species of Haustellum may have been derived from a single radiation in the Oligocene or early Miocene. Three distinct groups were present in the Miocene in areas as widely separated as Java, Okinawa, the Philippines and Fiji. Two of these groups, those represented by the presumed ancestors of $H$. bantamensis and $H$. rectirostris, are probably closely related. The relationships suggested in Table 55 are extremely speculative and are given only to indicate what appears to us to be the most likely relationships given the extremely meagre evidence provided by the fossil record.

It is probable that the diversification, in both genera, was due, at least in part, to initial geographic speciation in the early Tertiary, allowing eventual sympatry followed by further allopatric speciation. A major factor in the diversification of the group is the abbreviation of larval life that occurs independently in many groups (indicated by an asterisk in Tables 54 and 55).

Some indications of the patterns of speciation in Murex and Haustellum are given by their present distributions. A summary of these is given in Table 56 . These data clearly indicate that the most widely distributed species are those with a protoconch that indicates planktotrophic development but there are some that have similar protoconchs and yet have restricted distributions, e.g., $M$. coppingeri, $M$. brevispina macgillivrayi (although there is good evidence that the latter species had a wider range in 


\section{MIOCENE PLIOCENE PLEISTOCENE RECENT}
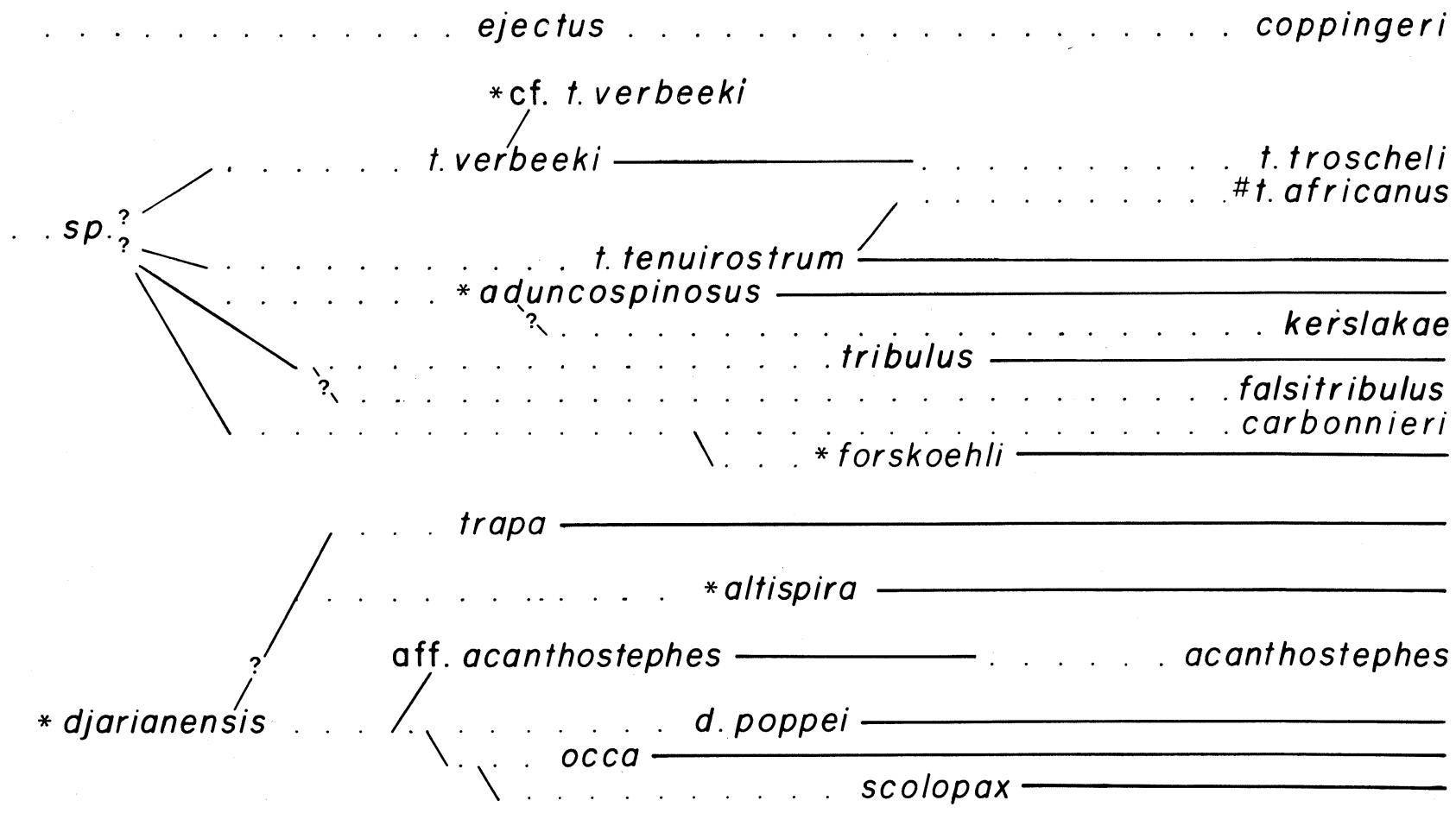

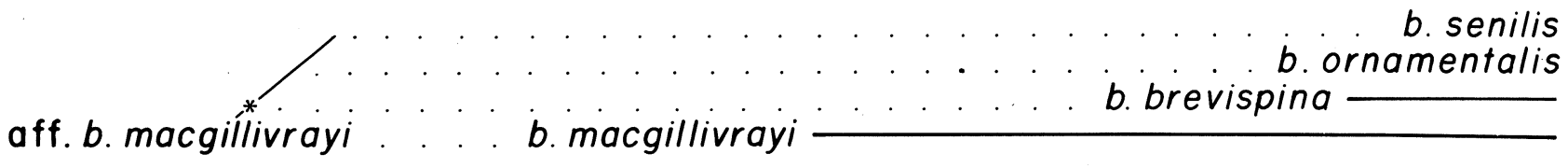

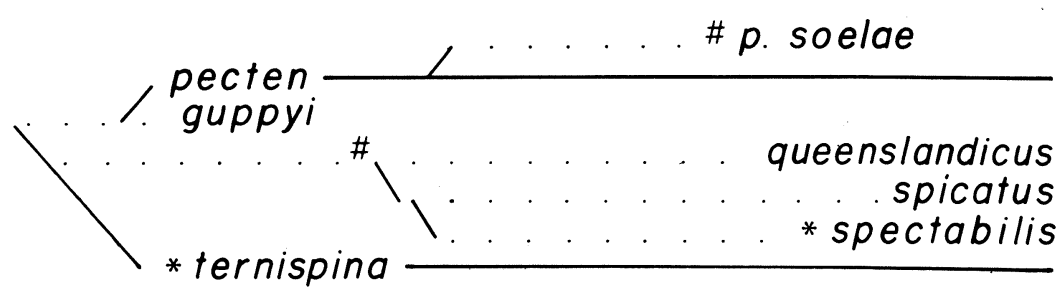

bullocki

antelmei

Table 54. A diagrammatic representation of the possible relationships between fossil and Recent species of Murex. Dotted lines indicate hypothetical lineages, ${ }^{*}$ - taxa with direct development, \# - taxa with assumed lecithotrophic development.

the late Tertiary) and $M$. (Promurex) antelmei, apparently restricted to Mauritius. It is of interest to note that three of the five most widely dispersed species have subspeciated in peripheral parts of their ranges ( $M$. tenuirostrum, $M$. pecten and $H$. haustellum) where they have adopted a different developmental strategy.

Shuto (1983) has discussed the presence of some species of Murex on oceanic islands and suggested means by which these distributions could be achieved. He makes the erroneous assumption that all species of Murex (in which he included many of the species of Haustellum) have direct development. Taxa such as $M$. tribulus, $M$. t. tenuirostrum, $M$. $p$. pecten and $H$. h. haustellum are found on oceanic islands and have planktotrophic larvae. Other species such as M. aduncospinosus and H. gallinago are found on islands separated from continental areas by deep 


\section{MIOCENE PLIOCENE PLEISTOCENE RECENT}
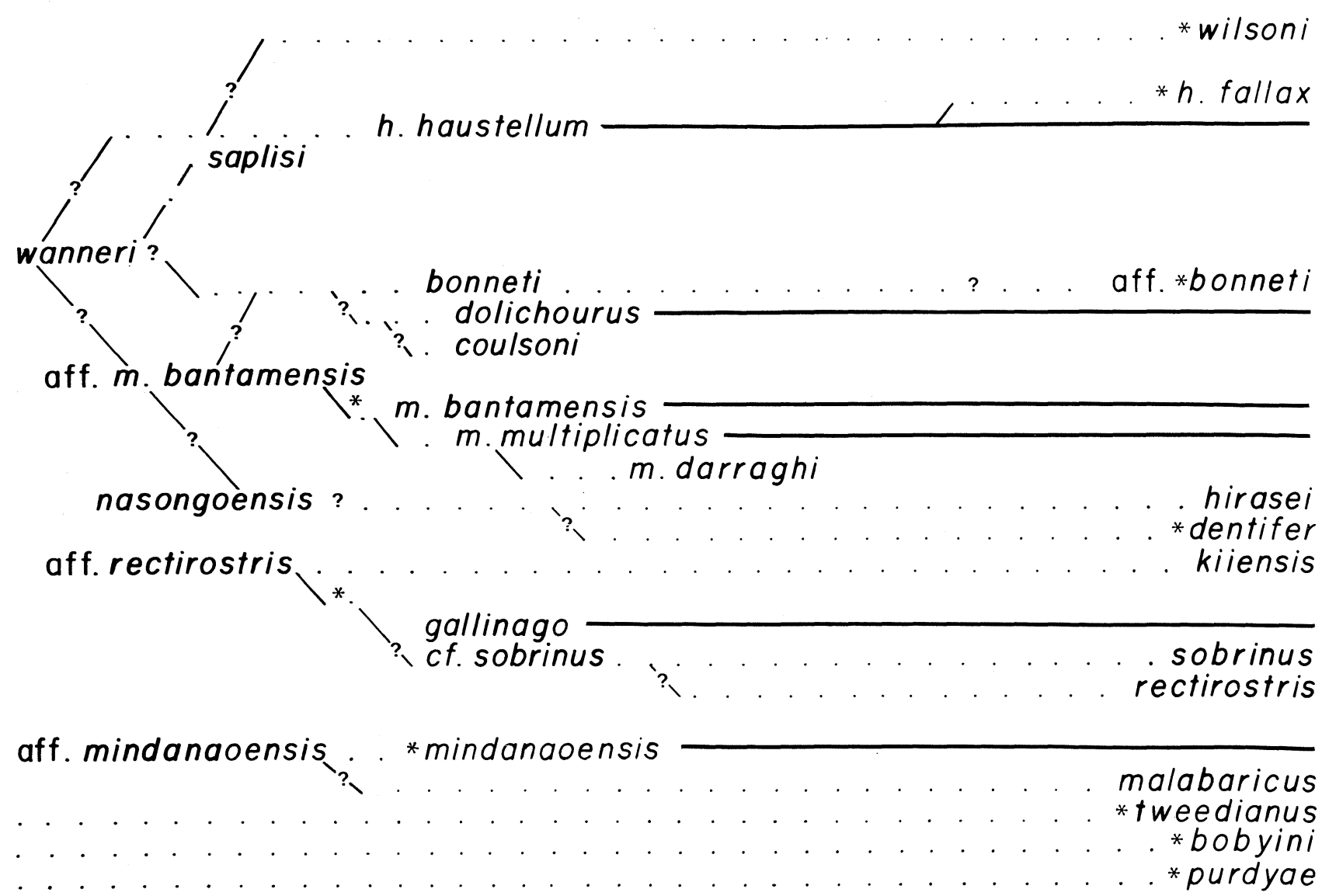

Table 55. A diagrammatic representation of the possible relationships between fossil and Recent species of Haustellum. Dotted lines indicate hypothetical lineages, ${ }^{*}$ - taxa with direct development.

oceans. These species have a paucispiral protoconch which we interpret as indicating direct development, but because the protoconchs are small compared with those of some species (e.g., Haustellum wilsoni), they could, in fact, possess a short larval life (i.e., have lecithotrophic development). Another possibility is that they have speciated to a greater extent than we recognise and the acquisition of direct development may have occurred independently. Certainly, the apparently disjunct distributions seen in $M$. aduncospinosus, $H$. gallinago and $H$. mindanaoensis may well be accounted for in this way. The records of $M$. brevispina brevispina from islands in the Indian Ocean are probably based on mislocalised material. All of the other species living on oceanic islands or having very disjunct distributions have protoconchs indicating planktotrophic development. These protoconchs have a conical shape, the whorls are rather flattened and the varix is of the sinusigera type, typical of planktotrophic veliger larvae.

Some general comments can be made about the distribution of Murex and Haustellum that apply equally well to both genera. They both have a tropical distribution, with no living species reaching north of southern Japan or to the south coast of Australia. There are no Recent or fossil species known from New Zealand, south-eastern Australia or from southern-most Africa. Only a few species extend into the Pacific islands, but no definite records further east than Samoa (one species), or Tonga (two species). This conforms rather closely to the eastward distribution noted by Kay (1979) of several genera of marine molluscs.

Of the geographic regions recognised in Table 56, the largest number of taxa (13) occur in the central part of the Indo-west Pacific (southern Japan, SouthEast Asia, the Philippines, Indonesia and Papua New Guinea). This pattern is a common one in many groups of animals (Kay, 1979). More surprising is the rather large number (nine) of species confined to the Australian shelf. The other areas showing endemism have few species confined to them: Persian Gulf-Red 


\begin{tabular}{|c|c|c|c|c|c|c|c|c|c|c|c|}
\hline SPECIES & IP & CIP & CIP-P IO-CIP & IPexInd & Ind-PG & PG & EAf & Aus & Jap & Dvlmpt & Sum \\
\hline Murex & & & & & & & & & & & \\
\hline tribulus & & & & $\mathrm{X}$ & & & & & & $\begin{array}{l}\mathrm{P} \\
\mathrm{L}\end{array}$ & $\begin{array}{l}4 \\
3\end{array}$ \\
\hline $\begin{array}{l}\text { carbonnieri } \\
\text { t.tenuirostrum }\end{array}$ & & & $\mathrm{X}$ & $\mathrm{X}$ & & & & & & $\begin{array}{l}\mathrm{L} \\
\mathrm{P}\end{array}$ & $\begin{array}{l}3 \\
4\end{array}$ \\
\hline t.africanus & & & & & & & $\mathrm{X}$ & & & $\mathrm{L}$ & 2 \\
\hline t. troscheli & & & $\mathrm{X}$ & & & & & & & $\mathrm{P}$ & 3 \\
\hline forskoehlii & & & & & & $\mathrm{X}$ & & & & $\mathrm{D}$ & 2 \\
\hline aduncospinosus & & & $\mathrm{X}$ & & & & & & & $\mathrm{D}$ & 3 \\
\hline kerslakae & & & & & & & & $\mathrm{X}$ & & $\mathrm{D}$ & 1 \\
\hline falsitribulus & & $\mathrm{X}$ & & & & & & & & $\mathrm{D}$ & 2 \\
\hline trapa & & & $\mathrm{x}$ & & & & & & & $\mathrm{P}$ & 3 \\
\hline coppingeri & & & & & & $\mathrm{X}$ & & $\mathrm{X}$ & & $P$ & 2 \\
\hline & & $\mathrm{X}$ & & & & $X$ & & & & $\begin{array}{l}\mathrm{D} \\
\mathrm{D}\end{array}$ & $\begin{array}{l}2 \\
1\end{array}$ \\
\hline $\begin{array}{l}\text { occa } \\
\text { acanthostephes }\end{array}$ & & & & & & & & $\mathrm{X}$ & & $\mathrm{D}$ & 2 \\
\hline altispira & & $\mathrm{X}$ & & & & & & & & D & 2 \\
\hline d.poppei & & $\mathrm{X}$ & & & & & & & & D & 2 \\
\hline b.brevispina & & & & & & & $\mathrm{X}$ & & & $\mathrm{D}$ & 2 \\
\hline b.senilis & & $\mathrm{X}$ & & & & & & & & $\mathrm{D}$ & 1 \\
\hline b.ornamentalis & & $\mathrm{X}$ & & & & & & & & D & 1 \\
\hline b.macgillivrayi & & & & & & & & $\mathrm{X}$ & & $P$ & 2 \\
\hline p.pecten & $\mathrm{X}$ & & & & & & & & & $P$ & 4 \\
\hline p.soelae & & & & & & & & $\mathrm{X}$ & & $\mathrm{L}$ & 1 \\
\hline queenslandicus & & & & & & & & $\mathrm{X}$ & & $\mathrm{L}$ & 1 \\
\hline $\begin{array}{l}\text { spicatus } \\
\text { sol }\end{array}$ & & & & & & & & & $\mathrm{X}$ & $\mathrm{L}$ & 1 \\
\hline spectabilis & & $\mathrm{X}$ & & & & & & & & $\mathrm{D}$ & 1 \\
\hline ternispina & & $\mathrm{x}$ & & & & & & & & D & 2 \\
\hline Haustellum & & & & & & & & & & & \\
\hline h.haustellum & $\mathrm{X}$ & & & & & & & & & $\mathrm{P}$ & $\begin{array}{l}4 \\
1\end{array}$ \\
\hline $\begin{array}{l}\text { h.fallax } \\
\text { wilsoni }\end{array}$ & & & & & & & $\mathrm{X}$ & & & $\begin{array}{l}\mathrm{D} \\
\mathrm{D}\end{array}$ & 1 \\
\hline $\begin{array}{l}\text { wison } \\
\text { tweedianus }\end{array}$ & & & & & & & & $\hat{X}$ & & D & 1 \\
\hline rectirostris & & & & & & & & & $\mathrm{X}$ & $\mathrm{D}$ & 1 \\
\hline m.multiplicatus & & & & & & & & $\mathrm{X}$ & & D & 2 \\
\hline m.bantamensis & & $\mathrm{X}$ & & & & & & & & D & 1 \\
\hline sobrinus & & & & & & & & & $\mathrm{X}$ & $\mathrm{D}$ & $?$ \\
\hline dentifer & & $\mathrm{X}$ & & & & & & & & $\mathrm{D}$ & 2 \\
\hline hirasei & & & $\mathrm{X}$ & & & & & & & $\mathrm{P}$ & 2 \\
\hline dolichourus & $\mathrm{X}$ & & & & & & & & & $\mathrm{P}$ & 4 \\
\hline gallinago & & & & $\mathrm{X}$ & & & & & & $\mathrm{D}$ & 3 \\
\hline kiiensis & & $\mathrm{X}$ & & & & & & & & $\mathrm{P}$ & 2 \\
\hline malabaricus & & & & & $\mathrm{X}$ & & & & & $\mathrm{P}$ & 3 \\
\hline mindanaoensis & & $\mathrm{X}$ & & & & & & & & D & 2 \\
\hline purdyae & & & & & & & $\mathrm{X}$ & & & D & 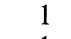 \\
\hline bobyini & & $\mathrm{X}$ & & & & & & & & $\mathrm{D}$ & 1 \\
\hline
\end{tabular}

Table 56. Summary of the distribution and development types of species of Murex and Haustellum. IP - Indo-west Pacific; CIP - central Indo-Pacific; CIP-P - central Indo-Pacific and western Pacific; IO-CIP - Indian Ocean and central Indo-Pacific; IPexInd - Indo-west Pacific excluding northern Indian Ocean; Ind-PG - northern Indian Ocean including Arabian Sea (+ Persian Gulf and Red Sea); PG - Persian Gulf and Red Sea; EAf - East Africa; Aus - Australia; Jap Japan-China Sea; Dvlpmt - assumed mode of development $(\mathrm{P}$ - planktotrophic; L - possible lecithotrophic; D direct); Sum - summary of extent of distribution (1 - very restricted; 2 - restricted to one geographic region; 3 - spread over more than one geographic region; 4 - widely dispersed within Indo-west Pacific region).

Sea (two), East Africa (four) and Japan-China Sea (three). Four of the 13 species occuring in the central Indo-west Pacific area appear to have very restricted ranges.

Several species that are assumed to have planktotrophic larvae have what appears to be disjunct distributions. These may be the result of inadequate collecting in intermediate areas (particularly in the case of $H$. hirasei, $H$. dolichourus and $M$. troscheli, which live in reasonably deep water) or, although most unlikely, competition with other species living in the intermediate areas. Murex tribulus and $M$. trapa are common, shallow-water species which occur through the central Indo-west Pacific but occur as far west as the east coast of India and Sri Lanka (M. trapa) and Indonesia (M. tribulus), except for the western part of the Indian Ocean. Both of these species are essentially replaced by $M$. carbonnieri along the northern part of the Indian Ocean. Similar replacement of species of Murex appears to occur in other areas but it is difficult to see this being the result of competitive interaction. Probably these patterns of distributions are the result of historical factors, including those influencing the dispersal of planktotrophic larvae, such as possible short-term changes in ocean currents. 
The data presented in Tables 56 and 57 clearly indicate that there is a very close correlation between the mode of development and distribution. The majority of the taxa (74.4\%) of Murex and Haustellum have restricted or semi-restricted distributions (categories 1 and 2 in Tables 56, 57). Of these $75 \%$ ( $55.8 \%$ of the total number of species) have probable direct development. Those with planktotrophic larvae (27.9\% of total species) include all five taxa (11.6\% of total species) that fall into the most widely distributed category.

\begin{tabular}{|c|c|c|c|c|}
\hline & Planktotrophic & Lecithotrophic & Direct & \\
\hline Restricted (1) & & $\begin{array}{c}3 \\
(60) \\
{[7]}\end{array}$ & $\begin{array}{c}13 \\
(50) \\
(30.2)\end{array}$ & $16(37.2)$ \\
\hline (2) & $\begin{array}{c}4 \\
(33.3) \\
{[9.3]}\end{array}$ & $\begin{array}{c}1 \\
(20) \\
{[2.3]}\end{array}$ & $\begin{array}{c}11 \\
(42.3) \\
{[25.6]}\end{array}$ & $16(37.2)$ \\
\hline (3) & $\begin{array}{c}3 \\
(25) \\
{[7]}\end{array}$ & $\begin{array}{c}1 \\
(20) \\
{[2.3]}\end{array}$ & $\begin{array}{c}2 \\
(7.7) \\
{[4.7]}\end{array}$ & $6(14)$ \\
\hline Widespread (4) & $\begin{array}{c}5 \\
(41.7) \\
{[11.6]}\end{array}$ & & & $5(11.6)$ \\
\hline Total & & $\begin{array}{c}5 \\
(11.6)\end{array}$ & $\begin{array}{c}26 \\
(60.5)\end{array}$ & \\
\hline
\end{tabular}

Table 57. Comparison of the assumed developmental mode and distribution of taxa of Murex and Haustellum. The numbers of taxa are given based on the information in Table 56. The percentage for each developmental type is given in parentheses, the percentage of the total taxa in square brackets. The totals for each horizontal and vertical column are given and each total is also expressed as a percentage of the total number of species, this figure being given in parentheses. The distribution categories are those used in Table 56. For further explanation see text.

ACKNOWLEDGEMENTS. As always.with a revision of this sort, the people that have assisted are many and far too numerous to mention all by name. Nearly all of the curators and/or collection managers of the institutions listed under Abbreviations have assisted either by sending material on loan or by providing facilities for it to be examined, or both. Some individuals have been particularly generous with their assistance. These include $\mathbf{J}$. Knudsen (ZMC), K. Way (BMNH), R.S. Houbrick, T.R. Waller and the late J. Rosewater (USNM), R. Robertson (ANSP), A.W. Janssen (GML), P. Bouchet (NHMP) and F.E. Wells (WAM).

Many collectors have provided specimens for examination and these include the late J. Kerslake, J. Bibby, V. Dan, T. Whitehead, D. Scott, A. Hinton, E. Wright, A. Richards, S. Stephens and J. Bennett.

The illustrations were mainly done by S. Dunlop, some by B. Duckworth. The majority of photographs were taken by J. Fields, some by the photographic services of the
BMNH and NHMG, and some by J. Ponder and E.H.V.

Locality data was arranged and distribution maps developed by D. Winn and J. Gillespie. D. Winn measured most of the specimens, mounted the radulae and took the SEM photos at the Sydney University Electron Microscope Unit.

E.H.V. thanks the Australian Museum Trust for providing support while on a visiting curatorship in 1980 . Funds for travel for W.F.P. were provided by the Australian Museum Trust, the Australian Research Grants Scheme, the British Council, Science and Industry Endowment Fund and the Ian Potter Foundation.

W.F.P. acknowledges G. Thornley and N. Coleman for their interest and help in the early part of this project.

The manuscript has been seen through several drafts by Mrs J. Adams and Mrs A. Thomas.

We would also like to record our thanks to Harold Vokes and Julie Ponder for their assistance in many ways during the course of this project. 


\section{References}

Abbott, R.T., 1962. Sea Shells of the World. A guide to the better-known species. Golden Press, New York. 160 pp., Illus.

Abbott, R.T. \& S.P. Dance, 1982. Compendium of seashells. E.P. Dutton, New York. 411 pp., Illus.

Ackworth, J., 1965. Communal egg case of Murex macgillivrayi. Keppel Bay Tidings 4(2): 4.

Adams, A., 1863. On the species of Muricinae found in Japan. Proceedings of the Zoological Society of London 1862: 370-376.

Adams, H. \& A. Adams, 1853-1858. The genera of Recent Mollusca arranged according to their organisation. 3 vols. London. Vol. 1 (1853-58): i-xl (1858), 1-256 (1853), 257-484 (1854).

Ahmed, M.M., 1975. Systematic study on Mollusca from Arabian Gulf and Shatt Al-Arab, Iraq. Center for Arab Gulf Studies, University of Bas,rah, Iraq. 78 pp.

Allan, J., 1950. Australian shells. With related animals living in the sea, in freshwater and on the land. Georgian House, Melbourne. 470 pp., 44 pls.

Altena, C.O. van, 1950. The marine Mollusca of the Kendeng Beds (East Java) Gastropoda. Part 5 (Families Muricidae-Volemidae inclusive). Leidse Geologische Mededelingen 15: 205-240.

Altena, C.O. van \& C. Beets, 1944. Eine Neogene Mollusken fauna vom Tji Gugur (Priangan), W. Java. Verhandelingen Geologisch-Mijnbouwkundig Genootschap Nederland en Koloniën. Geologisch Serie 14: 37-70, 1 pl.

Aoki, N. \& K. Baba, 1984. Molluscan fossils from Nobori. Institute of Geoscience, University of Tsukuba, Annual Report 10: 73-79. 39 figs.

Arakawa, K.Y., 1964. A study on the radulae of the Japanese Muricidae (2). The genera Vexilla, Nassa, Rapana, Murex, Chicoreus and Homalocantha. Venus 22(4): 355-364, pl. 21.

Argenville, A.J.D. d', 1742. L'histoire naturelle éclaircie dans deux de ses parties principales la Lithologie et la Conchyliologie dont l'une traite des Pierres et l'autre des coquillages, ..... Paris. 2 vols. $491+848$ pp., $33+19$ pls.

Baker, F.C., 1890. On the modifications of the apex in Murex. Proceedings of the Academy of Natural Sciences of Philadelphia 42: 66-72, 11 figs.

1891. Remarks on the Muricidae with descriptions of new species of shells. Proceedings of the Academy of Natural Sciences of Philadelphia 43: 5661 .

1894. Further notes on the embryonic whorls of the Muricidae. Proceedings of the Academy of Natural Sciences of Philadelphia 46: 223-224, 2 figs.

1897. Critical notes on the Muricidae. Transactions of the Academy of Natural Sciences of St Louis 7(16): 371-391.

Bandel, K., 1976. Morphologie der Gelege und ökologische Beobachtungen an Muriciden (Gastropoda) aus der südlichen Karibischen See. Verhandlungen der Naturforschenden Gesellschaft in Basel 85: 1-32, 20 figs.

Barash, A. \& Z. Danin, 1972. The Indo-Pacific species of Mollusca in the Mediterranean and notes on a collection from the Suez Canal. Israel Journal of Zoology 21: 301374, 25 figs.

Barnard, K.H., 1959. Contributions to the knowledge of
South African marine Mollusca. Part 2. Gastropoda : Prosobranchiata : Rhachiglossa. Annals of the South African Museum 45: 1-237, 52 figs.

Beets, C. 1941. Eine jungmiocäne Mollusken-Fauna von derHalbinsel Mangkalihat, Ost-Borneo. Verhandelingen Geologisch-Mijnbouwkundig Genootschap Nederland en Koloniën. Geologisch Serie 13(1): $1-218,4$ pls.

Biggs, H.E.J., 1973. The marine Mollusca of the Trucial Coast, Persian Gulf. Bulletin of the British Museum (Natural History) Zoology 24(8): 343-421, 6 pls.

Biggs, H.E.J. \& L.L. Grantier, 1960. A preliminary list of the marine Mollusca of Ras Tanura, Persian Gulf. Journal of Conchology 24: 387-392.

Bishop, M.J. and K. Way, 1976. Type specimens in the Jane Saul collection, University Museum of Zoology, Cambridge. Journal of Conchology 29: 41-46.

Blainville, H.M.D. de, 1825-27. Manuel de Malacologie et de Conchyliologie. F.G. Levrault, Paris. 664 pp., 87 pls.

Born, I., 1780. Testacea musei Caesarei Vindobonensis quae jussu Mariae Theresiae Augustae disposuit et descripsit. J.P. Kraus, Vindobonae. xxxvi + 442 pp. + unpaginated index and 18 pls.

Braga, J.M., 1952. Materiais para o estudo da fauna malacologica de Moçambique. Junta das Missões Geograficas e de Investigações do Ultramar 7: 63-127.

Brazier, J., 1877. List of marine shells, with descriptions of the new species collected during the 'Chevert' Expedition. Proceedings of the Linnean Society of New South Wales 1(3): 169-181.

1893. Catalogue of the marine shells of Australia and Tasmania. Part III. Gastropoda, Murex. Australian Museum Sydney, Catalogue 15: 45-74.

Buonanni, P., 1681. Recreatio mentis et ocvli in observatione Animalium Testaceorum curiosis naturae inspectoribus. Romae. $270+10$ pp., 512 figs.

Carriker, M.R., 1972. Observations on removal of spines by muricid gastropods during shell growth. Veliger 15(2): 69-74, 3 pls.

Catlow, A. \& L.A. Reeve; 1845. The conchologist's nomenclator. A catalogue of all the Recent species of shells included under the subkingdom 'Mollusca', with their authorities, synonymes, and references to works where figured or described. Reeve Brothers, London. iv $+326 \mathrm{pp}$.

Cernohorsky, W.O., 1967a. The Muricidae of Fiji (Mollusca: Gastropoda). Part 1. Subfamilies Muricinae and Tritonaliinae. Veliger 10(2): 111-132, pls. 14, 15. 1967b. Marine shells of the Pacific. Pacific Publications, Sydney. 248 pp.

1974. The taxonomy of some Indo-Pacific Mollusca with description of a new species. Records of the Auckland Institute and Museum 11: 121-142, 38 figs.

1978. Tropical Pacific marine shells. Pacific Publications, Sydney. 352 pp., 68 pls.

Chemnitz, J.H., 1795. Neues systematisches Conchylien Cabinet. Vol. 11. $312+124$ pp., pls 174-213.

Clench, W.J. \& I.Pérez-Farfante, 1945. The genus Murex in the western Atlantic. Johnsonia 1(17): 1-59, 29 pls.

Coleman, N., 1974. Muricids. Australian Shell News 7: 6-7.

1975. What shell is that? Lansdowne Press, Sydney. 298 pp. 1981. Shells alive! Rigby, Sydney. 96 pp. 
Colonna, F., 1616. Fabii Columnae Lyncei Purpura etc. Rome.

Cossmann, M., 1903. Faune Pliocénique de Karikal (Inde Française). Journal de Conchyliologie 51: 105-173, pls. 3-6.

Cotton, B.C., 1956. Family Muricidae. Royal Society of South Australia, Malacological Section, Publication 8: 8 unnumbered pages, 2 pls.

Cox, L.R., 1927. Neogene and Quaternary Mollusca from the Zanzibar Protectorate. Report on the Paleontology of the Zanzibar Protectorate. Zanzibar: 13-102, pls 3-19.

Cox, L.R., 1931. The geology of the Farsan Islands, Oizan and Kamaran Island, Red Sea. Part 2. Molluscan Palaeontology. The Geological Magazine 68: 1-13. 1948. Neogene Mollusca from the Dent Peninsula, British North Borneo. Schweizerische Palaeontologische Abhandlungen 66: 2-70, 6 pls.

Crichton, M.D., 1941. Marine shells of Madras. Journal of the Bombay Natural History Society 42: 323-341.

Crosse, H. \& P. Fischer, 1889. Note sur la Faune conchyliologique marine de l'Annam. Journal de Conchyliologie 29: 281-296.

Dall, W.H., 1915. An index to the Museum Boltenianum. Smithsonian Institution. Publication $2360.64 \mathrm{pp}$.

Dance, S.P., 1974. The collector's encyclopedia of shells. McGraw Hill, New York. 288 pp., Illus.

D'Attilio, A., 1979. A hard look at Murex nigrispinosus and M. tribulus. Hawaiian Shell News 27(5): 16.

D'Attilio, A. \& W.E. Old, 1971. A new muricid gastropod from Western Australia. Veliger 13(4): 316-318, 1 pl.

Dautzenberg, P., 1910. Liste de coquilles marines provenant de l'île Halmahera (Djilolo). Bulletin de l'Institut Océanographique 161: 1-4.

Dautzenberg, P. \& H. Fischer, 1907. Contribution a la faune malacologique de l'Indo-chine. Journal de Conchyliologie 54: 145-226.

Dean, J.D., 1936. Conchological cabinets in the last century. Journal of Conchology 20: 225-252.

Deshayes, G.P., 1832. Encyclopédie méthodique. Histoire naturelle des vers 3: 595-1152.

1843. Histoire naturelle des animaux sans vertèbres, by J.B.P.A. de Lamarck. 2nd edition (by G.P. Deshayes \& H. Milne Edwards). Vol. 9, 725 pp.

Deshayes, G.P. \& H. Milne Edwards, 1839. Histoire naturelle des animaux sans vertèbres. Third Edition. Volume 3. Meline, Cans et Compagnie, Brussels. 764 pp.

Dey, A.K., 1961. The Miocene Mollusca from Quilon, Kerala (India). Memoirs of the Geological Survey of India. Palaeontologia Indica 36: vii + 129 pp., 9 pls.

Dillwyn, L.W., 1817. A descriptive catalogue of Recent shells, arranged according to the Linnaean method; with particular attention to the synonymy. 2 volumes. $1092+$ 29 pp.

Dodge, H., 1957. A historical review of the molluscs of Linnaeus. Part 5. The genus Murex of the Class Gastropoda. Bulletin of the American Museum of Natural History 113: 73-224.

Dohrn, H., 1862. Descriptions of new shells. Proceedings of the Zoological Society of London 1862: 202-3.

Dunker, G., 1882. Index molluscorum maris Japonici conscriptus et tabulis iconum xvi illustralus. Theodori Fischer, vii +301 pp., 16 pls.

1883. Zwei neue Murices. Malakozoologische Blätter 6: 35-36, pl. 1 .

Eames, F.E., 1950. On the ages of certain Upper Tertiary beds of Peninsular India and Ceylon. Geological Magazine 87: 233-252.

Fair, R.H., 1976. The Murex book: An illustrated catalogue of Recent Muricidae (Muricinae, Muricopsinae, Ocenebrinae). R. Fair, Honolulu. 138 pp., 23 pls.

Favanne, J.G. de., 1784. Catalogue systématique et raisoné, ou description du magnifique cabinet appartenent ci-devant a M. le C. de. .. [M. le Comte de Latour d'Auvergne]. Paris.

Fischer, H., 1891. Catalogue et distribution géographique des mollusques terrestres, fluviatiles \& marins d'une partie de l'Indo-Chine (Siam, Laos, Cambodge, Cochinchine, Annam, Tonkin). Bulletin de la Société d'Histoire Naturelle d'Autun 4: 84(1)-277(193).

Fischer, P.J., 1927. Beitrag zur Kenntnis der Pliozänfauna der Molukken-inseln Seran und Obi. Paläontologie von Timor 15: 1-179, pls 212-217.Franca, M.L.P. da, 1960. Sobre una colecção malacológica recolhida na Ilha da Inhaca (Moçambique). Estudos de Biologia Maritima. Mem. Junta das Missões Geograficas e de Investigações do Ultramar, Series 2, 15: 43-102.

Fulton, H.C., 1936. Descriptions of five new species and varieties. Proceedings of the Malacological Society of London 22: 9-10, pl. 2.

Garrard, T.A., 1961. Mollusca collected by M.V. 'Challenge' off the east coast of Australia. Journal of the Malacological Society of Australia 1(5): 2-38, pls 1, 2. 1966. New species of Mollusca from eastern Australia (Part 2) with notes on some known species. Journal of the Malacological Society of Australia 1(10): $3-12$, pl. 1.

Gmelin, J.F., 1791 (1788-1793). Caroli a Linné systema nature. ed. 13 Lipsiae. Vol. 1(6): 3021-3910(1791); index, 3911-4120(1792).

Gray, J.E., 1839. Reptiles and Molluscous Animals. In: The Zoology of Captain Beechey's voyage; compiled from the collections on notes made by Captain Beechey, the officers and naturalist of the expedition during a voyage to the Pacific and Behring's Straits performed in H.M. Ship Blossom, under the command of Captain F.W. Beechey .... in the years 1825, 26, 27 and 28. London 1839.

Gray, M.E., 1842. Figures of molluscous animals, selected from various authors. Longman et al., London. Vol. 1, 40 pp., 78 pls.

Gualtieri, N., 1742. Index testarum conchyliorum quae adservantur in museo Nicolai Gualtieri. Florence. xxiii pp. +110 pls.

Habe, T., 1961. Coloured Illustrations of the Shells of Japan (II). Hoikusha, Osaka. ix + 183 pp., 66 pls.

1964. Shells of the Western Pacific in colour. Vol. II. English Edition. Hoikusha, Osaka. [7] + 233 pp., 66 pls.

Habe, T. \& S. Kosuge, 1966. Shells of the world in colour. Vol. 2. The tropical Pacific. Hoikusha, Osaka. vii +193 pp., 68 pls.

Hanley, S., 1855. Ipsa Linnaei Conchylia. The shells of Linnaeus, determined from his manuscripts and collection. Williams \& Norgate, London. 556 pp., 5 pls.

Harasewych, M.G., 1980. On the identity of the gastropod, Murex heros Fulton, 1936. The Nautilus 94(4): 141-2, 3 figs.

1984. Comparative anatomy of four primitive muricacean gastropods: implications for trophonine phylogeny. American Malacological Bulletin 3(1): 1126, 39 figs. 
Hatai, K. \& S. Nisiyama, 1952. Check list of Japanese Tertiary marine Mollusca. The Science Reports of the Tôhoku University, Sendai, Japan. Second Series (Geology). Special Vol. 3, 464 pp.

Hedley, C. 1901. A revision of the types of the marine shells of the 'Chevert' Expedition. Records of the Australian Museum 4: 121-130, pls 16-17.

1902. Studies on Australian Mollusca. Part VI. Proceedings of the Linnean Society of New South Wales 27: 7-29, 3 pls.

1916. A preliminary index of the Mollusca of Western Australia. Journal of the Royal Society of Western Australia 1: 152-226.

1918. Narrative of an expedition of exploration in North Western Australia by Herbert Basedow. Special Report. Mollusca. Transactions of the Royal Geographical Society of Australasia. South Australian Branch, 1916-1917: 263-283, pl. 41.

Hinton, A., 1972. Shells of New Guinea and the central Indo-Pacific. Robert Brown \& Associates, Port Moresby and Jacaranda Press, Milton. 94 pp., 44 pls.

1978. Guide to Australian shells. Robert Brown \& Associates, Port Moresby. 82 pp.

Hirase, Y., 1914-1915. The illustrations of a thousand shells. Part 1 (1914), parts 2-3 (1915).

Hirase, S., 1934. A collection of Japanese shells with illustrations in natural colours. Matsumura Sanshodo, Tokyo. $14+217$ pp., 129 pls.

Horst, R. \& M.M. Schepman, 1894 (1894-1908). Catalogue systématique des mollusques (Gastropodes prosobranches et Polyplacophores). Muséum d'Histoire naturelle des Pays-Bas 13(1): 1-176.

Houart, R., 1979. Le groupe tribulus Linné, 1758. (Gastéropodes: Muricidae). Informations de la Société Belge de Malacologie 7(4): 119-147, pls 1-5.

1980a. Some notes on Muricidae described by Shikama during the 1970's. Of Sea and Shore 94(4): $8-10$.

1980b. Le groupe tribulus Linné, 1758 (erratum) (Gastropoda: Muricidae: Muricinae). Informations de la Société Belge de Malacologie 8(4): 84-85.

Issel, A., 1869. Malacologia del Mar Rosso. Pisa. xi +353 pp., 5 pls.

Jousseaume, F., 1874. Description de quelques espèces nouvelles de coquilles appartenant aux genres Murex, Cypraea et Natica. Revue et Magasin de Zoologie 2: $3-25$.

1880. Division méthodique de la Familie des Purpuridés. Le Naturaliste 42: 335-336.

1881. Diagnoses de mollusques nouveaux. Le Naturaliste 44: 349-350.

Kaicher, S.D., 1973. Card catalogue of world-wide shells, Pack no. 2; Muricidae - I, figs 99-195. Publ. by the author, St Petersburg, Florida.

1974. Card catalogue of world-wide shells, Pack no. 6; Muricidae - II, figs 498-594. Publ. by the author, St. Petersburg, Florida.

1979. Card catalogue of world-wide shells, Pack no. 20; Muricidae - IV, figs 1976-2069. Publ. by the author, St. Petersburg, Florida.

1980. Card catalogue of world-wide shells, Pack no. 25 Muricidae - V, figs 2498-2603. Publ. by the author, St. Petersburg, Florida.

Kay, E.A., 1979. Little worlds of the Pacific. An essay on Pacific Basin biogeography. University of Hawaii, Honolulu. 40 pp.
Kiener, L.-C., 1843. Spécies général et iconographie des coquilles vivantes comprenant la collection du Muséum d'Histoire Naturelle de Paris etc. Vol. 7. Famille des Canaliferes, 3. Genre Rocher (Murex, Lin.), 130 pp., 47 pls.

Kilburn, R. \& E. Rippey, 1982. Sea shells of southern Africa. Macmillan South Africa, Johannesburg. 249 pp., 46 pls.

King, S.G. \& C. Ping, 1931. The molluscan shells of Hong Kong. Part II. The Hong Kong Naturalist, 2(4): 265286.

Kira, T., 1955. Coloured Illustrations of the Shells of Japan. Hoikusha Osaka. [8] + 204 pp., 67 pls.

1959. Coloured Illustrations of the Shells of Japan. Hoikusha, Osaka. [7] + 239 pp., 71 pls.

1962. Shells of the Western Pacific in Colour. Hoikusa, Osaka. 224 pp., 72 pls.

Klein, J.T., 1753. Tentamen Methodi Ostracologicae sive dispositio naturalis Conchlidum et concharum in suas classes, genera et species, iconibus fingulorum Generum aeri illustrata etc. Wishoff, $177+44+15$ pp. + indices, 12 pls.

Knorr, G.W., 1757-72. Vergnügen der Augen und des Gemüths in Vorstellung einer allgemeinen Sammlung von Schnecken und Muscheln. 3 vols. Nuremberg. $790+$ 100 pp., 190 pls.

Knudsen, J., 1950. Egg capsules and development of some marine prosobranchs from tropical West Africa. Atlantide Report 1: 85-130.

Kobelt, W., $1876 \quad(1876-1878)$ Illustrirtes conchylienbuch. Bauer \& Raspe, Nürnberg. 104 + xvi, 105-144 pp., 50 pls.

Koperberg, E.J., 1931. Jungtertiäre und Quatäre Mollusken vom Timor. 'S-Gravenhage. 165 pp., 3 pls.

Kosuge, S., 1980. Studies on the collection of Mr Victor Dan (2). Description of a new species of the genus Haustellum (Gastropoda: Muricacea). Bulletin of the Institute of Malacology, Tokyo 1(4): 57-58, pl. 17.

1983. Description of a new species of the genus Murex from Philippines (Gastropoda). Bulletin of the Institute of Malacology, Tokyo 1(9): 135-136, pl. 47.

Kuroda, T., T. Habe \& K. Oyama, 1971. The sea shells of Sagami Bay. Maruzen, Tokyo. xvi $+741+489+51$ pp., $121 \mathrm{pls}$.

Küster, C.H. \& W. Kobelt, 1845-1878. Die geschwänzten und bewehrten Purpur schnecken (Murex, Ranella, Tritonium, Trophon, Hindsia). Systematisches Conchylien-Cabinet von Martini und Chemnitz 3(2): $1-336$, pls $1-77$.

Ladd, H.S., 1934. Geology of Vitilevu, Fiji. Bernice P. Bishop Museum Bulletin 119: 1-263, 44 pls.

1977. Cenozoic fossil mollusks from western Pacific islands; Gastropods (Eratoidae through Harpidae). U.S. Geological Survey Professional Paper 533: i-iii, 1-84, 23 pls.

1982. Cenozoic fossil mollusks from western Pacific islands; Gastropods (Eulimidae and Volutidae through Terebridae). U.S. Geological Survey Professional Paper 1171: i-iii, 1-100, 41 pls.

Lamarck, M. de, 1822. Histoire naturelle des Animaux sans Vertèbres. Vol. 7. Paris. 711 pp.

Lightfoot, J., 1786. A catalogue of the Portland Museum, lately the property of the Duchess Dowager of Portland, deceased: which will be sold by auction etc. London. vii $+194 \mathrm{pp}$

Lindner, G., 1977. Seashells of the World. Australia \& New 
Zealand Book Company, Brookvale. 271 pp.

Linné, C., 1758. Systema naturae per regna tria naturae. . . editio decima. Vol. 1, Regnum Animale. Holmiae (Stockholm). 824 pp.

1764. Museum Ludovicae Ulricae Regine Svecorum, Gothorum, Vandalorumque etc. In quo Animalia rariora, exotica, Imprimis Insecta \& Conchilia describuntur \& determinantur. Holmiae. 717 pp.

1767. Systema naturae [etc.], 12th Edition. 1(2): 533-1327 + index.

Lischke, C.E., 1868. Diagnosen neuer Meeres-Conchylien von Japan. Malakozoologische Blätter 15: 218-226.

1869. Japanische Meeres-Conchylien. Ein beitrag zur kenntniss der Mollusken Japan's mit besonderer rücksicht auf die geographische verbreitung derselben. Volume 1. Theodor Fischer, Cassel. 192 pp., 14 pls.

Lister, M., 1685-1692[1697]. Historiae sive synopsis methodicae conchyliorum. London. 2 volumes (complete work not seen).

Ludbrook, N.H., 1978. Quaternary molluscs of the western part of the Eucla Basin. Geological Survey of Western Australia. Bulletin 125: 1-286, 24 pls, 7 figs.

Macdonald, J.D., 1868. Typical valve of lingual dentition in the Gasteropoda. Annals and Magazine of Natural History. Ser. 4, 2: 237-244, pl. 16.

MacNeil, F.S., 1960. Tertiary and Quaternary Gastropoda of Okinawa. U.S. Geological Survey Professional Paper 339: i-iv, 1-148, 19 pls.

Macpherson, J.H., 1959. New gasteropods from north Australia. Memoirs of the National Museum, Melbourne 24: 51-57, $1 \mathrm{pl}$.

1962. New name for Murex espinosus Macp. Memoirs of the National Museum, Melbourne 25: 176.

Makiyama, J., 1927. Molluscan fauna of the lower part of the Kakegawa Series in the Province of Tôtômi, Japan. Memoirs of the College of Science, Kyoto Imperial University, Series B, 3(1): 1-147, 6 pls.

1957. Matajiro Yokoyama's Tertiary fossils from various localities in Japan. Part I. Palaeontology Society of Japan, Special Papers, Number 3: 1-4, pls 1-24.

1958. Matajiro Yokoyama's Tertiary fossils from various localities in Japan. Part II. Palaeontology Society of Japan, Special Papers, Number 4: 1-6, pls $25-57$

Malusa, J.R., 1985. Attack mode in a predatory gastropod: labial spine length and the method of prey capture in Acanthina angelica Oldroyd. Veliger 28: 1-5.

Martin, K., 1884. Pälaontologische Ergebnisse von Tiefbohrungen auf Java - Pt. 2/3. Sammlungen des Geologischen Reichs-Museums in Leiden. Series 1, 3: 43-84, pls 4-9.

1895. Die Fossilien von Java auf grund einer sammlung von Dr R.D.M. Verbeek. Sammlungen des Geologischen Reichs-Museums in Leiden. New Series. 1(2-5): 1-132, pls 1-20.

1916. Die Altmiocäne fauna des WestProgogebirges auf Java. A. Gastropoda. Sammlungen des geologischen Reichs-Museums in Leiden. New Series. 2(6): 223-260, 3 pls.

1928. Mollusken aus dem Neogen von Atjeh in Sumatra. Wet. Dienst Mijnbouw 10: 1-35, 1 pl.

Martini, F.H., 1777. Neues systematisches ConchylienCabinet geordnet und beschrieben etc. Vol. 3, vi +434 pp., pls lxvi-cxxi.

Masuda, K. \& H. Noda, 1976. Checklist and bibliography of the Tertiary and Quaternary Mollusca of Japan, 1950-1974. Saito Ho-on Kai, Sendai. 494 pp.

McMichael, D.F., 1960. Some common shells of the Australian sea-shore. Jacaranda Press, Brisbane. 127 pp.

Melvill, J.C., 1928. The marine Mollusca of the Persian Gulf, Gulf of Oman, and north Arabian Sea, as evidenced mainly through the collections of Captain F.W. Townsend, 1893-1914. - Addenda, corrigenda, and emendanda. Proceedings of the Malacological Society of London 18(3): 93-117.

Melvill, J.C. \& R. Standen, 1898. The marine Mollusca of Madras and the immediate neighbourhood. Journal of Conchology 9: 30-48.

1899. Report on the marine Mollusca obtained during the first expedition of Prof. A.C. Haddon to the Torres Straits in 1888-89. Journal of the Linnean Society of London 27: 150-206, pls 1-2.

1901. The Mollusca of the Persian Gulf, Gulf of Oman, and Arabian Sea, as evidenced mainly through the collections of Mr F.W. Townsend, 1893-1900; with descriptions of new species. Part 1. Cephalopoda, Gastropoda, Scaphopoda. Proceedings of the Zoological Society of London for 1901, 2(1): 327-460, pls xxixxiv.

Melvin, A.G., 1966. Sea shells of the world. Charles E. Tuttle, Rutland. 167 pp.

Menke, C.T., 1843. Molluscorum Novae Hollandiae specimen, quod ad celebrandum diem jubilaeum vicesimum sextum mensis Februarii anni MDCCCXLIII quo per viginti quinque annos Professoris Muneri in illustri gymnasio academico Hamburgensi praefuit vir doctissimus, clarissimus Joannes Georgius Christianus Lehmann. Hannoverae. $46 \mathrm{pp}$.

Moazza, P.G., 1939. Mollusques testacés marins du Canal de Suez. Institute Égypt Memoire 38: 1-283, color pl. + pls 1-14, 4 maps.

Montfort, D. de, 1810. Conchyliologie systématique, et classification méthodique des coquilles. Tome second. Coquilles univalves, non cloisonnées. Schoell, Paris. $676 \mathrm{pp}$.

Mörch, O.A.L., 1852. Catalogus Conchyliorum quae reliquit d. Alphonso d'Aguirra \& Gadea Comes de Yoldi, regis daniae cubiculariorum princeps, ordinis dannebrogici in prima classe \& ordinis caroli Tertii eques. Part 1. Cephalophora. Hafniae. 170 pp.

Morlet, L., 1889. Catalogue des coquilles recueillies, par M. Pavie, dans le Cambodge et le Royaume de Siam, et description d'espèces nouvelles. Journal de Conchyliologie 29(2): 121-199.

Moura, A.R., 1969. Contribuição para o conhecimento dos grés costeiros do sul do save (Moçambique). Boletim dos serviços de Geologia e Minas Moçambique 35: 1-78.

Natarajan, A.V., 1957. Studies on the egg masses and larval development of some prosobranchs from the Gulf of Mannar and Palk Bay. Proceedings of the Indian Academy of Sciences 46(3): 170-228, 3 pls.

Newton, R.B., 1900. Pleistocene shells from the raised beach deposits of the Red Sea. The Geological Magazine, new series, 7(11): 500-560.

Nomura, S., 1935. Catalogue of the Tertiary and Quartery (sic) Mollusca from the Island of Taiwan (Formosa) in the Institute of Geology and Palaeontology, Tôhoku Imperial University, Sendai, Japan. Part 2, Scaphopoda and Gastropoda. The Science Reports of the Tôhoku 
Imperial University, Sendai, Japan. Second Series (Geology) 18(2): 53-228, pls 6-10.

Nuttall, C.P., 1965. Report on the Haile collection of fossil Mollusca from the Plio-Pleistocene Togopi Formation, Dent Peninsula, Sabah, Malaysia. Geological Survey, Borneo Region, Malaysia, Memoir 16: 155-192.

Odhner, N.H., 1917. Results of Dr E. Mjöbergs Swedish scientific expeditions to Australia 1910-1913. XVII. Mollusca. Kungl. Svenska Vetenskapsakademiens Handlingar 52(16): 1-115, 3 pls.

Olearius, A., 1666. Die Gottorfische Kunstkammer, worinnen allerhand ungemeine sachen, etc. Schleswig.

Oostingh, C.H., 1923. Recent Shells from Java. Part 1. Gastropoda. Mededeelingen van de Landbouwhoogeschool te Wageningen (Nederland) 26(3): $1-174,1$ pl.

1925. Report on a collection of Recent shells from Obi and Halmahera (Moluccas). Mededeelingen van de Landbouwhoogeschool te Wageningen (Nederland) 29(1): $1-362$.

1935. Die Mollusken des Pliozäns von Boemiajoe (Java). Dienst van den Mijnbouw in NederlandschIndië. Wetenschappelijke Mededeelingen 26: 1-247, 17 pls.

1940. Die Mollusken des Pliocäns von SüdBantam in Java. De Ingenieur in Nederlandsch-Indië. IV. Mijnbouw en Geologie 7(4): 45-62.

Oyama, K. \& Y. Takemura, 1957-58. The molluscan shells. Volumes 1 (1957) and 2 (1958). Murex pls 1-2 (vol. 1), 3-4 (vol. 2). Science and Photography Club, Tokyo.

Paine, R.T., 1966. Function of the labial spine, composition of diet, and size of certain marine gastropods. Veliger 9: 17-24.

Pallary, P., 1938. Les Mollusque marins de la Syrie. Journal de Conchyliologie 82: 5-58, pls 1, 2.

Paul, C.R.C., 1981. The function of the spines in Murex (Murex) pecten Lightfoot and related species (Prosobranchia: Muricidae). Journal of Conchology 30: 285-294, 2 pls.

Perry, G., 1810 (1810-1811). Arcana, or the Museum of Natural History; containing the most recent discovered objects. .. George Smeeton, London. 251 unnumbered pages, 84 pls.

1811. Conchology, or the natural history of shells: containing a new arrangement of the genera and species, illustrated by coloured engravings executed from the natural specimens and including the latest discoveries. Blumer \& Co., London. 61 pls.

Poirier, M.J., 1883. Revision des Murex du Muséum. Nouvelles Archives du Muséum Histoire Naturelle, Series 2, 5: 13-128, pls 4-6.

Popenoe, W.P. \& R.M. Kleinpell, 1978. Age and stratigraphic significance for Lyellian correlation of the fauna of the Vigo Formation, Luzon, Philippines. Occasional Papers of the California Academy of Sciences 129: 1-73.

Pusch, G.G., 1837 (1836-1837). Polens paläontologie, oder Abbildung und Beschreibung der vorzüglichsten und der noch undeschriebenen Petrefakten aus den Gebirgsformationen in Polen, Volhynien und den Karpathen. . Stuttgart. 218 pp., 16 pls.

Quoy, J.M.C. \& J.P. Gaimard, 1832-1835. Voyage de découvertes de l'Astrolabe, exécuté par ordre du Roi, pendant les années 1826-1829, sous le commandement de M.J. Dumont d'Urville. Paris. Zoologie, Mollusca, vol. 2: 1-320 (1832), 321-686 (1833); vol. 3: 1-366 (1834), 367-954 (1835); atlas, 107 pls.

Radwin, G.E. \& A. D'Attilio, 1976. Murex shells of the world. An illustrated guide to the Muricidae. Stanford University Press, Stanford. 284 pp., 32 pls, 192 figs.

Reeve, L.A., 1841-42. Conchologia systematica, or complete system of conchology: in which the Lepades and Conchiferous Mollusca are described and classified according to their natural organisation and habits. Longmans, London. 2 vols, vol. 1 (1841), vi + 195 pp.; vol. 2 (1842), 337 pp., 300 pls.

1845. Conchologia Iconica: or, illustrations of the shells of Molluscous animals. Volume 3. Murex: $36+1$ pls (1845-46, 1849).

1846. Descriptions of new species of Murex. Proceedings of the Zoological Society of London, 1845: 85-88.

Rehder, H., 1967. Valid zoological names of the Portland Catalogue. Proceedings of the United States National Museum (Smithsonian) 121(3579): 1-51.

Reichenback, 1828. Zoologie oder Naturgeschichte Thierreichs. Dresden. Vol. 1 (not seen).

Rippingale, O.H. \& D.F. McMichael, 1961. Queensland and Great Barrier Reef shells. Jacaranda Press, Brisbane. 210 pp., 29 pls.

Röding, P.F., 1798. Museum Boltenianum sive Catalogus cimeliorum e tribus regnis naturae quae olim collegerat Joa. Fried Bolten, M.D. p.d. Hamburg. viii +199 pp.

Rouillard, A., 1980. Is it the rarest? Hawaiian Shell News 28(4): 4.

Rumphius, G.E., 1705. Amboinische Rariteitkammer, of eene beschryvinge van allerhande Schoalvisschen; benevens de Voornaamste Hoorntjes en Schulpen, als ook zommige, mineraalen, gesteenten, enz. Amsterdam. Foreword $+340 \mathrm{pp}$. + index, 60 pls.

Schepman, M.M., 1911. The Prosobranchia of the Siboga Expedition Pt 4, Rachiglossa. Monograph 49d, 116 pp., 7 pls. Uitkomsten op Zoologisch, Botanisch, Oceanographisch en Geologisch gebied verzameld in Nederlandisch Oost-Indië 1899-1900 aan boord H.M. Siboga onder commando van Luitenant ter zee I?e? kl. G.F. Tydeman. Brill, Leiden.

Schumacher, H.C.F., 1817. Essai d'une nouveau système des habitations des vers testacés, etc. Copenhagen. iv + 287 pp., 22 pls.

Scott, D., 1973. Long Beach bonanza. Keppel Bay Tidings 12(3): 1,5 . 18(1): 1 .

1979. A puzzling Murex. Keppel Bay Tidings

Seba, A., 1758. Locupletissimi rerum naturalium thesauri accurata descriptio. Vol. 3. Amsterdam.

Shikama, T., 1964. Description of new species of Murex and Conus from the Arafura Sea. Venus 23(1): 33-37, pl. 3 .

1970. On some noteworthy marine Gastropoda from southwestern Japan (II). Science Reports of the Yokohama National University, Section II, BiologyGeology 16: 19-27, 1 pl.

1973. Description of new marine Gastropoda from the East and South China Seas. Science Reports of the Yokohama National University, Section II, BiologyGeology 20: 1-8, 2 pls, 2 text-figs.

1977. Descriptions of new and noteworthy Gastropoda from Western Pacific and Indian Oceans. Science Reports of the Yokohama National University, Section II. Biology-Geology 24: 9-23, 5 pls. 
Shuto, T., 1961. Palaeontological study of the Miyazaki Group - a general account of the faunas. Memoirs of the Faculty of Science, Kyushu University, Series D, Geology 10(2): 73-206.

1969. Neogene gastropods from Panay Island, the Philippines. Memoirs of the Faculty of Science, Kyushu University. Series D, Geology, 19(1): 1-250, 24 pls.

1982. Miocene molluscs from the Macasilao and Paghumayan Formations, Negros Island, the Philippines. Geology and Palaeontology of Southeast Asia 23: 101-135, pls 17-19.

1983. Larval development and geographical distribution of the Indo-west Pacific Murex. Bulletin of Marine Science 33(3): 536-544, 3 figs.

Smith, E.A., 1879. On a collection of Mollusca from Japan. Proceedings of the Zoological Society of London, 1879: 181-218, pls 19, 20.

1884. Report on the zoological collections made in the Indo-Pacific Ocean during the voyage of the 'Alert', 1881-82. Part 1. The collections from Melanesia. Mollusca: 34-508, 657-659, pls IV-XLIV. British Museum (Natural History), London.

1891. On a collection of marine shells from Aden, with some remarks upon the relationship of the molluscan fauna of the Red Sea and the Mediterranean. Proceedings of the Zoological Society of London 1891: 390-436, pl. 33.

1894. Natural history notes from H.M. Indian marine survey steamer 'Investigator' Commander C.F. Oldham, R.N. . series 2, no. 10. Report upon some Mollusca dredged in the Bay of Bengal and Arabian Sea. Annals and Magazine of Natural History, Series 6, 14 : $157-174 ; 366-368$, pls $3-5$.

1897-98. Illustrations of the Zoology of the Royal Indian marine survey steamer 'Investigator'. Government Printer, Calcutta. Part 1, pls 1-8. 1901. On South African marine shells, with descriptions of new species. The Journal of Conchology 10(4): 104-116, pl. 1.

1903. List of species of Mollusca from South Africa. Proceedings of the Malacological Society, London 5(6): 354-402, pl. 15.

Smith, E.H., 1967. The neogastropod stomach, with notes on the digestive diverticula and intestine. Transactions of the Royal Society of Edinburgh 67(2): 23-42.

Smith, M., 1953. An illustrated catalog of the Recent species of the Rock Shells. Muricidae, Thaisidae and Coralliophilidae. Tropical Laboratory, Windermere, Florida. ix +84 pp., 23 pls.

Sowerby, G.B. (1 st), 1828 (1820-34). The genera of Recent and fossil shells, for the use of students in conchology and geology. 2 volumes.

Sowerby, G.B. (2nd), 1832-1841a. The Conchological Illustrations. Sowerby, London. Murex 1834-1841, pls 58-67 (1834), pls 187-99 and catalogue, pp. 1-9 (1841).

$1841 \mathrm{~b}$. Descriptions of some new species of Murex, principally from the collection of $\mathrm{H}$. Cuming Esq. Proceedings of the Zoological Society of London 1840: $137-147$.

1879. Thesaurus conchyliorum, or monographs of genera of shells. Volume 4. Murex, parts 35-36, 55 pp., 23 pls.

1895. Descriptions of nine new species of shells. Proceedings of the Malacological Society, London 1(5): 214-217.
Sowerby, G.B. (3rd), 1903. Mollusca of South Africa. Marine Investigations in South Africa 2: 213-232, pls III-IV.

Sturany, R., 1903. Gastropoden des Rothen Meeres. Expeditionen S.M. Schiff 'Pola' in das Rothe Meer Nördliche und Südliche Hälfte 1895/96-1897/98. Zoologische ergebnisse. XXIII. Berichte der Commission für Oceanographische Forschungen. Wein. 75 pp., 7 pls.

Swainson, W., 1833(1820-33). Zoological Illustrations . . . etc. (Ser. 2) London. Pls 97-136 (1833).

1840. A treatise on malacology or the natural classification of shells and shell-fish. Longmans et al., London. 419 pp.

Takemura, Y. \& T. Okutani, 1955. Notes on animals attached to the shells of the Silver-lip Pearl Oyster, Pinctada maxima (Jameson), collected from the 'East' fishing ground of the Arafura Sea. Bulletin of Japanese Society of Scientific Fisheries 21(2): 91-101, 6 pls.

Tantanasiriwong, R., 1978. An illustrated checklist of marine shelled gastropods from Phuket Island, adjacent mainland and offshore islands, western Peninsula Thailand. Phuket Marine Biological Centre, Phuket, Thailand, Research Bulletin 21: 1-22, 259 figs.

Tapparone-Canefri, C.M., 1875. Studio monografico sopra I. Muricidi del Mar Rosso. Viaggio dei Signori O. Anthinori, O. Beccari ed A. Issel nel Mar Rosso, ..... anni 1870-71. Annali del Museo Civico di Genova $7: 560-640$, pl. 1 .

1876. Zoologia del viaggio intorno al Globo della R. Fregata Magenta diviante gli anni 1865-68. Malacologia. Memorie della R. Accademia delle Scienze di Torino, Ser. 2a, 28: 109-265.

Taylor, J.D., 1980. Diets of sublittoral predatory gastropods of Hong Kong. Proceedings of the first International Marine Biological Workshop: The Marine Fauna and Flora of Hong Kong and Southern China. Hong Kong University Press. Vol. 2: 907-920.

Taylor, M., 1954. Variation of the shells of Murex tribulus from the Great Bitter Lake, Egypt. Nature 174: 1111.

Tesch, P., 1915. IX. Jungtertiäre und quartäre Mollusken von Timor. 1 Teil. Paläontologie von Timor 5: 1-70; pls $73-82$.

Thorson, G., 1940. Studies on the egg masses and larval development of Gastropoda from the Iranian Gulf. Danish Sci. Invest. Iran. Pp. 159-238.

Troschel, F.H., 1866-1875. Das gebiss der schnecken zur begründung einer natürlichen classification. Berlin. Vol. 2 , parts $1-3,180$ pp., 16 pls.

Tryon, G.W., 1880. Manual of Conchology; structural and systematic. With illustrations of the species. Volume 2. Muricinae, Purpurinae. Philadelphia, privately printed. 289 pp., 70 pls.

Uozumi, S. \& T. Fujie, 1966. Neogene molluscan fauna in Hokkaido. Part II. Description of the Okushiri fauna associated with Vicarya, from Okushiri Island, Southwest Hokkaido. Journal Hokkaido University Faculty of Science. Series 4, Geology and Mineralogy 13(2): 139-163, pls 11-13.

Viader, 1938. Descriptions of nine marine shells from Mauritius and its dependencies. Bulletin of the Mauritius Institute 1(3): 3-8, pls 1-2.

Vokes, E.H., 1963. Cenozoic Muricidae of the Western Atlantic region, Part I - Murex s.s. Tulane Studies in Geology 1(3): 93-123, pls 1-4. 1964. Supraspecific groups in the subfamilies 
Muricinae and Tritonaliinae (Gastropoda: Muricidae). Malacologia 2(1): 1-41.

1967. Observations on Murex messorius and Murex tryoni, with the description of two new species of Murex. Tulane Studies in Geology 5(2): 81-90, pls $1-4$.

1970. Some comments on Cernohorsky's "Muricidae of Fiji" (The Veliger, 1967). Veliger, 13: 182-187.

1971a. Catalogue of the genus Murex Linné

(Mollusca: Gastropoda); Muricinae, Ocenebrinae. Bulletins of American Paleontology 61 (268): 1-141. $1971 \mathrm{~b}$. The geologic history of the Muricinae and the Ocenebrinae. The Echo 4: 37-54, 6 figs.

1974. Three species of Australian Muricidae (Gastropoda) with ancestors in the American Tertiary. Journal of the Malacological Society of Australia 3(1): 7-14, pls 1-3.

1978. Muricidae (Mollusca: Gastropoda) from the eastern coast of Africa. Annals of the Natal Museum 23(2): 375-418, pls 1-8.

Vredenburg, E., 1925. Descriptions of Mollusca from the Post-Eocene Tertiary formation of North-western India: Cephalopoda, Opisthobranchiata, Siphonostomata. Memoirs of the Geological Survey of India 50(1): i-xii, $1-351$, pls. i-xvi.

Wanner, J. \& E. Hahn, 1935. Miocäne Mollusken aus der Landschaft Rembang (Java). Zeitschrift der Deutschen geologischen Gesellschaft 87(4): 222-273, pls 17-21.

Watson, R.B., 1883. Mollusca of "H.M.S. Challenger" expedition. Journal of the Linnean Society, London 16: 494-611.

1885-86. Report on the Scaphopoda and Gasteropoda collected by "H.M.S. Challenger" during the years 1873-76. Report on the Scientific Results of the Voyage of "H.M.S. Challenger" during the years 1873-76. Zoology. Vol. XV(II): i-v, 1-756, 50 pls.

Webb, W.F., 1936. Handbook for shell collectors. Illustrations and descriptions of 2200 species of Mollusca. New York, 291 pp.

Wells, F.E., 1981. Molluscan fauna of the Admiralty Gulf, Cape Voltaire, and the Institut Islands, Kimberley, Western Australia. Chitons, meso- and neogastropods.
Biological Survey of Mitchell Plateau and Admiralty Gulf, Kimberley, Western Australia. Western Australian Museum, Perth. Pp. 249-263.

Wilson, B.R., 1985. Direct development in southern Australian cowries (Gastropoda: Cypraeidea). Australian Journal of Marine and Freshwater Research 36: $267-280$.

Wilson B.R. \& K. Gillett, 1971. Australian Shells, illustrating and describing 600 species of marine gastropods found in Australian waters. A.H. \& A.W. Reed, Sydney. 168 pp.

Wissema, G.G., 1947. Young Tertiary and Quaternary Gastropoda from the Island of Nias (Malay Archipelago). L.H. Becherer, Leiden. 212 pp., 6 pls.

Wood, W., 1818. Index testaceologicus; or a catalogue of shells, British and foreign, arranged according to the Linnean system; with the Latin and English names, references to figures, and places where found. Privately printed, London. 189 pp., 38 pls.

1828. Index testaceologicus; or a catalogue of shells, British and foreign, arranged according to the Linnean system; with the Latin and English names, references to authors and places where found. Illustrated with 2300 figures. Second Edition, corrected and revised. Privately printed, London. 212 pp., 38 pls, + Supplement, 59 pp., 38 pls.

Wood, W. \& S. Hanley, 1856. Index testaceologicus, an illustrated catalogue of British and foreign shells, containing about 2800 figures accurately coloured after nature. Willis \& Sotheran, London. 234 pp., $38+8$ pls.

Wu, S.-K., 1965. Studies on the radulae of Taiwan muricid gastropods. Bulletin Institute Zoology Academia Sinica (Taipei) 4: 95-106.

1973. Comparative studies on the digestive and reproductive systems of some muricid gastropods. Bulletin of the American Malacological Union 1972: 18.

Yokoyama, M., 1923 [1924]. Tertiary fossils from Kii. Japanese Journal of Geology and Geography 2: 47-58, pls 6,7 .

1926. Tertiary Mollusca from southern Totomi. Journal of the Faculty of Science, Imperial University of Tokyo, section 2, 1(9): 313-364, pls 38-41.

Accepted 10 April 1987 

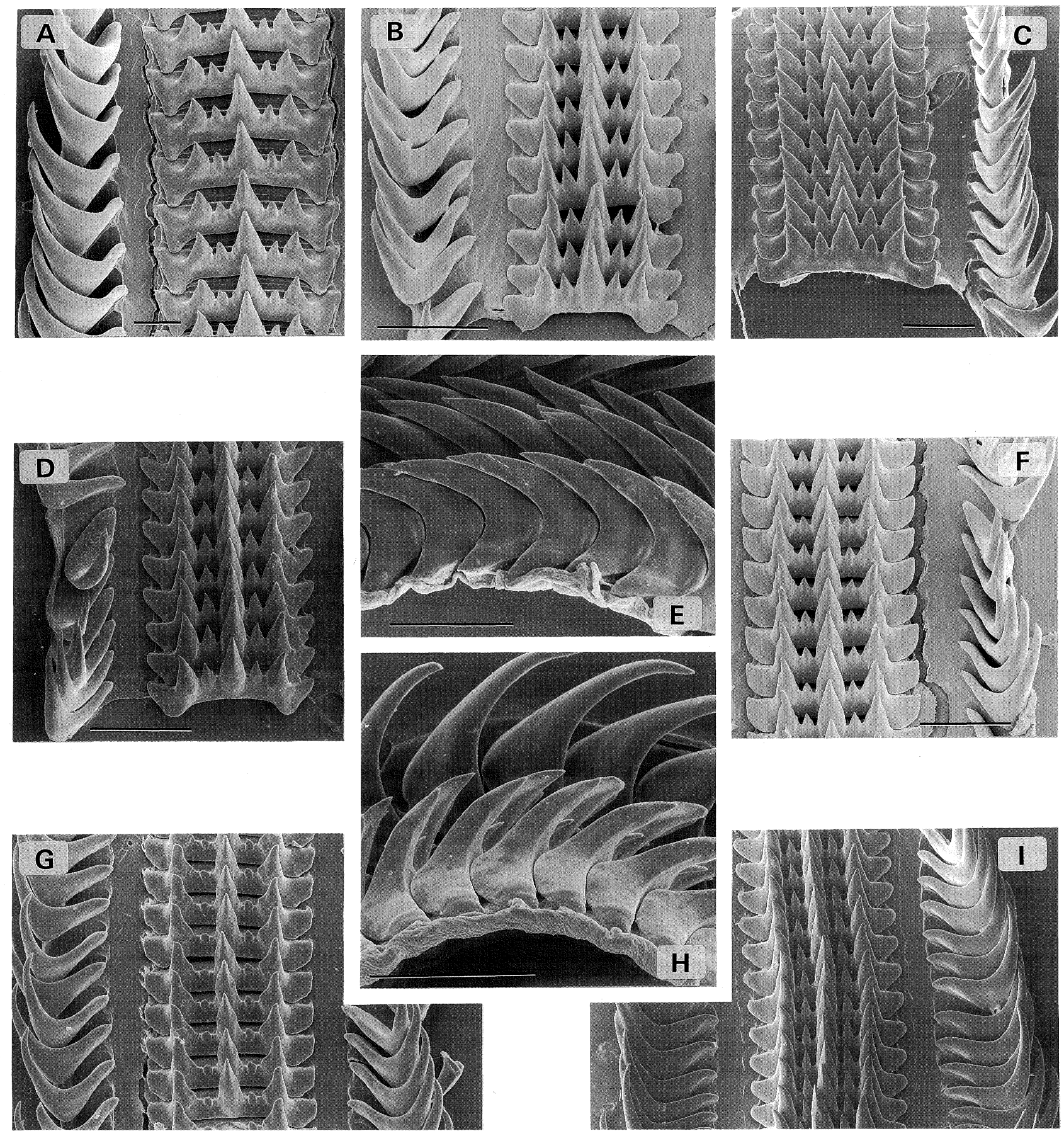

Figure 67. Radulae of species of Murex. A: Murex brevispina brevispina Lamarck; Zanzibar (MCZ, 3792). B: Murex queenslandicus n. sp.; inner Swain Reefs, Queensland, 4 m (AMS). C: Murex brevispina macgillivrayi Dohrn; west of Weipa, Gulf of Carpentaria, Queensland, 18 m (AMS). D,E: Murex tribulus Linné; Honiara, Guadalcanal, Solomon Ids (AMS). F: Murex acanthostephes Watson; south of Exmouth, Exmouth Gulf, Western Australia (AMS). G,H: Murex trapa Röding; Tolo Harbour, Hong Kong (AMS). I: Murex (Promurex) antelmei Viader; Arsenal Bay, Mauritius, 274$311 \mathrm{~m}($ ZMC). All scales $0.1 \mathrm{~mm}$. 


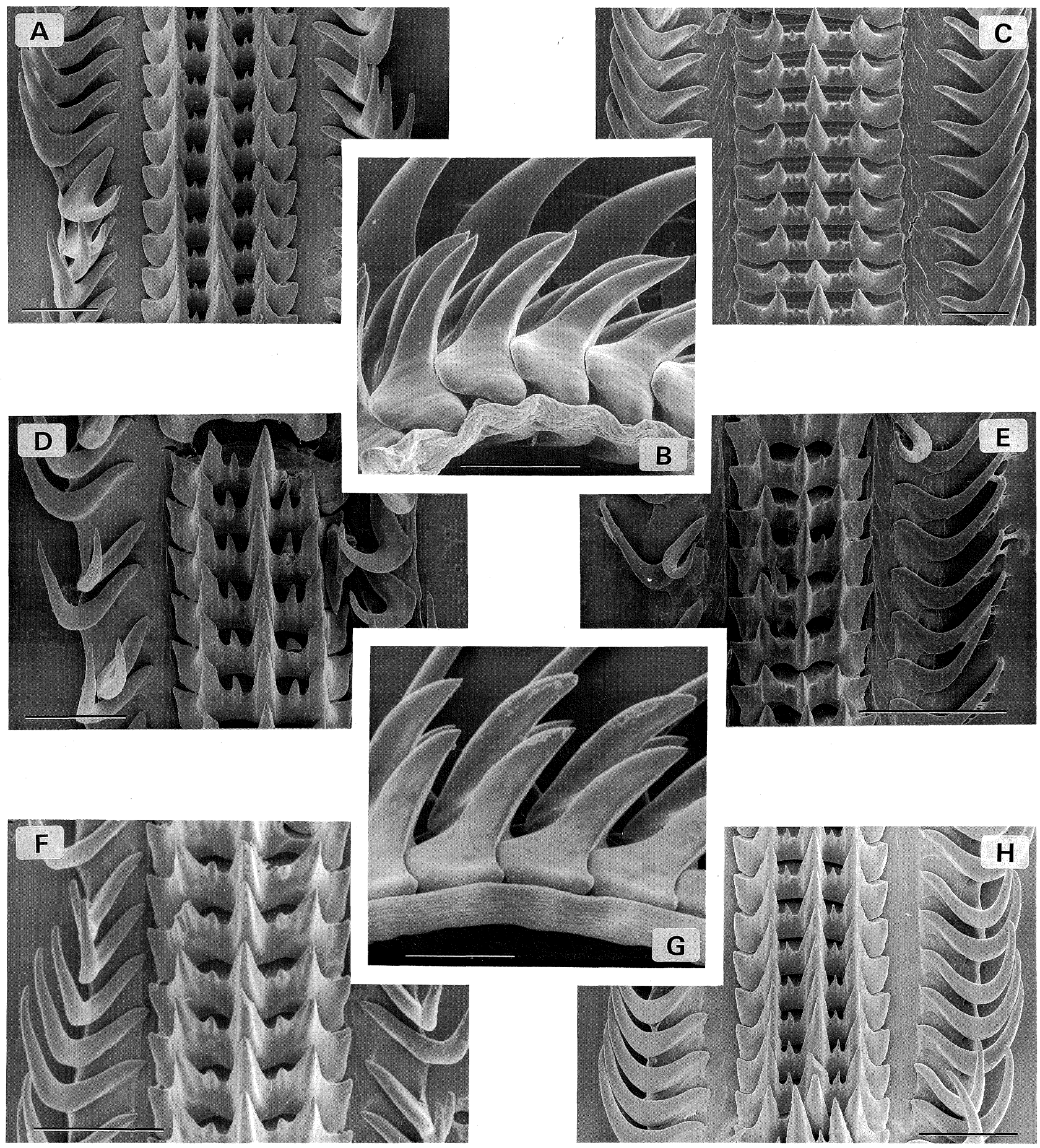

Figure 68. Radulae of species of Haustellum, Murex, Chicoreus and Siratus. A: Haustellum cabritii (Bernardi); Pta Patuca, Honduras (AMS). B: Siratus cailleti (Petit de la Saussaye); west of Dowling Shoals, Anguilla, West Indies, $219 \mathrm{~m}$ (USNM, 664307). C: Siratus pliciferoides (Kuroda); east of Cape Santiago, Balagan Bay, Batangas, Philippine Ids, 223231 m (AMS). D: Haustellum haustellum haustellum (Linné); Baie des Isoles, Duemo Magenta, Nouméa, New Caledonia (AMS). E: Haustellum messorius (Sowerby); Pta Patuca, Honduras (AMS). F: Murex pecten pecten Lightfoot; Kai Besar, Kepulauan Kai, Indonesia (ZMC). G: Chicoreus capucinus (Lamarck); Kiriwina Id, Trobriand Ids, Papua New Guinea (AMS). H: Haustellum dolichourus n. sp.; between Warbal and Ur Ids, Kai, Moluccas (WAM, 1584-70). Figures A-F, scale $0.1 \mathrm{~mm}$. Figures $\mathrm{G}, \mathrm{H}$ scale $0.01 \mathrm{~mm}$. 

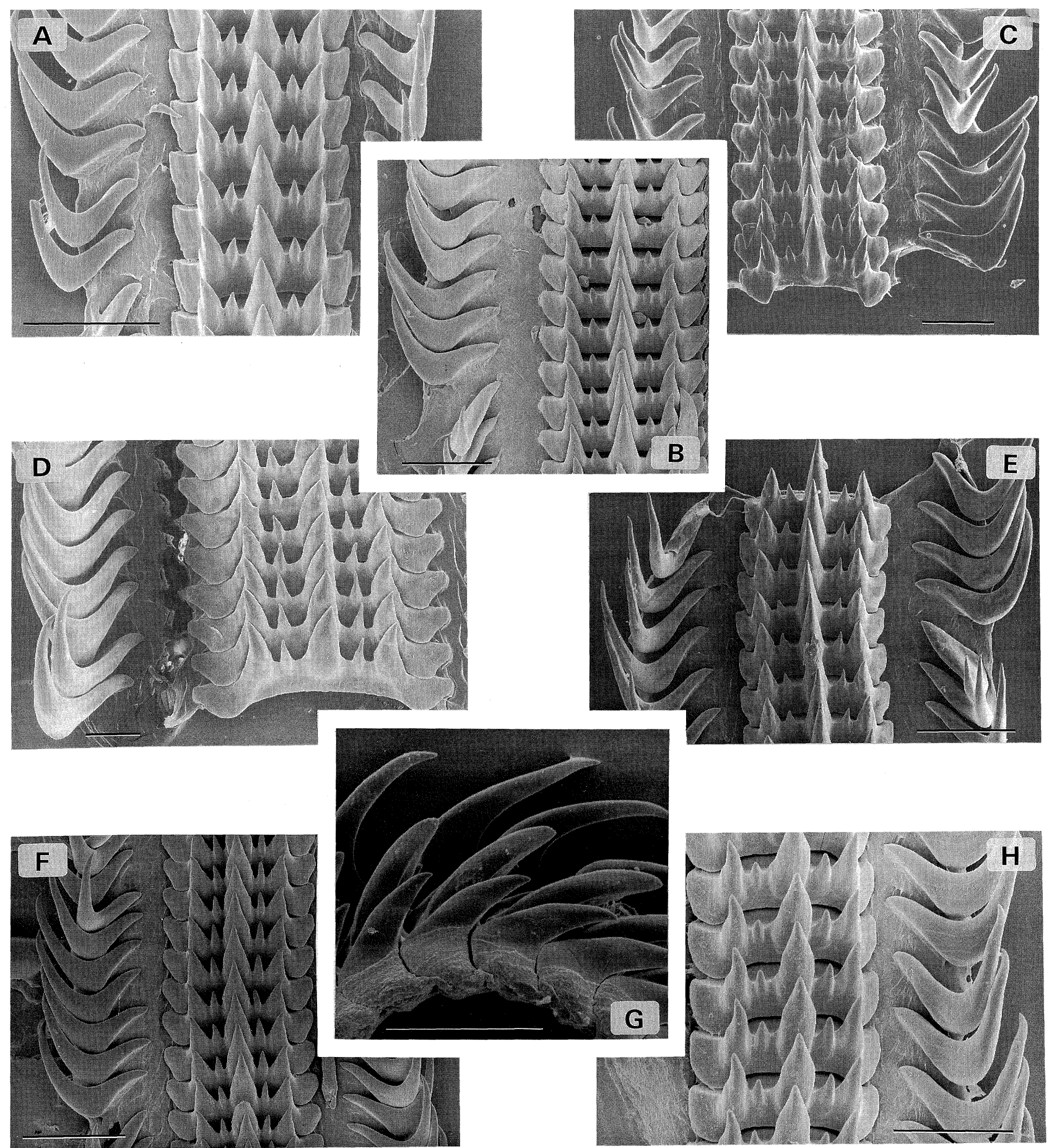

Figure 69. Radulae of species of Chicoreus and Hexaplex. A: Hexaplex cichoreum (Gmelin); Camarines Sur, Philippine Ids (AMS). B,C: Hexaplex trunculus (Linné); Mediterranean Sea (no other data) (AMS). D: Chicoreus longicornis (Dunker); off Moreton Bay, Queensland, 140 m (AMS, C. 113875). E: Chicoreus capucinus (Lamarck); Kiriwina Id, Trobriand Ids, Papua New Guinea (AMS). F,G: Hexaplex princeps (Broderip); Barra de Navidad, Mexico (AMS). H: Chicoreus cornucervi (Röding); East Arm, Darwin Harbour, Northern Territory, (AMS). All scales $0.1 \mathrm{~mm}$. 

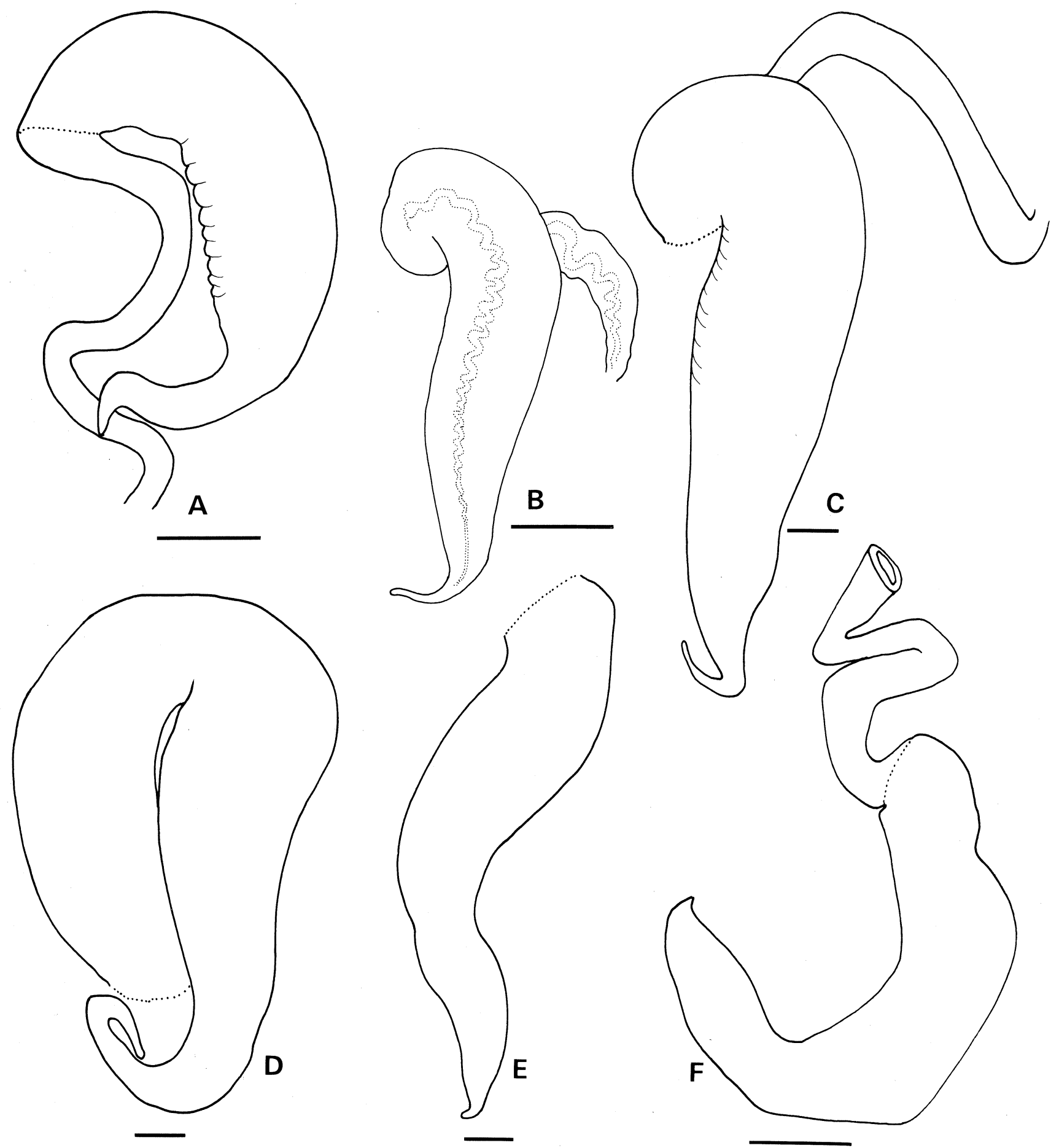

Figure 70. Penes of Murex species. A: Murex carbonnieri Jousseaume; Kharg Id, Persian Gulf, $44 \mathrm{~m}$ (ZMC). B: Murex tribulus Linné; Honiara, Guadalcanal, Solomon Id (AMS). C: Murex tenuirostrum tenuirostrum Lamarck; Bauan, Batangas Bay, Batangas Province, Luzon, Philippine Ids (WAM). D: Murex troscheli troscheli Lischke; Bali Sea, Indonesia. 150 m (ZMC). E: Murex forskoehlii Röding: Nuweiba. Sinai (AMS). F: Murex coppingeri Smith: off Karumba, Gulf of Carpentaria, Queensland (AMS). Scale $=2 \mathrm{~mm}$. 

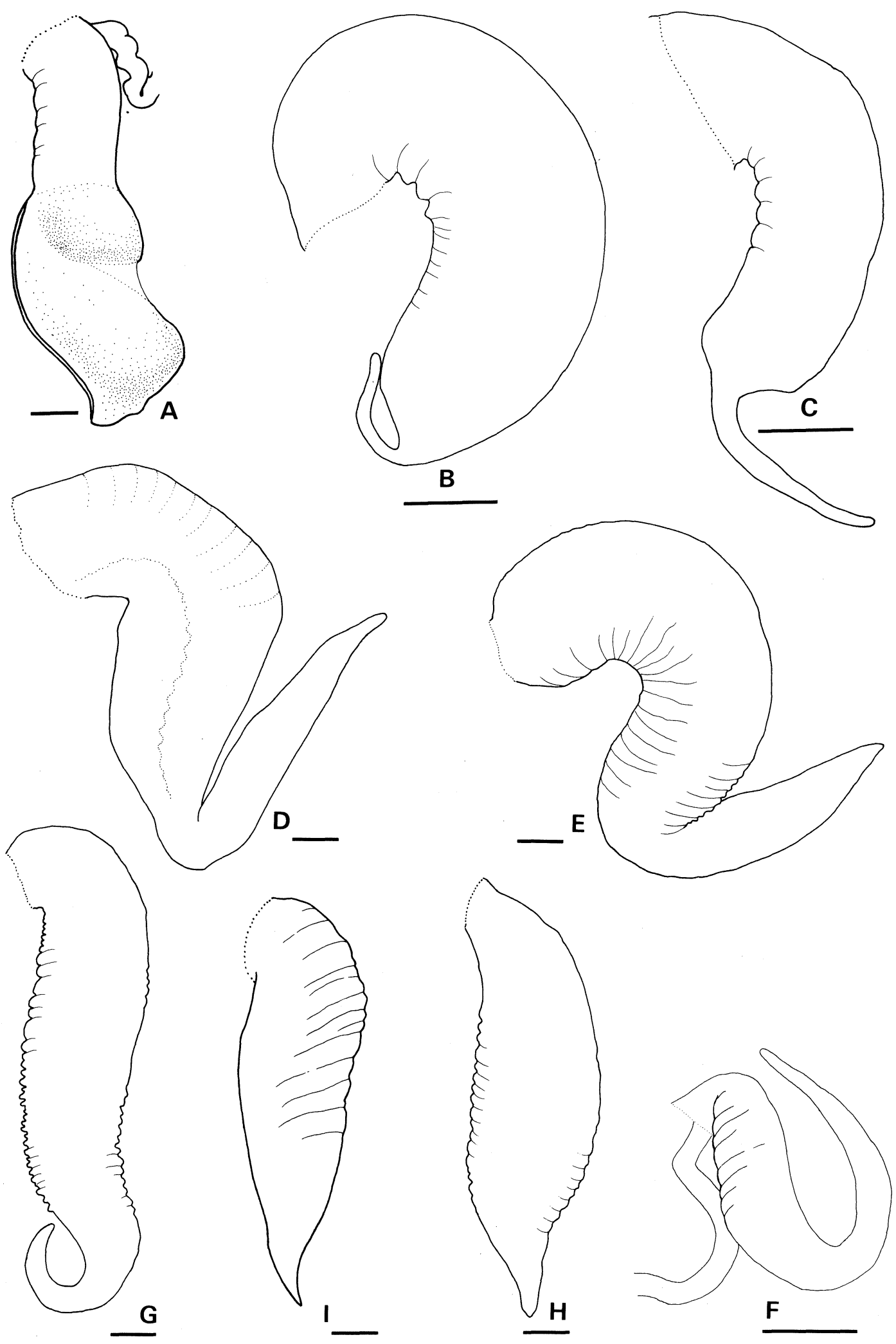

Figure 71. Penes of Murex species. A: Murex kerslakae n. sp.; paratype; north-east of Keppel Id, Queensland, (AMS). B,C: Murex trapa Röding. B: Lamma Channel, Hong Kong, 35-37 m (AMS). C: Tolo Harbour, Hong Kong (AMS). D-F: Murex aduncospinosus Sowerby. D,E: Tolo Channel, Hong Kong (AMS). F: Java Sea, 22 m (ZMC). G,H: Murex pecten pecten Lightfoot. G: Kai Besar, Kepulauan Kai, Indonesea (ZMC). H: east side of Mitduan Reef, west coast Nubu Tjut Kai. Moluccas (WAM). I: Murex queenslandicus n. sp.: inner Swain Reefs. Queensland. 4 m (AMS). Scale $=2 \mathrm{~mm}$. 

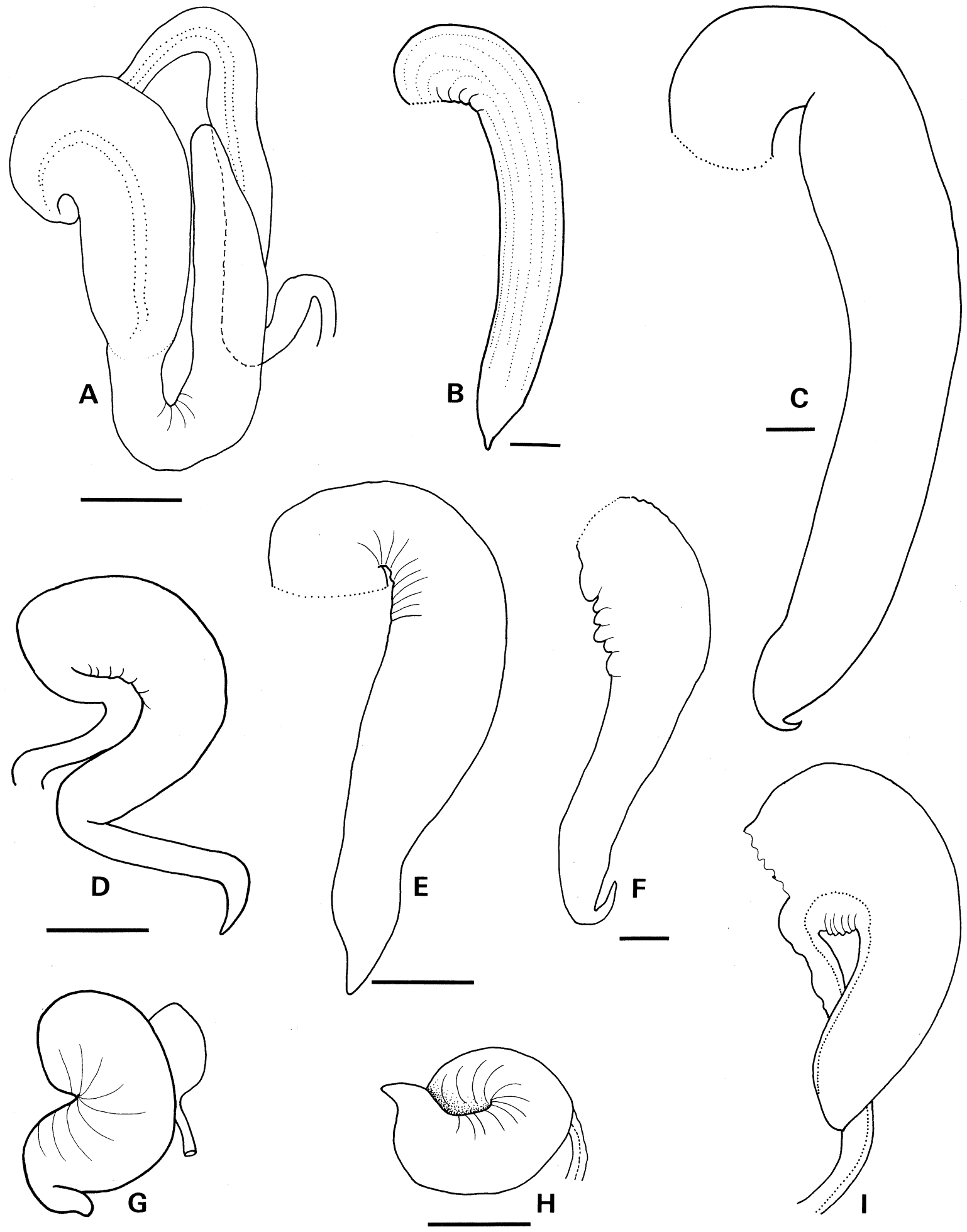

Figure 72. Penes of species of Murex and Haustellum. A: Murex brevispina macgillivrayi Dohrn; west Point, Darwin, Northern Territory (AMS). B: Murex acanthostephes Watson; south of Exmouth, Exmouth Gulf, Western Australia (AMS). C: Murex scolopax Dillwyn; Bahrain, $33 \mathrm{~m}$ (ZMC). D: Murex (Promurex) antelmei Viader; Arsenal Bay, Mauritius, 274-311 m (ZMC). E: Haustellum dolichourus n. sp.; between Warbal and Ur Ids, Kai, Moluccas, 64-73 m (WAM, 1584-70). F: Murex brevispina brevispina Lamarck; Zanzibar (MCZ, 3792). G: Haustellum rectirostris (Sowerby); south-east of Hong Kong, 116-128 m (AMS). H: Haustellum multiplicatus multiplicatus (Sowerby); west coast of Wasir Id, west Wokan, Aru, Moluccas, 49-59 m(WAM). I: Haustellum haustellum haustellum (Linné); Baie des Isoles, Ouemo, Magenta, Noumea, New Caledonia (AMS). Scale $=2 \mathrm{~mm}$. 


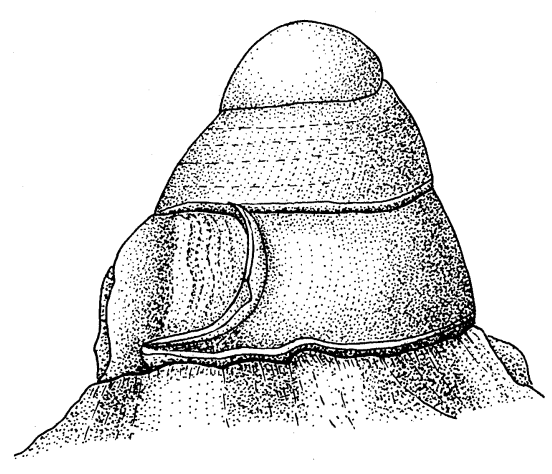

A

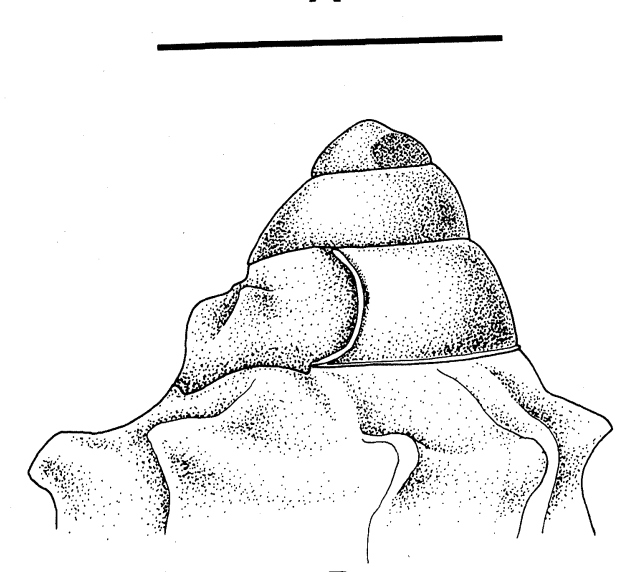

D

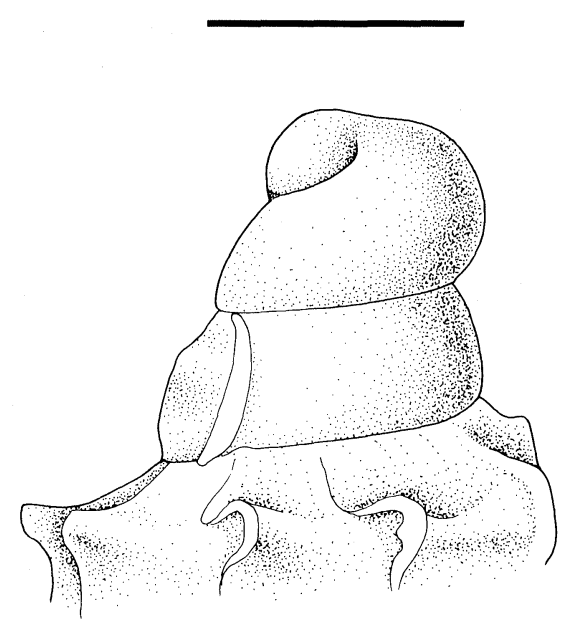

G

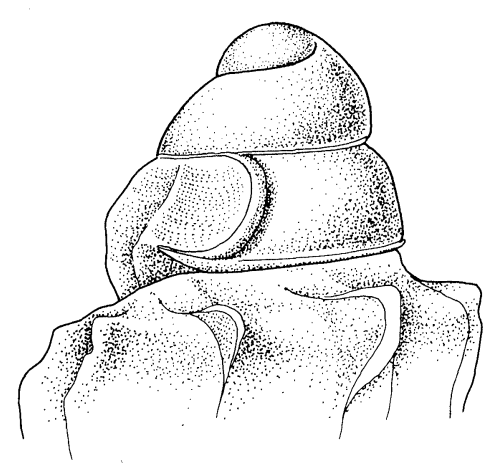

B

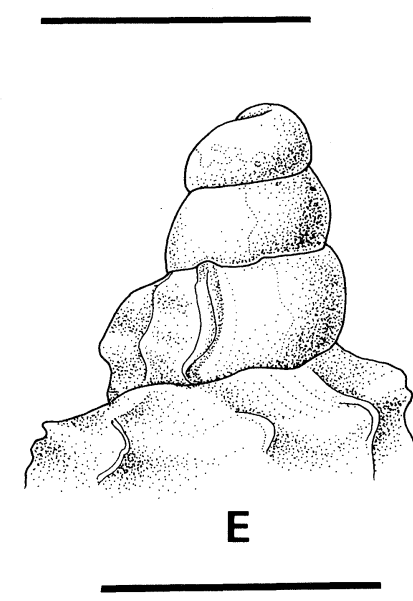

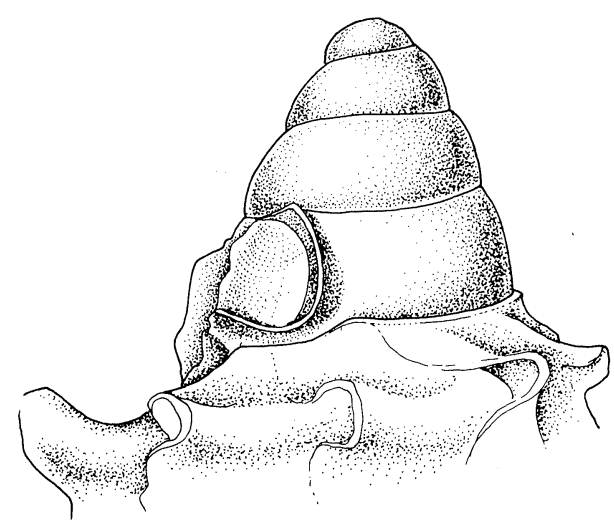

C

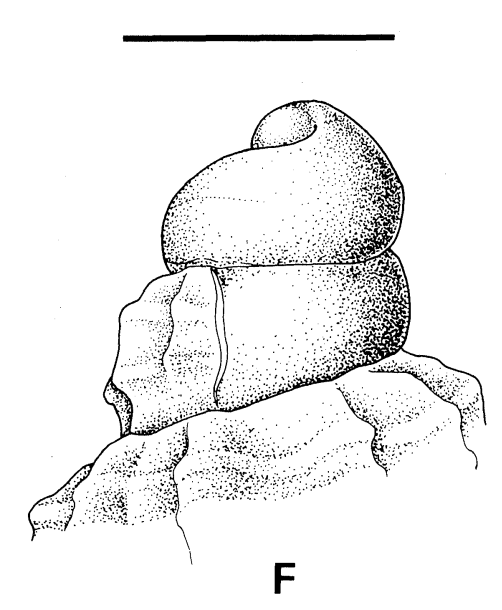

$\mathbf{F}$

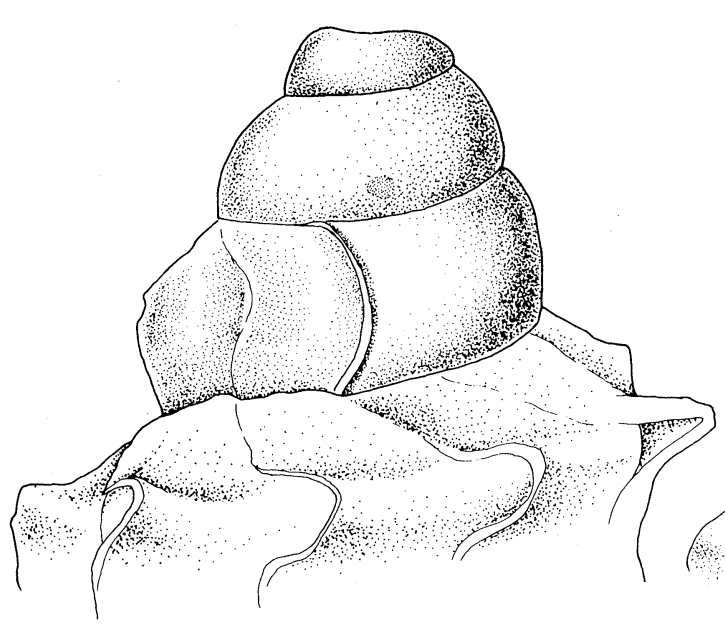

H 


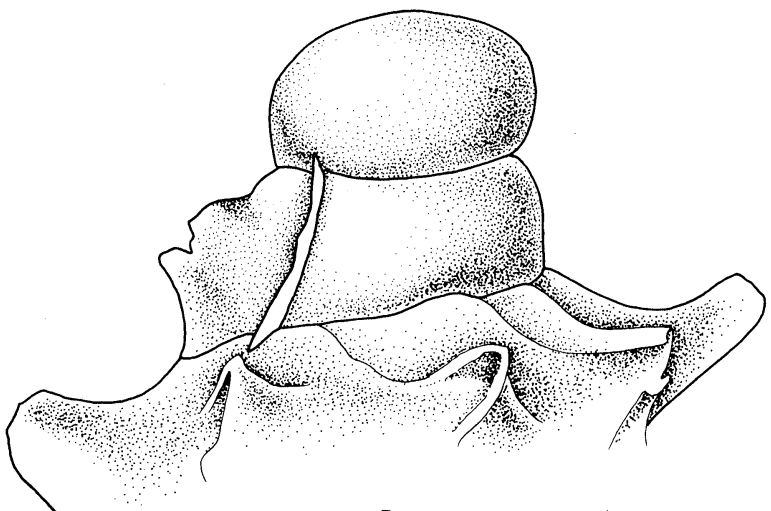

A

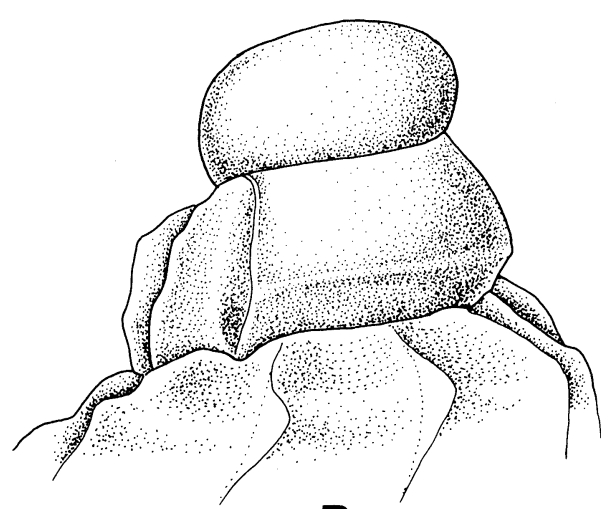

B

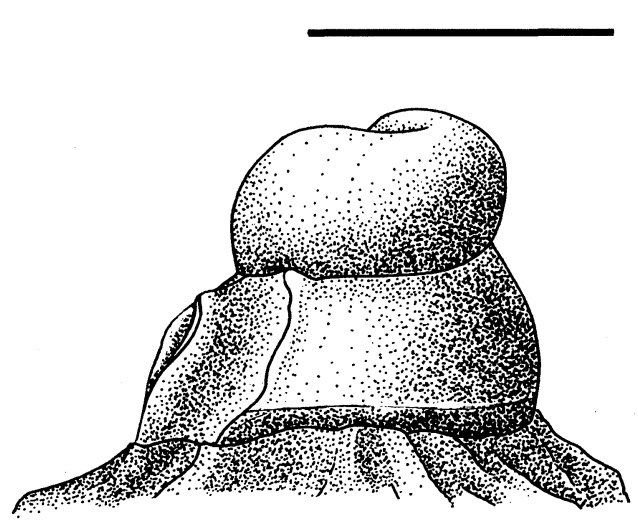

C

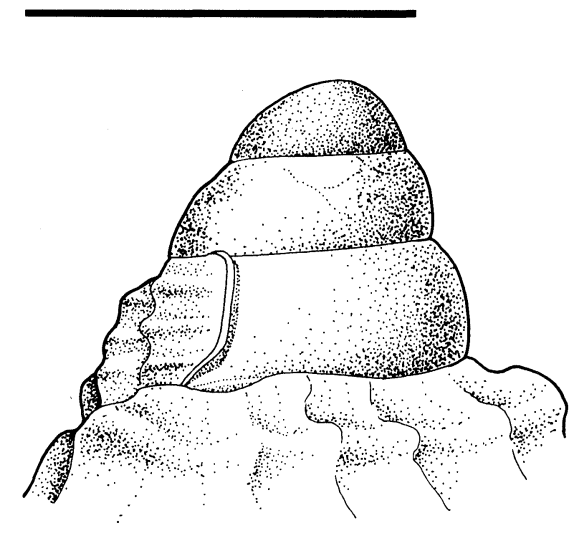

$\mathbf{F}$

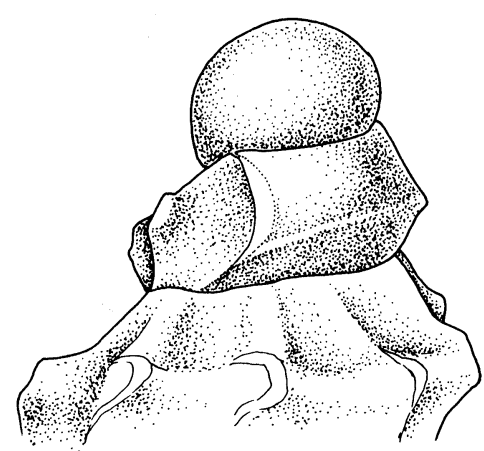

D

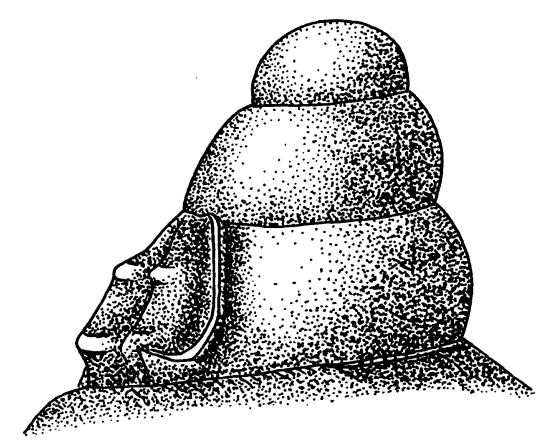

E

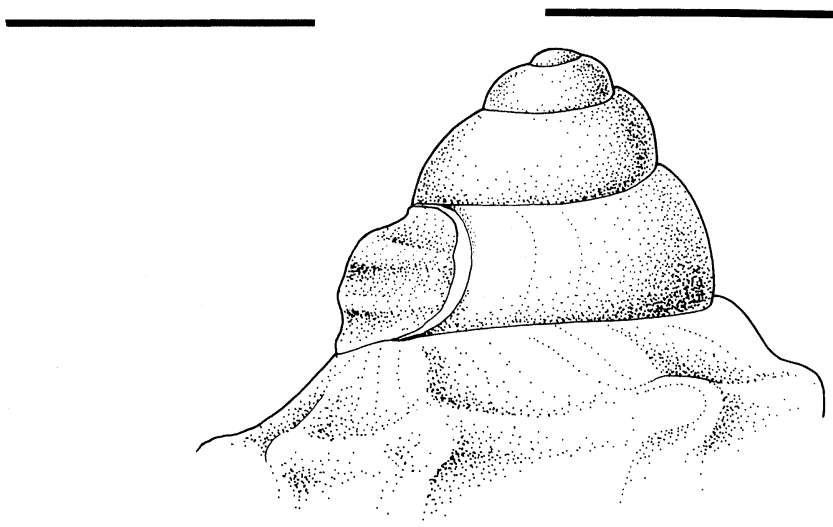

G

Figure 74. Protoconchs of Murex species. A: Murex forskoehlii Röding; south of Ismailia, Great Bitter Lake, Egypt (RML). B: Murex brevispina senilis Jousseaume; Surigoa, Philippine Ids (ANSP, 35361). C: Murex brevispina brevispina Lamarck; Port Reitz, Kenya, East Africa (AMS, C.78995). D: Murex brevispina ornamentalis n.subsp.; paratype; Tamjong Aru, Kota Kinabalu, Sabah (ANSP, 275165B). E: Murex brevispina macgillivrayi Dohrn; Albany Passage, Cape York, Queensland, 16-22 m (AMS, C.55658 pt). F: Murex (Promurex) antelmei Viader; Arsenal Bay, Mauritius, 274-311 m (ZMC). G: Murex (Promurex) spinicosta Bronn; Voslav, Austria, ?Miocene (AMS, F.3617). Scale =1 mm. 


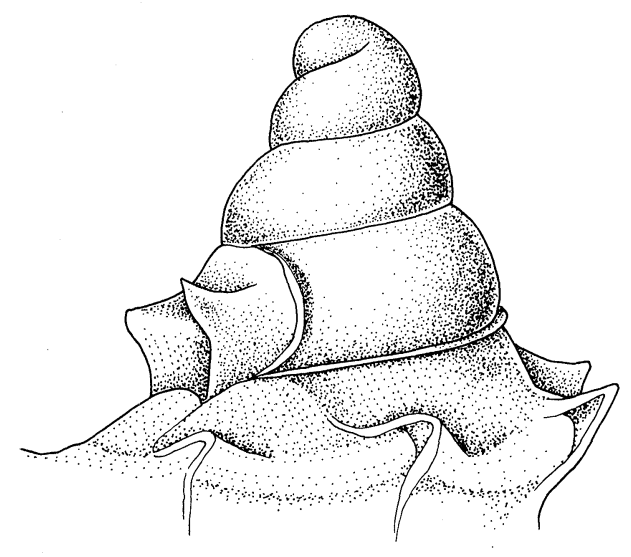

A

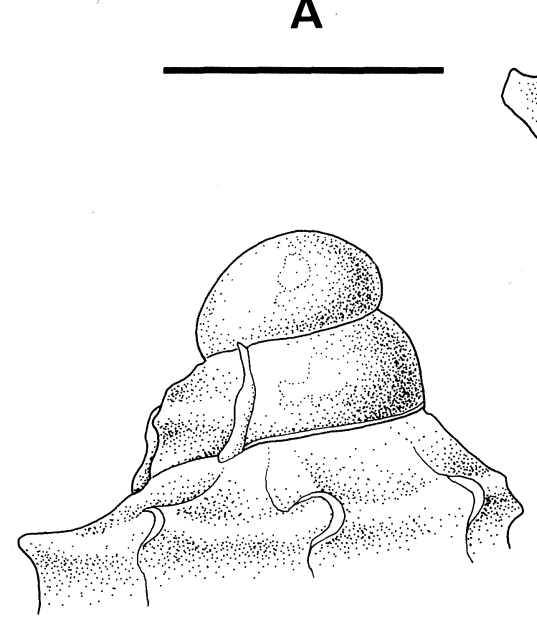

D

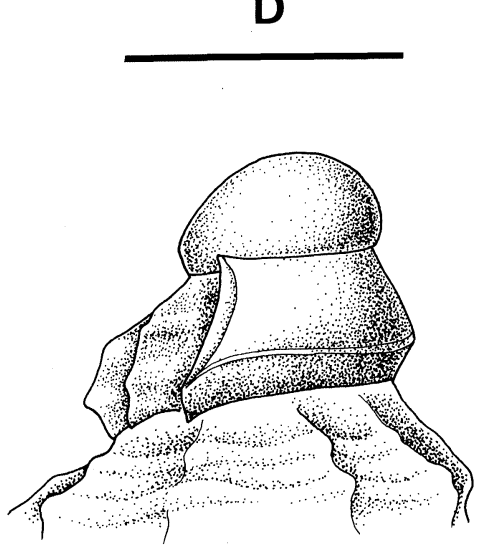

G

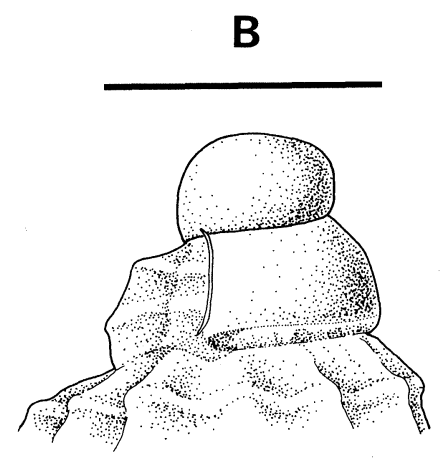

E

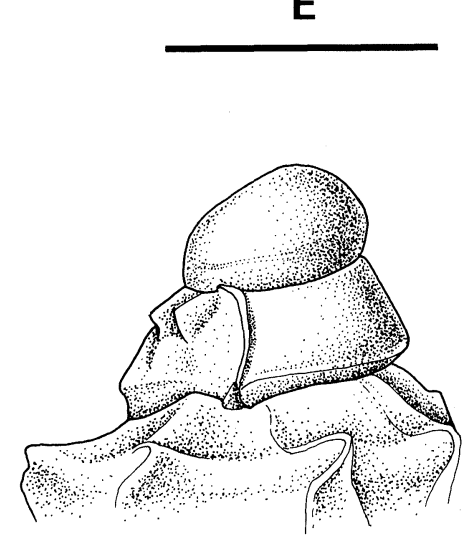

H

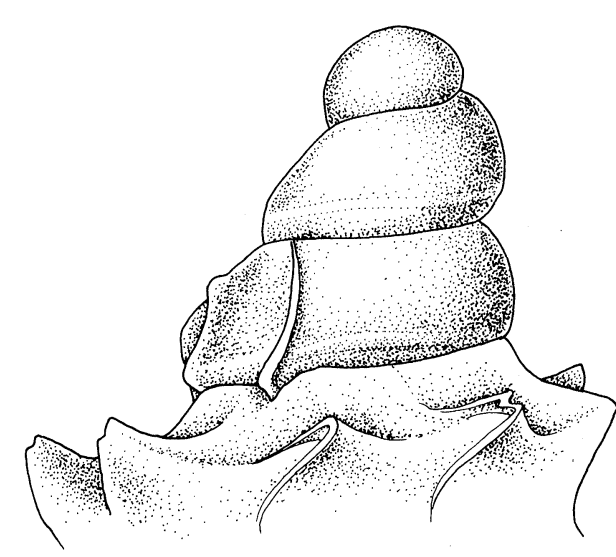

C

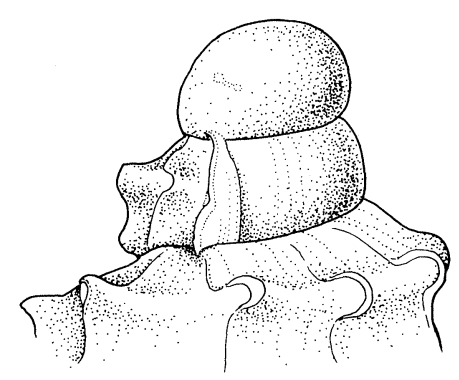

F

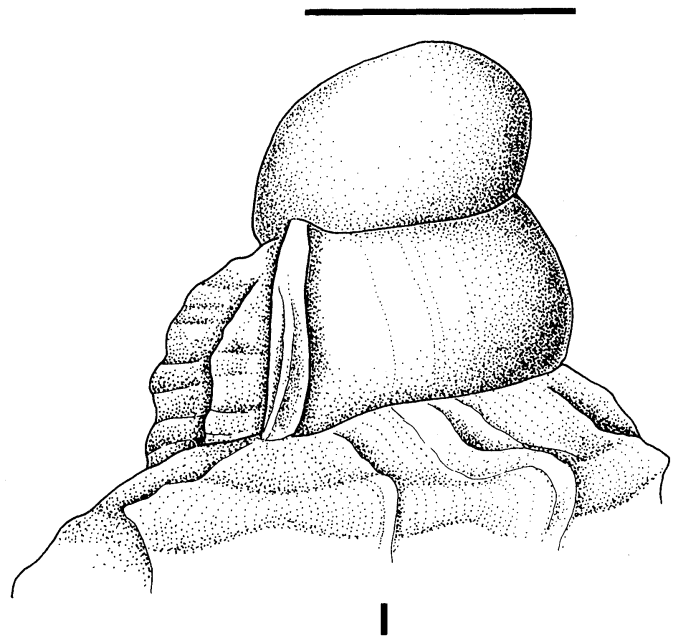

I

Figure 75. Protoconchs of Murex species. A-C: Murex carbonnieri (Jousseaume). A,B: west of Arrah. India. 46-55 m (MCZ. 262074). C: Sri Lanka (AMS. C.106343). D-H: Murex aduncospinosus Sowerby. D: Banguey Channel, Sabah, 49 m (WAM. 159-170) (concinnus form). E: Java Sea. 27 m (ZMC) (typical form). F: south-east of Hong Kong. $116-128 \mathrm{~m}$ (AMS. C. 142909) (China Sea form). G: Cowayan, Masbate, Philippine Ids (ANSP. 223898) H: Calapan. Mindoro. Philippine Ids (AMNH. 135292). I: Murex kerslakae n. sp.; trawled, south-east of Mackay. Queensland (WAM. 94-72). Scale $=1 \mathrm{~mm}$. 


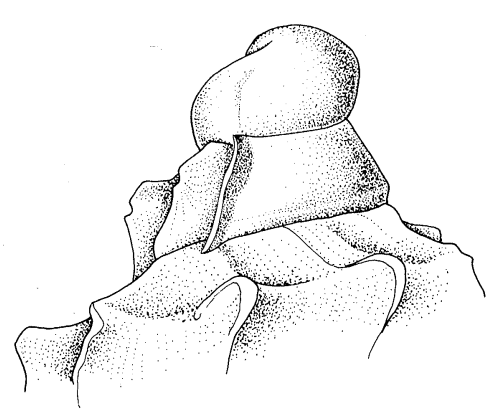

A

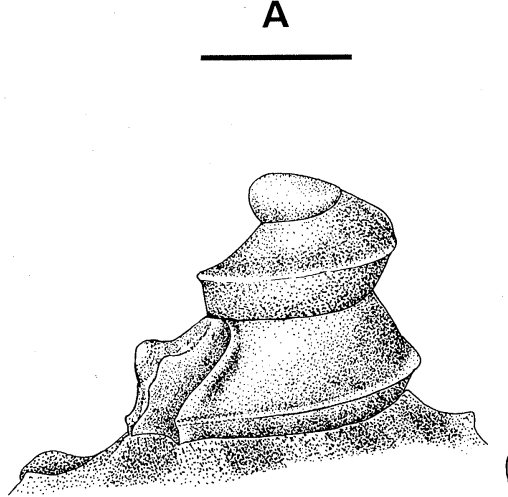

D

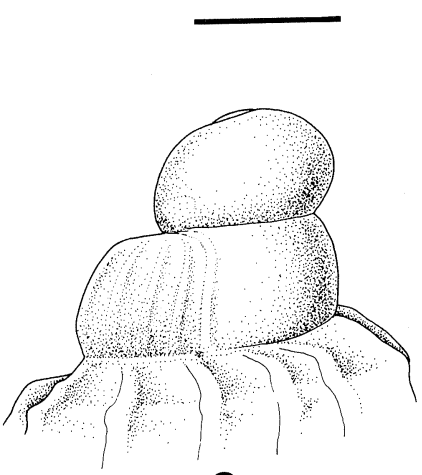

G

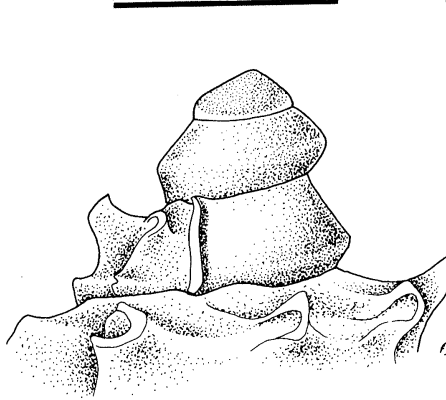

J

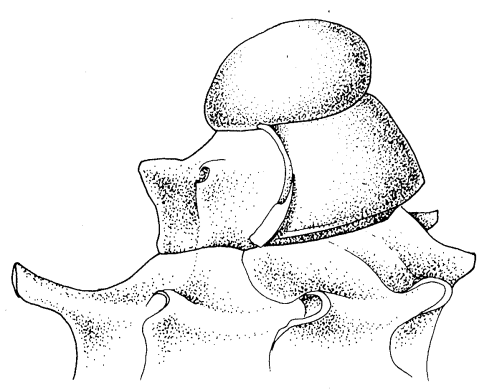

C

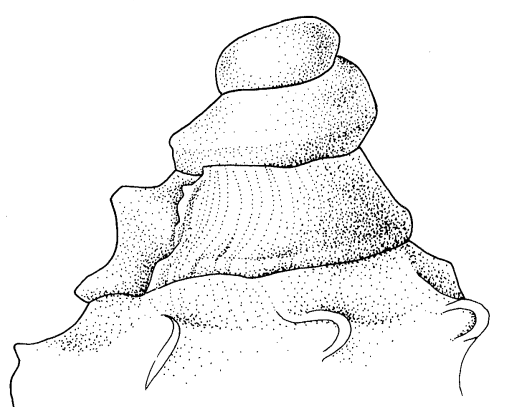

F

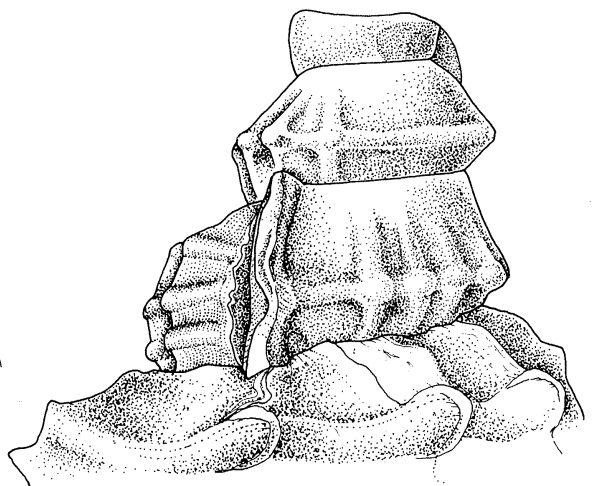

H

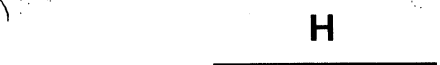

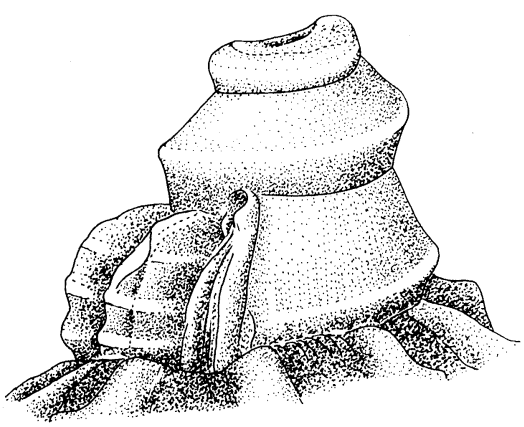

B

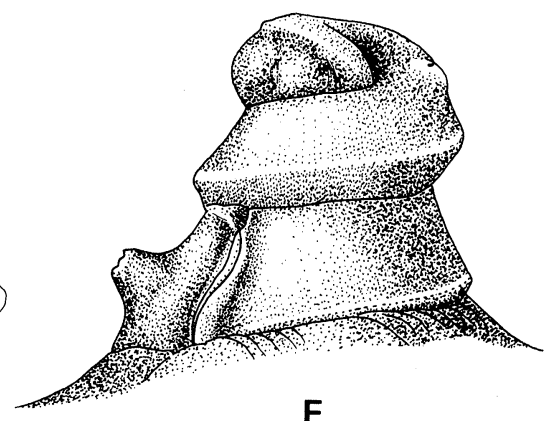

E
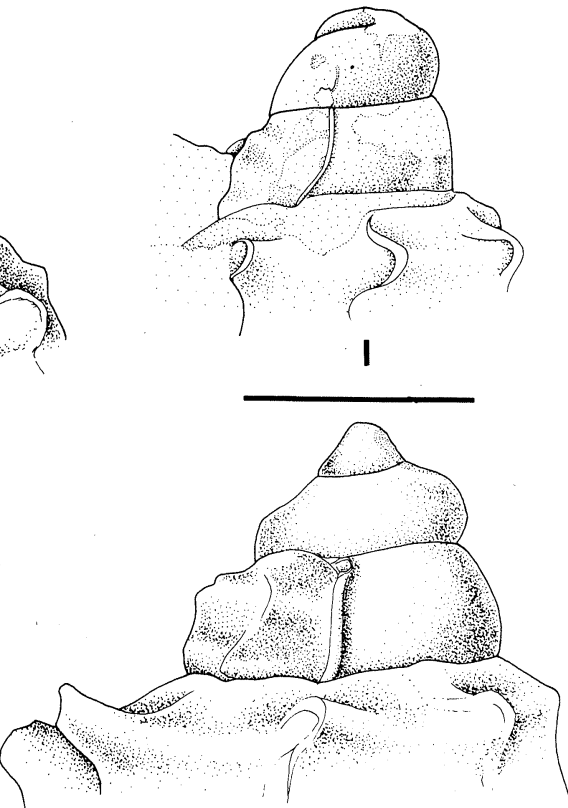

K

L

Figure 76. Protoconchs of Murex species. A,B: Murex scolopax Dillwyn. A: east of Dibbah, Saudi Arabia, $79 \mathrm{~m}$ (MCZ, 262386). B: Little Aden, Persian Gulf(AMS, C.79238). C: Murex altispira n.sp.; off Balembangan Id, north Sabah, $29 \mathrm{~m}$ (WAM, 1596-70). D-F: Murex occa Sowerby. D,E: Penang, Malaysia (AMS, C.90613). F: Pliocene, below Kampong Bodjong, Koempai, Java (PCB). G: Murex djaraniensis djaraniensis Martin; Tji Angsana, Java, Upper Miocene (GML, 9641). H: Murex djaraniensis poppei Houart; north-east of Lighthouse Id, Phuket Id, Andaman Sea, Thailand, $24 \mathrm{~m}$ (ANSP, 286250). I: Murex aff. acanthostephes Watson; Cape Possession, Papua, Papua New Guinea (BMR, F7215). J-L: Murex acanthostephes Watson. J: Exmouth Gulf, Western Australia (AMS, C.106479). K: paralectotype; off Cape York, Queensland, Australia (AMS, C.2964). L: trawled, off Broome, Western Australia (AMS, C.106329). Scale =1 mm. 


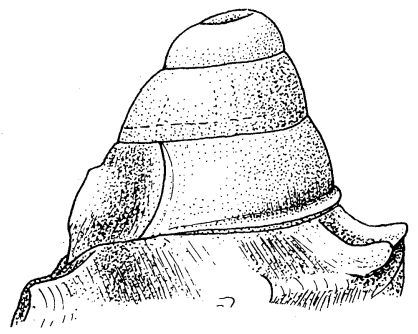

A

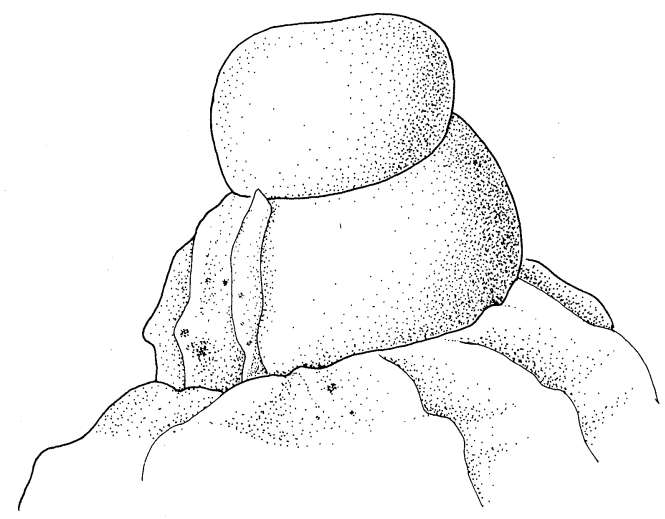

D

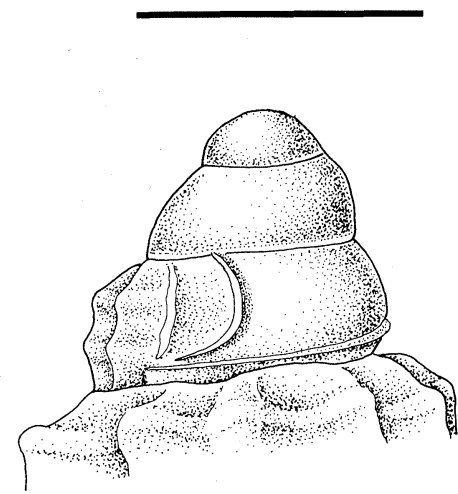

H

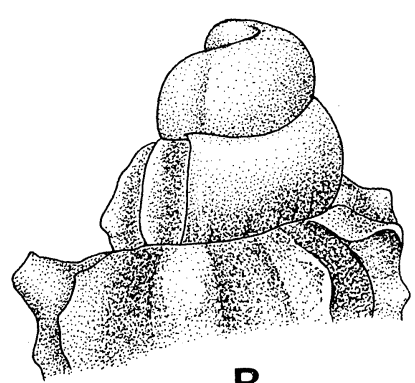

B

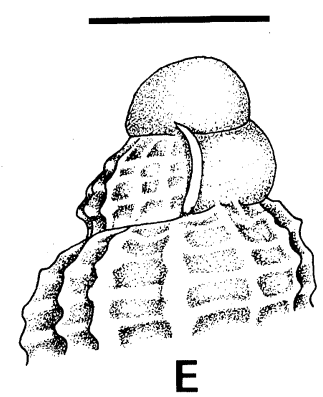

$E$

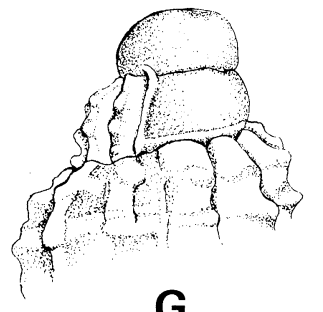

G

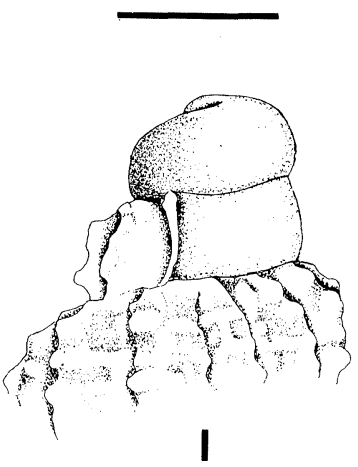

I

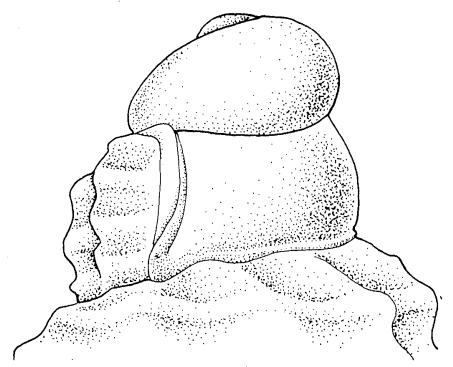

C
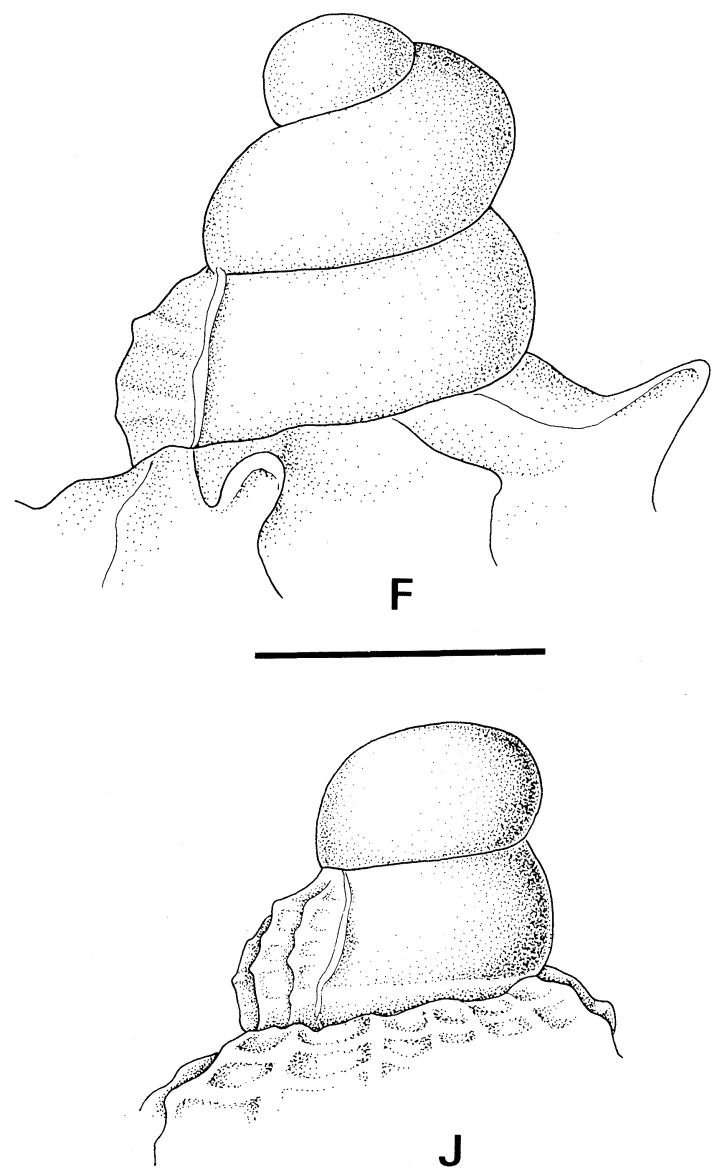

$J$

Figure 77. Protoconchs of Murex species. A: Murex coppingeri Smith; Karumba, Gulf of Carpentaria, Queensland (AMS, C.74798). B: Murex queenslandicus n.sp.; Swain Reefs, Queensland (AMS, C.86596). C: Murex pecten soelae $\mathrm{n}$. subsp.; north-west of Port Hedland, Western Australia, 116-120 m (AMS, 147951). D: Murex spectabilis n.sp.; holotype; off Bulan, Sorsogon Province, Luzon Id, Philippine Ids (AMS, C.147946). E: Murex falsitribulus n.sp.; paratype; Balabac Id, south Palawan, Philippine Ids (FMNH, 140646). F: Murex spicatus n.sp.; paratype; Motobu Peninsula, Okinawa Id, Japan (USNM, 622048). G,I: Murex aduncospinosus Sowerby; Borneo Bank, Indonesia, $59 \mathrm{~m}$ (ZMA). H: Murex pecten pecten Lightfoot; Blanche Bay, New Britain, Papua New Guinea (AMS, C.3155). J: Murex ternispina Lamarck: Malai Id, Siassi Ld Group, west New Britain, Papua New Guinea (AMS.C.74691). Scale $=1 \mathrm{~mm}$. 


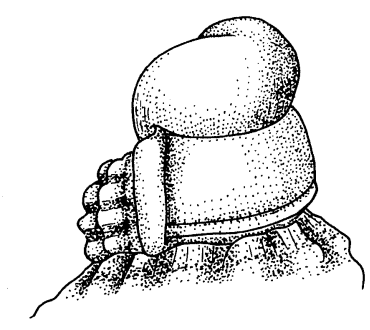

A

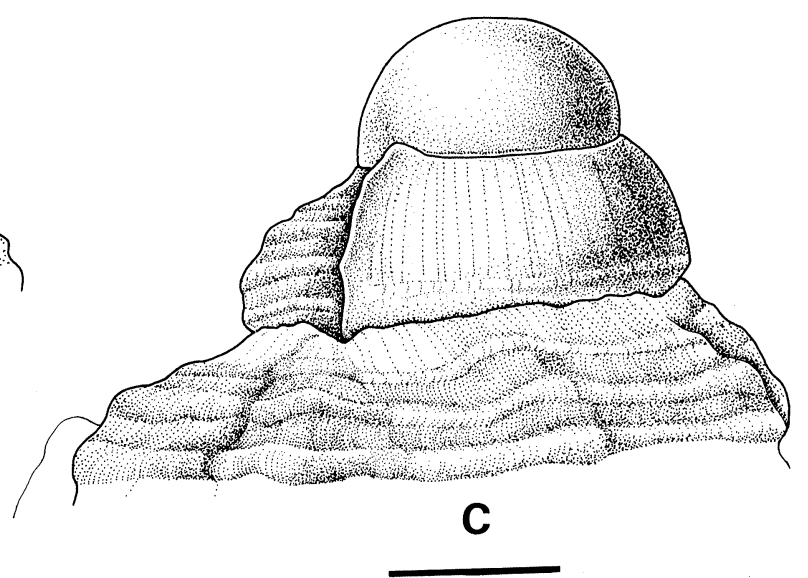

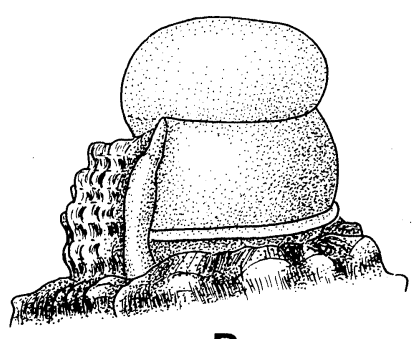

B

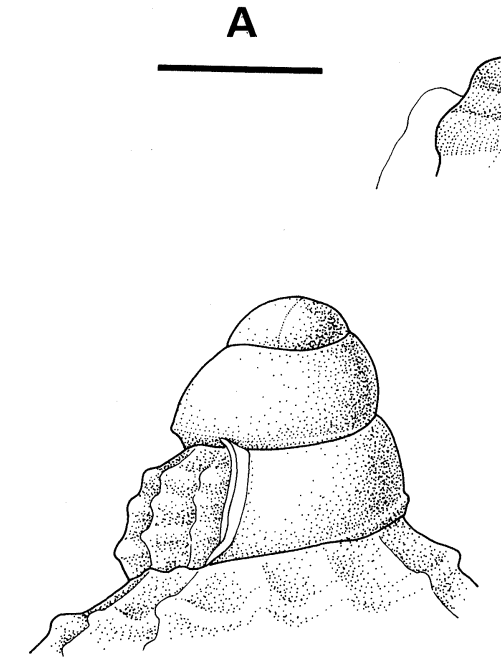

D

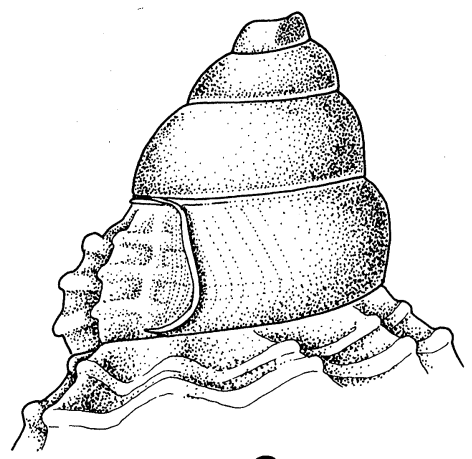

G

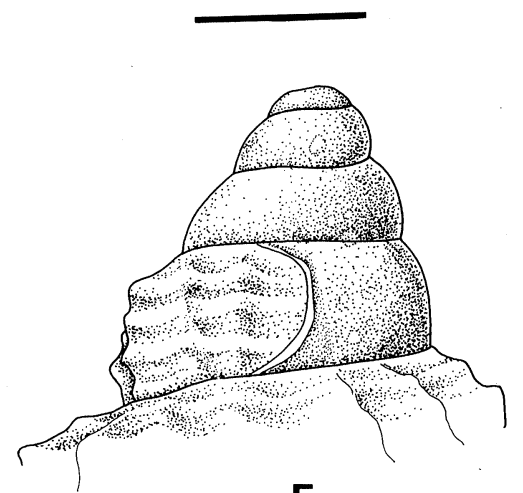

E

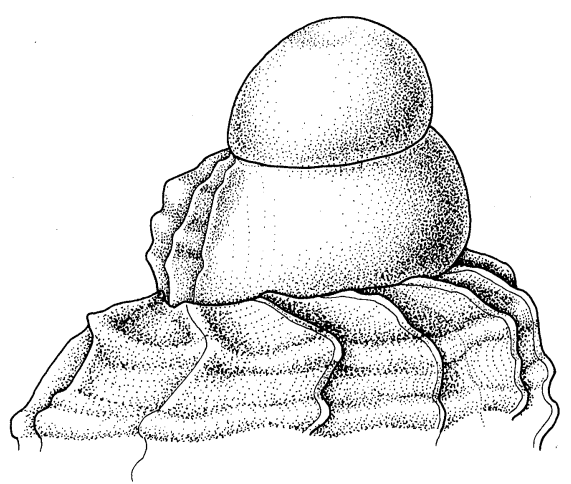

H

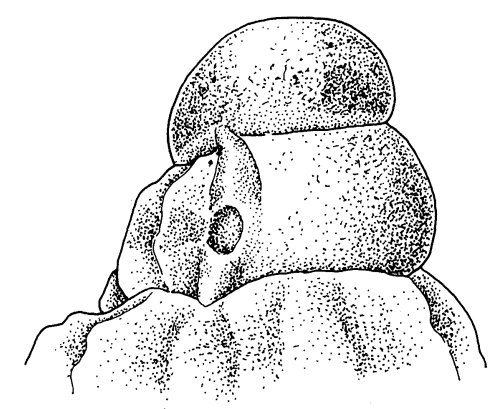

F

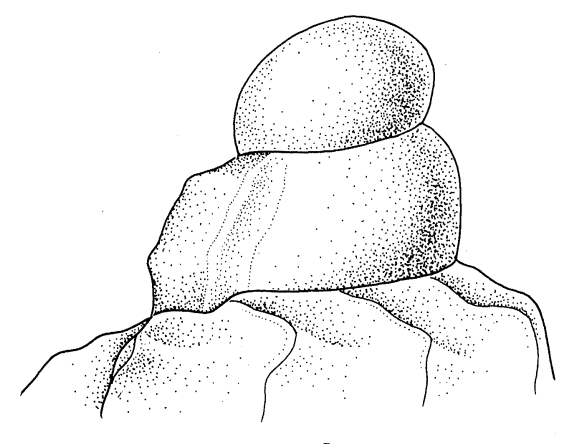

I

Figure 78. Protoconchs of Haustellum species. A,B: Haustellum tweedianus (Macpherson); trawled, off Southport, Queensland (AMS,C.63155). C: Haustellum wilsoni D'Attilio \& Old: off Dunsborough, Western Australia(WAM. 69.72). D: Haustellum haustellum haustellum (Linné); west coast Nuhu Ijut, Kai Ids (WAM, 11-85). E: Haustellum kiiensis (Kira); Mactan, Philippine Ids (AMS, 147958). F: Haustellum gallinago (Sowerby); $26^{\circ} 55^{\prime}-56.6^{\prime} \mathrm{N}, 125^{\circ} 00^{\prime}-$ $02.5^{\prime} \mathrm{E}$, East China Sea, 120 m (NSMT). G: Haustellum malabaricus (Smith); paratype; off Malabar, India (NMW). H: Haustellum mindanaoensis (Sowerby); Tayabas Bay, Philippine Ids (AMS, C.106346). I: Haustellum bobyini (Kosuge); off Balut, Philippine Ids. $300 \mathrm{~m}$ (AMS.C.143411). Scale = 1mm. 


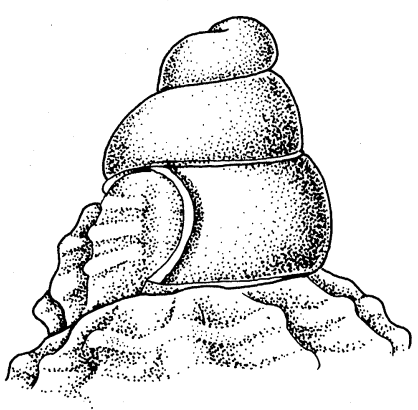

A

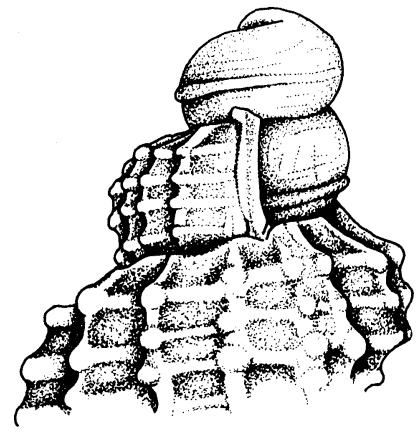

B

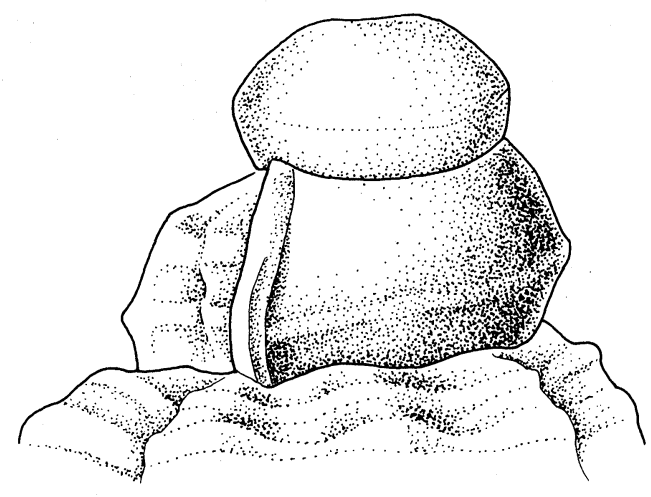

D

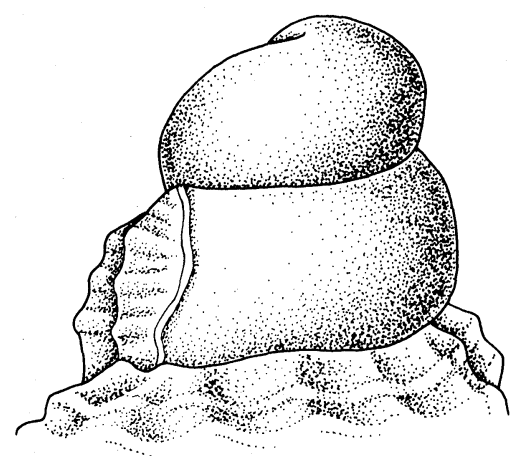

G

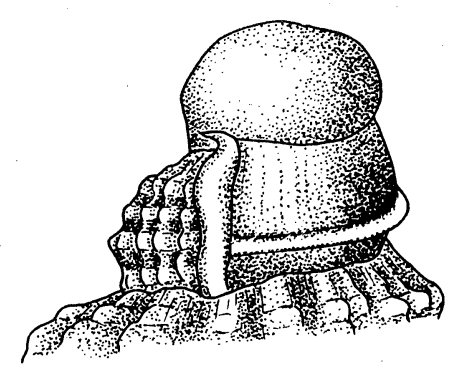

$\mathbf{E}$

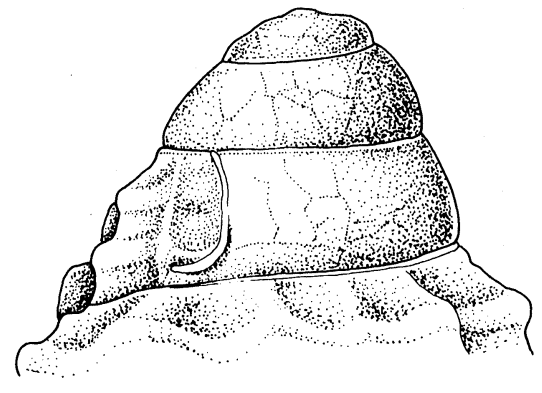

H

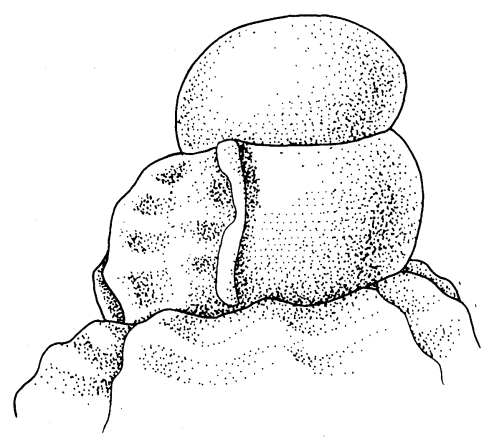

C

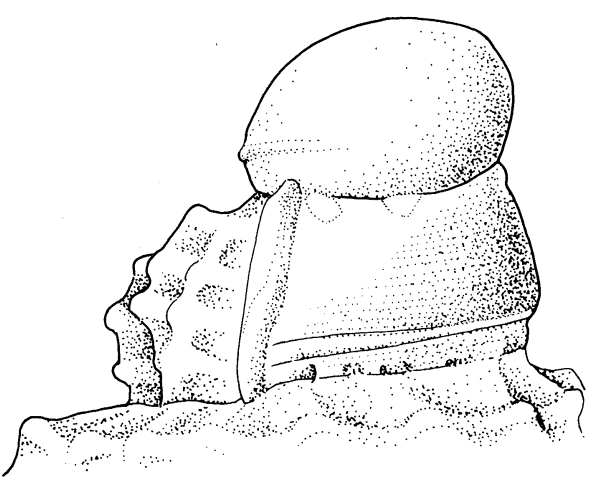

$\mathbf{F}$

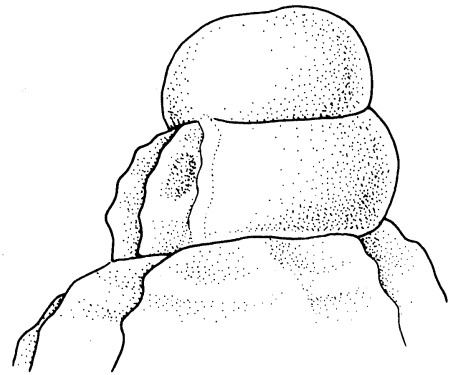

I

Figure 79. Protoconchs of Haustellum species. A: Haustellum dolichourus n. sp.; off Bohol, Philippine Ids, 95 m (WAM, 95-72). B: Haustellum sobrinus (A. Adams); Kii, Japan (RSM). C: Haustellum multiplicatus bantamensis (Martin); Hansa Bay, north-west of Madang, Papua New Guinea, 35 m (IRSB). D: Haustellum rectirostris (Sowerby); south-west Sea of Formosa (AMS, C.106333). E: Haustellum multiplicatus multiplicatus (Sowerby); Thursday Id, Torres Strait, Queensland (AMS, C.69077). F: Haustellum multiplicatus darraghi (Ludbrook); Plio-Pleistocene, $1.5 \mathrm{~km}$ west of Hampton Microwave Repeater Tower, Madura district, Roe Plains, Western Australia (WAM, 80.208). G: Haustellum dentifer (Watson); off Bohol, Philippine Ids (WAM, 1593-70). H: Haustellum hirasei (Hirase); Japan (no other data) (AMS, C.147959). I: Haustellum multiplicatus bantamensis (Martin); pliocene, below Kampong Bodjong, Koempai, Java (PCB). Scale $=1 \mathrm{~mm}$. 


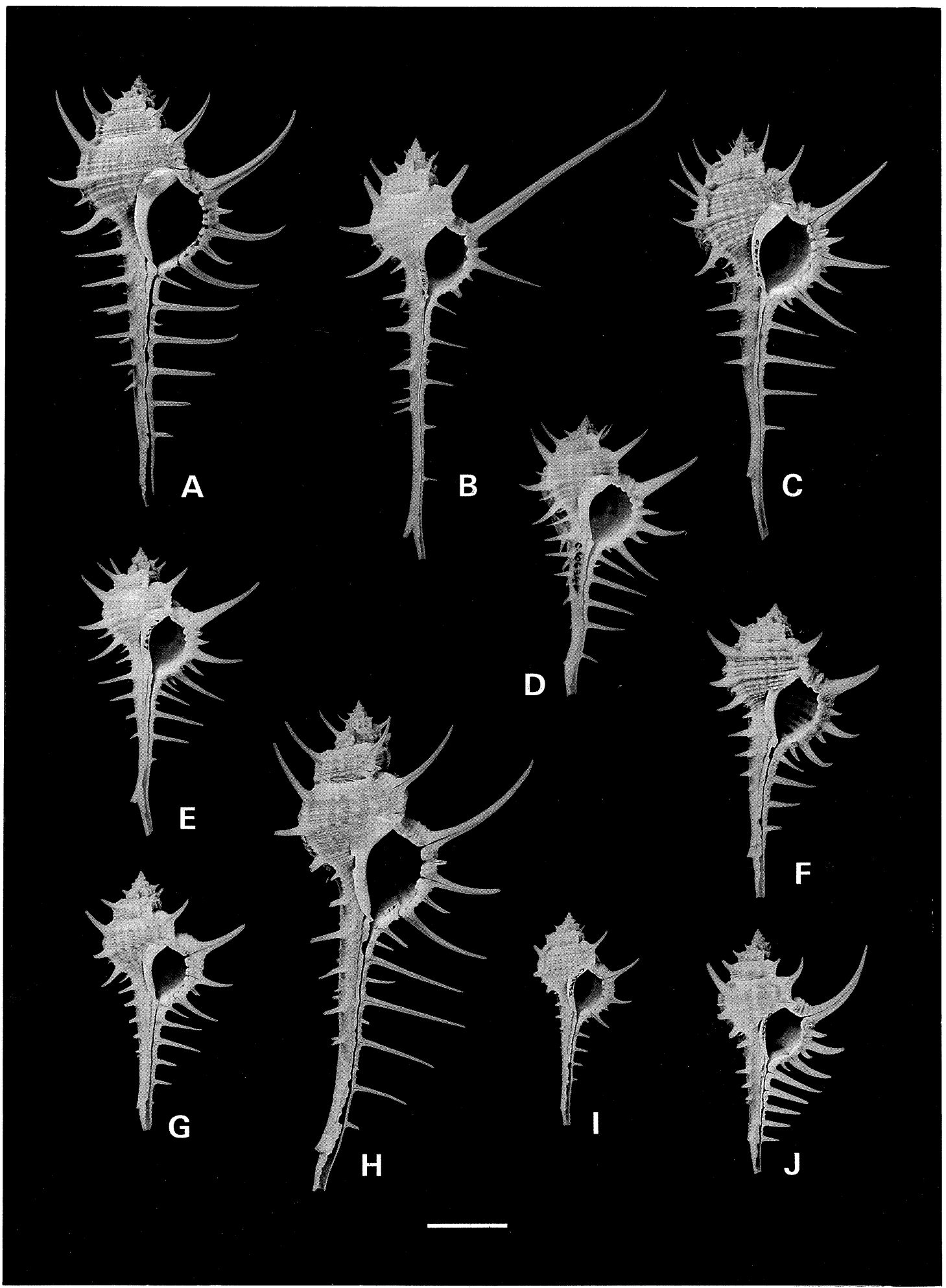

Figure 80. A: M. tribulus Linné; Teluk Awans, Lombok Id, Indonesia, 9-15 m (AMS, C.108649). B,C: M. tenuirostrum tenuirostrum Lamarck. B: Subic Bay, Luzon, Philippine Ids, 97 m (USNM, 235209) (long-spined form). C: Poum, north New Caledonia (AMS, C.81955). D-F: M. falsitribulus n. sp. D: holotype; Balabac, Palawan, Philippine Ids (AMS, C.106340). E: paratype; Palau, Philippine Ids (ANSP, 196387). F: paratype; Mandi Darragh Id, North Borneo (USNM, 657812) (colour-banded variety). G-I: M. carbonnieri (Jousseaume). G: Shore west of Mandapam, Gulf of Mannar, south-east India (ANSP, 302559). H: coast of Sumatra, Indonesia (RML, 40) (long-spined form). I: Gold Mohur Beach, Aden, Yemen (AMS, C.143952). J: M. coppingeri Smith; off Cape Possession, near Yule Id, Gulf of Papua, Papua New Guinea. $27 \mathrm{~m}$ (AMS. C.88002). Scale $=2 \mathrm{~cm}$. 


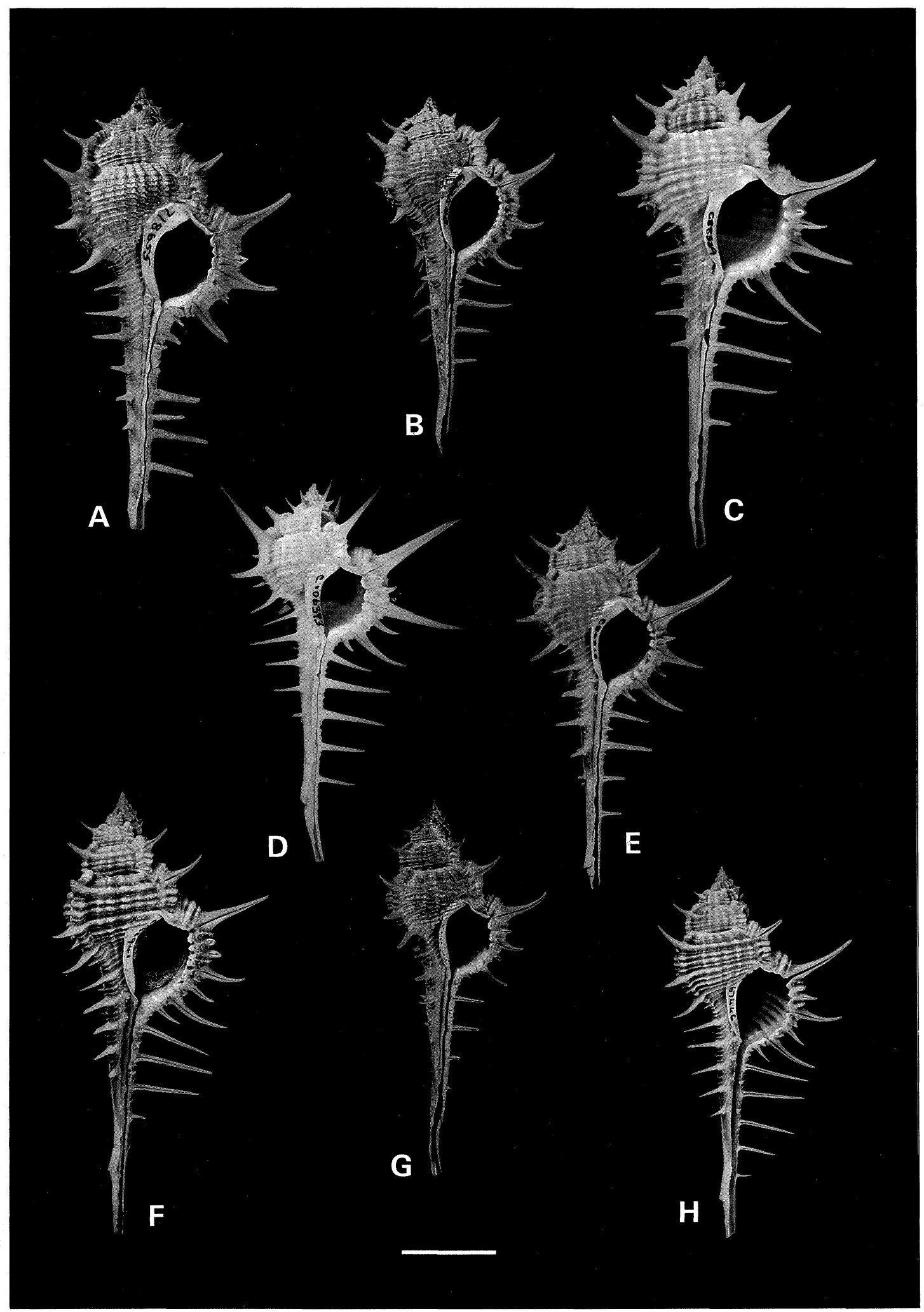

Figure 81. A,E: Murex tenuirostrum africanus n. subsp. A: paratype; about 40 miles south-east of Chinde, Mozambique, 45 m (USNM, 718655). E: paratype; Antsakoabé, Nosy-Bé, Madagascar (AMS. C.84219). B,C, F-H: Murex aduncospinosus Sowerby. B: Baler, Quezon, Luzon, Philippine Ids (USNM, 632540). C: trawled in the vicinity of Taiwan, China Sea (AMS, C88339). F: Suva, Viti Levu, Fiji (AMS, C.143941). G: Cebu, Philippine Ids (NMV, 27448). H: Nadi Bay, Vitu Levu, Fiji (AMS, C.67446). D: Murex kerslakae n. sp.; holotype; north-east of Keppel Bay, Queensland, $60 \mathrm{~m}(\mathrm{AMS}, \mathrm{C} .150000)$. Scale $=2 \mathrm{~cm}$. 

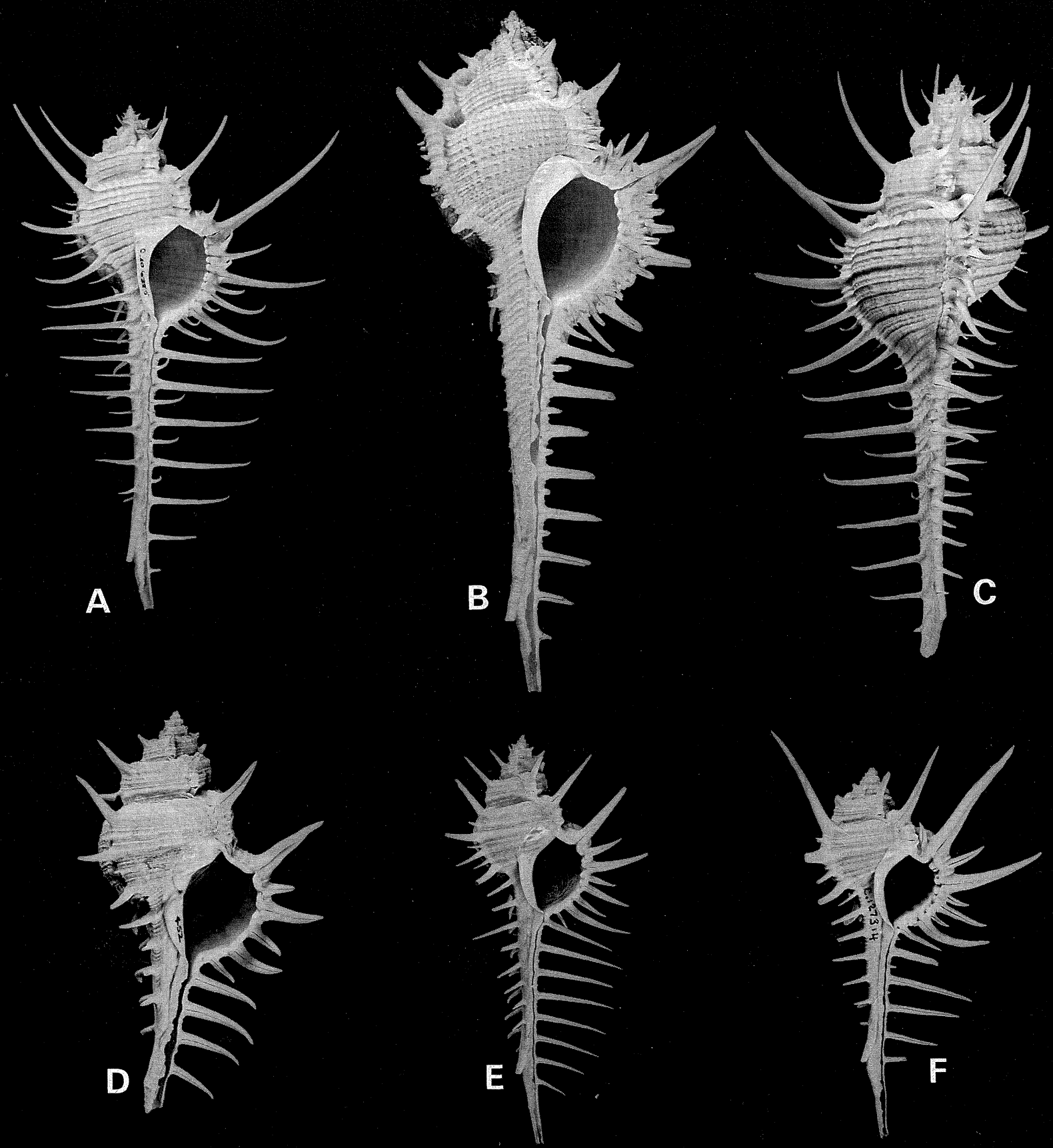

Figure 82. A-C: Murex troscheli troscheli Lischke. A: Philippine Ids (AMS, C.106385). B: Solomon Ids (AMS, C.36392) (thick-shelled M. heros form). C: Kinko Bay, near Moeshima, Kagoshima Prefecture, Japan (AMS, C.111129). D-F: Murex forskoehlii Röding. D: Il de Chevalier, north shore of Lake Timsah, Egypt (BMNH, Acc. no. 2258). E: Nuweiba, Sinai, Egypt, $300 \mathrm{~m}$ (AMS,C.138490) F: $20 \mathrm{~km}$ south of Eilat, Israel, $20 \mathrm{~m}$ (AMS,C.127314). Scale $=2 \mathrm{~cm}$. 


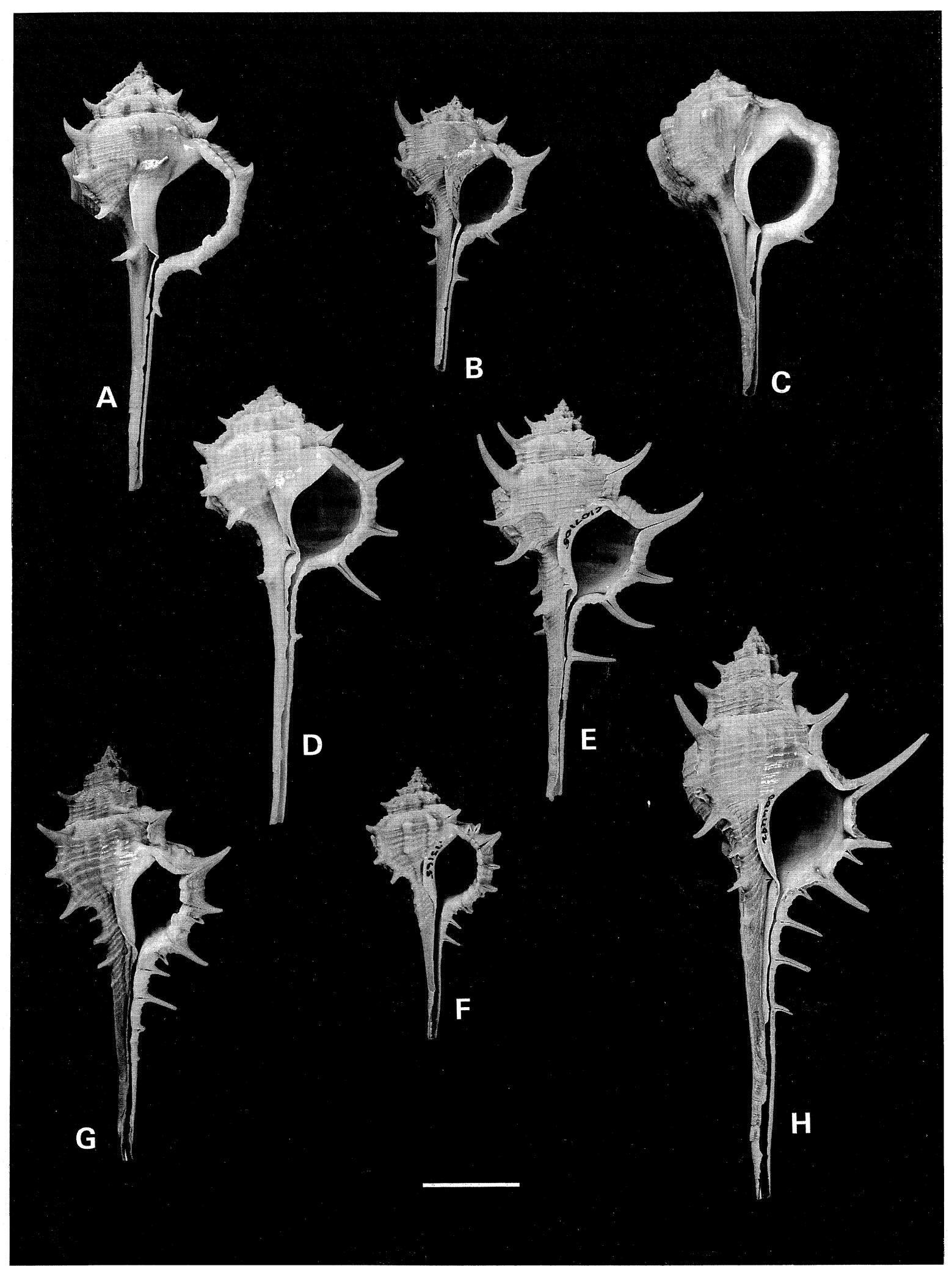

Figure 83. A-C: Murex brevispina brevispina Lamarck. A: Inhambane, Mozambique (AMS, C.121484). B: "Nicobar Ids" (AMNH, 5740A). C: Mazizini, west Zanzibar (ANSP, 214688). D: M. brevispina senilis Jousseaume; Cuyo, Philippine Ids (BMNH). E: M. brevispina macgillivrayi Dohrn; west of Weipa, Gulf of Carpentaria, Queensland, $18 \mathrm{~m}$ (AMS, C.107105). F: M. brevispina ornamentalis n. subsp.; holotype; Tamjong Aru, Kota Kinabalu, Sabah (ANSP, 275165A). G,H: M. trapa Röding. G: Tsoying Chung-kang, Taiwan, 21 m (AMS, C.106482). H: Chau Wan Bay, Lamma Id, Hong Kong, 9 m (AMS C.94492). Scale $=2 \mathrm{~cm}$. 

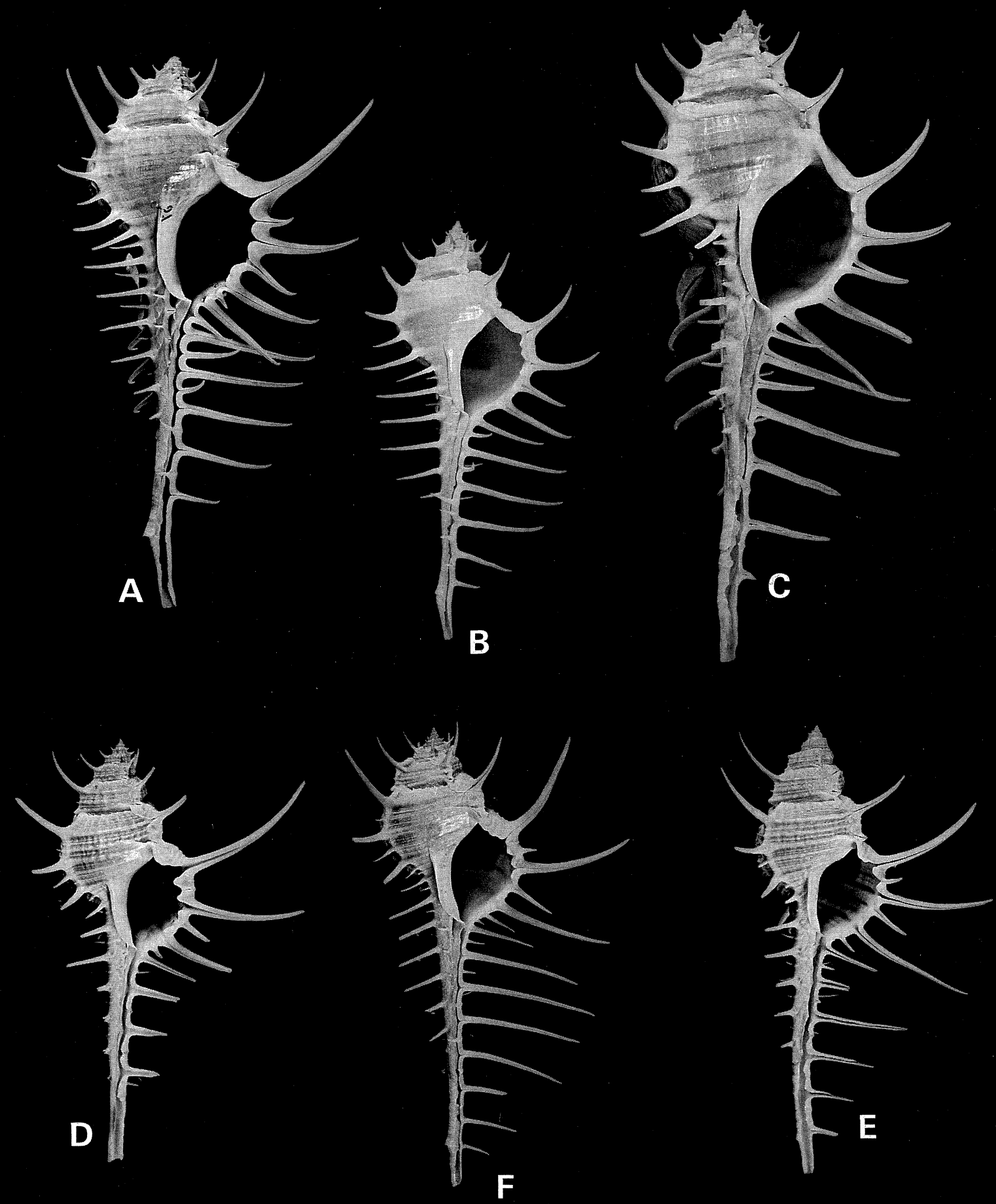

Figure 84. A-C: Murex scolopax Dillwyn. A: Muscat, Oman, Arabian Gulf (AMS C. 127147). B: Dahlak Id, Red Sea (AMS, C.88338). C: specimen figured by Chemnitz (1795: figure 1819-20) (ZMC). D,E: M. altispira n. sp. D: paratype; off "Nonoyan Id", Sandakan, Sabah (ANSP, 295510). E: holotype; Tambisan, Sabah (USNM, 657929A). F: M. djaraniensis poppei Houart; west coast Aceh, north-west Sumatra, Indonesia (RML). Scale $=2 \mathrm{~cm}$. 


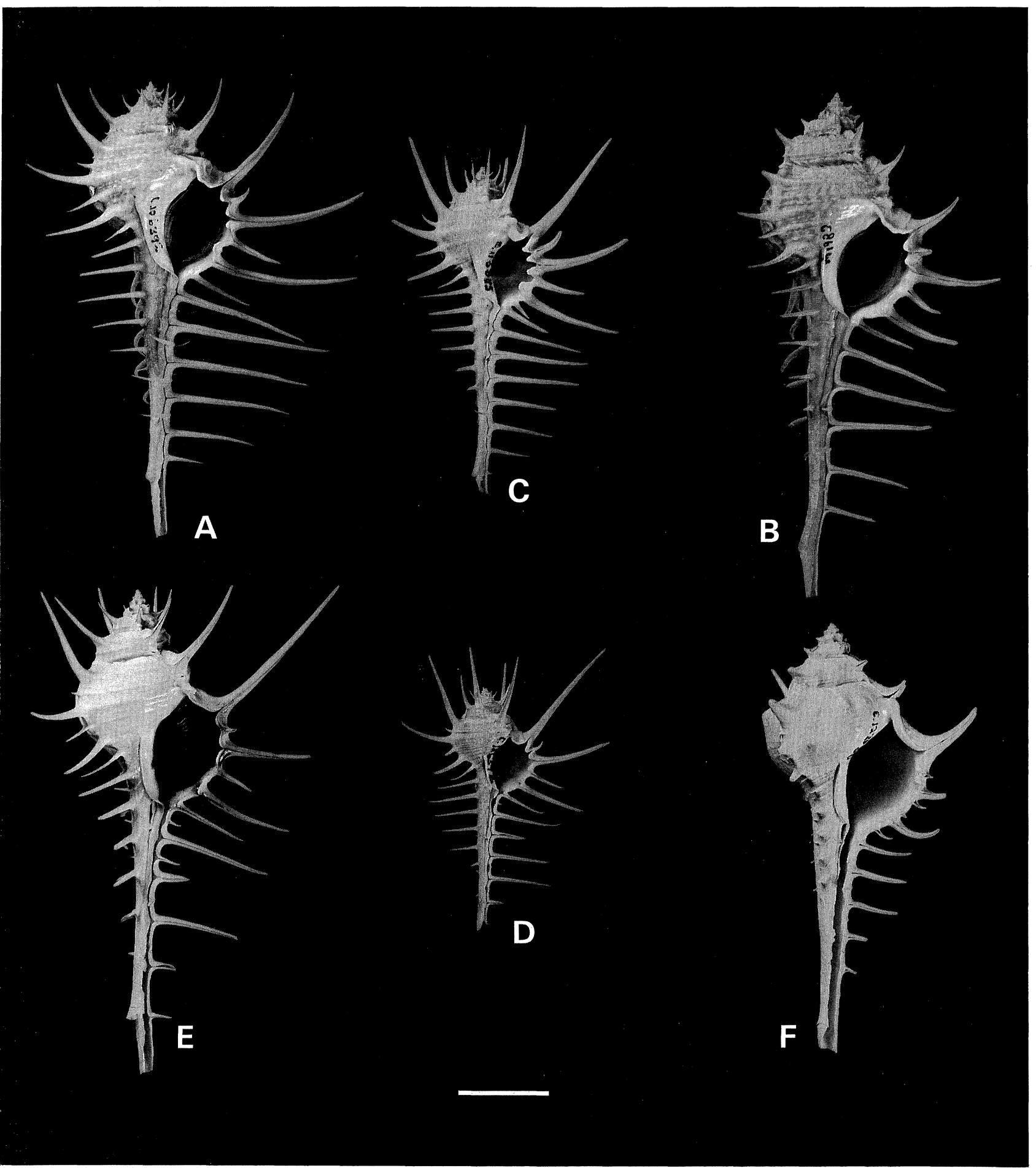

Figure 85. A-D: Murex acanthostephes Watson. A: Dampier, Western Australia, at low tide (AMS, C.106392). B: inner coast, North West Cape, Western Australia, at low tide (AMS, C.86141). C: Darwin Harbour, Northern Territory, $25 \mathrm{~m}$ (AMS, C.113883). D: Arafura Sea, Northern Territory, 72 m (AMS, C.126516). E: M. scolopax Dillwyn; Gulf of Oman, 82-165 m (BMNH). F: M. occa Sowerby; east coast of Malaysia (AMS, C.122630). Scale $=2 \mathrm{~cm}$. 


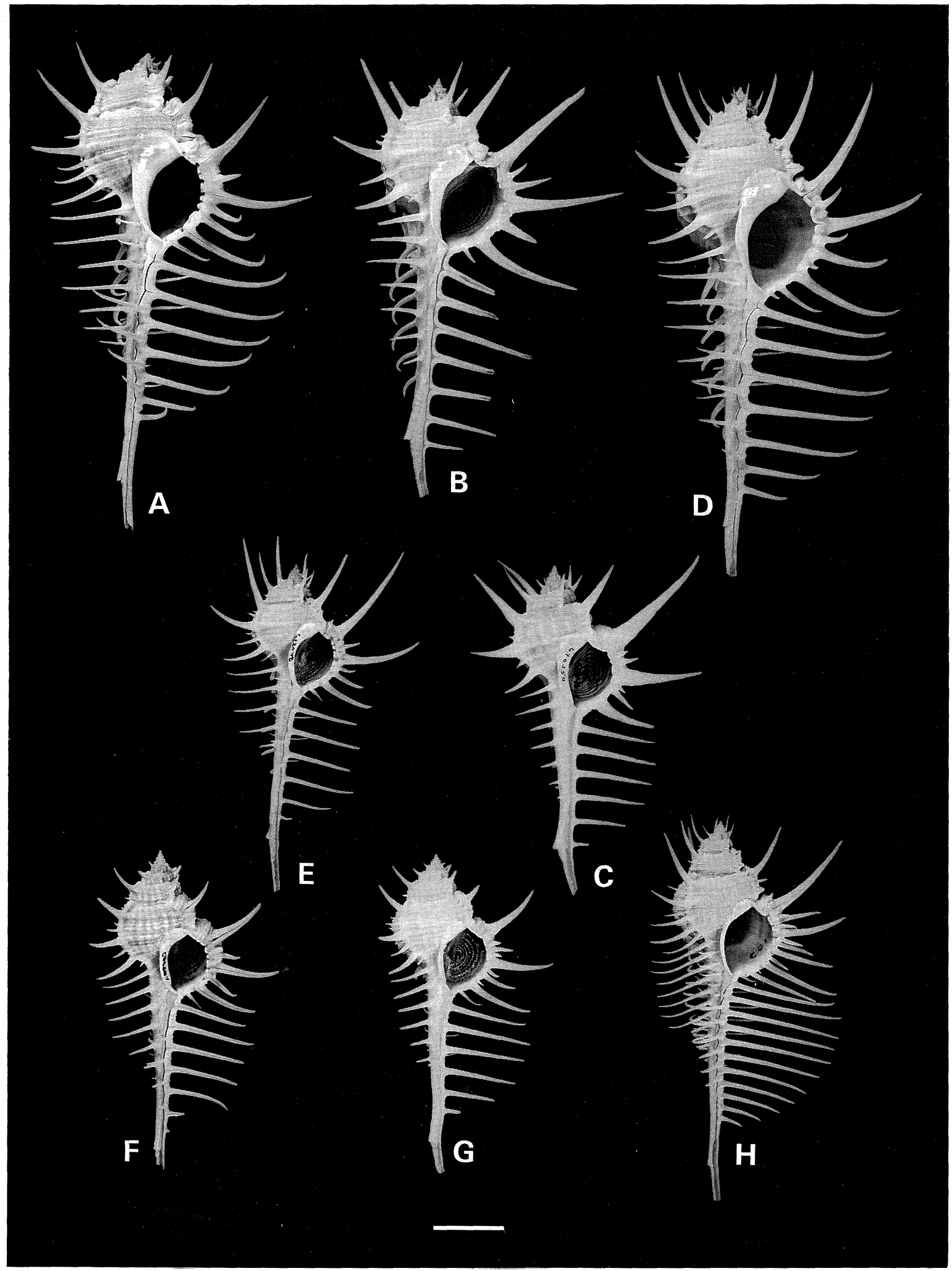

Figure 86. A: Murex spectabilis n. sp.; paratype; Palawan, Philippine Ids (SDMNH, 89267). B,C: M. ternispina Lamarck. B: Rove, Guadalcanal, Solomon Ids, 9 m (AMS, C.148209). C: Okinawa, Japan(USNM, 670350). D,E: M. spicatus n. sp. D: holotype; Okinawa, Japan (BPBM, 6891c). E: paratype; north side Motobn Peninsula, Okinawa, Japan (USNM, 622048). F,G: M. queenslandicus n. sp. F: holotype; off Townsville, Queensland, 37 m (AMS, C.149487). G: Swain Reefs, Queensland, dredged in lagoon, 5 m (AMS, 106401). H: M. pecten pecten Lightfoot; Torres Strait, Queensland, 27-36 m (AMS, C. 61885). Scale $=2 \mathrm{~cm}$. 


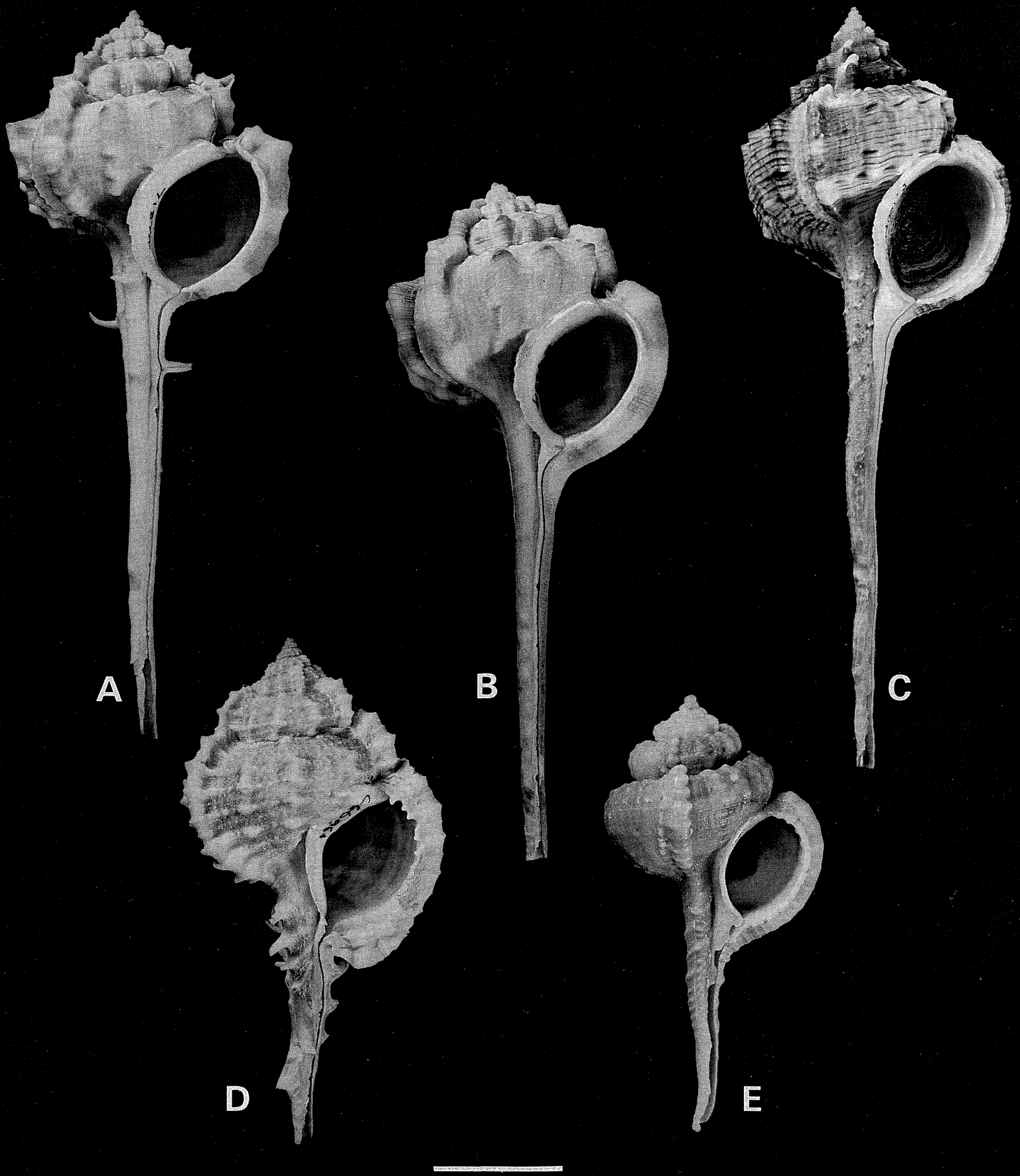

Figure 87. A-C: Haustellum haustellum haustellum (Linné). A: Sulu Sea, southern Philippine Ids(AMS, C.71875). B: off Bulan, Sorsogon Province, Luzon Id, Philippine Ids, in deep water (AMS, C.94514). C: New Caledonia (AMS, C.106402). D: H. tweedianus (Macpherson); off Wide Bay, Queensland, 64 m (AMS, C.66961). E: H. wilsoni D'Attilio \& Old; Bunbury, Western Australia, $12 \mathrm{~m}$ (AMS, C.106404).Scale $=2 \mathrm{~cm}$. 


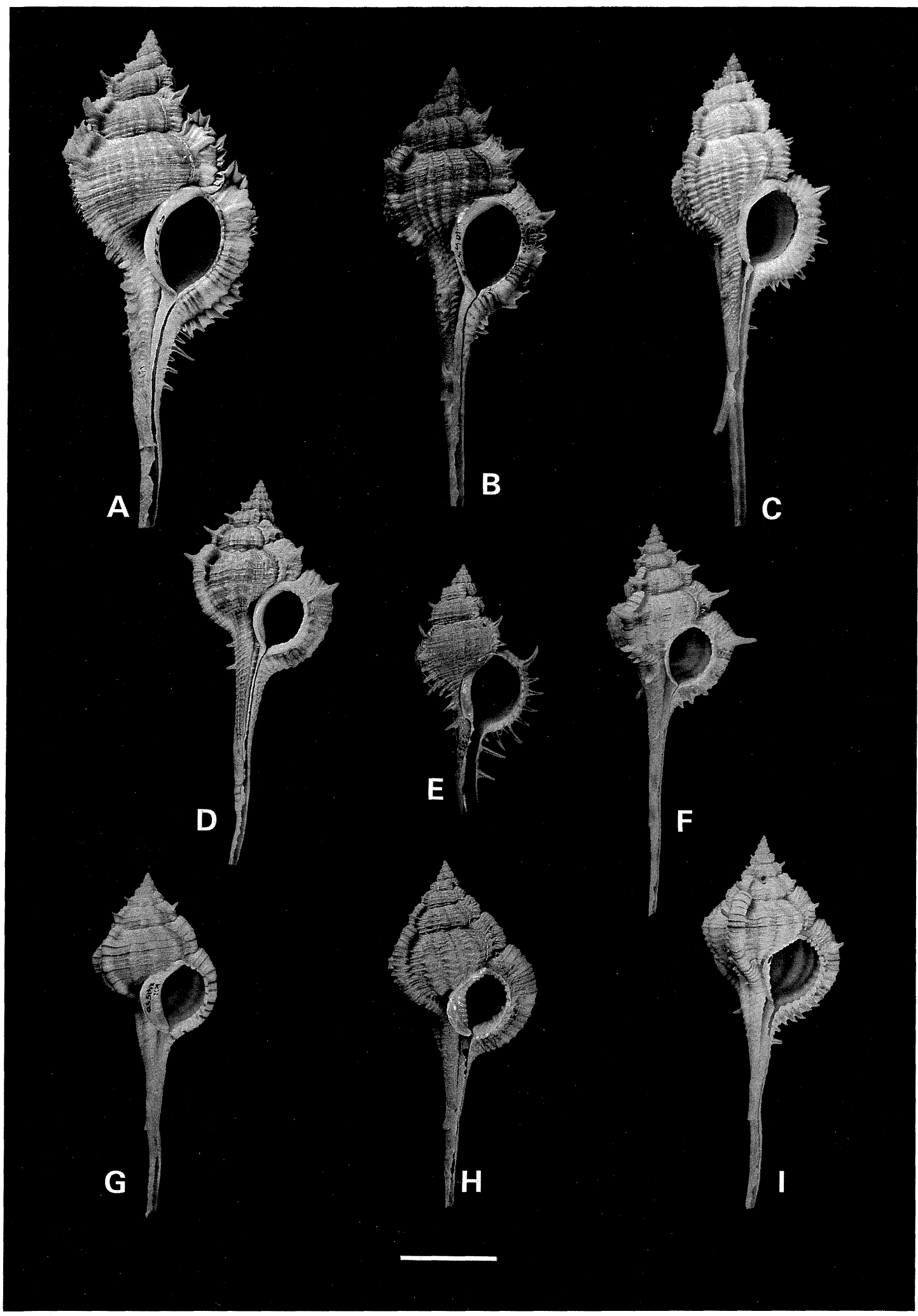

Figure 88. A,B: Haustellum malabaricus (Smith). A: probable paratype. Bay of Bengal, India. 119 m (AMS,C.3285). B: trawled, Gulf of Arabia (AMS,C.106328). C: H. mindanaoensis (Sowerby): trawled. Philippine Ids (AMS,C.103863). D: H. rectirostris (Sowerby); trawled off Taiwan (AMNH. 164923). E: Haustellum bobyini (Kosuge); South Cebu, Philippine Ids, $200 \mathrm{~m}$ (AMS,C.143411). F: H. dolichourus n. sp.: Bali Sea. north of Bali. Indonesia, $150 \mathrm{~m}$ (ZMC). G: H. hirasei (Hirase); Kii, Japan (ANSP, 241550). H, I: H. dentifer (Watson). H: Haruku Id. east of Ambon, Indonesia, 144-157 m (WAM. 1582-70). I:“Lady Island”, off Bohol, Philippine Ids, 109-128 m (WAM, 1593-70 pt.). Scale $=2 \mathrm{~cm}$. 

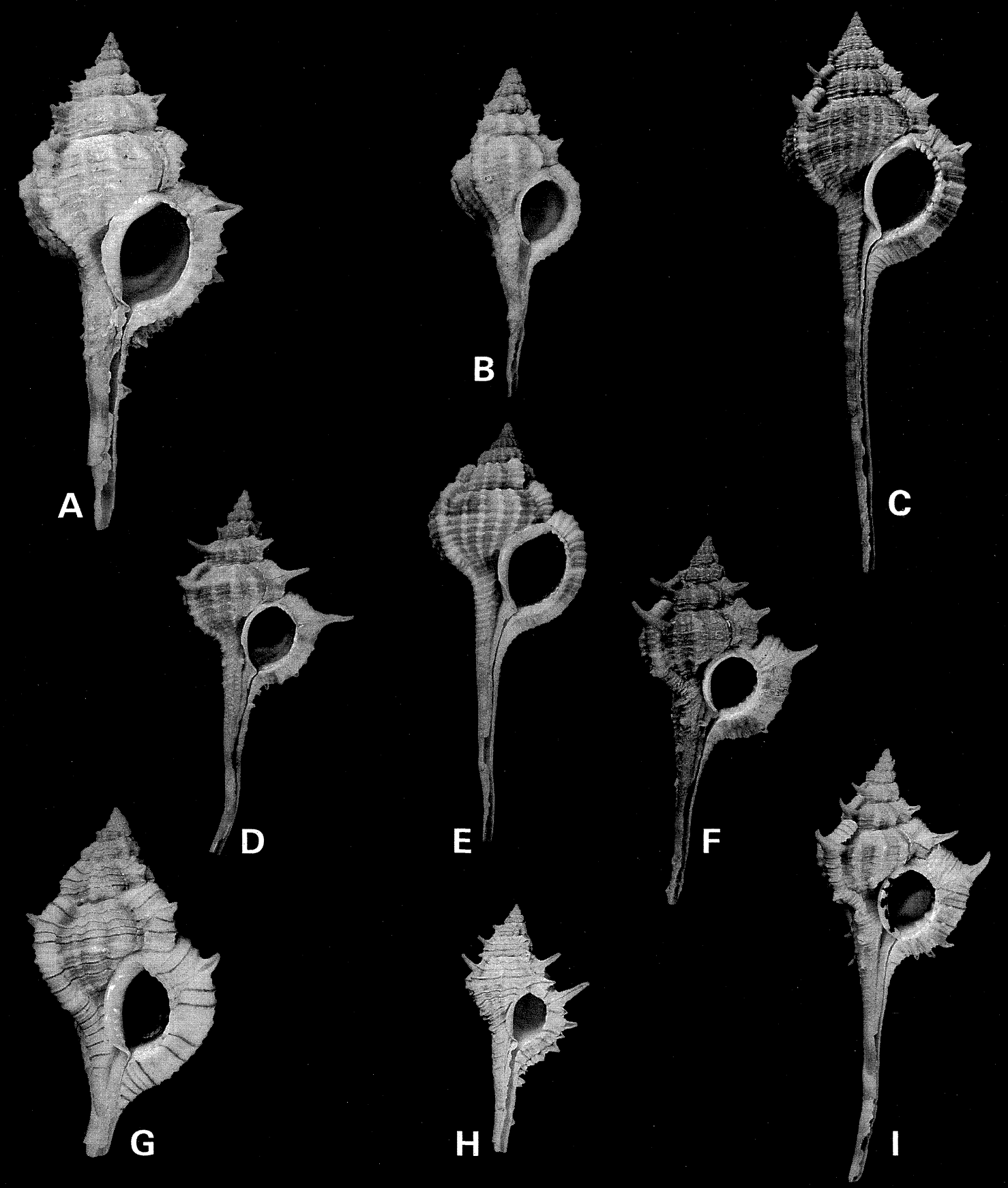

Figure 89. A,B: Haustellum gallinago (Sowerby). A: $26^{\circ} 55^{\prime}-56.6^{\prime} \mathrm{N}, 125^{\circ} 00^{\prime}-02.5^{\prime} \mathrm{E}$, East China Sea, $120 \mathrm{~m}$ (NSMT). B: topotype (?paratype); Hahajima, Ogasawara, Japan (RSM). C: H. multiplicatus bantamensis (Martin); Hansa Bay, northwest of Madang, Papua New Guinea, $35 \mathrm{~m}$ (R. Houart colln). D: H. sobrinus (Adams); Kyoto, Japan (AMS, C.72210). E: $H$. multiplicatus multiplicatus (Sowerby); King Sound, Western Australia (AMS, C.106365). F: H. rectirostris (Sowerby): south-east of Hong Kong, 116-128 m (AMS, C.142910). G,H: H. cf. dolichourus n. sp. G: off Nosy Bé, Madagascar, 480520 m (AMS, C.149488). H: off Nosy Bé, Madagascar, 308-314 m (AMS, C.149489). I:H dolichourus n. sp.; holotype; 25 miles north-north-west of Phuket Id, Andaman Sea, west Thailand, $42 \mathrm{~m}$ (ANSP, 291504). Scale $=2 \mathrm{~cm}$. 


\section{TAXONOMIC INDEX}

Principal references are given in italic letters, all secondary references are in roman letters. New taxa are in boldface. In this index no distinction is made between Murex, Murex s.s. and Murex (Murex).

\section{Acanthina 7}

acanthodes, Murex 65, 67, 68

acanthodes, Murex (Tribulus) 65

acanthostephes, Murex 3, 4, 6, 8, 17, 40, 51, 54, 55, 56, 57, $59,62,124,126,135,140,144,153$

acanthostephes, Murex (Tribulus) 54

aculeata, Aranea 22, 23

Acupurpura 14

aduncospinosa, Murex 39

aduncospinosus, Murex 6, 7, 8, 16, 17, 26, 28, 29, 32, 33,

$34,35,36,37,38,40,41,45,49,84,94,124,125,126$,

$139,143,145,149$

aduncospinosus, Murex rectirostris 35, 94, 99

aduncospinosus, Murex (Murex) tribulus 35

aduncospinosus, Murex ternispina 34

aduncospinosus, Murex tribulus 22, 33

aduncospinosus, Murex (Tribulus) 24, 35

africanus, Murex tenuirostrum 1, 16, 26, 27, 28, 29, 124, $126,141,149$

altispira,Murex $1,16,55,57,58,124,126,144,152$

angelica, Acanthina 7

antelmei, Murex 1, 15, 84, 85, 124, 135, 140, 142

antermai, Murex 84

Aranea 14

armatus, Murex 10

articulatus, Siratus 14

bantamensis, Haustellum multiplicatus 18, 96, 97, 99,

$100,102,107,121,123,125,126,147,157$

bantamensis, Murex 96, 113

bantamensis, Murex (Brontes) 96

beauii, Siratus 8

bentarsariensis, Murex (Murex) verbeeki 24, 35, 37

bobyini, Haustellum 3, 18, 114, 117, 118, 119, 125, 126 , 146,156

bobyini, Murex 117

Bolinus 6, 7, 11, 13, 14

bonneti, Haustellum 99, 106, 107, 119, 120, 125

bonneti, Murex 108, 119

bonneti, Murex (Haustellum) 94, 105, 116, 119

bonneti, Murex (Tubicauda) 119

brandaris, Bolinus 8

brandaris, Murex 13

brevifrons, Chicoreus 6, 7

brevispina, Murex 3, 7, 8, 14, 15, 54, 60, 61, 63, 65, 67, 68,69

brevispina, Murex brevispina 17, 60, 63, 64, 66, 124, 125, $126,135,140,142,151$

brevispina, Murex (Tribulus) 61

brevispina, Tubicauda 61,65

brevispinatus, Murex 61

brevispinus, Murex 65

Brontes 17

Brontesia 17

bullocki, Murex 15, 60, 85, 124

bullocki, Murex (Phyllonotus) 85

bullocki, Ocenebra 86

cabritii. Haustellum 8 cabritii. Murex 14, 136

cailleti, Siratus 8,136

capucinus, Chicoreus 8, 136, 137

carbonnieri, Acupurpura 22

carbonnieri, Murex 4, 6, 12, 16, 22, 23, 30, 32, 33, 34, 44 $124,126,138,143,148$

carbonnieri, Murex (Tribulus) 22

carbonnieri, Murex tribulus 22

Ceratostoma 7

cervicornis, Murex 85

Chicomurex 14

Chicoreus 4, 6, 7, 10, 11, 13, 15, 85

cichoreum, Hexaplex 8, 137

coca, Murex 52

Columbarium 7

concinna, Murex (Tribulus) aduncospinosus 35

concinnus, Murex 34, 35, 36, 37, 143

coppingeri, Murex 6, 8, 16, 45, 46, 47, 74, 123, 124, 126,

$138,145,148$

cornucervi, Chicoreus 8, 137

cornutus, Murex 13

coronatus, Murex 101

cospinosus, Acupurpura 41

coulsoni, Haustellum 120, 121, 125

coulsoni, Murex (Murex) 120

crassispina, Murex 12, 18, 49, 51, 52, 54

darraghi, Haustellum multiplicatus 102, 119, 120, 125, 147

darraghi, Murex (Haustellum) 96, 120

dentifer, Haustellum 17, 102, 103, 104, 105, 106, 112,

$121,125,126,147,156$

dentifer, Murex 102

dentifer, Murex (Haustellum) 102

denudata, Aranea 86

denudatus, Chicoreus 8,10

diderrichi, Murex 10

djarianensis, Murex 52, 54, 60, 86, 124

djarianensis, Murex (Acupurpura) 60, 86

djarianensis, Murex djarianensis 60, 61, 62, 144

dolichourus, Haustellum 1, 8, 18, 99, 100, 105, 106, 107,

$111,119,120,125,126,136,140,147,156,157$

Donax 7

duplicatus, Murex 41, 70

duplicatus, Murex tribulus 69

ejectus, Murex 46, 49, 123, 124

embryoliratus, Murex 94, 95, 96

erythrostoma, Murex 17, 86

erythrostomus, Murex 17, 86

espinosus, Chicoreomurex 92

espinosus, Haustellum 92

espinosus, Murex (Murex) 92

eximius, Murex 94, 96

fallax, Haustellum 90

fallax, Haustellum haustellum 6, 18, 87, 88, 90, 91, 125, 126

fallax, Murex 90

fallax, Murex (Haustellum) 90

falsitribulus, Murex 1, 16, 33, 40, 41, 46, 82, 124, 126, 145,148

fasciatus, Murex 6

FASCIOLARIIDAE 7

fimbriato-nodosum, Haustellum 86

formosus, Murex 41

Forreria 7 
forskoehlii, Murex 8, 12, 16, 18, 20, 21, 32, 33, 34, 124, $126,138,142,150$

fulvescens, Hexaplex 7

funiculatus, Murex (Tribulus) 102, 105

gallinago, Haustellum 18, 107, 108, 109, 110, 111, 112, $117,124,125,126,146,157$

gallinago, Murex 107

gallinago, Murex (Haustellum) 108

gallinago, Siratus 108

gracilis, Aranea 14, 70

gracilis, Murex 70

guembeli, Murex 12

guppyi, Murex 83, 84, 124

\section{Haustellaria 17}

Haustellum 1, 2, 3, 4, 6, 7, 8, 10, 11, 12, 13, 14, 15, 17, 92, $123,124,125,127$

haustellum, Haustellum 6, 8, 86, 90, 91, 124

haustellum, Haustellum haustellum 5, 17, 86, 87, 88, 89, $90,124,125,126,136,140,146,155$

haustellum, Murex 13, 17, 86

haustellum, Murex (Haustellum) 86

haustellum, Murex (Tribulus) 86

heros, Murex 29, 30, 31, 32, 150

Hexaplex 4, 6, 7, 10, 11, 12, 13, 14

hirasei, Haustellum 6, 17, 92, 104, 105, 111, 125, 126, 147, 156

hirasei, Murex 102, 104, 112

hystrix, Murex 69

hystrix, Murex 41, 49, 69

hystrix, Purpura 49

Jaton 7

kerslakae, Murex 1, 6, 8, 16, 33, 37, 39, 124, 126, 139, 143, 149

kiiensis, Haustellum 18, 92, 109, 110, 111, 112, 125, 126 , 146

kiiensis, Murex 104, 105, 108, 110

kurodai, Haustellum 86, 88, 89

kurodai, Murex (Haustellum) 86

kusterianus, Hexaplex 6

laeve, Haustellum 86

lebacanus, Murex 52, 53, 54

longicaudum, Haustellum 86

longicaudum, Murex haustellum 86

longicaudus, Fusus 86

longicaudus, Haustellum 86, 89, 90

longicaudus, Murex 86

longicaudus, Murex haustellum 86, 87, 90

longicornis, Chicoreus $8,15,85,137$

longispina, Murex guembeli 12

macgillivrayi, Acupurpura 65

macgillivrayi, Haustellum 65

macgillivrayi, Murex 6, 7, 8, 12, 65

macgillivrayi, Murex brevispina 4, 17, 62, 63, 65, 66, 67,

$68,69,123,124,126,135,140,142,151$

macgillivrayi, Murex (Tribulus) 65

macgilliwrayi, Murex 63

macgilliwrayi, Murex (Tribulus) 65

maegillivrayi, Murex 69

malabaricus, Haustellum 5, 18, 112, 113, 114, 115, 116 , $125,126,146,156$ malabaricus, Murex 112

martinianus, Murex 41, 43, 44, 57, 58

martinianus, Murex (Tribulus) 41

maximus, Murex tribulus 49

messorius, Haustellum 4, 6, 8, 136

messorius, Murex 13

mindanaensis, Murex 113

mindanaoensis, Haustellum 3, 18, 49, 113, 114, 115, 116 , $117,118,125,126,146,156$

mindanaoensis, Murex 113

mindanensis, Murex 113

mindanensis, Murex rarispina 113

mindanoensis, Murex 112, 116

mindinaoensis, Murex 113

mindinaoensis, Murex (Tribulus) 113

monospina, Nassaria 108

multiplicatum, Haustellum 94

multiplicatum, Murex 94

multiplicatus, Haustellum 6, 94, 99, 120

multiplicatus, Haustellum multiplicatus 8, 18, 94, 96, 97 , $99,102,120,125,126,140,147,157$

multiplicatus, Murex 94

multispinosus, Murex 83, 84

Murex 1, 2, 3, 4, 6, 7, 8, 10, 11, 12, 13, 14, 15, 17, 18, 85, $123,124,125,127$

Murexsul 84

MURICIDAE 1, 11, 14

MURICINAE 7, 10, 14

nagaidesu, Murex (s.s.) kiiensis 110, 112

nasongoensis, Haustellum 99, 101, 121, 122, 125

nasongoensis, Murex (Murex) 121

nigrispinosus, Acupurpura 80

nigrispinosus, Murex 39, 54, 80, 81, 82

nigrispinosus, Murex (Acupurpura) 80

nigrispinosus, Murex (Aranea) 80

nigrispinosus, Murex (Tribulus) 80

nigrospinosus, Murex 39, 40, 80

nigrospinosus, Murex (Murex) tribulus 80

nigrospinosus, Murex (Tribulus) 80

nobile, Haustellum 70

nobilior, Murex tribulus 70

noboriensis, Murex 86

occa, Murex 17, 33, 49, 51, 53, 54, 55, 59, 60, 124, 126, 144,153

occa, Murex (Tribulus) 52

oostinghi, Murex (Haustellum) bantamensis 96

Opeatostoma 7

ornamentalis, Murex brevispina 1, 17, 63, 65, 66, 69, 124, $126,142,151$

partschi, Murex 13

Paziella 10,11

pecten, Murex 2, 7, 8, 12, 14, 15, 18, 34, 49, 69, 70, 74, 75

$76,77,78,80,82,83,84,124$

pecten, Murex pecten $5,16,69,71,72,73,74,75,77,124$,

$126,136,139,145,154$

pecten, Murex tribulus 69

Phyllonotus 6, 13

pliciferoides, Siratus 8, 136

Poirieria 10, 11

poppei, Murex 59, 60

poppei, Murex djarianensis 4, 6, 16, 55, 59, 60, 62, 124,

$126,144,152$

princeps, Hexaplex 8, 137 
Promurex 1, 11, 14, 15, 84, 85, 86

Pterynotus 10

purdyae, Murex 117

purdyae, Haustellum 6, 18, 114, 117, 118, 125, 126

queenslandicus, Murex 1, 8, 16, 46, 74, 75, 77, 78, 80, 83, $84,124,126,135,139,145,154$

rarispina, Murex 12, 41, 99, 101

rarispinosus, Murex 41

rectirostris, Haustellum 6, 18, 93, 94, 95, 99, 101, 102,

$106,111,123,125,126,140,147,156,157$

rectirostris, Murex 93, 101, 105

rectirostris, Murex recurvirostris 93

rectirostris, Murex (Tribulus) 93

rectirostrum, Murex 93

recurvirostris, Murex (Murex) 93, 121

rubidus, Murex recurvirostris 4, 6

rufolirata, Murex 29

rufolirata, Murex (tribulus) ternispina 29, 32

saplisi, Haustellum 121, 122, 123, 125

saplisi, Murex 121

saplisi, Murex (Haustellum) bantamensis 121

scolopaceus, Murex 86

scolopax, Murex 6, 12, 17, 34, 45, 49, 50, 51, 52, 54, 55,

$56,57,59,60,65,82,124,126,140,144,152,153$

scolopax, Murex (Tribulus) 49

senilis, Murex 63

senilis, Murex brevispina 17, 63, 64, 66, 124, 126, 142, 151

senkakuensis, Murex (s.s.) rectirostris 108, 112

serratospinosus, Murex 112, 113, 115, 116

serratospinosus, Siratus 115

Siratus 4, 6, 7, 10,11,13,14, 92, 118

sobrinus, Haustellum 18, 94, 99, 101, 102, 106, 119, 125, 126, 147, 157

sobrinus, Murex 101, 105

sobrinus, Murex (Tribulus) 101

soelae, Murex pecten 1, 16,72,73, 74, 75, 77, 124, 126, 145

spectabilis, Murex 1, 16, 76, 77, 78, 80, 84, 124, 126, 145, 154

spinicosta, Murex 11, 12, 15, 60, 85, 86, 142

spicatus, Murex 1, 12, 16, 34, 77, 78, 79, 80, 82, 84, 124, $126,145,154$

stainforthi, Hexaplex 8

surinamensis, Murex 12, 13

tenuirostrum, Murex 6, 7, 24, 26, 28, 38, 124

tenuirostrum, Murex tenuirostrum 5, 16, 24, 25, 26, 27,

$28,124,126,138,141,148$

tenuis, Hexaplex 6

tenuispina, Acupurpura 70

tenuispina, Murex 12, 14, 16, 18, 69, 70

tenuispina, Murex (Tribulus) 70 tenuispinus, Murex 70

tenuispira, Murex 70

ternispina, Murex 8, 18, 21, 24, 26, 29, 33, 35, 40, 41, 59,

$76,78,79,80,81,82,83,124,126,145,154$

ternispina, Murex (Tribulus) 35, 80

teschi, Murex bantamensis 113, 115, 116

trapa, Murex 4, 6, 7, 8, 9, 12, 15, 17, 23, 26, 34, 35, 37, 41,

$42,43,44,45,51,52,54,59,124,126,135,139,141,151$

Tribulus 14

tribulus, Aranea 78

tribulus, Murex 4, 6, 8, 12, 14, 16, 18, 19, 20, 21, 22, 24,

$26,32,33,34,35,37,38,39,40,54,69,74,80,124$,

$135,138,141,148$

tribulus, Murex (Acupurpura) 33

tribulus, Murex (Tribulus) 33

triremis, Acupurpura 70

triremis, Aranea 70

triremis, Murex 70

triremis, Murex (Acupurpura) 70

triremis, Murex (Arenea) 70

tropa, Acupurpura 41

troscheli, Acupurpura 29

troscheli, Murex 3, 16, 32, 34, 47

troscheli, Murex (Acupurpura) 29

troscheli, Murex (Tribulus) 29

troscheli, Murex troscheli 28, 29, 30, 31, 47, 124, 126, 138, 141,150

Tribulus 14

trunculus, Hexaplex 8, 11, 137

Tubicauda 14

Tudicula 7

tunghaiensis, Murex (s.s.) 112, 113

turbinatus, Murex 6

TURBINELLIDAE 7

tweedianum, Haustellum 92

tweedianum, Murex 92

tweedianus, Haustellum 18, 88, 92, 93, 125, 126, 146, 155

tweedianus, Murex 92

unidentatus, Murex 35, 41

verbeeki, Murex 37, 38, 46, 47, 49, 70

verbeeki, Murex ternispina 47

verbeeki, Murex troscheli 46, 47, 48, 49, 116, 124, 141

verbeeki, Murex (Murex) verbeeki 47

vicdani, Haustellum 86, 88, 89

wanneri, Haustellum 122, 123, 125

wanneri, Murex (Haustellum) 123

wilsoni, Haustellum 6, 18, 88, 90, 91, 126, 155

wilsoni, Murex (Haustellum) 90, 125, 146

yokoyamai, Murex 86 